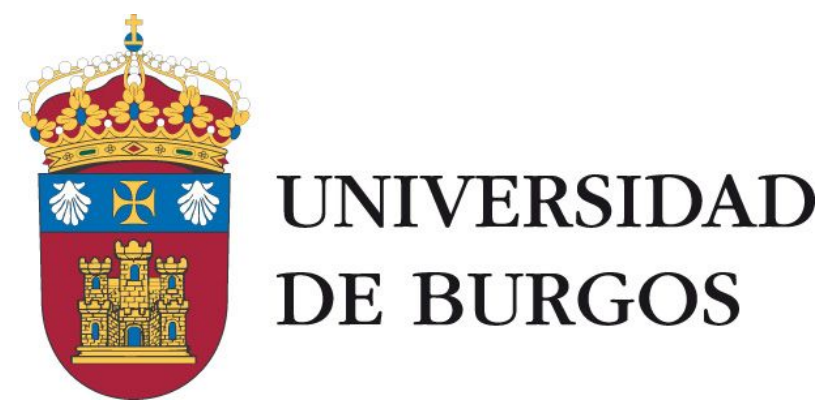

FACULTAD DE DERECHO

Doctorado en Ciencias Jurídicas, Económicas y Sociales

\title{
La Justicia Restaurativa y el poder de la comunidad en la resolución de conflictos. Análisis y propuesta de un nuevo paradigma de justicia penal.
}

\author{
Presentada por \\ RODRIGO MIGUEL BARRIO \\ Bajo la dirección de \\ MAR JIMENO BULNES

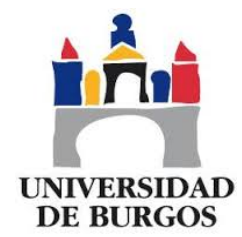

Burgos, 2018 
Todo trabajo de investigación se basa en un quehacer solitario y en la búsqueda incansable de fuentes de investigación que iluminen tu camino en pos de la conclusión de la obra a la que has dedicado una pequeña, pero completa, parte de tu vida. No obstante, la materialización de este trabajo no hubiese dado sus frutos si no fuese por aquellas aportaciones diarias que quiero mencionar y hacer visibles en unas pequeñas referencias.

A mi madre María del Carmen Barrio de la Iglesia, por todo el trabajo y dedicación realizada para que pueda encontrarme en esta disposición actual. Por esos valores de esfuerzo y constancia que me has enseñado con tu ejemplo y me han servido para la concreción de esta obra.

A mi hermano Antonio Miguel Barrio, por ser mi báculo en los momentos de debilidad, estar ahí para mí las veinticuatro horas del día durante todo este periodo, y ser el espejo al que mirarme, no sólo estos años doctorales, sino todos los años de mi vida.

A mi directora Mar Jimeno Bulnes, mi más sincera gratitud por guiarme y aconsejarme por el mundo de la investigación, encendiendo en mí la llama por el interés en la Justicia Restaurativa y en la docencia.

Al profesor Félix Valbuena González, por asistirme continuamente en mi trabajo, otorgándome su tiempo para responder todas mis dudas y por su desvelo en favor de mi situación.

Al profesor Julio Pérez Gil y restantes compañeros del área de Derecho Procesal: Francisco Horcajo Muro y Pablo Hernando Lara y en especial, a mis compañeras Serena Cacciatore y Cristina Ruiz López por su colaboración y apoyo en estos años, a quienes transmito mi ánimo para la realización de su proyecto doctoral. 
A los profesores y profesoras Esther Gómez Campelo, Raquel de Román Pérez, Santiago Bello Paredes y restante profesorado y personal de la Facultad de Derecho por su interés en mis progresos y apoyo constante.

A mis compañeros/as de doctorado, con especial consideración a Teresa Rodríguez Cachón y Rubén Villalmanzo Rivera, por todas esas vivencias positivas acaecidas entre los antiguos muros del Hospital del Rey o fuera de las dependencias universitarias.

Así, gracias a todos aquellos que aportaron su granito de arena para la consecución de este objetivo. 
"Más que la civilización, la justicia es la necesidad del pueblo."

Pietro Colletta (1775-1831) 


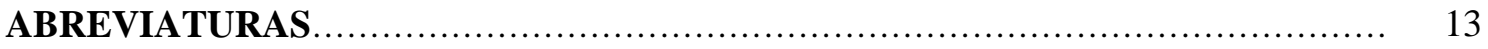

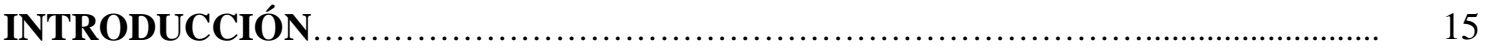

\section{Capítulo primero}

\section{LOS MÉTODOS ALTERNATIVOS PARA LA RESOLUCIÓN DE}

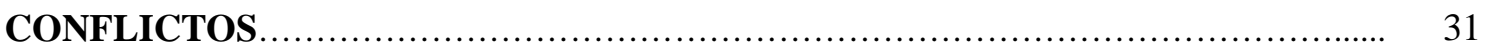

1. Autotutela, autocomposición y heterocomposición....................................... 31

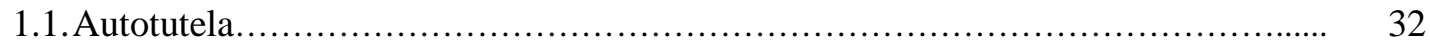

1.2. Autocomposición............................................................ 35

1.3. Heterocomposición................................................................ 36

2. El arbitraje: una breve referencia a la institución...................................... 37

2.1. Concepto y caracteres.............................................................. 37

2.2. Naturaleza del arbitraje.............................................................. 41

2.3. Un ejemplo de arbitraje: el Tribunal de Arbitraje Deportivo........................... 44

3. La negociación y la conciliación como medio alternativo de resolución de

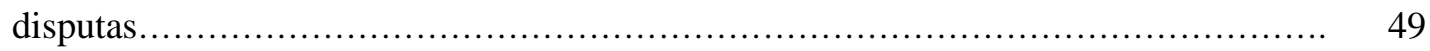

3.1.La negociación: concepto y caracteres............................................ 49

3.2. La conciliación: concepto y caracteres............................................ 52

\section{Capítulo segundo}

MEDIACIÓN: ASPECTOS GENERALES............................................ 56

1. Antecedentes históricos................................................................. 56

1.1.La mediación en el transcurso de la historia................................................. 56

1.2.La recepción de la mediación en España.................................................. 59

2. La mediación: concepto, características, fines y objetivos................................ 62

2.1.El concepto de mediación................................................................. 63

2.2. Características y ventajas propias de la figura..................................... 66

3. Tutela judicial efectiva y mediación............................................................. $\quad 72$

4. Modelos de mediación..................................................................... 75

4.1. Modelo tradicional-Lineal de Fisher y Ury.......................................... 75 
4.2. Modelo Circular Narrativo de Sara Cobb........................................... 77

4.3. Modelo Transformativo de Bush y Folger......................................... 78

5. El procedimiento de mediación nacional extratrajudicial e intrajudicial: dos formas de mediar casi idénticas........................................................... 80

5.1. Mediación Intrajudicial versus Extrajudicial: las mínimas pero sustanciales diferencias.

5.2. Acuerdo de mediación extrajudicial e intrajudicial: contenido y desarrollo.

\section{Capítulo tercero}

LA FIGURA DEL MEDIADOR

1. El estatuto del mediador......................................................... 94

1.1. Condiciones para ejercer de mediador......................................... 95

1.2. La responsabilidad como condición básica para el ejercicio de su

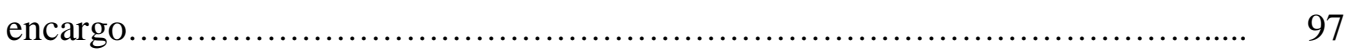

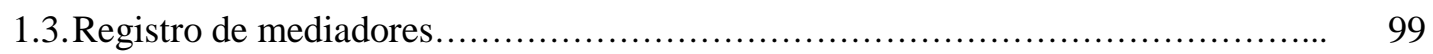

1.4. Costes de la mediación................................................................... 100

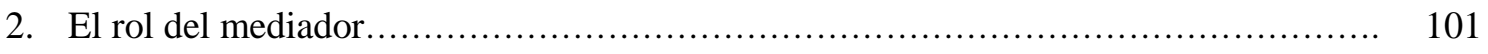

2.1.El mediador como conductor del proceso....................................... 101

2.2.El mediador como observador.................................................... 103

3. Abogacía y mediación: una relación complicada............................................. 105

3.1. Problemática por la actual situación................................................ 106

3.2. Problemática por las reclamaciones de abogados y papel de estos en la mediación...................................................................... 108

3.3. Propuestas de mejora................................................................ 111

3.3.1.El Derecho colaborativo. Un gran paso para la resolución pacífica de conflictos............................................................... 111

3.3.2.La formación de los letrados.................................................... 113

\section{Capítulo cuarto}

LA VÍCTIMA Y LA JUSTICIA RESTAURATIVA.................................. 117

1. La alternativa a la "crisis” del Derecho penal. ¿Crisis total o parcial? .............................. 117

2. La víctima: el sujeto olvidado del sistema de Justicia................................... 123 
2.1. La victimología y el interés por la víctima.

2.2. Concepto de víctima: posibles definiciones

2.3. Marco normativo europeo y nacional: desde la Resolución sobre indemnización a las víctimas de actos violentos hasta el Estatuto de la víctima.

2.3.1.Un camino de reconocimiento en favor de las víctimas.

2.3.2.El Estatuto de la Víctima del Delito, un breve estudio de su regulación.

2.4. Victimización secundaria y terciaria.

3. Origen y definiciones de Justicia Restaurativa.

3.1. Origen de una nueva filosofía.

3.2. Las diferentes definiciones existentes.

4. Aspectos generales de la Justicia Restaurativa.

4.1. La superación como base del nuevo paradigma.

4.2. Objetivos y caracteres propios.

4.3. La intervención de los sujetos en los procesos restaurativos: víctima, infractor y comunidad.

4.4. Justicia Restaurativa versus Justicia Retributiva: ¿enemigos íntimos o complementos necesarios?

5. Algunas consideraciones a la Justicia Restaurativa. 168

5.1. Críticas y observaciones.

5.2. La posible privatización del derecho a través de la Justicia Restaurativa

6. Modelos de Justicia Restaurativa.

6.1. Mediación víctima-infractor 180

6.2. Grupo de Comunidad o Conferencing..... 181

6.3. Círculos o circles

\section{Capítulo quinto}

\section{LA MEDIACIÓN EN EL ÁMBITO PENAL}

1. Aspectos generales: concepto y características.......................................... 185

2. Principios de la mediación penal.................................................... 190

3. Marco legal nacional e internacional................................................ 200 
3.1. Inexistencia de regulación legal: ¿un único culpable?.................................................. 200

3.2. Europa como potenciador de la mediación penal.................................... 201

3.3. La carente normativa nacional.................................................. 204

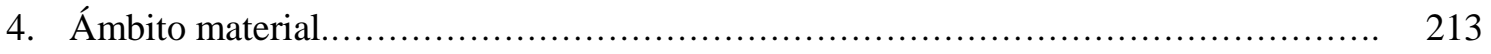

4.1. La mediación en los delitos leves, graves y muy graves............................. 213

4.2. Especialidades dentro de la práctica de la mediación penal.......................... 218

4.2.1.La mediación y el infractor reincidente............................................... 218

4.2.2.Personas jurídicas y el proceso de mediación penal............................. 220

4.2.3.Mediación penal en el sistema penal de menores............................... 222

4.2.4. Violencia de género y su ¿imposibilidad?............................................................. 232

4.2.5.Mediación policial: ¿ ¿una opción desaprovechada?............................................... 239

5. Situación en España ante la inexistencia de normativa: ejemplos

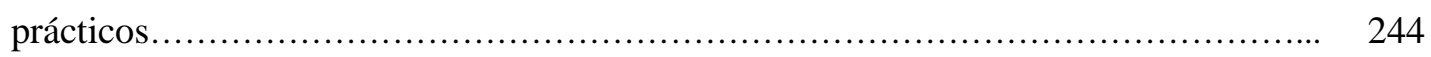

5.1. Protocolos de actuación del Consejo General del Poder Judicial.................... 245

5.2. Experiencias en el País Vasco: el Servicio de Mediación

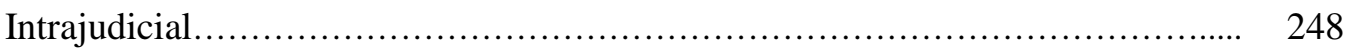

5.3.Experiencias en Castilla y León: el Servicio de Mediación Penal de Castilla y

León-AMEPAX

\section{Capítulo sexto}

EL GRUPO DE COMUNIDAD O CONFERENCING ................................... 287

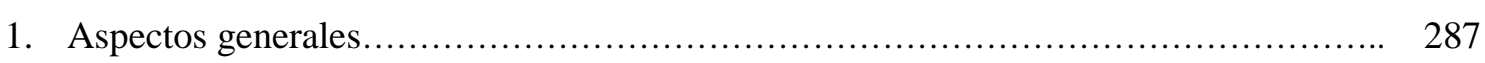

2. El conferencing como método de resolución de conflictos: concepto, clases y ámbito objetivo...

3. El Family Group Conferencing, el origen de las conferencias restaurativas.

3.1. Origen, peculiaridades e intervinientes........................................ 293

3.2. Objetivos y caracteres en definición del nuevo modelo............................ 298

3.3. Las tres fases para el desarrollo y culminación del proceso........................ 302

3.3.1.1 ${ }^{a}$ Fase: preparación................................................................ 302

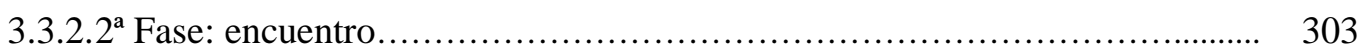

3.3.3.3 ${ }^{\text {a }}$ Fase: Seguimiento del plan de reparación.................................. 307

4. Del Wagga Wagga Model a los sistemas imperantes en Australia....................... 307 
5. La implantación en Irlanda del Norte................................................ 312

5.1.El conflicto irlandés como antecedente al diálogo..................................... 312

5.2. Las conferencias norirlandesas: una inmersión en la restauración................... 315

5.3.El Youth Conference Service: una figura adaptada a las necesidades de Irlanda...... 318

5.4. Algunos datos relativos a la práctica................................................ 322

6. La recepción en Bélgica................................................................. 323

6.1.1. El proyecto piloto de la Universidad Católica de Lovaina..................... 324

6.1.2. Del éxito de Flandes a su asentamiento en Valonia y

Bruselas................................................................................ 328

7. Otros modelos de Conferencias...................................................... 331

7.1.El servicio de Konfliktrådet: el modelo de conferencing en

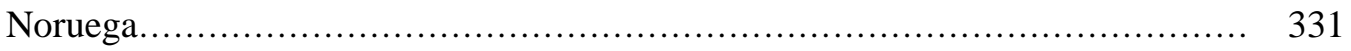

7.2. Sudáfrica y la idea de comunidad en la resolución de conflictos.................... 334

8. Las Conferencias y sus especialidades: bullying y violencia de género.................... 335

8.1.Las Conferencias restaurativas como "medida anti-bullying”....................... 336

8.2. Las Conferencias y la violencia de género. ¿Una posible solución? ............................. 337

Capítulo séptimo

LOS CÍRCULOS: EL PODER DE LA COMUNIDAD EN LA RESOLUCIÓN DE CONFLICTOS.

1. Concepto, origen y caracteres............................................................ 343

2. Desarrollo de los círculos................................................................ 348

2.1.Los círculos en Norteamérica: evolución en Canadá y Estados

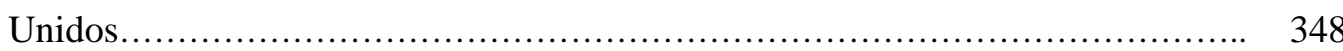

2.2. La expansión de los círculos a Reino Unido (UK Circles)............................ 353

2.3.Europa, Brasil y Asia: una expansión "sin prisa pero sin pausa”.................... 358

2.4.La importancia de las comunidades aborígenes para la implementación de los círculos en Australia...................................................................... 362

3. Tipos de Circles y sus participantes: un estudio con poca unanimidad................... 370

3.1.La participación de la comunidad: el amplio número de

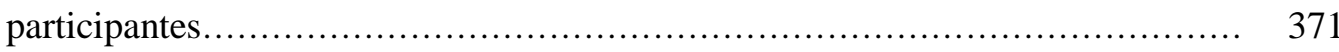

3.2. Los círculos de sentencia o de paz: la comunidad y la obtención de un acuerdo. 
3.3. Los círculos de sanación: la víctima y la superación de sus miedos.

3.3.1.El círculo de sanación, análisis y fundamento.....

3.3.2.Los Círculos de sanación y su proyección audiovisual. El ejemplo de "Jessica Jones".

3.4. Circles of Support and Acountability (CoSA)

3.4.1.El análisis de la institución

3.4.2.Los Círculos CoSA y su proyección audiovisual. El ejemplo de "Orange is the new Black".

3.5. Los círculos en el ámbito escolar. La enseñanza restaurativa en las escuelas.

3.5.1.El desarrollo de los círculos escolares.

3.5.2.La teoría de las sociedades paralelas y los círculos restaurativos

3.6. Los círculos y la violencia de género.

3.7.El círculo como sanador social más allá del delito: el ejemplo de Alcohólicos

Anónimos.

CONCLUSIONES 


\section{ABREVIATURAS}

ADR - Alternative Dispute Resolutions

AMEPAX - Asociación de Mediación para la Pacificación de Conflictos de Burgos

Aptdo - apartado

Art. - Artículo

As. - Asunto

Cap. - Capítulo

CC - Código Civil

CE - Constitución Española

CEE - Comisión Europea

CGPJ - Consejo General del Poder Judicial

coord. - coordinador

CoSA - Circles of Suppor and Accountability

CP - Código Penal

CPP - Código Procesal Penal

dir. - director

Ed. - edición, editorial.

esp. - Especialmente

et. al. - y otros

FGC - Family Group Conference

FJ - Fundamento jurídico.

GBDe - Global Business Dialogue on e-commerce

Hergo - Hertelgricht Groepsoverleg

IRA - Irish Republican Army

LEC - Ley de Enjuiciamiento Civil

LECrim - Ley de Enjuiciamiento Criminal

LORPM - Ley Orgánica de responsabilidad penal de los menores

MASC - Mecanismos Alternativos de Solución de Conflictos 
$n^{0}$ - Número

op. cit. - opinión citada

p., pp. - página, páginas

PLC - Police Led Conferencing

RD - Real Decreto

SMI - Servicio de Mediación Intrajudicial

SSTC - Sentencia del Tribunal Supremo

STJUE - Sentencia del Tribunal de Justicia de la Unión Europea

TABD - Transatlantic Business Dialogue

TACD - Transatlantic Consumer Dialogue

TAS - Tribunal de Arbitraje Deportivo

TC - Tribunal Constitucional

TS - Tribunal Supremo

UE - Unión Europea

vid. - véase

vol. Volumen

VOM - Victim Offender Mediation 


\section{INTRODUCCIÓN}

\section{Fundamento de la temática}

Este trabajo tiene por objetivo el análisis de la Justicia Restaurativa como técnica pacífica de resolución de conflictos y sus posibilidades de aplicación dentro de nuestro sistema de justicia.

La investigación es estrictamente de tipo deductivo con empleo de fuentes doctrinales y legales así como jurisprudencia tanto nacional como extranjera; no obstante, en alguna medida se hará uso también del método inductivo. Se pretende así partir de un estudio general de los Métodos Alternativos de Resolución de Conflictos, de su desarrollo normativo en los estados y de su aplicación por los mismos en favor de la sociedad, para posteriormente abordar un estudio de carácter más particular, con eje en la Justicia Restaurativa, centrándonos tanto en la teoría como en la praxis. Para ello, en primer lugar se hará uso de bibliografía nacional, europea, de países tanto dentro como fuera de la UE; en segundo lugar se hará uso de las técnicas de "trabajo de campo" a partir de las distintas experiencias llevadas a cabo tanto a nivel nacional como extranjero.

Se busca demostrar la existencia de figuras alternativas y complementarias al sistema de justicia clásico actual, basadas en el trabajo e interés de los implicados por el conflicto. No pretendemos alcanzar un método que sustituya a nuestro diezmado proceso, sino un complemento que presente flamantes oportunidades para los ciudadanos miembros de la comunidad.

Las prácticas mencionadas se basan en un principio de nuestra especie: el ser humano es un ser social por naturaleza. Ello nos lleva a organizar nuestra vida en torno a una sociedad o grupo de personas, las cuales, a través de un trabajo común, van formando una comunidad mayor con el transcurso del tiempo. De este trabajo colectivo 
van emergiendo diversos intereses que han de ser protegidos de posibles ataques de terceros. Cuanto más se desarrolla la sociedad en general y los individuos en particular, más conflictos surgen: la "conflictividad tanto en cuanto a la cantidad como a la

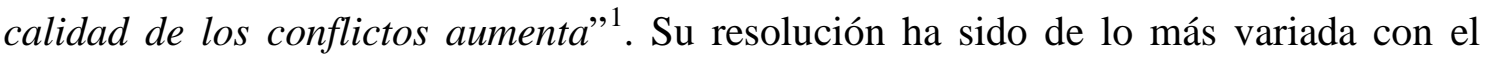
transcurso del tiempo, con una respuesta punitiva históricamente, derivando en la actualidad a ideas de marcado carácter restaurativo ${ }^{2}$.

En nuestros orígenes la Ley del Talión ${ }^{3}$ fue el método de aplicar justicia centrado en el principio de dar a cada uno lo suyo o unicuique suum, siendo un término más aproximado a la venganza que a la justicia. No obstante, es, tal y como señala BARONA VILAR, “el antecedente del principio de proporcionalidad entre el daño recibido y el daño producido, convirtiéndose en consecuencia en un límite a la anterior y libre venganza" ${ }^{4}$. Por ello, posteriormente, los ciudadanos han ido permitiendo que sea el Estado el que se ocupe del cumplimiento de la ley a través de la imposición de resoluciones judiciales.

El estudio del Derecho es ya conocido en las antiguas civilizaciones como Mesopotamia $^{5}$, Fenicia, Palestina, Egipto y Grecia, las cuales utilizan la costumbre como el pilar del derecho. Posteriormente es la sociedad romana la civilización que dedica sus mayores esfuerzos a regular las relaciones entre las personas, implementando un Derecho fuerte y e importante en nuestra historia. Encontramos en el Derecho

\footnotetext{
${ }^{1}$ BARONA VILAR, S., “Las ADR en la justicia del siglo XXI, en especial la mediación”, en Revista de Derecho Universidad Católica del Norte 2011, Año 18, n 1, pp. 185-211, esp. p. 186.

${ }^{2}$ Para un estudio pormenorizado del desarrollo histórico del proceso penal véase BARONA VILAR, S., "Esquizofrenia en la justicia penal: entre el expansivo derecho penal, la búsqueda de la minimización del proceso y el impulso de la mediación penal”, en J. Sigüenza López y G. García-Rostán Calvín (dirs.) Estudios sobre mediación y arbitraje desde una perspectiva procesal, Aranzadi, Cizur Menor, 2017, pp. 187-218, esp. pp. 189-208.

${ }^{3}$ La Ley del Talión viene recogida dentro del Código de Hammurabi, creado en el año 1750 a. C. por el rey de Babilonia Hammurabi. Para más información relativa a su contenido, véase LARA, F., Código de Hammurabi, Editora Nacional, Madrid, 1982; SANMARTíN, J., Códigos legales de tradición babilónica, Barcelona, 1999.

${ }^{4}$ BARONA VILAR, S., Proceso penal desde la historia, Tirant lo Blanch, Valencia, 2017, p. 34.

${ }^{5}$ El Código de Ur-Nammu, de Mesopotamia, es el código más antiguo que se conoce. Fue creado por el primer rey de la III Dinastía de Ur, Ur-Nammu, y recoge 195 artículos que describen el delito y luego fijan la pena.
} 
Romano regulación sobre las relaciones de familia, el matrimonio, la adopción, la emancipación, la patria potestad, los contratos y los Derechos reales. Todo ello sirvió de base para un estudio pormenorizado de diferentes figuras, las cuales han sido complementadas gracias a las interpretaciones de grandes juristas como Bártolo de Sassoferrato $^{6}$, Edward Coke ${ }^{7}$, Friedrich Karl von Savigny ${ }^{8}$, Hans Kelsen ${ }^{9}$, Robert Schuman ${ }^{10}$ o Eduardo García de Enterría ${ }^{11}$ entre otros.

Centrándonos ya en época más reciente, nuestro Derecho se basa en el pilar fundamental de la Constitución como norma básica e invulnerable. Y, dentro de ella, el artículo que hemos de tener como referencia es el artículo 24 sobre la tutela judicial efectiva. Este artículo otorga protección a las personas físicas, nacionales o extranjeras, titulares de derecho e intereses legítimos y a las personas jurídicas ${ }^{12}$. Es un auténtico derecho fundamental de carácter autónomo y con contenido propio, pero según el Tribunal Constitucional su naturaleza "no es la de un derecho de libertad ejercitable sin más, directamente a partir de la Constitución, sino la de un derecho de prestación, que sólo puede ejercerse por los cauces que el legislador establece o, dicho de otro modo, es un derecho de configuración legal”13.

Dentro de este articulado y observaremos el derecho de libre acceso a los Jueces y Tribunales. No en vano “desde la STC 37/1995, de 7 de febrero, el Tribunal

\footnotetext{
${ }^{6}$ Su estudio del derecho privado común le asciende al Olimpo de los mejores juristas de la historia de la humanidad. De esta opinión véase GARCÍA Y GARCÍA, A., Derecho común en España. Los juristas y sus obras, Universidad de Murcia, Murcia, 1991, pp. 99-128, esp. 99-101.

${ }^{7}$ Importantísimo jurista inglés que se llegó a enfrentar al Rey Jacobo I para defender la independencia judicial. Sus obras más conocidas son Institutes of the Lawes of England, The selected writings and speeches of Sir Edward Coke y The fourth part of the institutes of the laws of England.

${ }^{8}$ Conocidísimo jurista alemán fundador de la escuela histórica del derecho alemana, autor de las célebres obras System des heutigen römischen Rechts y The vocation of our age for legislation and jurisprudence.

${ }^{9}$ Su obra Teoría Pura del Derecho es el pilar del Derecho Positivo actual.

${ }^{10}$ Es considerado como uno de los "padres de Europa" por su participación en la creación de las Comunidades Europeas.

${ }^{11}$ Abogado y Catedrático de Derecho Administrativo de la Universidad Complutense de Madrid, así como miembro de la Real Academia de la Lengua Española en calidad de artífice de la construcción del Derecho Público en España e Hispanoamérica.

${ }^{12}$ SSTC 19/1983 de 14 de Marzo de 1983, 91/1991 de 25 de abril, 100/2000 de 10 de abril, 175/2001 de 26 de julio y 11 y 28/2008 de 11 de febrero.

${ }^{13}$ STC 99/1985 30 de Septiembre de 1985, FJ 4.
} 
Constitucional ha venido reiterando que el núcleo del derecho fundamental a la tutela judicial proclamado por el artículo 24.1 CE consiste en el acceso a la jurisdicción”14.

En este punto puede observarse que los ciudadanos tienen derecho a acudir a los tribunales, y en el artículo 24.2 de nuestra Carta Magna se señala un proceso público, sin dilaciones indebidas y con todas las garantías, pero en ningún momento aquí se habla de la posibilidad de que los ciudadanos puedan acudir a otros métodos de resolución de conflictos, a los famosos Alternative Dispute Resolution o Mecanismos Alternativos de Solución de Conflictos (ADR O MASC).

Países de nuestro entorno no han “dejado pasar” la oportunidad que les brindan estas prácticas, regulando sus actuaciones y potenciándolas como una opción en favor de los ciudadanos. Nuestro Estado obvió las ventajas que la mediación podía suponer para los miembros de la comunidad, siendo la regulación autonómica ${ }^{15}$, sobre todo en relación a mediación familiar, la que se ha ocupado de implementar esta figura en nuestras fronteras. Es necesario un mayor impulso estatal aun sin la existencia de una experiencia previa. CECILIA JULIN ${ }^{16}$ cree que la mediación ha triunfado en Suecia debido a una serie de factores históricos y caracteres propios de la personalidad de sus habitantes. Así señala que es fundamental la existencia en un Estado de tradición histórica que le otorgue credibilidad; imparcialidad e independencia política; honestidad; y habilidades personales desarrolladas gracias a todo lo anterior por sus habitantes.

\footnotetext{
${ }^{14}$ SSTC 223/2001 de 5 de noviembre, 73/2004 de 22 de abril, 237/2005 de 26 de septiembre, 119/2008 de 13 de Octubre, 29/2010 de 27 de abril.

${ }^{15}$ La primera ley sobre mediación en España es la Ley 1/2001, de 15 de marzo, de mediación familiar de Cataluña. Disponible en: http://dogc.gencat.cat (última visita 18/01/2018)

${ }^{16}$ JULIN, C., "Mediation: the Sweddis experience", en K. Brown y M. Concepción Rayón (coords.), Mediación: Experiencias desde España y alrededor del mundo, Universidad Complutense de Madrid, Madrid, 2016, pp. 31-34, esp. pp. 32-33
} 
Pero, como de costumbre, ha sido la Unión Europea la que apostó por los Métodos Alternativos para la Resolución de $\operatorname{conflictos}^{17}$, y más concretamente con el desarrollo de la Directiva 2008/52/CE del Parlamento Europeo y del Consejo, de 21 de mayo de $2008^{18}$, sobre ciertos aspectos de la mediación en asuntos civiles y mercantiles. La trasposición de esta Directiva en la Ley 5/2012, de 6 de julio, de mediación en asuntos civiles y mercantiles ${ }^{19}$, sirvió para la satisfacción de aquellas voces que exigían la mediación dentro de nuestras fronteras y la ampliación de "la oferta de formas de resolución de conflictos a disposición del ciudadano" ${ }^{20}$. Se consigue así, tal y como define CASTILLEJO MANZANARES, un proceso “en el que las partes son las protagonistas, son ellas las que llegan a los acuerdos, eso sí, con la intervención de un tercero imparcial, el mediador, que con su formación en este campo permite que las partes procedan en plena igualdad de oportunidades" 21.

El empuje que está suponiendo la mediación es evidente, y por ello es necesario un estudio pormenorizado de la figura tanto dentro como fuera del proceso. Esto servirá para una mejor regulación futura, que nos lleve al impulso final y necesario para la resolución satisfactoria de los conflictos. Desde aquí agradecemos el interés actual por parte de nuestros gobernantes, ya que, recientemente, el “Congreso de los Diputados ha aprobado una iniciativa en la que insta al Gobierno a fomentar la mediación extrajudicial como forma de la resolución de conflictos, "sensibilizando" a la

\footnotetext{
${ }^{17}$ Libro verde sobre las modalidades alternativas de solución de conflictos en el ámbito del derecho civil y mercantil. Bruselas, 19.04.2002 COM (2002). Disponible en: http://eur-lex.europa.eu/legalcontent/ES/TXT/PDF/?uri=CELEX:52002DC0196\&from=ES (Última visita: 17/04/2017)

${ }^{18}$ Para un estudio exento sobre la Directiva de mediación civil y mercantil véase GONZÁLEZ CANO, M.I., "La promoción de la mediación en el ámbito de la Unión Europea: la Directiva 2008/52/CE sobre ciertos aspectos de la mediación en asuntos civiles y mercantiles y su incorporación al derecho español”, en J. Martín Ostos (coord.) El Derecho Procesal en el espacio judicial europeo: estudios dedicados al catedrático Faustino Gutiérrez-Alviz y Conradi, Atelier, Barcelona, 2013, pp. 235-270.

${ }^{19}$ Ley 5/2012, de 6 de julio, de mediación en asuntos civiles y mercantiles. BOE núm. 162, de $07 / 07 / 2012$

${ }^{20}$ MARTÍN DIZ, F., "Ley 5/2012, de 6 de julio, de mediación en asuntos civiles y mercantiles [BOE n. ${ }^{\circ}$ 162, de 7-VII-2012]", en Ars Iuris Salmanticensis: AIS : revista europea e iberoamericana de pensamiento y análisis de derecho, ciencia política y criminología 2013, vol. 1, nº 1, pp. 212-213, esp. p. 212.

${ }^{21}$ CASTILLEJO MANZANARES, R., "La figura del mediador concursal en el "acuerdo extrajudicial de pagos"”, en Cuaderno electrónico de estudios jurídicos 2013, nº 1, pp. 19-36, esp. p. 24.
} 
ciudadanía a través de campañas de la utilización de esta alternativa y trabajando "estrechamente" con los especialistas en esta materia"22.

El "atasco" existente en nuestros Tribunales es patente, y en palabras de la Magistrada de la Audiencia Provincial de Barcelona RAQUEL ALASTRUEY, "en España. A finales de 2014, tuviéramos más de 2.500.000 de litigios pendientes, lo que supone una tasa de tres veces superior a otros países de la UE, que debíamos resolver no más de 5.200 jueces”,23.

Con esta investigación se pretende estudiar una visión en conjunto de la mediación, superando así la visión parcial que se investiga en la actualidad, empezando por un análisis desde la mediación, la cual ha servido como práctica ejemplar para la demostración de la resolución alternativa de conflictos, para así proseguir con el estudio de la Justicia Restaurativa, y en concreto, de sus métodos tales como la mediación penal, las conferencias y los círculos.

En este trabajo nos centraremos en primer lugar a un estudio de los ADR desde una visión general, profundizando en la figura de la mediación, sin obviar el desarrollo legal existente a través de la Ley de mediación en asuntos civiles y mercantiles ${ }^{24}$, para analizar exhaustivamente en segundo lugar las posibles prácticas complementarias derivadas de la Justicia Restaurativa a nivel global con las que complementar y mejorar nuestro sistema penal, tales como la mediación penal (incluyendo aquí las especialidades de personas jurídicas, ámbito penitenciario, violencia de género y menores), conferencias y círculos en sus variantes de mayor consideración. Todas derivan de una necesidad a consecuencia de la denominada "crisis" del sistema penal que no ha podido satisfacer las demandas de “justicia” de los ciudadanos. Se asientan

\footnotetext{
22 “El Congreso aprueba fomentar la mediación para la resolución de conflictos judiciales”. Iustel. 08/03/2017. Disponible en: http://www.iustel.com (Última visita: 13/03/2017)

${ }^{23}$ ALASTRUEY, R., "La mediación intrajudicial en España”, en K. Brown y M. Concepción Rayón (coords.), Mediación: Experiencias desde ..., op. cit.,, pp. 121-126, esp. p. 123.

${ }^{24}$ Ley 5/2012, de 6 de julio, de mediación en asuntos civiles y mercantiles. Disponible en: https://www.boe.es (última visita 18/01/2018)
} 
en la "combinación de la trilogía víctima-infractor-sociedad para poder alcanzar el equilibrio"25, y tal y como señala CARRETERO MORALES, "el entramado de relaciones jurídicas en nuestra sociedad actual (...) ha hecho crecer exponencialmente el número de conflictos y ha puesto de manifiesto la insuficiencia y la ineficacia de los mecanismos de decisión clásicos, basados únicamente en fórmulas heterocompositivas, en los que un tercero impone una solución que, presuntamente, pone fin a dichos conflictos"26.

En el Derecho europeo los modelos de Justicia Restaurativa han ido encontrando acomodo, con un mayor impulso en los ordenamientos jurídicos anglosajones, influenciados por un proceso penal acusatorio, dando cabida al principio de oportunidad y con mayores dificultades en aquellos sistemas basados en el principio de legalidad ${ }^{27} \mathrm{o}$ comúnmente conocidos como sistemas de Civil $\operatorname{Law}^{28}$. Tanto en España como en el resto de Europa ha sido la mediación la institución más generalizada ${ }^{29}$ con características propias en cada Estado ${ }^{30}$. España ya dispone de experiencia en cuanto a acuerdos de mediación, tanto en mediación intrajudicial como extrajudicial, sobretodo en País Vasco y Cataluña, los cuales han dejado un "elevado grado de satisfacción a las partes”31. La mediación nos ofrece una solución ágil, a poco coste, basada en las

\footnotetext{
${ }^{25}$ BARONA VILAR, S., “Esquizofrenia en la ...”, op. cit., p.212.

${ }^{26}$ CARRETERO MORALES, R., "La necesidad de cambios en los modelos de solución de conflictos", en H. Soleto Muñoz (dir.), E. Carretero Morales, C. Ruiz López (coords). Mediación y resolución de conflictos: técnicas y ámbitos, Tecnos, Madrid, 2011, 98-115 p. 101.

${ }^{27}$ GARCÍA HERRERA, A., "Justicia restaurativa: breve reflexión sobre su integración en el marco del proceso penal en España”, en La Ley 2015, nº 8654. Disponible en: https://www.diariolaley.es (última visita 05/04/217)

${ }^{28}$ Para una comparación relativa al proceso penal en sistemas de Civil Law y Common Law véase JIMENO BULNES, M., "El proceso penal en los sistemas de Common Law y Civil Law los modelos acusatorio e inquisitivo en pleno siglo XXI”, en Justicia: revista de derecho procesal 2013, n ${ }^{2}$, pp. 207310.

${ }^{29}$ Vid. BARONA VILAR, S., “El movimiento de las ADR en el Derecho comparado” en R. Castillejo Manzanares y $\mathrm{M}^{\mathrm{a}}$. C. Catalina Benavente (coord.), Violencia de género, justicia restaurativa y mediación, Wolters Kluwer, 2011, pp. 455-497.

${ }^{30}$ A modo de ejemplo Alemania regula la mediación en el parágrafo 46 del Código Penal a través de un modelo de compensación en favor de la víctima. Para un mayor análisis véase ROXIN, C., "Pena y reparación”, en ADPCP 1999, vol. LII, pp. 5-15.

31 FERNÁNDEZ MANZANO, M.L. y GOMÁ LANZÓN, I., “¿Mediación versus Derecho?”, en El Notario del Siglo XXI 2015, n 60 , pp. 176-178, esp. p. 178.
} 
necesidades de las partes y que garantiza el cumplimiento posterior del acuerdo. Pero, ¿y por qué no está siendo empleada? ¿Por qué desperdiciamos esta oportunidad?

Los ciudadanos no perciben qué son las instituciones restaurativas ni los beneficios que pueden ocasionarles y por consiguiente tiene un gran recelo sobre ello. El no comprender su desarrollo y la falta de confianza en sus actuaciones dentro del proceso provocan que prefieran acudir a un juicio donde un tercero aplicará la ley para resolver el conflicto. Pero, en la misma línea, existen ciudadanos con mayor capacidad de intervenir y ser partícipe en el proceso. Superar la clásica mentalidad ganadorperdedor que nos ofrece nuestro sistema penal actual y ser parte de un proceso encaminado a obtener un resultado consensuado conforme a las necesidades de los intervinientes.

Comprender las ventajas e inconvenientes de la mediación y demás prácticas restaurativas es primordial para la toma de la decisión afirmativa o negativa de inicio del proceso. Convencer a los ciudadanos que pueden trabajar y resolver un conflicto con la intervención de ambas partes y el apoyo de un mediador, será base para la implementación del sistema. Supone así superar la mentalidad ganador-perdedor, pudiéndonos ayudar a encauzar las relaciones sociales y prevenir futuros conflictos con esa otra persona.

Los avances llevados a cabo, aún positivos, no están ofreciéndonos resultados del todo positivos. La nula regulación existente en España nos conduce a una disparidad de actuaciones, sin una línea fija que seguir y con múltiples dudas en relación a los tipos delictivos a tratar e incluso la posible vulneración de la tutela judicial efectiva, aspecto sobre el que iremos ahondando.

Podemos encontrarnos con dos variantes de estas prácticas, la denominada intrajudicial y la extrajudicial. La primera de ellas supone un proceso de mediación u otra práctica sobre un asunto civil o penal ya conocido por los Tribunales, mientras que 
en la segunda de ellas el conflicto no está judicializado en el momento del inicio del proceso de mediación u otra práctica. Para que veamos un mayor uso de la mediación hemos de procurar su implantación dentro de los juzgados ${ }^{32}$, la cual ha de ser totalmente efectiva. Se ha de permitir el poder acudir a este sistema antes de proseguir con el juicio como ya está ocurriendo en diversos lugares, así como el asentamiento de las diversas instituciones de mediación ${ }^{33}$.

Es difícil poder predecir cómo se desarrollarán estas prácticas en un futuro. LEATHES $^{34}$ se pregunta cómo será la mediación en el 2020 y considera que el mediador será un profesional respetado porque en un contexto de crisis de empresas, se pone mucha atención en los resultados y se evitan riesgos innecesarios. Por ello, la mediación tendrá gran importancia ya que resolverá sus problemas con celeridad y sin riesgos. Para LEATHES la expansión de la mediación será un hecho si suceden los hechos siguientes:

- Se crea un organismo profesional por los mediadores, proveedores y formadores.

- El Gobierno aprueba un presupuesto por un periodo de 5 años y se evitan los over-head.

- Este organismo profesional recién creado funciona como una entidad sin ánimo de lucro.

- Creación de una red global de mediadores con transparencia y calidad.

- Preparación de jóvenes mediadores.

- Formación de alto nivel.

- El organismo profesional está abierto a quién cumpla los criterios de calidad.

- Creación de un Código ético.

\footnotetext{
${ }^{32}$ A modo de ejemplo podemos encontrarnos el anuncio efectuado en las Jornadas de presentación de la Mediación Intrajudicial Social: 'La mediación como instrumento de pacificación social y efectiva en la resolución de conflicto’ por el cual se informaba que antes del verano de 2015 Burgos sería la tercera ciudad, tras Madrid y Barcelona, en la implantación de un servicio de mediación intrajudicial.

${ }^{33}$ Como por ejemplo el Instituto de Justicia Restaurativa-AMEPAX

${ }^{34}$ LEATHES, M., 2020 Vision. Where in the World will mediation be within 10 years? Disponible en: http://www.mediate.com (Última visita: 09/11/2017)
} 
De modo aún más importante, la mediación penal, y, más concretamente, la Justicia Restaurativa, parece ser un modo de resolución de conflictos más “amigable” para la víctima, evitándose así el perjuicio que puede ocasionar a la víctima el atravesar el proceso y recordar el hecho dañoso (victimización secundaria). No hay que olvidar que del delito emanan una serie de consecuencias para la víctima, físicas y/o psicológicas, que al tener que "revivir” en un juicio (recordar el daño, la infracción, volver a encontrarse con el causante del hecho delictivo...), provocarán la reaparición en la víctima de los problemas y dolores sufridos, agravándose su situación.

Desde la perspectiva del victimario la Justicia Restaurativa supone un interés hacia su persona, su condición y hacia el fenómeno criminógeno que subyace al delito. Ello se enfoca con interés a la posibilidad de reinserción social de aquél sujeto que erró en su camino y eligió la senda delictiva vulnerando la paz social y lastimando con su conducta a los miembros de la comunidad. Estamos ante una "necesidad de justicia”, una filosofía o movimiento efectuado en diferentes sesiones in voce que entrega el poder a las partes, las cuales podrán llegar a resolver el conflicto a través de su diálogo y esfuerzo, tratándose de conseguir una reparación lo más satisfactoria posible y un retorno a la sociedad del infractor.

Estas nuevas figuras se hacen necesarias en nuestro ordenamiento necesitándose un soplo de aire fresco para la mejora de la justicia. No son un remedio mágico que solucione nuestros problemas ${ }^{36}$, pero sí van a proporcionan un impulso a la propia sociedad, la cual, en palabras de PILAR FUENTES, “reclama cada vez más espacios en los que su voz sea escuchada, se sienta comprendida, y sobre los que tenga una responsabilidad activa" ${ }^{37}$.

\footnotetext{
${ }^{35}$ BOLAÑOS HURTADO, E., “Justicia Restaurativa: una mirada panorámica”, conferencia impartida en la Mesa redonda "La Justicia Restaurativa en el contexto internacional: hacia una construcción de un modelo universal”, el IV Congreso de Justicia Restaurativa y Mediación Penal: del desiderátum a la realidad práctica, Burgos, 17 y 18 de Marzo de 2016.

${ }^{36}$ DE LA OLIVA SANTOS, A. “Mediación y justicia: síntomas patológicos”, en Otrosí 2011, nº 8, pp. 714, esp. pp. 7.

${ }^{37}$ FUENTES, P., “Ley Orgánica del Poder Judicial y mediación”, en Procuradores: Revista del Consejo General de procuradores 2016, n 115 , pp. 19-20, esp. p. 20.
} 
De modo concluyente, podemos afirmar que el objetivo general del proyecto es estudiar un tema de gran importancia en nuestra sociedad jurídica como es la Justicia Restaurativa. Para ello realizaremos un estudio general de la mediación con un énfasis mayor en las diversas prácticas reparativas, en todo caso, tanto en el ámbito interno como en el Derecho Comparado.

\section{Estructura}

Para el análisis de la temática de investigación, se va a proceder a organizar la obra a través de diferentes capítulos que irán introduciendo a las figuras principales. Todo ello se enfoca a través de un orden lógico y continuado, proporcionando un conocimiento básico para el entendimiento de los conceptos posteriores.

En primer lugar abordaremos el estudio de los Métodos Alternativos para la Resolución de Conflictos, analizando las diferentes formas de aplicar justicia existentes, como son la autotutela, autocomposición y heterocomposición. De ellos se desprenden una serie de prácticas, las cuales estudiaremos genéricamente, pues no es el fin de esta obra plantear un conocimiento especial sobre ellas. A tal fin, se ofrece una visión global relativa del arbitraje, la negociación y la conciliación, para así ir adentrándonos en el campo de los métodos alternativos o, como se defenderá en esta investigación, de los métodos complementarios de resolución de conflictos: sus antecedentes, modelos, principios, intervinientes y problemática. Este apartado no deja de ser un mero prolegómeno aclarativo de las figuras que serán estudiadas posteriormente.

En segundo lugar, la obra centrará su interés en la figura de la mediación, tanto desde una perspectiva nacional como europea, pues la influencia de esta última ha sido de vital carácter para la adaptación de la práctica en nuestro sistema de justicia. Centraremos nuestro interés en la construcción eminentemente teórica de la mediación y analizar cómo ha ido adaptándose la figura conforme aparecían nuevos modelos y nuevas necesidades a satisfacer, tanto como una institución alternativa al proceso 
judicial (mediación extrajudicial) como una figura incrustada dentro del procedimiento (mediación intrajudicial) como un complemento destino a satisfacer las necesidades de los litigantes y desatascar el actual saturado sistema judicial.

En tercer lugar se procede a un estudio de la figura del mediador y el estatuto que regula su profesión. Es fundamental analizar el rol que va a desempeñar en el proceso de mediación y las técnicas a ejercer para la conducción pacífica y óptima de las sesiones, pues es parte clave en el acordamiento psíquico-emocional de los intervinientes que concluya con un acercamiento de posturas y la consecución de un acuerdo que resuelva el conflicto. Así también se realiza una propuesta de mejora de la situación relativa a los abogados y su participación-conocimiento de la institución de mediación. Ello se fundamenta en el actual pensamiento dubitativo de gran parte de los letrados basado en el escepticismo de las prácticas de ADR y su labor en ellas. Para ello se finalizará este capítulo tercero con un análisis del Derecho colaborativo y de la formación recibida por los abogados en relación a la institución de la mediación.

En cuarto lugar, y con un marcado aspecto penal, la obra centra su interés en el análisis de la Justicia Restaurativa y sus figuras de mayor repercusión, como la mediación penal, las conferencias y los círculos. Aunque parezca arduo de comprender, el motivo por el cual arribamos al ámbito penal tras el estudio generalizado de prácticas civiles, tiene su fundamento en la inexistencia de normativa que regule la Justicia Restaurativa. Ante esta carencia legislativa en el ámbito penal, es de vital importancia observar la gran labor llevada a cabo con la mediación familiar, laboral ${ }^{38}$ y civil, la cual ha servido como base para la propuesta de regulación de la mediación penal en el “Código Procesal Penal”, debido a sus continuas remisiones ${ }^{39}$. Ello nos muestra la

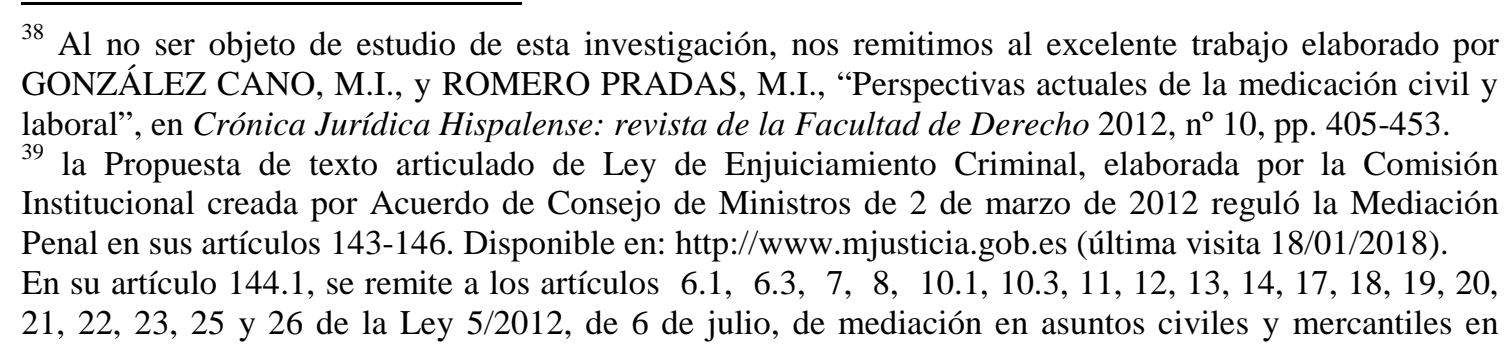


importancia derivada del estudio previo de estas prácticas como modelo de buen hacer para una mejor comprensión y futura adaptación de la mediación penal o cualquier otro instrumento restaurativo.

En este cuarto capítulo se analizará la denominada como “crisis del Derecho penal” y cómo ha repercutido en el sistema la necesidad de implementar nuevos cambios, como el auge de la víctima dentro del proceso y su reconocimiento a través de diferentes normativas como es el Estatuto de la víctima del delito, el cual ha ampliado el catálogo de derechos procesales y extraprocesales, y ha reforzado la posición de víctimas vulnerables, permitiendo el acceso a servicios restaurativos ${ }^{40}$, y en concreto de víctimas de delitos de violencia de género al reforzar la protección de los hijos e hijas de las mujeres víctimas de este tipo de violencia ${ }^{41}$. Así mismo se procede a un examen del origen, concepto y características de la Justicia Restaurativa.

Tras el análisis semántico de los diferentes términos, se procederá a detallar el marco normativo existente y prácticas más comunes, así como críticas y aportaciones doctrinales ajenas y propias a nuestro entendimiento personal en relación a la adecuación de estas instituciones en nuestro ordenamiento como de la posible colisión con nuestro ordenamiento jurídico, así como la necesidad de complementación entre esta nueva filosofía restaurativa y la justicia retributiva clásica. Todo ello servirá de preámbulo para la presentación de los apartados siguientes, que conglomeran las tres figuras más relevantes de la Justicia Restaurativa: la mediación penal, las conferencias y los círculos.

En quinto lugar y en relación a la mediación penal, se examina su vertiente jurídica, sus características y principios propios que le diferencian de las demás

relación con el procedimiento de mediación penal e instituciones y profesionales encargados de su desarrollo.

40 CASTILLEJO MANZANARES, R., “Mediación con víctimas especialmente vulnerables”, en Iuris: Actualidad y práctica del derecho 2014, n 215, pp. 38-43.

${ }^{41}$ CASTILLEJO MANZANARES, R., "El estatuto de la víctima y las víctimas de violencia de género", en Diario La Ley 2016, No 8884. Disponible en: www.diariolaley.es (última visita 19/04/2018) 
mediaciones anteriormente estudiadas. Este estudio doctrinal de la figura centrará su interés en analizar la inexistencia de normativa en España pero el afán potenciador de Europa. El capítulo continúa con un enfoque crítico de las posibilidades ofrecidas por esta práctica en referencia a los diferentes tipos delictivos. Nos detendremos en observar las diferentes posturas doctrinales relativas a la idoneidad en delitos muy graves, graves o leves, existiendo una gran división doctrinal al respecto.

Ello sin olvidar las especialidades existentes como personas jurídicas, mediación penal juvenil o violencia de género, que crean una mayor dificultad en la comprensión de la globalidad de la figura y el establecimiento de sus límites para la proposición de una normativa que regule esta figura como una opción dentro de nuestro ordenamiento. Todo el análisis teórico realizado se completará con un estudio de la praxis desarrollada en España a través de, entre otros, los proyectos pilotos desarrollados en diferentes municipios y regiones tales como País Vasco y Castilla y León, sin obviar los protocolos de actuación aconsejados por el Consejo del Poder Judicial.

En sexto lugar se ofrece una perspectiva del desarrollo teórico-práctico de las conferencias, aun siendo conscientes de la complejidad que esto supone. En la primera parte se desarrolla una obligada referencia a los antecedentes de la institución, con estudios doctrinales neozelandeses y referencias al pueblo maorí para así un mejor entendimiento del Family Group Conferencing. Este apartado servirá de comprensión de ulteriores conferencias desarrolladas en diferentes lugares del mundo pues, como veremos en el capítulo, tanto las prácticas desarrolladas en Australia como en Irlanda del Norte, Noruega o Bélgica, tienen una gran influencia de las prácticas y costumbres del pueblo aborigen maorí, el cual combinó sus costumbres con las efectuadas por otros poblados ya asentados en la actual Nueva Zelanda o que posteriormente irían desembarcando en sus costas provenientes tanto de Oceanía, Asia o Europa.

El esfuerzo por la comprensión de estas figuras radica en la posibilidad de adaptación a nuestro sistema de justicia, no sólo en el ámbito penal de adultos, sino en 
el sistema penal juvenil. Este último se ha visto altamente beneficiado precisamente por el desarrollo e implantación de tales instrumentos, consiguiéndose una disminución de la reincidencia y satisfacción de las víctimas y la comunidad.

En séptimo y último lugar se detallarán las características más singulares de la institución de los círculos como método de resolución comunal de conflictos. En un importante esfuerzo de sistematización se intenta dar estudio a tal instrumento, poniendo orden en la complicada y discrepante diversidad de criterios clasificatorios existentes. Para ello, abordaremos el desarrollo práctico que han efectuado los circles, analizando la dispersa práctica desplegada en Norte América, Reino Unido, Países Bajos o incluso Asia. Todo ello enfocado conforme un punto de vista regional que afectará a las múltiples subdivisiones existentes en esta figura para la resolución de problemas fácticos o incluso psicológicos en los diferentes protagonistas del conflicto: el infractor, la víctima y la comunidad.

Ello nos llevará a un entendimiento de las diferentes variantes de círculos existentes, tales como son los Círculos de sentencia, Círculos de sanación y los Circles of Support and Acountability con la finalidad de un estudio que facilite la visibilidad de las instituciones y a su vez sirva para una posible incorporación de los círculos en nuestro sistema de justicia a modo de complemento en favor de la sanación de la víctima y la resocialización de los infractores. Tras un examen exhaustivo de las diferentes propuestas que la práctica nos brinda, se atenderá a un novedoso análisis de la influencia de estas figuras en la sociedad con la representación efectuado de un círculo en el ámbito penitenciario en la serie de ficción televisiva “Orange is the New Black”.

Por último lugar, se exponen unas breves conclusiones con el propósito de presentar el resultado de la presente investigación, las cuales no son un punto final, sino el inicio de futuros estudios en la materia y línea de investigación elegida, con el fin de conseguir una justicia centrada en el beneficio común, en la sanación de la víctima, la resocialización del infractor y la paz social. 
CAPÍTULO PRIMERO

\section{LOS MÉTODOS ALTERNATIVOS PARA LA RESOLUCIÓN DE CONFLICTOS}

"Los conflictos existen siempre, no tratéis de evitarlos sino de entenderlos" Lin Yutang (1895-1976)

El acrónimo ADR sirve para designar a los Alternative Dispute Resolution ${ }^{42}$ traducido al español como los métodos alternativos de resolución de conflictos. Sin embargo, la determinación de los aspectos que definen a los ADR no es una cuestión pacífica en la doctrina.

\section{Autotutela, autocomposición y heterocomposición}

Las relaciones nacidas de la propia naturaleza humana crea una serie de intereses, los cuales pueden ser comunes o no. En la medida en que exista un mayor distanciamiento en las posiciones de los sujetos, el choque se irá convirtiendo en inevitable, surgiendo así el denominado “conflicto”.

Los bienes son limitados y necesarios para los sujetos, los cuales requerirán su uso menoscabando así la posición de otro sujeto. Al no poderse satisfacer las demandas de todos ellos, estaremos ante una situación conflictiva, pues ambos desean utilizar un bien pero su empleo es incompatible para varios sujetos. A modo ejemplificador, como indica CARNELUTTI, es la situación de existencia de escasez de comida y varios

\footnotetext{
42 A pesar del uso mayoritario del acrónimo “ADR”, los autores españoles también emplean otros términos como "MASC” (mecanismos alternativos de solución de conflictos o modalidades alternativas de solución de conflictos), o "MARC" (mecanismos alternativos de resolución de conflictos); y expresiones similares como mecanismos extrajudiciales de solución de conflictos o medios alternativos de solución de diferencias. Vid. ad. ex. BLANCO CARRASCO, M., Mediación y sistemas alternativos de resolución de conflictos. Una visión jurídica, Madrid, Reus, 2009, pp. 12-13.
} 
sujetos que necesitan de ella para alimentarse ${ }^{43}$. Ambos requieren un bien que sólo puede satisfacer las necesidades de uno de ellos, existiendo aquí un conflicto de intereses.

Las respuestas a este conflicto pueden ser muy variadas, y nosotros vamos a referirnos en las resoluciones formuladas a través del Derecho y la justicia. Estaremos ante una réplica en el momento en el que se frustren los fines de las normas, una respuesta necesaria para el restablecimiento a la legalidad. Históricamente han existido tres métodos: la autotutela, la autocomposición y la heterocomposición.

\subsection{Autotutela}

En relación con las posibilidades que nos ofrece la justicia para la resolución de conflictos, la autotutela o autodefensa ${ }^{44}$ es el método más arcaico y menos “justo”, pero a su vez es base indispensable para la regulación del actual modelo de justicia.

El ordenamiento jurídico confiere al propio interesado la protección del mandato secundario. Videlicet, el Estado permite que el perjudicado por el conflicto resuelva e imparta "justicia”. Estamos ante una ausencia de juez. Ante una imposición de la decisión por una de las partes interesadas ${ }^{45}$. Es considerara como una forma egoísta de resolver los litigios ya que la solución viene por una parte del conflicto, perdiendo la imparcialidad o trabajo común que se requiere a toda solución.

\footnotetext{
${ }^{43}$ CARNELUTTI, F., Sistema de Derecho Procesal Civil -Tomo I: Introducción y Función del Proceso Civil, traducción de Niceto Alcalá-Zamora y Castillo y Santiago Sentís Melendo, Uteha, Argentina, Buenos Aires, 1944, p. 11.

${ }^{44}$ En cuanto a la terminología, hay diferentes líneas doctrinales que aconsejan el uso de una u otra. En general, el término más usado es el de autotutela, pero autores como Alcalá Zamora prefieren la Autodefensa. ALCALÁ-ZAMORA Y CASTILLO, N., Proceso, autocomposición y autodefensa, $2^{\mathrm{a}}$ edición, UNAM, México, 1970, pp. 35 y ss.

${ }^{45}$ ALCALÁ-ZAMORA Y CASTILLO, N., Proceso, autocomposición y ..., op. cit., p. 53.
} 
El mayor ejemplo de autotutela es la ley del talión ${ }^{46}$. En las sociedades primitivas la justicia se auto aplicaba por los mismos perjudicados por los conflictos, pero a diferencia de las prácticas restaurativas en las que se busca una reparación, aquí primaba la venganza y el castigo. Las represalias que se imponían eran ilimitadas y no guardaban proporción con el daño causado, aunque este concepto fue limitándose con el transcurso del tiempo, aplicándose la célebre fórmula del ojo por ojo y diente por diente, por la cual se establecía una proporcionalidad entre el daño inferido y la represalia de la víctima. Las respuestas en este derecho primitivo eran “despiadadas y exageradamente desproporcionadas" ${ }^{47}$.

En el Código de Hammurabi ${ }^{48}$ el principio de reciprocidad exacta se utiliza con gran claridad $^{49}$. Por ejemplo:

- La Ley 229 establecía que si un arquitecto diseñaba una casa y dicha casa se había derrumbado, se le castigaba "matando" parte del cuerpo en proporción al daño causado.

- La Ley 195 establecía que si un hijo había golpeado al padre, se le cortarían las manos.

- La Ley 197 ratificaba que si un hombre quebraba un hueso de otro hombre, se quebraría el hueso del agresor.

- Las penas menores consistían en la reparación del daño devolviendo materias primas tales como plata, trigo, vino, etc.

\footnotetext{
${ }^{46}$ El término ley del talión se refiere a un principio jurídico de justicia retributiva en el que la norma imponía un castigo que se identificaba con el crimen cometido. El término "talión" deriva de la palabra latina "talis" o "tale" que significa idéntica o semejante, de modo que no se refiere a una pena equivalente sino a una pena idéntica. Para más información véase BARONA VILAR, S., Proceso penal desde ..., op. cit., pp. 33 y ss.

${ }^{47}$ BARONA VILAR, S., “Esquizofrenia en la ...”, op. cit., p. 190.

${ }^{48}$ El Código de Hammurabi, creado en el año 1760 a. C. por el rey de Kish Hammurabi, es uno de los conjuntos de leyes más antiguos. Creado en la antigua Mesopotamia, se basa en la aplicación de la ley del Talión. El código unifica diferentes códigos existentes en las ciudades del imperio babilónico. Entre otras recopilaciones de leyes se encuentran el Códice de Ur-Nammu, rey de Eridú (2050 A.C.), el Códice de Ešnunna (ca. 1930 a. C.) y el Códice de Sargón de Akkad (1870 A.C.).

${ }^{49}$ BARONA VILAR, S., Proceso penal desde ..., op. cit., p. 35.
} 
- En los casos en que no existía daño físico muchas veces se buscaba una forma de compensación física, de modo tal que al autor de un robo se le cortaba la mano.

La expansión de este sistema fue notorio ya que era la única vía de aplicación de justicia. Múltiples culturas apostaron por su implementación, y en el mismo Antiguo Testamento de la Biblia, más concretamente en la ley mosaica, aparecen directrices de estas prácticas, como las desarrolladas en el Éxodo 21:23-25, el Levítico 24:18-20 y el Deuteronomio. Se establece que el homicida “pagará alma por alma, ojo por ojo, diente por diente, mano por mano, pie por pie, quemadura por quemadura, herida por herida, golpe por golpe"; que el ofensor "rotura por rotura, ojo por ojo, diente por diente ha de pagar: cual fuere el daño causado, tal será forzado a sufrir”; y respecto al malhechor, se nos hace llegar que "no te compadecerás de él; sino que le harás pagar vida por vida, ojo por ojo, diente por diente, mano por mano, pie por pie”.

La autotutela fue cayendo en desuso, siendo incluso prohibida por el propio Derecho Romano, aunque no es menos cierto que las influencias germanas volvieron a traer ideas de venganza y represalia a los sistemas penales. Fue en la época Contemporánea, a influencia de las nuevas ideologías y del Derecho Canónico, cuando se limita la autotutela ${ }^{50}$ a situaciones excepcionales y debidamente justificadas, como la legítima defensa ${ }^{51}$.

Sin embargo, en pleno siglo XXI, bajo el gobierno de Irán presidido por Mahmud Ahmadinejad, el ciudadano iraní Majid Movahedi, quien en 1994 había arrojado ácido sulfúrico al rostro de Ameneh Bahrami a la cual dejó ciega y desfigurada

\footnotetext{
${ }^{50}$ CALAMANDREI, P., Instituciones de Derecho Procesal Civil según el nuevo Código, traducción de Santiago Sentís Melendo, Depalma, Buenos Aires, 1943, p. 147.

${ }^{51}$ Para más información relativa a la legítima defensa, véase SOTO NIETO, F., "La legítima defensa completa e incompleta”, en Diario La Ley 2005, $\mathrm{n}^{\circ}$ 6231, Disponible en: diariolaley.laley.es (última visita 22/10/2017); MONTIEL, J.P., Analogía favorable al reo. Fundamentos y límites de la analogía in bonam partem en el Derecho Penal, La Ley, Madrid, 2009; BORRAZ GARCÍA, G., "La agresión ilegítima a los bienes patrimoniales. Análisis del apartado primero del artículo 20.4 del Código Penal”, en Diario La Ley 2016, nº 8825 Disponible en: diariolaley.laley.es (última visita 22/10/2017)
} 
porque se negó a casarse con él, fue condenado en marzo del 2009 por la Corte de Justicia de Irán a recibir cinco gotas del mismo ácido en cada uno de sus ojos ${ }^{52}$.

La autotutela es un modo de aplicar justicia arcaico pero que fue necesario para la implantación del sistema actual. Un mal necesario para la consecución de figuras más humanas y restaurativas que iremos estudiando a continuación. Como decía CARNELUTTI, “el empleo de la violencia para solucionar conflictos hace difícil, si no imposible, la permanencia de los hombres en sociedad" 53 .

\subsection{Autocomposición}

Ha llegado el momento de proceder al estudio de los métodos autocompositivos de resolución de conflictos. En ellos se renuncia al derecho propio en beneficio del interés ajeno. Sus manifestaciones pueden ser unilaterales o bilaterales, según provengan de ambas partes del litigio o de una de ellas.

Se llega a la solución del conflicto con la presencia de las dos partes, ofendido y ofensor. Son las partes implicadas en el conflicto las que llegan a un acuerdo y satisfacen sus pretensiones. Modernamente se da en materia civil a través de tres formas procesales de solución del conflicto: desistimiento, allanamiento y la transacción. En materia penal solo se da el allanamiento y el desistimiento, casi nunca la transacción.

- El Desistimiento: El agraviado retira su pretensión de castigo de su ofensor.

- El Allanamiento: El ofensor reconoce la pretensión del ofendido aceptando lo que pida.

- La Transacción: Consiste en ceder ambas partes a sus pretensiones. Se da en materia civil, nunca en materia penal.

\footnotetext{
52 “Ojo por ojo, diente por diente: un iraní deberá quedarse ciego por tirarle ácido a una mujer”, El Mundo, 14 de mayo de 2011. Disponible en: http://www.lanacion.com.ar (última visita 19/01/2018)

${ }^{53}$ CARNELUTTI, F., Sistema de Derecho... op. cit. pp. 11 y 12.
} 
Existen dos tipos de respuestas, la autocomposición unilateral y la bilateral. La primera de ellas es un acto que sólo necesita la voluntad de una de las partes, siendo figuras importantes aquí la renuncia y el reconocimiento. En la segunda, es un acto complejo en el que intervendrán ambos sujetos e incluso, llegado el caso, terceros imparciales, necesitándose el consentimiento de los dos protagonistas y donde encuadraríamos la figura de la transacción ${ }^{54}$. Como hemos visto, su característica principal es que, sin que resuelva un tercero sobre el asunto, una de las partes o ambas deciden renunciar a sus pretensiones.

Un ejemplo de método autocompositivo es la mediación, figura por la cual ambas partes se reúnen en la búsqueda de una solución al conflicto iniciado, una respuesta beneficiosa en la mayor medida para ambos intervinientes. Estaremos ante una cesión en sus posturas iniciales para propiciar el entendimiento durante el desarrollo de las actuaciones.

\subsection{Heterocomposición.}

En tercer y último lugar, a través de la heterocomposición pueden resolverse conflictos en el cual la solución es dictada por un tercero imparcial. Se dota a un tercero de poder para dar una resolución ajustada a Derecho que solucione el conflicto. Es una forma ágil de solucionar un conflicto entre particulares, ya que el tercero no tiene relación alguna con el conflicto y no se ve mermado por sentimientos y emociones, sino que “actúa supra partes, imponiendo su decisión” 55.

A pesar de los beneficios que estas figuras nos ofrecen, su gran defecto es la propia resolución, ergo no son consensuadas ni basadas en las exigencias de los implicados. Es por ello que su utilidad es evidente cuando las partes no logran llegar a

\footnotetext{
${ }^{54}$ ALCALÁ-ZAMORA Y CASTILLO, N., Proceso, autocomposición y..., op. cit., pp. 83-92, esp. p. 84. 55 SAN CRISTÓBAL REALES, S., "Sistemas alternativos de resolución de conflictos: negociación, conciliación, mediación, arbitraje, en el ámbito civil y mercantil”, en Anuario Jurídico y Económico Escurialense 2013, nº XLVI, pp. 39-62, esp. p. 48.
} 
un acuerdo que satisfaga sus pretensiones y resuelva el conflicto. Pero se ha de aceptar que no son la única vía para aplicar justicia, sino que pueden ser complementadas con los métodos autocompositivos con el único fin de obtener un sistema de justicia más adecuado a las necesidades de los protagonistas del conflicto.

\section{El arbitraje: una breve referencia a la institución.}

El procedimiento arbitral es una vía de resolución de conflictos que permite “evitar ir a juicio ante los Juzgados ordinarios” y que pasa, necesariamente, por que exista un pacto inter-partes de sumisión al arbitraje $\mathrm{e}^{56}$. Esto es, un procedimiento por el cual las partes acuerdan someter ante una Corte Arbitral su conflicto, alegando sus pretensiones, en pos de conseguir una resolución favorable por parte de éste-

Su regulación legal en España la encontramos en la Ley 60/2003, de 23 de diciembre, la cual desarrolla el sistema arbitral como método de resolución de conflictos en las relaciones personales, mercantiles y jurídico-contractuales. Es de aplicación a los arbitrajes dentro del territorio español, sean de carácter interno o internacional ${ }^{57}$ y siempre teniendo presente lo dispuesto en los tratados de los que España sea parte. Pero hay que tener en cuenta que todas aquellas materias que tengan una regulación arbitral especial, se regirán por dicha normativa específica.

\subsection{Concepto y caracteres}

A falta de definición legal, podemos aclarar que el arbitraje es un contrato a través del cual las partes deciden someter las controversias que surgen de una determinada relación jurídica a la decisión del árbitro a través de un fallo vinculante ${ }^{58}$. Tal y como señala arbitraje es “un mecanismo extrajudicial de decisión de conflictos en materia de Derecho disponible al que las partes pueden someterse de forma voluntaria para que un tercero imparcial, denominado árbitro, resuelva, definitiva $e$

\footnotetext{
${ }^{56}$ SCHÜTZE, R., Shierdgericht und Shiedverfhahren, C.H.Beck, Munich, 2007, pp. 2 y ss.

${ }^{57}$ Para más información al respecto, véase, RAMOS MÉNDEZ, F., Arbitraje y litigios transfronterizos en un foro global, Atelier, Barcelona, 2005.

${ }^{58}$ TWEEDDALE, A., y TW EEDDALE, K., A practical approach to Arbitration Law, Blacks tone Press Limited, Londres, 1999. p.27.
} 
irrevocablemente, la controversia" ${ }^{59}$. Se sustituye la tutela de los jueces ordinarios por la de los árbitros desde el momento en que las partes deciden ventilar el asunto a través de esta institución a través de la firma del convenio arbitral ${ }^{60}$. Todo ello a través de unas garantías que aseguren el cumplimiento de los preceptos legales sin desvirtuar la institución arbitral ${ }^{61}$ y estar por tanto ante una verdadera impartición de justicia ${ }^{62}$ a través de un proceso en única instancia y con una resolución obtenida en un lapso temporal más breve ${ }^{63}$.

Para DÍEZ-PICAZO, el arbitraje es aquella institución jurídica por la que dos o más personas encomiendan a un tercero -árbitro- la solución de todas o algunas controversias que hayan surgido o puedan surgir respecto de una determinada relación jurídica, contractual o no contractual, excluyendo que los tribunales conozcan de las mismas ${ }^{64}$. MUNNÉ CATARINA define la institución como aquella "que tiene su origen en la autonomía de la voluntad de las partes que se someten a él y que constituye una alternativa a la Jurisdicción, como forma heterocompositiva de resolución de conflictos" ${ }^{65}$.

Para efectiva cumplimentación del proceso arbitral, es necesaria la firma de un convenio arbitral, en otros términos, un compromiso entre las partes, bien con carácter previo (a través de una cláusula contractual que así lo especifique), bien una vez nacido el litigio, de sustraer al conocimiento de los Tribunales estatales la existencia de una

59 SÁNCHEZ POS, M.V., "La tutela cautelar en el arbitraje -nacional e internacional- desde la perspectiva del ordenamiento español: viejas y nuevas cuestiones discutidas”, en J. Sigüenza López y G. García-Rostán Calvín (dirs.), Estudios sobre mediación ... op. cit., pp. 297-318, esp. p. 298.

${ }^{60}$ CORDÓN MORENO, F., El Arbitraje de Derecho Privado. Estudio breve de la Ley 60/2003, de 23 de diciembre, de Arbitraje, Aranzadi, Cizur Menor, 2005, pp. 27-29.

${ }^{61}$ FERNÁNDEZ ROZAS, J. C., Tratado de arbitraje comercial en América Latina, Iustel, Madrid, 2008, pp. 1092.

${ }^{62}$ MALUQUER DE MOTES I BENER, C., “Artículo 1. Ámbito de aplicación”, en V. Guilarte Gutierrez (dir.) y J. Mateo Sanz (coord.), Comentarios prácticos a la Ley de Arbitraje, Lex Nova, Valladolid, 2004, pp. 45-60, esp. p. 49-50

${ }^{63}$ CORDÓN MORENO, F., Arbitraje y jurisdicción: algunas cuestiones polémicas, Cuadernos Civitas, Navarra, 2010, pp. 39 y ss.

${ }^{64}$ DÍEZ-PICAZO GIMÉNEZ, I., Derecho procesal civil. Ejecución forzosa. Procesos especiales, Madrid, 2005, pp. 609

${ }^{65}$ MUNNÉ CATARINA, F., La administración del arbitraje. Instituciones arbitrales y procedimiento prearbitral, Cizur Menor, 2002, p. 19. 
controversia, y en su lugar, que ésta sea sometida a uno o varios árbitros que serán los que finalmente emitirán la sentencia arbitral o laudo.

El arbitraje es una institución cuya causa es la existencia de una controversia, actual o futura, que debe de ser resuelta por un árbitro gracias al acuerdo de voluntades de las partes contratantes, los cuales deciden acudir a él para la resolución de su controversia.

La característica principal del arbitraje es que el conflicto va a ser resuelto por un tercero, el árbitro, que dirime el conflicto mediante el laudo arbitral. Es por tanto quien decide, y mediante su resolución pone fin al proceso arbitral. También tiene un carácter fundamental que la controversia, como ya hemos adelantado, puede ser futura. Esto es, ambas partes pueden acordar acudir a un procedimiento arbitral en el supuesto en que suceda una controversia. Esta situación es muy común en contratos de suministro, por los cuales se acuerda que, en caso de impago o cualquier otra circunstancia, las partes acudirán a un árbitro designado previamente.

Este laudo va a tener gran importancia ya que constituye un título ejecutivo ${ }^{66}$ que permite instar la ejecución forzosa ante los órganos jurisdiccionales si no se produjere un cumplimiento voluntario. Así el Tribunal Constitucional señala que "la naturaleza del arbitraje, que es un equivalente jurisdiccional, mediante el cual las partes pueden obtener los mismos objetivos que con la jurisdicción civil, esto es, la obtención de una decisión al conflicto con todos los efectos de la cosa juzgada” ${ }^{67}$. En la misma línea el Tribunal Supremo ha manifestado su opinión sobre el laudo y sus efectos, al indicar: "los laudos arbitrales firmes sólo son susceptibles de ejecución judicial por los trámites del procedimiento de ejecución de sentencias, ... dentro de cuyo procedimiento ejecutorio podrán plantearse todos los incidentes que legalmente sean procedentes hasta alcanzar la verdadera intelección de lo resuelto por el árbitro

\footnotetext{
${ }^{66}$ El Estado ha otorgado esta característica al arbitraje. Un laudo arbitral tiene la misma validez (en cuanto a los efectos que produce) que una sentencia firme a través del art. 43 y ss. de la Ley de Arbitraje y el art. 517.2.2 $2^{\circ}$ LEC, que dan fuerza de título ejecutivo al laudo.

${ }^{67}$ STC de 62/1991, de 22 de marzo FJ 5.
} 
en el laudo arbitral firme que se trata de ejecutar, pero lo que en ningún caso puede ser procesalmente permisible es que trate de plantearse, a través de un procedimiento declarativo ordinario, la cuestión, verdaderamente insólita, atinente a la interpretación del repetido laudo, pues ello equivale, real y prácticamente, a que por esa vía indirecta, a plantear de nuevo ante el órgano jurisdiccional, con evidente infracción del principio de santidad de la cosa juzgada, la misma cuestión litigiosa que ya había sido resuelta por el expresado laudo arbitral firme, al que libre y voluntariamente se habían sometido las partes" 68

Existen multitud de características que le dan una distinción propia a esta figura. Las más determinantes en relación a su naturaleza son: la celeridad en la resolución del conflicto, la cual se realiza en un periodo máximo de 6 meses; es un proceso económico para las partes puesto que los gastos son mínimos para ellos ${ }^{69}$; es una vía eficaz de resolución de controversias que evita litigios futuros; profesionalización de la figura a través de árbitros expertos en la materia y debidamente entrenados y preparados para el ejercicio de sus funciones; resolución rápida y eficaz de conflictos presentes y establecimiento de las bases para la resolución de posibles conflictos futuros. En contraposición, la nula autodeterminación de las partes en el proceso de arbitraje proporciona nuevamente, tal y como sucede en el sistema de justicia ante los Tribunales, una resolución alejada de los intereses, necesidades de los intervinientes los cuales no serán partícipes en la obtención de un acuerdo que les proporcione a ambos el status de ganador.

\footnotetext{
${ }^{68}$ STS de 28 de Julio de 1995 , FJ 7.

${ }^{69}$ Ejemplo de ello es el Arbitraje de consumo, que tal y como señala VALBUENA GONZÁLEZ, F., "La protección del consumidor europeo: alternativas a la vía judicial”, en Revista de estudios europeos 2015, $\mathrm{n}^{\circ}$ 66, pp. 52-74, esp. p. 58 "no genera coste alguno para los intervinientes, al menos hasta la declaración del derecho, puesto que no es preceptiva una representación técnica del interesado, pudiendo éste comparecer por sí mismo".
} 


\subsection{Naturaleza del arbitraje}

Multitud de caracteres podemos hallar en el arbitraje, emanados tanto del Derecho Privado (origen contractual) o del Derecho procesal (resolución de la controversia con iguales efectos jurídicos que la Jurisdicción). Por ello ha existido una discusión doctrinal respecto a la naturaleza jurídica de la figura, debatiéndose si estamos ante una práctica contractual, jurisdiccional o mixta ${ }^{70}$. Depende de la naturaleza que le otorgue se podrá señalar que el arbitraje es un contrato privado o en cambio que es una institución pública al servicio de los intereses privados. Por ello realizaremos una breve descripción de cada una de las posiciones doctrinales.

La posición contractualista considera que el convenio arbitral es el elemento predominante en un arbitraje, estando ante concierto de voluntades que produce efectos jurídicos $^{71}$. Así, el arbitraje nace y se desarrolla a partir del contrato. Como bien explica GARY BORN, "La escuela de pensamiento "contractual" consideraba al arbitraje como una forma de relaciones contractuales. (...) La escuela contractualista enfatizó que los árbitros no eran jueces (puesto que no desempeñaban ninguna función "pública" y no ejercían poderes en nombre del Estado). En términos generales, la escuela contractualista hizo hincapié en el papel de la autonomía de las partes en el proceso arbitral”72. Siguiendo esta línea de pensamiento LEW, MISTELIS y KRÖLL, explican esta teoría indicando: “La teoría contractualista subraya que el arbitraje tiene un carácter contractual. Tiene su origen y depende, para su existencia y continuidad, del acuerdo de las partes. Los partidarios de esta teoría niegan la primacía o el control del Estado en el arbitraje y argumentan que la esencia misma del arbitraje es que es "creada por la voluntad y el consentimiento de las partes"73. Así mismo BULLARD afirma "que el arbitraje es finalmente un contrato. Lo que llamamos proceso arbitral no

\footnotetext{
70 Para mayor información relativa al tema véase MERCHÁN ÁLVAREZ, A., El arbitraje. Estudio histórico jurídico, Publicaciones de la Universidad de Sevilla, Sevilla, 1981.

${ }^{71}$ GUASP, J., El arbitraje en el Derecho español, Editorial Bosch Barcelona, 1956, p. 22.

${ }^{72}$ BORN, G., International Commercial Arbitration, Kluwer Law International, 2009, p. 185.

73 LEW JULIAN, D. M., et al., Comparative International Commercial Arbitration, Kluwer Law International, 2003, pp. 77-78.
} 
es otra cosa que la ejecución de ese contrato. Su origen es el acuerdo y no la delegación del Estado para administrar justicia, pues es falsa la percepción según la cual el origen de la justicia es estatal"74.

El principal problema que identificamos con esta teoría, es que desconoce que el arbitraje también depende del reconocimiento estatal. En efecto, esta teoría desecha algo trascendental: la necesidad del respaldo del Estado. Si el Estado no reconoce el arbitraje, el laudo no tendría otro valor que el de un simple contrato, siendo todo el proceso arbitral un trámite sin trascendencia.

En contraposición nos encontramos con la posición jurisdiccionalista, que "defiende que el origen del arbitraje está en la voluntad de las partes” ${ }^{, 75}$. Considera que los elementos esenciales del arbitraje son el procedimiento ante el árbitro y el laudo resolutorio, ya que tiene efectos análogos a la sentencia dictada por el juez en el marco del proceso judicial. La decisión arbitral tiende a resolver la controversia jurídica en la misma forma y con los mismos caracteres que el juez en la sentencia: con ejecutividad y efecto de cosa juzgada. Por tanto, este poder que tienen los árbitros les viene del Estado ${ }^{76}$.

Autores como LEW, MISTELIS y KRÖLL ${ }^{77}$ afirman que la teoría jurisdiccional se basa en el poder estatal regular aquellos arbitrajes desarrollados dentro de su jurisdicción. A tal efecto, las partes se someten al arbitraje en la medida expresamente establecida por una ley de arbitraje. Es el estado quien permite la práctica del arbitraje y otorga efecto jurídico a un laudo arbitral, otorgando al árbitro un papel de alternativa al juez.

\footnotetext{
${ }^{74}$ BULLARD, A., “¿Qué fue primero: el huevo o la gallina? El carácter contractual del recurso de anulación”, en Revista Internacional de Arbitraje 2013, nº julio - diciembre, pp. 55-93, esp. p. 61.

${ }^{75}$ IBOLEÓN SALMERÓN, B., El proceso arbitral: una perspectiva procesal del arbitraje de consumo, Dykinson, Madrid, 2012, p. 19.

${ }^{76}$ FENECH NAVARRO, M., "El arbitraje en Derecho Español", en M. Fenech Navarro y J. Carreras Llansana (dirs.), Estudios de Derecho procesal, Bosch, Barcelona, 1962, pp. 147-228, esp. pp. 217- 220.

${ }^{77}$ LEW JULIAN, D. M. y MISTELIS LOUKAS, A., et al., Comparative International Commercial ... op. cit., pp. 73-74.
} 
El principal problema de esta teoría, es que no reconoce que la autonomía de la voluntad de las partes es esencial para el nacimiento de la institución del arbitraje y para la aplicación de muchas de las reglas que requiere para su correcto funcionamiento y ello provoca que esta teoría no respete los principios consustanciales del arbitraje.

Entre ambas posturas hay un punto intermedio, la denominada teoría mixta, que no niega ni la naturaleza contractual ni la naturaleza institucional. El arbitraje por tanto tiene un origen contractual y un desarrollo jurisdiccional. Ab origine es un negocio jurídico de derecho privado, pero tiene una naturaleza procesal en cuanto a las sujeciones y limitaciones a que esta voluntad es sometida. ${ }^{78}$ La teoría mixta o híbrida es la teoría con mayor soporte ${ }^{79}$.

Existe una figura híbrida entre el arbitraje y la mediación, por la cual se combinan ambas prácticas para la obtención de un método que resuelva todas las diferencias. Nos otorga un sinfín de posibilidades en asuntos de altas cuantías económicas o de diversa complejidad ya que al combinarse ambas instituciones, pule los defectos de cada una en cada caso concreto y puede proporcionar una solución más eficaz en estos dos casos. Las formas híbridas ${ }^{80}$ tienen tres modos diversas de originarse $^{81}$ :

- Por un pacto expreso de carácter híbrido a través del cual las partes se comprometen a resolver el conflicto a través de una combinación entre

\footnotetext{
${ }^{78}$ PIETRO CASTRO, L, “La nueva regulación del arbitraje”, en Revista de Derecho Privado 1954, no 45, p. 450.

79 LEW JULIAN, D. M. y MISTELIS LOUKAS, A., et al., Comparative International Commercial ..., op. cit., p. 79. En la misma línea, véase FOUCHARD, P. y GOLDMAN. B., Fouchard, Gaillard, Goldman on International Commercial Arbitration, Kluwer Law International, 1999, p. 606: "La relación contractual entre los árbitros y las partes no puede reducirse a una categoría conocida en los sistemas de derecho civil. Comparte la naturaleza híbrida del arbitraje mismo: su fuente es contractual, pero su objeto es judicial, y los autores en todo el mundo son prácticamente unánimes en ese punto. Su objeto judicial no debe confundirse con las consecuencias puramente contractuales a las que da lugar".

${ }^{80}$ BERGER, P., "Integration of Mediations Elements into Arbitration", en Abitration International 2003, Vol. 19 n $^{\circ}$ 3, pp. 387-403.

${ }^{81}$ FULLERTON, R., "Med-Arb and its variants: ethical issues for parties and neutrals", en Dispute Resolution Journal 2010, n52, pp. 53-61, esp. pp. 54-56.
} 
MedArb $^{82}$ (primer mediación y luego arbitraje) o $\operatorname{ArbMed}^{83}$ (primero arbitraje y después mediación) ${ }^{84}$.

- Cuando se esté inmerso en un proceso de mediación, y aprovechando las partes la no resolución del conflicto, pacten la transformación de ese proceso en un arbitraje.

- Cuando se esté realizando un arbitraje (o se haya pactado uno) y las partes decidan finalizarlo a través de un acuerdo o transacción.

Tal y como puede señalarse, es una forma de utilizar las ventajas que ambas figuras ponen a disposición de los ciudadanos, a pesar de las diferencias que ambas tienen, tanto de origen como de procedimiento y efectos. Es una forma no utilizada hoy en día, pero que en el pasado tuvo relevancia y sobre la que se siguen realizando estudios en el extranjero.

\subsection{Un ejemplo de arbitraje: el Tribunal de Arbitraje Deportivo}

Existen múltiples ejemplos de arbitraje de gran valor en nuestro Derecho y sociedad, tal y como el arbitraje de consumo ${ }^{85}$. Nosotros, a modo de ejemplo y por ser

\footnotetext{
${ }^{82}$ La Asociación Americana de Arbitraje (American Arbitration Association) indicó sobre ello: "Si una disputa surge de o de este contrato, y la disputa no puede resolverse a través de discusiones directas, las partes pueden acordar utilizar primero una mediación administrada por la Asociación Americana de Arbitraje bajo sus Procedimientos de Mediación Comercial antes de recurrir al arbitraje. Cualquier controversia no resuelto que surja o esté relacionado con este contrato o su incumplimiento se resolverá mediante un arbitraje administrado por la Asociación Americana de Arbitraje de conformidad con sus Reglas de Arbitraje Comercial, y la sentencia sobre el laudo dictada por el árbitro podrá ser presentada en cualquier tribunal que tenga jurisdicción. Si todas las partes en la disputa están de acuerdo, se puede solicitar que un mediador involucrado en la mediación actúe como árbitro". Disponible en http://www.adr.org (Última visita: 09/11/2017)

${ }^{83}$ Una buena obra sobre esta figura, y que además recoge opiniones de diversos autores es Houzhi, T., "Combination of Arbitration with Conciliation: Arb/Med", en New Horizons in International Commercial Arbitration and Beyond, ICCA Congress Series, $\mathrm{n}^{\circ}$ 12, p.547.

${ }^{84}$ LIMBURY, A., Hybrid Dispute Resolution Processes - Getting the Best while Avoiding the Worst of Both Worlds? Disponible en: http://www.cedr-com (Última visita: 09/11/2017)

${ }^{85}$ Para más información relativa a la materia, véase en especial VALBUENA GONZÁLEZ, F., "Incidencia de la Ley 60/2003, de arbitraje, en el sistema arbitral de consumo", en Revista vasca de derecho procesal y arbitraje 2005, vol. 17, $\mathrm{n}^{\circ}$ 2, pp. 395-408; VALBUENA GONZÁLEZ, F., "La Directiva europea sobre resolución alternativa de litigios (ADR), en materia de consumo", en Justicia 2014, n² 2, pp. 409-443; VALBUENA GONZÁLEZ, F., "La plataforma europea de resolución de litigios
} 
menos conocido que el anterior, vamos a estudiar brevísimamente el Tribunal de Arbitraje deportivo $^{86}$, un órgano de resolución por medio de arbitraje de las cuestiones litigiosas que se susciten en materia deportiva. En la actualidad mantiene su sede en Lausanne (Suiza), si bien cuenta con dos sucursales permanentes en Sydney (Australia) y Nueva York (Estados Unidos). Además, con ocasión de los Juegos Olímpicos y otros grandes eventos deportivos, organiza y gestiona las llamadas Divisiones ad hoc. Los idiomas de trabajo del TAS son el francés y el inglés, si bien las partes pueden optar por otro idioma si así lo consiente el Tribunal.

Su origen radica en los años 80, cuando, en 1981, el Presidente del Comité Olímpico Internacional Juan Antonio Samaranch tuvo la idea de crear una jurisdicción especial para el deporte. En la Sesión del Comité Olímpico Internacional (en adelante COI) en Roma de 1982, el Juez Kéba Mbaye, encabezó el grupo de trabajo para preparar los estatutos de lo que se convertiría en el Tribunal Arbitral Deportivo. Pero no fue hasta 1983 cuando el COI oficialmente ratificó los estatutos del Tribunal de Arbitraje deportivo, los cuales entraron en vigor el 30 de junio de 1984. El TAS estaba compuesto por sesenta miembros nombrados por el COI, las Federaciones Internacionales, los Comités Olímpicos Nacionales y el Presidente del COI ${ }^{87}$. Los procedimientos eran gratuitos.

En 1991 se publicó una guía para arbitraje deportivo en la cual se incluyeron diferentes modelos de cláusulas arbitrales dando la posibilidad de acudir a un procedimiento de apelación ${ }^{88}$. Lo más destacado es que se contempló la posibilidad de que hubiere un procedimiento de apelación. La International Equestrian Federation fue el primer cuerpo deportivo que adoptó dicho arbitraje con apelación.

en línea (ODR) en materia de consumo”, en Revista de Derecho Comunitario Europeo 2015, n 52, pp. 987-1016.

${ }^{86}$ «CAS» (Court of Arbitration for Sport) o «TAS» (Tribunal Arbitral du Sport)

${ }^{87}$ Cada grupo de los nombrados tiene la potestad de nombrar quince miembros, que compondrían así el total de todos ellos.

${ }^{88}$ ROBINA BLANCO-MORALES, A., El dopaje en el deporte. La ley frente al dopaje, Dykinson, Madrid, 2016, p. 139 
El siguiente hito significativo tuvo lugar en febrero de 1992 cuando el jinete alemán Elmar Gundel interpuso un recurso ante el Tribunal Federal suizo contra un laudo del TAS al entender que el TAS no reunía las condiciones de imparcialidad e independencia necesarias para ser considerado un tribunal arbitral adecuado. El Tribunal Federal suizo, en sentencia de 15 de marzo de 1993, reconoció al TAS como auténtica corte de arbitraje, con independencia suficiente pero puso de manifiesto la existencia de uniones entre el TAS y el COI. Por ello hubo una revisión de las normas reguladoras buscando una mayor independencia del COI, modificándose las bases de la Corte arbitral a través del acuerdo de París. ${ }^{89}$. Las principales ventajas del arbitraje deportivo son:

- Igualdad: Propicia que se maneje como un "laboratorio deportivo autónomo”, lo cual asegura igualdad de trato a todos los atletas en todo el mundo. Todo ello porque es el mismo órgano a nivel mundial el que resuelve las controversias mediante el mismo marco jurídico y gracias a la intervención de una “jurisprudencia deportiva”.

- Evitar el recurso de tribunales estatales: Se logra evitar el retraso en la solución de la controversia y que se resuelvan bajo diferentes jurisdicciones con la aplicación de diferentes normativas para los mismos sucesos.

- Agilidad: la rapidez del procedimiento arbitral es crucial en materia deportiva para evitar el daño irreparable que puede generarse como resultado de las exigencias de cumplir con las agendas de las competiciones deportivas.

\footnotetext{
${ }^{89}$ Esta nueva estructura, aprobada en París, el 22 de junio de 1994, dio lugar a un nuevo Código de Arbitraje del Deporte, que entró en vigor el 22 de noviembre de 1994. Las principales modificaciones resultantes de esta revisión fueron:

- Constitución del «Consejo Internacional de Arbitraje del Deporte» (ICAS) el cual vino sustituyó al COI en su relación con el TAS,

- la creación de dos Divisiones de Arbitraje, la Ordinaria y la de Apelación, distinguiendo entre las disputas de una sola instancia y las derivadas de una decisión adoptada por un órgano deportivo.
} 
- Coste: uno de los objetivos es la disminución de los costes elevados puesto que en el supuesto de cifras elevadas pueden provocar una justicia para "disciplinas ricas” y otra justicia para las “disciplinas pobres”, y por ende, diferentes justicias dependiendo de la capacidad económica de los atletas. En general, los gastos que supone acudir a este procedimiento dependerán del valor del litigio y son los honorarios de los árbitros, gastos administrativos y aquellos derivados de la práctica de prueba testifical y pericial propuestos a instancia de parte. No obstante, existe una tasa de 1000 francos suizos cuyo depósito es conditio sine qua non para el inicio del arbitraje. A partir de ahí, y con diferentes críticas por las regulaciones que otorgaban gratuidad al proceso en el supuesto de ser “Internacional” como de las posibilidades de obtención de justicia gratuita ${ }^{90}$, el desarrollo de las diferentes actuaciones irá configurando el coste del procedimiento.

- Doping: Se cuenta con árbitros versados en el marco legal del doping los cuales al resolver los conflictos armonizan el régimen mundial antidoping que no siempre existe ni en los juzgados de cada país ni en los propios Tribunales de arbitraje deportivos estatales.

- Confidencialidad: Permite seguir el procedimiento arbitral dentro de un clima sereno que sea propicio para correctamente ventilar y resolver el caso. Así mismo evita la publicidad de aspectos negativos del propio deportista que puedan afectar su reputación.

- Cumplimiento: gracias a la Convención de Nueva York ${ }^{91}$ la ejecución de laudos arbitrales en materia deportiva está asegurada en todos los países del mundo

\footnotetext{
${ }^{90}$ CRESPO PÉREZ, J., y LEÓN LLEÓ, A., "La asistencia jurídica gratuita ante el CAS”, en Revista Aranzadi de Derecho de Deporte y Entretenimiento 2014, nº 42, pp. 563-578, esp. pp. 568-577.

${ }^{91}$ Convención sobre el Reconocimiento y Ejecución de Sentencias Arbitrales Extranjeras del 10 de junio de 1958. Mediante la misma se hace obligatoria la ejecución de acuerdos y laudos arbitrales a nivel mundial
} 
gracias a la estrecha colaboración entre todas las federaciones y su sometiendo al TAS.

- Neutralidad geopolítica: Evita así favoritismos y una resolución imparcial por parte de un estado en favor de un deportista icónico.

El procedimiento ordinario, regulado en el Código de arbitraje en materia deportiva del TAS ${ }^{92}$ surge de relaciones contractuales. Los intervinientes elegirán cada uno un árbitro, y éstos seleccionan uno más que obtendrá la posición de Presidente. Si no llegan a un acuerdo, el tercer árbitro y Presidente del Tribunal lo elige el Presidente de la División del procedimiento ordinario. Tiene una duración 6 a 12 meses como máximo. Para ello las partes son libres para acordar la legislación aplicable. En caso de desacuerdo siempre se utilizará el derecho suizo.

En cuanto al procedimiento de apelación, es utilizado para la impugnación de acuerdos dictados por federaciones deportivas u organizaciones deportivas. Se inicia con una declaración o anuncio de apelación. Para poder acudir a este procedimiento se requiere que este agotada la vía previa establecida en los estatutos o reglamentos de su federación. Los árbitros se someten a los reglamentos o estatutos que regulen la relación de las partes y, en su defecto, el derecho aplicable al estamento demandado.

Para ello en primer lugar se realiza el Brief Statement, un breve escrito en el que se describen sucintamente los hechos y antecedentes, se elige el árbitro de parte, el idioma del procedimiento, la sede, y se establece el petitum de la demanda. En segundo lugar, y una vez admitida a trámite, se amplía lo indicado anteriormente. En tercer lugar se prosigue con la fase oral, en donde las partes son escuchadas por los árbitros, normalmente en la sede del TAS en Suiza, aunque se pueden establecer otras sedes por acuerdo de las partes. En cuarto lugar se procede a las conclusiones de las partes, ya sea en vista oral o por escrito. En quinto y último lugar los árbitros designados dictan el laudo arbitral.

\footnotetext{
${ }^{92}$ Código de arbitraje en materia deportiva del TAS. Disponible en http://www.tas-cas.org
} 
Este tribunal resuelve múltiples conflictos, y sus temas sustanciales son la nacionalidad, sanciones ${ }^{93}$ (sobre todo respecto a su proporcionalidad), cumplimiento de principios generales, conflictos entre clubs ${ }^{94}$, jugadores y selecciones ${ }^{95}$ y doping. Este último es probablemente el tema más acusante del movimiento deportivo. En respuesta a ello en tiempos recientes se ha creado un instrumento que contiene un régimen legal exhaustivo: el Código Anti-Doping de la Agencia Mundial Anti Dopaje (WADA AntiDoping Code) ${ }^{96}$.

\section{La negociación y la conciliación como medio alternativo de resolución de disputas}

En el siguiente apartado se va a proceder a un breve análisis de los caracteres de las instituciones de la negociación y la conciliación.

\subsection{La negociación: concepto y caracteres.}

Prosiguiendo con el análisis de los ADR, centramos nuestra atención en la figura de la negociación, la cual la podríamos definir como un "proceso de comunicación, directo o indirecto entre las partes, según la existencia o no de representantes, es decir,

\footnotetext{
${ }^{93}$ A modo de ejemplo, puede acudirse a la página de la Institución para la visualización y estudio de variados laudos arbitrales. Ejemplo de ello es el Laudo arbitral del denominado "mordisco de Luis Suárez", por el cual se sancionó nueve partidos oficiales con la Selección Uruguaya de Fútbol y se le prohibió durante cuatro meses ejercer cualquier clase de actividad relacionada con el fútbol (administrativa, deportiva o de otra clase). Disponible en: http://www.tas-cas.org

${ }^{94}$ Ejemplo de ello es el "caso Keita”, por le cual el RC Lens reclamaba al Sevilla FC una cantidad económica por el traspaso del centrocampista al F.C. Barcelona. Vid. SAN TORCUATO CAFFA, S., "El 'caso Keita', cuando con una palabra no basta”, en Revista Aranzadi de deporte y entretenimiento: deportes, juegos de azar, entretenimiento y música 2012, nº 34, pp. 397-410.

${ }^{95}$ Ejemplo de ello es el "Caso Messi" por el cual el F.C. Barcelona acudió al TAS para FC Barcelona para reclamar que el jugador Lionel Messi no participase en los Juegos Olímpicos de Pekín con la Selección argentina de fútbol y disputase con su club la Previa de la UEFA Champions League. Vid. APARUSI SEGUÍ, J., "El 'caso Messi': comentarios al laudo arbitral que resuelve los asuntos CAS 2008/A/1622, CAS 2008/A/1623 y CAS 2008/A/1624 (FC Schalke 04, SV Werder Bremen y FC Barcelona vs FIFA)", en Revista jurídica de deporte y entretenimiento: deportes, juegos de azar, entretenimiento y música 2009, $\mathrm{n}^{\circ}$ 25, pp. 391-399.

${ }^{96}$ Disponible en https://www.wada-ama.org
} 
si aquellas negocian cara a cara o a través de otras personas debidamente apoderadas por ellas $" 97$.

Los defensores del concepto tradicional de ADR consideran que un método alternativo está compuesto por las partes y por un tercero imparcial que resuelva o ayuda a las partes a dirimir sus diferencias. De ahí surge la controversia de considerar a la negociación como parte o no de los ADR. Por su parte, las tesis más tradicionalistas del concepto de ADR consideran como tal a la negociación pues es un método destinado a la resolución de conflictos, mientras que otras corrientes dudaban del concepto y de su inclusión como ADR al no encontrarse la figura de un tercero imparcial. KOROBKIN, siguiendo las tesis tradicionalistas, considera que la negociación es el instrumento genérico de ADR y de él los demás son la especie ${ }^{98}$

Otro apunte importante a indicar es que en la negociación siempre (o mejor dicho, casi siempre) está presente la competencia ${ }^{99}$ entre las partes. Esto nos lleva a un planteamiento de ganador-perdedor, aspecto ya superado por la mediación y aspecto que otorga, aunque no haya conflicto, un resultado negativo para alguna de las partes. Del resultado de la negociación no nos encontraremos con dos posturas ganadoras, sino que habrá un ganador y un perdedor. Aunque otros autores consideran que la resolución del conflicto se realiza a través de un pacto o transacción entre las partes, existiendo por

\footnotetext{
${ }^{97}$ CALCATERRA, R., Mediación estratégica, Gedisa, Barcelona, 2002, p.76. Múltiples definiciones más se han concretado, tanto a nivel nacional como internacional. De acuerdo con CORIA la negociación es: “...todo aquel trato para intentar lograr acuerdos cuando se producen divergencias de intereses y de deseos, que reclaman ser resueltos de una u otra manera y que por ello, a las personas no les queda más alternativa que intentar resolverlos...”. CORIA, C., Las negociaciones nuestras de cada día, Paidós, Buenos Aires,-Barcelona-México, 1998, pp. 28-29.

${ }^{98}$ Para mayor información véase KOROBKIN, R., Negotiation Theory and Strategy, Wolter Kluvers, Frederick, 2014.

${ }^{99}$ FISHER, R., URY, W., y PATTON, B., llaman a este tipo de negociación “negociación posicional” ya que la entienden como una contienda de voluntades en el que cada lado intenta obligar al otro a cambiar de posición lo que a su vez produce ira, resentimiento, tensiones y en definitiva puede destrozar la relación. Cuanta más gente esté involucrada en una negociación más grave suelen ser las desventajas de una negociación posicional. Obtenga el Sí. El arte de negociar sin ceder, Gestión 2000, Barcelona 2002, pp. 24-25.
} 
tanto una figura que busca una solución donde todos ganen y cree una situación pacífica y equilibrada ${ }^{100}$, similar a la mediación.

Hay dos formas para llegar a la negociación. La primera es mediante una forma posicional, la cual dará lugar a un modo de negociar de regateo, y la segunda es de forma cooperativa. Esta vía cooperativa es la de mayor relevancia ya que, aunque se iniciar con una forma posicional, si se desarrolla correctamente terminará en una negociación cooperativa ${ }^{101}$.

La negociación se diferencia de la mediación en que, en multitud de ocasiones, ésta se desarrolla a través de sus representantes, no interviniendo ambas o alguna de las partes. El motivo de esta particularidad es la no exigencia del requisito de conversación, obteniéndose un proceso más "frío" e impersonal en el cual las emociones de las partes no entran a juego.

Al focalizar sus esfuerzos en la resolución del conflicto presente y evitación de futuras controversias, el auge de esta figura fue evidente, no sólo en relaciones interpersonales, sino en relaciones comercial. Las denominadas formas de Partnering o Alliancing ${ }^{102}$ nos muestran un deseo o interés por facilitar la comunicación de los contratantes, creándose grupos estables para conseguir que un proyecto o relación comercial sea más eficiente, rentable y duradero.

\footnotetext{
${ }^{100}$ MARTÍNEZ MARÍN, R., "La negociación” en G. Orozco Pardo y J.L. Monereo Pérez (Dir.) Tratado de mediación en la resolución de conflictos, Tecnos, Madrid, 2015, p.104 y siguiendo la misma idea FERNÁNDEZ BALLESTEROS, M.A., Avenencia o ADR. Negociación, Mediación, Peritajes, Conciliación, Pactos y Transacción, Iurgium, Madrid, 2013, p. 103.

${ }^{101}$ La necesidad del proceso previo deviene como consecuencia de la estructura del propio conflicto. WATZLAWICK, P., WEAKLAND, J.H., y FISH, R., Cambio, formación y solución de los problemas humanos, Herder, Barcelona, 1989: plantearon una nueva forma de entender los problemas y el cambio como un nivel diferente de buscar soluciones de modo distinto a lo realizado de forma habitual.

${ }^{102}$ En definitiva, el Partnering y Alliancing son una gestión de varias empresas de manera integrada muy similar a nuestras Uniones Temporales de Empresas en relación a los riesgos y beneficios que comparten las empresas. Suelen darse en contratos y programas de obras públicas en Estados Unidos, Reino Unido y Australia, y suelen definirse como: "Partnering is a structured management approach to facilitate team working across contractual boundaries. Its fundamental components are formalised mutual objetives, agreed problem resolution methods, and an active search for continuous measurable improvements" Partnering $n$ the Team realizado por el Construction Industry Board, Working Group 12 Staff, Construction Industry Board (Great Britain). GREENHALGH., B., y SQUIRES, G., Introduction to building Procurement, Spon Press, Nueva York, 2011, p. 53.
} 
El desarrollo de una negociación necesita una serie de condiciones indispensables ${ }^{103}$ como la interdependencia como interacción; los intereses compatibles, al menos que sean compatibles potencialmente; la cooperación mutua para maximizar sus respectivos intereses; la influencia recíproca que evite una imposición en vez de una negociación; la identificación y coincidencia de las cuestiones en disputa; y la existencia de unas estrategias que deben tener las partes, aprendidas o propias, siempre y cuando la negociación se realice sin intermediarios ${ }^{104}$.

La escuela de Harvard concretó en los años setenta una serie de principios de la negociación ${ }^{105}$ y que FERNÁNDEZ BALLESTEROS simplifica en: “(i) separar la controversia de las personas que están envueltas en ella; (ii) centrarse en lo que realmente interesa a cada parte y no en lo que es o ha sido su posición negociadora; (iii) calibrar con rigor las alternativas; (iv) esforzarse en crear soluciones conjuntas que satisfagan el interés de ambas partes; (v) establecer criterios objetivos sobre los que basar la negociación; (vi) asegurarse de que el acuerdo que se alcanza es razonable o equitativo" ${ }^{106}$.

Por tanto, el derecho se fija en la negociación y la otorga importancia, eficacia que no tiene por sí sola, y validez al pacto de negociar. Y es que se puede iniciar la negociación antes de que ocurra el conflicto (en el momento de perfeccionamiento del contrato) o una vez ya ocurrido este. Puede o no realizarse por escrito, incluso por medios digitales, pero deberá de incluir un acuerdo de confidencialidad, duración, partes negociadoras y sanción en caso de incumplimiento.

\subsection{La conciliación: concepto y caracteres.}

En último lugar hemos de profundizar en la figura de la conciliación. Estamos ante un proceso mediante el que un tercero, experto y neutral, a dos o más personas asiste - trabajando "con ellas, simultánea y singularmente” 107 - a buscar soluciones

\footnotetext{
${ }^{103}$ CALCATERRA. Mediación estratégica... op. cit., pp. 76-78

${ }^{104}$ FISHER, R., URY, W., y PATTON, B., Obtenga el Sí...., op. cit., p. 120.

105 "Program of Negotiation and dispute resolution" de la Facultad de derecho de Harvard.

${ }^{106}$ FERNÁNDEZ BALLESTEROS, M.A., Avenencia o ADR. ... op. cit., p. 107.

${ }^{107}$ BARONA VILAR, S., “Las ADR en la ...”, op. cit., p. 199.
} 
negociadas a su conflicto. La conciliación basa su fundamento en la voluntad de las partes de dialogar, por muy distantes que sean sus respectivas posturas. MOORE la define como "táctica psicológica aplicada que apunta a corregir las percepciones, atenuar los temores injustificados y mejorar la comunicación hasta el punto en que ella permita una discusión sensata y de hecho posibilite la negociación racional... La conciliación es el ingrediente psicológico de la mediación en que el tercero intenta crear una atmósfera de confianza y cooperación que conduzca a la negociación... en la práctica la conciliación es un proceso dinámico que se desarrolla a través de la negociación” 108.

La conciliación es una figura con bastantes similitudes a la mediación, siendo a veces confundidas entre ambas ${ }^{109}$. La conciliación es más formal y es una figura que perdura en nuestro ordenamiento como un acto de conciliación preprocesal (394 LEC) o como el acuerdo alcanzado dentro del proceso (415 LEC), de ahí que exista una “procedimentalización” de esta práctica y se identifique con proceso judiciales ${ }^{110}$. Pero hemos de ir a la práctica internacional, la cual distingue entre una avenencia clásica, denominada también como conciliación, que basa su actuación en las cualidades del conciliador, y una avenencia moderna, también denominada como mediación ${ }^{111}$, que basa su actuación en la participación de las partes sin tener prácticamente importancia las cualidades del mediador, que será un sujeto que acerque posturas.

Una buena descripción en relación a las diferencias esenciales la realiza BUSTELO ELIÇABE-URRIOL ${ }^{112}$, afirmando que en la conciliación existe una

\footnotetext{
${ }^{108}$ MOORE, C., El proceso de mediación, Ed. Granica, Buenos Aires, 1995, pp. 205-206.

${ }^{109}$ La ley italiana de mediación (Decreto Legislativo n ${ }^{\circ} 28$ de 4 de marzo de 2010 sobre la mediación para la conciliación en asuntos civiles y mercantiles) en su artículo 1 utiliza el término mediazione como la actividad tendente a alcanzar un acuerdo, y conciliazione como el acuerdo obtenido por el desarrollo de una mediación

${ }^{110}$ SASTRE IBARRECHE, R., “Consideraciones en torno a los medios de composición autónoma de conflictos en el ámbito laboral” en M. S., Velarde Aramayo (dir.), Introducción al Derecho del Arbitraje y la Mediación, Ratio Legis Librería Jurídica, Salamanca, 2006, pp. 97-118, esp. pp. 115-116.

${ }^{111}$ Para un mayor análisis del tema véase RAU, A., SHERMA, E., y PEPPET, S., Processes of Dispute Resolution, The Role of Lawyers, University Casebook Series, 2006.

112 BUSTELO ELIÇABE-URRIOL, D., “La Víctima del Delito y...¿̇us necesidades?”, en I Jornadas Nacionales de Victimología, Organizadas por la Consejería de Desarrollo Autonómico, Medio Ambiente
} 
desconfianza entre los intervinientes, se transigen derechos desde una perspectiva de intereses jurídicos protegidos y las concesiones entre las partes van sucediendo a medida que van obteniéndose beneficios en favor de las propias partes. Por su parte, la mediación se basa en la confianza recíproca gracias al trabajo de un mediador imparcial, facilitando así un acuerdo a través del clima de trabajo pacífico conseguido por el trabajo de todos los intervinientes.

Las personas que decidan acudir a la conciliación, deben hacerlo de modo abierto y dispuestos al diálogo como paso previo imprescindible para alcanzar soluciones mutuamente satisfactorias. La conciliación pretende plantear aspectos comunes sobre los que pueda construirse un acuerdo que satisfaga a ambas partes. Para ello Ambas partes transfieren a un tercero la gestión del conflicto. Cada interviniente cederá lo que considere más oportuno. El conciliador tendrá que actuar de la forma en que consiga, mediante su presión y actuación, que las partes lleguen a un acuerdo. El conciliador busca acercar posturas. Para ello tiene un punto de referencia en criterios generales valorados social y/o jurídicamente como razonables.

Tal y como señala BARONA VILAR ${ }^{113}$, pueden existir diferentes tipos de conciliación conforme a la fase procesal en la que se esté desarrollando o se decida efectuar. Así puede suceder la conciliación preprocesal, intraprocesal o postprocesal. En las dos primeras, ya sea cuando aún no se ha iniciado el proceso o éste esté pendiente, se busca la resolución del conflicto a través de un acuerdo previo al fallo judicial. Mientras que en la tercera de ellas ya se ha dictaminado sentencia, teniendo un fin de acercamiento de posturas o incluso de ejecución de lo resuelto judicialmente

La conciliación es una forma jerárquica ${ }^{114}$ y vertical $^{115}$. El conciliador induce a las partes hacia la solución más razonable o más acorde con los criterios, derechos o

y Administraciones Públicas del Gobierno de la Rioja y la Asociación de Ayuda a la Victima de la Rioja, La Rioja, 16 y 17 de Octubre de 1997.

113 BARONA VILAR, S., “Las ADR en la ...”, op. cit., p. 198.

${ }^{114}$ Porque se termina configurando una relación de dependencia respecto al tercero que se sitúa en una posición de capacitar (con mayor o menor dosis de autoridad implícita) para acercar las posiciones de las partes enfrentadas. CORIA, C., Las negociaciones nuestras... op. cit. p. 172. 
intereses legalmente establecidos. Puede ofrecer una opinión a las partes respecto a las propuestas que cada una presenta para la consideración de la otra. De esta manera, estamos ante una figura influyente directamente en el resultado del acuerdo que en su caso alcancen los intervinientes ya que dirige el debate, las intervenciones y puede incluso proponer resultados ${ }^{116}$.

115 SÁEZ VALCÁRCEL, R. "La mediación reparadora en el proceso penal. Reflexión a partir de una experiencia”, en R. Sáez Valcárcel y P. Ortuño Muñoz (Dirs.), Alternativas a la Judicialización de los Conflictos: la Mediación, Consejo General del Poder Judicial, Madrid, 2007, pp. 35-86, esp. p. 69.

${ }^{116}$ PEDRAZ PENALVA, E. Arbitraje, Mediación, Conciliación, Cuadernos de Derecho Judicial, Madrid, 1995, p. 41. 
CAPÍTULO SEGUNDO

\section{MEDIACIÓN: ASPECTOS GENERALES}

“La ciencia que se aparte de la justicia, más que ciencia debe llamarse astucia” Marco Tulio Cicerón (106 a.c.-43 a.c)

\section{Antecedentes históricos}

En el siguiente apartado se procederá a realizar un análisis de la figura de la mediación, con especial incidencia en su desarrollo histórico, caracteres, y los diferentes modelos que se han ido desarrollando.

\subsection{La mediación en el transcurso de la historia.}

Es complicado determinar una vigencia histórica de la mediación. Sus apariciones históricas han sido en muy variados lugares y épocas. Ha ido sufriendo una evolución constante adaptándose a las diferentes necesidades y culturas en función de las características sociológicas ${ }^{117}$.

Las tesis que sitúan el inicio de la mediación en épocas pretéritas se basan en las prácticas, entre otras, incluidas en el Nuevo Testamento. No estamos ante una mediación en sí, pero recoge figuras muy similares. El ejemplo más utilizado es cuando Pablo acudió a la congregación de Corinto para el nombramiento de un miembro de la comunidad para la conciliación de las controversias nacidas entre los ciudadanos (1 Corintio 6: 1-4) ${ }^{118}$.

117 FERNÁNDEZ RIQUELME, S., "La mediación social: itinerario histórico de la resolución de conflictos sociales”, en Contribuciones a las Ciencias Sociales, 2010. Documento en línea Disponible en http://www.eumed.net (última visita 16/02/2018). VALDÉS CRUZ, L., ZUBIZARRETA PRIETO, L. D., y PAREDES LEÓN, A., "Orígenes Históricos y Culturales de la Mediación", en Econlink 2010. Disponible en: https://www.econlink.com.ar (última visita 16/05/2017) 
Pero esto no sólo sucedía en el viejo continente, sino que en la antigua China, la conciliación y la mediación fueron los instrumentos para la resolución de controversias, hecho que ha servido para el mantenimiento de los Comités Populares de Conciliación. Confucio afirmaba la existencia de una armonía natural en las relaciones humanas que debía dejarse desenvolver. En su pensamiento, el apoyo unilateral y la intervención adversarial dificultan la comprensión y son la antítesis de la paz. En Japón, la mediación tiene viejas raíces en sus costumbres y leyes. El líder de una población se erigía mediador para ayudar a sus miembros a resolver sus desacuerdos. Tal es así su importancia que se dispuso legalmente la conciliación de desavenencias personales antes de la segunda guerra mundial. En África era la Asamblea Vecinal quien resolvía los conflictos entre los miembros de la comunidad ${ }^{119}$.

En la antigua Roma, podemos hablar de la mediación como una figura en la que el pater getis resolvía los problemas surgidos entre los miembros de su estirpe a través de un consejo de jefes domésticos. Pero realmente esta figura adquirió relevancia posteriormente con el principado y por influencia oriental para la resolución de conflictos mercantiles ${ }^{120}$.

En Derecho Romano arcaico también existía la figura de la transacción, a través de la cual las partes evitaban la prosecución de un litigio a través de una renuncia de parte de sus pretensiones para la obtención de un acuerdo que ponía fin al conflicto ${ }^{121}$. Para ello las partes acudían al Pretor que solía ser el que acercaba las posturas aunque no podía resolver. Como advertía Juliano, debían ser las partes, a través de su propia

\footnotetext{
${ }^{119}$ Gobierno de Santa Fé, Breve Historia de la mediación. Orígenes Históricos, pp. 1-7, esp. p. 2. Disponible en: https://www.santafe.gov.ar (última visita 16/02/2018);

${ }^{120}$ GARCÍA GERBOLES, L., y MUESMANN, M., "El entronque histórico - jurídico del concepto de la mediación desde el Derecho Romano hasta la actualidad”, en J. Rodríguez, A. Muñoz y M. De Prada Rodríguez (Dirs), La mediación. Presente, pasado y futuro de una institución jurídica, Netbiblo, Madrid, 2010, pp. 23 y 24, esp. p. 23.

${ }^{121}$ D. 2.14.17.1 (Paulus 3 ad ed).- Quaedam actiones per pactum ipso iure tolluntur: ut iniuriarum, item furti.
} 
voluntad y autonomía, las que llegasen a un acuerdo ${ }^{122}$, aunque el magistrado podía facilitar la gestión del conflicto.

Esto se fue desarrollando con el paso del tiempo y los gremios comerciales y mercaderes empezaron a resolver sus desavenencias sin la imposición de una autoridad externa, por lo que la mediación y el arbitraje eran la forma perfecta para la resolución de sus conflictos.

Los antecedentes de mediación más conocidos en los Estados Unidos provienen de los procedimientos de resolución de desavenencias laborales industriales. Es a finales de los años sesenta cuando la sociedad estadounidense expresa un gran interés por las formas alternativas de resolución de conflictos.

El origen de la mediación moderna se sitúa en EEUU en los años 70, gracias a la proliferación de las separaciones matrimoniales y la necesidad de resolver ágilmente estos conflictos. Esto se extendió velozmente a su país vecino, Canadá, donde no sólo se aplicó la mediación de EEUU, sino que hubo un desarrollo de la mediación familiar. En Norteamérica la mediación fue muy bien acogida, tanto que hubo grandes autores sobre este tema, como HAYNES ${ }^{123}$, el cual definió la figura como aquel "proceso en virtud del cual un tercero, el mediador, ayuda a los participes en una situación conflictiva a su resolución, que se expresa en un acuerdo consistente, mutuamente aceptable por las partes y escriturada de manera tal que permita, de ser necesario, la continuidad de las relaciones entre las personas involucradas en el conflicto" ${ }^{2124}$.

${ }^{122}$ D. 12.1 .21 (Iulianus 48 dig.).- Quidam existimaverunt neque eum, qui decem peteret, cogendum quinque accipere et reliqua persequi, neque eum, qui fundum suum diceret, partem dumtaxat iudicio persequi: sed in utraque causa humanius facturus videtur praetor, si actorem compulerit ad accipiendum id quod offeratur, cum ad officium eius pertineat lites deminuere,

${ }^{123}$ Fue presidente de Haynes Mediation Associates and Mediation Training Institute, un programa nacional de formación en mediación para abogados y profesionales de Salud Mental. Fue presidente fundador de la Academia de Mediadores de Familia, ejerciendo como asesor consultivo en los tribunales de EE.UU. (Arizona, Delaware, Idaho, Nuevo México, Texas, Washington), Canadá y Gran Bretaña.

${ }^{124}$ ÁLVAREZ GARCÍA, H., "La premediación como presupuesto procesal de admisibilidad versus el derechu fundamental de acceso a la jurisdicción”, en R. Cabrera Mercado (dir.) y P.M. Quesada López (coord.), La mediación como método para la resolución de conflictos, Dykinson, Madrid, 2017, pp. 8596, esp. p. 86. 
En los países europeos, hay que esperar al impulso de las Comunidades Europeas en los años 90, con el tratado de Maastricht y el Consejo de Tampere de 1999. Posteriormente se elaboraría el Libro verde ADR 2002 y la directiva 52/2008 sobre mediación civil y mercantil. Actualmente en España podemos jactarnos de tener desarrollada la mediación civil gracias a la Ley 5/2012, de 6 de julio, de mediación en asuntos civiles y mercantiles, la cual es una transposición de la directiva anteriormente indicada.

En Alemania la utilización de la mediación se ha incrementado y ha surgido el denominado -Alternative in der Ziviljustiz-, para la resolución de conflictos que afectan al medio ambiente, disputas entre vecinos, derechos económicos, arrendamientos, conflictos laborales, o consumidores. En el año 1995 entra en vigor en Francia la Ley de Mediación Procesal, que introduce la mediación. Además de la conciliación como proceso previo y obligatorio antes de iniciar el juicio, se instaura la figura del mediador, inspirado en el ombudsman sueco ${ }^{125}$, cuya función es hacer recomendaciones sobre cómo habría de resolverse la disputa.

\subsection{La recepción de la mediación en España}

A lo largo de la historia vamos surgen numerosos métodos alternativos para la resolución pacífica de conflictos, tales como los ya descritos, que por distintas causas, como la pérdida de confianza de las personas en el sistema judicial, la sobresaturación del mismo, la búsqueda de decisiones acordes con las necesidades de los participantes, el deseo de cercanía personal y social con la figura decisoria, etc., han ido ganando peso en la sociedad ${ }^{126}$. La finalidad principal era solventar los conflictos acudiendo a un tercero con autoridad reconocida por las partes intervinientes para que éste pudiera ayudar solucionarlo de forma pacífica, ya fuese acercando posturas o dirimiendo el asunto.

\footnotetext{
${ }^{125}$ En Suecia, el ombudsman es una figura jurídica de gran valor que se equipararía a nuestro defensor del pueblo, el cual ejerce laborar de mediador/conciliador en determinados procesos.

${ }^{126}$ MIRANZO DE MATEO, S., "Quiénes somos, a dónde vamos... origen y evolución del concepto mediación”, en Revista de Mediación 2010, n 5. pp. 8-15, esp. p. 9.
} 
Es complicado concretar una fecha exacta de inmersión de esta figura en España. Lo que podemos encontrarnos son referencias a figuras similares, las cuales van adquiriendo tintes de mediación según el conflicto que resuelven. Más la figura tuvo gran importancia en el Derecho Internacional, siendo éste su cauce para la implementación en nuestras fronteras. Tal como señala MIRANZO DE MATEO, “la mediación se utilizó especialmente en el ámbito del Derecho Internacional, debido a la importancia del establecimiento de relaciones y al respeto de los pactos basados en la autoridad, respeto siempre difícil de conseguir en este ámbito del Derecho. La coactividad de las normas es de complicado cumplimiento debido a la soberanía de los países, siendo difícil establecer vínculos de obligación que no se basen en la fuerza bruta o en la convicción asumida por respeto a la autoridad reconocida” ${ }^{27}$.

No es hasta las décadas de los años setenta y ochenta cuando convergen las primeras fases para considerar un verdadero inicio de la mediación en España. Los mediadores extranjeros hacen llegar a nuestras fronteras sus estudios y trabajos sobre este tema, provocando un interés entre ciertos sectores y la agrupación de eruditos de la materia para la realización de las primeras iniciativas. Estos buenos presagios iniciales se encuentran con el gran muro del desconocimiento absoluto de la materia ${ }^{128}$, provocando que no se sepa valorar la mediación como una actividad, una profesión, ni como desarrollarla en la práctica.

Pero no fue hasta el inicio de los años 90 cuando no se dio la denominada expansión de la mediación en España. Se provoca un gran avance en su estudio, incrementándose el número de entidades, asociaciones y colegios profesionales. Pero, a pesar de ello, existía una gran carencia de demanda, pocas garantías en la formación y un cierto respeto a que estas actuaciones sean consideraras como intrusismo laboral.

\footnotetext{
${ }^{127}$ MIRANZO DE MATEO, S., “Quiénes somos, a ...”, op. cit., p. 9

128 BOQUÉ TORREMORELL, M.C., "La mediación como disciplina y como profesión: El perfil competencial del mediador”, en R. Castillejo Manzanares (dir.) y C. Torrado Tarrío (coord.), La mediación: nuevas realidades, nuevos retos: análisis en los ámbitos civil y mercantil, penal y de menores, violencia de género, hipotecario y sanitario, La Ley, Madrid, 2013 pp. 41-100, esp. p.45.
} 
Es ya en el presente siglo cuando empezamos a ver como la práctica y el estudio de esta materia da un resultado más esperanzador. De una legislación escasa o nula, a un plus normativo que desencadena en multitud de leyes autonómicas relativas a la mediación. A modo de ejemplo señalamos aquella que nos es más cercana, como resulta ser Ley 1/2006, de 6 de abril, de Mediación Familiar de Castilla y León ${ }^{129}$.

Así, la mediación se empieza a consolidar como una profesión, originando una concienciación acerca de su importancia y de su posible práctica ya sea dentro del proceso (mediación intrajudicial) o como una alternativa a éste y fuera del ámbito procesal (mediación extrajudicial). Dicha actuación proporciona, definitivamente, el empujón necesario para su desarrollo y legitimación dentro del sistema judicial español.

El asentamiento de la mediación en nuestro sistema judicial ha provocado grandes ventajas y grandes inconvenientes, pero, el inconveniente más importante reside en la mentalidad de los ciudadanos acostumbrados a un sistema en el cual se consigue la solución de conflictos mediante sentencia, sin diálogo y con un resultado que será la victoria o la derrota, o el llamado “esquema ganar-perder"130.

Para el International Mediation Institute ${ }^{131}$, la mediación se convertirá en una profesión global debido a su extensión y a sus variadas modalidades que nos encontramos en muchísimos países del mundo, así como su filosofía dialogante y

\footnotetext{
${ }^{129}$ Multitud de ellas podemos encontrarnos, muchas de las cuales han sido ejemplo a seguir para el resto de autonomías para el desarrollo normativo de sus propias legislación. A modo de ejemplo: Ley 1/2001, de 15 de marzo, de Mediación de Cataluña; Ley 7/2001, de 26 de noviembre, de Mediación de Valencia; Ley 4/2001, de 31 de mayo, de Mediación de Galicia; Ley 15/2003, de 8 de abril de Mediación de Canarias; Ley 4/2005, de 24 de mayo de Mediación de Castilla La Mancha; Ley 18/2006, de 22 de noviembre de Mediación de Islas Baleares; Ley 1/2007, de 21 de febrero de Mediación de Madrid; Ley 3/2007, de 23 de marzo de Mediación de Asturias; Ley 1/2008, de 8 de febrero de Mediación de Euskadi; Ley 1/2009, de 1 de febrero de Mediación de Andalucía.

${ }^{130}$ BOQUÉ TORREMORELL, M.C., “La mediación como ...” op. cit., p.50.

${ }^{131}$ Asociación de estudio y promulgación de la mediación con establecimiento en La Haya pero en colaboración con diferentes asociaciones mundiales en pos del impulso de los ADR tales como el International Arbitration Association de Bruselas, Royal Institution of Chartered Surveyors de Londres, The Mediators' Institute of Ireland (The MII) de Dublín, Institut Français de Certification des Médiateurs (IFCM) de París, la Universidad Carlos III de Madrid, American Arbitration Association de Washington, Family Mediation Canada (FMC) de Ontario, Resolution Institute (LEADR/IAMA) de Sydney o el Conflict Coaching International (CCI) de Hong Kong. Para mayor información véase http://www.imimediation.org
} 
pacificadora. Actualmente la mediación es todavía un campo nuevo, casi inexplorado, y que está en proceso de evolución y desarrollo. Un sistema que supera el "esquema ganar-perder" que nos proporcionan los Tribunales, para transformarlo en un "esquema ganar-ganar”. Un largo camino queda por andar, una travesía que nos implemente social y jurídicamente la figura y que acabe con la situación actual en la que "no hay mediación sino mediadores" ${ }^{132}$.

\section{La mediación: concepto, caracteres, fines y objetivos.}

El Estado de Derecho es la garantía de la tutela judicial de los derechos de los ciudadanos Para ellos, unos de los pilares básicos es la existencia de una justicia que resuelva todo tipo de conflictos surgidos en el ámbito de las relaciones interpersonales. Para el cumplimiento de dichos fines, los ciudadanos acuden ante los tribunales, los cuales, no sólo resuelven el conflicto, sino que garantizan el cumplimiento de la sentencia.

Este proceso, largo y costoso económicamente, ha regido como único medio accesible a los miembros de la comunidad. Ello nos ha privado de la utilización de los Métodos Alternativos de resolución de conflictos hasta fechas muy recientes, despojándonos de sus rentabilidades. Pero en la medida en que el interés por su empleo ha ido incrementándose, han emergido "grandes especialistas, que hace no muchos meses despreciaban esta materia por considerarle sin interés jurídico”" ${ }^{133}$. A continuación analizaremos el concepto de mediación y proseguiremos con un breve estudio de las características y principios que informan todo proceso de mediación.

\footnotetext{
132 BOQUÉ TORREMORELL, M.C., “La mediación como ...” op. cit., p. 44.

${ }^{133}$ ORTUÑO MUÑOZ, P., “La mediación en el proceso de modernización de la justicia” en R. Castillejo Manzanares (dir.) y C. Torrado Tarrío (coord.) La mediación: nuevas... op. cit., pp. 27-40, esp. p. 29.
} 


\subsection{El concepto de mediación.}

Previo para a entablar la figura de la mediación, es fundamental el conocimiento y estudio del conflicto como situación que prevé todo proceso, sea cual fuera éste. Multitud de definiciones existen, pero nosotros nos quedamos con la interpretación enunciada por DE DIEGO y GUILLÉN, que configura el conflicto como aquella "la situación en la que dos o más personas entran en oposición o desacuerdo porque sus posiciones, intereses, necesidad o valores son incompatibles; donde la relación entre las partes puede salir robustecidad o deteriorada en función de cómo sea el proceso para la resolución de aquél conflicto..."134.

De aquí podemos desarrollar una serie de caracteres propios de todo conflicto. Lo primordial es la existencia de una oposición por un interés común, el cual no puede satisfacer a ambos sujetos. Estos bienes que provocan el choque de posiciones nos conduce a una situación de inestabilidad en la relación de ambos intervinientes, la cual se va a deteriorar por el interés contrapuesto que ambos tienen. Este interés puede ser muy variado, desde una inclinación hacia un mismo bien, hasta el uso de dos bienes opuestos e incompatibles en cuanto a su utilización en dicho suceso. Todo ello nos encamina a la colisión de posiciones que es el conflicto.

Existen múltiples tesis que reivindican una serie de elementos propios en todo conflicto, la denominada El Triángulo de las tres $p$ de LEDERACH ${ }^{135}$. En su obra nos desarrolla y escenifica el conflicto, apuntando que éste tiene una serie de caracteres especiales, como los vinculados a las personas implicadas, directa o indirectamente afectadas; los elementos propios del proceso o historia que conduce al conflicto; los hechos o acontecimientos. Ello nos hace concluir que es fundamental las peculiaridades de los sujetos partícipes en la situación, así como los antecedentes previos y

\footnotetext{
${ }^{134}$ DE DIEGO, R., y GUILLÉN, C., Mediación. Proceso. Tácticas y técnicas, Pirámide, Madrid, 2010, p. 36.

${ }^{135}$ LEDERACH, J., Enredos, pleitos y problemas. Una guía práctica para ayudar a resolver conflictos, Clara-Semilla, Guatemala, 1992, pp. 20 y ss.
} 
singularidades que nos han acarreado al conflicto. A esto, DE CASTRO-ACUÑA ${ }^{136}$ nos advierte de la existencia de dos elementos más, la interdependencia y la especialización.

Prosiguiendo en el estudio del tema objeto del presente trabajo, la mediación entendemos como una forma de resolver conflictos entre dos o más personas, con la asistencia de un tercer sujeto imparcial, el cual es el mediador. Éste último deberá de regular el proceso y conducir a las partes a una solución pacífica y razonada en un espacio de tiempo razonable. El único fin es la resolución del conflicto a través de la incoación de un procedimiento pacífico destinado a tal final. Tal y como nos hace saber BARONA VILAR, “en la mediación no hay proceso ni jurisdicción. Es un procedimiento extrajurisdiccional, en virtud de lo cual los sujetos en conflicto deciden voluntariamente reconocerse capacidad para participar en la resolución de un conflicto, con intervención del mediador, buscando una solución que deberá suscribirse en un acuerdo que implicará cesiones por ambas partes y un restablecimiento de la situación previa al conflicto, ora solucionándola ora aprendiendo a gestionar el mismo..." ${ }^{137}$.

Este sistema posibilita las partes al acceso a una práctica de resolución de sus divergencias sin tener que acudir a los tribunales, garantizándose una rápida y económica solución gestad por ellos mismos. Nos ofrece soluciones prácticas, efectivas y rentables a determinados conflictos entre partes ${ }^{138}$.

Tras ello, podemos acudir a multitud de definiciones de mediación. Nosotros vamos a centrar nuestro interés en dos de ellas que abarcan las diferentes características y posibilidades de esta institución. En primer lugar accedemos al estudio de la figura por parte de VINYAMATA, el cual define a la mediación como "el proceso de comunicación entre partes en conflicto con la ayuda de un mediador imparcial que

\footnotetext{
${ }^{136}$ DE CASTRO-ACUÑA, N., y PONTE GARCÍA, M., "La mediación como instrumento de resolución de conflictos interpersonales de carácter interno en las organizaciones sanitarias”, en R. Castillejo Manzanares (dir.) y C. Torrado Tarrío (coord.), La mediación: nuevas ..., op. cit., pp. 613-640, esp. p. 621.

${ }^{137}$ BARONA VILAR, S. Mediación en asuntos civiles y mercantiles en España, Tirant lo Blanch, Valencia, 2013, pp. 104-105.

${ }^{138}$ Exposición de motivos Ley 5/2012, de 6 de julio, de mediación en asuntos civiles y mercantiles.
} 
procurará que las personas implicadas en una disputa puedan llegar, por ellas mismas, a establecer un acuerdo que permita recomponer la buena relación y dar por acabado, o al menos mitigado, el conflicto, que actúe preventivamente o de cara a mejorar las relaciones con los demás...”139.

No menos importante es la descripción de la práctica realizada por HAYNES, el cual acertadamente nos expone a la mediación como aquel "proceso en virtud del cual un tercero, el mediador, ayuda a los participantes en una situación conflictiva a su resolución, que se expresa en un acuerdo consistente en una solución mutuamente aceptable y estructurada de manera que permita, de ser necesario, la continuidad de las relaciones entre las personas involucradas en el conflicto....la solución elegida deberá satisfacer a todos los participantes en la disputa....Así pues el proceso de mediación es la conducción de las negociaciones de otras personas, y el mediador es el director de las negociaciones, quién organiza la discusión de los puntos a resolver. Cuanto más coherente y organizado sea el proceso, más fácil será para los participantes llegar a soluciones que sean aceptables y apropiadas para todos...” 140 .

Multitud de definiciones hemos dejado atrás a pesar del gran valor e importancia que han servido a la comunidad científica para el desarrollo óptimo de la práctica jurídica, tales como los estudios de SARAH COBB ${ }^{141}$, MARINES SUARES ${ }^{142}$, BERNAL SAMPER ${ }^{143}$ o GROVER DUFFY ${ }^{144}$.

\footnotetext{
${ }^{139}$ VINYAMATA, E., Aprender mediación, Paidós, Barcelona, 2007, p. 17

${ }^{140}$ Presidente-fundador de la Academia de Mediadores de Familia (1981-1985) y del Mediation Training Institute.

${ }^{141}$ COBB, S., "Prólogo”, en M. Suares (dir.), Mediando en sistemas familiares, Paidós, 2002, Barcelona, p.18, "proceso que estructura la intervención de las partes involucradas en modos que favorecen simultáneamente, su participación y su legitimidad, permitiéndoles asumir responsabilidad en términos de diseñar la resolución de su disputa. Es por lo tanto, un proceso que otorga una voz a las partes en disputa, que les permite hablar y ser reconocidas por el otro...”.

${ }^{142}$ SUARES, M., Mediando en ... op. cit., pp. 28-29: "Un dispositivo no adversarial de resolución de disputas, que incluye un tercero "neutral" cuya función es ayudar a que las personas que están "empantanadas" en la disputa, puedan negociar en forma colaborativa y alcanzar una resolución de la misma"

${ }^{143}$ BERNAL SAMPER, T., La Mediación, una solución a los conflictos de ruptura de pareja, Colex, Madrid, 2002, p. 77: "Una técnica pacífica de resolver conflictos donde el protagonismo lo tienen las partes, cambiando el rol de los actores intervinientes en la situación conflictiva”.
} 


\subsection{Características y ventajas propias de la figura.}

En cuanto a la institución de mediación, existen una serie de características y ventajas que se van a analizar en las páginas posteriores. No obstante, la práctica de la mediación genera al mismo modo un conjunto de inconvenientes imposibles de soslayar en un análisis de la figura, los cuales, tal y como sucede con las ventajas, pueden derivar de alguna de las características propias de la mediación.

En cuanto a las características, y en primer lugar, la mediación es un modelo flexible. Esto significa que el proceso se adapta a las necesidades de las partes en un momento dado, pudiendo modificarse conforme van alterándose las posiciones de los intervinientes. Esta característica es una ventaja de la mediación conforme al proceso judicial clásico pues encamina las actuaciones a una satisfacción plena, o lo más plenamente posible, de los intervinientes. Pese a todo, el modelo flexible a las partes puede conducir a los intervinientes a un proceso más largo debido a la alteración de las necesidades de las partes, las cuales van mutando y prolongando indebidamente la resolución del conflicto

En segundo lugar la característica básica de la mediación es la voluntariedad. Sólo se puede iniciar un proceso de mediación si las partes han decidido libremente someterse a él, adaptándole a las necesidades que éstas dispongan, superándose así la rigidez del sistema clásico. Esta voluntariedad no sólo se refleja en la posibilidad de iniciar dicho proceso, sino que se va a mantener durante todo él, siendo las partes libres para poder ponerle final en cualquier momento y para tomar las decisiones resolutorias que escatimen necesarias, tales, por ejemplo, la consideración del acuerdo de mediación como título ejecutivo mediante su elevación a escritura pública. Según parte de la doctrina, la voluntariedad se ejemplifica en la "solicitud o demanda genuina" ${ }^{145}$ para el inicio o aceptación de participación en el proceso de mediación. Es por tanto una de las

\footnotetext{
${ }^{144}$ DUFFY, G., .La Mediación y sus contextos de aplicación, Paidos, Barcelona, 1996 p. 52: "la intervención en un conflicto de una tercera parte neutral que ayuda a las partes opuestas a manejar o resolver su disputa".

${ }^{145}$ CARAM, M.E., EILBAUM, D.T., y RISOLÍA, M., Mediación diseño de una práctica, Librería Histórica, Buenos Aires, 2006, p.45.
} 
mayores ventajas que ofrece la institución de la mediación a los ciudadanos. Posibilita a éstos el inicio del proceso en el único supuesto que ellos lo consideren óptimo para la resolución de sus conflictos y la satisfacción de sus intereses.

La voluntariedad del ciudadano para poder acudir a un proceso de mediación no ha de verse limitada por la imposibilidad de acceso a diferentes dependencias. Por ello el trabajo realizado por un equipo de investigadores de la Universidad Carlos III de Madrid, el cual confeccionó el SEMADISC ${ }^{146}$, una plataforma electrónica de mediación y arbitraje para la resolución jurídica de conflictos dirigida a personas con discapacidad, permite a estos ciudadanos ser parte activa de un proceso de mediación con la misma autonomía e independencia que cualquier otro ciudadano. Desde la Universidad nos indican que “...el proyecto surge gracias a las sinergias del Campus de Colmenarejo de la UC3M, en el que conviven profesores e investigadores de distintas ramas del conocimiento. En concreto, este proyecto multidisciplinar, a caballo entre el derecho y la ingeniería informática, ha sido creado por investigadores del Grupo de Inteligencia Artificial y Aplicada (GIAA) y el Instituto de Derechos Humanos 'Bartolomé de las Casas' de la UC3M. La idea principal del sistema es proporcionar los medios adecuados para que cualquier persona, y especialmente las personas con discapacidad, pueda disponer de forma gratuita y universal de un servicio con el que resolver sus problemas de manera cómoda, pacífica y dialogada. Es una herramienta electrónica accesible que permite a la personas con discapacidad gozar de la misma autonomía e independencia a la hora de luchar por sus derechos que otra persona sin discapacidad, de manera que la persona con discapacidad no dependa de un tercero para ejercer este tipo de defensa de sus derechos. Los investigadores ya han obtenido un primer prototipo de esta plataforma online, accesible desde cualquier navegador web y adaptada a las necesidades especiales de los usuarios, que permite realizar los trámites relacionados con el proceso de mediación, como crear un caso y realizar peticiones a los expertos, subir documentos relacionados con el caso, disponer de un acta donde se

\footnotetext{
${ }^{146}$ Para más información: http://www.uc3m.es/portal/page/portal/actualidad_cientifica/noticias/semadisc
} 
registra el avance del proceso o agilizar la comunicación de los implicados al avisar por diferentes medios cuando se produce alguna novedad...”.

En tercer lugar y con relación a la confidencialidad, es una de las características básicas de todo proceso alternativo para la resolución de conflictos, y no así de un proceso judicial. Los intervinientes entenderán que todo lo vertido en las sesiones será “inter nos”. La razón se basa en la necesidad de establecer unos límites a la publicidad de todos los datos expuestos por si existiera la circunstancia de fracasado en el proceso y ventilación por los tribunales ordinarios. Si no existiese esta confidencialidad, estos datos que las partes han puesto en común, ya sea ante el mediador o también ante la otra parte, podrían ser usados en su contra. SUARES ${ }^{147}$ considera que la confidencialidad debe respetarse igualmente, tras las reuniones privadas con cada parte, sobre los puntos que específicamente quieren que permanezcan silenciados por parte del mediador/a.

La valía de este principio es de vital importancia puesto que impide que los mediadores o las partes del procedimiento de mediación estén obligados a declarar o aportar documentación en un procedimiento judicial o en un arbitraje sobre la información y documentación derivada de un procedimiento de mediación o relacionada con el mismo, excepto cuando las partes de manera expresa y por escrito les dispensen del deber de confidencialidad o cuando, mediante resolución judicial motivada, sea solicitada por los jueces del orden jurisdiccional penal. Hemos de hacer hincapié en la excepción existente a este principio en el artículo 11.2 de la Ley 4/2001 de 31 de Mayo de Mediación Familiar, a través del cual se exceptúa la confidencialidad de todo proceso de mediación si la información relativa a un procedimiento de mediación en curso es requerida por el Juez; toda información requerida por el Ministerio Fiscal; la consulta de los datos personalizados con fines estadísticos.

\footnotetext{
${ }^{147}$ Solo exceptúa los casos en que se aprecie por el mediador la comisión de un delito grave y el abuso de menores. SUARES, M., Mediando en sistemas ..., op. cit., p.37.
} 
Para LUQUIN BERGARECHE ${ }^{148}$, la confidencialidad "es el deber de no revelar la información obtenida en el proceso de mediación, con la obligación, para el mediador de mantener el secreto profesional como para las partes de guardar silencio y renunciar, de este modo, a proponer al mediador como testigo y éste a actuar como perito o asesor en un eventual proceso sucesivo que recaiga sobre el mismo objeto de la mediación"

En cuarto lugar como característica básica de la institución de mediación se ha de observar que no es un proceso decisorio en relación a la intervención de un tercero. Tanto en el arbitraje como en el proceso judicial, existe la figura de un tercero imparcial investido de poder, que pondrá fin a la disputa a través de una resolución. En cambio, en la mediación, son las partes las que acuerdan esta resolución, quedando el tercero relegado a una posición más vigilante, siendo su única función la de hacer llegar a un acuerdo a los partícipes.

En la negociación, la intervención de un tercero no es obligatoria, pudiendo existir un negociador que buscará acercar posturas a través de propuestas de resolución, o pueden ser las propias partes las que resuelvan sin su intervención. Es aquí de donde derivan una ventaja de todo proceso de mediación. Respecto a la ventaja, se permite a los intervinientes ser parte en la toma de decisiones, resolviendo entre ellos el conflicto conforme a sus necesidades y sin imposición alguna. Ello es fundamental para otorgarle al ciudadano la capacidad de actuar en los procesos, de ser parte activa, y no sólo con miras en el proceso de mediación presente, sino como una experiencia para posibles procesos futuros. En consecuencia, aunque no todos los conflictos van a ser resueltos por mediación - ya sea por imposibilidad de la materia o incapacidad de llegar a un acuerdo por las partes- siempre existirá una mayor facilidad para la resolución pacífica de conflictos si existe un hábito en la materia.

\footnotetext{
${ }^{148}$ LUQUIN BERGARECHE, R., "Teoría y práctica de la mediación intrajudicial en España: Algunos factores de la mediación en conflictos familiares”, en Estudios de derecho judicial 2007, nº 136, pp. 1366.
} 
En quinto y último lugar, la neutralidad es parte fundamental de todo proceso de mediación puede crea un ambiente igualdad entre los intervinientes. Es básico para el desarrollo eficaz de todo proceso una situación de equidad entre las partes. Esto significa que el proceso no va a posicionarse a favor o en contra de nadie. El único fin del mediador es acercar posturas para la satisfacción de las partes a través de un acuerdo resolutorio adaptado a sus necesidades.

Tras observar y analizar brevemente las características propias de la mediación y las ventajas que de ello derivan, se ha de añadir que un aspecto fundamental para la existencia de un proceso exitoso es la confianza en la otra parte. No debe de iniciarse un procedimiento de mediación en casos de sospecha de fraude o mala fe o cuando se encontrare un riesgo de quiebra de la confidencialidad.

En síntesis la mediación es una técnica no adversarial ${ }^{149}$ de resolución de conflictos, en la cual un tercero neutral favorece a los participantes en la búsqueda de a un acuerdo de manera tal que ninguno "pierda" o, dicho de otra forma, que ambos "ganen". Estamos por tanto ante un procedimiento simple, cuyas características más significativas son la neutralidad, voluntariedad, confidencialidad, flexibilidad y autodeterminación de las partes. La figura del mediador no va a suponer un impedimento para el libre albedrío de las partes, sino que servirá como apoyo para la consecución del acuerdo. Si hubiere alguna circunstancia que pudiere afectar a su imparcialidad o generase un conflicto de intereses, el mediador lo comunicará a las partes en sesión informativa.

Todo ello busca, como objetivo general, la resolución pacífica de aquellos conflictos que surgen en los diferentes ámbitos de la relación humana (familiar, social,

149 Para un mayor análisis sobre el tema véase CAVALLI BUSTOS, M.C., y QUINTEROS AVELLANEDA, L. G. Introducción a la gestión no adversarial de conflictos, Reus, Madrid, 2010, p. 99101 y 145-148: En la misma línea ARGUDO PÉREZ, J.L., "Los sistemas no adversariales de resolución de conflictos en la legislación cooperativa autonómica”, en Revista vasca de economía social 2006, $\mathrm{n}^{\circ} 2$, pp. 105-130, esp. p. 125. 
laboral,...) sin tener que acudir a la vía judicial ${ }^{150}$. Tras observar su finalidad primordial, hemos de atender a la existencia de diversos propósitos de todo proceso de mediación, como el ofrecimiento de un espacio adecuado, neutral e imparcial, donde las partes expongas sus diferencias y el objeto del conflicto; el restablecimiento de la comunicación entre personas en disputa, potenciando la expresión de intereses y necesidades particulares; la promoción de la creación de alternativas y opciones que deriven en acuerdos consensuados y satisfactorios para todos ellos; y el otorgamiento a las partes de la responsabilidad y el protagonismo en la solución de sus diferencias.

GIMENEZ ROMERO ${ }^{151}$ resume esta figura indicando una serie de efectos beneficios y perjudiciales. Como beneficiosos nos expone la importancia del capital humano, el carácter innovador, la elaboración de redes de trabajo y la contribución a una sociedad plural y democrática. En otra parte, y con relación a los efectos perjudiciales, considera probada una carencia de fundamentación teórica, de formación profesional, de reconocimiento social y una presente y futura precarización profesional.

A las ventajas anteriormente indicadas, hemos de añadir otras de ellas que le dan una caracterización especial. En primer lugar, estamos ante un proceso con una gran celeridad en relación a la resolución de la disputa. Se busca que ésta se consiga en le menor tiempo posible, y la ser ellos mismos los que están interesados en ello, trabajarán constantemente para la obtención de un acuerdo que ponga fin a la controversia en breve. Este acuerdo de mediación responderá a las necesidades de las partes, otorgándonos un resultado en el que no existen ganadores y perdedores, sino que todos obtienen un beneficio y satisface sus pretensiones. Así obtenemos un proceso de resolución de conflictos más ágil, más justo, más humano, adaptado a las necesidades e intereses de los participantes, en el que son los ciudadanos quienes toman decisiones

\footnotetext{
${ }^{150}$ SALVADOR CODERCH, P., “ABC de la transacción”, en InDret 2002, n 101, pp. 1-22, esp. p. 4. Disponible en http://www.indret.com (última visita 20/02/2018) "la inmensa mayoría de los conflictos se resuelven extrajudicialmente: en la realidad social, las partes hacen y soportan casi todo antes de verse abocadas a la maldición de un litigio judicial”.

${ }^{151}$ GIMÉNEZ ROMERO C., “¿Cómo hemos llegado y por qué estamos aquí? Sobre las etapas, retos, oportunidades y riesgos de la mediación intercultural”, en Revista Asociación de enseñantes con gitanos, 2007, nº 29, pp. 6-17.
} 
resolutorias y que supone un aire fresco para nuestro sistema de justicia e incluso para nuestra sociedad.

De aquí podemos observar las grandes diferencias existentes entre el proceso de mediación con el resto de procedimientos, ya sean ante los Tribunales u otros métodos de resolución alternativa. En la tabla siguiente vamos a poder percatarnos de algunas de sus diferencias.

\begin{tabular}{|l|l|l|l|l|}
\hline & Negociación & Mediación & Arbitraje & $\begin{array}{l}\text { Proceso } \\
\text { judicial }\end{array}$ \\
\hline Confidencial & $\mathrm{SI}$ & $\mathrm{SI}$ & $\mathrm{SI}$ & $\mathrm{NO}$ \\
\hline $\begin{array}{l}\text { Decisorio } \\
\text { NO }\end{array}$ & $\mathrm{NO}$ & $\mathrm{SI}$ & $\mathrm{SI}$ \\
\hline $\begin{array}{l}\text { Intervención } \\
\text { de } \\
\text { tercero un }\end{array}$ & $\mathrm{NO}$ & $\mathrm{SI}$ & $\mathrm{SI}$ \\
\hline $\begin{array}{l}\text { Voluntario } \\
\text { Flexible }\end{array}$ & $\mathrm{SI}$ & $\mathrm{SI}$ & $\mathrm{SI}$ (pero) & $\mathrm{NO}$ \\
\hline
\end{tabular}

Figura 1. Diferencias entre los diferentes procesos para resolver conflictos. Fuente: La posición del abogado en el proceso de Mediación ${ }^{152}$

\section{Tutela judicial efectiva y mediación}

Al Estado le compete la potestad de resolver y dirimir los conflictos jurídicos nacidos entre los ciudadanos, conforme dispone el art. 117.3 de la Constitución Española $^{153}$ a través del Poder Judicial mediante la Administración de Justicia la cual recae en Juzgados y Tribunales.

\footnotetext{
${ }^{152}$ FAJARDO MARTOS P., La posición del abogado en el proceso de Mediación, Editorial Tecnos, p 5, disponible en: http://www.mediacion.icav.es (Última visita: 09/11/2017)

${ }^{153}$ Sin olvidar la concordancia con los artículos 53, 118, 119, 120, 161 y 162 de la Constitución Española.
} 
La tutela judicial efectiva ${ }^{154}$ se encuentra regulada en el artículo 24 de la Constitución Española como un derecho fundamental, los cuales representan los intereses básicos o elementales de los ciudadanos que conforman el Estado. Su modificación queda fuera del alcance de la voluntad democrática, para así proteger los intereses básicos de una sociedad y que no puedan ser modificados o eliminados en las ocasiones en que las mayorías que gobiernan el Estado decidan. Por ello, los Estados deben diseñar mecanismos para su protección como la obligatoriedad de respetar los derechos fundamentales por parte de los ciudadanos y de los poderes públicos, la obligatoriedad de protección por parte de los tribunales y su exclusión de la política ordinaria.

Realmente, ¿la tutela judicial efectiva puede verse mejorada por la resolución de conflictos a través de la mediación? La Constitución Española establece en su artículo 117 que únicamente Jueces y Magistrados serán los encargados de administrar Justicia conforme los procedimientos que por ley se establezcan, exclusivamente en sus Juzgados y Tribunales a través del Proceso Judicial.

En esto se han basado muchos autores para como impropio el hecho de que "la mediación sirva para 'hacer Justicia' o que la misma constituye una 'Justicia alternativa', al menos mientras al término 'Justicia' se le atribuya una connotación jurídica” ${ }^{155}$.

Existen diversas opiniones con relación al carácter jurisdiccional de la mediación. En primer lugar, y con convencimiento negativo, encontramos posturas que reniegan total o parcialmente de la figura, aludiendo a la carencia de poder jurisdiccional y la falta de poder de decisión sobre las partes. A parte, consideran que

\footnotetext{
${ }^{154}$ Para un estudio pormenorizado sobre la tutela judicial efectiva véase MARTíN DIZ, F., "Del derecho a la tutela judicial efectiva hacia el derecho a una tutela efectiva de la justicia", en Revista europea de derechos fundamentales 2014, n 23, pp. 161-176; PICÓ I JUNOY, J., Las garantías constitucionales del Proceso, Bosch, Barcelona, 1997, pp. 40-60; BUJOSA VADELL, L., y RODRÍGUEZ GARCÍA, B., "Algunos apuntes sobre el derecho a la tutela judicial efectiva en la jurisprudencia constitucional", en $\mathrm{La}$ Ley: Revista jurídica española de doctrina, jurisprudencia y bibliografía 1999, n 2, pp. 1828-1840.

${ }^{155}$ TARUFFO, M., Texto de la ponencia expuesta por el autor en el $9^{\circ}$ Seminario sobre derecho y jurisprudencia, organizado por la Fundación Coloquio Jurídico Europeo, los días 21-22 de julio de 2007.
} 
para la validez de un acuerdo de mediación se ha de acudir ante los tribunales, los cuales son los únicos que investidos de potestad jurisdiccional.

Nuestra postura se sitúa en favor que aquellos que proponen la inclusión de la mediación dentro del proceso judicial ${ }^{156}$. Una nueva figura en pos de la mejora de la tutela judicial efectiva, supliendo los inconvenientes de los que adolece el proceso judicial, focalizada en las víctimas como método reparativo en el ámbito penal y herramienta para la descongestión de los actuales saturados juzgados.

Es claro que el mediador no aplica ni ejecuta ley alguna, sino que su misión está encauzada en el acercamiento de posturas entre las partes. No posee poder coercitivo, pues la gran base de la mediación es permitir a los intervinientes la resolución motu proprio del conflicto iniciado. Sus atribuciones van a estar consignadas por la voluntad de las partes, las cuales fijarán las líneas que éste no podrá superar. La finalidad será obtener un proceso en el que las partes sean las protagonistas, el mediador impulse y fomente el procedimiento y se obtenga un acuerdo de mediación. Aunque para que éste tenga fuerza ejecutiva deberá elevarse a escritura pública, ello no significa que le procedimiento esté fuera del poder judicial, sino que esta acción servirá como medida para el auxilio de la parte reclamante frente a la parte no cumplidora.

No hemos de olvidar que la finalidad de todo proceso de mediación es ofrecer una alternativa al proceso judicial o un complemento a éste. En el supuesto de mediación intrajudicial, tal y como señala MEJÍAS GOMEZ, es un "procedimiento claramente complementario a éste, con el que puede acoplarse, complementarse $y$ colaborar al objeto de prestar una óptima tutela judicial efectiva, tal y como ordena el artículo 24 de nuestra Constitución”.

\footnotetext{
${ }^{156}$ A modo de ejemplo BONET NAVARRO, A., Proceso civil y mediación: su análisis en la Ley 5/2012, de mediación en asuntos civiles y mercantiles, Aranzadi, Pamplona, 2013.
} 


\section{Modelos de mediación}

Dada la existencia de varios modelos de mediación, a continuación se procede a elegir alguno de ellos a modo de ejemplo. Así se analizará el Modelo tradicionalLineal, el Modelo Circular Narrativo y el Modelo Transformativo. No son modelos incompatibles, sino que pueden ser utilizados de manera complementaria entre ellos ${ }^{157} \mathrm{o}$ pueden utilizarse indistintamente para una misma situación.

\subsection{Modelo Tradicional-Lineal de Fisher y Ury}

El llamado Modelo Tradicional-Lineal ${ }^{158}$ fue elaborado por Roger Fisher y William Ury, ambos miembros del Harvard Negotiation Project ${ }^{159}$, por lo que suele identificarse como Método de Harvard. Se trata del modelo más extendido, primeramente enfocado en la negociación bilateral en política internacional y extendido posteriormente al ámbito del Derecho ${ }^{160}$. El método se basa en cinco premisas centradas en la transmisión clara de información entre las partes ${ }^{161}$ :

- Separar a las personas del problema.

- Centrarse en intereses, no en posiciones.

- Inventar opciones para ganar-ganar (ganar ambos).

- Insistencia en el manejo de criterios objetivos.

- Utilización de preguntas tales como ¿por qué? ¿Y por qué no? para el análisis de los intereses de los intervinientes ${ }^{162}$.

- $\quad$ Conoce tu BATNA (Best Alternative To Negotiated Agreement).

\footnotetext{
${ }^{157}$ VINYAMATA CAMP, E., Aprender mediación... op. cit., p. 24.

158 También denominado Program On Negotiation (PON)

${ }^{159}$ Harvard Negotiation Project. Para más información en https://www.pon.harvard.edu

${ }^{160}$ OTERO PARGA, M., "Los modelos teóricos de la mediación”, en M. Otero Parga, y H. Soleto Muñoz (coords.), Mediación y Solución de conflictos: Habilidades para una necesidad emergente, Tecnos, Madrid, 2007, pp. 158-171, esp. p.159.

${ }^{161}$ FISHER, R., URY, W., PATTON, B., Getting to Yes: Negotiating an Agreement Without Giving In, Random House Business Books, Londres, 1999, pp. 33 y ss.

162 GIMÉNEZ ROMERO, C., "Modelos de mediación y su aplicación en mediación intercultural”, Revista Migraciones 2001, $\mathrm{n}^{\circ}$ 10, pp. 1-32, esp. p. 5. Disponible en: http://www.maparegional.gob.ar (última visita 21/02/2018)
} 
Este modelo tiene su base en la negociación que deberán llevar las partes mediante una estrategia de tipo colaborativo. Se utiliza la comunicación lineal, con preguntas abiertas, tratando de evitar los interrogatorios cerrados con el fin de que las partes centren su mirada hacia el futuro, dejando de lado el pasado. Hay por tanto una cierta restricción de uso de preguntas cerradas, en tanto en cuanto éstas no dan lugar a respuestas flexibles. Procura distinguir y despejar las posiciones y necesidades de cada una de las partes, lograr un diálogo que minimice las diferencias y así construir el acuerdo que contemple la satisfacción de los intereses de las partes ${ }^{163}$. Prima la comunicación verbal sobre la que no lo es, y entiende el desacuerdo como la causa del conflicto, sin dotar de excesiva importancia a las causas u orígenes de aquél.

El objeto del proceso es cualquier tipo de conflictos, aunque es preferible en aquellos en los que no se precisa una mejora en la relación entre los mediados, y sobre todo, en los conflictos mercantiles. Se permiten sesiones conjuntas o individuales, manteniendo la confidencialidad por los aspectos desarrollados en cada una de ellas, aunque el mediador puede utilizar la información obtenida en dichas sesiones individuales para intentar fomentar el acuerdo.

El aspecto positivo de este modelo es el enfoque en las posiciones e intereses de las partes y la búsqueda de un beneficio mutuo a través del diálogo y las cesiones recíprocas en pos de finalizar el conflicto. En su contra, es un modelo que no se centra en el origen del problema, sino en la consecución de una solución ágil, económica y eficaz $^{164}$.

163 DIEGO VALLEJO, R., y GUILLÉN GESTOSO, C., Mediacion: proceso, tacticas y tecnicas, Ediciones Pirámide, Madrid, 2006, p. 58.

${ }^{164}$ OTERO PARGA, M., “Los modelos teóricos ...”, op. cit., p.160. 


\subsection{Modelo Circular Narrativo de Sara Cobb}

El nacimiento de este modelo se le atribuye a Sara Cobb, aunque existen multitud de obras que desarrollan esta figura ${ }^{165}$. La comunicación es el pilar básico y está orientado tanto al acuerdo como a la modificación de las relaciones entre las partes. Entiende al conflicto como un fenómeno permanente en las relaciones humanas. La función del mediador es ayudar a las partes a construir una nueva historia a partir del reconocimiento del otro, mediante la comunicación de tipo causal circular que les haga llegar a una comprensión compartida ${ }^{166}$. Este método de mediación, siendo el eje central la comunicación y el manejo de ésta, se basa en cuatro etapas:

- En primer lugar se inicia una pre-reunión, efectuada de forma individual con cada parte pudiendo ser desarrollada por un mediador diferente al que intervendrá en el proceso posterior. Con esta reunión se va a explicar a las partes las características del proceso, el desarrollo y etapas, confidencialidad, honorarios y duración.

- La primera etapa se integra en la primera intervención del mediador, el cual promoverá la primera reunión conjunta de las partes. Se establecerán las primeras pautas de progreso del proceso, así como las sesiones iniciales.

- Segunda etapa: El desarrollo de las sesiones individuales se inicia en la segunda fase, por la cual el mediador se reúne con cada una de las partes con el fin de conocer el problema, los recursos, las necesidades y peticiones a la otra parte.

\footnotetext{
165 COBB, S., "A narrative perspective on mediation: towards the materialization of the "storytelling" metaphor”, en J. Folger y Tricia J. (dirs.) New Directions in Mediation: Communication Research and Perspectives, Sage Publications, California, 1994, pp. 48-66; y WINSLADE, J., "Mediation with a focus on discursive positioning”, en Conflict Resolution Quarterly 2006, Vol. 23, n. ${ }^{\circ} 4$, pp. 501-513.

166 PARKINSON, L., Mediacion familiar. Teoria y practica: principios y estrategias operativas, traducción de Ana María Sánchez Durán, Gedisa, Barcelona, 2005, p. 58.
} 
- En tercera etapa se inicia la construcción de una historia alternativa, la cual se edifica tras la escucha y comunicación con ambas partes, tanto de manera individual como colectiva. La finalidad es observar los problemas que hubieron y crear una narración positiva para todos los intervinientes.

- Cuarta etapa: por último, en la cuarta etapa se van a producir las reuniones conjuntas para llegar a un acuerdo beneficioso para ambos.

Los elementos que componen este modelo se pueden sistematizar en la psicología del yo, la comunicación humana, la causalidad circular y la construcción de historias $^{167}$. Todo en su conjunto permite aumentar la autoestima e identidad de los intervinientes y facilita la resolución del conflicto.

\subsection{Modelo Transformativo de Bush y Folger}

Aunque el objetivo del modelo es la obtención de un acuerdo, la diferencia manifiesta en relación a los dos anteriores es la búsqueda de una modificación en la relación de las partes. Se considera primordial la actitud de los intervinientes en el conflicto, una actitud positiva en pos de transformar su conducta destructiva en constructiva $^{168}$.

Para el cumplimiento de dicha finalidad se establecerán reuniones conjuntas o individuales, con una intervención más marca del mediador, el cual intenta introducir una comunicación relacional de causalidad circular. Se procura que cada parte, a través de potenciar su protagonismo, pueda reconocer sus propias cuotas de responsabilidad en el conflicto surgido. El reconocimiento supone la consideración de la situación propia y del otro, poniéndose así cada interviniente “en los zapatos del otro”. Es de vital

\footnotetext{
167 SUARES, M., Mediación. Conducción de disputas, comunicación y técnicas, Paidós, Buenos Aires, 2010, pp. 60-63.

${ }^{168}$ BUSH, R., y FOLGER, J., The promise of mediation: the transformative approach to conflict, JosseyBass, San Francisco, 2005, pp. 22-23.
} 
importancia el impulso de una verdadera empatía y un comportamiento acorde que permita reinterpretar la conducta y comportamiento anterior, el poder analizar las situaciones desde una perspectiva que se había desconsiderado.

Las características de este proceso son muy variadas, pero podríamos resumirlas en las siguientes: revalorización y reconocimiento; asunción de responsabilidad; apoyo positivo del mediador; focalización en el presente; utilización de las opiniones de las partes en el pasado para un uso productivo en el presente; elogiar la voluntad constructiva de las partes ${ }^{169}$.

Bush y Folger consideran que la mediación ha sido exitosa, no cuando en la misma se llega a un acuerdo como objetivo, sino cuando mejoramiento de la situación de las partes comparada con lo que era antes. El éxito del proceso radicará en una mejora de las personas gracias al desarrollo del proceso, revalorizándose así esa parte $^{170}$. Al comprender que es libre para continuar o no en el proceso, para aceptarlo o rechazarlo y todas las demás alternativas existentes, aumentan sus propias habilidades en la resolución de Conflictos ${ }^{171}$.

El despliegue de este modelo se ha producido en aquellos lugares don los grupos sociales intervienen en los conflictos, como Canadá o Nueva Zelanda. Todo ello nos lleva a pensar en conflictos "públicos" o "comunitarios", como los más pertinentes para su aplicación. Aunque realmente estaríamos ante comunidades dispuestas a reforzar las relaciones entre sus miembros, cooperando para la obtención de una sociedad más integrada y pacífica.

\footnotetext{
${ }^{169}$ DIEGO VALLEJO, R., y GUILLÉN GESTOSO, C., Mediación: proceso, tácticas ... op. cit., pp. 5758.

${ }^{170}$ Según Bush y Folger, una parte resulta revalorizada en la mediación cuando alcanza una comprensión más clara, comparada con la situación anterior. Comprende más claramente cuáles son sus metas y sus intereses en la situación dada, porque persigue esas metas considerando que ellas son importantes y merecen consideración. Se cobra conciencia de la gama de alternativas que puede garantizarles total o parcialmente la obtención de sus metas, y de su control sobre esas alternativas. Comprende que existen decisiones, con respecto a lo que se debe hacer en la situación y que ejerce cierto control sobre dichas decisiones.

${ }^{171}$ El participante aprende a escuchar, a mejorar la comunicación, organizar y analizar cuestiones, a presentar argumentos, utilizar técnicas como la ubicación de ideas, evaluar soluciones alternativas y a tomar conciencia de los recursos que posee.
} 


\section{El procedimiento de mediación nacional extratrajudicial e intrajudicial: dos formas de mediar casi idénticas.}

Es importante examinar las diferencias existentes entre la mediación intrajudicial y extrajudicial ya que dependiendo de cuál de ellas se elija, se iniciará o no un procedimiento judicial previo.

5.1 Mediación Intrajudicial versus Extrajudicial: las mínimas pero sustanciales diferencias.

Pueden destacarse multitud de caracteres que asemejan o diferencian a ambas figuras. Iniciando el estudio por las similitudes, la semejanza más considerable es su finalidad y el método para su consecución. Son un medio para la obtención de un acuerdo que solucione el conflicto y beneficie a ambas partes, y el desarrollo de este proceso se va a realizar conforme a la Ley 5/2012. La resolución pacífica de controversias será el pilar de ambas opciones. Estamos ante un mismo proceso, con las mismas características, idénticas finalidades y similar desarrollo de las sesiones.

La diferencia por la cual nos ha obligado a profundizar en el tema es el cauce utilizado para el inicio del proceso de mediación. Estamos ante un proceso de mediación intrajudicial ${ }^{172}$ cuando se ha iniciado ya un procedimiento judicial y es el juez el que invita a las partes a resolver sus diferencias a través de un procedimiento de mediación. Será por tanto aquella "que se lleve a cabo una vez se haya iniciado un proceso a través de demanda, y en cualquier momento de su devenir, es decir, que es posible que exista mediación al principio del proceso civil, en pleno proceso e incluso en fase de ejecución de sentencia” ${ }^{173}$. En cambio, estaremos ante un proceso de mediación

\footnotetext{
${ }^{172}$ Recuérdese que las partes enfrentadas que han iniciado un proceso Judicial son dirigidas por el Juez para resolver sus diferencias en un procedimiento de Mediación con un Mediador cualificado y fuera del proceso judicial.

${ }^{173}$ SOLETO MUÑOZ, H., "La nueva normativa estatal sobre mediación civil y mercantil y el proceso civil”, en Diario La Ley 2012, n 7834. Disponible en www.diariolaley.es (última visita 11/04/2018)
} 
extrajudicial cuando son las partes las que eligen resolver sus diferencias ante un mediador sin haber iniciado previamente un procedimiento judicial. En segundo lugar rige también la celeridad del proceso puesto que en la extrajudicial podemos observar que hay una mayor brevedad debido a la ausencia de iniciación previa de un procedimiento judicial, necesitándose la decisión judicial de ventilar el conflicto por métodos complementarios. A parte, la incoación previa del proceso judicial supondrá un aumento de los costes derivados del proceso ante los Tribunales a consecuencia de los recursos necesarios.

En cuanto a los medios necesarios para el desarrollo de la práctica, la mediación intrajudicial requiere abogados y/o procuradores de las partes, un mediador, un juez, un secretario judicial, y la infraestructura administrativa del juzgado, mientras que la mediación extrajudicial sólo requiere un mediador, un notario en el supuesto en que quieran elevar el acuerdo a escritura pública y la infraestructura administrativa del notario y del mediador.

\begin{tabular}{|c|c|}
\hline $\begin{array}{l}\text { MEDIACIÓN } \\
\text { INTRAJ UDICIAL }\end{array}$ & $\begin{array}{l}\text { MEDIACIÓN } \\
\text { EXTRAJ UDICIAL }\end{array}$ \\
\hline $\begin{array}{l}\text { Necesidad de procedimiento } \\
\text { judicial previo }\end{array}$ & $\begin{array}{l}\text { Sin necesidad de procedimiento } \\
\text { judicial previo. }\end{array}$ \\
\hline $\begin{array}{l}\text { Mayor brevedad y celeridad } \\
\text { respecto al procedimiento judicial }\end{array}$ & $\begin{array}{l}\text { Mayor brevedad y celeridad } \\
\text { respecto al procedimiento judicial y } \\
\text { a la mediación intrajudicial }\end{array}$ \\
\hline $\begin{array}{l}\text { Menores costes que el } \\
\text { procedimiento judicial pero } \\
\text { necesidad de un gran número de } \\
\text { recursos }\end{array}$ & $\begin{array}{l}\text { Pocos recursos y pocos costes para } \\
\text { ambas partes. }\end{array}$ \\
\hline
\end{tabular}

Figura 2. Mediación intrajudicial vs Mediación extrajudicial. Fuente: Elaboración propia 
Ambos procedimientos seguirán una serie de pautas para la consecución de un acuerdo exitoso que beneficie a ambas partes, prosiguiendo con lo estipulado en los artículos 16 y siguientes de la Ley 5/2012. En primer lugar, el proceso de mediación, ya sea intrajudicial o extrajudicial podrá iniciarse de varias maneras, conforme a lo estipulado en el artículo 16 de dicha Ley de mediación civil:

a) De común acuerdo entre las partes. En este caso la solicitud ${ }^{174}$ incluirá la designación del mediador o la institución de mediación en la que llevarán a cabo la mediación, así como el acuerdo sobre el lugar en el que se desarrollarán las sesiones y la lengua o lenguas de las actuaciones.

b) Por una de las partes en cumplimiento de un pacto de sometimiento a mediación existente entre aquéllas.

El legislador ha querido que el juez tenga importancia en este procedimiento y pueda ayudar a las partes a encontrar una solución ${ }^{175}$, conforme a lo estipulado en los artículos 414 y 428 de la LEC por los cuales se prevé la posibilidad de exhortar a las partes para la obtención de un acuerdo que ponga fin al litigio.

Cuando de manera voluntaria se inicie una mediación estando en curso un proceso judicial, las partes de común acuerdo podrán solicitar su suspensión de conformidad con lo dispuesto en el artículo 19 de la LEC. A través de la facultad de sometimiento a mediación del objeto del proceso se consigue una mayor facilidad de acceso a la mediación intrajudicial y la oportunidad de resolución de conflictos a través de medios complementarios al sistema de justicia actual.

Los Tribunales deben de valorar la controversia sometida a su decisión ${ }^{176}$ y esta valoración ha de indicarles cual es la vía más beneficiosa para su resolución. Si

\footnotetext{
${ }^{174}$ La solicitud se formulará ante las instituciones de mediación o ante le mediador propuesto por una de las partes a las demás o ya designado por ellas.

175 ALASTRUEY GARCÍA, R., Argumentario sobre la búsqueda de soluciones negociadas en el proceso civil, 2010, pp. 3-5 y 10-15. Disponible en: www.poderjudicial.es (Última visita: 09/11/2017)

${ }^{176}$ La selección de los casos que se van a derivar a mediación la realizará el órgano judicial, invitando a las partes y sus abogados a que acudan a una sesión informativa, la cual se realizará por los jueces o por los secretarios judiciales. El juzgado resolverá indicando la derivación del conflicto a la Institución de
} 
considerasen que es la mediación, harán ver a las partes y a sus letrados su postura, indicándole los fines de la mediación, sus ventajas, la posibilidad de recuperar ese diálogo roto entre las partes, la capacidad de éstas para actuar en el procedimiento, ser las protagonistas y buscar una solución que beneficie a ambos. Un sistema de Justicia eficaz y eficiente precisa de la implementación de servicios. TORRES GÁMEZ nos indica que “...en este contexto conseguir un acuerdo o no, es un éxito añadido, el verdadero éxito de la mediación reside en rebajar la tensión y animadversión acumulada entre las personas enfrentadas..."177.

Recibida la solicitud y salvo pacto en contrario de las partes, el mediador ${ }^{178}$ o la institución de mediación, citará a las partes para la celebración de la sesión informativa. En caso de inasistencia injustificada de cualquiera de las partes a la sesión informativa se entenderá que desisten de la mediación solicitada.

En dicha sesión de mediación, tanto judicial como extrajudicial, el mediador informará a las partes de las posibles causas que puedan afectar a su imparcialidad, de su profesión, formación y experiencia; así como de las características de la mediación, tales como la libre disposición, igualdad de las partes, voluntariedad e imparcialidad, neutralidad de los mediadores, su coste, la organización del procedimiento y las consecuencias jurídicas del acuerdo que se pudiera alcanzar, así como del plazo para firmar el acta de la sesión constitutiva.

La mediación, judicial y extrajudicial, será llevada a cabo por uno o varios mediadores. La duración del procedimiento de mediación será lo más breve posible y

Mediación o al mediador que acuerden las partes. El juzgado cumplimentará una ficha de derivación que indicará el tipo de proceso, cuestiones sobre las que versa el litigio, momento procesal en el que está la causa, datos personales de los litigantes y de sus abogados

177 TORRES GÁMEZ, A., "Mediación intrajudicial civil. Reflejo Jurisprudencial”, en Revista Aranzadi Doctrinal 2015, $\mathrm{n}^{\circ}$ 3, pp. 243-263, esp. p. 246. Disponible en: http://www.mediacion.icav.es (Última visita: 09/11/2017)

${ }^{178}$ El mediador deberá ser designado por las partes, ya sea a través de la solicitud de mutuo acuerdo en la cual se designe un mediador concreto, o a través de una propuesta a una institución de mediación, a diferencia de lo regulado en otros países, en los cuales, como por ejemplo en Italia, el mediador es designado únicamente por un organismo de mediación. DOMÍNGUEZ RUIZ, L., "La mediación civil y mercantil en Europa: estudio comparado del Derecho italiano y español”, en Revista Aranzadi Doctrinal 2012, no 11, pp. 139-157, esp. p. 148. 
sus actuaciones se concentrarán en el mínimo número de sesiones ${ }^{179}$. Se realizará una sesión constitutiva ${ }^{180}$ en la que las partes expresarán su deseo de desarrollar la mediación y dejarán constancia de los siguientes aspectos:

a) La identificación de las partes. En principio, deberán ser las partes las que actúen en el procedimiento, pero al no indicarnos nada en la Ley, podrán actuar por sí mismas o por representantes.

b) La designación del mediador y, en su caso, de la institución de mediación o la aceptación del designado por una de las partes.

c) El objeto del conflicto que se somete al procedimiento de mediación.

d) El programa de actuaciones ${ }^{181}$ y duración máxima prevista para el desarrollo del procedimiento, sin perjuicio de su posible modificación por el devenir del procedimiento.

e) La información del coste de la mediación o las bases para su determinación, con indicación separada de los honorarios del mediador y de otros posibles gastos.

f) La declaración de aceptación voluntaria por las partes de la mediación y a través de la cual se comprometen a asumir las obligaciones de ella derivadas.

g) El lugar de celebración y la lengua del procedimiento, pudiendo ser cualquier idioma oficial en España o idioma extranjero.

El procedimiento de mediación puede concluir en acuerdo o finalizar sin alcanzar dicho acuerdo, bien sea porque todas o alguna de las partes lo decidan así o bien porque haya transcurrido el plazo máximo acordado por las partes para la duración del procedimiento, así como cuando el mediador aprecie de manera justificada que las posiciones de las partes son irreconciliables.

\footnotetext{
179 Artículo 20 de la Ley 5/2012.

${ }^{180}$ Artículo 19 de la Ley 5/2012.

181 Según BUTTS GRIGGS, T., “¡Cuidado, calla!...: el dilema del negociador en la mediación”, en H. Soleto Muñoz (dir.), E. Carretero Morales, C. Ruiz López (coords), Mediación y resolución ... op. cit., pp. 225-238, esp. pp.229-230, el mediador ha de desarrollar este programa a través de: a) análisis del conflicto; b) búsqueda de intereses; c) generación de opciones; d) exploración de las opciones; y e) consecución de acuerdos).
} 
Con la terminación del procedimiento se devolverán a cada parte los documentos que hubiere aportado. Con aquellos que no tengan que devolverse, se formará un expediente que deberá conservar y custodiar el mediador o la institución de mediación por un plazo de cuatro meses.

El acta final determinará la conclusión del procedimiento y reflejará los acuerdos alcanzados de forma clara y comprensible, o su finalización por cualquier otra causa. Deberá ir firmada por todas las partes y por el mediador o mediadores y se entregará un ejemplar original a cada una de ellas.

El acuerdo de mediación puede versar sobre una parte o sobre la totalidad de las materias sometidas a la mediación. Deberá constar la identidad y el domicilio de las partes, el lugar y fecha en que se suscribe así como las obligaciones que cada parte contra. Debe de haber indicación del mediador o mediadores que han intervenido o de la institución de mediación en la cual se ha desarrollado el procedimiento. El acuerdo de mediación deberá firmarse por las partes o sus representantes. Tiene carácter vinculante y carácter ejecutivo como si de una sentencia se tratase, en consecuencia será refrendado por el juez que debiera de conocer del asunto y lo derivó al proceso de mediación. En el supuesto de mediación extrajudicial las partes pueden instar su elevación a escritura pública al objeto de configurar su acuerdo como un título ejecutivo.

Es importante implantar un sistema de mediación dentro de los Tribunales, no como un sistema obligatorio o como un sistema de mediación prejudicial obligatoria (aspecto ya planteado desde Europa ${ }^{182}$ ), sino como un sistema voluntario al servicio de los litigantes que así lo deseen y con una amplia participación de los agentes judiciales que velen por el cumplimiento de las legalidades y, sobretodo, por la satisfacción de las partes.

${ }^{182}$ ALASTRUEY, R., “La mediación intrajudicial en...” op. cit., p. 124. 


\subsection{Acuerdo de mediación extrajudicial e intrajudicial: contenido y desarrollo.}

Desde el cuerpo normativo no se confecciona una definición de "acuerdo de mediación”. Desde la doctrina se ha de detallar y delimitar dicho concepto nacido de aquellos puntos en común a los que han llegado las partes para resolver la controversia. El acuerdo sería un resultado deseable o exitoso de la mediación ${ }^{183}$. El artículo 1 define qué es la mediación y denomina al acuerdo como fin propio de aquel medio ${ }^{184}$. LORCA NAVARRETE lo considera como “... el único modo formal o adjetivo de poner término a la mediación; un acuerdo definitivo cuyo contenido será invariable...”185.

El acuerdo de mediación es un contrato ${ }^{186}$, que genera obligaciones para ambas partes y cuya finalidad es la solución de una controversia mediante la autocomposición $^{187}$ de las partes, con la asistencia de un mediador imparcial, permitiéndoles una satisfacción total o parcial de sus pretensiones y evitando así un pleito o poniendo fin al ya iniciado ${ }^{188}$.

Numerosos autores consideran que el acuerdo de mediación es una transacción ${ }^{189}$, con "estructura bifronte" ${ }^{190}$ y que despliega efectos en los planos

\footnotetext{
${ }^{183}$ FERNÁNDEZ BALLESTEROS, M. A., Avenencia o ADR. ... op. cit., p. 283. Al hablar sobre el acuerdo lo denomina como la "meta de la mediación"

${ }^{184}$ TAMAYO HAYA, S., “Artículo 23”, en L., García Villaluenga, C. Rogel Vide, (dirs.), Mediación en asuntos civiles y mercantiles. Comentarios a la Ley 5/2012, Reus, Madrid, 2012, p. 290: "En todo caso, la mediación no supone sino una posible vía para llegar a la transacción, que es el fin. Se configura pues la mediación como el medio o vehículo para alcanzar un resultado, la transacción, como resulta el proceso o el arbitraje el medio para lograr una sentencia o laudo".

${ }^{185}$ LORCA NAVARRETE, A.M., La mediación en asuntos civiles y mercantiles, Instituto Vasco de Derecho Procesal, San Sebastián, 2012, p. 183.

${ }^{186}$ FERNÁNDEZ BALLESTEROS, M. A., Avenencia o ADR. ... op. cit., p. 283

${ }^{187}$ Informe del Consejo General del Poder Judicial al Anteproyecto de Ley de Mediación en Asuntos Civiles y Mercantiles, p. 21: "la mediación es un método de solución de controversias jurídicas basado en la autocomposición, de tal forma que son las propias partes las que ponen fin al conflicto por vía del acuerdo".

${ }^{188}$ LÓPEZ DE ARGUMEDO, A., y FERNÁNDEZ DE LA MELA, J.M, “El acuerdo de mediación”, en La Ley 2015, n. ${ }^{\circ} 8477$, p.6.

${ }^{189}$ SENÉS MOTILLA, C., "La eficacia del compromiso de mediación y de los acuerdos de mediación”, en legaltoday.com 2012, Documento en línea; VARA GONZÁLEZ, J. M., "Aspectos notariales de la Ley de Mediación. Referencia a la mediación familiar”, en Revista Jurídica del Notariado 2012, nº 82, p. 456; y ANDRÉS CIURANA, B., "La mediación civil y mercantil: una asignatura pendiente en España", en Actualidad Jurídica Uría Menéndez 2005, nº 12, pp. 60-69, esp. p. 65.

${ }^{190}$ DíEZ-PICAZO PONCE DE LEÓN, L., Fundamentos del Derecho Civil patrimonial, vol. IV, Las particulares relaciones obligatorias, Civitas, , 2012, Cizur Menor pp. 706.
} 
obligacional y procesal ${ }^{191}$. Obligacional ya que es un contrato que crea obligaciones para ambas partes (art. 1089 CC) y tiene fuerza de ley para las partes (art. 1091 CC), y procesal porque el acuerdo podrá hacerse valer en un posterior proceso judicial o arbitral que tuviera por objeto alguna de las cuestiones tratadas y resueltas en el acuerdo de mediación ${ }^{192}$ mediante la excepción de transacción o exceptio pacti o exceptio litis per transactionem finitae, similar a la excepción de cosa juzgada material (art. 1816 CC) ${ }^{193}$

Una vez que las partes alcanzan el acuerdo, el cual puede versar sobre una parte o sobre la totalidad de las materias sometidas a la mediación, se dará por concluido el procedimiento de mediación, pasándose a la fase del cumplimiento del acuerdo pactado.

El acuerdo de mediación se elaborará por escrito, no siendo posible un acuerdo in voce. El fundamento a esta solemnidad es porque la forma escrita, como bien indica el profesor LORCA NAVARRETE ${ }^{194}$, es ad validitatem y ad substantion. En este acuerdo se deberá hacer constar la identidad y el domicilio de las partes, el lugar y fecha en que se suscribe, las obligaciones que cada parte asume y el procedimiento de mediación ajustado a las previsiones de la Ley, con indicación del mediador, mediadores o institución de mediación que han intervenido y desarrollado el procedimiento $^{195}$. Ambas partes deberán firma el acuerdo, ya sea por sí mismas o a través de sus representantes, y se entregará un ejemplar a cada parte y otro al mediador, el cual deberá de conservarlo.

\footnotetext{
${ }^{191}$ GULLÓN BALLESTEROS, A., “Artículo 1809”, en C. Paz-Ares Rodríguez, L. Díez-Picazo Ponce De León, R. Bercovitz, y P. Salvador Coderch, (coords.), Comentario del Código Civil, tomo II, Ministerio de Justicia, Madrid, 1991,: "Transacción y sentencia. La primera afirmación que hace el artículo que se comenta es la que la transacción tiene para las partes autoridad de cosa juzgada. Por tanto, no se trata de una mera duplicación del art. 1091, se quiere decir algo más que es un contrato del que surge una ley privada. Se quiere darle una eficacia procesal, en cuanto es productor de una excepción, oponible a cualquiera de los transigentes que, vigente la transacción, pretenda llevar la cuestión que se discutió y zanjó al conocimiento de la autoridad judicial”, p. 1774.

${ }^{192}$ DÍEZ-PICAZO PONCE DE LEÓN, L., Fundamentos del Derecho ... op. cit., p. 712.

${ }^{193}$ GULLÓN BALLESTEROS, A., “Artículo 1809...” op. cit. p. 1774: “Esa excepción es la exceptio rei per transactionem finitae, paralela a la excepción de cosa juzgada material, y sujeta por tanto a los mismos límites subjetivos que delimitan ésta (STS 28-XI-84 y 10-IV-85)”.

${ }^{194}$ LORCA NAVARRETE, A.M., La mediación en asuntos ... op. cit., p. 185.

${ }^{195}$ Artículo 23 de la Ley 5/2012.
} 
Una vez que ya tenemos el acuerdo, a través de éste se podrá exigir su cumplimiento, porque si el acuerdo de mediación es válido en derecho en virtud del art. 1255 CC, éste es “una ley entre las partes” ex art. 1091 del Código Civil, así, en virtud del principio pacta sunt servanda, la parte que esté interesada en su cumplimiento tendrá a su alcance los remedios previstos para la defensa y protección de sus intereses contractuales $^{196}$.

En principio podríamos aducir que al acudir las partes voluntariamente y llegar a la realización del acuerdo, éste se cumplirá de forma voluntaria. Pero esto no es siempre así y por ello la Ley 5/2012 recoge la posibilidad de convertir ese acuerdo en escritura pública para que tenga así fuerza ejecutiva. Como acertadamente señala LORCA NAVARRETE, “...tras la "voluntariedad” concretada en el compromiso de someter a mediación las controversias surgidas o que puedan surgir, nos topamos con un título ejecutivo. E insisto, ¡no hay jurisdiccionalismo que valga! O, en fin, justificación jurisdiccionalista de semejante título ejecutivo....”197.

Nuestro ordenamiento jurídico sólo otorga fuerza ejecutiva a los acuerdos de mediación extrajudiciales cuando las partes opten voluntariamente a su elevación a escritura pública ante notario, el cual deberá de comprobar si el acuerdo cumple con todos los requisitos legales anteriormente señalados, y si fuera así, pasaría a ser por tanto un título ejecutivo ante los Tribunales. Es el artículo 25 de la Ley 5/2012 el que regula la elevación a escritura pública, señalándonos que las partes deberán de entregar al notario el acuerdo junto a la copia de las actas de sesión constitutiva y final del procedimiento. Pero no se nos indica nada acerca de si han de ser ambas partes o sólo una (con el consentimiento de la otra) la que ha de entregar el acuerdo para su elevación

\footnotetext{
${ }^{196}$ La parte interesada podrá ejercitar la acción de cumplimiento contractual (actio ex contractu) del art. 1091 CC, la acción de indemnización de daños y perjuicios (art. 1101 CC), la acción de remoción (art. 1098 II CC) o la acción resolutoria (art. 1124 CC).

${ }^{197}$ LORCA NAVARRETE, A.M., La mediación en asuntos ... op. cit., p. 195.
} 
a escritura pública, aspecto que regula la Directiva 2008/52/CE al advertir que basta con que lo presente una de las partes pero con consentimiento de la otra ${ }^{198}$.

A la hora de su ejecución, será competente conforme al art. 26 de la Ley 5/2012 el Juzgado de Primera Instancia del lugar en que se hubiera firmado el acuerdo de mediación, de acuerdo con lo previsto en el apartado 2 del artículo 545 de la Ley de Enjuiciamiento Civil: a través del cual cuando el título sea un laudo arbitral o un acuerdo de mediación, será competente para denegar o autorizar la ejecución y el correspondiente despacho el Juzgado de Primera Instancia del lugar en que se haya dictado el laudo o se hubiera firmado el acuerdo de mediación.

En cuanto al acuerdo de mediación intrajudicial, aquel alcanzado con posterioridad al inicio de un procedimiento judicial, el artículo 25.4 de la Ley 5/2012 indica que "cuando el acuerdo se hubiere alcanzado en una mediación desarrollada después de iniciar un proceso judicial, las partes podrán solicitar del tribunal su homologación de acuerdo con lo dispuesto en la Ley de Enjuiciamiento Civil”. Este auto tendrá fuerza ejecutiva de conformidad al artículo 517 de la Ley de Enjuiciamiento Civil. CUENCA BURGOS nos indica que “... si la mediación ha sido alcanzada después de haberse iniciado un proceso judicial las partes podrán pedir su homologación judicial, lo que supone que el efecto del acuerdo de mediación se equipara a cualquier resolución judicial, a excepción hecha de los acuerdos que sean contrarios a derecho..." ${ }^{199}$. Siguiendo a SÁNCHEZ HERNÁNDEZ ${ }^{200}$, puede darse que si el acuerdo es total, el procedimiento finaliza cuando las partes lo solicitan mediante el dictado de un auto que homologue el acuerdo, como nos indica el artículo 206.1.2 ${ }^{\mathrm{a}}$ LEC,

\footnotetext{
${ }^{198}$ Recuérdese artículo 6 de la Directiva 2008/52/CE: “Los Estados miembros garantizarán que las partes, o una de ellas con el consentimiento explícito de las demás, puedan solicitar que se dé carácter ejecutivo al contenido de un acuerdo escrito resultante de una mediación. El contenido de tal acuerdo se hará ejecutivo a menos que, en el caso de que se trate, bien el contenido de ese acuerdo sea contrario al Derecho del Estado miembro donde se formule la solicitud, bien la legislación de ese Estado miembro no contemple su carácter ejecutivo".

${ }^{199}$ CUENCA BURGOS, ML., "Mediación en el ámbito mercantil: una solución alternativa”, en REFOR Revista 2011, n 34, pp. 29-31, esp. p. 30.

${ }^{200}$ SÁNCHEZ HERNÁNDEZ, R., "Procedimiento y ejecución de acuerdos", en C. BOLDÓ RODA (coord.), La mediación en asuntos mercantiles, Tirant Lo Blanch, Valencia, 2015, pp. 111-144, esp. p. 135
} 
pero si el acuerdo es parcial el procedimiento judicial continuaría por el resto de pretensiones $^{201}$.

Respecto al órgano competente para la ejecución el artículo 26 de la Ley 5/2012 señala que "la ejecución de los acuerdos resultado de una mediación iniciada estando en curso un proceso se instará ante el tribunal que homologó el acuerdo". En estos casos se acudirá al juez que conoció del asunto y lo derivó a un proceso de mediación para que ejecute el acuerdo de mediación.

Puede suceder que el ejecutado se oponga a la ejecución del acuerdo de mediación, aspecto de gran relevancia aunque no muy ocasional en la práctica. Para la resolución de esta situación hemos de acudir al artículo 556 LEC, el cual señala que "si el título ejecutivo fuera una resolución procesal o arbitral de condena o un acuerdo de mediación, el ejecutado, dentro de los diez días siguientes a la notificación del auto en que se despache ejecución, podrá oponerse a ella por escrito alegando el pago o cumplimiento de lo ordenado en la sentencia, laudo o acuerdo, que habrá de justificar documentalmente”. También cabe la oposición por defectos procesales como indica el artículo 559.1.3 LEC cuando el acuerdo de mediación “no cumpla los requisitos legales exigidos para llevar aparejada ejecución, o por infracción, al despacharse ejecución, de lo dispuesto en el artículo 520”.

Se podría considerar que la firmeza de este acuerdo de mediación erosiona su esencia contractual, se borran las fronteras con el arbitraje ${ }^{202}$ y que la regulación de esta figura sólo conseguirá que haya más acuerdos, pero de menos calidad. No es menos cierto que aunque la mediación sea una figura espontánea y libre, es necesaria una regulación. En cuanto al acuerdo de mediación es necesario que tenga firmeza y fuerza ejecutiva ya que asegura su cumplimiento. ¿De qué sirve un acuerdo si no se puede cumplir?

\footnotetext{
${ }^{201}$ Véase SÁNCHEZ MARTÍN, P., “Incidencia de la mediación en el proceso civil”, en La Ley: Práctica de los Tribunales 2012, ${ }^{\circ}$ 98-99, pp. 60-71.

${ }^{202}$ Como sucede con la Ley de Marruecos sobre Convenios arbitrales y de mediación de 2008. Véase MESBAHI, A.R., “The new Moroccan Law”, en Jorunal of Arab Arbitration 2009, Vol. 1, nº 05, pp. 1126.
} 


\section{CAPÍTULO TERCERO}

\section{LA FIGURA DEL MEDIADOR}

"Si tu única herramienta es un martillo, tiendes a tratar cada problema como si fuera

un clavo"

Abraham Maslow (1908-1970)

La Ley 5/2012, de 5 de marzo, de mediación en asuntos civiles y mercantiles, configura en sus artículos 11 al 15 el Estatuto del Mediador, indicándonos que puede ser mediador la persona natural en pleno ejercicio de sus derechos civiles, siempre que no se lo impida la legislación que regula su ejercicio profesional.

Si miramos atrás en el tiempo, podemos encontrarnos con una figura del mediador ya existente y de gran valor, aunque con una connotación parcialmente diferente. Los pueblos nómadas y las tribus solían resolver sus problemas mediante la mediación del más anciano ${ }^{203}$ del clan, el cual se basaba en su sabiduría y experiencia para resolver el conflicto o para ayudar a las partes que lo resolviesen.

Esta figura fue desarrollándose con el transcurso del tiempo dentro de las diferentes culturas y de los diferentes pueblos, desde la Edad Antigua pasando por la Edad Media y llegando a nuestros tiempos, con gran relevancia incluso en asuntos de Estado. A modo de ejemplo, y en palabras de MIRANZO DE MATEO, pueden encontrarse procesos de mediación en el Tribunal de las Aguas de Valencia, el cual, desde el siglo XIII, y con la participación de campesinos, consiguió el efectivo desarrollo de una institución con características similares a la mediación para el reparto

\footnotetext{
${ }^{203}$ El pater familias de la sociedad romana, el padrino de la camorra o el patriarca gitano son considerados los responsables de la sociedad de referencia y su decisión tenía una fuerza mayor que la de cosa juzgada.
} 
equitativo del agua; en el Papa Inocencio X y su ejercicio de mediador entre Austria y Francia en 1648; o la gestionada por Napoleón III en 1866 entre Austria y Prusia ${ }^{204}$.

En las culturas orientales, como China y Japón, la mediación ha existido desde los orígenes de las primeras civilizaciones. En el primero de ellos, esta práctica era el principal recurso para la solución de conflictos ${ }^{205}$.

\section{El estatuto del mediador}

Tal y como se reconoce en el propio Preámbulo de la Ley 5/2012, “la figura del mediador es, de acuerdo con su conformación natural, la pieza esencial del modelo, puesto que es quien ayuda a encontrar una solución dialogada y voluntariamente querida por las partes”

La Ley regula el Estatuto del mediador en el Título III, en el cual determina cuáles han de ser los requisitos que ha de cumplir un mediador para poder desempeñar profesionalmente su labor, así como los principios que han de regir su actuación y su responsabilidad civil. Así también el Real Decreto 980/2013, de 13 de diciembre, por el que se desarrollan determinados aspectos de la Ley 5/2012, de 6 de julio, de mediación en asuntos civiles y mercantiles regula aspectos relativos al estatuto del mediador, señalando que las instituciones de mediación podrán exigir mayores requisitos que los que se establecen en las citadas normas. Este Real Decreto, tal y como advierte MARTÍN DIZ, "supone la intervención directa del Gobierno [...], en aras de incrementar la seguridad jurídica y la confianza y conocimiento de la mediación por los ciudadanos y las empresas, el contenido de la norma de referencia en cuatro grandes aspectos que son de vital importancia: formación del mediador, publicidad y registro público del ejercicio de la profesión de mediador, responsabilidad del

\footnotetext{
204 A modo de ejemplo puede citarse. Vid. MIRANZO DE MATEO, S., "Quiénes somos, a dónde vamos... origen y evolución del concepto de mediación”, en Revista de Mediación 2010, n 5, pp. 8-15, esp. pp. 10-11.

${ }^{205}$ Confucio afirma que "la resolución adecuada de un conflicto se logra únicamente a través de la persuasión moral del tipo de conducta a seguir siendo inadmisible la imposición de un acuerdo a través de la coacción”. Vid. MIRANZO DE MATEO, S., “Quiénes somos, a ...”, op, cit., p. 11.
} 
mediador y de las instituciones de mediación y, finalmente, el establecimiento de un modelo legal de procedimiento de mediación a través de medios electrónicos y de telecomunicaciones" 206 .

\subsection{Condiciones para ejercer de mediador}

El artículo 11.1 de la Ley 5/2012 indica que sólo pueden ser mediadores las personas naturales, no obstante el segundo párrafo supera esta limitada concepción permitiendo que las sociedades jurídicas se dediquen al ejercicio de esta profesión; si bien para ello deberán designar para su ejercicio a una persona natural que reúna los requisitos previstos en la Ley. El requisito de la existencia de una persona física será de indispensable cumplimiento, pudiendo existir o no una sociedad jurídica que resuelva el conflicto.

Para que una persona física pueda desempeñar dicha función, en primer lugar deberá de hallarse en pleno ejercicio de sus derechos civiles, dicho de otra manera, tener capacidad para obrar o desarrollar una actuación válida y eficaz desde el punto de vista jurídico $^{207}$. Ello impide que pueda ejercer de mediador todo aquél que esté incapacitado por sentencia judicial firme (sin importar el grado de incapacitación), aquél que haya sido declarado pródigo, ni aquél que haya sido declarado en concurso (menos cuando este sea declarado como concurso culpable $\left.{ }^{208}\right)$.

En segundo lugar, no ha de existir impedimento legal por ejercicio de profesión, función o cargo, aunque en principio prima la no existencia de actividades que

\footnotetext{
206 MARTÍ́N DIZ, F., "Real Decreto 980/2013, de 13 de diciembre, por el que se desarrollan determinados aspectos de la Ley 5/2012, de 6 de julio, de mediación en asuntos civiles y mercantiles [BOE n. ${ }^{\circ}$ 310, de 27-XII-2013]”, en Ars Iuris Salmanticensis: AIS : revista europea e iberoamericana de pensamiento y análisis de derecho, ciencia política y criminología 2014, vol. 2, nº 1, pp. 268-269, esp. p. 268.

${ }^{207}$ BOLDÓ RODA, C., La mediación en asuntos mercantiles, Tirant lo Blanch, Valencia, 2015, p.50.

${ }^{208}$ Vid. Artículos 40 y 172 de la Ley 22/2003, de 9 de julio, Concursal
} 
ocasionen este impedimento ${ }^{209}$. Las actuaciones del mediador favorecen al no ejercicio de ninguna profesión con incompatibilidades funcionales con dicha ocupación ${ }^{210}$.

En tercer lugar va a ser el artículo 11.2 de la ley, exige que el mediador deba estar en posesión de título oficial universitario o de formación profesional superior ${ }^{211}$. Aquí no se indica a qué área de conocimiento debe de pertenecer el título, así que no se limita a ningún sector específico de la cultura, ciencia o la tecnología ${ }^{212}$. Aunque es de lógica que se necesitará estar en posesión de unas habilidades psicológicas y jurídicas que le permitan ofrecer una resolución del conflicto adecuada a las necesidades de los participantes.

En cuarto lugar el mediador ha de ser un experto en las cuestiones en disputa, debiendo de dominar un amplio conocimiento acerca de cuestiones legales. Los mediadores han de conocer la norma aplicable al caso concreto, ya sea como límite máximo o mínimo de la negociación ${ }^{213}$. No en vano, estas competencias en leyes deberán ser complementadas por una sabiduría de la rama de la psicología, pues es de indudable importancia la necesidad de ellos para la afrontación de las múltiples situaciones emocionales a las cuales puede enfrentarse todo mediador. Una composición de ambos discernimientos (sin desmerecer cualquier otro estudio que el sujeto pueda dominar) debería ser primordial para una resolución de los conflictos en todo tipo de ámbitos jurisdiccionales, una consecución de un acuerdo beneficioso y acondicionado a sus necesidades. Todo esto sin obviar con aquella y necesaria formación detallada que será adquirida a través de los cursos específicos que deberán de impartir las instituciones debidamente acreditadas para el ejercicio de la actividad mediadora.

\footnotetext{
${ }^{209}$ Eso sí, la Ley 60/2003, de 23 de diciembre, de Arbitraje, en su artículo 17.4, impide que un sujeto ejerza como árbitro en aquellos conflictos en los que ejerció como mediador. Su finalidad es que este individuo árbitro no tenga una visión ya del problema y una opinión sobre las posturas de las partes que le impidan el cumplimiento de sus obligaciones de imparcialidad.

${ }^{210}$ BARONA VILAR, S., Mediación en asuntos ... op. cit., pp. 231 y ss.

${ }^{211}$ El título necesitado va a ser la titulación de Diplomado, Ingenio Técnico o Arquitecto Técnico, Graduado, Licenciado, Máster Oficial o doctor.

${ }^{212}$ BARONA VILAR, S., Mediación en asuntos ... op. cit. pp.234-235

${ }^{213}$ LUQUIN VERGARECHE, R., Los principios de la mediación, en La mediación en asuntos civiles y mercantiles. La transposición de la Directiva 2008/52 en Francia y España, La Ley, Madrid, 2013, p.133.
} 
El Gobierno, a iniciativa del Ministerio de Justicia, podrá determinar la duración y contenido mínimo del curso o cursos que con carácter previo habrán de realizar los mediadores para adquirir la formación necesaria para el desempeño de la mediación, así como la formación continua que deben recibir ${ }^{214}$. Este contenido se verá indicado en el Real Decreto 980/2013 por el que se desarrollan determinados aspectos de la Ley 5/2012 a cuyo contenido nos remitimos.

Con carácter general se ha de señalar una serie de aspectos de gran relevancia. Es de vital alcance señalar que la formación será pilar básico para el desarrollo del proceso, debiéndose proporcionar a los mediadores conocimientos y habilidades suficientes para el ejercicio profesional de mediación. La generalidad de estos conceptos desarrollados normativamente nos muestra la necesaria regulación específica acerca de ellos, lo cual nos conducirá a una mayor uniformidad a desarrollar en los distintos programas de formación. Un desarrollo y estudio tanto a nivel teórico como práctico será necesario para el perfeccionamiento de la figura, correspondiendo a este último, un 35 por ciento de la duración mínima del curso prevista para la formación del mediador, que será al menos de 100 horas, tanto a nivel nacional como a través de agencias internacionales. En cuanto a la formación continua de los mediadores, el legislador establece en el artículo 6 que éstos deberán realizar una o varias actividades de formación al menos cada cinco años con una duración mínima de 20 horas.

\subsection{La responsabilidad como condición básica para el ejercicio de su encargo.}

Expuesta ya la formación de los mediadores, la responsabilidad de éstos será el foco de atención en estos momentos. Podemos situarla en el artículo 14 de la ley cuando nos indica que "la aceptación de la mediación obliga a los mediadores a cumplir fielmente el encargo, incurriendo, si no lo hicieren, en responsabilidad por los daños y perjuicios que causaren. El perjudicado tendrá acción directa contra el mediador y, en su caso, la institución de mediación que corresponda con independencia de las acciones de reembolso que asistan a ésta contra los mediadores. La responsabilidad de

${ }^{214}$ Disposición Final Octava, (apartado 2) Ley 5/2012. 
la institución de mediación derivará de la designación del mediador o del incumplimiento de las obligaciones que le incumben”.

No obstante habrá de completarse con aquellas regulaciones autonómicas que de modo previo regularon otros tipos de mediación. Es de nuestro interés analizar y valorar lo contemplado en la Ley 1/2006, de 6 de abril, de Mediación Familiar de Castilla y León.

En esta Ley se regulan una serie de infracciones que podríamos tipificar como leves, graves o muy graves, a las cuales se les asigna una sanción previa la instrucción de un procedimiento administrativo contradictorio llevado a cabo por la Consejería competente en materia de mediación familiar. Surge la posibilidad de mejorar e implantar una regulación similar a nivel estatal. Según dicha ley de mediación familiar de Castilla y León, en los artículos 22 a 25, el mediador puede cometer infracciones leves, graves y muy graves en el ejercicio de sus funciones.

A estas infracciones hay que añadirle una serie de sanciones reguladas en el artículo 26 de dicha Ley de mediación familiar, las cuales se corresponderán según la gravedad de la actuación del mediador. A aquellas infracciones leves, se les impondrá una sanción de amonestación por escrito; a las infracciones graves se les castiga con una suspensión temporal, con baja en el Registro de Mediadores Familiares de Castilla y León, para poder actuar como profesional de la mediación por un período de hasta un año; a las infracciones graves se les aplica también una suspensión temporal pero de mayor entidad, con baja en el Registro de Mediadores Familiares de Castilla y León, para poder actuar como profesional de la mediación por un período de uno a quince años y si se castigase el ejercicio de la mediación familiar incumpliendo los requisitos exigidos para el ejercicio de la actividad, se castigará además con multa por importe entre 1.000 y 5.000 euros $^{215}$.

\footnotetext{
${ }^{215}$ Estas infracciones varían mucho, y como bien dice PAZ-PEÑUELAS BENEDÉ, Ma.P., "El mediador civil y mercantil en el ordenamiento jurídico español: una propuesta de lege ferenda", en Diario La Ley 2015, n 8621, pp. 1-14, esp. p. 11, en "Illes Balears sube la cuantía máxima de la multa muy grave hasta
} 


\subsection{Registro de mediadores.}

Este Real Decreto 980/2013 crea el Registro de Mediadores e Instituciones de Mediación en los artículos 8 a $24^{216}$, que tiene por finalidad facilitar el acceso de los ciudadanos a este medio de solución de controversias a través de la publicidad de los mediadores profesionales y las instituciones de mediación. El Registro de Mediadores e Instituciones de Mediación depende del Ministerio de Justicia y el Director General de los Registros y del Notariado tiene la condición de responsable del Registro.

La inscripción de los mediadores y de las instituciones de mediación en el Registro será voluntaria ${ }^{217}$, y permitirá acreditar la condición de mediador, así como el carácter de institución de mediación. El alta no excluye la responsabilidad del mediador ni de la institución de mediación respecto del cumplimiento de los requisitos que les son exigibles ni la que les corresponda en el ejercicio de su actividad.

Para que los mediadores puedan inscribirse, deben enviar la solicitud correspondiente al registro, en el que constarán, junto a la declaración responsable sobre su veracidad, los siguientes datos recogidos en el artículo 14: su nombre, apellidos y número de identificación fiscal; dirección profesional e información de contacto, incluidos su correo electrónico y sitio web si lo tuvieren; titulación, formación específica de mediación y experiencia profesional; área geográfica principal o preferente de actuación profesional, incluido cuando sea todo el territorio nacional o comprenda también otros Estados; póliza del contrato de seguro de responsabilidad civil profesional o, en su caso, del certificado de cobertura expedido por la entidad aseguradora o la garantía equivalente que se hubiera constituido. Se indicará una dirección electrónica de la entidad aseguradora o de la entidad de crédito en la que

los 120.000 euros y, finalmente, Castilla-La Mancha aumenta todas las cuantías, de manera que la multa por infracción leve puede llegar a los 3.005,06 euros, por infracción grave hasta 15.025,30 euros y por infracción muy grave hasta 601.012,10 euros”.

${ }^{216}$ El Registro de Mediadores e Instituciones de Mediación se estructura en tres secciones:

1 En la sección primera del Registro se inscribirán los mediadores.

2 En la sección segunda del Registro se inscribirán los mediadores concursales.

3 En la sección tercera del Registro se inscribirán las instituciones de mediación.

217 Según el artículo 11 la solicitud de inscripción en el Registro comportará el consentimiento para el tratamiento de los datos que se proporcionen y su publicidad. 
constituyera la garantía equivalente; su integración en alguna institución de mediación; y su inscripción, en su caso, en algún otro registro de mediadores dependiente de otra Administración pública.

\subsection{Costes de la mediación}

El desarrollo de todo proceso de mediación ocasiona una serie de gastos que serán a cargo de las partes, de los cuales podemos desglosarlos en los honorarios del mediador y cualquier otra circunstancia que pueda surgir o facturarse.

En la primera sesión informativa, el mediador ha de comunicar a las partes el coste de sus servicios $^{218}$, así como la obligatoriedad de división de dichas tarifas en partes iguales, salvo que exista pacto en contrario acordado por los intervinientes. Esta comunicación se hará efectiva una vez ya iniciado el procedimiento, repitiéndose a tal fin dicha información en la sesión constitutiva y añadiéndose al acta del acuerdo.

Existen otras cuantías que surgen con el devenir de los acontecimientos, otros gastos que incluso le pueden perjudicar al propio mediador, los cuales deberán ser satisfechos por las partes. Éstos gastos pueden ser de muy diferente tipología, ya sean por los desplazamientos para escuchar y atender a las partes, los gastos de comunicación, desembolsos por el uso del espacio donde se desarrolle el proceso, el empleo de medios electrónicos, grabaciones, videoconferencias, etc. ${ }^{219}$

La Disposición Adicional Segunda de la Ley de mediación centra su atención en el “Impulso a la mediación”, previendo que las Administraciones públicas competentes procuren en incluir la mediación dentro del asesoramiento y orientación gratuita previo al proceso, previstos en el artículo 6 de la Ley 1/1996, de 10 de enero, de Asistencia Jurídica Gratuita, en la medida que permita reducir tanto la litigiosidad como sus costes. La finalidad de esta disposición es la ayuda a aquellas personas sin recursos económicos

\footnotetext{
${ }^{218}$ Los mediadores podrán exigir a las partes la provisión de fondos que estimen necesaria para atender el coste de la mediación. Si alguna de las partes o ambas no realizarán en plazo el pago, el mediador podrá dar por concluida la mediación.

${ }^{219}$ BOLDÓ RODA, C., La mediación en asuntos ..., op. cit., p.75
} 
para acudir al proceso de mediación, procurando que los costes de la mediación no sean un obstáculo que impidan a cualquier ciudadano poder acudir a ella para resolver sus conflictos.

\section{El rol del mediador.}

En el presente subcapítulo se realiza referencia al rol del mediador, videlicet, a las funciones que éste tiene para el desarrollo exitoso del proceso, así como las técnicas que puede prácticas para la consecución de sus fines.

\subsection{El mediador como conductor del proceso.}

El mediador es un conductor en los inicios, el desarrollo y el final de las sesiones de mediación. Para la correcta ejecución de dicha función se debe de estar ante un líder, pero no un líder unidireccional, sino aquel que debe de adecuarse a las circunstancias de la situación y las características de las partes.

Pueden encontrarse dos estrategias totalmente dispares y polarizadas. En primer lugar el mediador iría invadiendo el rol de protagonista de las partes, perdiéndose la naturaleza del proceso; en segundo lugar se está ante una mediación metodológicamente fija, inmutable, la cual nunca se adaptaría a la naturaleza del conflicto, sino que éste se adaptaría al proceso. Ambos son erróneos, ya quela mediación ha de adaptarse a las partes y éstas han de ser las protagonistas a través de la utilización de multitud de estilos que le adapten al mediador a aquellas circunstancias que se escapen de la normalidad.

Por ello la pregunta clave ¿cuál es el rol del mediador? La respuesta es sencilla: “facilitar una discusión centrada en los intereses, mediante técnicas relativas al proceso y la comunicación entre las partes, que permita desvelar las preocupaciones y problemas de las partes, e implicándolas en la búsqueda de soluciones y acuerdos”220.

\footnotetext{
${ }^{220}$ ALCOVER DE LA HERA, C., "La mediación como estrategia para la resolución de conflictos: una perspectiva psicosocial”, en M. Gonzalo Quiroga (dir.), Métodos alternativos de solución de conflictos: perspectiva multidisciplinar, Dykinson, Madrid, 2006, pp. 113-129, esp. p. 119.
} 
Así que el mediador debe de profundizar su labor en mejorar la comunicación entre las partes, a los cuales ayudará a comprender el origen del problema, conociendo así sus intereses, permitiéndoles conocer los intereses del otro interviniente y acercarles a la consecución de una solución consensuada entre ambos protagonistas.

La función del mediador deberá ser permitir que fluya le diálogo entre ambas partes, las deberán de respetar los turnos de palabra del contrario. No permitirá las descalificaciones ni faltas de respeto entre ellos, reconduciendo la plática a un punto de vista positivo y pacífico. Para ello es imprescindible una actuación neutral e imparcial, sin posicionamiento en favor de ninguno pero buscando que cada uno de ellos comprenda la situación de la otra parte.

La labor del mediador no tendrá como objetivo por sí mismo la resolución del conflicto sino que centrará sus actuaciones en ayudar a que las partes encuentren la solución que más les convenga; pero si el proceso ha llegado a un estancamiento y no se prevén avances, podrá sugerir alguna solución que tenga que ver con aquellas que han estado tanteando las partes. Ello puede ser algo contraproducente cuando la solución del mediador conduzca a una intervención precipitada o parcial, o cuando pueda producir un sentimiento de presión en alguna de las partes debido a que la figura del mediador le influye.

La última gran función del mediador será decidir si es posible o no resolver la cuestión a través del procedimiento de mediación, analizando y detectando el problema que impide dicha resolución. No podrá continuar con el proceso si existe un gran desequilibrio de poder entre las partes; la relación esté tan deteriorada que sea imposible, no sólo llegar a un acuerdo, sino incluso darse capacidad de escucha o comunicación; se observe que por la relación o circunstancia, deba de intervenir la figura de un tercero que resuelva el conflicto; se requiera la intervención de otras instancias como jueces; existan indicios de delito o de trastornos psicológicos graves; y/o las soluciones afectan a terceras personas que no quieren implicarse en la mediación. 


\subsection{El mediador como observador}

La función del mediador no es únicamente la conducción del proceso, sino que podemos catalogarle como un observador, ya que debe de tener una mirada "hacia sí mismo” y “mirada hacia el otro" 221.

Respecto al primero de los puntos controvertidos, la mirada "hacia sí mismo”, su utilidad está focalizada en el desarrollo de un conocimiento relativo a sus expresiones y emociones que deberá de transmitir durante el proceso de manera corporal. Es fundamental que el mediador tenga una debida formación y especialización para el conocimiento de sus debilidades, sus puntos fuertes, sentimientos, emociones y todas aquellas facetas que desplegará. Difundir confianza y seguridad será esencial para las partes y la consecución de un procedimiento eficaz. Estas habilidades de diálogo y sobretodo de exteriorización, ayudarán al cumplimiento de los fines de la mediación: como decirlo y cómo moverse al decirlo son la triple estructura básica de la comunicación humana ${ }^{222}$.

Es primordial que a la hora de formar a mediadores se realicen actividades para que el mediador desarrolle esta mirada hacia sí mismo y así comprenda las reacciones que su cuerpo tiene ante estas situaciones. Por tanto, se han de dominar materias como la autoconciencia emocional (el conocimiento que uno tiene sobre sí mismo, sus reacciones emocionales y físicas ante las situaciones), una coherencia en las reacciones de su cuerpo, emoción y el lenguaje, y una reconstrucción lingüística de las conversaciones $^{223}$ para comprender las emociones que subyacen. Por tanto, de esto podemos ultimar que de cada frase que se haga se puede conocer la emoción de la persona, ya sea arrepentimiento, venganza o miedo.

\footnotetext{
${ }^{221}$ MÉNDEZ BARRIO, M., “La comunicación no verbal y las técnicas activas aplicadas a la mediación”, en R. Castillejo Manzanares (dir.) y C. Torrado Tarrío (coord.), La mediación: nuevas ..., op. cit., pp. 101-126, p. 106.

${ }^{222}$ POYATOS, F., La comunicación no verbal. Cultura lenguaje y conversión, Ediciones Istmo S.A., Madrid, 1994, p. 175

${ }^{223}$ MÉNDEZ BARRIO, M., “La comunicación no verbal” op. cit., pp. 101-126, p.106.
} 
En cuanto a la mirada "hacia el otro", es un aspecto de gran consideración ya que el mediador ha de estar a las reacciones corporales y anímicas de los mediados y percibir así sus sentimientos. Esto es significativo puesto que en multitud de ocasiones con las palabras no se expresa todo lo que uno tiene en su interior, aquello que una persona siente acerca de un tema o de otro ser, pero con los gestos que realice se pueden encontrar sus sentimientos. Es en estas conductas no verbales donde la expresión de cuantiosos sentimientos sin que uno mismo se esté dando cuenta de ello “fundamentaliza” el proceso y proporciona una base para el entendimiento. No siempre las palabras expresan la verdadera intención de un sujeto, la cual puede habitar oculta bajo una máscara endulzada con palabras, siendo elemental el lenguaje corporal para el florecimiento de las verídicas pretensiones. La conducta no verbal puede debilitar, confirmar o reforzar un mensaje hablado, de ahí su vital valor en este tipo de procesos.

El mediador deberá atender a detalles surgidos imprevisiblemente, como un gesto, una lágrima, la respiración del sujeto, un tono de voz o una mirada. Ello otorgará una mejor capacidad de entendimiento de la postura de las partes, acercándonos a una pronta solución del conflicto. La respiración del sujeto tiene gran importancia y puede indicarnos si una conducta nos lleva a un sitio o a otro, o si un gesto significa miedo o resentimiento. Por ello hay que estudiar muy minuciosamente la respiración del mediado para poder analizar sus emociones. Esto es algo que nos explica muy bien BLOCH ARENDT ${ }^{224}$ de lo cual nos parece oportuno explicar.

La autora descubrió la existencia de una serie de patrones efectores emocionales y la manera en que pueden iniciarse a través de la respiración. Aplicando un enfoque experimental al estudio del proceso de emocionarse, los resultados que obtuvo representaron un avance significativo al conocimiento de las emociones, y de impacto en las interrogaciones acerca del funcionamiento cerebral. Con ello demostró la existencia de una propagación o efecto desde las respuestas comportamentales hacia los estados motivacionales internos.

\footnotetext{
${ }^{224}$ BLOCH ARENDT, S., Alba emoting. Managing emotions through breathing. The alba of emotions, Ediciones Ultramarinos, Santiago de Chile, 2006, p. 261.
} 
Midiendo patrones respiratorios bajo inducción emocional en condiciones controladas de laboratorio, identificó la existencia de seis patrones respiratorios diferenciados, correspondientes a seis emociones básicas: alegría (risa, felicidad), tristeza (llanto, depresión), miedo (angustia, ansiedad) rabia (enojo, agresión, ira,) erotismo (sexualidad) y ternura (amor parental, filial, amistad). Esta serie de emociones tendrán repercusiones en relación a la respiración del sujeto, encontrándonos con unas características propias de cada una de ellas, salvo que el individuo tenga capacidad de dominar su respiración y la kinésica que lo acompaña.

El efecto negativo a todo lo anteriormente desarrollado lo encontramos en una serie de variables no fijas, las cuales pueden modificarse por diferentes razones, tales factores culturales o entrenamiento previo. La presencia de multitud de factores pueden altera el lenguaje verbal y no verbal, no existiendo un listado invariable o consolidado de expresiones que signifiquen lo mismo, sino que es el mediador el que, en cada caso concreto, ha de analizar las expresiones en un entorno y situación determinada, para poder comprender el conflicto y favorecer su solución.

\section{Abogacía y mediación: una relación complicada}

En nuestra cultura judicial existe la creencia de que en un conflicto ha de existir un ganador y un perdedor. Esto se vio potenciado desde las primeras legislaciones y han sido los Colegios de abogados, la judicatura y las universidades ${ }^{225}$ las que lo han asentado como una creencia única. Pero hoy en día podemos observar una creciente doctrina que reniega de esta única posibilidad, pudiendo existir conflictos que otorguen el status de ganador a ambas partes, las cuales se habrán servido del apoyo y de la ayuda del mediador para llegar a ese resultado satisfactorio para ambos.

\footnotetext{
${ }^{225}$ BARONA VILAR, S. “La incorporación de la Mediación en el nuevo modelo de justicia”, en AA.VV. Estudios jurídicos en homenaje a Vicente L. Montés Penadés, Tirant lo Blanch, Valencia, 2011, pp. 227 250, esp. p. 228 y ss.
} 


\subsection{Problemas por la actual situación.}

En la regulación actual la figura del abogado queda “alejada” del proceso de mediación, sólo pudiendo acudir como un apoyo en favor de su cliente. Para ejemplificar esto sólo debemos de acudir a la gran mayoría de los contenciosos que se producen en la práctica negocial, los cuales terminan en acuerdos propiciados por los letrados buscando no llegar a los tribunales y evitar así todos los inconvenientes que esto supone a modo de transacción extrajudicial

En algunos países del mundo, como Argentina, la figura del mediador se relaciona con la abogacía, siendo obligatorio que el primero de ellos sea un profesional de la abogacía. En España, el legislador ha preferido no optar por este sistema y no limitar el acceso a otros profesionales cuya intervención, por la especialidad de la materia, pudiera resultar conveniente ${ }^{226}$.

En las conclusiones presentadas en el "Taller de Derivación a la Mediación. Mediación conectada con el Tribunal”, daban valor a la actuación de todo abogado en un proceso de mediación ${ }^{227}$, recogiéndose las siguientes actuaciones como propias e indispensables de los letrados ${ }^{228}$ :

- Asesorar sobre la conveniencia o no de acudir a la mediación, teniendo en cuenta el asunto concreto y el tipo de conflicto

- Redactar el acuerdo para mediar, en el que deben incluirse las condiciones y fases de la mediación, los representantes de las partes, las bases para la elección del mediador y regular, en su caso, la intervención de terceros.

- Preparar la estrategia de las partes para la mediación.

- Representar a las partes o asistirlas durante las sesiones.

\footnotetext{
${ }^{226}$ Un buen ejemplo de esto son los conflictos de familia, en los que la intervención del experto en psicología y relaciones sociales no sólo está justificada, sino que es altamente recomendable.

${ }^{227}$ Consejo General del Poder Judicial, Conclusiones Taller de Derivación a la Mediación. Mediación conectada con el Tribunal, Madrid, 24, 25 y 26 de mayo de 2010, pp. 1-23, esp. pp. 4-6, 12-13, y 16-18. ${ }^{228}$ FAJARDO MARTOS, P., La posición del abogado en el proceso de Mediación, p 5, disponible en: http://www.mediacion.icav.es (Última visita: 09/11/2017)
} 
- Redactar el acuerdo y controlar que se cumplen los requisitos de capacidad y de forma así como la viabilidad del cumplimiento.

- Que no obstaculice los intentos de mediación o el desarrollo de la misma.

Pero aquí nos podemos encontrar con ciertos problemas, algunos innatos de la situación, y otros por las quejas de los propios abogados, los cuales iremos analizando a continuación.

En este apartado se estudian los problemas derivados por la actual situación de la mediación respecto a la posición de los abogados. Hay materias cuya tecnicidad jurídica permiten la presencia de un abogado, el cual posee unos conocimientos sobre la materia que desconocen los expertos en otras disciplinas. Por ello acudimos a la opinión de ÍSCAR ÁLVAREZ que nos indica “qué sentido tiene que abogados en ejercicio se vean obligados a realizar unos cursos específicos para acceder a la condición de mediador, siendo así que el conocimiento de la materia de estos cursos de formación, según el dictado de la ley, y con exclusión de los conocimientos en materia de psicología, se le suponen al abogado, por su condición profesional"229. Efectivamente, los conocimientos jurídicos, técnicas de comunicación y negociación forman parte de la formación del abogado, pudiendo ser unos perfectos mediadores en el supuesto en que así se necesite.

En efecto, la necesidad de una formación específica es una exigencia de Directiva 2008/52/CE del Parlamento Europeo y del Consejo, de 21 de mayo de 2008, sobre ciertos aspectos de la mediación en asuntos civiles y mercantiles, que prescribe la necesidad de que todo mediador haya realizado previamente unos cursos de mediación. Esto es algo lógico y necesario, pero sólo para aquellos que no tienen formación legal y pretenden practicar este modo alternativo de resolución de conflictos.

${ }^{229}$ ÍSCAR ÁLVAREZ, F., Abogacía y mediación, Artículo en línea. Disponible en http://www.forjib.org (Última visita: 09/11/2017) 


\subsection{Problemática por las reclamaciones de abogados y papel de estos en la mediación.}

No es un secreto decir que la gran mayoría de la abogacía rehúye de la institución de la mediación. La opinión de los letrados depende del conocimiento que tengan sobre esta figura y sobre sus expectativas profesionales. Gran mayoría ha rechazado la práctica y su futuro. La tachaban de un mecanismo sin sentido y una forma de alargar el proceso innecesariamente pues, para ellos, todo conflicto acabará finalmente ante los Tribunales, previo o no proceso de mediación.

El rechazo a la mediación por parte de muchos abogados está originado por la ausencia de mediación en nuestra historia, y por consiguiente, por la poca o nula formación y conocimiento que atesoran sobre la materia. Este desconocimiento provoca la aparición de miedos y recelos. Temen perder su status, sus funciones, viendo su trabajo sustituido o sencillamente comprometer a su cliente a consecuencia del desconocimiento de la institución y de los profesionales que de ella se encargan ${ }^{230}$. En la mediación se utilizan técnicas del mundo psicosocial, desconocidas para la mayoría de los abogados, los cuales están anclados en el sistema del proceso tradicional.

Otro aspecto al cual temen, es el denominado intrusismo. Consideran a la entrada de la mediación como la apertura del derecho a otros profesionales, los cuales irrumpen en su oficio, alejándoles de su papel y provocando que se disipe su "poder" dentro de la resolución de conflictos y pierdan así ingresos con la posible disminución de “clientela”231. Es más, gran parte de los letrados se consideran mediadores ya que estiman su función como conciliadora o negociadora, estando dentro del término que ellos entienden por mediación.

\footnotetext{
${ }^{230}$ ORTUÑO MUÑOZ, P., "Perspectivas de futuro de los métodos alternativos y complementarios de resolución de conflictos”, en J. Sigüenza López y G. García-Rostán Calvín (dirs.) Estudios sobre mediación ... op. cit., pp. 45-66, esp. p. 53

${ }^{231}$ QUINTANA GARCÍA, A., “Abogados, mediación y viceversa (una reflexión personal)”, en K. Brown y M. Concepción Rayón (coords.), Mediación: Experiencias desde ..., op. cit.,, pp. 155-163, esp. p. 157.
} 
La amplia dispersión normativa existente sobre mediación ocasiona un gran recelo en los abogados. La normativa autonómica indica dispares requisitos para la obtención del título de mediador, diferentes servicios de mediación, desemejantes organismos públicos implicados, etc. Ello nos conduce a una gran desconfianza relativa a su inclusión por parte de los poderes públicos. El recelo incluso se expande hasta la normativa estatal, creando así multitud de dudas y confusiones.

No obstante, uno de los principales temores de este colectivo a la mediación tiene un marcado aspecto económico. En ocasiones observan a esta figura como un impedimento para la obtención de sus honorarios, los cuales pueden llegar a descender en proporción al aumento de los procesos de mediación. Recelos basados en suposiciones sin una base sólida al no existir en la actualidad una práctica de mediación lo suficientemente avanzada y asentada que proporcione datos sobre la situación. Estas retribuciones deberán de fijarse en unos criterios de minutación mínimos y máximos y nunca deberán fijarse a modo de quota litis porque su función en el proceso de mediación no es conseguir a su cliente una cuantía o resultado, sino auxiliarle para que él lo pueda lograr

ALES SIOLI trata efectivamente este problema, y por ello no hay mejor que citar sus palabras: "Bajo el prisma del pesimismo están quienes entienden que la mediación no es un método alternativo a la justicia, tan sólo se trata de una complementariedad que tienda a diversificar el trabajo de resolución, y que supondría un alargamiento en la resolución de los mismos: De igual forma, existe una especial resistencia al cambio por parte de los profesionales que trabajan en el ámbito de la atención familiar, quizás producido por el temor a una pérdida de poder en la decisión de la solución de los conflictos, una pérdida de ingresos por honorarios o el temor que pueden tener ciertos profesionales a trabajar sin la existencia de documentos y si tan solo con relaciones personales. Por último, incluiríamos entre los puntos de vista pesimistas, la desvalorización que hacen los abogados, trabajadores sociales o 
psicólogos, al entender que siempre han sido a través de la historia, negociadores, y la mediación no es algo nuevo, distinto a lo que ya se hace”232.

Por tanto, es importante hacer ver a todos los abogados su importancia en la mediación, y adecuarla lo suficiente para que ellos se vean valiosos en el proceso, no teniendo temor alguno. Así, el abogado puede tener gran importancia como "filtro" a la hora de valorar si un ciudadano debe de acudir a sede judicial o a la mediación. Será él quien reciba al cliente, el que escuche su problema y el que valore cómo ha de resolverse, indicando qué camino ha de escogerse para la solución de la controversia.

Pero, aunque se tome el camino de la mediación, la labor del letrado no se quedará estancada en ser un filtro, sino que podrá asesorar a su cliente. MARTÍN DIZ lo indica extraordinariamente, al decir que "es muy recomendable, desde el primer momento que surge el conflicto, la asistencia y consejo del profesional del Derecho. Aunque las normas legales vigentes en materia de mediación guardan silencio absoluto al respecto, nosotros consideramos de capital importancia el dotarse de orientación profesional del abogado o abogada desde el primer momento, aunque la mediación sea $n$ medio de solución extrajudicial. Es cierto, y así debe mantenerse según nuestro criterio, que no debe de ser en ningún caso obligatoria la utilización de abogado o abogada en la mediación" 233.

El abogado deberá de favorecer en todo momento el desarrollo de la mediación, intentando no inmiscuirse nada más que en asesorar a su cliente. Su papel no es cosechar un pacto, sino socorrer a su cliente y asesorarle para que sea él quien trabaje por ese convenio de mediación. Una vez finalizada la mediación, el letrado debe de supervisar el acuerdo y aconsejar al cliente en todo aquello en que pueda haber salido desfavorecido. Una vez que se considere válido, debe de buscar que ese acuerdo sea eficaz y lo homologará judicialmente.

\footnotetext{
${ }^{232}$ ALES SIOLI, J., “La deontología del Abogado en la mediación familiar”, en Revista La Toga 2004, nº 147, pp. 66-69, esp. p. 67.

${ }^{233}$ MARTÍN DIZ, F. "La mediación, sistema complementario de Administración de justicia”, Consejo General del Poder Judicial, Madrid, 2010, p 110.
} 
Por tanto su papel en la mediación puede ser muy importante, siempre y cuando sea la de asesorar al cliente. El papel del abogado ha de ser de orientación a su cliente para la obtención de un acuerdo, nunca la de negociación por él mismo con otro abogado o con la otra parte directamente.

\subsection{Propuestas de mejora.}

La necesidad de cambios dentro de la abogacía es evidente pues es inevitable la adaptación de esta profesión a los nuevos aires reparativos que hacen su aparición. Han de tratar de ser los propios colegios profesionales los que se esfuercen en promover un cambio. Una aclimatación necesaria a las corrientes negociadoras o colaborativas.

\subsubsection{El Derecho colaborativo. Un gran paso para la resolución pacífica de} conflictos.

La sustitución del sistema adversarial por un sistema colaborativo puede ser beneficiosa. La abogacía ha de dar un paso y afrontar los conflictos con un enfoque multidisciplinar, incoando un procedimiento basado en el trabajo común para la resolución de dichas posiciones enfrentadas.

Para ello se ha de implementar el denominado Derecho colaborativo ${ }^{234}$. Una nueva visión de las actuaciones de los letrados por las cuales, a través de la firma de un convenio, las partes renuncien a la incoación de un procedimiento ante los Tribunales en pos de una resolución pacífica y común, atendiendo a sus intereses. Para la consecución de estos fines, será vital la intervención de diversos profesionales de diferentes ramas, como mediadores o psicólogos.

Se parte de un derecho contrario al sistema adversarial, primando el diálogo y la voluntariedad para la toma de decisiones. La resolución no va a estar dictada por un órgano investido de justicia, sino que serán los propios afectados, representados por los

\footnotetext{
${ }^{234}$ Para un estudio pormenorizado de la materia, vid. SOLETO MUÑOZ, H., y RUIZ LÓPEZ, C., "Elementos esenciales del Derecho colaborativo", en Anuario de mediación y solución de conflictos 2015, $\mathrm{n}^{\circ}$ 3, pp. 95-117.
} 
abogados, los que trabajen en común. Se prima satisfacer los intereses y necesidades de las partes. El proceso se desarrollará conforme a las técnicas de la negociación ${ }^{235}$, estando así ante un proceso muy similar en el que la búsqueda de un acuerdo resultará de un pacto entre los abogados de ambas partes.

Su origen se remonta en Estados Unidos, años 70, cuando el profesor SANDER $^{236}$ expuso sus teorías relativas a una mejora de la justicia a través de resoluciones más convenientes a la situación surgida. Se permite así ventilar los conflictos fuera de los Tribunales a través del denominado Multidoor Courthouse ${ }^{237}$. Son diferentes metodologías para la resolución alternative de conflictos como el arbitraje o la mediación, aunque, en el Derecho Colaborativo se enfocaría más concretamente en la negociación.

Al resolverse la disputa en favor de la satisfacción de los intereses de las partes, va a compartir con los ADR los mismos principios, tales la voluntariedad, confidencialidad, flexibilidad, igualdad y autodeterminación de las partes. Como podemos observar, este Derecho Colaborativo podría equipararse a estos métodos alternativos, pero existen una serie de características propias que le dan una significación distinta de todos ellos.

Tal y como exponen SOLETO MUÑOZ y RUIZ LOPEZ ${ }^{238}$, esta figura permite que sean los abogados quienes intenten resolver el conflicto. Para ello tendrán reuniones conjuntas entre los letrados de las partes, en las que intervendrán diferentes sujetos multidisciplinares que permitan una resolución más adecuada. Estas aportaciones comunes suponen una ocupación y contacto entre los “colegas” de la abogacía a fin de existir una actuación conjunta y sistemática en favor de los clientes. Todo ello

\footnotetext{
${ }^{235}$ Para un mayor examen de la negociación y sus técnicas vid. FISHER, R., et al., Getting to Yes: Negotiating Agreement without Giving in, Houghton Mifflin, Boston, 1991.

${ }^{236}$ Vid. SANDER, F., "Varieties of dispute processing", en A. Levin y R. Wheeler (eds), The Pound Conference: Perspectives on Justice in the Future, West Publications, Saint Paul, 1976, pp. 111-134.

${ }^{237}$ SOLETO MUÑOZ, H., y RUIZ LÓPEZ, C., “Elementos esenciales del ...” op. cit., pp. 95-117, esp. p. 97.

${ }^{238}$ SOLETO MUÑOZ, H., y RUIZ LÓPEZ, C., “Elementos esenciales del ...” op. cit., pp. 95-117, esp. pp. 102-106.
} 
excluyendo las actuaciones de la vía judicial, desatascando así los Tribunales de multitud de asuntos sin relevancia jurídica ${ }^{239}$.

Aunque la inclusión de este Derecho Colaborativo pueda suponer una ardua tarea para multitud de abogados, puesto que el sistema confortativo ha sido pieza clave en la composición de Estudios de Derecho, observamos un halo de esperanza. Observamos que ya es una realidad a pequeña escala, pero siempre increscendo, siendo un claro reflejo del cambio social y jurídico ${ }^{240}$ que está sucediendo en España. No obstante, expandir este paradigma colaborativo constituye no solo un nuevo sistema educacional, sino también una permuta en la visión de los letrados acerca de la resolución de conflictos.

\subsubsection{La formación de los letrados.}

La formación de este colectivo profesional ha de ir encaminada a un entendimiento de la mediación como un complemento, nunca como un sustitutoria del sistema clásico de aplicación de justicia. Han de comprender las ventajas que la mediación puede aportar al ciudadano e incluso a ellos mismos. Se ha de potenciar la figura del abogado dentro del proceso de mediación como un apoyo a su cliente o, incluso, la figura del abogado-mediador, el cual podrá compaginar ambas profesiones $^{241}$.

Este segundo apartado ha de ser fundamental ya que la formación tendrá que ir enfocada a conocimientos psicológicos que les son extraños en su día a día, obviándose

\footnotetext{
${ }^{239}$ CARRETERO MORALES, E., "Los jueces muchas veces se quejan, y con razón, de que tienen que resolver cuestiones que no deberían haber llegado a los tribunales”, en Blog: Diálogos de Actualidad. Disponible en: https://dialogosdeactualidad.com (Última visita: 09/11/2017); BRAVO, J.A., "El atasco judicial pasa factura a la economía”, en Invesión\&finanzas.com, 22 de febrero de 2016. Disponible en: http://www.finanzas.com (Última visita: 09/11/2017)

${ }^{240}$ SOLETO MUÑOZ, H., y RUIZ LÓPEZ, C., “Elementos esenciales del ...” op. cit., pp. 95-117, esp. p. 117.

${ }^{241}$ En relación a la formación de abogados-mediadores realizado por el MediaIcam véase NAVAS PAÚS, E., "La formación del mediador”, en K. Brown y M. Concepción Rayón (coords.), Mediación: Experiencias desde ..., op. cit.,, pp. 201-207.
} 
todos aquellos que ya formen parte de su práctica diaria. La formación de abogadosmediadores, a modo de mejora en el futuro, deberá profundizar en:

- Conocimiento legal y estratégico del sector en el que se desarrolla la actividad comercial del cliente. Este conocimiento es fundamental para poder analizar debidamente el conflicto y elegir la estrategia de solución adecuada.

- Conocimiento de la mediación así como de las diversas instituciones de mediación nacionales e internacionales y de sus Estatutos y Reglamentos. Podrán orientar a su cliente hacia una institución o mediador más adecuado y explicarles el desarrollo de la mediación.

- Habilidades de negociación, comunicación y desbloqueo, para asesorar a estratégicamente a su cliente durante las sesiones de mediación.

- Conocimientos de Derecho civil y procesal, así como de la legislación específica sobre mediación del lugar en el que esta se desarrolle o del que debe ser cumplido el acuerdo.

Toda formación de los letrados irá encaminada a la aceptación de su papel en una mediación, a la naturalización de la mediación como un nuevo instrumento a su alcance para la consecución de una resolución en favor de su cliente. Así los abogados deberán, según QUINTANA GARCÍA ${ }^{242}$, informar sobre la mediación y las características a su representado, acompañarle a las sesiones informativas, asesorarle durante todo el proceso de mediación y ayudar a redactar el acuerdo que ponga fin al conflicto.

Según las conclusiones del Consejo General del Poder Judicial, las experiencias pilotos realizadas sobre mediación confirman "que para el éxito de la derivación de la mediación desde los Tribunales de familia, se ha de contar con la colaboración de los abogados. Si esta derivación se hace de forma sorpresiva para el letrado, es lógico que éste lo perciba como una inmisión a su quehacer profesional. Mientras la abogacía no perciba que existen dos modelos metodológicos para intentar solucionar el litigio, uno

${ }^{242}$ QUINTANA GARCÍA, A., “Abogados, mediación y viceversa ...”, op. cit., p. 160. 
el contencioso clásico, y el otro la mediación, y que sea él quien en cada caso aconseje al cliente, según las circunstancias del caso, las ventajas de uno y otro sistema, la mediación no se implantará. Como es obvio, el papel y la función del abogado ha de quedar definida por igual en uno y otro caso, su intervención como asesor, y, especialmente, como redactor de los acuerdos o convenios, debe quedar salvaguardada, y garantizada, así mismo, la remuneración de su trabajo". ${ }^{243}$

Como conclusión, un mayor conocimiento de la materia y una mayor formación provocarán una variación de la situación, conduciéndonos a un asentamiento definitivo en nuestro territorio. Así que, como dijo WAYNE W. DYER, "El progreso y el desarrollo son imposibles si uno sigue haciendo las cosas tal como siempre las ha hecho".

${ }^{243}$ MARÍN MIGUEL, I.M., “Justificado recelo”, en Revista La Toga 2007, nº 164, pp. 32-34, esp. p. 34. 


\section{CAPÍTULO CUARTO}

\section{LA VÍCTIMA Y LA JUSTICIA RESTAURATIVA}

"Siempre se recuerda mejor el nombre de los culpables que el de las víctimas"

Donato Carrisi

\section{La alternativa a la "crisis" del Derecho Penal: ¿crisis total o parcial?}

En la actualidad existe una corriente de pensamiento doctrinal que valora la actual situación nuestro sistema de Derecho Penal considerado en crisis desde tiempo atrás $^{244}$. Algo ya vaticinado por el experto VON LISTZ ${ }^{245}$ que desencadenó en diferentes medidas a fin de revertir la situación y modernizar el sistema y que FERRAJOLI sostiene al mantener que la globalización ha mostrado la ineficacia del Derecho Penal para dar respuesta a la nueva criminalidad ${ }^{246}$.

El sistema de justicia penal ha mostrado dificultades en el cumplimiento de sus fines. El colapso existente en nuestros juzgados a consecuencia de los casi seis millones de asuntos que ingresan en la justicia española ${ }^{247}$ conlleva una menor agilidad de los procesos. De ello no es únicamente responsable el Sistema de Justicia por sus actuaciones en sí mismas, sino que es consecuencia directa de la creencia existente de tipificar todo tipo de comportamientos llegando a "hipertrofiar el aparato judicial”248, como consecuencia de la necesidad existente en 1978, superada en la actualidad, de

\footnotetext{
${ }^{244}$ Muchos autores consideran que esta crisis se inició en los años 60 y que todavía aún perdura. Vid. VALVERDE MOLINA, J., La cárcel y sus consecuencias: la intervención sobre la conducta desadaptada, Editorial Popular, Madrid, 1997; SEGATO, R.L., "El color de la cárcel en América latina. Apuntes sobre la colonialidad de la justicia en un continente en deconstrucción" en Revista Nueva sociedad 2007, $n^{\circ}$ 208. Disponible en: http://nuso.org (última visita 22/01/2018); MANNOZZI, G., La giustizia senza spada. Uno Studio comparato su giustizia riparativa e mediazione penale, Giuffreè, Milano, 2003, p. 23.

${ }^{245}$ VON LISTZ, F. La idea del fin en el Derecho penal (traducción de César Pérez del Valle), Universidad Autónoma de México, Ciudad de México, 1994, p. 133.

${ }^{246}$ BARONA VILAR, S., “Esquizofrenia en la ...”, op. cit., p. 205.

${ }^{247}$ Memoria del Consejo General del Poder judicial 2015 correspondiente al ejercicio 2014, p. 433 y ss. Disponible en: http://www.poderjudicial.es (Última visita: 09/11/2017)

${ }^{248}$ ALONSO SALGADO, C., La mediación en el proceso penal, Tirant lo Blanch, Valencia, 2018, p.21.
} 
establecer un auténtico poder judicial que velase las garantías de todos los litigantes. Tal y como señala BARONA VILAR, "era necesario en el contexto político de aquel entonces la consagración del Poder Judicial desde el marco constitucional, como el mecanismo a través del cual se alcanza la tutela efectiva de todos los ciudadanos. Los acontecimientos de finales de este siglo han desbordado, con mucho, las previsiones que garantizaban lo que en aquellos años setenta era imprescindible garantizar"249. Esta idea de resolver los conflictos y diferencias, por muy leves que sean, ante los juzgados penales, provocan un considerable atasco, privándoles de las ventajas que el propio sistema les otorgaría e incluso de aquellas que otras figuras aportan a pesar de la escasa o nula representación de éstas en la Justicia española.

Pero no hemos de obviar uno de los grandes obstáculos que nos encontramos, y es la utilización del Derecho Penal como herramienta política, utilizada con populismo $^{250}$ y para la captación de votos a través de un castigo penal y agravamiento de penas cuando suceden hechos que conmocionan a la ciudadanía debido a su gravedad $^{251}$. A los políticos en general les gusta proyectar una imagen pacificadora, a modo de un "Justiciero amparado en la Ley” proporcionando seguridad en nuestras calles con la legislación de un Código Penal más eficiente, de modo que, un Derecho Penal más intervencionista y más ejemplificador, satisfaciendo las demandas de pueblo que cree así sentirse seguro.

El populismo punitivo es "disfrutado" en su beneficio de una manera igual de eficiente por los medios de comunicación, los cuales obtienen gran utilidad mediática de

249 BARONA VILAR, S., Solución extrajurisdiccional de conflictos. Alternative dispute resolution (ADR), y Derecho Procesal, Tirant lo Blanch, Valencia, 1999, p. 13.

${ }^{250}$ Es lo que se conoce como populismo punitivo (populist punitveness). Para más información acerca de ello, Sir BOTTOMS, A., “The Philosophy and Politics of Punishment and Sentencing”, en C. M. V. Clarkson (ed.), The Politics of Sentencing Reform, Oxford University Press, Oxford, 1995, pp. 17-49.

${ }^{251}$ Un ejemplo de ello es el "Caso Marta del Castillo", el cual, debido al impacto que generó en la sociedad, no faltó tiempo al Partido Popular para "llevar” a Antonio del Castillo, padre de Marta, para defender la prisión permanente revisable. Véase noticia con titular "El PP lleva al Congreso al padre de Marta del Castillo para defender la prisión permanente” en Diario ABC del día 05/02/2014. Disponible en: http://www.abc.es (Última visita: 09/11/2017). 
la comisión de actos delictivos ${ }^{252}$. Un delito para ellos es una posibilidad de “complacer" al espectador con múltiples horas de "entretenimiento", viéndose incrementado exponencialmente el share o cuota de pantalla en relación a la gravedad delictiva. Cuanto más reprochables sean las actividades delictivas, más audiencia generarán, iniciándose los telediarios con dicha determinada información. Incluso dedicándose diferentes programas al desarrollo de interminables y frívolos debates. Dicha violencia genera interés en el ciudadano, una tendencia que va progresivamente transformándose en miedo e inseguridad. Así se consigue modular la conducta y pensamiento del sujeto, el cual acaba aceptando cualquier medida punitiva con el fin de la disminución de la actividad delictiva y el castigo ejemplificador de las conductas reprochables. El punishment se convierte en pilar indestructible de la justicia, obviándose la reparación.

Esta idea generalizada en la sociedad de aumento del castigo no conlleva una disminución de la actividad delictiva. El pensamiento global del ciudadano se deja influir por episodios trágicos y crueles, obviando la realidad general práctica. No estamos en una sociedad delictiva. La delincuencia lleva un ritmo, por lo general, estable o a lo sumo levemente creciente, a pesar de la imagen que muchos los miembros de la comunidad tienen gracias al “empapamiento” sufrido a partir de los medios de comunicación en reproducción de noticias violentas ${ }^{253}$. Es necesaria una intervención mínima del Derecho Penal, debiendo de existir, tal y como defiende FERRAJOLI, una “minimización de la reacción violenta frente al delito"254.

${ }^{252}$ CEREZO DOMínGUEZ, A. I., El protagonismo de las víctimas en la elaboración de las leyes penales, Tirant lo Blanch, Valencia, 2010, pp. 32-35; FUENTES OSORIO, J. L., "Los medios de comunicación y el Derecho penal”, en Revista Electrónica de Ciencia Penal y Criminología 2005, n 7, pp. 1-51, esp. pp. 2-8.

${ }^{253}$ GARCÍA ESPAÑA, E. et al., "Evolución de la delincuencia en España. Análisis longitudinal con encuestas de victimización”, en Revista Española de Investigación Criminológica 2010, nº 8, pp. 1-27, esp. p. 22. Según este estudio, el 90\% de los encuestados creía que entre 1989 y 2008 la violencia había crecido, cuando ha sido al contrario. Eso sí, un 90\% de la población de la encuesta afirmaba ver noticias sobre delitos violentos en los medios de comunicación.

${ }^{254}$ BARONA VILAR, S., “Esquizofrenia en la ...”, op. cit., p. 203. 
La generación de miedo es utilizada por los legisladores para el desarrollo de un Derecho Penal más expansivo y más limitador de derechos de los ciudadanos. Se buscan unos “enemigos de la seguridad” y para ello se crea un mayor temor en el ciudadano. El pánico creado en la sociedad le lleva a aceptar un recorte de garantías procesales en pos de la seguridad ciudadana, debido a esos hechos cometidos o incluso aquellos no cometidos pero que están en disponibilidad de cometerse en el futuro ${ }^{255}$.

En último lugar, el denominado “Derecho penal de emergencia ${ }^{256 ”, ~ e l ~ c u a l ~ s u r g e ~}$ cuando la ciudadanía exige al gobernante una solución ante un problema nuevo y potenciado por los medios de comunicación, ahonda aún más en la crisis del sistema penal. El gobernante, a petición popular, legisla nuevas leyes, no para solucionar el problema, sino para que el pueblo se vea satisfecho y seguro. Aquí se legisla sin saber muy bien la situación, y como bien indica FERRAJOLI, se crea un sistema punitivo especial con un carácter administrativo ${ }^{257}$. Y más claramente nos lo señala $\operatorname{ESER}^{258}$ al catalogar estas circunstancias como “droga alternativa” para la solución de una falsa política social. El Derecho Penal está siendo conducido a una quiebra de valores, utilizado como un instrumento de "direccionismo estatal" 259 o como un "mecanismo políticamente deseado de encubrimiento y ocultación de las contradicciones del sistema”260 ${ }^{26}$ que está potenciando la aparición de nuevos delitos y la elevación de las penas de manera preocupante ${ }^{261}$.

\footnotetext{
255 JAKOBS, G., CANCIO MELIÁ, M., Derecho penal del enemigo. Madrid, Civitas, 2003, p. 80.

${ }^{256}$ FERRAJOLI, L., Derecho y razón. Teoría del garantismo penal (trad. de Perfecto Andrés Ibáñez y otros originalmente publicado en italiano, Diritto e ragione, Laterza, Bari, 1989), Trotta, Madrid, 2009, pp.10 y ss.

${ }^{257}$ FERRAJOLI, L., Derecho y razón. Teoría del garantismo penal, op. cit., p. 342.

${ }^{258}$ ESER, A., "Una justicia penal 'a la medida del ser humano' en la época de la europeización y la globalización”, en Modernas tendencias en la ciencia del derecho penal y en la criminologia: Congreso Internacional Facultad de Derecho de la UNED, UNED, Madrid, 2001, pp. 15-38, esp. 29.

${ }^{259}$ HASEERMER, W., "El destino de los derechos del ciudadano en un Derecho penal eficaz" (trad. De Francisco Muñoz Conde), en Estudios Penales y Criminológicos 1990, nº 15, pp. 181-198, esp. p. 198.

${ }^{260}$ ALBRETCH, P. A., "El Derecho penal en la intervención de la política populista", en AA.VV La insostenible situación del Derecho penal, Comares, Granada, 1999, pp. 471-487, esp. p. 477.

${ }^{261}$ Fiscalía General del Estado, Memoria elevada al Gobierno de S. M. presentada al inicio del año judicial. Centro de Estudios Jurídicos del Ministerio de Justicia, Madrid, 2012, p. XXVI de la Introducción a cargo del Fiscal General del Estado. Aquí el Fiscal General del Estado muestra su preocupación por que "la mecánica elevación de las penas se pueda esgrimir como mágico talismán ante una sociedad agobiada por problemas que no encuentran solución en otros ámbitos”
} 
Si a ello añadimos un sistema con escasez de medios personales y materiales, más una población temerosa de la delincuencia y ansiosa por las resoluciones ejemplificadoras de los Tribunales, únicas vías para la resolución de los conflictos así como reparación mediante el castigo del interés lesionado ${ }^{262}$, nos encontramos con un sistema arcaico, desfasado y antediluviano. En vez de desvelarse por la reparación de la víctima, el sistema fomenta la imposición de un castigo ejemplificador que satisfaga a los demás ciudadanos preocupados por sufrir ese mismo acto en un futuro. Un sistema penitenciario que no favorece la resocialización de los reclusos al estar más centrado en la mejora de la estructura del ámbito de prisión que de los propios reclusos ${ }^{263}$. No obstante, dichas mejoras estructurales han supuesto una mejora en la vida de los $\operatorname{presos}^{264}$, otorgándoles dignidad y servicios básicos y les puede facilitar al abandono de la vida delictiva si se complementa con medidas de carácter resocializador.

Aún con las carencias del propio sistema penitenciario, los diversos factores socioculturales, políticos y financieros son una de las grandes trabas para la resocialización de los presos ${ }^{265}$. Esta falta de conciencia social, que llega incluso a posicionarse en la venganza como respuesta al delito, el escaso interés real de algunos políticos, que sólo valoran al delincuente como arma política, y la escasez de medios asignados, nos posiciona en una situación de difícil reeducación y superación de los escollos actuales.

\footnotetext{
262 ORTUÑO MUÑOZ, J. P., HERNÁNDEZ GARCÍA, J., Sistemas alternativos a la resolución de conflictos (ADR): la mediación en las jurisdicciones civil y penal, Fundación Alternativas, Madrid, 2007, p.16

263 MANZANOS BILBAO, C., "Reproducción de lo carcelario: el caso de las ideologías resocializadoras", en I. Rivera Beiras (coord.) Tratamiento penitenciario y derechos fundamentales: Jornadas Penitenciarias, J. M. Bosch Editor, 1994, pp. 121-140, esp. p. 134.

${ }^{264}$ A modo de ejemplo añadimos el relato de un miembro de la población reclusa a finales del s.XX, valorándose a través de él una situación deplorable y satisfactoriamente ya superada en la actualidad, recogido en GAMELLA, JUAN F., La historia de Julián, Madrid, Ed. Popular, 1990, p. 30: "La celda estaba oscura. Se abría una puerta de hierro, entrabas y a la derecha estaba el tigre, un espacio cuadrado separado por una mampara de cristal. Allí había una taza y un lavabo. No había agua ni luz. El tigre estaba atrancado y olía a podrido. En la celda dormían otros tres, en dos literas que dejaban un pasillito en el medio. Me acosté y me tapé con la manta. Las ventanas estaban rotas y hacía un frío tremendo".

${ }^{265}$ AYUSO VIVANCOS, A., Visión crítica de la reeducación penitenciaria en España, NAU LLIBRES, Valencia, 2006, p. 19 y ss.
} 
Como último factor a tener en cuenta es la proliferación legislativa que conlleva una actuación del Estado en cualquier nivel y sector de manera innecesaria ${ }^{266}$, lo que ha puesto en palabras de ALONSO SALGADO tanto una "saturación de la justicia” como "un aumento de la complejidad técnica" ${ }^{267}$. Esta excesiva regulación ha supuesto una mayor complejidad en el entendimiento del marco normativo y sobretodo, una mayor interacción del poder estatal en ámbitos donde no era necesaria su intromisión.

Todo esto ha despertado la idea de un nuevo sistema, de unos nuevos modelos menos formales y más flexibles ${ }^{268}$ que satisfagan a la víctima y a la sociedad. La Justicia Restaurativa se preocupa por la víctima, responde a las necesidades de $\operatorname{estas}^{269}$ y pretende devolver a la sociedad a un infractor que ya daban por perdido. Un interés nacido a través de la unión de varias necesidades exigidas por las víctimas, los delincuentes y las diversas comunidades aborígenes que no encontraron respaldo en el sistema penal clásico.

Tal y como señala BARONA VILAR, la Justicia Restaurativa insufla, en esta sociedad en crisis de identidad, "nuevos planteamientos sociales, integradores colectivamente y de convivencia, que inspiran una verdadera y mejor transformación social” ${ }^{270}$, ofreciendo a una sociedad desmotivada y desilusionada una bocanada de aire fresco $^{271}$. Es el momento de dar el paso y introducir la restauración dentro de nuestro sistema de justicia, adaptándolo las prácticas reparadoras conforme a nuestro

\footnotetext{
${ }^{266}$ A modo de ejemplo véase MARTín BARBERÁN, J., DAPENA MÉNDEZ, J. y CANO LÓPEZ F., "La transformación del campo del control de la criminalidad y la justicia penal" en P. Casanovas Romeu, L. Díaz Echenique y M. Poblet Balcells (coords.), Materiales del Libro Blanco de la Mediación en Cataluña, Centre d’Estudis Jurídics i Formació Especializada, Generalitat de Catalunya, Barcelona, 2009, pp. 95-96.

${ }^{267}$ ALONSO SALGADO, C., La mediación en el ... op. cit., p.22.

${ }^{268}$ LANDROVE DÍAZ, G., La moderna victimología. Tirant lo Blanch, Valencia, 1998, p. 12.

${ }^{269}$ Intervención de VAN CAMP en el Congreso Europeo de Justicia Restaurativa y Terapéutica, celebrado en San Sebastián los días 16, 17, 18 de junio de 2016.

${ }^{270}$ BARONA VILAR, S., “Esquizofrenia en la ...”, op. cit.,. p. 211.

${ }^{271}$ BARONA VILAR, S., "Del escepticismo al entusiasmo en mediación penal, de la restorative justice a la reconstructive justice (referencia especial al estatuto jurídico de la víctima y a los encuentros restaurativos víctimas-condenados por terrorismo)”, en J.L. Gómez Colomer (coord.), El proceso penal en la encrucijada. Homenaje al Dr. César Crisóstomo Barrientos Pellecer. Vol. I, Universitat Jaume I, Castelló de la Plana, 2015, pp. 201-239, esp. pp. 202-203.
} 
ordenamiento legislativo, en consecuencia ahora sólo "se ha trabajado en la línea de la Administración de justicia como productora de decisiones judiciales, y que se desconoce la otra faceta o la otra función que puede desempeñar la administración de justicia, como instrumento útil y necesario para dar solución a los conflictos jurídicos en los que se ven involucrados los ciudadanos" ${ }^{272}$.

\section{La víctima: el sujeto olvidado del sistema de Justicia}

El proceso penal olvidó que la comisión de un delito no sólo vulnera una ley sino que también lastima a una persona. Es por ello que tuvo que ir desarrollándose la ciencia denominada victimología, centrada en el estudio de la víctima y en la necesidad de situarla de nuevo como protagonista del proceso. El nacimiento de una nueva corriente de pensamiento, a la que se han ido sumando progresivamente los Estados, otorga una serie derechos a las víctimas dentro del proceso penal ${ }^{273}$, permitiéndole así combatir contra todos los daños que este le provoca en la lucha contra el crimen y la resolución de conflictos.

\subsection{La victimología y el interés por la víctima}

El término "victimología” es acuñado en los años cuarenta del pasado siglo, siendo utilizado primero por nuestros vecinos como Victimology o Victimologie ${ }^{274}$, proviniendo ambas de la unión del término latín víctima y el vocablo griego logos, dando lugar a la traducción de "estudio de los sacrificados o damnificados”. Los orígenes de la víctimología están en los estudios de HANS VON HENTIG ${ }^{275}$ y de

\footnotetext{
272 ORTUÑO MUÑOZ, J.P., y HERNÁNDEZ GARCÍA., Sistemas alternativos a la... op. cit., p. 18,

${ }^{273}$ Hecho realidad a través de la Directiva 2012/29/UE del Parlamento Europeo y del Consejo de 25 de octubre de 2012 por la que se establecen normas mínimas sobre los derechos, el apoyo y la protección de las víctimas de delitos, y por la que se sustituye la Decisión marco 2001/220/JAI del Consejo, DOUE de 14 de noviembre de 2012, $\mathrm{n}^{\circ} \mathrm{L}$ 315, pp. 57-73.

274 Para un estudio pormenorizado de los orígenes del vocablo “victimología”, véase JIMÉNEZ DE ASÚA, L., Estudios de Derecho Penal y Criminología, Bibliográfica Omeba, Buenos Aires, 1961, pp. 1941.

${ }^{275}$ La obra de Hans Von Hentig es básica para el nacimiento de esta ciencia: The Criminal and his Victim. Yale University Press, New Haven, 1948.
} 
FREDRICK WERTHAM, el cual es el primero en indicar el término Victimology en su obra The show of violence ${ }^{276}$.

No hay mejor forma para explicar la victimología que empezar con la definición de TAMARIT, el cual considera que la "victimología es la ciencia multidisciplinar que se ocupa del conocimiento de los procesos de victimación y desvictimación es decir de las diversas dimensiones de la victimación (primaria, secundaria y terciaria) y de las estrategias de prevención, reducción, de respuestas sociales, jurídicas y asistenciales tendientes a la reparación y reintegración social de la víctima” ${ }^{277}$.

El Derecho Penal no tiene ningún interés en la víctima, a la cual valora como un simple “testigo”,278 del delito, despreocupándose de su situación ${ }^{279}$. Su único fin es castigar el hecho delictivo, obviando la situación de la víctima, la cual se sentirá ignorada en el sistema clásico de justicia ${ }^{280}$. Un abandono de la víctima que nos ha llevado a un doble castigo sobre esta: Un doble castigo por recibir un hecho dañoso injustificado, y por no poder ser protagonista ante los Tribunales.

El aislamiento de la víctima dentro del proceso penal es una situación potenciada desde tiempos lejanos, provocando que la resolución judicial no aclare el conflicto a nivel personal ${ }^{281}$. Antiguamente la justicia penal era privada, y nos encontrábamos con un sistema basado en las venganzas de los sujetos contra los infractores sin límite alguno. Debido a estas vendettas ilimitadas, se hizo necesario la elaboración de cuerpos

276 HERRERA MORENO, M., “Historia de la Victimología” en E. Baca Baldomero, E. Echeburúa Odriozola, J.M. Tamarit Sumalla, (coords.), Manual de Victimología, Tirant lo Blanch, Valencia, 2006, pp. 51-78, esp. p. 62.

${ }^{277}$ TAMARIT SUMILLA, JM., “La victimología: cuestiones conceptuales o metodológicas”, En E. Baca Baldomero, et. al.,... op., cit., pp. 17-50, esp. pp. 17-18.

${ }^{278}$ ESER, A., “Acerca del renacimiento de la víctima en el procedimiento penal” en De los delitos y las víctimas (trad. de Fabricio O. Guariglia y Fernando J. Córdoba), Ad-Hoc, Buenos Aires, 1992, p. 16.

${ }^{279}$ CID MOLINÉ, J., "Medios alternativos de solución de conflictos y Derecho penal”, en Anuario de la Facultad de Derecho de la Universidad Autónoma de Madrid (Ejemplar dedicado a: Medios alternativos de solución de controversias) 2007, n 11, pp. 151-168, esp. p. 157.

${ }^{280}$ Intervención de VAN CAMP en el Congreso Europeo de Justicia Restaurativa y Terapéutica, celebrado en San Sebastián los días 16, 17, 18 de junio de 2016 .

${ }^{281}$ BARONA VILLAR, S., Mediación penal. Fundamento, fines y régimen jurídico, Tirant lo Blanch, Valencia, 2011, p. 40. 
normativos que estipulasen una proporcionalidad, y de ahí el nacimiento de la Ley del Talión ${ }^{282}$, que establecían un sistema “equitativo”. En estos sistemas arcaicos, la víctima era clave para la aplicación de "justicia”, puesto que era ella misma la que lo requería e incluso la que imponía ese castigo.

El transcurso del tiempo fue proporcionándonos un olvido de la víctima. En la época medieval se acentúa este problema al enfocar el proceso únicamente en el infractor y la medida que se le va a aplicar. Esta situación de relegación de la víctima fue acentuándose, y con el ascenso de la burguesía se llega al apogeo del abandono de la víctima, concentrándose el proceso como un castigo contra en infractor por la agresión contra las normas del Estado. Como indica ESER, la víctima se convierte en una víctima de la dogmática de la teoría del delito ${ }^{283}$, ya no estamos ante un delito contra la víctima, sino ante un trasgresión de la normativa penal.

El culmen de esta situación también nos condujo al inicio del pensamiento crítico, y, aún en manifiesta minoría, autores como CARRARA ${ }^{284}$ y GAROFALO ${ }^{285}$ iniciaron su propia cruzada para el estudio de la víctima y sus necesidades. Es digno de mencionar el empleo del sarcasmo en una de las grandes y famosas citas de la victimología por parte de ADOLPHE PRINS ${ }^{286}$, en el Congreso Penitenciario de París de 1895: "el hombre culpable, albergado, alimentado, calentado, alumbrado, entretenido a expensas públicas en una celda modelo, salido de ella con una suma de

\footnotetext{
282 SCHAFER, S., Victimology: The victim and his criminal, Reston Publishing Company Inc., New Jersey, 1977, pp. 5 y ss.

283 ESER, A., Sobre la exaltación del bien jurídico a costa de la víctima, Universidad Externado de Colombia, Bogotá, 1998, p. 35.

${ }^{284}$ CARRARA, F., Programa de Derecho Criminal. Parte general, vol. II, Temis, Bogotá, 1956, pp. 688693. Miembro de la escuela italiana, defendió la denominada reparación subsidiaria para la indemnización de las víctimas en casos de delitos cometidos por infractores insolventes.

${ }^{285}$ Vid. TAMARIT SUMALLA, J.M., La reparación a la víctima en el Derecho Penal, Fundaciò Jaume Callìs, Barcelona 1994, pp. 106 y ss. Miembro de la Escuela Positiva, exigía una regulación legal relativa a la pena de reparación como alternativa a la clásica pena de prisión.

${ }^{286}$ Adolphe Prins fue un Profesor de Derecho y Procesal Penal en la Universidad de Bruselas e inspector general de las cárceles. Conocido por ser Fundador en 1889 de la Unión Internacional de Derecho Penal, ser seguidor de la escuela positiva italiana y organizador del Tribunal de menores y la ley de 1912 sobre la protección de la infancia. Su obra más destacada es La défense sociale et les transformations du droit pénal de 1910.
} 
dinero legítimamente ganada, ha pagado su deuda con la sociedad. Pero la víctima tiene su consuelo; puede pensar que con los impuestos que paga al Estado ha contribuido al cuidado paternal que el delincuente ha tenido durante su estancia en prisión”. 287

Este problema se ha mantenido hasta la actualidad debido a la poca aceptación por parte de las normativas estatales a las nuevas prácticas restaurativas y victimológicas, girando el proceso penal en torno a la culpabilidad o no del imputado y al castigo que se merece. Castigo que será impuesto por el Estado, el cual también, a través del Ministerio Fiscal, buscará cimentar una acusación.

Es la Victimología la ciencia que se ha preocupado en el redescubrimiento de la víctima, al otorgarle un papel de suma importancia dentro del proceso penal, siendo dueña del conflicto, posición de la que venía siendo relegada ${ }^{288}$. No importa la consideración a la Victimología como una ciencia autónoma o dependiente de la Criminología $^{289}$, sino lo fundamental es su carácter primordial en la otorgación de valor y consideración a la víctima.

\subsection{Concepto de víctima: posibles definiciones}

El vocablo "víctima”, como ya hemos hecho referencia anteriormente, proviene del latín, que significa “damnificado o sacrificado a Dios”290, teniendo en un inicio un concepto religioso, tanto en creencia romana como otras religiones. A modo de ejemplo, en la Biblia, Levítico. Cap. I, vers. 2-5 “Cuando alguno de vosotros quiera presentar al Señor una ofrenda de los ganados, esto es, una víctima de bueyes o de ovejas....... pondrá la cabeza de la hostia y será acepta y servirá a su expiación [...] Por tanto los

\footnotetext{
${ }^{287}$ LANDROVE DÍAZ, G., Victimología ..., op. cit., p. 25.

${ }^{288}$ MONTESINOS GARCÍA, A., “La mediación penal en Inglaterra y Gales”, en S. Barona Vilar (coord.) La mediación penal para adultos. Una realidad en los ordenamientos jurídicos, Tirant Lo Blanch, Valencia, 2009, pp. 85-123, esp. pp. 97-98.

${ }^{289}$ ALASTUEY DOBÓN, M. C., La reparación a la víctima en el marco de las sanciones penales, Tirant lo Blanch, Valencia, 2000, p. 39

${ }^{290}$ RAMÍREZ, R., La victimología, Editorial Temis, Bogotá, Colombia, 1983 p. 5.
} 
hijos de Israel deberán presentar al sacerdote las víctimas, en vez de matarlas en el campo; para que sean sacrificadas al Señor como víctimas pacíficas”. Todo ello fue modificado por las diferentes lenguas nacidas a partir del latín. A modo de ejemplo se puede citar a la Asociación vasca de Criminología, quien considera a las víctimas como "incómodas para la gente porque recuerdan la fragilidad del ser humano y exponen en toda su crudeza los límites de la crueldad humana" ${ }^{291}$.

La Declaración sobre los principios fundamentales de justicia para las víctimas de delitos y de abuso de poder de 29 de noviembre $1985^{292}$ se refiere a las víctimas de delitos en su artículo 1 como “... personas que, individual o colectivamente, hayan sufrido daños, inclusive lesiones físicas o mentales, sufrimiento emociona, pérdida financiera o menoscabo sustancial de sus derechos fundamentales como consecuencia de acciones u omisiones que violen la legislación penal vigente en los Estados Miembros, incluida la que proscribe el abuso de poder". Son víctimas de abuso de poder, según el artículo 18 de la Declaración, aquellas que hayan sufrido los mismos años a consecuencia de acciones u omisiones que no lleguen a constituir violaciones del Derecho Penal nacional, pero violen normas internacionalmente reconocidas relativas a los derechos humanos.

Otra definición a tener en cuenta es la proporcionada por la Ley 4/2015, de 27 de abril, del Estatuto de la víctima del delito, que, a la hora de articular los derechos de las víctimas, nos define en su artículo 2 "como víctima directa, a toda persona física que haya sufrido un daño o perjuicio sobre su propia persona o patrimonio, en especial lesiones físicas o psíquicas, daños emocionales o perjuicios económicos directamente causados por la comisión de un delito”. A todo ello le incluye el novedoso concepto de víctima indirecta, catalogando como tal al cónyuge no separado legalmente o de hecho y a los hijos de la víctima o del cónyuge no separado legalmente o de hecho y a los demás parientes en línea recta y a sus hermanos en el supuesto de muerte o desaparición

\footnotetext{
${ }^{291}$ Disponible en: http://Asociacionvascadecriminologos.wordpress.com (última visita 23/01/2017)

292 Adoptada por la Asamblea General de las Naciones Unidas el 29 de noviembre de 1985. Disponible en http://www2.ohchr.org (Última visita: 09/11/2017)
} 
de la víctima. Ante esta definición y clasificación conjunta realizada por el Estatuto de la Víctima en la que diferencia entre víctima directa e indirecta, se puede realizar una ampliación. Este añadido es el denominado víctima colectiva en el cual es la colectividad la titular de dichas cualidades, tal y como sucede en delitos contra consumidores, medioambiente, etc. Actualmente a la víctima se le puede denominar como ofendido o perjudicado, pero consideramos que el término de víctima engloba a todos los anteriores y es más completo al afectar, no sólo a la persona que sufre el delito en primera persona, sino a todos aquellos que lo sufren de una manera indirecta, ya por ser familiares de la víctima o por sufrir cualquier menoscabo (incluso económico) por la comisión del delito.

A nuestro juicio defendemos a la víctima como protagonista del delito. Es el sujeto que sufre las consecuencias directas del hecho delictivo. No en vano se trata de la persona titular del bien jurídico lesionado por el ilícito penal, y por ello ha de otorgársele un papel llamativo dentro del proceso, así como una serie de derechos que la otorguen el protagonismo perdido. Hemos de indicar que, con carácter general, la cualidad de víctima es personal e intransmisible ${ }^{293}$.

Para VON HEITING, la víctima es la persona que sufre una lesión de bienes jurídicos creándole un dolor o malestar ${ }^{294}$ al que Derecho Penal le trata como "un blanco fijo al que el autor dirige sus disparos. Ella sufre, puede defenderse, pero su resistencia es vencida, en casos graves mediante la fuerza y la amenaza. [...] Según la dogmática, el ofendido, como objeto de ataque, es casi siempre arcilla blanda, que se acomoda a la mano del alfarero, pasivamente, sin vida propia y su resistencia es sólo reacción a un mal sufrido o que amenaza. El que la víctima se haya colocado antes en una situación de peligro, que en el hurto del carterista no haya tenido cuidado, que en

\footnotetext{
293 GIMENO SENDRA, V., Derecho procesal penal, Madrid, Colex, 2015, p. 181 y ss.

${ }^{294}$ VON HENTIG, H., "Remarks on the Interaction of Perpetrator and Victim", en Journal of Criminal Law and Criminology 1940, vol. 31, n³, pp. 303-309, esp. pp. 307-308.
} 
la estafa no haya estado atenta, o en la apropiación indebida no haya obrado inteligentemente, no afecta a la culpabilidad del autor" 295.

Numerosos estudios fueron surgiendo a partir de estas palabras. MENDELSOHN catalogaba a la víctima como "la personalidad del individuo o de la colectividad en la medida en que está afectada por las consecuencias sociales de su sufrimiento determinado por factores de origen muy diverso, físico, psíquico, económico, político o social, así como el ambiente natural o técnico [...] se puede ser víctima de un criminal, de sí mismo, por deficiencias o inclinación instintiva, impulso psíquico o decisión consciente, del comportamiento antisocial, individual, o colectivo, de la tecnología, de energía no controlada”296.

Para BACA BALDOMERO la víctima es "todo ser humano que ve su vida interrumpida o gravemente alterada por hechos traumáticos no derivados directamente de actos voluntarios realizados por dicho individuo o por circunstancias de enfermedad" 297 . Aquí hemos de completar las palabras del autor ya que "circunstancias de enfermedad” queda excesivamente incompleto. Nos muestra una víctima de enfermedad por actos voluntarios y maliciosos del infractor o causante del daño, pero también se puede ser víctima por actos negligentes, los cuales, aún sin voluntariedad, pueden causar en la víctima una enfermedad.

Como vemos, es una figura muy estudiada, y los diversos institutos y sociedades de Victimología ${ }^{298}$ han ayudado a una mayor comprensión y entendimiento a través de

\footnotetext{
295 VON HENTIG, H., El Delito. II El Delincuente Bajo la Influencia de las Fuerzas del Mundo Circundante, Espasa-Calpe, Madrid, 1971, pp. 408-409.

${ }^{296}$ MENDELSOHN, B., "La Victimología y las tendencias de la sociedad contemporánea”, en Ilanud al día (San José) 1974, n 10, México, pp.55-67, esp. p. 58.

297 BACA BALDOMERO, E., "Desvictimización. Un proceso complejo”, en II Jornada sobre Victimologia, Centre d’Estudis Jurídics i Formació Especialitzada, Generalitat de Catalunya, 2011. Disponible en: http://www.slideshare.net (Última visita: 09/11/2017)

298 El Instituto de Victimología define el termino de víctima como "toda persona afectada por un acontecimiento traumático, sea éste de la naturaleza u origen que sea. Asimismo, es víctima aquella que sufre las consecuencias de una agresión aguda o crónica, intencionada o no, física o psicológica, por parte de otro ser humano". Vid. Instituto de Victimología, Fundación Archivos de Neurobiología, 2003, pp. 139-185. Por su parte, La Sociedad española de Victimología recoge en sus Estatutos una definición
} 
sus aportaciones y de centrarse en sus necesidades. Incluso el TS estudia esta figura en al indicar como elementos fácticos "las relaciones que ligasen a autor y víctima; personalidad de agresor y agredido; incidencias observadas o acaecidas en momentos precedentes al hecho, particularmente si mediaron actos provocativos, insultos o amenazas"299.

El concepto de víctima está siendo recogido desde un punto de vista más amplio, adaptándose a las nuevas corrientes dogmáticas y a los nuevos hechos y pensamientos de la sociedad actual. No es un término fijo en su totalidad, sino que está siempre en proceso de adaptación a la regulación de los países, a la protección que se la otorgue y a la idea de dignidad de la persona que estos Estados adopten.

\subsection{Marco normativo europeo y nacional: desde la Resolución sobre indemnización a las víctimas de actos violentos hasta el Estatuto de la víctima}

Hace ya años que las políticas de acción comunitaria de la Unión Europea empezaron a crear una preocupación en los derechos de las víctimas dentro de un procedimiento. Una serie de actuaciones que han ido in crescendo paulatinamente, obteniéndose poco a poco un mayor protagonismo de la víctima. Se ha potenciado, a través de diferente normativa, una protección a la víctima y una armonización que sirva "para vertebrar un espacio de libertad, justicia y seguridad"300. Poco a poco se fueron realizando reducidos reconocimientos de derechos en favor de las víctimas, tales como

de víctima muy similar a la recogida por la Sociedad francesa de Victimología en la que indica que "se entiende principalmente por víctima, a los efectos de la delimitación de las actividades de la Sociedad, toda persona que haya sufrido personalmente, de modo directo o indirecto, las consecuencias de un hecho delictivo, haya sido declarada formalmente o no como tal la existencia del mismo por parte de un órgano jurisdiccional. En un sentido más extenso también son consideradas víctimas las personas que hayan sufrido los efectos de la guerra, enfrentamiento armado, catástrofe natural o accidente”. La misma definición también la encontramos en el art. 6 de los Estatutos de la Sociedad Catalana de Victimología. Disponible en: http://www.victimologia.cat/estatutscc.html (última visita 23/01/2018) 299 STS 30 de Junio de 1994 FJ 1.

300 SÁNCHEZ TOMÁS, J.M., "El renacer de las víctimas y el reconocimiento de sus derechos en la Unión Europea”, en AA.VV, Justicia Restaurativa mediación penal y penitenciaria: un renovado impulso, Reus, Madrid, 2011, pp. 69-107, esp. p. 80 
las conclusiones del Consejo Europeo de Tampere de los días 15 y 16 de octubre de 1999, hasta que se llegó a la aprobación del Estatuto de la víctima del delito de $2001^{301}$.

\subsubsection{Un camino de reconocimiento en favor de las víctimas.}

El primer texto escrito que reconocía un conjunto de derechos en favor de la víctima fue la Resolución de 13 de marzo de 1981, del Parlamento Europeo sobre la indemnización a las víctimas de actos de violencia ${ }^{302}$, que incidía en la necesidad de aprobación de una Directiva comunitaria con el fin de procurar dicha indemnización. La preocupación proseguía, y pronto se aprobó la Resolución de 12 de septiembre de 1989, del Parlamento Europeo sobre indemnizaciones a las víctimas de delitos violentos ${ }^{303}$, en el que se volvía a poner de manifiesto la necesidad de dicha Directiva. Al tiempo se proponen las primeras ideas de un Estatuto de la víctima y se buscaba la armonización de las normativas europeas con, entre otros aspectos, la ratificación del Convenio del Consejo de Europa de 24 de noviembre de $1983^{304}$. Estas dos peticiones del Parlamento fueron prácticamente ignoradas hasta la publicación de la Directiva 2004/80/CE, de 29 de abril, sobre indemnizaciones a las víctimas de delitos ${ }^{305}$.

El 14 de julio de 1999, la Comisión presentó al Parlamento Europeo, al Consejo y al Comité Económico y Social una comunicación titulada «Víctimas de delitos en la Unión Europea - Normas y medidas» ${ }^{306}$, que se estructuraba en cinco apartados:

\footnotetext{
${ }^{301}$ Decisión marco 2001/220/JAI, de 15 de marzo de 2001, relativa al estatuto de la víctima en el proceso penal. DOUE de 22 de marzo de 2001, n L 082, pp. 16-20.

${ }^{302}$ DOUE de 6 de abril de $1981, \mathrm{n}^{\circ} \mathrm{C} 77$, pp. 77-78.

${ }^{303}$ DOUE de 9 de octubre de 1989, $n^{\circ}$ C 256, p. 27.

${ }^{304}$ Dicho Convenio fue ratificado en España el 29 de diciembre de 2001, BOE núm. 312

305 Directiva 2004/80/CE del Consejo, de 29 de abril de 2004, sobre indemnización a las víctimas de delitos (DOUE de 6 agosto de 2004, $\mathrm{n}^{\circ}$ L 261, pp. 15-18). Vid. SANZ-DÍEZ DE ULZURRUN LLUCH, M., "La víctima ante el derecho: la regulación de la posición jurídica de la víctima en el derecho internacional, en el derecho europeo y en el derecho positivo español”, en Anuario de Derecho Penal y Ciencias Penales 2004, n57, pp. 219-310, esp. p. 260.

${ }^{306}$ Comunicación de la Comisión, de 14 de julio de 1999, al Consejo, al Parlamento Europeo y al Comité Económico y Social - Víctimas de delitos en la Unión Europea - Normas y medidas [COM de 14 de julio de 199, n 349 final - no publicada en el Diario Oficial]
} 
prevención, ayuda, posición de la víctima en el proceso penal, indemnizaciones y cuestiones referidas a información, lengua y formación.

Las conclusiones del Consejo Europeo de Tampere de los días 15 y 16 de octubre de $1999^{307}$, en particular su punto 32, establecen que deberán elaborarse normas mínimas acerca de la protección de las víctimas de los delitos, en particular sobre su acceso a la justicia y su derecho a ser indemnizadas por los daños sufridos. Además, deberán crearse programas nacionales para financiar medidas, tanto públicas como privadas, de asistencia y protección de las víctimas.

Por fin llegó la ansiada Decisión marco 2001/220/JAI del Consejo, de 15 de marzo de 2001, relativa al estatuto de la víctima en el proceso penal, normativa muy ansiada pero muy criticada a su vez. Estamos ante el primer proyecto profundo del legislador europeo para lograr un reconocimiento homogéneo de la víctima en el ámbito de la Unión Europea, reconociendo un conjunto de derechos de las víctimas en el ámbito del proceso penal, como por ejemplo el derecho de protección e indemnización, pero cuyo ejercicio y disfrute no se han sistematizado, sino que han sido incluidos por los Estados en diversas normativas.

La Comisión Europea en abril de 2009 realizó un informe sobre el grado de cumplimiento de dicha Decisión Marco, obteniéndose un resultado muy negativo al mostrarse que ningún Estado miembro había aprobado un texto legal único, aunque sí que se habían ampliado los derechos de las víctimas en numerosas normativas internas, que recogiera, sistemáticamente, los derechos de la víctima y destacó la necesidad de un desarrollo general y efectivo de algunos aspectos del mencionado Estatuto ${ }^{308}$.

\footnotetext{
${ }^{307}$ Disponible en http://www.europarl.europa.eu (última visita (11/04/2018)

${ }^{308}$ En España esto es algo que había estado sucediendo, existiendo un marco normativo garante de los derechos de la víctima, aunque gran parte de esos derechos son exclusivamente procesales o se centran en algunos tipos muy concretos de víctimas de acuerdo con su normativa particular: la Ley 35/1995, de 11 de diciembre, de ayudas y asistencia a las víctimas de delitos violentos y contra la libertad sexual (desarrollada por el Real Decreto 738/1997, de 23 de mayo); la Ley Orgánica 1/1996, de 15 de enero, de Protección Jurídica del Menor; la Ley Orgánica 1/2004, de 28 de diciembre, de Medidas de Protección
} 
La Comunicación de la Comisión al Parlamento Europeo, al Consejo, al Comité Económico y Social Europeo y al Comité de las Regiones de 18 de mayo de 2011 bajo el título “Refuerzo de los derechos de las víctimas en la Unión Europea” volvía a hacer hincapié en el examen de los aspectos de la protección existente hasta la fecha que conviene reforzar y la necesidad de un marco europeo de protección, como el diseñado con la Directiva 2011/99/UE del Parlamento Europeo y del Consejo, de 13 de diciembre de 2011, sobre la orden europea de protección. Así se demostraba la insatisfacción actual conforme a la aplicación de la Decisión Marco del Consejo de 2001 y “su grado de implementación por parte de los Estados miembros ha sido notablemente deficiente»309.

En la Resolución del Consejo sobre un Plan de Trabajo para reforzar los derechos y la protección de las víctimas, en particular en los procesos penales ${ }^{310}$ sobre un plan de trabajo para reforzar los derechos y la protección de las víctimas focalizados sobre todo en los procesos penales (Plan de trabajo de Budapest), el Consejo declaró que debían tomarse medidas a escala de la Unión para reforzar los derechos, el apoyo y la protección de las víctimas de delitos.

Tras los diversos esfuerzo, el 25 de octubre de 2012 se aprobó definitivamente la Directiva 2012/29/UE del Parlamento Europeo y del Consejo por la que se establecen normas mínimas sobre los derechos, el apoyo y la protección de las víctimas de delitos $^{311}$, y por la que se sustituye la Decisión Marco 2001/220/JAI del Consejo, a

Integral contra la Violencia de Género; la Ley 29/2011, de 22 de septiembre, de Reconocimiento y Protección Integral a las Víctimas del Terrorismo.

309 PÉREZ RIVAS, N., "Los derechos de las víctimas en la Unión Europea. Análisis de la Directiva 2012/29/UE”, en Boletín CeDe UsC 2014, p.2. Disponible en: http://revistas.usc.es (última visita 23/01/2018)

${ }^{310}$ DOUE de 28 de junio de 2011, nº $\mathrm{C}$ 187/01, pp. 1-5.

311 Para un estudio pormenorizado sobre la materia véase GONZÁLEZ CANO, M.I., “Cooperación judicial penal, tutela de la víctima y justicia restaurativa (especial consideración de la directiva 2012/29/UE, del Parlamento Europeo y del consejo, de 25 de octubre de 2012, por la que se establecen normas mínimas sobre los derechos, el apoyo y la protección de las víctimas de los delitos)”, en M.I. González Cano (dir.) Cooperación judicial penal en la Unión Europea: Reflexiones sobre algunos aspectos de la investigación y el enjuiciamiento en el espacio europeo de justicia penal, Tirant lo Blanch, Valencia, 2015, pp.411-434. 
través la cual se consolidan las instituciones restaurativas como modelos reconocidos y normalizados $^{312}$. Constituye un gran avance para la implantación de los servicios de justicia restaurativa en toda Europa al otorgar "valor determinante, en su caso, a la voluntad de la víctima que opte por participar" ${ }^{\text {313 }}$ en un proceso restaurativo.

\subsubsection{El Estatuto de la Víctima del Delito, un breve estudio de su regulación.}

En cuanto se inicia la comisión de un acto delictivo, comenzándose la instrumentaría penal consecuente, debe garantizarse a la víctima los derechos establecidos en la Directiva como entender y ser entendidas; recibir información sobre el proceso, traducción e interpretación; tener acceso a servicios de apoyo a las víctimas; ser escuchadas; reembolso de gastos; asistencia jurídica; restitución de bienes sustraídos; evaluación individual para determinar sus necesidades de protección especial; evitar el contacto con el infractor; que se desarrollen las menores entrevistas posibles; intimidad; etc. La finalidad es la obtención de un proceso enfocado en la víctima, la cual será escuchada previa a la eventual victimización secundaria acaecida por el desarrollo de las actuaciones judiciales ${ }^{314}$.

Por ello era fundamental elaborar un compendio que diese cabida a todos los derechos de la víctima, y el Reino de España transpuso la Directiva con la aprobación de la Ley 4/2015, de 27 de abril, del Estatuto de la víctima del delito ${ }^{315}$, la cual a su vez "requería de forma imprescindible e inaplazable de un desarrollo normativo"316 para

\footnotetext{
312 TAMARIT SUMALLA, J.M., "La reparación y el apoyo a las víctimas”, J.M. Tamarit Sumalla, C. Villacampa Esiarte y M. Serrano Masip (coords.), El estatuto de las Víctimas de delitos. Comentarios a la Ley 4/2015, Tirant lo Blanch, Valencia, 2015, pp. 305-354, esp. p. 313

${ }^{313}$ ARMENTA DEU, T., "Justicia restaurativa, mediación penal y víctima: vinculación europea y análisis crítico”, en Revista General de Derecho Europeo 2018, no 44, pp. 204-243, esp. p. 242

314 GOMEZ COLOMER, J.L., Estatuto Jurídico de la Víctima del Delito: la posición jurídica de la víctima del delito ante la Justicia Penal. Un análisis basado en el Derecho comparado y en las grandes reformas que se avecinan, Aranzadi, Pamplona, 2015, p. 360.

${ }^{315}$ BOE de 28 de abril de 2015, $\mathrm{n}^{\circ}$ 101, pp. 36569-36598.

${ }^{316}$ MARTíN DIZ, F., "Real Decreto 1109/2015, de 11 de diciembre, por el que se desarrolla la Ley 4/2015, de 27 de abril, del Estatuto de la Víctima del delito, y se regulan las Oficinas de Asistencia a las Víctimas del Delito [BOE n. ${ }^{\circ}$ 312, de 30-XII-2015]”, en Ars Iuris Salmanticensis: AIS : revista europea e iberoamericana de pensamiento y análisis de derecho, ciencia política y criminología 2016, vol. 4, nº 1 , pp. 342-345, esp. p. 342.
} 
perfeccionar ciertos aspectos regulados como las Oficinas de Asistencia a las Víctimas. Una norma ambiciosa que fue más allá de la Directiva (la cual sólo establecía unas normas mínimas), creando un Estatuto de la víctima completo y “trasladando al mismo las demandas y necesidades de la sociedad española, en aras a completar el diseño del Estado de Derecho, centrado casi siempre en las garantías procesales y los derechos del imputado, acusado, procesado o condenado"317. El Estatuto es por tanto un catálogo general de los derechos, procesales y extraprocesales, de todas las víctimas de delitos. Nace como un compendio de derechos enfocados en otorgar el debido protagonismo que se merece la víctima en todo proceso. Se busca garantizar a las víctimas la información, el apoyo, la protección adecuada y la participación en los procesos penales. Es obligación de los países de la UE el reconocimiento de las víctimas de delitos su condición como tales y qué sean tratadas de manera respetuosa, sensible y profesional de acuerdo con sus necesidades específicas sin discriminación de ningún tipo.

Se parte de un concepto amplio de víctima, por cualquier delito y cualquiera que sea la naturaleza del perjuicio físico, moral o material que se le haya irrogado. Esta alusión a "víctima en singular" ha creado opiniones variadas respecto a las intenciones del legislador con su terminología. TAMARIT SUMALLA ${ }^{318}$ considera que, aún sin consecuencias legales, el término en singular nos conduce a un pensamiento de “idealidad victimal”319, pudiéndonos llevar a una diferencia entre víctimas "buenas” y “malas”, aun, como ya hemos hecho hincapié, sin efectos jurídicos trascendentes. El término, tanto en singular como en plural, comprende a la víctima directa, pero también a víctimas indirectas, como familiares o $\operatorname{asimilados}^{320}$ y busca ofrecer a la víctima las

\footnotetext{
${ }^{317}$ Considerando II Ley 4/2015, de 27 de abril, del Estatuto de la víctima del delito.

318 TAMARIT SUMALLA, J.M., "Los derechos de las víctimas”, en J.M. Tamarit Sumalla (coord.) El Estatuto de las ..., op. cit., pp. 15-68, esp. p. 40.

${ }^{319}$ TAMARIT SUMALLA, J.M., "Paradojas y patologías de la construcción social, jurídica y política de la victimidad”, en InDret 2013, n¹, pp. 1-31, esp. pp. 9-11. Disponible en: http://www.indret.com (Última visita: 09/11/2017)

${ }^{320}$ En su artículo segundo se reconoce la condición de víctima indirecta al cónyuge o persona vinculada a la víctima por una análoga relación de afectividad, sus hijos y progenitores, parientes directos y personas a cargo de la víctima directa por muerte o desaparición ocasionada por el delito, así como a los titulares
} 
máximas facilidades para el ejercicio y tutela de sus derechos, con la reducción de trámites innecesarios que supongan una segunda victimización; así también otorgarle una información y orientación eficaz de los derechos y servicios que le corresponden, la derivación por la autoridad competente, un trato humano y la posibilidad de hacerse acompañar por la persona que designe en todos sus trámites.

Es ya en el artículo 3 cuando se encuentra la primera referencia a la justicia restaurativa al adviertir que toda víctima tiene derecho a la "protección, información, apoyo, asistencia y atención, así como a la participación activa en el proceso penal y a recibir un trato respetuoso, profesional, individualizado y no discriminatorio desde su primer contacto con las autoridades o funcionarios, durante la actuación de los servicios de asistencia y apoyo a las víctimas y de justicia restaurativa, a lo largo de todo el proceso penal y por un período de tiempo adecuado después de su conclusión, con independencia de que se conozca o no la identidad del infractor y del resultado del proceso”. Y a lo largo del articulado va desarrollando estos derechos, siendo objeto de estudio en esta investigación los denominados Servicios de justicia restaurativa, regulados en el artículo 15 del cuerpo legal. La terminología de "Justicia Restaurativa”, Este detalle es más relevante de lo que parece ya que dicho vocablo no es utilizado en España, donde se prefiere utilizar erróneamente el término “mediación”321. De aquí podemos deducir que el legislador, al trasponer la Directiva ha preferido mantener este término, admitiendo así el gran abanico de instrumentos que nos ofrece la Justicia Restaurativa en vez de acotarlo a uno de sus instrumentos como es el ya citado.

Dicho artículo 15 otorga a las víctimas la posibilidad de acceder a servicios de Justicia Restaurativa para la obtención de una reparación material y moral de los daños y perjuicios que se hayan derivado del hecho delictivo. Esta posibilidad de iniciación de

de la patria potestad o tutela en relación a la desaparición forzada de las personas a su cargo, cuando ello determine un peligro relevante de victimización secundaria

${ }^{321}$ A modo de ejemplo, CASTILLEJO MANZANARES, R., El principio de oportunidad en el proceso penal, Disponible en: www.fiscal.es (Última visita: 09/11/2017), nos indica sobre este artículo 15 "pues bien, congratulándonos de la inserción de la mediación en el proceso penal”. Un acierto matizado pues la Justicia Restaurativa engloba otras figuras igual o incluso más efectivas y restaurativas que la mediación para el apoyo y reparación de la víctima. 
un proceso reparativo sucederá cuando se reúnan una serie de requisitos: a) que el infractor haya reconocido los hechos esenciales de los que deriva su responsabilidad; b) que la víctima haya prestado su consentimiento, después de haber recibido información exhaustiva e imparcial sobre su contenido, sus posibles resultados y los procedimientos existentes para hacer efectivo su cumplimiento; c) que el infractor haya prestado su consentimiento $^{322}$; d) que el procedimiento de mediación no entrañe un riesgo para la seguridad de la víctima, ni exista el peligro de que su desarrollo pueda causar nuevos perjuicios materiales o morales; y e) que no esté prohibida por la ley para el delito cometido $^{323}$. Es el artículo 29 el cual le atribuye a las Oficinas de asistencia a las víctimas la función de apoyo a los servicios de Justicia Restaurativa, dicho de otro modo, todas las labores de información y conocimiento en favor de la víctima de la existencia de estos programas en su favor, los posibles resultados y beneficios ${ }^{324}$.

En último lugar cabe acudir con la regulación que el último Borrador del Código Procesal Penal (CPP), el cual no vio la luz finalmente, realizaba sobre la víctima, basándose en la ya citada Ley de mediación civil. El capítulo IV del Título II del Libro I CPP regulaba el Estatuto Procesal de la víctima en los artículos 59 a 68, recogiendo, entre otros, el derecho a ser tratado con pleno respeto a su dignidad en toda diligencia policial o actuación procesal; el derecho a no sufrir intervenciones corporales sin su

\footnotetext{
${ }^{322}$ Y aunque la Ley no indique nada, consideramos que el consentimiento del infractor también deberá ser posterior al conocimiento de la información acerca de su contenido, resultados y cumplimiento, para así poder valorar las consecuencias que van a emanar del proceso hacia él. No hay que obviar la vital importancia del victimario en todo proceso restaurativo, no sólo como un agente activo en la reparación de la víctima, sino en pos de su resocialización.

${ }^{323}$ En el momento en que se aprobó esta Estatuto, al no haber ninguna normativa sobre mediación penal (o Justicia Restaurativa), con este precepto se aludía a la prohibición contenida en el art. 87 ter.5 LOPJ como consecuencia de la promulgación de la LO 1/2004, de 28 de diciembre, de Medidas de Protección Integral contra la Violencia de Género, que nos indica que en todos los delitos de violencia de género está vedada la mediación. Vid ARANGÜENA FANEGO, C., "La mediación penal en el ámbito de la violencia de género ¿ha llegado el momento para replantearse su prohibición?”, en X. Abel Luch (coord.), Las medidas preventivas de conflictos jurídicos en contextos económicos inestables, Bosch, Barcelona 2014, pp. 145-162; CASTILLEJO MANZANARES, R., SANDE MAYO, M.J. y TORRADO TARRÍO, C., Justicia restaurativa y violencia de género. Más allá de la LO 1/2004, Universidad Santiago de Compostela 2014; FERNÁNDEZ LÓPEZ, A., La mediación en procesos por violencia de género, Aranzadi, Cizur Menor, 2015; GUARDIOLA LAGO, M.J., "La víctima de violencia de género en el sistema de justicia y la prohibición de la mediación penal”, en Revista General de Derecho Penal 2009, $n^{\circ} 12$, Disponible en http://www.iustel.com (última visita 11/04/2018)

${ }^{324}$ TAMARIT SUMALLA, J.M., "La reparación y el apoyo a las víctimas", en J.M. Tamarit Sumalla (coord.) El Estatuto de las ... op. cit., pp. 305-354, esp. p. 353.
} 
consentimiento, cuando se trate del ofendido por el delito; derecho a ser oída por el Ministerio Fiscal en el curso de la investigación; o, el derecho a obtener la restitución, reparación o indemnización del daño ocasionado por el hecho punible del responsable.

La víctima es una figura procesal que ha empezado a interesar al legislador, el cual no ha dudado en asignarle derechos dentro del proceso y equipararle a la figura del infractor. La víctima está adquiriendo la posición que se merece dentro del proceso, como un sujeto más, el más importante, que ha de ser informado y tenido en cuenta. Ahora es cuestión de tiempo que el asentamiento en esta nueva posición y el potenciamiento de la figura. Hay dos últimos aspectos a tratar. El primero es que lo importante no es sólo regular derechos en favor de la víctima, sino que para ayudar a la víctima se necesita "escucharlas, y después, escucharlas, y después, escucharlas” ${ }^{325}$. Y en segundo lugar, ha de tenerse en cuanta que la víctima no es sólo una figura procesal, sino una persona que ha sufrido y necesita ser socorrida por los instrumentos de justicia del Estado.

\subsection{Victimización secundaria y terciaria.}

De la comisión del acto delictivo nacen una serie de consecuencias o daños que afectan a la víctima, la cual necesita una reparación. Pero dichos actos no son los únicos que ocasionan dolor en ella, sino que todas aquellas actuaciones nacidas de la relación entre víctima-sistema jurídico penal pueden agravar los daños derivados del delito, siendo necesaria una intervención estatal para la disminución o desaparición de éstas.

El primer daño que surge del delito se podría denominar como victimización primaria, que son todos los perjuicios que sufre la víctima por la acción directa o indirecta del delito, pudiendo ser lesiones físicas y/o psicológicas, pérdida emocional o

\footnotetext{
${ }^{325}$ GÓMEZ GARCÍA, L., "Presupuestos, alcance y límites de la Justicia Restaurativa como derecho de las víctimas y beneficios para el infractor", Conferencia impartida en el IV Congreso de Justicia Restaurativa y Mediación Penal: del desiderátum a la realidad práctica, Burgos, 17 y 18 de Marzo de 2016.
} 
pérdida financiera. Cuando la víctima se relaciona con el aparato judicial, surgen (o mejor dicho, pueden surgir) unos nuevos trastornos denominados victimización secundaria $^{326}$, que son aquellos que la víctima recibe por parte de los "profesionales de los servicios sanitarios, policiales o de la judicatura a través de los interrogatorios, reconstrucciones de los hechos, asistencia a juicios, identificaciones de acusados, lentitud y demora de los procesos, etcétera”327. Estamos por tanto, como indica MAGRO SERVET ante "los sufrimientos que a las víctimas, a los testigos y mayormente a los sujetos pasivos de un delito les infieren las instituciones más o menos directamente encargadas de hacer justicia: policías, jueces, peritos, criminólogos, funcionarios de instituciones penitenciarias, etc. ${ }^{328}$, definición seguida por entre otros BERISTAIN ${ }^{329}$. A ello MONTERDE FERRER agrega “que la victimización secundaria es consecuencia de la interacción de la víctima con el complejo aparato jurídico penal del Estado y que con frecuencia resulta más negativa que la primaria al incrementar el daño causado por el delito con otros de dimensión psicológica o patrimonial”330.

Los agentes de policía buscan esclarecer los hechos, y mediante sus actuaciones muchas veces pueden obviar el dolor de la víctima, considerándolo en un segundo plano frente a la labor policial. La intromisión de éstos elude a la víctima y sus sentimientos, no teniéndola en cuenta nada más que para declaraciones o cotejos de fotografías por ejemplo. Los médicos forenses tampoco realizan tareas psicológicas en apoyo de la víctima, buscando únicamente pruebas y la comprobación de la salud mental o credibilidad de la víctima.

\footnotetext{
${ }^{326}$ En palabras de LANDROVE, "que se deriva de las relaciones de la víctima con el sistema penal. Vid. LANDROVE DÍAZ, G., Victimología ... op. cit., p. 139

327 DEL CORRAL GARGALLO, P., Asistencia a las Víctimas de Experiencias Traumáticas: Victimización primaria, secundaria y terciaria, Universidad del País Vasco, San Sebastian, 2015, p.8. Disponible en: http://www.sociedadvascavictimologia.org (Última visita: 09/11/2017)

${ }^{328}$ MAGRO SERVET, V., "La victimización secundaria de los menores en el proceso penal”, en Diario La Ley 2005, n 6282, pp. 1942-1952, esp. p. 1946.

${ }^{329}$ BERISTAIN IPIÑA, A., “¿La sociedad/judicatura atiende a sus víctimas/testigos?”, en AA.VV, Nueva Criminología desde el Derecho Penal y la Victimología, Tirant lo Blanch, Valencia, 1994, pp. 233-290, esp. pp. 233-235; Véase del mismo autor, Las víctimas en el proceso penal, Eusko Jaurlartiza, Gobierno Vasco, 2000.

330 MONTERDE FERRER, F., “Victimología. Proyecciones asistenciales prácticas”, en Cuadernos de Derecho Judicial 1993, n 15, pp. 243-286, esp. p. 274.
} 
En último lugar nos encontramos con el personal laboral de los Tribunales, los cuales siguen la misma línea que los anteriores sujetos citados. Los jueces aplican la ley, castigando al culpable como fin más importante del Derecho Penal. ¿Y qué pasa con las víctimas? No hay preocupación por su estado, solamente son testigos. Al tener que volver a revivir todo el hecho dañoso ante unos Tribunales más preocupados en la pena que en la reparación: ese dolor se agrava, no viéndose satisfecho por una pena no reparadora ni rehabilitadora.

La víctima se encuentra con una interminable repetición y exploración de esos actos que ocasionaron su daño, además del aislamiento en el procedimiento y la falta de información que le provoca un sentimiento de ser alguien ajeno a este interés. Y no sólo eso sino que durante el juicio, no sólo deberá detallar, sin apoyo alguno, el hecho dañoso, sino que tendrá que ser expuesta a un duro y cruel interrogatorio. A ello hay que añadir dos factores posibles más, así son la publicidad del proceso y la posibilidad, sobretodo en delitos de terrorismo, de que un grupo social apoye al infractor, aumentando el miedo, la soledad y el dolor de la víctima.

Un caso especial en este sentido son los Servicios de Asistencia a las víctimas quienes han de prevenir al máximo nivel posible la victimización secundaria de los sujetos pasivos de cualquier delito, pero sobre todo, de las víctimas de violencia de género. Éstas últimas, según GARCÍA RODRÍGUEZ, sufren un mayor riesgo de revivir esta victimización, debiéndose de impulsar su protección a través de la información de derechos, su participación en el proceso penal y la protección de la seguridad e intimidad, sobre todo a través la orden de protección, "facilitando a las víctimas de violencia de género a las que asista su solicitud, poniendo a su disposición información sobre su contenido, y realizando todas las actuaciones necesarias para garantizar su asistencia y protección social tras recibir su notificación telemática a través del Punto de Coordinación de las Ordenes de Protección” 331. ${ }^{331}$ GARCÍA RODRÍGUEZ M.J., “La Importancia de Los Servicios de Asistencia a las Víctimas en la
Administración de Justicia para minimizar el riesgo de su doble victimización en el proceso de violencia
de género”, en III Congreso para el estudio de la violencia contra las mujeres, Justicia y Seguridad. 
Desde otra perspectiva podemos añadir la controvertida victimización terciaria. Este supuesto trata sobre todos los daños y estigmas que afectan al infractor y a las personas afines a este como estigmatización como delincuente, dificultad en planificación de su vida, etc. ${ }^{332}$. Todo delincuente también sufre las consecuencias del proceso, desde el "mal trago" de sentirse prejuzgado, hasta las consecuencias que el cumplimiento de la condena le suponen al sujeto infractor. Como acertadamente señala CARNELUTTI“...la gente cree que el proceso penal termina con la condena, y no es verdad; la gente cree que la pena termina con la salida de la cárcel, y no es verdad; la gente cree que el ergástulo es la única pena perpetua y no es verdad. La pena, si no propiamente siempre, en nueve de cada diez casos, no termina nunca. Quien ha pecado está perdido. Cristo perdona, pero los hombres no"333.

El delincuente sufrirá un castigo por sus actos, siendo de interés examinar el motivo que sobrellevó la comisión de ese acto. Es usual la existencia de delincuentes que arrastran problemas desde tiempo atrás, ya sea por familias desestructuradas, por haber sufrido o convivido con violencia en su infancia ${ }^{334}$ o por ser estigmatizados por razón de su raza u origen. El caso más extremo de victimización terciaria es la pena de muerte, que es, como indica LANDROVE ${ }^{335}$, ese “asesinato jurídico” que se impone a ciertos delincuentes, siendo la raza uno de caracteres más influyentes en la aplicación de este castigo $^{336}$.

Nuevos retos, Granada: Consejería de Justicia e Interior de la Junta de Andalucía, 2012. Disponible en: http://www.violenciageneroasistenciavictimas.es (última visita 15/02/2017).

${ }^{332}$ TAMARIT SUMALLA, J., "La victimología. Cuestiones conceptuales y metodológicas”, en AA.VV. Manual de Victimología ... op. cit., pp. 17-50, esp. p. 33.

${ }^{333}$ CARNELUTTI, Las miserias del proceso penal, Temis, Bogotá, 2005, p. 33.

${ }^{334}$ GIMENEZ SALINAS considera como victimización terciaria a lo que ella misma denomina como "transmisión intergeneracional de la violencia, o efecto de aprendizaje", o dicho de otro modo, a la tendencia que tiene la persona que ha sufrido maltrato en su infancia a reproducirlo en épocas posteriores de su vida. Para más información, véase. GIMÉNEZ-SALINAS I COLOMER, E., "La otra cara del maltrato: ¿Una tercera victimización?", en A. García-Pablos (coord.), Víctima, prevención del delito y tratamiento del delincuente, Comares, Granada, 2009, pp. 3-16.

${ }^{335}$ LANDROVE DÍAZ, G., Victimología ... op. cit., pp. 141-142.

${ }^{336}$ Informe de Amnistía Internacional, Estados Unidos de América. Muerte por discriminación: la raza sigue influyendo en los casos de pena de muerte, 24 de abril de 2003. Disponible en: http://www.amnesty.org (Última visita: 09/11/2017) 
Algunos autores catalogan la victimización terciaria desde otro punto de vista, indicando que es una figura contra la sociedad. NÚÑEZ DE ARCO la considera como “la dirigida contra la comunidad en general, es decir contra la población total”337. En la misma línea BACA BALDOMERO valora la victimización terciaria como aquella que "se produce cuando el agresor ya identificado y condenado obtiene legalmente la libertad y sale a la calle” la cual ocurre también "en los casos de medidas de gracia para los agresores”338.

A partir de todo esto se puede deducir que conjuntamente el agresor, la víctima y la sociedad sufren las consecuencias del delito, tanto en el momento inmediatamente posterior de su comisión, como en las épocas posteriores. Un sistema como el actual no ampara a que la víctima pueda verse reparada del delito teniendo que hacer frente al estigma de haber sufrido un daño injusto. Tampoco socorre al infractor ni le permite rehabilitarse superando el gran estigma social que le marcará para siempre. Dos estigmas sociales por una actuación equivocada nos muestran que, no sólo se ha de preocupar en una asistencia a ambos desde la Administración, sino que hay que emprender una educación a los ciudadanos para el progreso dirigido a una pacificación social.

\section{Origen y definiciones de justicia restaurativa.}

Una vez comprendida la figura de la víctimología así como de la posición jurídica de la víctima en el proceso penal, es el momento de abordar el estudio de la Justicia Restaurativa $^{339}$. Un análisis teórico-pragmático de una figura filosófica que

\footnotetext{
${ }^{337}$ NÚÑEZ DE ARCO MENDOZA, J., El Informe pericial en Psiquiatría Forense, 2008. Disponible en: http://www.nunezdearco.com/victimologia.html (Última visita: 09/11/2017)

${ }^{338}$ GUERRICAECHEVARRÍA, C., y ECHEBURÚA ODRIOZOLA, E., "Especial consideración de algunos ámbitos de victimación”, en AA.VV., Manual de Victimología ... op. cit., pp. 129-234, esp. p. 199.

339 Existen multitud de estudios doctrinales de la Justicia Restaurativa tanto nacionales como internacionales, así como con diferentes enfoques más teóricos o pragmáticos. A modo de ejemplo, DOMINGO DE LA FUENTE, V., “¿Qué es la Justicia Restaurativa?”, en Criminología y Justicia, n 4, 2012, pp. 6-11; FODDAI, M.A., "Responsabilita e Giustizia Riparativa”, en Rivista italiana di diritto $e$ procedura penale, Vol. 59, n 4, 2016, pp. 1703-1723; JIMENO BULNES, M., "La giustizia riparativa
} 
comprende diversas prácticas restaurativas en aras de mejorar la situación de la justicia, de la víctima, del infractor y de toda la comunidad.

\subsection{Origen de una nueva filosofía.}

No es nuevo observar cómo nuestro sistema de justicia abandona a la víctima y centra su interés en el infractor para iniciarse lo que nosotros llamamos un "duelo" infractor versus Estado. El segundo busca demostrar la culpabilidad del primero por la vulneración de un precepto penal, olvidándose que detrás de esa vulneración existe una víctima, una persona que ha sufrido un daño. El sistema obvia a uno de los protagonistas del delito, el cual, como ya hemos indicado en el capítulo anterior, su posición queda sustituida por la del Estado, a través de la fiscalía, asumiendo la posición en “defensa de los intereses de la víctima”340.

Por ello se ve necesario un nuevo sistema más justo, más humano y que redescubra y atienda a la víctima ${ }^{341}$; que se centre en la resocialización del delincuente, que entienda el delito como un daño injusto que ha de solucionarse a través de una

nel sistema spagnolo", en L. Luparia (coord.), Lo statuto europeo delle vittime di reato: modelli de tutela tra diritto dell'Unione e buone pratiche nazionali, Wolters Kluwer, 2015, pp. 165-181;SOLETO MUÑOZ, H., "La justicia restaurativa como elemento complementario a la justicia tradicional", en AA.VV., Sobre la mediación penal (posibilidades y límites en un entorno de reforma del proceso penal español), Aranzadi, Cizur Menor (Navarra), 2012, pp. 41-90; SOLETO MUÑOZ, H., "Aportaciones internacionales al desarrollo de la Justicia Restaurativa en España", en I.J. Subijana Zunzunegui, et al., Justicia restaurativa, una justicia para el siglo XXI: potencialidades y retos, Publicaciones de la Universidad de Deusto, Bilbao, 2013, pp. 77-106; PEMBERTON, A., "Terrorism, Forgiveness and Restorative Justice”, en Oñati socio-legal series, Vol. 4, no 3, 2014, pp. 369-389; TOULLIER, M., "Restorative justice in France: status artis and future perspectives", en L. Luparia (dir.), Victims and criminal justice : european standards and national good practices, Wolters Kluwer, 2015, pp. 139-152; ZARAGOZA HUERTA, J., VILLAREAL SOTELO, K., "Justicia restaurativa”, en M. Gonzalo Quiroga, F. J. Gorjón Gómez, y A. Sánchez García (coord.), Métodos alternos de solución de conflictos: herramientas de paz y modernización de la justicia, 2011, Dykinson, Madrid, pp. 93-106.

${ }^{340}$ Nuestro sistema entiende que la defensa de los intereses de la víctima es la búsqueda de un castigo al infractor, olvidándose de la reparación efectiva de los intereses de la víctima del delito, aspecto abordado por otros métodos de aplicación de justicia, como los instrumentos restaurativos.

341 RÍOS MARTÍN, J.C., BIBIANO GUILÉN. A., SEGOVIA BERNABÉ, J.L., y PACUAL RODRÍGUEZ, E., La mediación penal y penitenciaria: experiencias de diálogo en el sistema penal para la reducción de la violencia y el sufrimiento humano, $2^{\mathrm{a}}$ ed., Colex, Madrid, 2008, pp. 51 y ss. 
restitución o reparación ${ }^{342}$; que anteponga las “necesidades reales de los sujetos” al ius puniendi $^{343}$. La Justicia Restaurativa ${ }^{344}$, o justicia reparadora ${ }^{345}$, es un nuevo paradigma de afrontar la justicia, en consecuencia, en palabras de KEARNEY, "se cuestiona la forma en que se ha hecho justicia hasta ahora, y ofrece un nuevo enfoque que sitúa a víctima e infractor en el centro de la búsqueda de la justicia. Por un lado, para la víctima, la Justicia Restaurativa ofrece un ambiente seguro para hacer preguntas y encontrar respuestas que sólo el infractor puede dar, ofrece una oportunidad para que la víctima explique al infractor el alcance de los daños causados por el delito y encuentra una forma de evitar el daño causado y restablecer la paz. Por otro lado, apoya al infractor para que rinda cuentas directamente con la persona más perjudicada por el delito, proporciona un espacio seguro para ofrecer una disculpa y demostrar que el daño no se repetirá" ${ }^{346}$, es un nuevo impulso a nuestra justicia, estudiada en la mayor parte de países europeos ${ }^{347}$, con la finalidad de la obtención de un proceso más justo y enfocado en la reparación del daño injusto creado a la víctima. Ello sin olvidarse de la figura de otros intervinientes como el infractor, el cual se resocializará a través de esta reparación, o la sociedad, la cual se hará participe en la elaboración del plan de reparación ${ }^{348}$. Pero, ¿por qué la sociedad se hará partícipe?

\footnotetext{
${ }^{342}$ Nosotros preferimos optar el término restauración, aunque los dos indicados son totalmente aceptados y podrían utilizarse indistintamente. Una buena definición de restitución es la indicada por BOLDT: "comprende cualquier actividad dirigida a reparar el daño o a restaurar a la víctima en la situación previa a la comisión del hecho delictivo, siempre que se realice a cargo del delincuente" vid. BOLDT, R.C., "Criminal Law: Restitution, Criminal Law, and de Ideology of Individuality", en Journal of Criminal Law and Criminology1986, $\mathrm{n}^{\circ}$ 77, pp. 969- 1022, esp. p. 970.

${ }^{343}$ TAMARIT SUMALLA, J.M., "El necesario impulso de la Justicia Restaurativa tras la Directiva Europea de 2012”, en Ars Iuris Salmanticensis 2013, n 1, pp. 139-160, esp. pp. 140-141.

344 BELLOSO MARTÍN, N., "Mediación penal ¿Beneficios reales o potenciales?", en Revista Criminología y Justicia 2012, no 4, pp. 21-34., esp. p. 24 nota 34.

${ }^{345}$ Noción adoptada por la Directiva 2012/29/UE de la Unión Europea por la que se establecen normas mínimas sobre los derechos, el apoyo y la protección a las víctimas de los delitos.

${ }^{346}$ BELLOSO MARTÍN, N., “Anotaciones sobre alternativas al sistema punitivo: la mediación penal”, en Revista Eletrônica de Direito Processual 2016, Vol. V, pp.146-186, esp. pp. 154-155.

${ }^{347}$ Aunque antiguo, el compendio AERTSEN, I., y WILLEMSENS, J., The European Forum for VictimOffenderMediation and Restorative Justice, Leuven University Press, Leuven, 2000 estudia los modelos que existían en Europa a inicios del presente siglo.

${ }_{348}$ Para entender la importancia de la comunidad en los proceso restaurativos, vid. FRANCÉS LECUMBERRI, P., y SANTOS ITOIZ, E., "La mediación penal, ¿̇un modelo de justicia restaurativa en el sistema de justicia penal?”, en Revista nuevo foro penal 2010, vol. 6, nº 75, pp. 53-93, esp. pp- 77-83.
} 
Porque la gente desea ayudar al prójimo y a todo ser humano le mueve la necesidad de ayudar $^{349}$.

Respecto a la terminología, ha existido una alta discusión doctrinal existiendo hasta numerosos autores que manejaban repertorios como Justicia Positiva, Pacificadora, Temporal, Transformadora, Comunitaria, Conciliativa, Reintegradora, Reintegrativa, Conciliadora, Reparativa, Reparadora ${ }^{350}$ o Restitutiva ${ }^{351}$. No fue hasta el Congreso Internacional de Budapest de $1993^{352}$ cuando determinó un vocablo fijo, que posteriormente se asentaría en subsiguientes simposios tales como Adelaida (1994), Ámsterdam (1997) ${ }^{353}$ o Montreal (2000) $)^{354}$ entre otros.

Se consideró a la expresión “restaurativa” como la más acertada al considerar que reconocía los derechos de las víctimas ${ }^{355}$, obviaba la venganza y se centraba en la reparación, buscando crear un estado de paz. Pero a pesar de ello, muchos autores no terminan de aceptar dicha locución ya que la expresión inglesa Restorative Justice no

\footnotetext{
${ }^{349}$ Intervención de VAN CAMP en el Congreso Europeo de Justicia Restaurativa y Terapéutica, celebrado en San Sebastián los días 16, 17, 18 de junio de 2016 .

${ }^{350}$ La justicia reparadora se centra fundamentalmente en la recuperación y reinserción del delincuente. Una gran diferencia acerca de estos conceptos lo encontramos en: PALMA CHAZARRA, L., La mediación como proceso restaurativo en el sistema penal, Tesis doctoral, Universidad de Sevilla, 2007, pp. 506-512: "Puede decirse que la justicia restaurativa tiene tres modelos derivados de sus orígenes: a) el religioso, cuyo objetivo es la búsqueda del perdón y de la reconciliación; b) el social, dirigido al restablecimiento de las relaciones y de la paz en la comunidad; c) el ubicado y utilizado por los sistemas de control social, desde su inicio y en su ejecución, por los órganos judiciales. (...) La justicia restaurativa es una concepción de la justicia manifiestamente distinta a la denominada "justicia reparadora" a pesar de que ambos términos son utilizados indistintamente".

${ }^{351}$ Término utilizado por Highton en su obra: HIGHTON, E.I., ÁLVAREZ, G.S., y GREGORIO, C.G., La resolución alternativa de disputas y Sistema penal, Ed. Ad-Hoc, Buenos Aires, 1998, pp. 71 y ss.

352 KEMELMAJER DE CARLUCCI, A., "En búsqueda de la tercera vía. La llamada Justicia Restaurativa, Reparativa, Reintegrativa o Restitutiva”, en S. García Ramírez (coord.) Memoria del Congreso Internacional de Culturas y Sistemas Júridicos Comparados, Instituto de Investigaciones Jurídicas de la UNAM Mexico D.F., 2005, pp.271-324. p. 272.

${ }^{353}$ VARONA MARTÍNEZ, G., La mediación reparadora como estrategia de control social. Una perspectiva criminológica, Comares, Granada, 1998, pp. 8 y ss.

${ }^{354}$ CHRISTIE, N., "Conflicts as property", en A. von Hirsch y A. Ashworth, (eds), Principled Sentencing. Readings on Theory and Policy, Hart Publishing, Oxford, 1998, pp. 312-316, esp. pp. 312313.

${ }^{355}$ Tal y cómo pone de manifiesto Sampedro en el desarrollo de investigación: SAMPEDRO ARRUBIA, J. A., “¿Qué es y Para qué sirve la Justicia Restaurativa?” en Derecho Penal Contemporáneo: Revista Internacional 2005, $\mathrm{n}^{\circ}$ 12, pp. 53-85, esp. p. 55.
} 
tiene una traducción sencilla, pudiendo dar lugar a actividades más materiales ${ }^{356}$ tales como la restitución o restauración a través de cantidades económicas. Pero hemos de indicar que el modelo de restorative se basa en las famosas tres " $\mathrm{r}$ "357:

- Responsibility: responsabilidad del autor por las conductas que realiza libremente.

- Restoration: restauración de la víctima, la cual ha de ser reparada.

- Reintegration: reintegración de la víctima en la sociedad.

Una vez analizados la terminología hemos de dar un paso más atrás en el tiempo y observar aquellos hechos que desencadenaron en dichos estudios. Su origen se remonta a Norteamérica ${ }^{358}$, y más concretamente, a Ontario, Canadá, en los años setenta ${ }^{359}$; de modo concreto cuando un oficial de libertad vigilada propuso al juez un castigo diferente para dos chicos que habían causado daños en vehículos estacionados en las calles de los diferentes distritos de la ciudad. Esta nueva corrección fue una serie de encuentros con las víctimas, pedirles perdón y reparar el daño producido ${ }^{360}$. Tras ello, fue en la misma ciudad canadiense de Ontario, en 1974 cuando se implementó el Mennonite Central Committee (Church) ${ }^{361}$ para la resolución de conflictos a través de la mediación, que se complementaba con el proyecto de conciliación víctima-ofensor en dicha ciudad $^{362}$. Un hito importantísimo ya que esta nueva visión acerca de un posible castigo, unidas a otras tradiciones más antiguas, como las "reparaciones” de tribus

\footnotetext{
${ }^{356}$ MIERS, D., An International Review of Restorative Justice, Londres, Home Office, Londres, 2001, nota 2.

${ }^{357}$ MIERS, D. et al., And Exploratory Evaluation of Restorative Justice Schemes, Home Office, Londres, 2001, p.9

${ }^{358}$ ROSS, H., “Alternative Dispute Resolution: Mediation in the federal courts began in 70's", The Alaska Bar Rag 2007, nº enero-marzo, pp. 30-31.

${ }^{359}$ GIMÉNEZ-SALINAS I COLOMER, E., "La mediación en el sistema de justicia juvenil: una visión desde el Derecho comparado”, en J.M. Martínez-Pereda Rodríguez, (Dir.), Menores privados de libertad. CGPJ, Madrid, 1996, pp. 53-81, esp. pp. 63-67.

360 BELTRÁN MONTOLIU, A., "Modelo de mediación en los Estados Unidos de América", en S. BARONA VILAR (coord.), La mediación penal para adultos. Una realidad en los Ordenamientos jurídicos, Tirant lo Blanch, Valencia, 2009, pp. 53-84, esp. p.60.

${ }^{361}$ MERA GONZÁLEZ-BALLESTEROS, A., "Justicia restaurativa y proceso penal garantías procesales: límites y posibilidades”, en Revista Ius et Praxix 2009, vol. 15, no 2, pp. 165-195, esp. p. 169.

${ }^{362}$ Véase, POWELL, E., "Victim-offender Reconciliation program: bringing Restorative to the Local Community", en Quaker Comité on Jails \& Newsletter 1997, $\mathrm{n}^{\circ} \quad 40$. Disponible en http://restorativejustice.org (última visita 10/05/2017).
} 
maoríes o indígenas americanos, ha conducido al nacimiento de una figura basada en el trabajo y esfuerzo de los implicados que restablece los canales de comunicación y genera un tercer espacio ${ }^{363}$.

Los pueblos indígenas consideraban a la comunidad como vía fundamental para la reparación del daño, y por ello basaban gran parte de su Derecho Penal en el diálogo entre víctima, infractor y comunidad. Todo delito dentro de su comunidad afectaba al conjunto de los miembros, trataba como un daño creado a todos los individuos; por ello era fundamental la participación de la comunidad para la resolución de dicho conflicto. Afirmaba que este perjuicio damnificaba a la totalidad de la sociedad, "las enseñanzas y tradiciones tribales sintetizan la aplicación de la Justicia Restaurativa, en el entendimiento de la forma de vida de las personas y de cómo la conducen, las cuales sirven como métodos prácticos que promueven la armonía en la comunidad. Por este motivo la dimensión de la Justicia Restaurativa es cultural y abarcadora: no se centra en delitos solamente ${ }^{364}$.

Hay que advertir que no hay que confundirse y atribuirle un único origen, normalmente "indígena", a esta figura o incluso un origen en las sociedades premodernas $^{365}$. DOMINGO DE LA FUENTE considera que la Justicia Restaurativa es un concepto existente en culturas primitivas, acudiendo al código de Hammurabi o la Biblia (Lucas 19.8 "Zaqueo se levantó entonces y dijo al señor: Mira Señor, voy a dar a los pobres la mitad de lo que tengo y si he robado a alguien le devolveré cuatro veces más"), y nos indica que "la Justicia Restaurativa es la Justicia que existió en el inicio

\footnotetext{
${ }^{363}$ MARTÍNEZ ARRIETA, A., “Mediación como Tercera Vía de Respuesta a la Infracción Penal”, en Familia: Revista de ciencias y orientación familiar 2010, no 41 , pp. 85-117, esp. p. 97.

${ }^{364}$ LEUNG, M., The Origins of Restorative Justice, 1999, pp. 1-22, esp. p. 6-7. Documento en línea. Disponible en: http://www.cfcj-fcjc.org (Última visita: 09/11/2017)

365 DIGNAN, J., Understanding Victims and Restorative Justice, Maidenhead, Open University Press, 2005, p. 94. Dignan nos indica: "Quienes sostienen que los mismos principios y prácticas fueron universalmente implementados por las sociedades pre modernas han exagerado y selectivamente interpretado la evidencia antropológica disponible".
} 
de los tiempos y que perdimos con la evolución de nuestra sociedad y de nuestros sistemas jurídicos y políticos” ${ }^{366}$.

Consideramos esta visión errónea pues la Justicia Restaurativa como tal es un concepto muy reciente. Es un compendio de diferentes actuaciones que se han dado en épocas antiguas. Nunca perdimos la Justicia Restaurativa porque no existía: simplemente existían prácticas con algunas similitudes a las figuras actuales y, más que a las prácticas en sí, a la idea de reparación, el cual es el fin de la Justicia Restaurativa. Estamos ante un conjunto de ideas y actuaciones presentes y pretéritas en el tiempo; presentes en obras, prácticas y cuerpos legales antiquísimos como la Ley Brehon irlandesa, los Consejos de Paz de Macedonia ${ }^{367}$ o las prácticas tribales de las First Nations, de los maorís neozelandeses, de los nativos hawaianos, la shula palestina, la jirga de Afganistán ${ }^{368}$ e incluso las actuaciones contenidas en la Biblia ${ }^{369}$ o, como acertadamente señaló ZEHR, ejercidas por el pueblo romano o griego ${ }^{370}$. La unión de todas ellas ha ido generando diversos instrumentos de reparación, siendo cada uno de ellos diferentes dependiendo de las características propias del lugar de su utilización pero bajo un modelo lo suficientemente flexible que puede adecuarse a los intereses y valores de las diferentes culturas involucradas ${ }^{371}$.

Tal y como se ha podido apreciar los modelos de desjudicialización de la justicia juvenil son los primeros ejemplos prácticos que hubo de Justicia Restaurativa siendo "el

\footnotetext{
${ }^{366}$ DOMINGO DE LA FUENTE, V., "El origen de la Justicia Restaurativa” en Blog de la Justicia Restaurativa, entrada de 5 de julio de 2012. Artículo Disponible en: http://blogdelajusticiarestaurativa.blogspot.com.es (Última visita: 09/11/2017)

${ }^{367}$ DÜNKEL, F., "Justicia Restaurativa en Europa”, en el Congreso Europeo de Justicia Restaurativa y Terapeútica, celebrado en San Sebastián los días 16, 17, 18 de junio de 2016.

368 OLALDE ALTAREJOS, A. J., "Encuentros restaurativos en victimización generada por delitos de terrorismo: bases teóricas”, en E. Pascual Rodríguez (coord.) Los ojos del otro; Encuentros restaurativos entre víctimas y ex miembros de ETA, Sal Terrae, Santander, 2013, pp. 23-84, esp. p. 30, nota 10.

${ }^{369}$ Ejemplo de ello es: "Evitar la muerte del delincuente y de procurar que se corrija y viva"; "busca un arreglo con el que te pone pleito mientras vais de camino, no sea que te entregue al juez, y el juez al guardia, y te metan en la cárcel, Lucas” (Lucas 12,58 y Mateo 5,25). Más ampliadamente MARTINI, C. M., y ZAGREBELSKY, G., La exigencia de justicia, Trotta, Madrid, 2006.

${ }^{370}$ ZEHR, H., Changing lenses: a new focus for crime and Justice, $3^{\mathrm{a}}$ ed., Herald Press, Scottsdale, 2005, pp. 99-100.

${ }^{371}$ MERA GONZÁLEZ-BALLESTEROS, A., “Justicia restaurativa y proceso penal garantías procesales: límites y posibilidades”, en Revista Ius et Praxix 2009, vol. 15, nº 2, pp. 165-195, esp. p. 169.
} 
principio fundamental de una ley de responsabilidad penal juvenil”372. A través de la desjudicialización se mantiene la efectividad de la Administración de justicia a través de la disminución de carga $^{373}$, y aunque éste no sea el fin más importante, no puede negarse como un fin no perseguido ${ }^{374}$.

Para aplicar esta desjudicialización se puede optar por dos caminos, la renuncia a la aplicación de métodos alternativos renunciándose a la intervención penal, o a través de la aplicación de otro tipo de medidas y métodos ${ }^{375}$. Es en el ámbito del Derecho Penal de menores, “donde se dan las condiciones más favorables para la aplicación de los planes de conciliación delincuente-víctima, visto el carácter especial de las normas aplicables a la población juvenil”,376, siendo así "un marco apropiado para fomentar estos mecanismos de la justicia reparadora”377. Es aquí donde más planteamientos han existido, buscando dar una respuesta diferente al sistema penal juvenil debido a las consecuencias que el sistema penal clásico puede infringir en un menor ${ }^{378}$, estigmatizándole y conduciéndole a una posible reincidencia ${ }^{379}$.

Para GORDILLO SANTANA ${ }^{380}$ son múltiples factores que han provocado el acercamiento de este nuevo modelo a nuestra sociedad, así como el renacimiento de la víctima, el fracaso de la política resocializadora, la estigmatización que tiene la prisión

372 MAXERA, R., "Mecanismos restaurativos en las nuevas legislaciones penales juveniles: Latinoamérica y España”, en F. Bernal Acevedo y C. Castillo Vargas, (Coord.), Justicia Restaurativa en Costa Rica: Acercamientos teóricos y prácticos, CONAMAJ, San José, 2006, pp. 93-114, esp. p. 108.

${ }^{373}$ DÜNKEL, F., "Reacciones en los campos de la administración de justicia y de la pedagogía social a la delincuencia infantil: un estudio comparativo a escala europea”, en Cuadernos de Derecho Judicial, CSPJ, Madrid, 2001, pp. 119-186, esp. p.153.

${ }^{374}$ QUERALT JIMÉNEZ, J., "Víctimas y garantías: algunos cabos sueltos. A propósito del proyecto alternativo de reparación”, en J. M. Silva Sánchez (dir.) Política criminal y nuevo derecho penal. Libro homenaje a Claus Roxin, Bosch, Barcelona, 1997, pp. 145-172, esp. p. 149.

${ }^{375}$ GARCÍA PÉREZ, O., "Los actuales principios rectores del Derecho penal juvenil: un análisis crítico”, en Revista de Derecho Penal y Criminología 1999, n 3, pp. 33-76, esp. p. 33.

${ }^{376}$ FUNES I ARTIAGA, J., Mediación y Justicia juvenil. Fundació Jaume Callís, Barcelona, 1995, p. 29.

377 SANZ HERMIDA, A.M ${ }^{\mathrm{a}}$., Víctimas de delitos: derechos, protección y asistencia, Iustel, Madrid, 2009, p. 137.

${ }^{378}$ GARCÍA PABLOS DE MOLINA, A., Criminología: una introducción a sus fundamentos teóricos, $6^{\mathrm{a}}$ ed., Tirant Lo Blanch, Valencia, 2007, p. 479.

${ }^{379}$ HIGHTON, E.I., ÁLVAREZ, G.S., GREGORIO, C.G., La resolución alternativa ..., op. cit., p. 60.

380 GORDILLO SANTANA, L.F., La Mediación en el ámbito penal. Caminando hacia un nuevo concepto de Justicia. Tesis Doctoral, Universidad de la Rioja, 2005, pp. 30-42; GORDILLO SANTANA, L. F., La Justicia Restaurativa y La Mediación Penal, Iustel, Madrid, 2007, pp. 57-61. 
en los delincuentes, las teorías abolicionistas y la crisis que ha sufrido el modelo de justicia tradicional.

Es fundamental advertir que la Justicia Restaurativa no tiene un único germen, sino que en su árbol genealógico podemos encontrar múltiples fases y ramificaciones, estando ante una “compilación” de diferentes formas de ver justicia. Si unimos la búsqueda de un nuevo sistema de justicia, la preocupación por la víctima, el interés por un sistema resocializador, las diversas formas de impartir cultura que tenían los pueblos indígenas como maorís y navajos, así como su preocupación por todos los individuos afectados por el delito (contabilizando aquí a la comunidad), se ofrece un sistema amplio que, aun subdivido en múltiples modelos, todos tienen el objetivo de procurar una resolución más humana del conflicto que beneficie a víctima, infractor y comunidad.

\subsection{Las diferentes definiciones existentes.}

De modo inicial se ha de señalar un conjunto de definiciones relativas a qué es Justicia Restaurativa, pudiendo determinar que “es una teoría de justicia que enfatiza reparar el daño causado o revelado por el comportamiento criminal” ${ }^{381}$. Múltiples son los autores que han otorgado conceptos y que con sus estudios han dado lugar a la actual definición ${ }^{382}$, aún con las constantes disimilitudes existentes en todas ellas. Como indicó MARTIN WRIGHT: "Si preguntamos a dos personas economistas sobre un problema, ellas ofrecerán tres soluciones. Existe una situación similar si se pregunta a las personas defensoras de la Justicia Restaurativa acerca de una definición; no hay manera de que se pongan de acuerdo" 383 .

\footnotetext{
${ }^{381}$ BERNAL ACEVEDO, F., “Justicia Restaurativa en Costa Rica: Acercamientos Teóricos y Prácticos”, en I Congreso de Justicia restaurativa, CONAMAJ, Costa Rica, 2006, p.35.

382 Véase HUDSON, J. GALAWAY, B., Restitution in Criminal Justice: A Critical Assessment of Sanctions, Lexington Books, Lexington, 1977.

383 OLALDE ALTAREJOS, A. J., “Encuentros restaurativos en ...” op. cit. pp. 23-84, esp. p. 26.
} 
Esta dificultad a la hora de conseguir una unanimidad en la definición de Justicia Restaurativa no nos ha impedido poder estudiar diferentes vías, todas ellas acertadas, de entender este nuevo paradigma. No hay mejor modo de iniciar este apartado que con la definición propuesta por MARSHALL, el cual indica que Justicia Restaurativa es “un proceso mediante el cual todas las partes implicadas de un delito en particular se reúnen para resolver colectivamente la manera de afrontar las consecuencias del delito y sus implicaciones para el futuro",384

Esta definición es la más citada y traducida (de ahí las diferentes versiones que existen, dependiendo de la traducción elegida) pero también una de las más cuestionadas. Como indica BRAITHWAITE ${ }^{385}$, la definición no indica qué debe de ser restaurado y sólo señala partes implicadas, aspecto sobre el que creemos incompleto ya que parece referirse a encuentros víctima-infractor como los que nos propone la mediación.

Otra interesante definición de Justicia Restaurativa es la aportada por RÍOS MARTÍN al indicar que Justicia Restaurativa es: “la filosofía y método de resolver los conflictos que atienden prioritariamente a la protección de la víctima y al restablecimiento de la paz social, mediante el diálogo comunitario y el encuentro personal entre los directamente afectados, con el objeto de satisfacer de modo efectivo las necesidades puestas de manifiesto por los mismos, devolviéndoles una parte significativa de la disponibilidad sobre el proceso y sus eventuales soluciones, procurando la responsabilización del infractor y la reparación de las heridas personales y sociales provocadas por el delito" 386

\footnotetext{
${ }^{384}$ MARSHALL, T., “The evolution of restorative justice in Britain”, en European Journal on Criminal Policy and Research 1996, vol 4, nº4, pp. 21-43, esp. p. 37.

385 BRAITHWAITE, J., Restorative Justice and Responsive Regulation, Oxford University Press, Oxford, 2002, p.3.

${ }^{386}$ RÍOS MARTÍN, J.C., La mediación penal y penitenciaria. Experiencias de diálogo en el sistema penal para la reducción de la violencia y el sufrimiento humano, $2^{\mathrm{a}}$ ed., Colex, Madrid, 2008, pp. 31-32.
} 
Para CERETTI, la Justicia Restaurativa es el paradigma de una “justicia que comprende la víctima, el imputado y la comunidad en la búsqueda de soluciones a las consecuencias del conflicto generado por el hecho delictuoso con el fin de promover la reparación del daño, la reconciliación entre las partes y el fortalecimiento del sentido de seguridad colectivo”, ${ }^{387}$ Esta definición la completa KEMELMAJER al advertir que "el desafío es superar la lógica del castigo pasando a una lectura relacional del fenómeno criminal, entendido primariamente como un conflicto que provoca la ruptura de expectativas sociales simbólicamente compartidas” ${ }^{388}$.

Pero no hemos de olvidarnos de la completa exposición que nos proporciona la Declaración de los Principios Básicos del uso de programas de justicia reparadora en materia penal de 7 de enero 2002 del Congreso de las Naciones Unidas para la prevención del crimen y el tratamiento del víctimario, la cual la define como "un proceso en el cual la víctima, el ofensor y/o cualquier otro miembro individual o colectivo afectado por el delito participaron conjunta y activamente en la resolución de las cuestiones vinculadas al delito, generalmente con la ayuda de una tercero justo e imparcial” ${ }^{389}$.

Sin duda, una de las más valiosas aportaciones es la efectuada por ZEHR, uno de los llamados “padres” de la Justicia Restaurativa, el cual afirma que se produce una reestructuración de los daños morales y materiales con la interacción víctimavictimario ${ }^{390}$. Define la Justicia Restaurativa como "un proceso para involucrar, en la medida en que sea posible, a aquellos que tienen una participación en un delito

\footnotetext{
${ }^{387}$ CERETTI, A., “Giustizia riparativa e mediazione penale: esperienze e practiche a confronto”, en F. SCAPARRO, Il coraggio di mediare, Guierini e Associati, Milán, 2001, pp. 307-356, esp. p. 309; KEMELMAJER DE CARLUCCI, A., En búsqueda de ... op. cit., pp. 274-275.

${ }^{388}$ KEMELMAJER DE CARLUCCI, A., En búsqueda de ... op. cit., p. 275.

389 ORGANIZACIÓN DE NACIONES UNIDAS (ONU), Principios Básicos del uso de programas de justicia reparadora en materia penal, en el Informe de la reunión del grupo de expertos sobre justicia restaurativa. Comisión de Prevención del delito y justicia penal, 11 período de sesiones, Viena, 2002. Disponible en http://www.unodc.org (última visita 24/01/2018)

390 Para más información relativa a esta materia, véase TRUJILLO, J., Mediation: World it work in Spain too?, Universidad de Lovaina, Bélgica, faculty of Law, Master in European Criminology, 2000.
} 
específico y colectivamente identificar y abordar perjuicios, necesidades $y$ obligaciones, con el fin de sanar y poner las cosas tan correctas como sea posible”391

Como podemos comprobar, han sido mucho los estudios sobe esta figura y muchas las definiciones otorgadas, algunas exitosas y otras, como la otorgada por la Comisión de Prevención del Delito y Justicia Penal de las Naciones Unidas, sin tanta fortuna $^{392}$.

Esta figura tiene muchas definiciones, todas ellas basadas en el diálogo, y de todas ellas nacen una serie de principios que GIMENEZ-SALINAS I COLOMER ${ }^{393}$ recoge:

1) “La reparación nace del movimiento a favor de la víctima y la recuperación de su papel en el proceso penal.

2) La reparación cumple no solamente una función individual del autor respecto de la víctima, sino también un fenómeno pacificador propio del Derecho penal.

3) La reparación penal no se puede confundir con la indemnización civil a las víctimas.

4) La voluntariedad en la reparación es un punto crucial.

5) La reparación forma parte de un concepto de justicia negociada aunque no por ello más rápida.

6) La Justicia reparadora se sitúa en el seno del Derecho penal.”

${ }^{391}$ ZEHR, H., The Little Book of Restaurative Justice, Good books, Pennsylvania, 2002, p.37. Como indica Howard Zehr en la nota final número 6 de la página 74, su definición es una adaptación propia de la definición de Tony Marshall.

${ }^{392}$ Aunque a pesar del fracaso de la Comisión en este sentido, sí que hubo algunos países que desarrollaron un acertado concepto de esta figura, como Filipinas que propuso que la Justicia Restaurativa "es una vía alternativa de justicia penal que no tiene carácter punitivo sino que procura más bien hacer justicia a delincuentes y víctimas por igual, en vez de inclinar la balanza marcadamente a favor de una de las partes en detrimento de la otra. Busca recomponer las relaciones sociales, que son el objetivo último de la justicia restaurativa, y pretende abordar tanto la acción delictiva como el sufrimiento que de ella se deriva, lo que es también el objetivo de la justicia correctiva", p. 3. Disponible en: https://www.unodc.org (última visita 24/06/2017).

${ }^{393}$ GIMÉNEZ- SALINAS I COLOMER, E., "La mediación: una visión desde el derecho comparado", en D. Rossner (ed.), La mediación penal, Centro de Estudios Jurídicos y Formación Especializada de la Generalitat de Cataluña, Barcelona, 1999, pp. 87-108, esp. pp. 94-96. 
Sirva aquí aventurar nuestra propia definición de Justicia Restaurativa, considerando que es aquella filosofía orientada en la posibilidad de obtención de una resolución de conflictos penales de una manera más humana y justa a través del diálogo y trabajo en común de las partes implicadas y de la comunidad, que lleve a víctima e infractor a una normalización de sus relaciones, a una restauración de la situación anterior, a una recuperación de la armonía social, y por ello, a la reparación del daño causado.

Es una filosofía integral ${ }^{394}$ que permite retomar el diálogo entre víctima e infractor con el fin de dar expresión a las emociones y sentimientos originados por el delito, dejando ver una cara más “amable” y humana del Derecho Penal, evitando la victimización secundaria ${ }^{395}$, la cual, en palabras de JIMENO BULNES, “llega a mostrarse más perniciosa y perjudicial para la víctima que la «victimización primaria»" ${ }^{396}$.

El uso de la Justicia Restaurativa, en palabras de la profesora BELLOSO MARTÍN, "no menoscaba el ius puniendi del Estado", sino que "lo complementa con otras medidas" ${ }^{397}$. Por tanto, la Justicia Restaurativa ha de introducirse como un

\footnotetext{
${ }^{394}$ En palabras de Braithwaite, a holistic philosophy. Vid. BRAITHWAITE, J., Restorative justice and responsive regulation, Nueva York, Oxford University Press, 2002, VII

${ }^{395}$ GORDILLO SANTANA, J.L., La Justicia Restaurativa y la mediación penal, Iustel, Madrid, 2007, p. 55.

396 JIMENO BULNES, M., “¿Mediación penal y/o justicia restaurativa? Una perspectiva europea y española”, en Diario La Ley 2015, n ${ }^{\circ}$ 8624, p. 3. Disponible en: http://diariolaley.laley.es (última visita $12 / 04 / 2016)$

${ }^{397}$ A su vez BELLOSO MARTIN prosigue indicando como los principales rasgos que "los procesos restaurativos deben utilizarse únicamente cuando haya pruebas suficientes para inculpar al delincuente, y con el consentimiento libre y voluntario de la víctima y del delincuente; La víctima y el delincuente podrán retirar ese consentimiento en cualquier momento del proceso; Se llegará a los acuerdos de forma voluntaria y solo contendrán obligaciones razonables y proporcionadas; La víctima y el delincuente normalmente deben estar de acuerdo sobre los hechos fundamentales de un asunto como base para su participación en un proceso restaurativo; La participación del delincuente no se admitirá como prueba de admisión de culpabilidad en procedimientos jurídicos ulteriores"]. Vid. BELLOSO MARTíN, N., "Anotaciones sobre alternativas al sistema punitivo: la mediación penal" en Revista Eletrônica de Direito Processual 2010, Año 4, Vol. V, pp. 146-186, esp. p. 154, traduciendo las palabras de KEARNEY, Niall, Presidente del European Forum for Restorative Justice (Carta de Presentación del I Congreso Internacional sobre Justicia Restaurativa y Mediación Penal. Dimensiones teóricas y repercusiones prácticas”, celebrado en la Facultad de Derecho de la Universidad de Burgos (España) entre los días 04 y 05 de marzo de 2010).
} 
complemento voluntario de nuestro sistema penal, y nunca como una alternativa ${ }^{398}$, a pesar de la existencia de opiniones que propugnan la Justicia restaurativa como un modelo “alternativo a la justicia retributiva"399. Tal y como señala GONZÁLEZ CANO, "la solución restaurativa no es ni debe ser ajena al Derecho, [...] debe estar insertada en el ordenamiento, porque es el ordenamiento jurídico el que debe responder a las necesidades ${ }^{400}$.

Todas estas definiciones que hemos ido recogiendo nos muestran los diferentes estudios existentes sobre esta "filosofía”, estudios que van desde un mero desarrollo teórico de la figura, hasta un análisis pragmático en otros posibles ámbitos del derecho $^{401}$. Lo importante es que todos ellos nos llevan a comprender que esta nueva manera de aplicar justicia no deja de ser un conjunto de actuaciones, más o menos restaurativas, que buscan acabar con la injusticia, centrado en todos los miembros de la comunidad y en su participación activa. Y esto es importante, pues es la participación de los miembros de la sociedad la que nos va a conducir a que una práctica sea más o menos restaurativa, y por tanto, de mayor utilidad social para la comunidad ${ }^{402}$.

\footnotetext{
${ }^{398}$ BARONA VILAR, S. "Mediación penal como pieza del sistema de tutela penal en el siglo XXI. Un paso más hacia la resocialización y la justicia restaurativa", en Revista de Derecho Penal 2009, n 26, págs. 11-53, esp. p. 23.

399 TAMARIT SUMALLA, J.M., "La justicia restaurativa: concepto, principios, investigación y marco teórico”, en J.M. Tamarit Sumalla (coord.), La justicia restaurativa: desarrollo y aplicaciones, Comares, Granada, 2012, p. 6.

${ }^{400}$ GONZÁLEZ CANO, M.I., "La integración de la mediación en el sistema procesal penal a través de medidas de diversión”, en M. Jimeno Bulnes y J. Pérez Gil (coords.), Nuevos horizontes del derecho procesal: libro-homenaje al Prof. Ernesto Pedraz Penalva, Bosch, Barcelona, 2016, pp. 671-695, esp. p. 673.

${ }^{401}$ Un estudio de la Justicia Restaurativa en relación a otras figuras del derecho es el relativo a la orden europea de detención y Justicia Restaurativa. Vid. MIGUEL BARRIO, R., "La Euroorden, ¿Es recomendable cuando el infractor está inmerso en un proceso de Justicia Restaurativa?”, en J. Burgos Ladrón de Guevara (coord.), La cooperación judicial entre España e Italia, Instituto Vasco de Derecho Procesal, San Sebastián, 2017, p. 115-135

${ }^{402}$ Como acertadamente indica Wright, "un procedimiento es más restaurativo cuando supone un apoyo a la víctima (especialmente para aquellas cuyos ofensores no son conocidos o no están de acuerdo en tomar parte), por ejemplo a través de las diferentes ayudas de compensación; cuando ayuda a los ofensores a comenzar un nuevo camino de medidas de rehabilitación; o cuando ofrece la oportunidad de que la comunidad se vea envuelta, especialmente a través del voluntariado. Un proceso restaurativo hace todas estas cosas, al mismo tiempo ofrece la participación directa de víctimas y ofensores" WRIGHT, M., "The court as last resort. Victim-sensitive, community-based responses to crime" en The British Journal of Criminology 2002, no 42, pp. 654-667, esp. p. 654. En la misma línea y siguiendo a WRIGHT véase OLALDE ALTAREJOS, A. J., “Encuentros restaurativos en ...” op. cit. pp. 23-84, esp. p. 26.
} 


\section{Aspectos generales de la justicia restaurativa}

En el siguiente apartado vamos a analizar una serie de características propias de esta nueva filosofía, examinando todas las ventajas que otorga a sus participantes, objetivos y diferencias con el modelo tradicional.

\subsection{La superación como base del nuevo paradigma}

La Justicia Restaurativa supera la concepción del delito al considerar que no sólo se ha vulnerado un precepto penal sino que se ha dañado a la víctima y a la sociedad, emergiendo unas relaciones de este daño ${ }^{403}$. Supera la situación actual al conceder el papel protagonista a las partes intervinientes en el propio hecho delictivo. La respuesta al delito ya no es un monopolio del Estado ${ }^{404}$. Las prácticas restaurativas otorgan el poder del conflicto a la víctima, infractor, familiares, personas de apoyo y a la comunidad.

Supera la concepción de éxito que entraña el castigo impuesto al infractor, centrando su interés en la reparación de la víctima como aspecto vital e incluso en la reparación de la sociedad y resocialización del infractor. Va más allá de castigar al infractor. Centra su interés en la víctima y el infractor, en su reintegración pacífica y sanada en la sociedad.

Se ha de añadir que los modelos de justicia reparativa no obvian al Estado, no desean apartarlo, no evitan su posible participación, sino que consideran que su intervención ha de limitarse a verificar de la legalidad, para permitir una mayor participación de la sociedad ${ }^{405}$ pero revisar la posible vulneración del sistema legal en

\footnotetext{
${ }^{403}$ ZEHR, H., The Little Book of ... op. cit., p.21.

404 QUINTERO OLIVARES, G., "El nuevo paradigma de la justicia restaurativa: la pretensión de superación del modelo vigente”, en R. Castillejo Manzanares M.J. Sande Mayo, y C. Torrado Tarrío (coords.), Justicia restaurativa y ... op. cit., pp. 145-168, esp. p. 146.

${ }^{405}$ LARRAURI, E., “Tendencias actuales de la Justicia Restauradora”, en F. Pérez Álvarez, Serta: In memoriam Alexandri Baratta, Universidad de Salamanca, Salamanca, 2004, pp. 67-104, esp. p. 446.
} 
estos procesos restaurativos. Consideramos que es el Ministerio Fiscal el primer garante de la legalidad del proceso.

A través de esta figura los afectados por el hecho delictivo (víctimas, infractores y comunidad) toman el control del proceso, siendo parte de las decisiones acerca de él, siendo sus protagonistas. Su diálogo y sus posturas se irán acercando hasta la consecución de un plan de reparación que satisfaga a la víctima. Se va a analizar el hecho delictivo, sus posibles causas, cómo se ha de reparar y quién ha de ejecutar dichas actuaciones $^{406}$. Es clave observar cómo el diálogo contribuye a la resolución. El sistema actual subestima el poder de las palabras, creyendo que víctima e infractor no pueden ni deben- ponerse de acuerdo en la resolución de un conflicto, debiendo de mantener una postura de enemistad manifiesta, sin la posibilidad de acercar posturas ni tener contacto alguno. En realidad son las partes las que han de trabajar para la consecución de una reparación, y es su trabajo en común el que las proporciona seguridad y confianza. Este plan de reparación nacido del consenso, diálogo y trabajo de los intervinientes, nos lleva a una justicia más “justa” y humana, que a la vez es más transformadora y, por ende, reparadora.

\subsection{Objetivos y caracteres propios.}

Analizado el origen y definición de la Justicia Restaurativa, se ha de centrar la atención en los objetivos de esta nueva filosofía. Es de vital importancia abordar las motivaciones que propulsaron esta nueva manera de aplicar justicia: prácticas basadas en la participación de toda la comunidad.

El primer propósito de estas prácticas reside en afrontar las consecuencias que ha supuesto la actividad delictiva en la vida de la víctima y las secuelas futuras.

\footnotetext{
${ }^{406}$ MATELLANES RODRIGUEZ N., "La Justicia Restaurativa en el sistema penal. Reflexiones sobre la Mediación”, en F. Martin Diz (dir.), La mediación en materia de familia y Derecho Penal, Andavira, Santiago de Compostela, 2011, pp. 207-231, esp. p. 208.
} 
OLALDE ALTAREJOS ${ }^{407}$ determina una serie de objetivos generales de estas figuras como: brindar un apoyo a la víctima, dándole voz en el proceso; reparar las relaciones que se han visto dañadas por la actividad delictiva; conseguir unanimidad para declarar la conducta criminal como inaceptable; aceptar la responsabilidad por parte del infractor; identificar los factores que han llevado a la comisión del delito; y reducir de la reincidencia.

Pero algunos autores consideran que hay que tener mucha cautela respecto a los objetivos del proceso restaurativo porque una restauración plena de la víctima, infractor y sociedad no es posible ${ }^{408}$; determinarlo como un fin puede generar unas altas expectativas que, al no verse cumplidas, generen una desilusión y abandono del proceso restaurativo $^{409}$.

La Justicia Restaurativa está destinada a satisfacer los intereses de la víctima, la cual ha de ser restaurada en su anterior situación, y por ello restaurada en las relaciones personales. Este objetivo posee una ardua dificultad pues la restauración nunca será plena debido a la imposibilidad del retorno pleno a la situación anterior ${ }^{410}$. No obstante la Justicia Restaurativa ha de tener un aspecto de reconstrucción positivo y en ánimo de la mejora de la vida de la víctima y los demás intervinientes. Todo ello con la introducción de un proceso “amable” que evite la victimización secundaria ${ }^{411}$. Es una figura que se centra en la víctima como protagonista del proceso, dándola voz y mando, y otorgándola la protección que se merece.

En segundo lugar hemos de observar la novedosa aplicación con la que estas prácticas moldean el sistema de justicia. Ya no sólo en el enfoque primordial que se otorga a una serie de valores como el respeto, la reparación o la resocialización, sino en

\footnotetext{
${ }^{407}$ OLALDE ALTAREJOS, A. J., “Encuentros restaurativos en ...”, op. cit., pp. 34-35.

408 JOHNSTONE, G., Restorative Justice. Ideas, Values, Debates, Willan Publishing, Devon, 2002, p. 19.

409 PETERS, T., "Victim-Offender Mediation: Reality and Challenges", en The European forum For victim-offender mediation and restorative justice (ed.) Victim-Offender Mediation in Europe. Making Restorative Justice Work, Leuven University Press, Lovaina, 2000, pp. 9-15, esp. p.15

410 TAMARIT SUMALLA, J.M., “El necesario impulso ...”, op. cit., p. 144.

${ }^{411}$ CERETTI, A., “Giustizia riparativa e ...”, op. cit., p. 310.
} 
relación con la aborda el hecho delictivo. En todo proceso restaurativo se parte de la concepción de no existencia de una vulneración de un precepto normativo, sino en la otorgación de valor al sujeto que ha sufrido el delito. Se supera la concepción normativista en la que le delito afecta a las leyes del Estado acudiéndose a una concepción más humana del Derecho Penal por la cual la normativa es la representación de los derechos de la víctima. Por tanto, se valora enormemente la posición jurídica, emocional y sentimental de la víctima del delito.

Para afrontar las consecuencias emanadas del hecho delictivo, hemos de partir de una de las características más fundamentales y básicas de las prácticas restaurativas, la voluntariedad. Dichas actuaciones han de ser de motu proprio: han de ser libres y voluntarias y por consiguiente no se puede obligar a nadie a acudir o a mantenerse en un proceso de Justicia Restaurativa. La víctima y el infractor han de emanar una voluntad, tanto interna como externa, de acudir al proceso para la resolución del conflicto. Este consentimiento implícito ha de ser duradero en el tiempo, acabando el proceso restaurativo en el momento en el que víctima y/o infractor decidan no continuar, pues su consentimiento puede ser retirado en cualquier momento del proceso restaurativo.

En tercer lugar, la restauración es aspecto fundamental para el desarrollo de cualquier proceso restaurativo. Su gran consideración reside en que "el éxito del proceso judicial no está dado por el quantum de la pena, sino por la reparación efectiva del daño causado" ${ }^{412}$. En la Justicia Restaurativa la pregunta no es ¿cuál es el castico? ¿Cuántos años “le han caído”? sino que la cuestión es ¿cuál es la reparación? Pero, ¿qué es la reparación del daño?

Algunos autores han asociado erróneamente la reparación del perjuicio con las figuras desarrolladas en el ámbito del Derecho Civil ${ }^{413}$. No obstante, se trata de un

\footnotetext{
${ }^{412}$ Sobre esta cuestión y problemática, véase ARIAS MADRIGAL, D.M., Reflexiones teóricas y prácticas sobre la reparación del daño y la justicia restaurativa. Documento en línea. Disponible en: http://www.justiciarestaurativa.org (Última visita: 09/11/2017) ${ }^{413}$ GARCÍA-PABLOS, A. en Tratado de Criminología, Tirant lo Blanch, Valencia, 2009, p. 1058.
} 
concepto más amplio que abarca diferentes conductas como la reparación económica, la reparación simbólica, trabajos en favor de la víctima, trabajos en favor de la comunidad o la disculpa. Todas ellas tienen, aparte de una gran consideración en el ámbito penal, un marcado componente filosófico-moral, siendo así básicas en la restauración del orden social $^{414}$. Para BRAITHWAITE, la restauración o reparación puede suceder de muy diversas maneras, pudiendo encontrar una restauración de la propiedad, de la lesión provocada, de la dignidad, de la libertad, de la seguridad, de la democracia deliberativa, de la justicia y demás valores de las víctimas, infractores y de la sociedad ${ }^{415}$.

Es primordial que el cumplimiento de este plan de reparación preserve la dignidad del infractor ${ }^{416}$. No puede acordarse un plan que no sea digno y justo para el delincuente, no permitiéndose aquellas actuaciones de la víctima de humillación y vejación de su figura jurídica y social en búsqueda de una venganza por el daño recibido anteriormente por el infractor a través del delito. Es básico este punto pues estamos ante figuras restaurativas, que priman la reparación individual y colectiva, superando el castigo como única vía de aplicación de justicia y desechando cualquier idea de venganza. No podemos propugnar la Justicia Restaurativa si existe la revancha. Se busca acercar posturas, recomponer la situación y habilitar un espacio de paz social dentro de la comunidad. En estas ideas pacíficas de justicia no entran las tesis de desafío. La vendetta es un objetivo del derecho punitivo, o mejor indicado, del Derecho Penal arcaico, el cual ha sido superado y olvidado a través de sociedad humanistas y restaurativas.

En cuarto lugar, como fin y carácter primordial, se encuentra situada la participación de los intervinientes en el proceso. La Justicia Restaurativa da valor a la colaboración de los protagonistas activos y pasivos del delito; dependiendo de la figura de que se trate, el número de partícipes podrá ser mayor o menor. A modo de ejemplo,

\footnotetext{
${ }^{414}$ LARRAURI, E., “Tendencias actuales de ...” op. cit., p. 448.

${ }^{415}$ BRAITHWAITE, J., Crime and Justice, University of Chicago, Chicago, 1999.

${ }^{416}$ BAZEMORE, G., “A Vision for Community Juvenile Justice”, en Juvenile and Family Court Journal 1998, vol. 49, no. 4, pp. 55-87, esp. p. 72.
} 
la mediación impulsa un proceso de intervención de víctima, infractor y mediador, pudiendo participar en las actuaciones otros sujetos pero de manera puntual. No es así en los círculos, los cuales proporcionan a todos los miembros de la comunidad la oportunidad de intervenir y ayudar en todo momento a la resolución del conflicto.

\subsection{La intervención de los sujetos en los procesos restaurativos: víctima, infractor y comunidad.}

La intervención de la víctima es fundamental para toma de decisiones pues uno de los fines de estas figuras es la obtención de un plan de reparación satisfactorio para ella. Es imprescindible que si la víctima desea volver a la normalidad en su día a día: participe en un proceso de Justicia Restaurativa ${ }^{417}$ para así sanar todas sus heridas emocionales. Este plan ha de adecuarse a sus necesidades, siempre y cuando sean razonables y no vengativas, siendo indispensable su cumplimiento para la finalización exitosa del proceso restaurativo.

El infractor u ofensor ha de aceptar su responsabilidad, entendiendo el alcance que han provocado sus actos y pudiendo estar en condiciones de realizar actuaciones responsables para la reparación del daño ocasionado. Asimismo su participación en el proceso restaurativo no será admitida como prueba de admisión de culpabilidad en un futuro procedimiento ante los tribunales ${ }^{418}$.

Ambas partes, con la participación de otros miembros de la comunidad, que podrán variar dependiendo del instrumento o modelo elegido, trabajarán para la elaboración de un plan de reparación. Este plan de reparación abordará todas las necesidades y situaciones específicas tanto de la víctima como del infractor, focalizando sus esfuerzos en una reparación de la víctima y resocialización del infractor. Una vez

\footnotetext{
417 Intervención de VAN CAMP en el Congreso Europeo de Justicia Restaurativa y Terapéutica, celebrado en San Sebastián los días 16, 17, 18 de junio de 2016 .

${ }^{418}$ BELLOSO MARTÍN, N., “Anotaciones sobre alternativas ...” op. cit. pp. 146-186, esp. p. 154.
} 
ventilado positivamente el asunto por esta vía, tanto víctima como infractor podrán “pasar página” ${ }^{419}$ y volver a su lugar en la sociedad.

El papel fundamental de los procesos restaurativos en favor de las víctimas no es únicamente la reparación del daño causado, sino que tendrán lugar otros beneficios derivados de la propia práctica que le permitirán a la víctima una sanación emocional. Estas actuaciones serán básicas para la consecución de los fines de dicha práctica, siendo además sencillas y al alcance de cualquier sistema de justicia. Nos estamos refiriendo a conductas relativas a la víctima como ser escuchada, ser valorada con la importancia que merece, sentirse de valía en el proceso, incrementación de autoestima y capacidad para la resolución de problemas ${ }^{420}$. Las víctimas podrán compartir el perdón, ayudar a otras víctimas presentes o futuras, evitar futuros delitos y reforzar las actitudes humanas $^{421}$.

Las actuaciones restaurativas irán encaminadas a procurar en favor de las víctimas el vencimiento de los temores, como el pavor a lugares y circunstancias similares a las que acaecieron el delito. Todo ello a través de medidas y actividades conjuntas que hagan comprender la no existencia de razones para el sufrimiento en dichas eventualidades. Ello ayuda a "disminuir el miedo al delito, o como mínimo, aumentan la percepción de seguridad” ${ }^{422}$ y otorgar a la víctima la confianza perdida.

\footnotetext{
${ }^{419}$ ZEHR, H., The Little Book ... op. cit., p.38. Howard Zehr utiliza el término closure significando un cierre de la situación para el inicio de una nueva etapa, aunque él mismo, en las nota final número 7 de la página 74, nos indica la posibilidad de ofensa que podrán sufrir las víctimas con este término ya que puede entenderse como "ponerlo todo detrás y cerrar el libro" cuando en realidad ha de interpretarse en el sentido de ser capaz de seguir adelante.

${ }^{420}$ Como acertadamente indica DALY, en determinados delitos violentos las víctimas no esperan solamente una reparación y una "disculpa sincera", sino que esperan un castigo que "pueda garantizarle a la víctima que ha tenido un reconocimiento público y apoyo". Vid. DALY, K., "The Limits of Restorative Justice”, en D. Sullivan, y L. Tifft, (cords.) Handbook of Restorative Justice: A Global Perspective, Ed. Routledge, Nueva York, 2006, pp. 134-147, esp. pp. 137-138.

${ }^{421}$ Intervención de VAN CAMP en el Congreso Europeo de Justicia Restaurativa y Terapéutica, celebrado en San Sebastián los días 16, 17, 18 de junio de 2016 .

${ }^{422}$ BUIL GIL, D., "Presupuestos, alcance y límites de la Justicia Restaurativa como derecho de las víctimas y beneficios para el infractor", Conferencia impartida en el IV Congreso de Justicia Restaurativa y Mediación Penal: del desiderátum a la realidad práctica, Burgos, 17 y 18 de Marzo de 2016.
} 
El encuentro con el victimario otorgará a la víctima la posibilidad de superar el dolor y de cerrar las heridas que el delito destapó. La víctima únicamente sellará el sufrimiento una vez que, tal y como indica RIOS MARTÍN, reconozca a la otra parte como ser humano, como un igual con unas cualidades específicas y una humanidad imperfecta, pero digna. Así la víctima abandonará su rol y se reintegrará en la sociedad sin ataduras $^{423}$.

El ofensor también se sentirá beneficiado con la participación en dichas prácticas, pues superará su propia posición de “óbice” en la sociedad a través de su valía para la ayuda de la víctima. Todo trabajo de reparación que realice va a ir encaminando a una pérdida de la estigmatización existente contra todo delincuente ${ }^{424}$. El victimario dejará atrás su comportamiento delictivo para restaurar el daño ocasionado, aceptará su mal hacer, su culpa, su arrepentimiento florecerá, indagará en las causas de su comportamiento, admitiendo su responsabilidad ${ }^{425}$ y cambiando la dirección de su vida, reduciéndose notablemente las posibilidades de reincidencia ${ }^{426}$.

El resultado de la reparación para el infractor puede variar en gran medida. El posible castigo penal posterior al proceso restaurativo va a estar supeditado a diferentes variables, como cuanto ha reparado, tipo delictivo cometido, reincidencia, etc. En nuestro ordenamiento podemos encontrar la aplicación del atenuante del artículo 21.5 del $\mathrm{CP}^{427}$, o bien la aplicación del artículo 84.1 para la suspensión de la pena ${ }^{428}$; una conciliación o en el supuesto de haber sido ya condenado previamente el infractor se

${ }^{423}$ RÍOS MARTÍN, J.C., Justicia Restaurativa y transicional en España y Chile, Comares, Granada, 2017, p. 55.

${ }^{424}$ CARRASCO ANDRINO, M.M., "La mediación del delincuente-víctima: el nuevo concepto de justicia restauradora y la reparación (una aproximación a su funcionamiento en Estados Unidos)”, en Jueces para la Democracia 1999, no 34, pp. 69-86, esp. p.72.

${ }^{425}$ LARRAURI, E., “Tendencias actuales de ...” op. cit., p. 444.

${ }^{426}$ JOHNSTONE, G., Restorative Justice. Ideas ... op. cit., p. 21.

${ }^{427}$ Artículo 21.5 Código Penal: "La de haber procedido el culpable a reparar el daño ocasionado a la víctima, o disminuir sus efectos, en cualquier momento del procedimiento y con anterioridad a la celebración del acto del juicio oral"

${ }^{428}$ Artículo 84.1 del Código Penal: “El juez o tribunal también podrá condicionar la suspensión de la ejecución de la pena al cumplimiento de alguna o algunas de las siguientes prestaciones o medidas: $1{ }^{a}$ El cumplimiento del acuerdo alcanzado por las partes en virtud de mediación. “ 
podría aplicar un indulto o un tercer grado. Aplicaciones restaurativas que se están adoptando siempre y cuando el infractor cumpla el plan de reparación previsto o cuando haya realizado todos los actos posibles para su cumplimiento pero este no fuere posible por la oposición de la víctima.

Por último la Justicia Restaurativa la idea de beneficio de la comunidad. A este interrogante no muchos encuentran respuesta, pues la búsqueda de un beneficio común dentro de unas actuaciones entre particulares no genera, en principio, un lucro a la generalidad. La primera rentabilidad que todo ciudadano obtiene es un sistema más ágil y con una reducción sustancial de los costes de la justicia penal ${ }^{429}$. Pero no hemos de limitar nuestra visión a un aspecto meramente económico, pues, y de forma más importante y en segundo lugar, el provecho común se escenifica en una participación y aprendizaje global en la resolución de los conflictos. Con la comisión de un hecho delictivo, la víctima sufre una pérdida respecto a su estado precedente, y a su vez el infractor modifica su condición pacífica por violenta, suponiendo una variación en los patrones de convivencia establecidos en la propia sociedad. Ello va a necesitar una acción común pues la comunidad se compone de miembros individuales, pero su carácter reside en la unión de esas individualidades. Para el mantenimiento de esta conexión, se necesita un proceder conjunto en la restauración del daño ocasionado.

Cuando se consume el plan de reparación, se tiende a la pacificación de la sociedad $^{430}$. El infractor se resocializa, con comprensión el aspecto negativo que tiene todo hecho delictivo, y la víctima se ve restituida en su situación anterior. La comunidad reintegra a dos miembros que había perdido, reconstruye la paz social quebrada por el delito ${ }^{431}$ y la propia comunidad adquiere experiencia del perjuicio ocasionado y de su reparación. Serán de vital valía estas fases con este proceso

\footnotetext{
${ }^{429}$ MIERS D. et al., An Exploratory Evaluation of Restorative Justice Schemes, Home Office, Londres, 2001, p. 9 nota 8.

${ }^{430}$ ROXIN, C., "La reparación en el sistema jurídico penal de sanciones", en Cuadernos del Consejo General del Poder Judicial, no 8, pp. 19-30, esp. p. 25 y ss. En la misma idea: GORDILLO SANTANA, L. F., La Justicia Restaurativa y la mediación penal, Iustel, Madrid, 2007, p. 70.

${ }^{431}$ BELLOSOMARTÍN, N., "Mediación penal ¿Beneficios ...” op. cit.,. p. 24.
} 
restaurativo pues se están estableciendo unas bases para una mayor simplicidad en el supuesto de resolución de otro conflicto futuro, ya sea con los mismos intervinientes como protagonistas, con alguno de ellos, o con otros miembros de la amplia comunidad, ganando un mayor grado de democratización ${ }^{432}$ y de paz social.

Una comunidad espectadora del delito, como ocurre lamentablemente en la actualidad, es cómplice del daño ocasionado pues no ha tomado medida alguna para prevenirlo o repararlo, dejando esas tareas a los "especialistas del Derecho". Para que exista una paz social ha de existir una colaboración de la totalidad ciudadana en los procesos de Justicia Restaurativa, abandonando su posición de espectador y proporcionando apoyo a los intervinientes ${ }^{433}$. Estos participantes comunitarios no han de ser expertos en materia alguna, son simples ciudadanos y vecinos, personas corrientes, con afán de auxilio al prójimo y que servirán un acto de auxilio para proseguir pacíficamente con sus vidas.

\subsection{Justicia Restaurativa versus Justicia Retributiva: ¿enemigos íntimos o complementos necesarios?}

Siempre han existido las tesis separatistas en búsqueda de una escisión de la Justicia Restaurativa y la Justicia Retributiva. Pero no hemos de polarizar las ideologías y contraponer las dos oportunidades sin un análisis previo de sus variables en favor de los sujetos intervinientes. Actualmente ya han sido superados, como indica TAMARIT SUMALLA $^{434}$, los estudios enfocados en la sustitución de la justicia convencional a través de la creación de un nuevo modelo de justicia.

La primera gran diferencia es la figura de la reparación. Un punto controvertido pues la valoración acerca de la división entre "restaurativo” y "retributivo” genera

\footnotetext{
${ }^{432}$ GORDILLO SANTANA, L. F., La Justicia Restaurativa ... op. cit., p. 62

${ }^{433}$ Intervención de TIM CHAPMAN en el Congreso Europeo de Justicia Restaurativa y Terapéutica, celebrado en San Sebastián los días 16, 17, 18 de junio de 2016 .

${ }^{434}$ TAMARIT SUMALLA, J.M., “El necesario impulso ...”, op. cit.,. p. 143.
} 
múltiples controversias. La cuestión nos conduce ante una duda existencial: estamos ante dos procesos incompatibles o simplemente ante la posibilidad de conjuntar dos vías de entender y aplicar justicia.

Adelantando nuestra postura, consideramos que para una mejor aplicación pragmática de la Justicia Restaurativa, ambos procesos han de complementarse pues su finalidad es idéntica, el esclarecimiento y resolución del conflicto nacido del acto delictivo. Su diferencia radica en los medios utilizados para conseguir dicho fin $^{435}$ : métodos que van a variar en la aplicación y entendimiento de la justicia. La pregunta aquí será, ¿el castigo o la reparación? Y nos preguntamos, ¿por qué no una conjunción de ambas praxis?

La Justicia Restaurativa se interesa en el crimen, pero lo enfoca como un problema de orden interrelacional ${ }^{436}$. Centra su atención en mayor medida en la consecución de una reparación en favor de la víctima que resocialice al infractor y restituya a la comunidad, ahondando en los sentimientos, con especial incidencia en el perdón y la culpa. Por su parte, la justicia retributiva centra su interés predominante en el castigo al delincuente través de una pena de prisión que no constituye ventaja alguna en la víctima. No obstante ambas actuaciones no han de estar separadas, sino que han de ser parte del proceso, ofreciendo tanto el diálogo como el castigo un método de obtener una reparación y una resocialización.

Existe una gran disparidad de opiniones doctrinales en relación a esta posibilidad. Se evidencia que la disimilitud de ambas figuras, como la no imposición de

\footnotetext{
${ }^{435}$ Sobre este tema, una visión interesante es la ofrecida por DOMINGO DE LA FUENTE, V., "La Justicia Restaurativa y Retributiva no deberían estar tan alejadas”, en blog de la justicia restaurativa, 3 de febrero de 2016. Disponible en: http://blogdelajusticiarestaurativa.blogspot.com (Última visita: 09/11/2017)

${ }^{436}$ CASTILLEJO MANZANARES, R., “Justicia Restaurativa, mediación penal y víctima”, en M. de Hoyos Sancho (coord.) La víctima del delito y las últimas reformas procesales penales, Aranzadi, Cizur Menor, 2017, pp. 275-294, esp. p. 276.
} 
castigos por parte de la justicia restaurativa ${ }^{437}$, no nos permite su utilización conjunta. Se establece así una diferenciación categórica, estando entre dos prácticas diferentes. DALY ha señalado sobre esta división absoluta entre ambos conceptos que “todos los elementos asociados a 'lo bueno' (a una superior forma de justicia) están situados en la columna restaurativa, mientras que todos los asociados con 'lo malo' (o una forma inferior de justicia) están en la columna retributiva" ${ }^{438}$.

Así, multitud de opiniones doctrinales, y profesionales dentro del mundo jurídico, han creído que la aplicación de métodos restaurativos supone desechar el castigo pues su eficacia y utilidad quedaría manifiestamente no probada e innecesaria en el siglo actual ${ }^{439}$. Este es el motivo más evidente por el cual desestiman estas vías restaurativas tan favorables, pues estiman que es necesaria una elección, restaurar o castigar, sin contemplar la posibilidad de aplicar ambas de manera complementaria y potenciadora de las dos.

El propio DALY comenta que de sus experiencias en conferencias en Australia y Nueva Zelanda, ha observado cómo se utilizan métodos restaurativos y retributivos ${ }^{440}$, creándose un beneficio mutuo y en favor de los intervinientes. En la misma línea nos encontramos a DUFF, el cual critica esta división considerando que lo retributivo y lo restaurativo no están tan alejados ya que "una vez que se entiende que hay que restaurar en un contexto de una ofensa criminal... veremos que la restauración no es solamente compatible con la retribución y el castigo, sino que los requiere" ${ }^{441}$.

Concluyendo, si realmente la mejora del sistema de justicia es uno de nuestros objetivos, no hemos de vetar ninguna posibilidad que pueda suponer un beneficio para

${ }^{437}$ BRAITHWAITE, J., "Setting Standards for Restorative Justice”, en British Journal of Criminology 2002, no 42, pp. 563-577.

${ }^{438}$ DALY, K., "Restorative Justice: the real story", en Punishment \& Society 2002, no 55, pp. 55-79, esp. p. 56.

${ }^{439}$ BARNETT, R.E., "Restitution: a new paradigm of criminal justice”, en Ethics 1977, no 4, 279-301, esp. p. 279.

${ }^{440}$ DALY, K., “Restorative Justice: the ...” op. cit., pp. 55-79, esp.p. 56.

${ }^{441}$ DUFF, R., "Restorative punishment and punitive restoration" en G. Johnstone (ed.), Restorative Justice and the Law, Willan Publishing, Michigan, 2002, pp. 82-100, esp. p. 82. 
el bien común. No es una elección entre ambas opciones; no es un “ir o volver”. Se ha de integrar justicia restaurativa y retributiva ${ }^{442}$, utilizar los puntos en común para fortalecer el actual sistema, así como surtir a los ciudadanos e intervinientes de las ventajas que los dos modelos nos ofrecen: limitándose así sus propios defectos a través de las virtudes del otro. Ambos modelos buscan una misma meta con distintos caminos, pero son más las similitudes que les unen que las diferencias que les separan. Si pensamos el alcance de ambas para las personas, tanto la Justicia Restaurativa como la Retributiva han de perfeccionarse a través de las características de la otra, sustentando ambas un sistema de justicia justo, equitativo y satisfactorio con las necesidades de los ciudadanos.

\section{Algunas consideraciones a la Justicia Restaurativa}

Las ventajas de la Justicia Restaurativa son evidentes, pero existen una serie de dificultades a tener en cuenta para una futura asimilación de estas prácticas por parte de nuestro Derecho.

\subsection{Críticas y observaciones}

Múltiples han sido las críticas vertidas por diferentes autores en relación al nuevo paradigma que supone la Justicia Restaurativa, tales y como señala QUINTERO OLIVARES $^{443}$, entre las que destaca falta de seguridad jurídica, imposibilidad de aplicación de la proporcionalidad, alejamiento de los jueces en el proceso restaurativo, diferencias entre víctimas, la privatización de la justicia o la discriminación en relación a las posibilidades económicas en aras a una posible reparación.

\footnotetext{
442 SHERMAN, L.W. y STRANG, H., Restorative justice: the evidence, The Smith Institute, Londres, 2017, p. 52.

443 QUINTERO OLIVARES, G., "El nuevo paradigma de la justicia restaurativa: la pretensión de superación del modelo vigente”, en R. Castillejo Manzanares, M. J.Sande Mayo, C. Torrado Tarrío (coords.) Justicia Restaurativa y violencia de género: más allá de la Ley Orgánica 1/2004, Universidad de Santiago de Compostela, Santiago de Compostela, 2014, pp. 146-165.
} 
La principal duda concerniente a este nuevo modelo de Justicia, tal y como explica entre otros TAMARIT SUMALLA ${ }^{444}$, ha sido la posibilidad de instrumentalización de la víctima en favor del infractor, pues sus orígenes estaban centrados en otorgar de una oportunidad en favor del ofensor. Una visión sesgada y reducida de las oportunidades reales que el sistema le ofrece, no sólo al autor de los hechos, sino a todos los sujetos intervinientes.

Con la Justicia Restaurativa se sustituyen los valores del castigo, imposición y exclusión por otros más novedosos como los de mediar, reintegrar o compensar ${ }^{445}$. Un nuevo modo de entender la justicia que "colisiona” con el modelo punitivo, el cual se centra en un castigo mayor al delincuente para ofrecer más sensación de seguridad a unos ciudadanos “desprotegidos e incapaces de poder resolver su conflicto”. Esta visión es superada por la Justicia Restaurativa al otorgar la potestad resolutoria a las partes implicadas e incluso a la comunidad; pero sobre todo al observar que los delitos no se evitan con penas más duras, sino que la vía es hacer comprender al delincuente el daño que ha creado, apartándole de la vida delictiva. Volver a unir los lazos víctimadelincuente-comunidad restaura un nexo emocional destruido por el delito, un vínculo necesario para la convivencia, pero, ¿es siempre posible restaurar esta relación? Dependerá de la gravedad delictiva así como de la voluntad de los intervinientes.

Al no existir un numerus clausus de delitos que puedan ser resueltos por la Justicia Restaurativa, existen multitud de prácticas y cada una de ellas será más o menos conveniente para la conclusión eficaz del procedimiento. Por ello, hemos de valorar individualmente, no sólo las características y capacidades de los intervinientes, sino también de la práctica que vamos a utilizar. Desde nuestro punto de vista, debido al escaso número de intervinientes en la mediación, los delitos graves y muy graves no han de ser resueltos por esta vía, sino que se han de utilizar otras prácticas más adecuadas para ello, como las conferencias o los círculos; otras prácticas en las que la intervención

\footnotetext{
444 TAMARIT SUMALLA, J.M., “El necesario impulso ...” op. cit., 145.

445 LARRAURI PIJOAN, E., “La reparación”, en J. Cid Moliné y E. Larrauri Pijoan (eds.), Penas alternativas a la prisión, Bosch, Barcelona, 1997, pp. 169-196, esp. p. 173.
} 
de un amplio número de participantes o incluso de "toda la comunidad" 446 posibilitan un acuerdo más perfeccionado y beneficioso para las víctimas ${ }^{447}$. Esta es una opinión personal acerca de la materia, sobre la cual existen pareceres de muy diversa índole, tales como los vertidos por diversos estudiosos de la materia como el mediador BOLAÑOS HURTADO, el cual ha realizado este tipo de mediaciones en México e indica que allí sí que existen mediaciones en los “delitos de sangre” ${ }^{448}$.

Antes de pasar a valorar este punto, es necesario indicar la existencia de diferentes tipos delictivos que, al no existir una víctima individualizada, existe una dificultad para ser resueltos por métodos restaurativos. Estamos hablando aquí de los delitos supraindividuales, como ordenación del territorio o salud pública, en los cuales no podemos definir exactamente una víctima. No obstante, existen diversas prácticas por las cuales, a través de las víctimas subrogadas, se han podido llevar a cabo procesos de mediación ${ }^{449}$. A nuestro modo de ver, la no existencia de una víctima individualizada no impediría la no resolución restaurativa de los conflictos. Sería posible señalar un miembro de alguna organización que represente esa "víctima”. A modo de ilustración, en el supuesto de delitos medioambientales, cualquier miembro de ONGs ambientalistas, como por ejemplo Greenpeace, podría acudir a representar y defender sus derechos como si a él le hubiesen ocasionado los daños, satisfaciendo así las necesidades existentes.

\footnotetext{
${ }^{446}$ En ningún proceso nunca interviene toda la comunidad, pero sí que podemos encontrar que toda ella se vea representada a través de voluntarios debidamente preparados, como así sucede en los círculos.

${ }^{447}$ DOMINGO DE LA FUENTE, V., “¿Por qué la Justicia Restaurativa es buena para las víctimas incluso de delitos graves?”, en Criminología y Justicia, 2014. Disponible en: http://cj-worldnews.com (Última visita: 09/11/2017)

${ }^{448}$ BOLAÑOS HURTADO, E., “Justicia Restaurativa: una mirada panorámica” Conferencia impartida en la Mesa redonda "La Justicia Restaurativa en el contexto internacional: hacia una construcción de un modelo universal” el IV Congreso de Justicia Restaurativa y Mediación Penal: del desiderátum a la realidad práctica, Burgos, 17 y 18 de Marzo de 2016.

${ }^{449}$ SUBIJANA ZUNZUNEGUI, I. J., PORRES GARCÍA, I., Y SÁNCHEZ RECIO, M., "El modelo de justicia restaurativa: una propuesta de aplicación tras la entrada en vigor de la Ley 4/2015 del Estatuto de la víctima del delito", en Revista de victimología 2015, n 2, pp. 125-15, esp. p.137, recogiendo la idea de SOLETO, H. y CARRASCOSA, A., "La participación de la víctima en la Justicia restaurativa”, Curso on line Estatuto de la Víctima, Consejo General del Poder Judicial, 2015.
} 
Retornando al tema que nos atañe, y en cuanto al por qué limitaría la aplicación de la mediación en los delitos graves y muy graves, se aprecia que la base de esta consideración es la falta de igualdad entre víctima e infractor y la escasez de participantes que puedan compensar la situación. Una persona que ha sufrido un caso traumático de cierta relevancia, tal y como puede ser una víctima de violación ${ }^{450}$, nunca estará en igualdad respecto a su agresor, el cual tendrá una posición dominante desde el punto de vista psicológico.

La comisión del delito no sólo provoca un daño visible en la víctima, sino que le otorga una inseguridad y un dolor psicológico. Todo esto conlleva a una posición dominada por el miedo, no permitiéndole tomar las riendas de la situación, ventaja que podrá ser utilizada por el infractor para obtener un acuerdo ventajoso. Es por ello que consideramos que en este tipo de hechos delictivos de mayor gravedad en los cuales la víctima sufre un notable perjuicio físico y psicológico, que disminuye su seguridad y posición, la mediación no es conveniente si lo que queremos es resolver satisfactoriamente el conflicto. Existiendo múltiples prácticas que promueven la participación de la sociedad en su conjunto, su potenciación en sustitución de la mediación para la resolución de estos conflictos de mayor gravedad es fundamental en aras de una resolución pacífica de la controversia. El conjunto de los ciudadanos aportarán una mayor seguridad, limarán las posibles situaciones de desigualdad e incluso confeccionarán un plan de reparación de mayor calidad en cuanto a la elaboración, con multitud y variadas ideas que servirán para la finalización exitosa del proceso.

\footnotetext{
${ }^{450}$ DOMINGO DE LA FUENTE, V., "La historia real de una superviviente de un delito de violación a través de la Justicia Restaurativa”. Relato Disponible en: http://cj-worldnews.com (Última visita: 09/11/2017)

En este artículo, se nos habla de cómo una víctima de violación superó la situación de inferioridad que el delito la producía y acudió a un proceso de justicia restaurativa, un año después de la condena al autor de los hechos. Este proceso le sirvió de beneficio para poder superar el odio y recibir el perdón del delincuente. Una gran noticia pero muy arriesgada porque, en este tipo de delitos, no siempre la víctima puede encontrarse con infractor benévolo que acepte su responsabilidad, sino con un infractor que no acepte su responsabilidad o incluso se jacte de su situación.
} 
Nos encontramos con la ardua tesitura de considerar si es o no conveniente la Justicia Restaurativa en aquellos delitos cuales la restauración es “imposible”. Nos referimos a delitos muy graves en los cuales la víctima fallece o su vuelta al Estado anterior es imposible. El ejemplo perfecto para esta postura es el homicidio o el asesinato.

Si la base de la Justicia Restaurativa es la reparación del daño, en el supuesto de un homicidio o asesinato, ¿cómo se repara o restaura? Una restauración a la situación anterior es imposible, ya que no se puede revivir al fallecido. Así que la otra opción de restauración es la compensación a los familiares, ya sea con la realización de alguna actividad en su favor o de terceros, con la compensación económica o la compensación simbólica. Para unos familiares rotos de dolor por la pérdida de un ser querido, aunque parezca algo inverosímil, puede ser de ayuda la realización de actividades en favor de ellos mismos o de la comunidad y actos simbólicos como el perdón, la desintoxicación de cualquier sustancia si este fue uno de los motivos de la comisión del hecho delictivo y/o la reinserción. Las víctimas, directas o indirectas, no están exentas de sentimientos de odio y venganza, pero como se ha demostrado, su satisfacción no se basa en un sufrimiento del infractor, sino en la comprensión y restauración ${ }^{451}$. Es en este tipo delictivo de mayor gravedad en el cual podemos observar con mayor eficacia la utilización complementaria de las prácticas restaurativas y retributivas, yendo en conjunto la realización de actuaciones reparativas con la aplicación de un castigo punitivo.

En cuanto a la compensación económica, somos más reticentes en aquellos delitos en los cuales no sea fundamental para la reparación material. Además, si planteamos que la compensación económica sea válida por ella sola para la obtención de las ventajas penitenciarias que ofrece la participación exitosa en un proceso restaurativo, nos llevaría a dos consecuencias:

${ }^{451}$ GOLLWITZER, M. y DENZLER, M., "What makes revenge sweet: Seeing the offender suffer or delivering a message?”, en Journal of Experimental Social Psychology 2009, n 45, pp. 840-844. 
1. El pago de una cuantía económica ya colisiona con el artículo 113 del Código Penal $^{452}$, que versa sobre la indemnización como responsabilidad civil derivada del delito ${ }^{453}$. ¿En qué se diferencian? En que en un caso la pactan las partes sin intervención judicial, y en el otro caso es el juez el que decide la cuantía en congruencia con las cuantías solicitadas por las partes. Entonces, el importe estipulado durante el proceso restaurativo no estaría otorgando ningún beneficio moral o restaurativo.

2. Si con una indemnización económica se puede conseguir una atenuante, una conciliación o una suspensión de la pena, estamos ante un gran fracaso del sistema de justicia ya que se van a primar los recursos económicos por encima de la verdadera voluntad. Estaríamos creando dos tipos de justicia, la de pobres y la de ricos. Si un ciudadano con escasos medios comete un delito, deberá cumplir la condena y/o realizar una serie de actuaciones pactadas en el acuerdo. Mientras por el contrario, aquél miembro de la sociedad con mayores recursos económicos podrá abonar una suculenta cuantía y obtener así una serie de beneficios sin la obligación de una efectiva reparación emocional. La palabra justicia quedaría totalmente desvirtuada, perdiendo su sentido ${ }^{454}$, e incluso perdería su concepto el propio término de Derecho, proveniente del latín

\footnotetext{
${ }^{452}$ Artículo 113 Código Penal: "La indemnización de perjuicios materiales y morales comprenderá no sólo los que se hubieren causado al agraviado, sino también los que se hubieren irrogado a sus familiares o a terceros".

${ }^{453}$ Sobre la responsabilidad civil derivada del delito, véase GÓMEZ POMAR, F., Responsabilidad civil ex delicto, Universidad Pompeu Fabra, pp 1-34, esp. p. 2-5 Disponible en: https://www.upf.edu (Última visita: 09/11/2017); GONZÁLEZ-ALEGRE BERNARDO, M., La responsabilidad civil en el proceso penal; algunos ejemplos prácticos de su evaluación a través de sentencias de la Audiencia Provincial de Albacete, Universidad de Murcia, pp. 219-245, esp. p. 220-223. Disponible en: http://revistas.um.es (Última visita: 09/11/2017)

${ }^{454}$ Según la RAE, justicia es el "principio moral que lleva a dar a cada uno lo que le corresponde o pertenece; derecho, razón, equidad; conjunto de todas las virtudes, por el que es bueno quien las tiene; aquello que debe hacerse según derecho o razón; pena o castigo público; poder judicial".

Sobre el término justicia véase PONCE ESTEBA, M.R., "Los conceptos de justicia y derecho" en Kant, Kelsen, Hart, Rawls, Habermas, Dworkin y Alexy, en Jurídica: anuario del Departamento de Derecho de la Universidad Iberoamericana 2005, $\mathrm{n}^{\circ}$ 35, pp. 211-234; PASCUAL PLANCHUELO, V.C., "Reflexiones sobre el concepto de justicia", en Revista Aposta 2005, $\mathrm{n}^{\circ}$ 19. Disponible en: http://www.apostadigital.com (última visita 12/04/2018)
} 
directum, que viene a significar lo correcto, lo justo ${ }^{455}$. Tras esto, sólo cabe preguntar como que KELSEN en su famosa obra, “¿Qué es la justicia?”456.

Es así que consideramos que la indemnización económica como método reparativo ha de ser un complemento a las actuaciones pactadas, a no ser que así lo decida voluntariamente la víctima, la cual tratará entonces su interés más en el "vil metal” que en una sanación efectiva.

No hemos de obviar que la Justicia Restaurativa también centra su interés además de en la reparación de la víctima, en la resocialización del infractor y la consecución de la paz social. En esta lista de delitos que han sido enumerados a modo de ejemplo, tales como el asesinato, aunque no se consiguiese una restauración a la situación anterior, el proceso reparativo puede llevarnos a algo también realmente valioso, cual es la resocialización del infractor. Ello no sólo supondrá un beneficio para el delincuente, el cual abandonará la senda del delito para volver a la pacífica sociedad, sino que también la propia comunidad obtendrá provecho. Se alcanzará una sociedad con una menor tasa delictiva, disminuyéndose así las eventualidades de que otro sujeto pueda volver a sufrir el hecho delictivo o que pueda existir el miedo subyacente de una futura comisión.

Como acertadamente indica DOMINGO DE LA FUENTE “precisamente la importancia de los procesos restaurativos con respeto a la reparación es que esta actividad reparadora no es impuesta por un tercero ajeno al delito (el juez) sino que es asumida por el infractor de forma totalmente voluntaria. Esto conlleva que al querer reparar el daño es porque ha asumido su responsabilidad, se ha dado cuenta del daño causado y acepta esta obligación como algo normal”457.

\footnotetext{
455 MARTINEZ ROLDAN, L. y FERNÁNDEZ SUÁREZ, J.A., Curso de teoría del Derecho, Editorial Ariel S.A., Barcelona, 1999, p. 213.

${ }^{456}$ KELSEN, H., ¿Qué es la justicia?, Ariel S.A., Barcelona, 2008.

457 DOMINGO DE LA FUENTE, V., "La reparación del daño en la Justicia Tradicional y la Justicia Restaurativa”, en Blog de la Justicia Restaurativa, Entrada de 3 de diciembre de 2015, disponible en: http://blogdelajusticiarestaurativa.blogspot.com.es (Última visita: 09/11/2017)
} 
En la generalidad de procesos restaurativos la idea de voluntariedad es clara, y proporciona un proceso exitoso para todos los participantes. Pero existe un cierto escollo en la resocialización de ciertos individuos, pues aquellos que han “mamado” la actividad delictiva a lo largo su vida, lo perciben como un juego o bien simplemente no pueden comprender lo negativo de su conducta. Por ello tendrán mayores dificultades a la hora de la elaboración eficaz de un proyecto restaurativo.

Será así fundamental centrar nuestra atención, no sólo en el desarrollo óptimo de programas restaurativos, sino en la potenciación de la figura. La publicidad de la eficacia de las actuaciones podrá ser un motivo para incentivar su empleo por aquellos infractores que, lamentablemente, copan la actualidad informativa. La función de la Justicia Restaurativa es fundamental para la enseñanza de la conducta errónea de los ciudadanos. De ahí la fuerza resocializadora de la Justicia Restaurativa y sus prácticas, pues pueden dirigirse únicamente a la resocialización del individuo si esto fuera lo necesario.

La elaboración de planes reparativos didácticos a nivel estatal generará una disminución de la actividad delictiva al mostrar a los ciudadanos las consecuencias de sus actuaciones. De gran valor podrán servir tales enseñanzas y difusión de la Justicia Restaurativa para aquellos ciudadanos que no comprenden el riesgo de su proceder, así como los infractores de tráfico ${ }^{458}$ que suben sus actos a YouTube ${ }^{459}$ o redes sociales ${ }^{460}$, infractores reincidentes ${ }^{461}$ o delincuentes que agreden a personas mientras lo graban ${ }^{462}$. Este tipo de personas reincidentes, a las que parece no surtirle efecto el sistema clásico

\footnotetext{
458 "Los líos de Karim Benzema”, El mundo a fecha de 4 de noviembre de 2015. Noticia disponible en: http://www.elmundo.es (Última visita: 09/11/2017).

459 "Imputado un joven por conducir en una vía interurbana de León a 200 kilómetros por hora”, en $E l$ Norte de Castilla, 24 de septiembre de 2015; en la noticia un varón de 25 años colgó un vídeo en una red social mostrando su velocímetro a $200 \mathrm{~km} / \mathrm{h}$. Disponible en: http://www.elnortedecastilla.es (Última visita: 09/11/2017)

460 “¿Qué tiene Benzema en la cabeza? Publica vídeos conduciendo con el móvil y sin cinturón”, en Voz Pópuli. 27/01/2016. Disponible en: https://vozpopuli.com (Última visita: 09/11/2017)

461 "Caen dos bandas de carteristas muy reincidentes que actuaban en el Metro de Barcelona", en 20 Minutos. 02/02/2012. Disponible en: http://www.20minutos.es (Última visita: 09/11/2017)

462 "Un grupo de jóvenes apalea a tres menores para grabarlo en sus móviles”, en El Mundo a fecha de 26 de enero de 2016. Disponible en: http://www.elmundo.es (Última visita: 09/11/2017)
} 
de justicia penal, si cabe parece que el sistema clásico les provoca que se genere más violencia si cabe ${ }^{463}$, son sujetos que demandan prácticas restaurativas que acaben con sus conductas negativas así como con el peligro que suponen para el ciudadano.

Las prácticas restaurativas suponen una chance para nuestra comunidad de alcanzar una pacificación social. Pero ello no nos ha de posicionar erróneamente en una creencia de deidad restaurativa, en la cual dichas actuaciones sean insuperables y su esplendor sea inalcanzable. Existen fallos e incertidumbres. No toda práctica restaurativa es conveniente para todo tipo delictivo, ni así es adecuada para todo tipo de circunstancias. La regulación ha de ser muy cabal, otorgando libertad para el avance de las sesiones según las necesidades emanadas por las partes y las contrariedades surgidas, solventadas por "un mediador preparado y concienciado para que resuelva el conflicto. Se necesita un trabajo individual con las partes, escucharlas y concienciarlas” ${ }^{464}$. Como bien indica DIGNAN “... al menos llaman la atención sobre la necesidad de establecer estándares adecuados para las víctimas y ofensores. Pero también la necesidad de que los partidarios de la justicia restaurativa reconozcan que las dudas y preocupaciones que muestran los escépticos, como por ejemplo las relativas a la proporcionalidad y equidad, son bien fundadas y necesitan ser confrontadas” 465 .

Se trata de proporcionar una nueva opción para nuestro sistema de justicia penal, a modo de un complemento para ayudar a víctimas e infractores. Aún las controversias surgidas, la necesidad de implantación de las diferentes figuras es innegable, pues el

\footnotetext{
${ }^{463}$ Para más información relativa al sistema penitenciario actual y el incremento de la criminalidad dentro de él, véase en su conjunto las siguientes obras: BELTRÁN VERDES, E., Derechos torcidos: tópicos, medias verdades y mentiras sobre pobreza, política y derechos humanos, Debate, Barcelona, 2009; CID MOLINÉ, J. "El incremento de la población reclusa en España entre 1996-2006: Diagnóstico y remedios", en Revista Española de Investigación Criminológica 2008, n 6, pp. 1-31; HARCOURT, B.E., Illusion of order: the false promise of broken Windows Policing, Harvard University Press, Harvard, 2001; RÍOS MARTÍN, J.C., y CABRERA CABRERA, P.J., Mil voces presas, Universidad Pontificia Comillas, Madrid, 1998.

${ }^{464}$ BOLAÑOS HURTADO, E., “Justicia Restaurativa: una mirada panorámica” Conferencia impartida en la Mesa redonda "La Justicia Restaurativa en el contexto internacional: hacia una construcción de un modelo universal" el IV Congreso de Justicia Restaurativa y Mediación Penal: del desiderátum a la realidad práctica, Burgos, 17 y 18 de Marzo de 2016.

${ }^{465}$ DIGNAN, J., Understanding Victims and ... op. cit, p.3, nota 6.
} 
bienestar de víctimas e infractor es un propósito innegociable. Supone un avance para mejorar nuestro sistema de justicia, una justicia penal menos retributiva ${ }^{466}$, una nueva justicia, una justicia del siglo XXI.

\subsection{La posible privatización del derecho a través de la Justicia Restaurativa.}

La titularidad del ius puniendi ha ido variando conforme al transcurso del tiempo, perteneciendo en un principio a la víctima, más tarde al monarca absolutista, para terminar siendo potestad del Estado, el cual ha seguido hasta ahora haciendo uso de él $^{467}$. A pesar del avance que esta situación nos ofreció en su día, el desamparo de la víctima generó nuevas ideas. El surgimiento de nuevas corrientes proporcionan una mayor importancia decisoria a favor de la víctima y el infractor. La consideración de una pérdida del ius puniendi estatal en favor de los participantes es errónea, pues, como avanzamos, el objetivo no es ello, sino el dar voz y capacidad de resolución a las partes, pero sin olvidar que dicho proceso va a ser valorado y verificado por la "maquinaria estatal” compuesta por jueces y fiscales. Por tanto, la Justicia Restaurativa nace dentro del proceso, se desarrolla adyacente a él, y se reintegra para su finalización, no siendo su fin la abolición ${ }^{468}$ del sistema de justicia actual, sino complementarlo y auxiliarlo para dar una respuesta más acertada al conflicto. Un nuevo camino necesario ${ }^{469}$. Estos nuevos modelos no deslegitiman el ius puniendi del Estado, sino que nos muestran la cabida de estas prácticas sin la necesaria intervención de un órgano estatal ${ }^{470}$.

\footnotetext{
${ }^{466}$ BELLOSOMARTÍN, N.: “Mediación penal ¿Beneficios ... “ op. cit. p. 24.

${ }^{467}$ MARTÍNEZ ESCAMILLA, M. “Justicia reparadora, mediación y sistema penal: diferentes estrategias, ¿los mismos objetivos?” en Estudios penales en homenaje a Enrique Gimbernat, Edisofer, Tomo I, Madrid, 2008, pp. 465-497, esp. p. 473.

${ }^{468}$ MARTINEZ ESCAMILLA , M. “Justicia reparadora, mediación ...” op. cit., p. 473. La autora nos indica que las tesis abolicionistas no pueden suplir satisfactoriamente las garantías que el actual sistema de justicia penal nos otorga a los ciudadanos.

469 GIMÉNEZ-SALINAS I COLOMER, E. "La conciliación víctima-delincuente como alternativa a la justicia penal”, en Papers d'estudis i formació 1992, n 8, p. 89. El autor nos indica que “la justicia necesita nuevos caminos. Ello no significa abandonar el camino del derecho penal, el principio de legalidad, o el de las garantías. Significa simplemente reconocer que, al menos en España, la justicia no pasa solamente por poner más jueces o hacer más leyes”.

${ }^{470}$ CASTILLEJO MANZANARES, R., “Justicia Restaurativa, mediación ...”, op. cit., p. 275.
} 
La complementación de ambos entendimientos de justicia proporciona un modelo punitivo dialogado y humanizado. Nunca estaríamos ante una privatización de la justicia, sino, como ya adelantó nuestra Carta Magna, ante una justicia basada en los términos de participación ciudadana y pacificación social. Los instrumentos de Justicia Restaurativa encajan perfectamente en nuestro modelo de justicia. El Estado mantiene el ius puniendi permitiendo a su vez, a través del principio de oportunidad, que los ciudadanos puedan insertarse en él con capacidad resolutoria.

Deberíamos modificar la forma de apreciar el Derecho. La comisión de un hecho tipificado en la norma penal no es sólo la vulneración de dicho precepto, sino la comisión de un daño real sobre la víctima. La finalidad de nuestro Derecho es hacer realidad el ius puniendi ${ }^{471}$, no reparar a la víctima, aspecto que la Justicia Restaurativa invierte en cuanto a trascendencia, dando más valor a la restauración de la víctima que a la aplicación de un castigo.

Con la promulgación de las prácticas restaurativas no estamos impulsando la abolición del sistema penal, sino la complementación a través de figuras novedosas que instan la actuación ciudadana. Por ello los instrumentos entrarían dentro del artículo 24 CE, pues no se vulnera la tutela judicial efectiva al otorgarse el control de legalidad a juez y fiscal. No se pretende impeler al exterior al sistema punitivo actual, sino que la Justicia Restaurativa es un mecanismo complementario que impulsa a satisfacer unas demandas ciudadanas que el sistema actual no puede saciar ${ }^{472}$.

\footnotetext{
${ }^{471}$ MUERZA ESPARZA, J. "La autonomía de la voluntad en el proceso penal: perspectivas de futuro”, en Revista electrónica del Departamento de Derecho de la Universidad de La Rioja 2011, nº 9, pp. 191202, esp. p. 200.

${ }^{472}$ Nuestro sistema de justicia ha tenido varios objetivos no cumplidos, como la reparación de la víctima, la paz social y la rehabilitación del infractor. En cuanto a la reparación de la víctima, a pesar de ser un objetivo, nunca ha sido primordial, simplemente una posibilidad que tenía el infractor y que si realizaba, obtenía la atenuante del artículo 21.5 CP. En cuanto a la rehabilitación del infractor, se ha demostrado que las cárceles no rehabilitan, sino que llegan a ejercer un efecto contrario en muchos sujetos, creándose, paradójicamente, delincuentes en los lugares para resocializarles. Y en cuanto a la paz social, es imposible la disminución de delitos si nuestro sistema no resocializa a los infractores ni repara a las víctimas, quedando dos sujetos marcados por el delito.
} 
Como conclusión, podemos negar rotundamente que exista una privatización del Derecho Penal con la incursión de la Justicia Restaurativa. Es necesaria una ley que englobe las variadas posibilidades de resolución de conflictos, tales como mediación, conferencing y circles, aspecto que iremos desarrollando en los capítulos posteriores. Estos instrumentos se han de introducir, o mejor dicho, se han de impulsar ${ }^{473}$, como un complemento del actual sistema de justicia penal con el fin de ayudar a conseguir los beneficios de reparación, resocialización y paz social. El proceso no se aparta de los cauces legales, sino que el juez y el fiscal ejercerán un papel de garantes de la legalidad al controlar el desarrollo de las sesiones y del plan de reparación. Todo ello en aras del cumplimiento de los fines del Derecho Penal y de la satisfacción de las necesidades de la comunidad.

\section{Modelos de Justicia Restaurativa}

Existen un variado número de programas de justicia restaurativa de muy dispar índole, como la mediación víctima-infractor, el conferencing, los circles, las comisiones de vecinos ${ }^{474}$, los comunity board ${ }^{475}$, etc. Sobre ellos, tal y como señalan MCCOLD y WACHTEL $^{476}$ es de ardua tarea una valoración conforme a determinar cuales son "plenamente restaurativos", “principalmente restaurativos o "parcialmente restaurativos”. A continuación introduciremos las figuras para un posterior desarrollo en ulteriores capítulos.

\footnotetext{
473 Sobre la importancia del impulso de los modelos de Justica Restaurativa para una correcta implantación en el ordenamiento jurídico español véase TAMARIT SUMALLA, J.M., "El necesario impulso de ...” op. cit., pp. 139-160.

${ }^{474}$ Son aquellas prácticas restaurativas que buscan la resolución de delitos leves, muchos de ellos sin víctima concreta, pero que afectan a la vida comunitaria. KURKI, L., "Evaluating Restorative Justice Practices” en A. Von Hirsch (ed.), Restorative Justice and Criminal Justice, Hart Publishing, Oxford, 2003, pp. 293-314, esp. pp. 294-295.

475 Son los comúnmente denominados en España como mediación comunitaria o en Francia como mediación social.

${ }^{476}$ Idea recogida en O’MAHONY, D., y DOAK, J., Reimagining Restorative Justice, Hart Publishing, Portland, 2017, p. 9.
} 


\subsection{Mediación víctima-infractor.}

La figura de la mediación víctima-infractor es la práctica por antonomasia de nuestro sistema jurídico restaurativo. Consiste en un encuentro victimario y víctima, con la ayuda de un mediador, con el fin de la consecución de un acuerdo de reparación que ponga fin al conflicto. Es una solución alternativa o complementaria dentro del proceso penal que busca eludir o facilitar, dependiendo de si estamos ante una mediación alternativa o complementaria, el inicio del proceso penal.

Normalmente la mediación suele ser directa (face to face), pero puede darse la eventualidad de que un tercero realice las funciones de transmisor de la información entre víctima e infractor, evitando así un contacto inmediato entre ellos o facilitando el diálogo en sucesos de dificultad o imposibilidad de reunión conjunta. Aunque su inviabilidad es una de las que dan lugar al inicio de más procesos de mediación indirecta, no hemos de olvidarnos la alternativa de no existencia de posición de igualdad entre víctima-infractor, el cual generaría una desigualdad manifiesta y un plan de reparación beneficioso exclusivamente para el infractor ${ }^{477}$. Para evitar esta posible presión psicológica sobre la víctima se deniega el face to face y se mantiene a ambas partes separadas, creando una situación más estable y favorable para el uno y el otro, la cual podrá expresarse sin el temor a la posición del infractor.

Como adelanto, cabe señalar la no existencia de una ley que regule la mediación penal de adultos en España, pero nos encontramos con dos excepciones. La primera es la LO 5/2000, de 12 de enero, reguladora de la responsabilidad penal de los menores,

\footnotetext{
477 En palabras del magistrado-juez del Juzgado de Violencia sobre la Mujer ${ }^{\circ} 2$ de Sevilla, Francisco Manuel Gutiérrez Roncero en el seminario "Derecho y Psicología: Gestión de conflictos. IV edición”, dentro del marco de los cursos de verano de la Universidad Pablo de Olavide en Carmona "La mediación parte de un principio básico, y es que ambas partes tienen que tener una igualdad, de manera que no puede existir un dominio de nadie sobre nadie. Si la igualdad se rompe por la gravedad del delito o por la vulnerabilidad de la víctima, ya no se puede realizar la mediación". Disponible en: http://noticias.universia.es (Última visita: 09/11/2017)
} 
permitiendo la mediación penal en el ámbito de menores ${ }^{478}$, y la segunda es la LO 1/2004, de 28 de diciembre, de medidas de protección integral contra la violencia de género, prohibiendo en este caso cualquier tipo de mediación ${ }^{479}$.

\subsection{Grupo de Comunidad o Conferencing}

Las prácticas de conferencias o conferencing se caracterizan por la búsqueda de un plan de reparación entre víctima e infractor pero con la intervención de otros sujetos de apoyo. La intervención en las sesiones se va a complementar con los familiares, tanto cercanos como más lejanos de ambos partícipes, en suma, personas allegadas a ambos, los cuales van a servir para intentar reconducir al infractor y ayudar en la creación de un elaborado plan de restauración. Además y en segundo lugar, la intervención de miembros de la comunidad tales trabajadores sociales y policías proporcionarán un conocimiento y experiencia a la causa. Por tanto, la Comunidad es parte del proceso, apoyando a la víctima, buscando la reparación del daño y auxiliando al infractor en su reinserción ${ }^{480}$.

Esta figura tiene ciertas variaciones según la zona geográfica de la que se trate, aunque siempre mantiene las mismas bases anteriormente citadas que la configuran en una figura especial y con un futuro prometedor. En los capítulos posteriores

\footnotetext{
${ }^{478}$ Vid. GARCIA PÉREZ, O., "La mediación en el sistema español de justicia penal de menores”, en Revista Criminalidad 2011, Vol. 53, $\mathrm{n}^{\circ}$ 2, pp. 73-98, esp. p. 75. Nos indica el consenso internacional existente para la introducción de mecanismos desjudicializadores -como la mediación penal- en el ámbito de la justicia penañ de menores.

479 GUARDIOLA LAGO, M.J., "La víctima de violencia de ..." op. cit., . Disponible en: http://www.iustel.com (Última visita: 11/07/2017) quien textualmente refiere cómo el legislador español, sin haber regulado la mediación penal, "la prohíbe en algunos casos de violencia de género. Sin embargo, más allá de esta contradicción, España no incumple la Decisión Marco por el hecho de prohibir la mediación penal en los casos de violencia de género. Y ello es debido a la prudencia de la Unión Europea a la hora de establecer la obligación de los Estados de implantar la mediación, ya que ésta se refiere «a las infracciones que a su juicio se presten a este tipo de medida». Por lo tanto, en las infracciones que los Estados miembros estimen convenientes, la Unión establece la obligación de que éstos impulsen la mediación y velen para que pueda tomarse en consideración todo acuerdo entre la víctima y el inculpado que se haya alcanzado con ocasión de la mediación en causas penales"

${ }^{480}$ GUARDIOLA LAGO M. J., et al., "Conferencing: Origen, Transferencia y Adaptación”, en J. Tamarit Sumalla (coord.), La Justicia Restaurativa, desarrollo y aplicaciones, Comares, Granada, 2012, pp. 237267, esp. p. 239.
} 
estudiaremos los diferentes lugares en los que tiene lugar su desarrollo así como sus peculiaridades, centrándonos en el Family Group Conferencing neozelandés, el Wagga Wagga model australiano ${ }^{481}$ y su posterior implantación en países europeos como Irlanda del Norte o Bélgica.

\subsection{Círculos o circles}

Los circles son el modelo restaurativo por excelencia pues involucran a todo tipo de agentes de la sociedad. Se caracterizan por una reunión conjunta de víctima y sus familiares, infractor y sus familiares, policía, fiscal, juez, abogados e incluso cualquier persona representativa de la comunidad con interés en el asunto ${ }^{482}$. Esta figura es denominada como "círculo" por el hecho de que los participantes se sientan en dicha forma geométrica, para procurar la búsqueda de una resolución a su conflicto y así conseguir la implicación de todos los participantes.

Tiene origen en los antiguos círculos de resolución de conflictos de las antiguas comunidades indígenas de América del Norte, como las First Nations. Estas prácticas fueron evolucionando, dando lugar a multitud de especializaciones como los sentencing circles, healing circles o peacemaking circles entre otros.

Una de las características que más identifican a estas figuras son sus sesiones. Antes del inicio de éstas, el facilitador (circle keeper) deberá preparar a las partes con la suficiente antelación posible para que no les afecten las opiniones vertidas durante desarrollo del proceso. Una vez que todo esté dispuesto, las partes, familiares y demás miembros iniciarán las actuaciones. Se empezará realizando una serie de preguntas a cada uno de ellos, los cuales irán respondiendo en un turno marcado por el paso de un objeto denominado talking piece (normalmente suele utilizarse un palo o bolígrafo, y

\footnotetext{
${ }^{481}$ Esta figura tiene su origen en una acción policial de prevención colectiva para jóvenes infractores, utilizando los principios de la Justicia Restaurativa aplicada en Nueva Zelanda a través del Family Group Conferencing, en la ciudad Wagga Wagga, situada en Nueva Gales del Sur, Australia.

482 BELTRÁN MONTOLIU, A. "Justicia Restaurativa y violencia de género: Experiencias del Derecho comparado”, en J.L. Gómez Colomer, El proceso penal en ..., op. cit., pp. 241-279, esp. p. 255.
} 
está basado en las antiguas tradiciones aborígenes, el cual era representado por una pluma del líder la tribu). A través de ello, las partes aprenden a escucharse, a comprender la situación de los demás, y a aportar nuevas ideas al plan de reparación. La única vía para la resolución del conflicto es a través de las diversas aportaciones que han realizado de los presentes en el círculo, encaminadas a un triple objetivo: sanar a la víctima, resocializar al infractor y restaurar la paz social en la comunidad. 


\section{CAPÍTULO QUINTO}

\section{LA MEDIACIÓN EN EL ÁMBITO PENAL}

“Un conflicto no resuelto es como un disco rayado, impide que pasemos a la siguiente

melodía”

Cristóbal Jodorowsky

\section{Aspectos generales. Concepto y características}

El término mediación es muy difuso, siendo utilizado indiscriminadamente para actividades que poco o nada tienen que ver con el significado de la mediación. No ha sido hasta la entrada en vigor de las diferentes normativas cuando dicho vocablo ha ido adquiriendo un lenguaje más formal ${ }^{483}$.

Normalmente esta figura es erróneamente confundida con diferentes prácticas. En el ámbito penal, podemos observar cómo se equipara el término mediación con Justicia Restaurativa, suponiendo un grave equívoco. No estamos ante dos figuras idénticas o dispares sino que la mediación es uno de los instrumentos que conforman la filosofía comúnmente conocida como Justicia Restaurativa, no siendo por ello ni mucho menos lo mismo ${ }^{484}$. Podríamos decir, por tanto, que la Justicia Restaurativa es una filosofía que explora los campos de la resolución pacífica de los conflictos, búsqueda que realiza a través de una serie de mecanismos, entre ellos por ejemplo la mediación.

Respecto a las definiciones de la figura, existen múltiples y de variada índole. Una de las definiciones de mayor interés es la enunciada por ROLDÁN que nos indica que la mediación penal es "la interacción entre víctimas y ofensores con la asistencia de un tercero, el cual facilita el arreglo del conflicto de una manera no punitiva en

\footnotetext{
483 CONFORTI, F., “Los 'enemigos' de la mediación de conflictos”, en lawyerpress 2013, Disponible en: http://www.lawyerpress.com (Última visita: 09/11/2017)

${ }^{484}$ Sobre las diferencias JIMENO BULNES, M., “¿Mediación penal y/o ...”, op. cit.,.
} 
función de los deseos y sentimientos de las partes”485. MARTÍNEZ ESCAMILLA completa estas palabras advirtiendo que estamos ante un "encuentro entre víctima y autor del delito, que tiene lugar con el fin de que ambas partes, a través del diálogo, lleguen a un acuerdo sobre cómo reparar el daño inferido y resolver el conflicto. Dicho encuentro es conducido por una persona imparcial: el mediador ${ }^{486}$.

Otra interesante interpretación del concepto de la figura es la proporcionada por DOMINGO DE LA FUENTE expuesta en el marco las Conclusiones del I Congreso Internacional sobre Justicia Restaurativa y Mediación Penal, al indicarnos que "la mediación penal se puede definir como un proceso de dialogo y comunicación gratuito $y$ voluntario entre víctima e infractor conducido por un mediador imparcial con el objeto de llegar a acuerdos reparadores satisfactorios y libremente aceptados por las partes. Es un proceso voluntario, gratuito, confidencial, alternativo o complementario al sistema de justicia tradicional, intervención de un tercero imparcial, economía de tiempo y esfuerzo ya que supone agilizar el proceso, informal pero con estructura y no se pierden derechos (las partes siempre tienen abierta la vía judicial y en cualquier momento pueden desistir de la mediación penal)" ${ }^{487}$.

La Directiva 2012/29/UE del Parlamento Europeo y del Consejo de 25 de octubre de 2012 por la que se establecen normas mínimas sobre los derechos, el apoyo y la protección de las víctimas de delitos, y por la que se sustituye la Decisión marco 2001/220/JAI del Consejo, no define la figura de la mediación, ya que hace una referencia más extensa al referirse a la Justicia Restaurativa como figura resolutoria de conflictos. Pero la derogada Decisión marco del Consejo de la Unión Europea 2001/220/JAI, de 15 de marzo, relativa al Estatuto de la Víctima en el

${ }^{485}$ ROLDÁN BARBERO, H. "La mediación penal: entre el orden legal y la voluntad de mejorar”, en Revista Penal 2003, n 11, pp. 118-137, esp. p. 135.

${ }^{486}$ MARTÍNEZ ESCAMILLA, M., "La mediación penal en España: estado de la cuestión”, en M. Martínez Escamilla y M.P. Sánchez Álvarez, (coords.), Justicia restaurativa, mediación penal y penitenciaria: un renovado impulso, Reus, Madrid, 2011, pp. 15-46, esp. p.16.

${ }^{487}$ DOMINGO DE LA FUENTE, V., Conclusiones del I Congreso Internacional sobre Justicia Restaurativa y Mediación Penal: dimensiones teóricas y repercusiones prácticas, 4 y 5 de marzo de 2010, Universidad de Burgos, p. 13. Disponible en: http://www.justiciarestaurativa.org (última visita $12 / 12 / 2017)$ 
Proceso Penal ${ }^{488}$, centra su foco de interés en la mediación penal al definirla en su artículo 1 apartado e) como "la búsqueda, antes o durante el proceso penal, de una solución negociada entre la víctima y el autor de la infracción, en la que medie una persona competente”.

Recopilando las ideas vertidas anteriormente, podríamos definir la mediación penal como aquél proceso ${ }^{489}$ que se caracteriza por un encuentro cara a cara entre víctima y victimario, con la ayuda de un mediador, a través del cual buscan dialogada y pacíficamente un acuerdo de reparación que solucione el conflicto emanado del delito. Es una solución complementaria -“asumiendo que la Justicia está al servicio de los ciudadanos y no al revés" ${ }^{490}$ - dentro del proceso penal que busca evitar el inicio del mismo ${ }^{491}$ o dar una respuesta más concorde a las necesidades de los intervinientes una vez ya se ha iniciado el mismo - sin importar la fase procesal en la que se encuentren las partes- o incluso ya se ha dictaminado sentencia.

Una de las características de esta nueva aplicación del Derecho es el encuentro víctima e infractor. En principio por dicha reunión se entiende que sea directa, pero se permite, en diferentes y justificados motivos, un encuentro indirecto. Todo ello es en aras de una facilitación en el desarrollo del diálogo y de las diferentes actuaciones dentro del seno de la aplicación y práctica de la figura de la mediación penal.

En primer lugar nos encontramos con el encuentro directo, el cual sucede cuando víctima e infractor se encuentran en el mismo lugar y son ellos mismos los que comparten diálogo, situándose en una posición de cara a cara (face to face mediation).

\footnotetext{
${ }^{488}$ Para un estudio más pormenorizado véase GONZÁLEZ CANO, M.I., "La mediación en el proceso penal: especial consideración de la decisión marco del consejo de la Unión Europea de 15 de marzo de 2001 (2001/220/JAI)”, en J. F. Etxeberria Guridi (dir.) Estudios sobre el significado e impacto de la mediación: ¿una respuesta innovadora en los diferentes ámbitos jurídicos?, Aranzadi, Cizur Menor, 2012, pp. 299-330

${ }^{489}$ CARRIZO GONZÁLEZ-CASTELL, A., "La mediación penal en España”, en F. Martín Diz (coord.), Mediación en materia de familia y derecho penal, Andavira, Santiago de Compostela, 2011, pp. 233-255, esp. p. 238. Para el autor la mediación no es un proceso porque no existe un tercero imparcial que resuelva el conflicto.

${ }^{490}$ BARONA VILAR, S., "Esquizofrenia en la ...”, op. cit., p.214.

${ }^{491}$ BELTRÁN MONTOLIU, A., “Justicia Restaurativa y violencia...” op. cit., p. 253.
} 
Es el método más común, pero a su vez puede generar riesgos derivados de la desigualdad de las partes. Por ello, es fundamental garantizar la existencia de una situación de equidad entre ambos intervinientes para el correcto progreso de las sesiones y elaboración de un plan de reparación.

En segundo lugar nos encontramos con la variante de mediación indirecta (shuttlemediation $^{492}$ ). Un tercero, normalmente el mediador o alguien cercano a los intervinientes, realiza el papel de transmisor entre víctima e infractor, evitando con esta medida el contacto entre ambos. Esta figura se lleva a cabo en situaciones de desigualdad entre víctima infractor, quedando una de las partes desamparada frente al “poder” de la otra oponente, pero en las que existe una voluntad de proseguir con las actuaciones y certeza de superación de esta situación negativa a través de la utilización de esta vía. Es importante la figura de este transmisor para asegurar que la parte con más ventaja psicológica no pueda alterar en su beneficio la situación anímica de la otra. En la actualidad, el auge de las nuevas tecnologías ha permitido recurrir a este modalidad de mediación cuando las partes no pueden acudir físicamente al lugar establecido, pudiendo utilizar medios como la videoconferencia para el ejercicio de estas actuaciones, sin que exista una motivación derivada de la desigualdad, simplemente una imposibilidad de reunión conjunta.

Es importante que antes del inicio de estos procesos la víctima reciba la suficiente preparación y apoyo psicológico para poder afrontar debidamente el encuentro cara a cara con el infractor, ya que en caso de no estar dispuesta, los efectos de la mediación pueden ser perjudiciales y asemejarse a aquellos que el proceso penal clásico le afligiría. Así, dichas sesiones preparatorias servirán de base para procurar una víctima segura y con capacidad de manifestar sus sentimientos y emociones así como aceptar las consecuencias y efectos que produjo la comisión del hecho delictivo en el devenir de su vida cotidiana.

${ }^{492}$ MONTESINOS GARCÍA, A., “La mediación penal en ...”, op. cit., p. 101. 
Existen tres requisitos básicos para el inicio de un proceso de mediación ${ }^{493}$ :

- El delincuente tiene que aceptar su responsabilidad. Si el infractor no asume su culpa en la comisión del hecho delictivo, nunca podrá comprometerse a una verdadera y sincera reparación, desapareciendo las posibilidades de una futura resocialización.

- Voluntariedad de ambas partes de intervenir en el proceso. Es fundamental que el compromiso ejercido por los partícipes sea libre y espontáneo, pues es pilar fundamental de todo proceso restaurativo que nadie se vea forzado a concurrir en dichas actuaciones.

- Ambos intervinientes han de considerar que es segura la participación. Es fundamental que exista una mutua idea de no ejercer un daño al otro a través del proceso. Si la mediación tiene como objetivo el establecimiento de un proceso pacífico que resuelva el conflicto a través del diálogo y evite así la victimización secundaria de la víctima y terciaria del infractor, no se puede permitir que dicha práctica acabe ocasionando los perjuicios a evitar, debiéndose de valorar la garantía para ellos de las actuaciones a desarrollar.

Como conclusión a este primer apartado, podemos decir que la mediación es una práctica restaurativa que centra su interés en la consecución de un acuerdo por las partes ${ }^{494}$, obteniéndose un “compromiso personal y una voluntad de superar la distancia generada con el delito" ${ }^{495}$ sin menoscabar “el derecho de los Estados a perseguir a los presuntos delincuentes" ${ }^{496}$.

\footnotetext{
${ }^{493}$ Manual sobre programas de Justicia Restaurativa, Serie de Manuales sobre Justicia Penal, Naciones Unidas, Nueva York, 2006, p. 18. Disponible en: https://www.unodc.org (Última visita: 09/11/2017) ${ }^{494}$ PÉREZ SANZBERRO, G., Reparación y conciliación en el sistema penal. ¿Apertura de una nueva vía?, Comares, Granada, 1999, pp. 21-22.

${ }^{495}$ CERVELLÓ DONDERIS, V., "La mediación en el sistema penal español”, en V. Cervelló Donderis (dir.), Cuestiones prácticas para la aplicación de la mediación penal, Tirant lo Blanch, Valencia, 2016, pp. 69-108, esp. p. 74.

496 PASQUAL DEL RIQUELME HERRERO, M., Mediación penal: marco conceptual y referentes: Guía conceptual para el diseño y ejecución de planes estratégicos nacionales de mejora y fortalecimiento de la mediación penal, Secretaría General de la Conferencia de Ministros de Justicia de los Países Iberoamericanos (COMJIB), 2013, p.30, aludiendo a la Resolución 2002/12 de 24 de julio, del Consejo Económico y Social de ONU sobre principios básicos para la aplicación de programas de Justicia
} 


\section{Principios de la mediación penal.}

La mediación, como instrumento de la Justicia Restaurativa, tiene una serie de principios propios que le diferencian del resto de figuras reparativas y le están llevando a ser implementada dentro de nuestras fronteras. Hemos decidido hablar de los principios de la mediación penal y no de la Justicia Restaurativa en modo general debido a la importancia que está ganando la mediación en nuestras fronteras al contrario de los demás instrumentos de justicia Restaurativa.

Todos los referentes internacionales ${ }^{497}$ coinciden en la necesidad del principio de voluntariedad para la existencia de un proceso de Justicia Restaurativa, y podríamos definirlo como la libertad de las partes para iniciar un proceso de mediación, así como, y en la misma línea, para mantenerse en el mismo, sin que depare perjuicio alguno el abandono del proceso ${ }^{498}$. Nadie ha de verse obligado a emprender un procedimiento de mediación o a mantenerse pues si no existiese voluntariedad el proceso estaría destinado al fracaso ${ }^{499}$. Esta frustración de las actuaciones desembocaría en la no alcance de un acuerdo de reparación, lo que acabaría por dañar más a las partes que el acudir a un procedimiento ante los tribunales. Si los intervinientes acuden voluntariamente se

\footnotetext{
restaurativa en materia penal. Disponible en: https://mediacionesjusticia.files.wordpress.com (última visita $25 / 01 / 2018$ )

${ }^{497}$ Un buen resumen de cuales lo encontramos en: DEL RIQUELME HERERO, M.P., Mediación penal: marco..., op. cit., p. 33, nota 48: “Reglas I, II.1 y V.4.31 de la Recomendación $N^{\circ}$ R (99) 19 del Comité de Ministros del Consejo de Europa sobre Mediación en Materia Penal; Artículo 31 de la Guía para una mejor implementación de las recomendaciones concernientes a la mediación en materia penal. CEPEJ (2007) 13; Artículo 7 de la Resolución 2002/12 del Consejo Económico y Social de ONU sobre principios básicos para la aplicación de programas de Justicia restaurativa en materia penal; Artículo 12.1.a) y d) de las Normas mínimas sobre los derechos, el apoyo y la protección de las víctimas de delitos, aprobadas por la Directiva 2012/29/UE del Parlamento Europeo y del Consejo de 25 de octubre de 2012”.

498 PASCUAL RODRÍGUEZ, E., La mediación en el sistema penal Propuestas para un modelo reparador, humano y garantista, tesis doctoral, dirigida por la profesora Margarita Martínez Escamilla. Universidad Complutense, Madrid, 2012, p. 163.

${ }^{499}$ RÍOS MARTÍN, J.C., PASCUAL RODRÍGUEZ, E., BIBIANO GUILLÉN, A., y SEGOVIA BERNABÉ, J.L., La mediación penal y penitenciaria: Experiencias de diálogo en el sistema penal para la reducción de la violencia y el sufrimiento humano, Colex, Madrid, 2008, p. 100. Como indica GORDILLO SANTANA, J.F., La justicia restaurativa y la mediación penal, Iustel, Madrid, 2007: "precisamente su éxito radica en la libertad, la autonomía y la voluntad de las partes para intentar llegar a una solución dialogada. Sólo así podrá darse la garantía de que el acuerdo que se alcanza tras el proceso sea efectivamente cumplido". p. 199
} 
convertirán en sujetos activos del proceso de mediación ${ }^{500}$ y demostrarán un mayor interés por resolver el conflicto ${ }^{501}$, lo que se traducirá en un acuerdo de reparación satisfactorio para ambos.

Para que las partes acudan a un proceso de mediación han de conocer a qué se van a enfrentar y por ello la mediación ha de ser informada ${ }^{502}$. El mediador o institución correspondiente deberá proporcionar a ambas partes la debida información sobre sus derechos y obligaciones, así como todas las fases que van a desarrollar, fechas, horarios, lugar de desarrollo de las sesiones, etc. La notificación se llevará a cabo en una sesión informativa que será de obligatoria asistencia, pero su “obligatoria asistencia” no conllevará un preciso inicio de la mediación ${ }^{503}$. A todo esto, ORTUÑO MUÑOZ añade que: “...en todo caso, en dicha información debe procurar trasladarse también no sólo los costes y beneficios del proceso, tanto desde la perspectiva dela persona responsable del daño como de la víctima, sino también las razones del proceso, "la filosofía pública" que lo inspira y las condiciones rituales de desarrollo. La información debe actualizarse a lo largo del todo el proceso judicial, pues en cada fase debería garantizarse la entrada en juego del mecanismo de mediación cuyos objetivos restaurativos vendrán, en lógica consecuencia, determinados por el grado de desarrollo alcanzado en el proceso judicial con el que debe articularse” ${ }^{504}$. Si las partes, o alguna de ellas, no comprenden estas características anteriormente indicadas, o no están capacitadas para su comprensión, el mediador no podrá iniciar el procedimiento ya que no existirá una emanación libre y completa de voluntad al no

\footnotetext{
${ }^{500}$ PÉREZ SANZBERRO, G., Reparación y conciliación ... op. cit., p. 172.

${ }^{501}$ MARTÍN DIZ, F., "La mediación: marco general para su implantación como sistema complementario de administración de justicia”, en F. MARTÍN DIZ, Mediación en materia de familia y derecho penal, Andavira, Santiago de Compostela, 2011, p. 41.

502 SÁEZ RODRÍGUEZ, C., La mediación familiar. La mediación penal y penitenciaria. El estatuto del mediador. Un programa para su regulación, Aranzadi, Cizur Menor, 2008, p. 319.

503 SÁEZ RODRÍGUEZ, C., La mediación familiar ... op. cit., p. 27. En la misma línea desde un punto de vista civilista, ORTEMBERG, O.D., Mediación familiar. Aspectos Jurídicos y Prácticos, Biblos, Buenos Aires, 1996, p. 133 al afirmar que: “lo obligatorio es intentar la mediación, pero la ley no obliga a arribar a un pacto que resuelva los conflictos”.

${ }^{504}$ ORTUÑO MUÑOZ, J. P., HERNÁNDEZ GARCÍA, J., Sistemas alternativos a la... op. cit., pp. 7172.
} 
existir el debido discernimiento por el sujeto para el desarrollo del procedimiento de mediación penal en el que va a ser parte activa ${ }^{505}$.

La voluntad de ambos va a depender de diversos factores. La víctima ${ }^{506}$ tendrá anhelo de acudir a estos procesos si considera que la pena no es el remedio necesario, sino que la reparación del daño es la solución del delito, sin obviar una posible, futura y complementaria pena atenuada. Aunque también pueden sentirse moralmente “obligadas” a participar en dichos procesos si su posición de víctima les lleva a creer que puede ser la única opción de obtener una reparación.

Para el infractor la situación es más compleja. Muchos de ellos ven el proceso como una opción de resarcir a la víctima por su mal comportamiento y empezar a “cambiar el desarrollo de su vida”. Pero pueden existir otros victimarios que observen la mediación como una oportunidad de conseguir una ventaja procesal traducida en una disminución de la pena, suponiendo que los tribunales verán con buenos ojos siempre un acuerdo de reparación (muchas veces por meros motivos de disminución de carga laboral $^{507}$ ), sin entender que la ventaja procesal será únicamente consecuencia de una reparación efectiva.

Las partes no sólo son libres de comenzar y mantenerse en dicho proceso de mediación, sino que han de tener también plena libertad para poder llegar o no a un acuerdo. Han de trabajar por ello, dialogar y acercar posturas, pero no han de estar obligados a la consecución de un acuerdo de reparación que solucione el conflicto. Es más, el mediador tampoco puede obligarles a ello o dar a entender que han de llegar a

\footnotetext{
${ }^{505}$ LARRAURI PIJOÁN, E, “Tendencias actuales de ...” op. cit. p. 451.

506 Hemos de indicar que la víctima puede acudir ella misma o por representante. En casos de enfermedad, salud o estancia lejana, la víctima puede no acudir físicamente y que sea un representante quien ocupe su lugar. Un ejemplo de ello es la Sentencia $n^{\circ} 460$ del Juzgado de lo Penal $n^{\circ} 20$ de Madrid de 1 de diciembre de 2006 , en el que la víctima no acude a la mediación por motivos de salud y es su sobrino quien la representa

${ }^{507}$ Véase MANZANARES SAMANIEGO, J. L., Mediación, reparación y conciliación en el Derecho Penal, Comares, Granada, 2007, p. 48; MANZANARES SAMANIEGO, J.L, “La Mediación Penal”, en Diario La Ley 2008, n 6900, p. 3. Disponible en http://diariolaley.laley.es (última visita 11/10/2017).
} 
un acuerdo, ya que su función es dar indicaciones y acercar posturas, nunca resolver el conflicto $^{508}$.

Por su parte, el principio de confidencialidad se define como aquél que permite no hacer público los acontecimientos transcurridos durante un proceso de mediación. Todo lo acontecido desde el inicio delas sesiones hasta la finalización del proceso es reservado, pudiéndose dar solamente publicidad al acuerdo de reparación. La confidencialidad se extiende a todas las comunicaciones de mediación, a “cualquier declaración, ya sea oral o en cualquier clase de soporte o registro, verbal o no verbal, que se produce durante una mediación o se realiza a los efectos de considerar, realizar, participar, iniciar, continuar o volver a convocar una mediación” ${ }^{509}$.Y para que exista este principio, las partes deberán de suscribir un convenio de confidencialidad ${ }^{510}$.

Esta figura proporciona a las partes la libertad suficiente para poder expresarse con sinceridad en la mediación al saber que lo que manifiesten en las sesiones quedará dentro de la privacidad del proceso. Su valía en el ámbito penal es fundamental pues la exteriorización de todas las emociones e informaciones es parte básica de las actuaciones $^{511}$. Además, el infractor podrá obtener la garantía de que toda información vertida ante el mediador y la víctima no podrá ser usada en su contra en un juicio posterior en su caso. Por ello no será legal la utilización como prueba de su admisión de responsabilidad en el acto de mediación, debiéndose respetar sus derechos de presunción de inocencia ${ }^{512}$ y a no declarar contra sí mismo.

\footnotetext{
${ }^{508}$ CHRISTIE, N., Los Límites del dolor (trad. de Mariluz Caso), Fondo de Cultura Económica, México D. F., 1984, p.14. El autor nos indica la importancia de que el mediador no pueda resolver el conflicto cuando nos dice que "cuanto menos poder detente el mediador, más difícil se hará llegar a una respuesta punitiva”

509 Secciones 2 (2) y 4 de la Uniform Mediation Act, aprobada por la National Conference of Commissioners on Uniform State Laws (EEUU, 2003).

${ }^{510}$ PAZ, S.M., y PAZ S.S., La mediación penal y los principios procesales, 2001. Disponible en http://mediadoresenred.org.ar (Última visita: 09/11/2017)

${ }^{511}$ RÍOS MARTÍN, J.C. et al.La mediación penal... op. cit., pág. 101

512 Para un estudio más pormenorizado sobre la materia y su vital importancia e interés por los ordenamientos jurídicosvéase MARTÍN DIZ, F., "Presunción de inocencia como derecho fundamental en el ámbito de la Unión Europea”, en Revista europea de derechos fundamentales 2011, n 18, pp. 133-166
} 
La confidencialidad también afecta al número de sujetos presentes en el acto de mediación, pudiendo estar en las sesiones sólo el mediador, la víctima y el infractor. Los familiares, abogados, jueces y fiscales sólo podrán conocer el acuerdo de mediación alcanzado. El incumplimiento de la confidencialidad a través de una manifestación pública de los testimonios obtenidos en dicha mediación debe de ser considerado como una falta grave $\mathrm{e}^{513}$.

La Ley 4/2015, de 27 de abril, del Estatuto de la víctima también hace mención a este principio al indicarnos en general en su artículo 15.2 que "los debates desarrollados dentro del procedimiento de mediación serán confidenciales y no podrán ser difundidos sin el consentimiento de ambas partes. Los mediadores y otros profesionales que participen en el procedimiento de mediación, estarán sujetos a secreto profesional con relación a los hechos y manifestaciones de que hubieran tenido conocimiento en el ejercicio de su función”.

En materia penal la confidencialidad es un principio fundamental pues permite proteger a víctima e infractor de todas las repercusiones que supondría la publicidad de las informaciones expuestas en el proceso, protegiendo así la intimidad y previniéndoles del sufrimiento de perjuicios futuros.

Pese a todo lo explicado anteriormente, el principio de confidencialidad no es completo, pues existen diversos matices a tener en cuenta, recogidos en normativa internacional, que nos permiten el no mantenimiento de este principio si:

- Las partes acuerden la no aplicación de la confidencialidad ${ }^{514}$, introduciendo una excepción a la regla general.

\footnotetext{
${ }^{513}$ Artículos 17 y 18 de la Guía para una mejor implementación de las recomendaciones concernientes a la mediación en materia penal. CEPEJ (2007) 13

${ }^{514}$ Regla II.2 de la Recomendación $N^{o}$ R (99) 19 del Comité de Ministros del Consejo de Europa sobre Mediación en Materia Penal y Considerando 46; artículo 12.1.e de las Normas mínimas sobre los derechos, el apoyo y la protección de las víctimas de delitos, aprobadas por la Directiva 2012/29/UE del Parlamento Europeo y del Consejo de 25 de octubre de 2012; y Sección 5 de la Uniform Mediation Act, aprobada por la National Conference of Commissioners on Uniform State Laws (EEUU, 2003).
} 
- Cuando el mediador reciba información durante las sesiones de la comisión de actos constitutivos de delitos por parte de víctima o infractor ${ }^{515}$, haya iniciado la mediación para intentar o cometer el delito u ocultar una actividad criminal $^{516}$ o de un riesgo de daño psíquico o físico a un menor ${ }^{517}$.

- Cuando sea necesario hacer públicas ciertas informaciones por responsabilidad contra el mediador u otros sujetos intervinientes en un previo procedimiento de mediación ${ }^{518}$.

- Cuando así lo disponga una ley nacional ${ }^{519}$.

Prosiguiendo con el desarrollo de los principios propios de la mediación penal, la neutralidad consiste en una serie de obligaciones en favor del mediador por el cual, en el ejercicio de sus funciones, ha de actuar con imparcialidad y neutralidad, no posicionándose en favor de ninguna de las partes ${ }^{520}$, e intentando que ambas acerquen sus posturas. Su actuación neutral ha de durar durante todo el proceso con el fin de que los intervinientes obtengan un acuerdo que les beneficie; no obstante deberá intervenir en supuestos desequilibro de poder. El reequilibrar el proceso está dentro de su tarea de conductor de la mediación, pero sus actuaciones nunca podrán ir encaminadas a beneficiar o posicionarse en favor de alguna de ellas, ha de mantener una cierta distancia $^{521}$, dejando de lado su opinión sobre el conflicto, no empatizando ni pactando con parte alguna.

\footnotetext{
${ }^{515}$ Regla V.3.30 de la Recomendación No R (99) 19 de la Uniform Mediation Act, aprobada por la National Conference of Commissioners on Uniform State Laws (EEUU, 2003).

${ }^{516}$ Sección 5 (c) de la Uniform Mediation Act.

${ }^{517}$ Parágrafo 211 de la Guía de Buenas Prácticas sobre Aspectos Civiles en el Secuestro Internacional de Menores, aprobado por la Conferencia de La Haya el 25 de Octubre de 1980.

${ }^{518}$ Sección 6 (a5) de Uniform Mediation Act.

519 Artículo 14 de la Resolución 2002/12 del Consejo Económico y Social de ONU sobre principios básicos para la aplicación de programas de Justicia restaurativa en materia penal y Considerando 46 y artículo 12.1.e de las Normas mínimas sobre los derechos, el apoyo y la protección de las víctimas de delitos, aprobadas por la Directiva 2012/29/UE

${ }^{520}$ LAUCIRICA ARRIOLA, N., "Propuesta de la regulación legal de la figura y funciones de la persona mediadora”, en Cuadernos José María Lidón 2011, nº 8, pp. 209-216, esp. p. 214; Véase también PORTELA, J. G., "Estructura y fases de la mediación”, en H. Soleto Muñoz y M. María Otero Parga (coords.) Mediación y solución de conflictos. Habilidades para una necesidad emergente, Tecnos, Madrid, 2007, pp. 225-233, esp. p. 220.

${ }^{521}$ PORTELA, J. G., "Características de la mediación” en AA.VV., Mediación y solución de..., op. cit., p. 220.
} 
La actuación del mediador es activa, debiendo de comprender las posturas y emociones de la partes, así como conducir el desarrollo de la mediación. En palabras de HIERRO, el mediador actúa desde “dentro del conflicto y, por ello, no como un observador neutral del mismo sino como un agente peculiar, ya que no actúa con independencia de las partes en conflicto sino al servicio delas dos partes en conflicto ${ }^{522}$.

La flexibilidad del proceso es uno de los éxitos que tienen tanto esta figura así como los demás instrumentos de Justicia Restaurativa. El procedimiento es libre y consensuado $^{523}$, y se va adaptando a las necesidades de las partes, sin tener que seguir un riguroso programa de actuaciones. Eso sí, la libertad de desarrollo del procedimiento no quiere decir que no vaya a existir ningún límite legal, los cuales, a nuestro entender, deberán fijarse necesariamente en la duración del procedimiento de mediación. Creemos que el proceso no ha de alargarse en exceso a no ser que, por razón motivada (como puede ser la complejidad del asunto) deba de ser alargado por el periodo que el juez y el mediador estimen oportuno.

Algunos autores ${ }^{524}$ consideran que la flexibilidad se refiere también a los asuntos que pueden ser derivados a mediación, afirmación que para nosotros es errónea. Los asuntos que deberán ser derivados a mediación deben de ser establecidos legalmente ya que si no fuese así y la derivación no estuviese tasada en una ley, podríamos adentrarnos con el principio de legalidad.

Ya hemos indicado que todos los instrumentos de la Justicia Restaurativa han de introducirse dentro de nuestro sistema de justicia penal como un complemento al servicio del ciudadano. Y si la Justicia Restaurativa, y más, en concreto, la mediación,

${ }^{522}$ HIERRO SÁNCHEZ-PESCADOR, L., "Aspectos éticos de los medios alternativos de solución de controversias (ADR): ética y deontología en la mediación”, en Anuario de la Facultad de Derecho de la Universidad Autónoma de Madrid 2007, nº 11, pp. 27-48, esp. p.44

${ }^{523}$ NORDENSTAHL, U. C. E., Mediación penal. De la práctica a la teoría, Librería Histórica, Buenos Aires, 2005, p. 71

${ }^{524}$ RÍOS MARTÍN, J.C., et al., La mediación penal..., op. cit., p. 89. 
se encuentra dentro del sistema público de justicia penal, deberá de tener la misma condición de gratuidad.

La justicia penal es gratuita, siendo el Estado quien asume los gastos del procedimiento; y por tanto, si se inicia un procedimiento de mediación penal, será también el Estado el que asuma dichos costes ${ }^{525}$ ya que es un instrumento para aplicar y resolver justicia criminal. Este principio de gratuidad se quebrará en caso de mala fe de alguna de las partes al acudir a la mediación ${ }^{526}$. Esta mala fe se podrá escenificar en conductas que no busquen un acuerdo de reparación o simplemente se centren en alargar indebidamente el proceso para la obtención de un beneficio propio o un perjuicio ajeno. Será la Administración la que cubra los gastos de estos procedimientos, debiendo por tanto sufragar los honorarios de los mediadores y demás personal encargado del correcto funcionamiento del proceso, aunque estos no tengan la obligación de ser funcionarios, pudiendo ser profesionales laborables.

Aún el gasto económico que un proceso de mediación pueda suponer el Estado al deber sufragar los importes derivados de dicho proceso, se podrá economizar una gran suma de dinero debido a la gran cantidad de trámites, documentos y tiempo ${ }^{527}$ respecto al sistema clásico de justicia. Es, por tanto, un proceso más económico ${ }^{528}$ que la justicia ordinaria.

El proceso penal depende de la Administración, la cual se encargar de impartir justicia. La mediación, como complemento del sistema, también se encuentra dentro del proceso penal estatal u oficial, siendo un método público y con trascendencia jurídica.

\footnotetext{
${ }^{525}$ MARQUES CEBOLA, C., "Los sistemas de mediación pública en Portugal: una visión comparativa con las experiencias de mediación en España”, en F. Martín Diz (coord.) La mediación en ..., op. cit., pp. 351-385, esp. p. 359.

${ }^{526}$ El artículo 240.3 LECrim dispone que tanto el querellante particular como el actor civil serán "condenados al pago de las costas cuando resultare de lasactuaciones que han obrado con temeridad o mala fe... No se impondrán nunca las costas a los procesados que fueren absueltos” Por analogía, consideramos que se puede aplicar ese artículo en la mediación ya que la mediación debe de estar implementada en el proceso de justicia penal.

${ }^{527}$ SÁEZ RODRÍGUEZ, C., La mediación familiar ..., op. cit., p. 319

${ }^{528}$ FERNÁNDEZ LÓPEZ, M.A., La mediación en procesos ... op. cit., pp. 233-255, esp. p.235.
} 
Por tanto, a pesar de que las partes tengan la capacidad de resolver el conflicto por ellas mismas, la mediación es una respuesta del proceso público penal.

El principio de oficialidad nos demuestra que la mediación penal se ha de incorporar dentro del procedimiento penal como una mediación intrajudicial. Acaba con las críticas ya expuestas en el tema anterior acerca de la posible privatización del Derecho Penal $^{529}$ al ser un instrumento más de la Administración para la impartición de justicia. Una justicia basada en la reparación del daño a la víctima y en el castigo al infractor, el cual verá rebajada su condena en caso de reparar el daño, siendo la reparación y la rebaja de la condena ${ }^{530}$, un ejemplo del carácter público de la mediación penal

Pero la oficialidad no sólo se demuestra con el cumplimiento de los objetivos de la justicia, sino que se traduce también en la ausencia de limitación respecto de los derechos y obligaciones que tiene las víctimas e infractores en el proceso penal ${ }^{531}$ como por ejemplo el derecho a la defensa ${ }^{532}$.

El mediador o institución de mediadores no puede ser un ente privado sino que será un ente al servicio de la Administración pública ${ }^{533}$, “un colaborador del juez en la resolución de las causas” ${ }^{534}$, no teniendo como objetivos la obtención de lucro, sino la consecución de justicia. En cuanto a su procedencia puede ser funcionario de carrera, personal laboral o lo que estime conveniente el legislador.

\footnotetext{
${ }^{529}$ Sobre esto, ya el frustrado Anteproyecto de Ley de Enjuiciamiento Criminal (ALECr), aprobado por el anterior Gobierno el 22 de julio de 2011, en su Exposición de Motivos (apartado XXVI) nos indicaba que la mediación penal: “...no puede consistir en una especie de renuncia del Estado a la titularidad exclusiva del ius puniendi. No se trata de otorgar a los particulares un poder omnímodo de disposición como el que les está atribuido en los estrictos supuestos de delito privado. Al contrario, la mediación ha de concebirse como un instrumento al servicio de la decisión expresa del Estado..."

${ }^{530}$ CARRIZO GONZÁLEZ-CASTELL, A., “La mediación penal en España”, en F. Martín Diz (dir.), La mediación en materia ... op. cit., p. 88.

${ }^{531}$ GONZÁLEZ CANO, M.I., "La mediación penal en España”, en S. Barona Vilar, (dir.), La mediación penal..., op. cit., pp. 19-52, esp. p. 32 y ss.

${ }_{532}$ RÍOS MARTÍN, J.C. et al, La mediación penal... op. cit., p. 101

${ }^{53}$ MARTín DIZ, F., La mediación: sistema complementario de Administración de Justicia, Consejo General del Poder Judicial, Madrid, 2010, pp. 142 y ss.

${ }^{534}$ FERNÁNDEZ LÓPEZ, M.A., La mediación en procesos..., op. cit., p.104
} 
A través del principio de bilateralidad, son las partes las que van a ser las protagonistas, la víctima y el infractor, sin la intervención de ningún sujeto más excepto el mediador o aquél que se considere oportuno para el desarrollo eficaz de las sesiones. Con este principio se da valía a los dos verdaderos protagonistas del conflicto, siendo ellos los que tengan que llegar a un acuerdo a través de su diálogo y trabajo.

Este principio excluye del proceso a otros posibles intervinientes, como los familiares o los abogados, los cuales podrán aconsejar a la víctima o infractor, pero ambos participantes serán los que expresen sus ideas y sentimientos quedando fuera de la influencia de sus familias y abogados, los cuales podrían cohibir la expresión de los sentimientos ${ }^{535}$.

Esta bilateralidad ha de estar basada en el principio de igualdad entre ambos participantes, y en una suficiente capacidad intelectual y volitiva ${ }^{536}$ que les permita entender las diferentes actuaciones y poder llegar a un acuerdo de reparación que les beneficie.

Finalmente, como ha sido puesto de manifiesto, este principio se basa en un contacto directo o indirecto entre víctima e infractor para la resolución del conflicto. No obstante existen opiniones doctrinales que consideran que este principio podría congregar la denominada mediación on line, la cual empieza a tener éxito en materias civiles y mercantiles pero que su uso en materia penal no está probado. CARRETERO MORALES $^{537}$ ve viable la mediación on line para delitos de violencia de género al considerar que así la víctima tiene más libertad para expresarse y más tiempo para prepararse y contestar sin tener la presión del agresor. En nuestra opinión es una posible

\footnotetext{
${ }^{535}$ GORDILLO SANTANA, L. F., La justicia restaurativa ..., op. cit., pp. 61 y ss.

${ }^{536}$ GORDILLO SANTANA, L. F., La justicia restaurativa ..., op. cit., p. 201.

537 CARRETERO MORALES, E., "Mediación online: una posible vía para introducir la justicia restaurativa en asuntos de violencia de género”, en P. M. Garciandía González y H. Soleto Muñoz (dirs.) Sobre la mediación penal (posibilidades y límites en un entorno de reforma del proceso penal español). Aranzadi, Cizur Menor, 2012, pp. 211-243.
} 
opción para el futuro, pero es excesivamente "valiente" lanzarlo como una gran oportunidad cuando todavía la mediación en violencia de género es un tema prácticamente tabú y muy poco llevado a la práctica debido a la prohibición legal existente. Creemos que se deberían iniciar primero con asiduidad procedimientos de mediación penal en casos de violencia de género para poder pensar en una mediación on line de esta figura.

\section{Marco legal nacional e internacional.}

En nuestro ordenamiento jurídico a fecha de hoy no existe legislación alguna acerca de la mediación penal. Es una figura todavía por desarrollar por el legislador a pesar de los intentos que serán de inmediato expuestos.

\subsection{Inexistencia de regulación legal: ¿Un único culpable?}

A nuestro parecer no existe un único motivo para explicar esta falta de regulación, sino que son un conjunto de causas que han provocado la situación actual de desconfianza y desconocimiento.

La mediación, así como en general la Justicia Restaurativa, es una figura desconocida dentro de nuestras fronteras. Este desconocimiento casi absoluto de esta figura por parte de la sociedad propicia una desconfianza hacia dichas actuaciones. Es necesaria una publicidad de los múltiples estudios doctrinales y prácticas llevadas a cabo para una concienciación de la comunidad.

Ya han sido expuestos los argumentos y críticas de aquellas opiniones que señalan a la Justicia Restaurativa como un instrumento privatizador de la Justicia o como un elemento que "choca” con nuestro ordenamiento. Pero a nivel global con carácter general estos pensamientos todavía no han sido superados, entendiéndose esta figura como un obstáculo a la justicia y un impedimento para obtener una justicia real. 
Es por ello que en la actualidad no existe normativa alguna que regula la mediación penal con carácter general ni ningún otro instrumento restaurativo. No obstante, intentos ha habido, pero todos ellos han caído en el olvido y la desdicha, sin otorgarnos finalmente una figura necesitada y requerida para un mejor funcionamiento de la justicia.

Si el propio Estado no consigue trabajar firmemente en la implantación de la figura volveremos a estar ante un fracaso normativo. En la actualidad las esperanzas no son positivas tras los dos intentos sin éxito, siendo únicamente una figura incrustada pragmáticamente en nuestros juzgados, con escasa visibilidad y menor profundidad.

Son pues supuestos que se retroalimentan entre sí pues. La ciudadanía no podrá conocer la mediación penal si el Estado no la regula e impulsa. El Estado no regulará la figura si la sociedad no la exige. Así pues, mientras los órganos públicos no decidan dar un paso al frente y abordar la problemática de la mediación penal a través de una correcta regulación, nos encontraremos con una ausencia clara de normativización. Ello nos conduce a las prácticas llevadas a cabo en nuestras sedes judiciales, la cual, a pesar de su valía, sigue siendo insuficiente para el impulso de la figura.

\subsection{Europa como potenciador de la mediación penal}

En el marco europeo ${ }^{538}$, no han sido pocas las recomendaciones del Consejo de Europa. Por ello, y de manera breve, se procede al examen de algunas de ellas. La primera norma en este sentido es la Recomendación R (99) 19, del Comité de Ministros,

\footnotetext{
${ }^{538}$ Existe normativa de entes supranacionales que regulan la Justicia Restaurativa y, más concretamente, la mediación: Declaración de las Naciones Unidas de 29 de noviembre de 1985, sobre los Principios Fundamentales de Justicia para las víctimas de Delitos y del abuso del Poder o la Resolución 2000/14 de 7 de Julio de 2000, del Consejo Económico y Social de las Naciones Unidas, sobre Principios Básicos sobre la utilización de Programas de Justicia Restaurativa. Vid. LABORDA VALLE, E., Protección de los consumidores y mediación penal, Editorial Jurídica Sepín, Madrid, 2014, p. 153, nota 16.
} 
de 15 de septiembre de 1999, sobre la Mediación en Materia Penal, la cual propone a los Estados miembros la incursión en sus ordenamiento de dicha figura restaurativa.

Es la Decisión Marco del Consejo de la Unión Europea 2001/220, de 15 de marzo $^{539}$, relativa la Estatuto de la Víctima en el Proceso Penal, la siguiente normativa en la que nos vamos a centrar. Un cuerpo legal cuyo destino en la protección de las víctimas de delitos y que, en su artículo 10 establece que "los Estados miembros procurarán impulsar la mediación en las causas penales para las infracciones que a su juicio se presten a este tipo de medida. Los Estados miembros velarán por que pueda tomarse en consideración todo acuerdo entre víctima e inculpado que se haya alcanzado con ocasión de la mediación en las causas penales”. Esta Decisión Marco pretendía una implantación de la mediación penal en los Estados miembros, acto que no sucedió debido a la no obligatoriedad de aplicación de las Decisiones Marco ${ }^{540}$. El texto suponía interés por los métodos restaurativos, bien resultare sencillo e ingenuo al sólo impulsar tenuemente, y no compeler, la figura de la mediación.

Con el transcurso del tiempo mayor normativa fue "emergiendo”, así como en sede europea la Recomendación (2006) 8, del Comité de Ministros del Consejo de Europa, de 14 de junio $^{541}$, la cual centra su interés en la figura procesal de la víctima, pero en su punto 13 del Anexo regula la mediación como una posibilidad para la resolución de conflictos beneficiosa para las víctimas. Este interés por la mediación no desapareció y fue la Directiva 2012/29/UE del Parlamento Europeo y del Consejo de 25 de octubre de 2012 por la que se establecen normas mínimas sobre los derechos, el apoyo y la protección de las víctimas de delitos, la que retomó su importancia dentro de

\footnotetext{
539 DOUE de 22 de marzo de 2001, $n^{\circ}$ L/82/1, pp. 1-4.

${ }^{540}$ Amplios sectores de la doctrina consideran que existe una obligatoriedad jurídica idéntica de directivas y Decisiones Marco. Más ampliamente: MUÑOZ DE MORALES. M., "La aplicación del principio de interpretación conforme a las Decisiones Marco, ¿hacia el efecto directo? Especial referencia al caso Pupino”, en L.A. Arroyo Zapatero, A. Nieto Martín y M. Muñoz de Morales Romero (coords.) El Derecho Penal de la Unión Europea. Situación actual y perspectivas de futuro, Cuenca, 2007, pp. 291324 y esp. pp. 291 y ss.

${ }^{541}$ Disponible en: https://www.coe.int (última visita 10/06/2017)
} 
la Unión como un medio beneficioso para las víctimas pero que necesitan garantías para evitar la victimización secundaria y terciaria ${ }^{542}$.

El estatuto de la víctima europeo hace numerosas alusiones a los sistemas de justicia restaurativa o reparadora, ya sea en el Preámbulo o en el propio articulado. A modo didáctico, el artículo 4 letra j) que enuncia como derecho de toda víctima recibir información relativa de los servicios de justicia reparadora; el artículo 12 sobre el derecho a garantías en el contexto de los servicios de justicia reparadora, en el que se enumeran una serie de condiciones y garantías para que "aquellas víctimas que opten por participar en procesos de justicia reparadora tengan acceso a servicios de justicia reparadora seguros y competentes, siempre que se cumplan" ${ }^{543}$; y el artículo 25 que pide la financiación debida para que las personas que prestan servicios de apoyo a las víctimas y servicios de justicia reparadora reciban la formación adecuada de un nivel que sea el adecuado al tipo de contactos que mantengan con las víctimas, y observen

${ }^{542}$ Considerando (45): "Los servicios de justicia reparadora, incluidos, por ejemplo, la mediación entre víctima e infractor, las conferencias de grupo familiar y los círculos de sentencia, pueden ser de gran ayuda para la víctima, pero requieren garantías para evitar toda victimización secundaria y reiterada, la intimidación y las represalias. Por tanto, estos servicios deben fijarse como prioridad satisfacer los intereses y necesidades de la víctima, reparar el perjuicio que se le haya ocasionado e impedir cualquier otro perjuicio adicional. A la hora de remitir un asunto a los servicios de justicia reparadora o de llevar a cabo un proceso de justicia reparadora, se deben tomar en consideración factores tales como la naturaleza y gravedad del delito, el grado de daño causado, la violación repetida de la integridad física, sexual o psicológica de una víctima, los desequilibrios de poder y la edad, madurez o capacidad intelectual de la víctima, que podrían limitar o reducir su capacidad para realizar una elección con conocimiento de causa o podrían ocasionarle un perjuicio. Los procedimientos de justicia reparadora han de ser, en principio, confidenciales, a menos que las partes lo acuerden de otro modo o que el Derecho nacional disponga otra cosa por razones de especial interés general. Se podrá considerar que factores tales como las amenazas o cualquier forma de violencia cometida durante el proceso exigen la divulgación por razones de interés general".

${ }^{543}$ Las condiciones son las siguientes:

"a)que se recurra a los servicios de justicia reparadora si redundan en interés de la víctima, atendiendo a consideraciones de seguridad, y se basan en el consentimiento libre e informado de la víctima; el cual podrá retirarse en cualquier momento;

b) antes de que acepte participar en el proceso de justicia reparadora, se ofrecerá a la víctima información exhaustiva e imparcial sobre el mismo y sus posibles resultados, así como sobre los procedimientos para supervisar la aplicación de todo acuerdo;

c) el infractor tendrá que haber reconocido los elementos fácticos básicos del caso;

d) todo acuerdo deberá ser alcanzado de forma voluntaria y podrá ser tenido en cuenta en cualquier otro proceso penal;

e) los debates en los procesos de justicia reparadora que no se desarrollen en público serán confidenciales y no se difundirán posteriormente, salvo con el acuerdo de las partes o si así lo exige el Derecho nacional por razones de interés público superior". 
normas profesionales para garantizar que tales servicios se prestan de manera imparcial, respetuosa y profesional.

Como se percibe, desde Europa se ha potenciado cuantiosamente la figura de la mediación penal. Una búsqueda de implantación de las figuras restaurativas a través de diversas recomendaciones y Directivas, pero sin la obligatoriedad real de normativización de todos estos esfuerzos. Un trabajo exiguo pues, aún muy estudiada, la falta de una normativa de forzoso cumplimiento que regulase la institución nos ha conducido a una deficiente o incluso nula legislación a nivel nacional.

\subsection{La ausencia normativa nacional.}

Dentro de nuestras fronteras no hemos encontrado prácticamente impulso alguno de la mediación o cualquier otro instrumento de Justicia Restaurativa por parte de las Administraciones Públicas. El despreocupado Estado español no ha ejercido su papel de impulsador de la figura dando simples destellos de ello, los cuales han quedado en el vacío del cosmos jurídico. Así, en nuestro Derecho podemos encontrarnos referencias a la institución de la mediación, como la establecida en el Estatuto de la víctima, los Anteproyectos de Código Penal frustrados, la mediación penal en menores infractores y la prohibición en casos de violencia de género. Centelleos insuficientes comparados con el laborioso esfuerzo de juzgados e instituciones de mediación penal en el panorama diario.

La Ley 4/2015, de 27 de abril, del Estatuto de la víctima del delito, y que traspone la Directiva 2012/29/UE, indica en su artículo 3 una serie de derechos (protección, información ${ }^{544}$, apoyo, asistencia, atención, participación activa en el

\footnotetext{
${ }^{544}$ Así mismo, el artículo 5 del citado estatuto completa la información al añadir que "toda víctima tiene derecho, desde el primer contacto con las autoridades y funcionarios, incluyendo el momento previo a la presentación de la denuncia, a recibir, sin retrasos innecesarios, información adaptada a sus circunstancias y condiciones personales y a la naturaleza del delito cometido y de los daños y perjuicios sufridos, sobre los siguientes extremos: k) Servicios de justicia restaurativa disponibles, en los casos en que sea legalmente posible".
} 
proceso penal y a recibir un trato respetuoso, profesional, individualizado y no discriminatorio) que tiene toda víctima durante la actuación de los servicios de asistencia y apoyo a las víctimas ${ }^{545}$ y de justicia restaurativa. El artículo busca que los efectos negativos que pueden conducir a sufrir victimización secundaria no emerjan, salvaguardando así su defensa. Por ello, profundiza en la figura de la Justicia Restaurativa $^{546}$ como medio para la evitación de estos perjuicios.

El artículo 15 centra su interés en los servicios de justicia restaurativa, indicándonos que las víctimas podrán acudir a dichos servicios para obtener una adecuada reparación material y moral de los perjuicios derivados del delito siempre y cuando se cumplan una serie de condiciones: a) el infractor reconozca los hechos esenciales de los que deriva su responsabilidad; b) la víctima y el infractor, tras recibir la debida información acerca del contenido, resultados y demás características del procedimiento, presten su consentimiento ${ }^{547}$; d) el procedimiento de mediación ${ }^{548}$ no entrañe un riesgo para la seguridad de la víctima, ni exista el peligro de que su desarrollo pueda causar nuevos perjuicios materiales o morales para la víctima; e) y no esté prohibida por la ley para el delito cometido ${ }^{549}$.

El estatuto establece una confidencialidad para los debates, diálogos e informaciones que se desarrollen en estos encuentros restaurativos, no pudiéndose difundir sin el consentimiento de los mediados. Esta confidencialidad recaerá también

\footnotetext{
${ }^{545} \mathrm{El}$ artículo 29 del articulado da el control de los servicios de justicia restaurativa a las oficinas de asistencia y apoyo a las víctimas: "Las Oficinas de Asistencia a las Víctimas prestarán, en los términos que reglamentariamente se determine, apoyo a los servicios de justicia restaurativa y demás procedimientos de solución extraprocesal que legalmente se establezcan”

${ }_{546}$ Algo anecdótico pero inusual que el legislador haya optado por la utilización de esta terminología cuando en nuestras fronteras es un término desconocido y confundido con la institución de la mediación. Desconocemos si es un error al confundirlo con mediación como comúnmente sucede, o simplemente el legislador ha querido dejar la puerta abierta a una posible utilización de cualquier práctica restaurativa.

${ }^{547}$ En el punto $3^{\circ}$ del mismo artículo se añade que tanto la víctima como el infractor podrán revocar su consentimiento para participar en el procedimiento de mediación en cualquier momento.

${ }^{548} \mathrm{El}$ legislador tras valorar la figura de la Justicia Restaurativa dentro del articulado, centra su interés en la mediación. Ignoramos si es un equívoco de confundir mediación con justicia restaurativa, sin saber que la mediación es un instrumento de la justicia restaurativa o simplemente es que se quería referir sólo a la mediación en vez de a las demás posibilidades que nos ofrece esta filosofía.

${ }^{549}$ Clara alusión del legislador a la prohibición de acudir a un acto de mediación en los delitos de violencia de género.
} 
en los mediadores, los cuales estarán sujetos a secreto profesional respecto a todos los hechos que conozcan debido a los procesos restaurativos.

Aunque durante el gobierno socialista de José Luis Rodríguez Zapatero se normativizó un borrador de Anteproyecto de LECrim que incorporó la mediación penal, nosotros vamos a centrarnos en el $\mathrm{CPP}^{550}$ del gobierno del Partido Popular, el cual tampoco vio la luz pero regulaba la mediación penal dentro de nuestro ordenamiento, empezando con un interesante análisis en la exposición de motivos en el que se valora las necesidades existentes, tanto por obligaciones internacionales como las derivadas de la práctica, así como las ventajas que la mediación penal - y la Justicia Restaurativa en general- ofrece a los ciudadanos y la sistema de Justicia. Y empezamos con la definición que nos ofrecía el artículo 143 del CPP, el cual define a la mediación penal como el "procedimiento de solución del conflicto entre el encausado y la víctima libre y voluntariamente asumido por ambos en el que un tercero interviene para facilitar que alcancen un acuerdo”.

En el siguiente artículo, el CPP hace una remisión a la Ley 5/2012 de mediación en asuntos civiles y mercantiles ${ }^{551}$ en relación a los principios que han de regir todo proceso de mediación, el estatuto del mediador, al inicio, desarrollo y terminación del procedimiento y a la ejecución de los acuerdos de mediación.

El CPP no establece un listado de delitos que puedan ser derivados a un proceso de mediación, sino que establece que es el Ministerio Fiscal quien, una vez que se le ha comunicado la voluntad de la víctima a someter el conflicto a mediación, el que debe de considerar adecuado o no la realización de la mediación en razón a la naturaleza del hecho. A nuestro juicio nos parece un error que sea el Ministerio Fiscal el que pueda valorar la conveniencia o no de la mediación por la naturaleza del hecho. Se ha de tipificar una serie de conductas (por ejemplo, delitos con una pena de prisión inferior a 5

\footnotetext{
${ }^{550}$ Disponible en http://www.juecesdemocracia.es (última visita 25/01/2018)

${ }^{551}$ Exactamente se remite a los artículos arts. 6.1, 6.3, 7, 8, 10.1, 10.3, 11, 12, 13, 14, 17, 18, 19, 20, 21, 22, 23, 25 y 26.
} 
años) que pueden ser resueltas por un acto de mediación, y es el fiscal el que debe de valorar si es o no conveniente para la integridad física y psíquica de la víctima por razones de posiciones de igualdad entre víctima e infractor.

Prosigue -y esta vez acertadamente- que se le deberá de comunicar al Ministerio Fiscal, por parte del mediador o institución de mediación, el inicio, finalización y resultado de la mediación. El Ministerio Fiscal uno de los ejes de control de la legalidad del acto de mediación, debiendo de tener conocimiento de dicho acto en todo momento, y sobre todo, conocimiento del resultado de la mediación, para así corroborar el plan de reparación, su legalidad, y poder ejercer la posterior acusación o no.

El CPP termina este artículo 144 con dos indicaciones obvias pero fundamentales: la mediación será gratuita; y el mediador se encuentra sometido a secreto profesional no pudiendo declarar sobre los hechos de los que tenga conocimiento con ocasión de su intervención en el procedimiento.

Los dos siguientes artículos trataban sobre las diligencias de investigación, las cuales podrán ser suspendidas por parte del Ministerio Fiscal si lo considera oportuno por la existencia de un acto de mediación, y sobre los efectos de la mediación, provocando que el único sometimiento a un procedimiento de mediación no conllevará ventaja alguna en el posterior juicio para el encausado.

Una regulación excesivamente apática e insuficiente. Redirige, en cuanto al procedimiento, a la ley de mediación civil, obviando las claras diferencias existentes en ambos procesos al existir la figura de la víctima y el infractor. No legislaba un numerus clausus en el que fijase los delitos mediables, sino que otorgaba libertad al Ministerio Fiscal para proseguir o no con el procedimiento valorando únicamente el hecho delictivo, no las posiciones emocionales y de paridad de los sujetos. 
En otra parte, el Código Penal ha recogido diferentes posibilidades de reparación en favor de la víctima. A modo de ejemplo el artículo 21.5 CP establece como atenuante aplicable al delito la reparación a la víctima con anterioridad a la celebración del juicio oral, suponiendo, tal y como destaca SANCHEZ ALBORNOZ, que “este precepto tiene una indudable operatividad en el campo de la mediación penal, pues su amplia formulación no exige que la reparación sea únicamente de contenido económico, caben reparaciones morales o de cualquier otra índole. En definitiva se trata de que la víctima se sienta menos víctima”552, pudiendo incluirse la reparación moral ${ }^{553}$.

Por su parte, la LO 1/2015, de 30 de marzo, de modificación del Código Penal, realiza una tímida referencia ${ }^{554}$ a la institución de mediación penal de adultos. Otorga la facultad al Ministerio Fiscal para de solicitar el sobreseimiento y archivo de las actuaciones en el supuesto de restauración en delitos leves de carácter patrimonial, atribuyendo así efectos así a la reparación en relación a la suspensión de la pena, valorando el juez la situación conforme al esfuerzo del victimario por restaurar a la víctima o cumplir lo acordado en un plan de reparación ${ }^{555}$.

Se ha de legislar, ya sea como un cuerpo legislativo autónomo o como parte de la LECrim, la posibilidad de acudir a las instituciones de la Justicia Restaurativa para satisfacer las necesidades de los litigantes que así lo deseen. Respecto a la mediación es, más que una posibilidad, una necesidad. Estamos ante una figura restaurativa, no la de mayor calidad o capacidad resolutoria, pero sí la más aceptada, adoptada y distinguida dentro de nuestras fronteras.

\footnotetext{
${ }^{552}$ SÁNCHEZ ALBORNOZ, C., Sesión de trabajo sobre la mediación penal, Consejo General del Poder Judicial y Centro de Estudios Jurídicos y Formación Especializada del Departament de Justicia de la Generalitat de Catalunya, Barcelona, 2000, p. 15.

${ }^{553}$ LUZÓN CUESTA, J. M., Compendio de Derecho Penal. Parte General, Dykinson, Madrid, 2003, p. 161.

${ }^{554}$ GARCÍA HERRERA, A., “Justicia restaurativa: breve reflexión...”, op. cit. Disponible en: https://www.diariolaley.es (última visita 05/04/217)

${ }^{555}$ Para más información con relación a este aspecto véase ROIG TORRES, M., "Suspensión de la ejecución de las penas privativas de libertad”, en J.L. Gonzalez Cussac, A Matallin Evangelio, y E. Górriz Royo (coords.), Comentario a la Reforma del Código Penal de 2015, Tirant lo Blanch, Valencia, 2015, pp. 325-341.
} 
Se trata de encontrar un complemento del actual sistema de justicia, en suma una opción al servicio de los ciudadanos para la resolución pacífica de conflictos. Tal y como indica acertadamente DEL RÍO FERNÁNDEZ la despenalización de pequeñas infracciones o la aplicación del principio de intervención mínima no son las mejores soluciones ${ }^{556}$. Creemos que el Estado ha de seguir penalizando las mismas conductas, pero ha de dar oportunidad a los miembros de la sociedad a la utilización de instrumentos de variada naturaleza para la resolución de los conflictos. El pilar para un desarrollo eficaz de la justicia no es restar conductas sino sumar prácticas que cumplan los fines del sistema y satisfagan las necesidades de los intervinientes a través de un proceso que potencie las ideas de democracia participativa y ciudadanía ${ }^{557}$.

Ante la dificultad y polémica que en la actualidad produce el fenómeno de la mediación, el establecimiento de un marco legal definido será clave para la consolidación de la mediación penal en nuestro sistema de justicia. De ahí que aventuremos las siguientes propuestas:

- Regulación de una ley de Justicia Restaurativa como un complemento al sistema actual y a su vez se modifique la LECrim para ajustarla al proceso penal $^{558}$. Tal y como señala BARONA VILAR, “la mediación es pieza de ese nuevo modelo de justicia, pero no un ingrediente de reducción de lo público" 559 , siendo por tanto fundamental su engranaje dentro del proceso penal actual como un complemento y no así como una técnica tal y cómo se concibieron inicialmente por ZEHR las prácticas restaurativas. En dicha Ley

\footnotetext{
556 DEL RÍO FERNÁNDEZ, L., "El reto de la mediación penal: el principio de oportunidad”, en Diario La Ley 2006, nº 6520, pp. 1957-1968, esp. pp. 1965-1967.

${ }^{557}$ LUNA JIMENEZ DE PARGA, P., "Presente y futuro de la Mediación Penal”, en I Jornadas sobre Mediación penal y Drogodependencias, Madrid, Asociación Apoyo 3-4 de octubre de 2002, 48. Actas de las Jornadas en www.uc3m.es/larevistilla

558 Sobre esta posibilidad véase GARCIANDÍA GONZÁLEZ, P. M., "La regulación de la mediación penal en España: opciones legislativas y contenidos mínimos”, en J.L. Gómez Colomer, S. Barona Vilar, M. Pía Calderón Cuadrado (coords.), El derecho procesal español del siglo XX a golpe de tango. Liber Amicorum, en homenaje y para celebrar su LXX cumpleaños, Tirant lo Blanch, Valencia, 2012, pp. 10051032.

559 BARONA VILAR, S., "Integración de la mediación en el moderno concepto de "Acces to Justice". Luces y sombras en Europa”, en Indret: Revista para el Análisis del Derecho 2014, n 4, documento en línea. Disponible en: http://www.indret.com (última visita 08/03/2018)
} 
se han de especificar 4 grandes apartados o Títulos. El primero de ellos debe de versar sobre la Justicia Restaurativa en general y las nociones comunes a todas ellas. Seguido de ello se establecerían los 3 Títulos que regulen las características propias de cada institución restaurativa como son la mediación penal, las conferencias y los círculos. Todo ello desde el vértice de instrumentos complementarios al compartir funciones y finalidad con el proceso penal $^{560}$.

- Implantación del principio de oportunidad dentro de nuestro sistema ${ }^{561}$ como un concepto amplio ${ }^{562}$ para un correcto desarrollo constitucional y legal de los instrumentos restaurativos.

- Conforme a la mediación penal se establecerán todos los detalles concernientes a la tipología delictiva, procedimiento o acuerdos. Así podrá implantarse esta institución para todo tipo de delitos o, como creemos conveniente, una promulgación progresiva, introduciéndose en primer lugar la posibilidad de resolución a través del proceso de mediación de los delitos de menor gravedad - aquellos con una pena de prisión inferior a 5 años para posteriormente, y si se considerase óptimo por los resultados positivos obtenidos si los hubiere, ampliarse el catálogo delictivo progresivamente. A prima facie, y en relación con la práctica de métodos restaurativos para la resolución de conflictos graves o muy graves, estimamos más apropiado el uso de otras instituciones, tales como las conferencias o los círculos, en consonancia al mayor número de participantes en las sesiones restaurativas así como a la intervención en éstas de miembros de los cuerpos de seguridad y del sistema de justicia.

\footnotetext{
${ }^{560}$ BARONA VILAR, S., “Esquizofrenia en la ...”, op. cit., p.215.

561 Para poder establecer la mediación en nuestras fronteras es fundamental la regulación de este principio, tal y como recomendaba el Informe de la participación de los tribunales de La Rioja en el proyecto UE, sobre experimentación de la mediación penal junto a tribunales de Francia, Italia y Bulgaria, 2008, p. 69. Disponible en: http://www.poderjudicial.es (Última visita: 09/11/2017).

562 Para una mayor análisis véase ARMENTA DEU, T., "Principio de legalidad vs Principio de oportunidad: una ponderación necesaria”, en J. Picó Junoy (dir.), Principios y Garantías Procesales. Liber Amicorum en homenaje a la profesora $M^{a}$. Victoria Berzosa Francos, Bosch Editor, Barcelona, 2013, pp. 441-456
} 
- La LO 1/2004 debe de ser revisada en profundidad para subsanar sus deficiencias ${ }^{563}$ y debiéndose reformar en nuestra opinión la prohibición de la mediación penal en casos de violencia de género. Ha de existir la voluntariedad de inicio de un proceso de mediación siempre y cuando el maltrato no sea grave ni continuado en el tiempo ni la víctima se encuentre en situación de dependencia emocional ${ }^{564}$. Todo ello servirá de base para un desarrollo posterior de diversas prácticas restaurativas más eficientes en la resolución pacífica de este tipo de conflictos.

- El procedimiento de mediación ha de estar limitado temporalmente. Un plazo que creemos conveniente es de dos meses para la preparación y seis meses prorrogables por otro periodo de misma cuantía en caso de justificada necesidad para el desarrollo del proceso.

- Establecimiento de la fase procesal en la cual puede efectuarse la derivación del asunto a un servició de mediación penal. Así, y desde nuestra opinión, consideramos que puede incoarse un procedimiento de mediación en cualquier fase procesal, ya sea previa al inicio del procedimiento ${ }^{565}$, enjuiciamiento penal o post sentencia -generalmente dentro del ámbito penitenciado aunque puede efectuarse posteriormente también, ambas con un fin reparador en favor de la víctima y resocializador del infractor-.

- La Preparación debe de ser un periodo de información a las partes sobre el desarrollo del proceso, su contenido, actuaciones y demás características. Tras esto, y si las partes siguen adelante, se iniciará la preparación psicológica de la víctima si fuere necesaria.

- En el Acto de mediación tendrá lugar el diálogo sincero. Es el procedimiento clave, salvaguardándose los intereses de ambas partes y no permitiendo una posible situación de desigualdad. Esta fase acabará con o sin acuerdo.

\footnotetext{
${ }^{563}$ MARTÍNEZ GARCÍA, E., "Violencia de género, igualdad y autonomía de la voluntad. Claves para entender la prohibición de mediar en el proceso penal por estos delitos” en E. Martínez García, J.C. Vegas Aguilar y F.J. Boix Reig (coords.), La prevención y erradicación de la violencia de género. Un estudio multidisciplinar y forense, Aranzadi, Cizur Menor, 2012, pp. 413-434, esp. p. 414.

${ }^{564}$ MANZANARES SAMANIEGO, J., "Mediación, reparación y conciliación ...” op. cit., p. 131

${ }^{565}$ FERNÁNDEZ FUSTES, M.D., La intervención de la víctima en el proceso penal (especial referencia a la acción civil), Tirant lo Blanch, Valencia, 2004, p. 399.
} 
- En la última fase y en caso de acuerdo, la ejecución del plan de reparación se tendrá que ejecutar el plan acordado por las partes en el plazo estipulado, devolviéndose a su vez el caso a los Tribunales para que tanto el fiscal y el juez conozcan de dicho plan y valoren su legalidad y el cumplimiento de los diferentes principios básicos de toda actuación de mediación tales como la imparcialidad, la igualdad de partes y la autodeterminación de los intervinientes. El Fiscal deberá interponer su escrito de acusación y el juez deberá de resolver teniendo en cuenta la acusación del Ministerio Fiscal y el plan de reparación.

- Tanto en mediación como en cualquier otra institución restaurativa se han de regular las consecuencias jurídicas que suponen para el victimario la reparación en favor de la víctima. La atenuación de la pena por reparación, la conformidad, el proceso por aceptación de decreto incoado por el Ministerio Fiscal como propuesta punitiva premiada ${ }^{566}$ y la suspensión de la ejecución de la pena (en supuestos de penas privativas de libertad inferiores a dos años y cuando exista esfuerzo en la reparación ${ }^{567}$ ) han sido las repuestas del ordenamiento en favor del infractor que restaura a la víctima. En nuestra opinión, se ha de valorar previamente cual ha sido la conducta delictiva y la circunstancia del infractor, así como el grado de reparación llevado acabo y se ha de permitir que el victimario y Ministerio Fiscal opten la opción que consideren más oportuna. Así, y en delitos de mayor gravedad, la atenuante, en el supuesto de cumplimiento del plan de reparación, será una posibilidad para la disminución del periodo de prisión establecido por la sentencia judicial firme, sin la posibilidad de eximir dicha pena de prisión por la restauración de la víctima.

Ante todo se ha de aclarar que lo fundamental aquí es la resolución de los conflictos nacidos entre las personas, entre seres humanos que sufren, y por ello lo

\footnotetext{
${ }^{566}$ MARCHENA GÓMEZ, M., y GONZÁLEZ-CUÉLLAR SERRANO, N., La reforma de la Ley de Enjuiciamiento Criminal en 2015, Castillo de Luna Ediciones Jurídicas, Madrid, 2015, pp. 76-78. ${ }^{567}$ GONZÁLEZ CANO, M.I., “La integración de la ...”, op. cit., p. 673.
} 
importante a la hora de regular la mediación penal no es recurrir a un numerus clausus de tipologías, sino a las necesidades de los ciudadanos. Y es que "siempre que haya voluntariedad, autonomía y equilibrio de las partes cualquier conducta es susceptible de ser objeto de un proceso de mediación" 568 .

\section{4. Ámbito material.}

Hemos llegado aquí a uno de los puntos más controvertidos pero sin duda más importantes en el estudio de la mediación penal. No hay un consenso sobre qué tipos delictivos deben de ser “mediables”. Se indicará aquí, en opinión particular, cuales son las infracciones consideradas más óptimas para la resolución a través de un proceso de mediación así como las cuatro especialidades de mayor magnitud como son la mediación en infractores reincidentes, personas jurídicas, la mediación en menores, la mediación en víctimas de violencia de género y la mediación policial.

\subsection{La mediación en los delitos leves, graves y muy graves.}

¿Para la resolución de qué delitos se ha de acudir a un acto de mediación? La respuesta es variada y depende de los autores, existiendo disparidad de conceptos. Unos consideran la mediación válida para todo tipo crímenes, otros centran su interés en delitos leves basándose en la idea de “imprescindibilidad del Derecho Penal para la resolución de los conflictos creados con la realización de conductas penales tan importantes" 569 . Nosotros podemos adelantar que consideramos que la mediación puede utilizarse en un gran número de delitos, prácticamente todos, pero es en los delitos leves donde más eficacia creemos puede tener. Opinamos que el legislador, a la hora de establecer el ámbito de aplicación, deberá de disponer inicialmente un límite de delitos con una pena de prisión inferior a 5 años. Este límite es el recomendable ya que estamos hablando de delitos con una gravedad moderada, y cuando nos hallamos ante un país que desconoce por completo la mediación. Es por ello que establecemos este límite

${ }^{568}$ CERVELLÓ DONDERIS, V., "La mediación en el ...” op. cit., p. 77.

${ }^{569}$ CERVELLÓ DONDERIS, V., "La mediación en el ...” op. cit., p. 76 
como aconsejable con el fin de ir acostumbrando a la sociedad española a sus peculiaridades conforme se inicia la práctica de la mediación.

La mediación es una figura muy controvertida, siendo recomendada para delitos leves ${ }^{570}$ o de poca gravedad, aunque también puede resultar beneficiosa en delitos de mayor trascendencia como un método de resocialización y pacificación social ${ }^{571}$. Aunque en este último supuesto no resulta, desde nuestra perspectiva, la figura más aconsejable. En su lugar entendemos que la existencia de otras prácticas restaurativas, tales como los círculos o las conferencias, se posicionan como una variante más adecuada para la respuesta ante transgresiones de mayor gravedad.

Cada vez un menor número países están imponiendo un elenco cerrado de delitos susceptibles de mediación ${ }^{572}$, dejando la posibilidad de elección a este recurso en manos de la víctima, la cual decidirá si considera este método el más conveniente para la resolución de su conflicto. Todo esto se puede basar en experiencias realizadas a nivel nacional ${ }^{573}$ como internacional ${ }^{574}$, donde no encontramos un numerus clausus, sino que se permite que cualquier delito pueda ser susceptible de resolución a través de un proceso de mediación.

\footnotetext{
${ }^{570}$ Resolución 1999/26 del Consejo Económico y Social de ONU, sobre Elaboración y aplicación de medidas de mediación y Justicia restaurativa en materia de Justicia penal. Disponible en https://www.unodc.org (última visita 25/10/2016)

${ }^{571}$ Conclusiones del $11^{\circ}$ Congreso de las Naciones Unidas sobre Prevención del Delito y Justicia Penal (Bangkok, abril de 2005). Disponible en: http://www.cinu.org.mx (última visita 26/01/2018)

572 BARONA VILAR, S., "El presente y el futuro de la mediación en España”, en J. Tamarit Sumalla (coord.), Víctimas olvidadas, Tirant lo Blanch, Valencia, 2010, p. 243.

573 VARONA MARTÍNEZ, G., Justicia restaurativa a través de los servicios de mediación penal en Euskadi. Evaluación externa de su actividad (octubre 2008-setiembre 2009), Instituto Vasco de Criminología, Donostia-San Sebastián. Diciembre de 2009, p. 64. Disponible en: www.ehu.es (Última visita: 09/11/2017)

${ }^{574}$ BELTRÁN MONTOLIU, A., "Modelo de mediación en ...” op. cit., p, 70. Vid. DÍAZ LÓPEZ, A., "Propuestas para la práctica de la mediación penal. Delitos patrimoniales cometidos entre parientes y responsabilidad penal de las personas jurídicas”, en InDret 2011, nº 3, pp. 1-50, esp. p 20.
} 
Como ya hemos indicado anteriormente, estamos multitud de división doctrinal. Hay autores que propugnan un numerus clausus según el tipo delictivo ${ }^{575}$ al considerar la inadecuación de esta figura para ciertos actos delictivos los que, debido a la gravedad del delito, podrían suponer un grave desequilibrio para la víctima. Hay que dejar claro que la restauración y el castigo han de complementarse y que en delitos graves, especialmente, "en ningún caso el empleo de mecanismos de justicia restaurativa concluye en impunidad" ${ }^{576}$.

La mediación - o cualquier otro método restaurativo - es una gran oportunidad para ambas partes; se presenta como una opción voluntaria para la resolución del conflicto, para la “integración, reconstrucción y pacificación personal, que les permita reconocer al otro como persona” ${ }^{577}$, y para la obtención de unas ventajas ${ }^{578}$ no

${ }^{575}$ QUINTERO OLIVARES, G., "Sobre la mediación y la conciliación en el sistema penal español: Situación y perspectiva de futuro", en R. Castillejo Manzanares y Ma. C. Catalina Benavente (coords.), Violencia de género... op. cit.,, pp. 501-528, esp. p 523; URBANO CASTRILLO, E., "La justicia restaurativa penal”, en La ley penal 2010, $\mathrm{n}^{\circ}$ 73, p 16.

${ }^{576}$ ETXEBARRIA ZARRABEITIA, X., "Justicia para la convivencia”, en AA.VV. Justicia para la convivencia. Los puentes de Deusto. Encuentro «Justicia retributiva y restaurativa: su articulación en los delitos de terrorismo, Universidad de Deusto, Bilbao, 2012, pp. 143-150, esp. p. 146. En el mismo sentido: ECHANO BASALDUA, J. I., "Justicia restaurativa y justicia transicional en los delitos de terrorismo: algunas reflexiones”, en AA.VV. Justicia para la convivencia. ... op. cit., pp. 123-130, esp. p. 126; ETXEBERRIA MAULEÓN, X., "Justicia retributiva y restaurativa ante los delitos de terrorismo", en AA.VV. Justicia para la convivencia. ... op. cit., pp. 151-158, esp. p. 156.

${ }^{577}$ ECHANO BASALDUA, J.I., "Mediación penal entre adultos: ámbito de aplicación en atención a la clase de infracción”, en I.J. Subijana Zunzunegui, et al., Justicia restaurativa, una ..., op. cit., pp. 157204, esp. p. 190

${ }^{578}$ RÍOS MARTÍN, J., et al., "Reflexiones sobre la viabilidad de instrumentos de justicia restaurativa en delitos graves”, en M. Martínez Escamilla y M.P. Sánchez Álvarez, (coords.), Justicia restaurativa, mediación penal ... op. cit., pp. 127-171, esp. pp. 141 y 142. En esta obra se nos indican una serie de ventajas de la mediación en delitos graves para la víctima: "Conocer la verdad completa; Poder volcar las emociones tanto tiempo contenidas en un espacio de seguridad y en un horizonte de construcción colectiva de la paz que le dote de sentido; Poder encontrar la paz individual y el sosiego espiritual; Iniciar una nueva etapa en la vida en la que se abandone el desgaste provocado por el odio cronificado; Empoderar a la víctima y potenciar el propio protagonismo; Acudiendo a metodologías apreciativas, recuperar la propia historia o la del ser querido desde lo positivo y no como una vivencia con final traumático que coloniza el resto de lo bueno de la vida compartida; Obtener respuestas a preguntas como: ¿Qué ocurrió?, ¿por qué me ocurrió a mí?, ¿por qué actué en la forma en que lo hice en ese momento?, ¿por qué he actuado como lo he hecho desde que me ha ocurrido esto?, ¿qué pasaría si me ocurriera esto otra vez?, ¿qué significa esto para mí y para mi perspectiva (mi fe, mi visión del mundo, mi futuro)?; Aumentar la propia seguridad; Ganar madurez personal en un camino recorrido con muchos aprendizajes; Socializar las transformaciones a las siguientes generaciones en clave de paz familiar; Cerrar una etapa importante del propio ciclo vital; Procurar el reconocimiento del daño causado por parte del agresor; Lograr que el agresor caiga en la cuenta de que existen otras alternativas que no habrían causado tanto dolor a personas concretas; Obtener una reparación económica. Aunque 
alcanzables en el proceso penal retributivo que nos lleven a la reparación del delito, resocialización del infractor ${ }^{579}$ y a la paz social.

Como conclusión, defendemos que la mediación es más viable en los delitos leves que en los graves, en los que existe una víctima que en los que son de peligro abstracto $^{580}$. En nuestra opinión, la imposición de un numerus clausus es correcta. Se debe de establecer unos delitos según su gravedad, unos delitos "más mediables" inicialmente. Debido a la existencia de figuras más adaptadas para la resolución de crímenes graves, la mediación podría ser un medio útil en la resolución de conflictos que acarreen una pena de prisión inferior a 5 años. ¿Por qué este tipo de delitos? La respuesta es simple, son delitos leves o de ínfima gravedad, en los que la víctima no necesita una amplia preparación para el encuentro con el infractor, y por tanto, nos llevará a actos de mediación más o menos sencillos y no muy duraderos en el tiempo, que acostumbrarán al sistema de justicia.

No se pretende una exclusión de conductas delictivas por razón de su pena ${ }^{581}$ sino que simplemente se defiende la aplicación de los métodos más acordes para el

esta motivación suele encauzarse en los niveles judicial y político y por exigencias de la legislación penitenciaria las personas condenadas por el delito de terrorismo deben satisfacer la responsabilidad civil."

${ }^{579}$ Pero no sólo el infractor obtiene su resocialización, sino que obtiene otras ventajas. Como bien nos indica RÍOS MARTÍN, J., et al., "Reflexiones sobre la viabilidad ...” op. cit. p.157, el infractor obtiene "la paz consigo mismo y eventualmente contar con el perdón del otro al reconocer la responsabilidad de su conducta. El ejercicio de perdonar no deja de ser una forma de empoderamiento. También podrían producirse consecuencias jurídicas favorables para el infractor en el orden jurídico y político"

${ }^{580}$ Este tipo de delitos en los cuales no existe una víctima individualizada crea muchos problemas y, sobretodo, se hacen muy difícil de mediar ya que no existe un sujeto concreto al que se le ha dañado, por ello creemos que no deben de ser tratados desde parámetros restaurativos. Vid. MARTínEZ ESCAMILLA, M., “Justicia reparadora, mediación ...”, op. cit., p. 466. Dicho esto no quiere decir que no pueda existir una posible reparación. Un ejemplo de ellos son los delitos contra los recursos naturales y el medio ambiente (arts. 332 y ss. CP), los cuales tienen un tipo atenuando en el art. 340, lo cual indica que "si el culpable de cualquiera de los hechos tipificados en este Título hubiera procedido voluntariamente a reparar el daño causado, los Jueces y Tribunales le impondrán la pena inferior en grado a las respectivamente previstas".

${ }^{581}$ ETXEBARRIA ZARRABEITIA, X., “Justicia restaurativa y fines del derecho penal”, en M. Martínez Escamilla y M.P. Sánchez Álvarez, (coords.), Justicia restaurativa, mediación penal ... op. cit., pp. 4768, esp. pp. 55-56. El autor indica que "ha de defenderse la no exclusión ab initio de ningún hecho con base en criterios relacionados con la gravedad objetiva, jurídico penal, del hecho. La exclusión por ejemplo de los delitos graves - aquellos castigados con pena de prisión superior a 5 años o inhabilitación absoluta o prohibición de aproximarse al a víctima por tiempo superior a 5 años, por 
cumplimiento de los objetivos propuestos en el Derecho Penal. Por ello, los círculos, una figura que potencia la participación de la comunidad, puede dar una respuesta más efectiva a las necesidades surgidas con la comisión del hecho delictivo gravoso. No obstante, no se ha de obviar que el éxito de cualquier práctica restaurativa, y en concreto de la mediación penal, no depende tanto de la infracción sino de la voluntad de los participantes $^{582}$, pues pueden existir delitos con una reparación factible pero no resueltos por falta de motivación de los intervinientes, o al contrario, infracciones graves de compleja reparación pero con una resolución exitosa. Así es de nuestra consideración una implantación progresiva de esta institución, ampliándose el ámbito material a infracciones más gravosas en los supuestos de éxito en las experiencias y desarrollándose en cualquier fase procesal, con el único fin de proporcionar a las partes un instrumento que repare a la víctima y que atenúe la pena de prisión del infractor y le ayude a su resocialización a través de la restauración en fases posteriores.

Es importante la introducción de este tipo de instituciones como la mediación o los círculos en nuestro ordenamiento, instituciones que complementan el retributivo sistema actual y que de algún modo reportan más satisfacción a todos los participantes. Las víctimas sienten así una justicia más cercana a sus sentimientos y necesidades. No en vano, tal y como señala RÍOS MARTÍN, “para la reparación y recuperación de las víctimas, rara vez el cumplimiento de la pena impuesta en el régimen más duro hasta el último día es lo más efectivo” ${ }^{583}$.

ejemplo, según arts. 13 y 33.2 CP-, como ocurre en la Ley de responsabilidad penal de los menores, constituye un perjuicio para las víctimas de dichos delitos, al privarles de la posibilidad de participar en un proceso de mediación con base en un criterio restrictivo planteado desde la perspectiva de la necesidad de castigo al infractor. En la selección de los casos a derivar a mediación creo que deberían ser más relevantes criterios de tipo subjetivo".

${ }^{582}$ VALL RIUS, A., "El desarrollo de la Justicia restaurativa en Europa: Estudio comparado con la legislación española”, en Diario La Ley 2006, n 6528, p. 21. Disponible en http://www.diariolaley.es (última visita 11/10/2017)

${ }^{583}$ RÍOS MARTÍN, J., et al., “Reflexiones sobre la viabilidad ...”, op. cit. p.157 


\subsection{Especialidades dentro de la práctica de la mediación penal.}

En este apartado se propone el estudio de una serie de mediaciones “especiales” por las características propias de algunos o todos los participantes, tales como; infractores reincidentes; personas jurídicas; víctimas de violencia de género; y mediación policial. Se analizará la situación actual y si es o no conveniente su uso. También desarrollaremos la especialidad de la mediación penal en menores infractores, un tipo de mediación primerizo en nuestras fronteras, base del futuro procedimiento de mediación penal de adultos, y un pilar de la resocialización de los futuros miembros de la sociedad.

\subsubsection{La mediación y el infractor reincidente}

Cuando un infractor es reincidente en su conducta delictiva surge la duda de si merece o no la pena la elección de un proceso restaurativo. La reincidencia es un motivo entendible para no permitir acudir a un proceso de mediación. Opinión respecto de la cual nos permitimos discrepar. Cada acto delictivo es diferente y debe de recibir un tratamiento diferenciado ${ }^{584}$, y más aún cuando estamos hablando de la reparación en favor de la víctima.

Precisamente los infractores reincidentes que nunca han acudido a un proceso de mediación ya han comprobado la poca efectividad de la pena por lo que conviene para ello acudir a un proceso restaurativo y abandonar así el crimen como forma de vida. Es una oportunidad nueva ante ellos que no se había presentado antes y que quizás les ayude a reconducir el camino de su vida. Si antes no han tenido la oportunidad de observar los efectos del delito o el daño provocado a la víctima, no han podido reconducir su conducta. Con la mediación se les ofrece este camino: una vía de resocialización, difícil, pero no imposible.

${ }^{584}$ SÁEZ RODRÍGUEZ, C., La mediación familiar..., op. cit., pp. 325 y ss. 
Otro caso muy diferente son los infractores que ya han acudido a métodos restaurativos, y a pesar de ello, siguen cometiendo delitos sin remordimiento alguno. Este tipo de sujetos en principio no debería de acudir a ningún método restaurativo porque lo único que sería es perder el tiempo. El infractor reincidente que no ha aprendido nada de los procesos restaurativos previos será muy complicado que acuda a uno de ellos otra vez y vea la luz: el camino correcto de su vida.

Hay que partir de la idea de que la mediación, y cualquier proceso restaurativo, tiene como uno de sus fines la resocialización del individuo. Si el individuo tras un acto de mediación reincide, está claro que con dicho sujeto la mediación no ha cumplido su fin y es momento de utilizar otro método.

Hay que advertir también que la mediación, como cualquier método restaurativo, no es un método perfecto que asegure una resocialización inmediata del infractor. Hay que recordar que ciertos infractores viven el delito con naturalidad; es parte de su vida, su manera de vivir. Aunque puedan llegar a comprender que no es el camino correcto, no siempre se puede salir de una vida delictiva si la sociedad no apoya a estos sujetos o si ellos mismos no ven opciones reales.

Se advierte la posibilidad de utilizar estos métodos restaurativos en infractores reincidentes cuando se hay o no aplicado previamente un proceso de mediación o no. Aun así, consideramos que figuras como las conferencias o los círculos son más eficaces en la consecución de los objetivos de resocialización de cualquier infractor, siendo preferible su utilización. Por ello, no hemos de perder la esperanza en la resocialización de dicho infractor. Puede que un proceso restaurativo no haya concluido con éxito, pero no por ello se ha de arrojar la toalla. Existen diferentes variables restaurativas, las cuales pueden suponer la resocialización del sujeto. Y, además, nunca se ha de negar la posibilidad de iniciación de cualquier proceso reparativo, y menos cuando estemos valorando un beneficio en favor de la víctima. 


\subsubsection{Personas jurídicas y el proceso de mediación penal.}

La posibilidad de que una persona jurídica pueda participar en un proceso de mediación es ampliamente aceptada ${ }^{585}$. Es un caso complejo ya que la persona jurídica no puede acudir por ella misma al acto de mediación, necesitando un representante para la práctica de las sesiones. No obstante varias barreras legales con respecto a la mediación penal con personas jurídicas, ya sean como víctimas o como infractores.

La primera de las barreras es la Ley Orgánica 5/2010, de 22 de junio, por la que se modifica la Ley Orgánica 10/1995, de 23 de noviembre, del Código Penal, y que introduce en nuestro ordenamiento la responsabilidad penal de las personas jurídicas. Nos condujo al hecho histórico del primer auto de imputación de una persona jurídica del 11 de octubre de 2011 por el Juzgado Central de Instrucción $n^{\circ}$ 6. Esta figura ha sufrido una modificación a través de la L.O. 1/2015, de 30 de marzo, por la que se modifica la L.O. 10/1995, de 23 de noviembre, del Código Penal, que aunque modifica todos los artículos de la responsabilidad penal de las personas jurídicas, se centra especialmente todo en el artículo 31 bis CP. Esta modificación ha supuesto multitud de críticas $^{586}$ al ser considerada como una ley que busca soslayar la imputación de las personas jurídicas ${ }^{587}$, que es un "plagio de la ley italiana” 588 con los problemas que ello supone y que no tiene fundamento en dudas interpretativas como así nos indica la reforma, ya que apenas ha habido imputaciones de personas jurídicas y el marco

\footnotetext{
${ }^{585}$ Vid. BARONA VILAR, S., Mediación penal. Fundamento ..., op. cit., pp. 312 - 317; DÍAZ LÓPEZ, J.A., "Propuestas para la práctica ...” op. cit., pp. 1-50; PÉREZ CEPEDA, A. I., "Las víctimas ante el Derecho penal. Especial referencia a las vías formales e informales de reparación y mediación”, en AA.VV., Homenaje al dr. Marino Barbero Santos: “in memoriam”, Universidad de Castilla-La Mancha/Universidad de Salamanca, Cuenca, 2001, vol. I, p. 472.

${ }^{586}$ El informe del Consejo de Estado 358/2013, de 27 de junio, realiza numerosas críticas a esta nueva regulación. Disponible en https://www.boe.es (última visita 12/04/2018)

587 QUINTERO OLIVARES, G., La reforma del régimen de responsabilidad penal de las personas jurídicas, Aranzadi, Cizur Menor, 2015, p. 80.

${ }^{588}$ DOPICO GÓMEZ-ALLER, J., Análisis crítico del nuevo régimen de responsabilidad penal de las personas jurídicas, según el Proyecto de Reforma de 2013, Tirant Lo Blanch. Valencia 2014, pp.19 - 24.
} 
internacional no ha cambiado ${ }^{589}$. De este modo si no hay imputación no existirá mediación penal desde el punto de vista de persona jurídica infractor.

El segundo impedimento, de origen legal, radica en la Directiva 2012/29/UE referente al Estatuto de la víctima la cual, siguiendo la línea de la Decisión Marco 2001/220/JAI, al hablarnos de víctima en su artículo 1, la define como "la persona física que ha sufrido un daño o perjuicio”. Esta definición de víctima excluye a la persona jurídica de plano. Dada la redacción del cuerpo normativo se puede deducir la intención del legislador de excluir a las personas jurídicas del término de víctimas, y en consecuencia, de los métodos restaurativos.

La tercera barrera que nos encontramos es en este caso la jurisprudencia del Tribunal de Justicia de la Unión Europa y así en sentencia del TJUE de 28 de junio de 2007, caso Dell'Orto, el cual se ha pronunció en la línea de la no extensión del concepto de víctima a las personas jurídicas al indicar en su fallo: “...En virtud de todo lo expuesto, el Tribunal de Justicia (Sala Tercera) declara: La Decisión marco 2001/220/JAI del Consejo, de 15 de marzo de 2001, relativa al estatuto de la víctima en el proceso penal, debe interpretarse en el sentido de que, en un proceso penal y, más específicamente, en un procedimiento de ejecución posterior a una sentencia definitiva de condena, como el del litigio principal, el concepto de «víctima» a efectos de dicha Decisión marco no incluye a las personas jurídicas que hayan sufrido un perjuicio directamente causado por un acto u omisión que infrinja la legislación penal de un Estado miembro" ${ }^{590}$.

Sin embargo el mismo Tribunal de Justicia de la Unión Europea en sentencia de TJUE de 21 de octubre de 2010, más conocido como caso Eredics ha matizado la interpretación de la Decisión Marco 2001/220/JAI acerca del término víctima como

\footnotetext{
589 GONZÁLEZ CUSSAC, J.L., "Responsabilidad penal de las personas jurídicas: Arts. 31 bis, ter, quarter y quinquies”, en Comentarios a la reforma del Código Penal de 2015, Librería la Jurídica, Barcelona, 2015, pp. 151 - 155.

${ }^{590}$ As. C-467/05. Disponible en: https://www.curia.europa.eu (última visita 26/01/2018)
} 
persona física, permitiendo que las personas jurídicas también sean consideradas como tal al advertir que "Ia Decisión marco ni impide ni obliga a los Estados miembros a aplicar lo en ella dispuesto también en los casos en que la víctima sea una persona jurídica" 591 .

Una cuarta barrera sería la valoración efectuada por el mediador, quien ha de estimar la capacidad de las partes de poder comprender el acto -aspecto que en las personas jurídicas no puede suceder- debiendo de apreciar, aparte de la capacidad del representante, si la persona jurídica es un buen ciudadano corporativo ${ }^{592}$, o en otros términos, si cumple con la legalidad y si participa en el discurso público.

Hemos de señalar que en la práctica no se están teniendo en cuenta los antecedentes acaecidos, tanto legales como jurisprudenciales. Se están desarrollando actos de mediación con personas jurídicas como participantes ${ }^{593}$. Lo único que necesitan es un representante que sepa la situación de la empresa y pueda defender lo mejor posible su posición.

\subsubsection{Mediación penal en el sistema penal de menores.}

La mediación penal de menores es la consecuencia del interés suscitado tanto por la doctrina ${ }^{594}$ como por el legislador por la restauración y reparación de los conflictos surgidos en el ámbito penal de menores. Una respuesta basada en la educación por encima del castigo punitivo encaminada en la resocialización de los jóvenes delincuentes. Múltiples precedentes nos han conducido a esta regulación.

\footnotetext{
${ }^{591}$ As. C-205/09, aptado. 29.. Disponible en: http://curia.europa.eu (última visita 20/02/2017)

592 DÍAZ LOPEZ, J.A., "Dilemas sobre la apreciación de la idoneidad de la mediación: responsabilidad penal de las personas jurídicas”, en Justicia restaurativa, una ... op. cit., pp. 129-156, esp. p. 141.

${ }^{593}$ Ejemplos de ellos son las experiencias piloto de Cataluña, en las cuales un 24,3\% de las víctimas en mediaciones penales eran personas jurídicas. Vid. GUIMERA I GALIANA, A., "La MediaciónReparación en el Derecho penal de adultos: un estudio sobre la experiencia piloto de Cataluña”, en Revista Española de Investigación Criminológica 2005, n³ 3, pp. 1-22, esp. p. 9.

${ }^{594}$ Un estudio pormenorizado de la materia que muestra el creciente interés que ha venido teniendo esta mediación véase: CASTILLEJO MANZANARES, R., "La mediación en el proceso de menores”, en Revista de Derecho Penal 2011, n 32, pp. 9-28.
} 
El primer antecedente son las Reglas de Beijín ${ }^{595}$, las cuales exponen una serie de principios y prácticas para la Administración de justicia a los jóvenes. En sus artículos 11.2 y 11.4 se refiere a la remisión de asuntos a métodos alternativos al sistema penal, indicando que "Ia policía, el Ministerio fiscal y otros organismos que se ocupen de los casos de delincuencia de menores estarán facultados para fallar dichos casos discrecionalmente, sin necesidad de vista oficial, con arreglo a los criterios establecidos al efecto en los respectivos sistemas jurídicos y también en armonía con los principios contenidos en las presentes Reglas. [...] Para facilitar la tramitación discrecional de los casos de menores, se procurará facilitar a la comunidad programas de supervisión y orientación temporales, restitución y compensación a las víctimas”.

Con esta remisión dicha normativa procura mitigar los efectos negativos que tiene el sistema penal en los jóvenes, siendo otros métodos más beneficiosos para el menor. Incluso en delitos leves la no intervención es la respuesta más óptima siempre y cuando los sujetos que componen el ámbito del menor (familia, escuela y demás instituciones) ya han reaccionado al hecho delictivo y han tomado las oportunas medidas contra él. Se busca la aplicación de otras “tácticas” que resocialicen al menor y para ello se deben de aplicar medidas de seguimiento con el fin de evitar una futura e hipotética reincidencia.

La Convención de los Derechos del Niño de 20 de noviembre de $1989^{596}$ garantizaba a través de sus legislaciones una serie de derechos de todos los menores debido a que por su madurez física y mental era necesaria una protección legal. Y respecto al tema que nos concierne, el artículo 40 en sus apartados 2 y 3 regula una serie de derechos de todos los niños. De este modo el artículo 40.2 dispone de un conjunto de derechos procesales como: la imposibilidad de que se declare como culpable a un niño

\footnotetext{
${ }^{595}$ Reglas mínimas de las Naciones Unidas para la administración de la justicia de menores, integradas en la Resolución 40/33 de la Asamblea General, de 29 de noviembre de 1985, por recomendación del séptimo congreso. Disponible en: https://www.unicef.org (última visita 10/04/2018)

${ }^{596}$ Disponible en http://www.ohchr.org (última visita 27/01/2018)
} 
por la comisión de delitos no tipificados en ese momento; presunción de inocencia; derecho a ser informado de los cargos que pesan sobre él; derecho a asistencia letrada; derecho a un proceso imparcial, independiente y sin demora; derecho a no prestar testimonio ni declararse culpable; asistencia gratuita de un intérprete; y, con carácter extraprocesal, respecto a su vida privada. Por su parte el apartado posterior, en la letra b, señala que "siempre que sea apropiado y deseable, la adopción de medidas para tratar a esos niños sin recurrir a procedimientos judiciales, en el entendimiento de que se respetarán plenamente los derechos humanos y las garantías legales”.

El último de los antecedentes internacionales se trata de la Recomendación $n^{\circ} \mathrm{R}$ (2003) 20, de 24 de septiembre del Consejo de Europa, sobre "Nuevas formas de tratamiento de la delincuencia juvenil y el papel de la justicia de jóvenes” ${ }^{597}$ recomienda a los Estados miembros la implantación de medidas innovadoras que permitan el desarrollo de la mediación en materia de delincuencia juvenil.

En España, las primeras experiencias en el ámbito de la mediación penal de menores se localizan en Cataluña en el año 1990 a través del Programa de mediación y reparación en el ámbito de la justicia de menores. Todo ello se desarrolló tras un gran consenso de jueces y equipos de mediación ${ }^{598}$, al amparo de la Ley de Tribunales Tutelares de Menores de 11 de junio $1948^{599}$ y basándose en las diferentes experiencias desarrolladas en el extranjero. Estas experiencias pioneras surgidas en el extranjero, empezando por las experiencias de Canadá (1975 en Kitchener, Ontario), Estados Unidos (programa Elkhart de Indiana) e Inglaterra (el programa de Leeds), los cuales fueron pioneros al ir dejando paso a la intervención penal por métodos de intervención sociocomunitaria a través de un amplio espectro de modelos basados en principios pedagógicos y con un amplio éxito, que va desde el 30\% al 90\% dependiendo de los

\footnotetext{
${ }^{597}$ Disponible en www.legislationline.org (última visita 27/01/2018)

598 DAPENA, J., MARTÍN, J., La mediación penal juvenil en Cataluña, España. Dirección General de Medidas Penales Alternativas y de Justicia Juvenil, Barcelona, 1998, pp. 12-14.. Disponible en: http://restorativejustice.org (Última visita: 09/11/2017)

599 GÍMENEZ-SALINAS I COLOMER, E., “La justicia juvenil en España: un modelo diferente”, en T. Martín López (coord.), La responsabilidad penal de los menores, Ediciones Universidad de Castilla-La Mancha, Cuenca, 2001, pp. 19-44, esp. p. 27 y ss.
} 
programas. Después analiza los métodos de mediación en países europeos, indicándonos que, en Francia, durante el año 1991, las autoridades señalaban un número de cuatro mil menores a los que se les había aplicado la medida. Diferentes programas fueron implementándose, como los programas de Reutlingen y Colonia de 1985 o el proyecto “Die Waage” desarrollado también en Colonia desde $1985^{600}$.

La promulgación de la LO 4/1992, de 5 de Julio, reguladora de la competencia y el procedimiento de los juzgados de menores, estableció dos posibilidades para los jóvenes infractores. La primera se regulaba en el artículo 15.6 e indicaba que “atendiendo a la poca gravedad de los hechos, a las condiciones o circunstancias del menor, a que no se hubiese empleado violencia o intimidación, o que el menor haya reparado o se comprometa a reparar el daño causado a la víctima, el juez, a propuesta del Fiscal, podrá dar por concluida la tramitación de todas las actuaciones”. La ley permitía una finalización del proceso si el menor reparaba durante la fase de la investigación de los hechos previo un informe del Equipo Técnico ${ }^{601}$ y Auto motivado tras Decreto Fiscal que pongan fin a las diligencias de investigación ${ }^{602}$.

La segunda eventualidad se encontraba regulada en el artículo 16.3 de la misma ley, la cual expresaba que "en atención a la naturaleza de los hechos, el Juez de Menores, de oficio o a instancia del Ministerio Fiscal o del Abogado podrá decidir la suspensión del fallo por tiempo determinado y máximo de dos años, siempre que, de común acuerdo, el menor, debidamente asistido, y los perjudicados, acepten una propuesta de reparación extrajudicial. Ello, no obstante, podrá acordarse la suspensión del fallo si los perjudicados, debidamente citados, no expresaran su oposición o ésta fuera manifiestamente infundada”. En este supuesto el juez ya ha dictado sentencia y el

\footnotetext{
600 SANCHA MATA, V., "Reparación extrajudicial del daño en el ámbito del Derecho Penal de menores”, en Cuadernos del Instituto Vasco de Criminología 2001, n 15, pp. 153 -165.

${ }^{601}$ MARTÍN-CARO, J.A., "El Fiscal y la Instrucción en el Proceso de Menores”, en Estudios Jurídicos. Ministerio Fiscal (VI), Centro de Estudios Jurídicos de la Administración de Justicia, Madrid, 1998, pp. 47-74.

602 Para más información véase VARGAS CABRERA, B., “La Ley Orgánica 4/92 sobre competencia y procedimiento de los Juzgados de Menores: estudio de sus normas sustantivas y procesales”, en Anuario de Derecho Penal y Ciencias Penales, Tomo XLVI, fascículo I, Madrid, 1993, pp. 167-197.
} 
acuerdo de reparación conlleva la suspensión del fallo del juez por acuerdo entre las partes al obtenerse una reparación del conflicto.

La entrada en vigor de la L.O. 5/2000 de 12 de enero, reguladora de la responsabilidad penal del menor ${ }^{603}$ (LORPM), fue un hito en nuestra legislación penal en el ámbito juvenil. Introduce en el sistema de justicia el principio de oportunidad y “abre las puertas” de prácticas restaurativas, utilizando el término "medidas sancionadoras-educativas" en lugar de "pena"604. Es sin embargo una norma que se caracteriza por continuas reformas de carácter agravatorio ${ }^{605}$ debido a la presión social ejercida por los continuos sucesos. La LORPM muestra en diversas ocasiones su espíritu reformista al introducir prácticas restaurativas, como por ejemplo en la Exposición de Motivos, apartado II.13, párrafo $1^{\circ}$ que nos señala: “Un interés particular revisten en el contexto de la Ley los temas de la reparación del daño causado y la conciliación del delincuente con la víctima como situaciones que, en aras del principio de intervención mínima, y con el concurso mediador del equipo técnico, pueden dar lugar a la no incoación o sobreseimiento del expediente, o a la finalización del cumplimiento de la medida impuesta, en un claro predominio, una vez más, de los criterios educativos y resocializadores sobre los de una defensa social esencialmente basada en la prevención general y que pudiera resultar contraproducente para el futuro.”.

De este modo la LORPM introduce la manifestación del principio de oportunidad al permitir al Fiscal poder desistir de la continuación del proceso por:

- Desistimiento de la incoación del expediente por corrección en el ámbito educativo y familiar (artículo $18^{606}$ ): cuando los hechos denunciados constituyan

\footnotetext{
${ }^{603}$ BOE de 13 de enero de 2000, $n^{\circ}$. 11, pp 1422-1441.

${ }^{604}$ VALL RIUS, A., "El desarrollo de la ...”, op. cit., p. 21.

605 Véase. BARQUÍN SANZ, J., CANO PAÑOS, M. A., "Justicia penal juvenil en España: una legislación a la altura de los tiempos”, en Revista de Derecho Penal y Criminología 2006, n 18, pp. 3795.

${ }^{606}$ Como bien lo ha indicado nuestra jurisprudencia, a modo de ejemplo: AP Barcelona, Secc. $3^{\text {a }}$, de 15 de mayo de 2008, donde se afirma que "son expresiones de dicho principio de oportunidad la posibilidad de que el Ministerio Fiscal acuerde no incoar el procedimiento penal de menores (art. 18 LORPM) o los
} 
delitos menos graves sin violencia o intimidación en las personas tipificados en el Código Penal o en las leyes penales especiales. Se dará traslado de lo actuado a la entidad pública de protección de menores para la aplicación de lo establecido en el artículo 3 de la presente Ley ${ }^{607}$. Asimismo, el Ministerio Fiscal comunicará a los ofendidos o perjudicados conocidos el desistimiento acordado. No obstante, cuando conste que el menor ha cometido con anterioridad otros hechos de la misma naturaleza, el Ministerio Fiscal deberá incoar el expediente y, en su caso, actuar conforme autoriza el artículo 27.4 de la presente Ley. Este artículo es un ejemplificador de la inmersión del principio de oportunidad dentro de nuestro sistema legal, lo que ha supuesto multitud de críticas, sobre todo por estar introducido dentro de la corrección en el ámbito educativo o familiar ${ }^{608}$. Está limitado a delitos leves, pues en conductas delictivas de mayor trascendencia existe una presión social ante situaciones de impunidad requiriendo una respuesta penal del Estado y por consiguiente una responsabilidad del menor sobre sus $\operatorname{actos}^{609}$, y en los que no haya existido violencia o intimidación sobre las personas o las cosas, explícitamente exigida

supuestos de desistimiento por corrección en el ámbito educativo y familiar o por resarcimiento anticipado o conciliación con el infractor (art. 19 LORPM)"FJ 2.

${ }^{607}$ El artículo trata sobre el régimen de los menores de 14 años indicando: "Cuando el autor de los hechos mencionados en los artículos anteriores sea menor de catorce años, no se le exigirá responsabilidad con arreglo a la presente Ley, sino que se le aplicará lo dispuesto en las normas sobre protección de menores previstas en el Código Civil y demás disposiciones vigentes. El Ministerio Fiscal deberá remitir a la entidad pública de protección de menores testimonio de los particulares que considere precisos respecto al menor, a fin de valorar su situación, y dicha entidad habrá de promover las medidas de protección adecuadas a las circunstancias de aquél conforme a lo dispuesto en la Ley Orgánica 1/1996, de 15 de enero".

${ }^{608}$ ORNOSA FERNÁNDEZ, M.R., Derecho penal de menores: comentarios a la Ley Orgánica 5/2000, de 12 de enero, reguladora de la responsabilidad penal de los menores, reformada por la Ley Orgánica 8/2006, de 4 de diciembre y a su Reglamento, aprobado por el Real Decreto 1774/2004, de 30 de julio, Bosch, Barcelona, 2003. El autor critica esta figura indicándonos que "pueden ser un arma de doble filo para el menor, porque a veces esa sanción o corrección puede ser más grave que la que le podía corresponder a través del procedimiento, en el que incluso podía haber sido absuelto. Pero, lo que en realidad preocupa es que si el menor pertenece a una familia con problemas, de las llamadas desestructuradas, o bien no está escolarizado, no se va a poder beneficiar de esta posibilidad, con lo que el principio de igualdad resultaría afectado puesto que se criminalizaría la desigualdad social", (p.251).

${ }^{609}$ LÓPEZ LÓPEZ, A.M., Ley Orgánica reguladora de la responsabilidad penal de los menores (Comentarios, concordancias y jurisprudencia), Comares, Granada, 2004, p. 158. 
por el tipo penal o no ${ }^{610}$. Si el menor ha cometido otros hechos de la misma o diferente naturaleza pero en los que exista violencia o intimidación, el menor no podrá beneficiarse de este beneficio.

- Sobreseimiento del expediente por conciliación o reparación entre el menor y la víctima (artículo 19): el Ministerio Fiscal podrá desistir de la continuación del expediente, atendiendo a la gravedad y circunstancias de los hechos y del menor, de modo particular a la falta de violencia o intimidación graves en la comisión de los hechos, y a la circunstancia de que además el menor se haya conciliado con la víctima; o haya asumido el compromiso de reparar el daño causado a la víctima o al perjudicado por el delito; o se haya comprometido a cumplir la actividad educativa propuesta por el equipo técnico en su informe. El desistimiento en la continuación del expediente sólo será posible cuando el hecho imputado al menor constituya delito menos grave o falta.

El artículo 19.2 establece una doble vía para llegar a consenso a través de la conciliación o la reparación ${ }^{611}$. Diferenciadas ambas en que la primera es un acto simbólico mientras que la segunda es un acto de reparación, siendo para diversos autores un error de redacción al considerarse sólo debería existir una vía y no $\operatorname{dos}^{612}$ ya que siempre ha de existir una disculpa ${ }^{613}$. Aunque la disculpa y la reparación parecen ser no obligatorias según se nos indica desde el artículo 19.4 al señalar que el Ministerio Fiscal concluirá la instrucción y solicitará del Juez el sobreseimiento y archivo de las actuaciones cuando "una u otros no pudieran llevarse a efecto por causas ajenas a la

\footnotetext{
${ }^{610}$ VARELA GÓMEZ, B.J. "Mecanismos alternativos de solución en procedimientos de menores: una opción de futuro", en en R. Castillejo Manzanares (dir.) y C. Torrado Tarrío (coord.), La mediación: nuevas ..., op. cit., pp. 355-396, esp. p. 365.

En contra de esta opinión al considerar que no es relevante la violencia o la intimidación si no son recogidos del tipo, DOLZ LAGO, M.J., "El principio de oportunidad del Fiscal, las soluciones extrajudiciales, el sistema de recursos, la regulación legal de la ejecución de las medidas”, en Estudios jurídicos 2000, Ministerio Fiscal, nº 6, pp. 487-536, esp. p. 491.

${ }^{611}$ FRANCÉS LECUMBERRI, P., "El principio de oportunidad y la justicia restaurativa”, en InDret, Revista para el Análisis del Derecho 2012, nº 4, pp. 1-43, esp. pp. 16-17.

${ }^{612}$ CUCARELLA GALIANA, L. A., "Justicia restaurativa y menores infractores de la ley penal", en P.M. Garciandía González, y H. Soleto Muñoz (dirs), Sobre la Mediación ... op. cit., pp. 547-570, esp. p. 565.

${ }^{613}$ CRUZ MÁRQUEZ, B., "La mediación en la LO 5/2000, reguladora de la responsabilidad penal de los menores: conciliación y reparación del daño", en Revista Electrónica de Ciencia Penal y Criminología 2005, nº 7, p. 4. Disponible en: http://criminet.ugr.es (Última visita: 09/11/2017)
} 
voluntad del menor", dando a entender que tiene un mayor valor el intentar reparar que el resultado de la reparación ${ }^{614}$.

Junto al principio de oportunidad rige el principio de legalidad. Sólo se podrá incoar un procedimiento de mediación cuando el menor haya cometido delitos leves, algo que ha conllevado a multitud de críticas de la doctrina ${ }^{615}$. Han de ser delitos leves y la infracción, a diferencia de lo que ocurre con el artículo 18, puede resultar de la existencia de violencia o intimidación sobre las personas o los bienes, e incluso puede realizarse por menores reincidentes ${ }^{616}$. Ha llegado a ser aceptada en los casos de "acoso escolar" debido a que se entiende que puede tener importancia en los casos de acoso leve o inicial; pero, como indica FERREIROS MARCOS, “no será adecuada cuando el acosador no tiene el menor interés en cesar en sus actos o cuando la víctima ha llegado a una situación de pánico que le inhabilita para tomar parte en el proceso”617. El autor incluso da la misma solución en casos de violencia de género en menores al considerar que "la norma del artículo 19 es la directamente aplicable al ámbito de la justicia de menores puesto que el artículo 87ter de la LOPJ se limita a regular la competencia de los Juzgados de Violencia sobre la mujer" ${ }^{618}$.

\footnotetext{
${ }^{614}$ La SAP Barcelona, Secc. $3^{\text {a }}$, de 15 de mayo de 2008, FJ 3, Disponible en www.poderjudicial.es, sigue este criterio al archivar el caso debido a la actitud positiva del menor y su intención de reparación a pesar de que la víctima se negaba a someterse a mediación. Un error desde nuestro parecer puesto que no se tiene en cuanta la voluntad de la víctima de no acudir a un proceso de mediación, y como bien dice FERNÁNDEZ CARRÓN, estaríamos ante una vulneración del principio de voluntariedad al aplicarse los efectos de una mediación a una víctima que no ha querido acudir al proceso, no teniéndosele en cuenta en el proceso y volviéndose a olvidar de ella. FERNÁNDEZ CARRÓN, C., "Algunas cuestiones controvertidas en torno al desistimiento del ejercicio de la acción penal y el sobreseimiento del proceso por acuerdos a resultas de la mediación entre el menor y la víctima”, en P.M. Garciandía González, y H. Soleto Muñoz (dirs) Sobre la mediación penal ... op. cit., pp. 665-680, esp. pp. 677-678.

${ }^{615}$ COBOS GÓMEZ DE LINARES, M. A., "La mediación en la ley orgánica reguladora de la responsabilidad penal de los menores, y su reglamento”, en M. Martínez Escamilla y M.P. Sánchez Álvarez (coords.) Justicia restaurativa, mediación penal... op. cit., pp. 309-339, esp. p. 337; TAMARIT SUMALLA, J. M., "La justicia reparadora en el sistema penal de menores", en E. Sola Reche et.al (dirs.)., Derecho penal y psicología del menor, Comares, Granada, 2007, pp. 137-168, esp. p. 139.

${ }^{616}$ CRUZ MÁRQUEZ, B., "La mediación en la Ley ...” op. cit., pp. 14 y ss.

${ }^{617}$ FERREIRAS MARCOS, C.E., SIRVENT BOTELLA, A., SIMONS VALLEJO, R., y AMANTE

GARCÍA, C., La mediación en el Derecho Penal de menores, Dykinson, Madrid, 2011, p. 183.

${ }^{618}$ Idem. pp. 182-183.
} 
Respecto a las garantías existentes en el ámbito de justicia de menores en su aplicación nos referimos a las siguientes: la garantía criminal o de legalidad, es decir, que sólo se puede condenar a un menor que haya cometido actuaciones tipificadas como infracciones en la ley penal; la garantía procesal por la cual se ha de proseguir el procedimiento establecido en la ley; la garantía penal por la cual sólo se puede condenar al menor conforme a la ley penal y; garantía de ejecución por la cual sólo se pueden ejecutar las sentencias por el procedimiento establecido en la ley.

La mediación, tal y como expone la LORPM en su artículo 19.3, es un método eficaz para la obtención de la conciliación y la reparación ya que el “correspondiente equipo técnico realizará las funciones de mediación entre el menor y la víctima o perjudicado, a los efectos indicados en los apartados anteriores, e informará al Ministerio Fiscal de los compromisos adquiridos y de su grado de cumplimiento".

Las actuaciones del Equipo Técnico vienen desarrolladas en los artículos 4 y 5 del RD 1.774/2004, de 15 de julio, por el que se aprueba el Reglamento de desarrollo de la LORPM (en adelante RRPM). Estarán compuestos por diferentes profesionales como psicólogos, educadores y trabajadores sociales cuya función es asistir técnicamente a los jueces de menores y al Ministerio Fiscal en las materias propias de sus disciplinas, a través de la elaboración de los informes, efectuando propuestas, y prestando asistencia profesional al menor desde el momento de su detención. También realizarán las funciones de mediación entre el menor y la víctima o perjudicado. Estos equipos técnicos podrán incorporar de modo temporal o permanente a otros profesionales cuando así se requiera, siendo este apartado primordial para la incorporación de personal cualificado en mediación.

El procedimiento de mediación se incoa por el Ministerio Fiscal, ya sea de oficio o a instancia del Equipo Técnico ${ }^{619}$, aunque también puede iniciarse a instancia del

\footnotetext{
619 Como indica Circular 1/2000, de 18 de diciembre, relativa a los criterios de aplicación de la Ley Orgánica 5/2000, de 12 de enero, por la que se regula la responsabilidad penal de los menores, (apartado VI.3.E), el informe del equipo técnico es una herramienta imprescindible para el Fiscal, de manera que:
} 
letrado del menor ${ }^{620}$. Es en este punto donde creemos conveniente modificación para acoger también al letrado de la víctima en virtud del principio de igualdad procesal aun sin ser parte la víctima en el proceso.

En cuanto al desarrollo del procedimiento, el Equipo Técnico recibirá la solicitud y citará al menor, a sus representantes legales y a su letrado. Se le expondrá la posibilidad de la solución del conflicto a través del proceso de mediación y se dará audiencia a sus representantes legales. El menor deberá de decidir si acepta o no la solicitud y si consiente acudir a un acto restaurativo se recabará la conformidad de sus representantes. Este punto es importante pues se está dando voz al menor para que decida si desea o no acudir a un método no judicial para la resolución del conflicto. Pero si el menor o sus representantes no quisiesen acudir a la solución restaurativa, el Equipo Técnico se lo deberá de comunicar al Fiscal y elaborará un informe.

Posteriormente, y en caso de que la respuesta del menor y sus representantes sea positiva, el Equipo Técnico contactará con la víctima para que muestre su conformidad o disconformidad con su posible participación en un acto de mediación. Su participación podrá ser directa o indirecta, permitiéndose por tanto ambas modalidades en aras del beneficio del menor. En caso de que la víctima sea menor de edad o incapaz, este consentimiento deberá ser confirmado por sus representantes legales y a su vez ser puesto en conocimiento del juez de menores competente. Hemos de recordar que, aunque en la redacción original de la ley no pudiese sucederse, desde la LO 15/2003, de

\footnotetext{
“...el ejercicio por el Fiscal de sus facultades discrecionales queda en gran medida condicionado, aunque no vinculado, por el trabajo del Equipo Técnico, pues gran parte del contenido reglado de sus decisiones favorables al sobreseimiento y archivo debe remitir su razón a la expresada en las propuestas del Equipo". Disponible en https://www.fiscal.es (última visita 28/01/2018)

${ }^{620}$ Artículo 5.1.a) RRPM: "Si el Ministerio Fiscal, a la vista de las circunstancias concurrentes o a instancia del letrado del menor, apreciara la posibilidad de desistir de la continuación del expediente, solicitará del equipo técnico informe sobre la conveniencia de adoptar la solución extrajudicial más adecuada al interés del menor y al de la víctima”.
} 
25 de noviembre, es factible el supuesto de una acusación particular, siendo indispensable su participación en el proceso para que pueda sobreseerse a la causa ${ }^{621}$.

El equipo técnico, en la conjetura de imposibilidad de realización de la mediación, propondrá al menor la realización de tareas socioeducativas o la prestación de servicios en beneficio de la comunidad. Deberá comunicar al Fiscal el resultado del proceso, el acuerdo alcanzado y su cumplimiento para que el Fiscal pueda solicitar al juez el sobreseimiento y archivo de la causa. Si el menor no cumpliese la reparación o la actividad educativa acordada, el Fiscal ha de continuar con la tramitación del expediente.

El legislador ha sido cauto al examinar la reparación, indicando que su contenido serán “determinadas acciones” en favor de la víctima. Debemos entender que estamos ante una mediación penal que busca resolver el conflicto pero con un componente educativo. Lo más considerable es que el menor aprenda el hecho negativo que ha cometido, analice sus efectos y no vuelva a repetirlo.

\subsubsection{Violencia de género y su ¿imposibilidad?}

La violencia de género ${ }^{622}$ es una lacra existente en nuestra sociedad anclada en ideales de superioridad del hombre sobre la mujer. Es una problemática a nivel

\footnotetext{
${ }^{621}$ Para más información relativa a la materia, véase. CANO PAÑOS, M. A., "La acusación particular en el proceso penal de menores. ¿La represión como alternativa?”, en Revista del poder judicial 2004, nº 76, pp. 283-319.

${ }^{622}$ La violencia de género es "aquella que sufren las mujeres por el hecho de serlo, y que se debe a la posición de inferioridad a la que han sido relegadas históricamente". En esta línea DELGADO ÁLVAREZ, C., 161 respuestas sobre la violencia de género, Globalia Artes Gráficas, Salamanca, 2008, p. 31. Para que exista violencia de género la violencia debe de ser ejercida por razón de género. Así la STS 1177/2009 de 24 de noviembre, disponible en http://www.poderjudicial.es, en su FJ 3 afirma: "Si, como hemos establecido líneas atrás, la aplicación del art. 153 requiere no sólo la existencia de una lesión leve a la mujer por parte del compañero masculino, sino también que esta acción se produzca en el seno de una relación de sumisión, dominación y sometimiento a la mujer por parte del hombre, esto es, de una discriminación de todo punto inadmisible, habrá de ser el Tribunal sentenciador el que, a la vista de las pruebas practicadas a su presencia, oyendo con inmediación y contradicción al denunciante y denunciador y los testimonios de otros posibles testigos, el que establezca el contexto en el que tuvieron lugar los hechos, analizando los componentes sociológicos y caracteriológicos concurrentes a fin de establecer, mediante la valoración razonada de los elementos probatorios si le hecho imputado es
} 
global $^{623}$, basado en la falta de educación y cultura de muchos individuos que consideran a la mujer inferior "únicamente por el mero hecho de serlo"624.

El artículo 44.5 de la debatida ${ }^{625}$ Ley Orgánica 1/2004, de 29 de diciembre sobre Medidas de Protección integral contra la violencia de género, enumera los supuestos de competencia de los Juzgados de Violencia sobre la Mujer en el orden penal y en el civil, advirtiendo que está vedada la mediación en los casos de violencia de género. Una negativa que ha generado debate en la doctrina sobre la posibilidad o no de práctica de mediación, llegando a ser tildada la posición favorable al desarrollo de estas prácticas como "postmachismo latente",626.

La finalidad de esta prohibición es no permitir un encuentro cara a cara entre víctima e infractor por razones de una posible desigualdad debido al desequilibro emocional, el cual dejaría a la víctima en una situación de inferioridad durante el proceso $^{627}$. El legislador ha querido proteger a la víctima, sobreprotegerla diríamos, sin

manifestación de la discriminación desigualdad y relaciones de poder del hombre sobre la mujer, y obedece a otros motivos o impulsos diferentes".

${ }^{623}$ Se estima que un 35 por ciento de las mujeres han sufrido violencia física y/o sexual en el contexto de relaciones de pareja o violencia sexual fuera de relaciones de pareja. Pero hay otros estudios que elevan hasta un 70 por ciento de mujeres sufre violencia física y/o sexual a lo largo de su vida. Organización Mundial de la Salud, Global and Regional Estimates of Violence against Women, p. 2

${ }^{624}$ DEL POZO PÉREZ, M., “¿Es adecuada la prohibición de mediación del art.22.5 de la Ley Orgánica 1/2004?”, en F. Martin Diz (coord.), La mediación en ..., op. cit., pp. 283-324, esp. p. 284

${ }^{625}$ A modo de ejemplo PRIETO MORALEDA, T., "Violencia contra la mujer, mediación y justicia restaurativa”, en el blog, ¿Hay Derecho?, 6 de junio de 2015. Disponible en: http://hayderecho.com (Última visita: 09/11/2017). El autor indica lo siguiente: "Respecto a esta Ley, y con carácter previo, un vistazo a las estadísticas de mujeres víctimas a manos de su pareja, publicadas en el Observatorio contra la Violencia Doméstica y de Género del CGPJ nos permiten concluir que ha fracasado en sus objetivos. No ha hecho disminuir este tipo de violencia y ha dado pie a la potencial criminalización de una gran parte de la población por el solo hecho de pertenecer al género masculino. Es una Ley discriminatoria por sexo que establece una práctica presunción de culpabilidad contra el hombre desde el momento en que es denunciado. Es el imputado el que ha de probar su inocencia, con una inversión de la carga prueba que supone una auténtica quiebra del Estado de Derecho. Favorece la proliferación de denuncias falsas por parte de algunas mujeres en busca de privilegios en los procesos de divorcio. Atribuir un tipo de violencia específica a un género determinado es tan erróneo como querer explicarla a través de los genes".

${ }^{626}$ FUENTES SORIANO, O., "Sobre la mediación penal y su prohibición en violencia de género”, en J. Sigüenza López y G. García-Rostán Calvín (dirs.) Estudios sobre mediación ... op. cit., pp. 239-279, esp. p. 275

${ }^{627}$ ESQUINAS VALVERDE, P., La mediación entre víctima y agresor en la violencia de género, Tirant lo Blanch, Valencia, 2009, pp. 59-63. 
tener en cuenta sus posibles necesidades. Esta sobreprotección la conduce a un distanciamiento con el proceso, quedando aislada y sin conocimiento alguno de los que sucede. Aspecto modificado gracias al ya comentado Estatuto de la Víctima y su priorización por el conocimiento de la causa por parte de la víctima.

La violencia de género no está desapareciendo a pesar de las medidas adoptadas desde las Administraciones públicas. Se obvia a las víctimas y no se adoptan medidas en su favor, disposiciones en aras a apoyarlas y ayudarlas a superar el problema. Se ha optado en su mayoría por la represión al infractor como única respuesta ${ }^{628}$.

Está claro que la violencia de género supone una clara desigualdad entre ambas partes $^{629}$. La coacción ejercida por el maltratador contra la víctima disminuye su poder de decisión así como condiciona su actuación en este tipo de procesos. Consideramos acertada en parte la prohibición de mediación en la violencia de género, pues la falta de igualdad entre víctima y maltratados es evidente. Pero del mismo modo no se han de valorar al mismo nivel todo tipo de actuaciones. En aquellos casos de actos leves esporádicos $^{630}$ es comprensible una mayor vacilación a nuestra postura inicial. Es la víctima quien deberá decidir acudir o no al acto de mediación, puesto que puede mantener todavía una posición de igualdad ante el maltratador, pudiendo optar incluso por participar únicamente en sesiones individuales o a través de representante mediación indirecta - para así evitar la posible manipulación que puede ejercer sobre

628 "El Tribunal Constitucional avala aumentar las penas a los hombres en los casos de violencia de género" El Correo, 14 de marzo de 2008. "La respuesta del TC, contribuirá a desactivar la respuesta organizada por parte de algunos sectores de la sociedad deseosos de impedir la consolidación de los derechos reconocidos a las mujeres y el impulso de la respuesta coordinada y cada vez más eficaz para hacer realidad una vida libre de violencia contra las mujeres". Disponible en: http://www.elcorreo.com (Última visita: 09/11/2017)

${ }^{629}$ En relación a cómo la posición de superioridad injustificada del hombre sobre la mujer histórica afecta en la actualidad a la víctima de violencia de género véase FUENTES SORIANO, O., "La constitucionalidad de la Ley Orgánica de medidas de protección integral contra la violencia de género", en Diario La Ley 2005, nº 6362, Disponible en: www.diariolaley.es (Última visita: 13/03/2018).

${ }^{630}$ También denominada como violencia circunstancial al aparecer en conflictos puntuales. Véase sobre esta materia a LAURENZO COPELLO, P., "La violencia de género en el Derecho Penal: un ejemplo de paternalismo punitivo", en P. Laurenzo Copello, M.L. Maqueda Abrue, A. Rubio Castro (dirs.), Género, violencia y derecho, Tirant Lo Blanch, Valencia, 2008, pp. 329-362; En la misma línea ACALE SÁNCHEZ, M., La discriminación hacia la mujer por razón de género en el Código Penal, Reus Madrid 2006, pp. 204 y ss. 
ella el maltratador ${ }^{631}$. En este tipo de casos en los que no existe una espiral de violencia al ser sucesos esporádicos, puede ser recomendable un acto de mediación como método para la solución del conflicto ${ }^{632}$.

Las prácticas restaurativas son útiles para conocer la situación de la víctima, cuáles son sus sentimientos, sanar sus heridas, analizar el origen del problema y poder incluso tener opciones de resocializar a los infractores. Así podremos examinar cuál es la verdadera y necesaria demanda de las víctimas, su opinión sobre cómo resolver el conflicto y si hay posibilidades o no de ello, siendo beneficiosa para la víctima, agresor y la sociedad ${ }^{633}$. Es más, en algunos países de nuestro entorno donde el abierto debate de mediación en violencia de género ha generado aún más diferentes opiniones y prácticas, se ha considerado que al nacer el conflicto dentro del ámbito familiar, la mediación puede resultar más exitosa que el sistema retributivo clásico ${ }^{634}$, siendo no sólo viable sino eficaz en la resolución de conflictos personales existentes ${ }^{635}$. Tal y como señala CASTILLEJO MANZANARES, este tipo de instituciones restaurativas están enfocadas en que "el delincuente no vuelva a repetir estos actos con ellas, sus hijos u otras futuras víctimas, la resocialización del autor, junto con la recuperación de la víctima, tienen que convertirse en los fines principales del proceso penal futuro, por encima de un castigo en forma de pena" 636.

${ }^{631}$ CUADRADO SALINAS, C., “La mediación: ¿Una alternativa real al proceso penal?”, en Revisa Electrónica de Ciencia Penal y criminología, 2015, nº 17, pp. 1-25, esp. p. 15.

${ }^{632}$ MATEFI, G., “Mediation bei häuslicher Gewalt?”, en Revista Die Praxis des Familienrechts 2003, nº 2, pp. 260 y ss.

${ }^{633}$ OUBIÑA BARBOLLA, S. "La distancia que les separa, la distancia que nos separa: mediación en casos de violencia doméstica en España y en otros sistemas” en P.M. Garciandía González y H. Soleto Muñoz (dirs) Sobre la mediación penal ..., op. cit., pp. 179-209, esp. p. 200.

${ }^{634}$ RIOS, J.C.; PASCUAL, E; BIBIANO, A y SEGOVIA, J.L., La mediación penal y penitenciaria... op. cit., p.107

${ }^{635}$ LOBO GUERRA, M., y SAMPER LIZARDI, F., “¿Es posible la mediación en aquellos casos en los que ha existido violencia de género?”, en P.M. Garciandía González y H. Soleto Muñoz (dirs), Sobre la mediación penal ... op. cit., pp. 163-178, esp. pp. 163-165.

${ }^{636}$ CASTILLEJO MANZANARES, R., "Hipótesis de partida acerca de la posibilidad de mediación en supuestos de violencia de género”, en Diario la Ley 2016, $\mathrm{n}^{\circ}$ 8882. Disponible en: www.diariolaley.es (última visita 19/04/2018) 
En contraposición, cuando suceden casos de violencia continuada durante el tiempo y de una fuerte dominación del hombre frente a la mujer, está más que justificada una prohibición de acudir a un acto de mediación debido al peligro que supondría para la víctima el iniciar este tipo de procesos frente al sujeto que la maltrató $^{637}$. Incoar un procedimiento de mediación en este último caso supondría una situación de desigualdad en la que la víctima se vería inferior frente al maltratador, el cual obtendría un acuerdo beneficioso para él e injusto para la víctima.

La mediación es una posibilidad que se va a otorgar a las víctimas, una posibilidad que puede ser beneficiosa para evitar que dichos actos vayan a más y que ha de efectuarse cuando éstos actos se empiezan a producir y no cuando ya hay un maltrato continuado, o como indica MARTIN DIZ, en agresiones de escasa intensidad ${ }^{638}$. Se ha de posibilitar en este tipo de supuestos una resolución ágil del conflicto, un remedio que pueda satisfacer a la víctima más que la sentencia proporcionada por jueces y tribunales, una opción de obtener una justicia dialogada y centrada en los sentimientos y el origen del problema, no sólo en el acto delictivo.

Como acertadamente indica EIRAS, “lo que habría que constatar es que se den las condiciones para que su uso coadyude a la solución pacífica del conflicto, pasando a ser uno de los instrumentos de intervención posibles, tanto o a igual nivel que la terapia o la implantación de alguna medida coactiva por parte de la autoridad judicial. Eso dependerá de las partes en conflicto, previa determinación de los niveles de riesgo" 639 .

\footnotetext{
${ }^{637}$ La violencia de género crea en la víctima, según Golding, trastorno de estrés postraumático. Más ampliamente véase GOLDING, J.M., "Intimate Partner Violence as a Risk Factor for Mental Disorders: A Meta-Analysis”, en Journal of Family Violence 1999, Vol. 14, n² 2, pp 99-132. Además a parte del Trastorno de Estrés Postraumático, la violencia ejercida por el maltratador crea en la víctima otros trastornos como ansiedad, depresión o sentimientos de culpabilidad. Vid. ECHEBURÚA, E., CORRAL, P., Manual de Violencia Familiar, Siglo XXI, Madrid, 1998, pp. 11 y ss.

${ }^{638}$ MARTíN DIZ, F., "Mediación en materia de violencia de género. Análisis y argumentos", en M. de Hoyos Sancho (coord.), Tutela jurisdiccional frente a la violencia de género. Aspectos procesales, civiles, penales y laborales, ed. Lex Nova, Valladolid, 2009, pp. 669-688, esp. p. 687.

${ }^{639}$ EIRAS NORDENSTAHL, U.C., La mediación penal. De la teoría a la práctica, Librería-Editorial Histórica Emilio J. Perrot, Buenos Aires, 2005, pp. 103.
} 
SAINZ RODRÍGUEZ sigue esta misma línea de pensamiento al afirmar que "parece razonable sostener que la fórmula más acertada para la reparación integral de las víctimas de los delitos —incluidas las de violencia de género- no consiste, pues, en eliminar o restringir su apreciación como circunstancia atenuante de la responsabilidad del infractor, sino en establecer herramientas que permitan acceder al conocimiento de las auténticas necesidades reparatorias de las víctimas y restablecerlas en su derecho por la vía más rápida y eficaz. Y no cabe duda de que esto se pude producir (...) a consecuencia de un proceso de mediación penal” ${ }^{\prime 40}$.

La mediación, o mejor dicho, cualquier práctica restaurativa, puede ser un buen instrumento para combatir la violencia de género ${ }^{641}$ a través de dos líneas de actuación. La primera consiste en reforzar a la víctima y otorgarla el respeto, dignidad y posición que se merece, siendo informada y escuchada en todo momento, recibiendo un apoyo psicológico especializado que le permita superar esta situación ${ }^{642}$; la segunda es a través de la resocialización del infractor, el cual puede observar el daño que ha provocado y se puede indagar el porqué de su conducta, pudiéndosele educar y hacerle ver lo erróneo de su pensamiento.

$\mathrm{Y}$ a pesar de que nuestro ordenamiento a fecha de hoy no permita la utilización de la mediación, no está vetando la posible desarrollar de otra práctica restaurativa ${ }^{643}$

\footnotetext{
${ }^{640}$ SÁEZ RODRÍGUEZ, C., "La estrategia penal contra la violencia de género en su complicado encaje con la mediación penal”, en M. Martínez Escamilla y M.P. Sánchez Álvarez, (coords.), Justicia restaurativa, mediación penal ..., op. cit., pp. 211-272, esp. p. 269.

${ }^{641}$ En palabras de dijo la Ilma. Fiscal Delegada de Violencia de Genero María Boado Olabarrieta, "no nos podemos posicionar en contra de algo que mejore nuestro sistema de justicia tradicional". Conclusiones del I Congreso Internacional sobre Justicia Restaurativa y Mediación Penal: dimensiones teóricas y repercusiones prácticas. Celebrado en Burgos el 4 y 5 de marzo de 2010, Universidad de Burgos, p. 16. Disponible en: www.justiciarestaurativa.org (última visita 29/01/2018)

${ }^{642}$ DELGADO ÁLVAREZ, C., 161 respuestas sobre la ... op. cit., p.55. La autora indica una serie de beneficios que tiene el apoyo psicológico para las víctimas de violencia de género, la cual se sentirá: (a) cómoda y segura en la sesión; (b) escuchada y comprendida; (c) en cuenta en sus necesidades y sentimientos; (d) percibirá retroalimentación por parte de la terapeuta; (e) protegida en caso de riesgo; (f) sentirá un trato igualitario y no paternalista; (g) no culpable del maltrato; (h) con la ayuda suficiente para encontrar estrategias para salir de la situación, y; (i) segura para reconocer los puntos fuertes que hay en ella.

${ }^{643}$ En esta misma línea, diferentes afirmaciones señalan la práctica no sólo de procesos restaurativos sino incluso de la mediación ante la imposibilidad de prohibición de materias no reguladas. En este línea
} 
que ayude a la solución del problema ya que en la Ley "lo único que se excluye es la mediación, pudiendo ser utilizados otros instrumentos de carácter restaurativo" ${ }^{\text {,44 }}$. No hay que olvidar que es la educación el modo primordial para acabar con este tipo de violencia, una educación que ha de iniciar en edades tempranas si queremos poner fin a estos actos de violencia ${ }^{645}$.

Aunque la mediación pueda ser un instrumento complejo en cuanto a su utilización en casos de violencia de género, y el cual sin duda crea recelo debido a la improbable restitución de la comunicación entre ambas partes y la dificultad de conseguir un proceso libre y voluntario ${ }^{646}$, no hemos de olvidar de otras posibilidades. La Justicia Restaurativa contempla más vías para la consecución de sus objetivos, y aún otras figuras otorgan un mayor empoderamiento a la víctima, una mayor protección, y un sistema más eficaz a la hora de conseguir la sanación de la víctima y la resocialización del infractor. En los temas siguientes veremos como los círculos o las conferencias pueden ser una buena opción para la consecución de tales objetivos propuestos en el análisis de la Justicia Restaurativa y a los que en su momento hicimos oportuna referencia.

SÁEZ RODRIGUEZ, La mediación familiar... op. cit., "es significativo que se prohíba lo que ni siquiera está previsto en la ley. Es posible que el legislador estuviera pensando en la mediación civil toda vez que dicha prohibición recae en un artículo referido al proceso civil”, p. 324

${ }^{644}$ TAPIA BALLESTEROS, P., "La Justicia Restaurativa en España. Régimen legal vigente y perspectivas de futuro", Conferencia impartida en el IV Congreso de Justicia Restaurativa y Mediación Penal: del desiderátum a la realidad práctica, Burgos, 17 y 18 de Marzo de 2016.

${ }^{645}$ En Burgos nos encontramos con el programa 'Caminando hacia la Igualdad', desarrollado en el Colegio Círculo de la capital burgalesa, dentro del proyecto educativo de "La Caixa Violencia: Tolerancia Cero". Para Chelo Quintana, directora de Educación Primaria del centro, "la semilla de la violencia se siembra en los primeros años de vida, se cultiva y desarrolla durante la infancia y comienza a dar sus frutos malignos durante la adolescencia». Esa semilla llega a través de la repetida exposición a la violencia, al sexismo, a los malos tratos o a la explotación que aparece en los medios de comunicación y en algunos programas de la televisión y en las situaciones que ven en su familia, [...] esa habituación hace que consideren todas esas cosas como normales. [...] Los principales instrumentos para erradicar la violencia de género son la educación y la prevención. Una educación que lamentablemente sólo se destina a los niños y a los profesores y no "al conjunto de la sociedad". Disponible en: http://www.elcorreodeburgos.com (Última visita: 09/11/2017)

${ }^{646}$ MARTÍN DIZ, F., “Mediación en materia ...”, op. Cit., p. 687; MARTín DIZ, F., La mediación: sistema ..., op. cit., p. 397. 
Cabe finalizar con las acertadas conclusiones que realizan a nuestro juicio CASTILLEJO MANZANARES, TORRADO TARRIO y ALONSO SALGADO sobre la mediación y la violencia de género: “En cualquier caso, admitir la mediación en supuestos de violencia de género, debe implicar necesariamente asumir una serie de precauciones como son: la absoluta necesidad de que las y los mediador es se especialicen en este campo y estén sometidos permanentemente a un continuo reciclaje de conocimientos, prácticas, etc.; la garantía de total seguridad para la víctima, tanto mientras dure el proceso mediador, como con carácter posterior al mismo; y la aceptación preceptiva por parte de la víctima de someterse, con carácter previo a la mediación, a un proceso de empoderamiento, quedando por tanto condicionada su participación, no sólo a su consentimiento personal, sino también al informe positivo del profesional de la psicología que evalúe su estado ${ }^{647 " .}$.

\subsubsection{Mediación policial: ¿una opción desaprovechada?}

Como veremos a continuación, son las instituciones de las conferencias y los círculos las que han conseguido la introducción de los miembros de las fuerzas y cuerpos de seguridad del Estado en los procesos restaurativos, otorgándoles diferentes roles fundamentales en el desarrollo de las actuaciones, como el puesto de facilitador, de testigo, de ayudante, etc.

Ello no impide la existencia de dispares prácticas policiales ${ }^{648}$ de carácter extraprocesal enfocadas en la resolución de determinados problemas de convivencia. Su papel versa en la aclaración y mejora de las relaciones vecinales. Estos conflictos resueltos a través de la mediación policial son de muy variada índole, tales como

647 CASTILlEJO MANZANARES, R., TORRADO TARRÍO, C., y ALONSO SALGADO, C., “Mediación en violencia de género”, en Revista de Mediación 2011, n 7, pp. 38-45, esp. p. 44.

${ }^{648}$ A modo de ejemplo para un conocimiento de las exitosas prácticas efectuadas en el Valle del Támesis véase HOYLE, C., "Restorative justice policing in Thames Valley”, en Journal of Police Studies 2009, Vol. 11, n 2, pp. 189-213.; HOYLE, C., YOUNG, R., y HILL, R., Proceed with caution: An evaluation of the Thames Valley Police initiative in restorative cautioning, Joseph Rowntree Foundation, York, 2002 
problemas de convivencia vecinal, molestias por ruidos, malos olores, salubridad, uso de espacio público, etc. ${ }^{649}$

La existencia de numerosos estudios y prácticas respecto a tales prácticas de mediación policial ${ }^{650}$ nos conduce a una referencia de la institución en nuestro tema de estudio, aun cuando la inexistencia de delictividad en las actuaciones objeto aquí de resolución no nos llevaría a ello. Su inclusión como proceso restaurativo es obvia al resolver los conflictos a través de las variantes que nos ofrece la Justicia Restaurativa, pero, al ser actos de tan ínfima o incluso nula gravedad, ¿no es esto una excesiva limitación para las posibilidades existentes?

Es significativa la intervención de los policías en procesos restaurativos en otros países y modelos ya que, aunque muchos ciudadanos los puedan prejuzgar como aspecto negativo, son una pieza fundamental para garantizar la justicia y la paz social. La función de los cuerpos de fuerza y seguridad del Estado no ha de versar exclusivamente en la detención de los delincuentes. Han de auxiliar a la implementación pacífica de métodos restaurativos enfocados en la resocialización y reparación de los miembros del colectivo.

Es por ello que la mediación policial se ha de incluir dentro de los sistemas restaurativos como una ulterior alternativa para el cumplimiento de los fines de la Justicia Restaurativa. La inserción ha de realizarse en aras de una entrega a los "gendarmes" de un cometido fundamental en la pacificación social.

\footnotetext{
${ }^{649}$ BERLANGA, A., "La mediación policial”, en V. Cervelló Donderis (Dir.), Cuestiones prácticas para la ... op, cit., pp. 411-434, esp. pp. 417-420.

${ }^{650}$ Más ampliamente, vid. BUERGUER, M.E., PETROSINO, A.J., y PETROSINO, C., "Extending the police role: implications of Police Mediation as a problem- solving tool”, en Police Quarterly 2000, vol 2, $\mathrm{n}^{\circ}$ 2, pp. 125-149; GOLDSTEIN, H., Problem-oriented policing, McGraw-Hill, USA, 1990; MONJARDET, D., "Professionalisme et mediation de l'action policière. Les partages de la sécurité", en Les cahiers de la sécurité interieure 1998, n 33, pp. 21-49; 1998, del mismo autor "Réinventer la police urbaine. Le travail policier à la question dans les quartiers", en Les Annales de la Recherche Urbaine 1999, $\mathrm{n}^{\circ}$ 83, pp. 14-22. PALENSKI, J.E., "The use of mediation by Police", en Mediation Quarterly 1984, nº 5, pp. 31-38; TOCH, H., y GRANT, J.D., Police as problem solvers, Plenum Press Nueva York y Londres, 1991.
} 
Por ello cabe adaptar esta figura e insertarla en nuestro sistema restaurativo como una variante de la mediación penal clásica, con las características propias nacidas de un sistema en el que los policías ejercen las labores de mediador. Si encuadramos la mediación policial dentro del sistema de mediación penal como una variante de esta última, podremos conseguir que la policía, para una serie de conflictos debidamente tasados, pueda intervenir en el proceso de mediación como facilitadores. No hemos de olvidar que para ello es necesaria una adecuada formación de los miembros de los cuerpos de policía y seguridad del Estado para poder asegurar el correcto desarrollo de la práctica.

En general, en España podemos encontrar múltiples ejemplos exitosos de mediación policial, tales como los desarrollados en las ciudades de Valencia ${ }^{651}$, Málaga $^{652}$, Vila-real ${ }^{653}$. A continuación unas gráficas elaboradas por el Ayuntamiento de Vila-real ${ }^{654}$.

\footnotetext{
${ }^{651}$ BERLANGA, A., “La mediación policial” ... op. cit., pp. 411-434, esp. pp. 417-18.

${ }^{652}$ Información disponible en: www.malaga.eu (Última visita: 09/11/2017)

${ }^{653}$ Información disponible en: www.vila-real.es (Última visita: 09/11/2017)

${ }^{654}$ Policía Local de Vila-real, UMEPOL: Unidad de Mediación Policial, estadísticas 2015. Disponible en: http://www.vila-real.es (Última visita: 09/11/2017)
} 

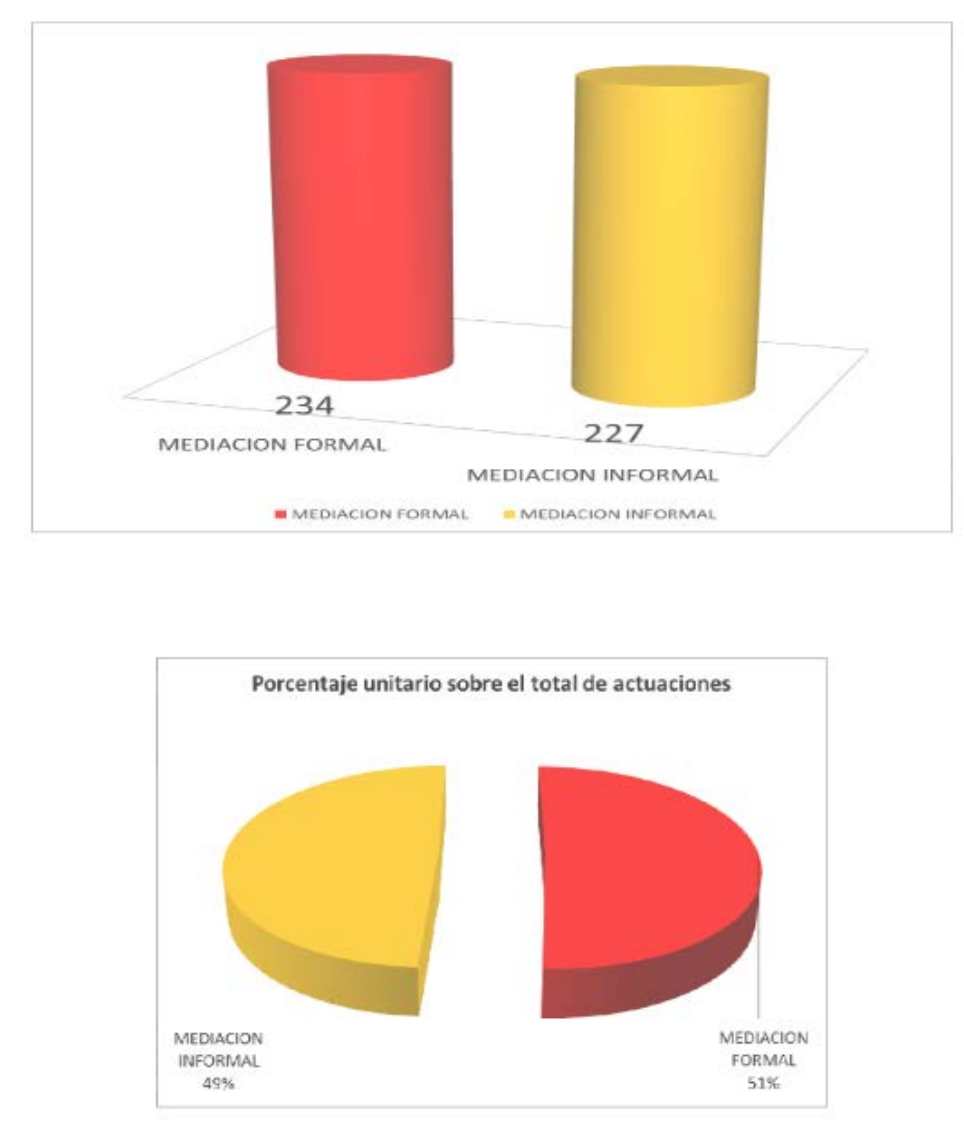

Figura 3. Porcentaje unitario sobre el total de actuaciones

Se puede observar la realización de un total de 461 mediaciones policiales efectuadas en el año 2015. Se realizaron 234 mediaciones formales ${ }^{655}$ y 227 mediaciones informales ${ }^{656}$.

${ }^{655}$ Mediaciones policiales finalizadas con la confección de un documento en el que las partes establecen sus premisas y sus acuerdos.

${ }^{656}$ Mediaciones policiales finalizadas sin la confección de un documento en el que las partes establezcan sus premisas y sus acuerdos pero con el compromiso verbal de aceptación de compromisos. 


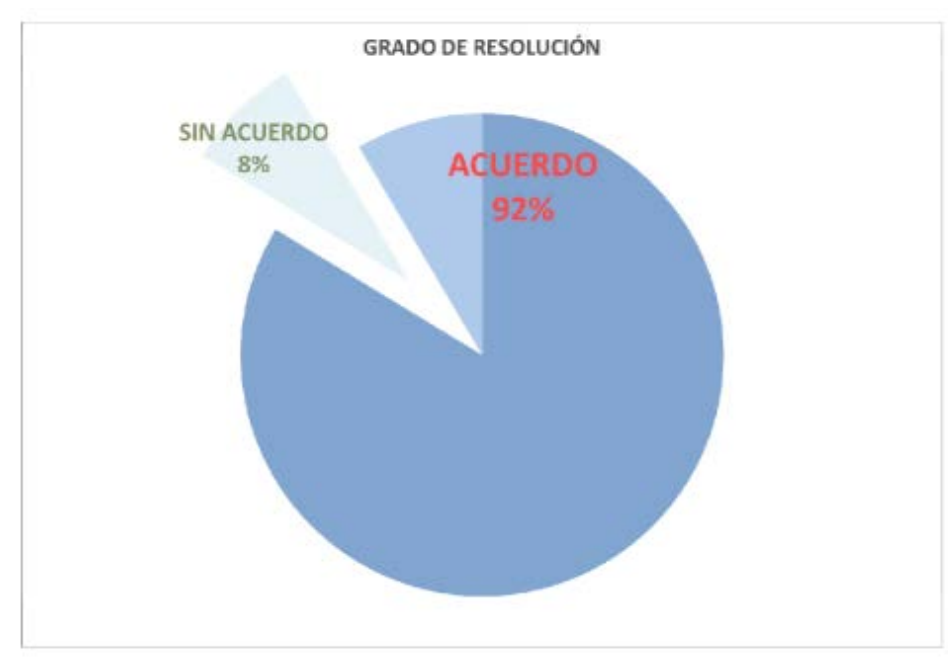

Figura 4. Grado de resolución.

Un proceso restaurativo con un 92\% de acuerdos, aun en la resolución de pequeños conflictos, es una muestra de la efectividad de estas figuras. Muestra las posibilidades que tiene la mediación policial como práctica restaurativa capaz de obtener un alto grado de acuerdos.

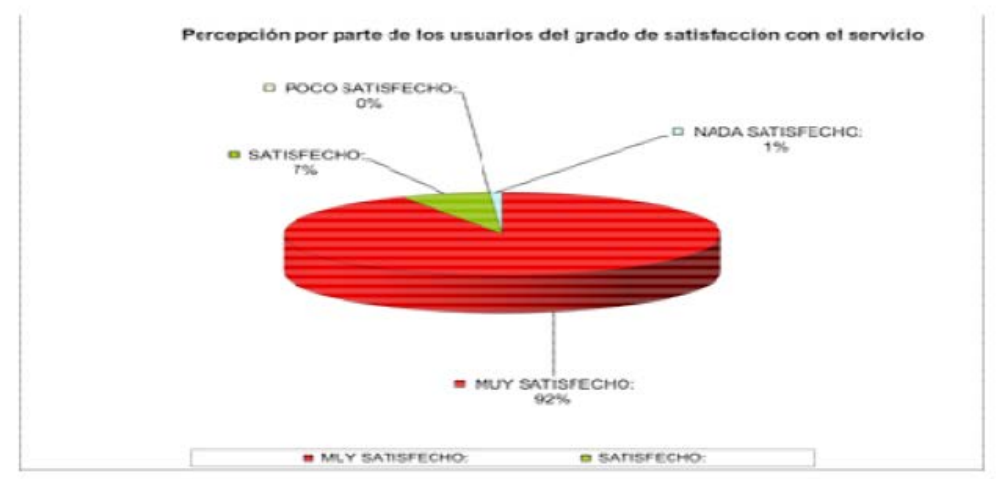

Figura 5. Percepción por parte de los usuarios del grado de satisfacción con el servicio.

No sólo la obtención de acuerdos es un dato positivo, sino que el alto grado de satisfacción en hasta un 92\% de los participantes muestra la importancia de la policía como parte activa de un proceso restaurativo, pudiendo acercar posturas, ayudar a resolver el conflicto y satisfacer a los interesados. 
En conclusión podemos observar que las experiencias en este ámbito están siendo muy positivas, y por ello consideramos que ha de darse un paso más allá. Una potenciación a nivel nacional de tal figura solventaría aquellos conflictos que no han de tener respuesta penal por su ínfima gravedad pero que distorsionan la convivencia pacífica, e incluso pueden ser detonantes de una futura agravación de las conductas y necesaria respuesta del sistema punitivo. Su progreso ha de ir encaminado al desarrollo como una especialidad dentro del complejo sistema de mediación penal ya analizado. En palabras de REDORTA LLORENTE, "Ia mediación policial se tiene que considerar como una especialidad en mediación o también como una forma diferente de práctica de la mediación" ${ }^{657}$.

\section{Situación en España ante la inexistencia de normativa: ejemplos prácticos}

Tras un estudio del concepto y regulación de la institución de la mediación, es momento de centrarnos en la aplicación práctica que han potenciado Tribunales e instituciones. Aún sin regulación alguna que lo amparase, el ímpetu e insistencia de diversas organizaciones y miembros del sistema de Justicia ha propiciado un incremento y auge digno de estudio y oportuna legislación. El modelo de mediación penal de adultos ha ajustado sus actuaciones conforme a la situación actual, como un complemento durante las fases de instrucción, juicio oral o ejecución, respetando no obstante los caracteres que caracterizan a la mediación e incluyendo aquellos necesarios para el encaje en nuestro ordenamiento, tales como la gratuidad y oficialidad ${ }^{658}$.

Como antecedentes a los proyectos del Servicio de Mediación Intrajudicial del País Vasco y de AMEPAX, podemos situar los proyectos desarrollados en Valencia y

\footnotetext{
${ }^{657}$ REDORTA LORENTE, J., “Aspectos críticos para implantar la mediación en contextos de policía”, en Revista Catalana de Seguretat pública 2004, $\mathrm{n}^{\circ}$ 15, pp. 29-46, esp. p. 35. Disponible en: http://www.raco.cat

${ }^{658}$ GARCÍA HERRERA, A., “Justicia restaurativa: breve reflexión...”, op. cit. Disponible en: https://www.diariolaley.es (última visita 05/04/217)
} 
Cataluña. En el primero de ellos, Valencia, en el año 1993, el juzgado de Instrucción $\mathrm{n}^{\circ} 2$ impulsó un programa de mediación penal de adultos para infracciones constitutivas de delito o falta. Para ser la primera "prueba”, el resultado fue bastante satisfactorio puesto que el $20 \%$ de los asuntos se resolvieron exitosamente y el 25\% fue imposible la conclusión de un acuerdo; el resto quedaron en suspenso. En Cataluña, aunque los primeros programas de conciliación fueron implementándose a inicios de la década de los 90, no fue hasta el año 1998 cuando se inició el proyecto de mediación penal en adultos. En los 4 años que duró dicha iniciativa, se derivaron a este servicio 452 asuntos, acabando en un acuerdo de mediación el $66 \%{ }^{659}$.

\subsection{Protocolos de actuación del Consejo General del Poder Judicial.}

El Consejo General del Poder Judicial (en adelante CGPJ) no ha sido ajeno al “boom” de la mediación, trabajando desde 2005 para su implantación en nuestro ordenamiento a través del Plan de Modernización de la Justicia de $2008^{660}$. Indaga en la figura para consolidar la mediación intrajudicial como sistema de resolución de conflictos complementario a la jurisdicción, visualizar la labor del Consejo respecto esta figura ante los profesionales de la mediación y la ciudadanía en general y velar por un ejercicio de calidad de la mediación intrajudicial. Por ello se han realizado diferentes actuaciones y firmado convenios con las diferentes Comunidades Autónomas con el fin de su introducción en la justicia ${ }^{661}$. Para su mejor implantación el CGPJ elaboró la Guía

\footnotetext{
${ }^{659}$ Más ampliamente en GÓNZALEZ VIDOSA, L.F., DE JORGE DE MESA, F., "Mediación: primera experiencia de adultos en España”, en Poder Judicial 1995, n 40, pp. 459-475; RÍOS, J., et al., Mediación Penal, Penitenciaria y encuentros restaurativos, Universidad Pontífica Comillas, Madrid, 2016, pp.40-41; VALL RIUS, A., VILLANUEVA REY, N., El programa de mediación en la jurisdicción penal ordinaria; un estudio sobre tres años y medio de experiencia, Generalitat de Cataluña, Centro de estudios jurídicos y formación especializada, 2003.

${ }^{660}$ Disponible en http://www.poderjudicial.es (última visita 30/01/2018)

${ }^{661}$ A modo de ejemplo se citan dos Convenios realizados en Castilla y León:

1. Convenio entre el Consejo General del Poder Judicial y la Asociación Concierta de Salamanca para aplicar la mediación en el ámbito penal de 18 de junio de 2015. Disponible en: http://www.poderjudicial.es (Última visita: 09/11/2017)

2. Acuerdo de colaboración para la promoción de la mediación, entre el Consejo General del Poder Judicial y el Ministerio de Justicia de fecha de 25 de mayo de 2016. Disponible en: http://www.poderjudicial.es (Última visita: 09/11/2017)
} 
para la práctica de la mediación intrajudicial con fecha de 13 de octubre de $2013^{662}$. Dada su importancia se realizará una breve referencia a la misma.

De este modo el grupo de expertos ${ }^{663}$ inició el protocolo de mediación penal con un breve análisis de la institución, analizando sus principios y ventajas, para continuar indicando la imprescindible regulación en nuestro ordenamiento a través de la “necesaria unificación o homogeneización a nivel territorial de la implantación del procedimiento de mediación penal dentro del proceso penal vigente ${ }^{664}$. Seguidamente se desarrolla la derivación de la mediación penal en la fase de instrucción, fase de juicio oral y en la fase de ejecución.

Tras ello prosigue con el desarrollo del marco legislativo existente citando normativa Internacional de Naciones Unidas ${ }^{665}$, del Consejo de Europa ${ }^{666}$, los Estatutos de la víctima de 2001 y 2012 de la Unión Europea, y la legislación nacional. Analiza la tipología de las infracciones que pueden o no resolverse por un acto de mediación,

${ }^{662}$ Guía para la práctica de la mediación intrajudicial. Disponible en: http://www.poderjudicial.es (Última visita: 09/11/2017)

${ }^{663}$ El grupo de expertos estaba formado por:

1. D. ${ }^{a}$ Ana Carrascosa, Inspectora del CGPJ, que ha actuado como coordinadora del grupo.

2. D. ${ }^{a}$ Rosa Garrido, Abogada y mediadora en el programa intrajudicial de Madrid.

3. D. ${ }^{a}$ Rosa M. ${ }^{a}$ Freire, Magistrada y Letrada de la Escuela Judicial en Barcelona.

4. D. ${ }^{a}$ María Silva, Fiscal de la Secretaría Técnica de la Fiscalía General del Estado.

5. D. ${ }^{a}$ Esther Erice, Presidenta de la Audiencia Provincial de Navarra.

${ }^{664}$ Guía para la práctica..., op. cit., p. 91.

665 Carta de los Derechos Humanos, de 26 de junio de 1945, Capítulo VI, artículo 34, refleja para la solución de controversias "la negociación, la investigación, la mediación, la conciliación, el arbitraje, el arreglo judicial, el recurso a organismos o acuerdos regionales u otros medios pacíficos a su elección”; Resolución 53/243, de 6 de octubre de 1999, sobre la declaración y programa de acción sobre una cultura de Paz; Resolución 55/59 sobre Plan de acción sobre Justicia Restaurativa; Resolución 26/1999, de 28 de julio, sobre el desarrollo y la implementación de la mediación y las medidas de la Justicia Restaurativa en la Justicia criminal; Resolución 14/2000, de 27 de julio, sobre principios básicos del uso de la Justicia Restaurativa en los procesos criminales, que anima el intercambio y experimentación en el ámbito de la mediación penal; Informe del Secretario General del Consejo Económico y Social de las Naciones Unidas, de 7 de enero de 2002, sobre la reforma del sistema de justicia penal: logro de la eficacia y la equidad. La Justicia Restaurativa; Standards y normas para la prevención del crimen y la Justicia criminal, Comisión de Prevención del Crimen y Justicia Criminal, de 18 de abril de 2002, sobre Principios básicos sobre el uso de los programas de Justicia Restaurativa en los procesos criminales; etc.

${ }^{666}$ La Recomendación núm. R (83)7 está orientada a potenciar la participación del público en la elaboración y aplicación de políticas criminales que tienden a prevenir la criminalidad y a facilitar la indemnización y la reparación a la víctima; y la Recomendación núm. R (85)11, relativa a la posición de la víctima en el marco del proceso y del Derecho Penal. 
indicando que un "listado cerrado puede resultar contraproducente porque puede obstaculizar y hasta impedir el acceso a mediación de tipos no incluidos en él al crear estereotipos que operan a modo de freno automático en los operadores jurídicos para impedir una actitud más abierta y amplia ante la mediación penal”667.

Respecto a la tipología delictiva a resolver a través de la mediación penal, al ser infracciones en las que existen relaciones personales dañadas y continuadas en el tiempo y las cuales no se ven satisfechas por los juzgados para los intereses de las partes provoca que "las denuncias se multiplican, se superponen, y se cruzan, provocando numerosos juicios pendientes con relación a las mismas personas”, ${ }^{\natural 68}$. En cuanto a los delitos más graves, considera que no hay que descartarlos de la mediación, debiendo de estarse a la voluntad de la víctima y la infracción para poder iniciar o no un acto de mediación.

Añade también que a nivel de delitos muy graves, la mediación puede ser muy efectiva cuando el infractor ya se encuentra en prisión, al ser las prácticas restaurativas un buen instrumento de resocialización del preso. Por el contrario descarta la utilización de la mediación en delitos sin víctima. En cambio aconseja una mediación para supuestos en delincuentes reincidentes al considerar que cada infracción es cometida en un momento diferente y que hasta ese momento no han tenido la oportunidad de responder por el delito cometido. Acepta la mediación en caso de que el infractor haya reincidido tras un acto de mediación siempre y cuando la víctima desee acudir a la mediación, debiendo el mediador de controlar que el infractor "no participe en el procedimiento con fines espurios”669. Para terminar expone unas situaciones polémicas de derivación a los servicios de mediación, como: “cuando la persona acusada está en situación irregular en España; en el delito continuado (art. 74 del Código Penal);

\footnotetext{
${ }^{667}$ Guía para la práctica..., op. cit., p. 114.

668 Ídem.

669 Ídem p. 115.
} 
cuando una de las partes no está en el pleno uso de sus facultades mentales; cuando hay varias personas víctimas o acusadas y sólo participa una”670.

\subsection{Experiencias en el País Vasco: el Servicio de Mediación intrajudicial.}

El análisis de las experiencias pragmáticas desarrolladas en la Comunidad Autonómica del País Vasco es el mejor ejemplo del apogeo de la figura. Será objeto de examen la Memoria del Servicio de Mediación Intrajudicial (SMI) sobre Mediación Penal de los años $2014^{671}, 2015^{672}$ y $2016^{673}$.

En el año 2014 el SMI atendió a un total de 1.783 asuntos, derivados en la gran mayoría (1.557) por los Juzgados y Tribunales. Una cantidad bastante elevada de asuntos derivados a los servicios de mediación que muestran el gran impacto que tiene la mediación penal en los territorios de Euskadi así como la confianza que está empezando a ganarse entre la población. De todos ellos, el SMI consiguió cerrar 1.526 asuntos, quedando pendientes 257 para el año 2015, concluyendo mediante un proceso de mediación un 58,26\% (889 asuntos), de los cuales, 688 asuntos, casi el 77\%, finalizaron tras un acuerdo entre las partes.

\footnotetext{
${ }^{670}$ Ídem p. 116.

${ }^{671}$ Memoria Servicio de Mediación Intrajudicial sobre Mediación Penal del año 2014, disponible en: http://www.justizia.net (Última visita: 09/11/2017)

${ }^{672}$ Memoria Servicio de Mediación Intrajudicial sobre Mediación Penal del año 2015, disponible en: http://www.justizia.net (Última visita: 09/11/2017)

${ }^{673}$ Memoria Servicio de Mediación Intrajudicial sobre Mediación Penal del año 2016, disponible en: http://www.justizia.net (Última visita: 30/01/2018)
} 


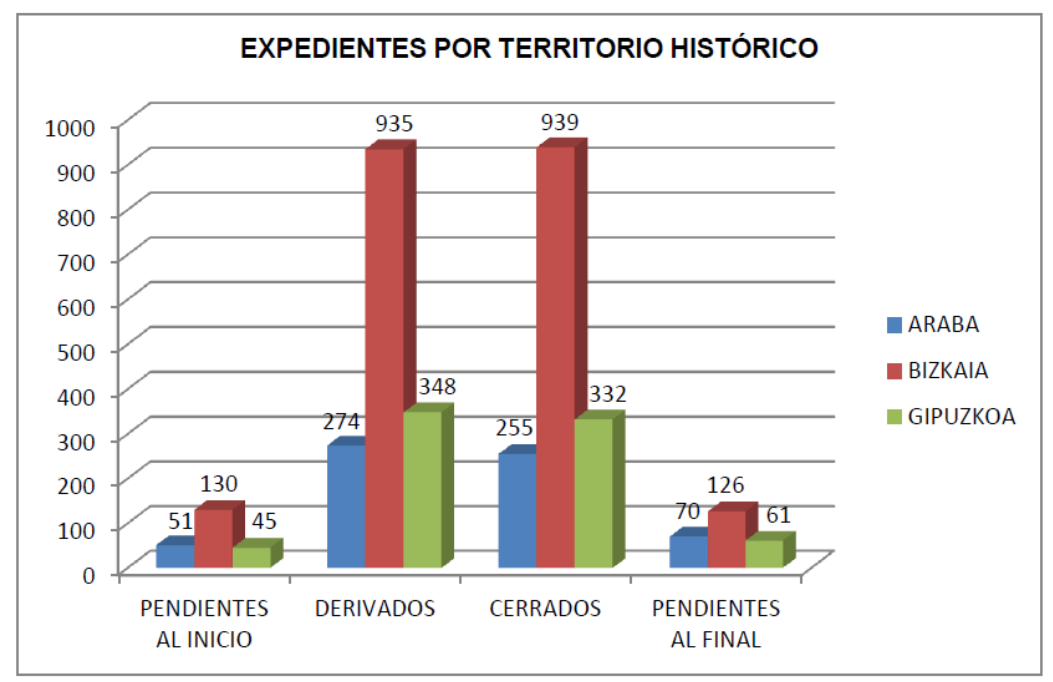

Figura 6. Expedientes por territorio histórico. Fuente: Memoria 2014 SMI, p.7.

Figura 7. Porcentaje de expedientes cerrados acabados en mediación o no. Fuente: Memoria 2014 SMI,

p.8.

La propia memoria hace una distinción acerca de los expedientes cerrados, expedientes con mediación llegando o no a un acuerdo, pero la distinción más llamativa es que la realiza conforme a los diferentes territorios, pudiéndose observar los datos de cada provincia. Como vemos es en Vizcaya donde más expedientes se llevan a cabo y, por ende, más mediaciones. En Álava es donde los datos son menores pero, como dato llamativo, tiene un grandísimo número de mediaciones finalizadas con acuerdo. No en vano es en Álava donde casi un 50\% de los expedientes que llegan acaba con un 
acuerdo de mediación, mientras que en las demás provincias, aunque las cifras están cerca, son algo inferiores.

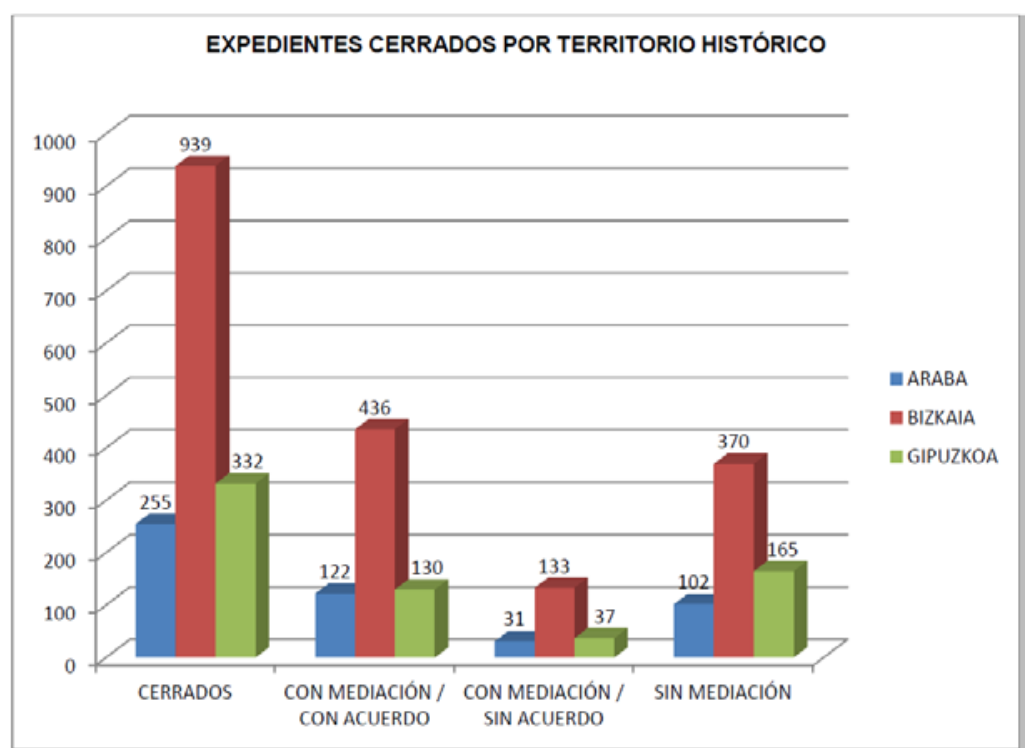

Figura 8. Expedientes cerrados por territorio histórico. Fuente: Memoria 2014 SMI, p.10.

Las faltas constituyen la tipología delictiva más derivada al SMI por parte de los operadores jurídicos (1.615 faltas, el 84,78\% del total). Los delitos derivados (290, $15,22 \%)$ correspondieron en su totalidad a la categoría de conductas delictivas menos gravosas. Como observamos en las figuras siguientes, Vizcaya es la provincia con más interés en la resolución pacífica de conflictos, siendo aquella con mayor número de derivación de delitos y faltas al SMI con un total de 1.128 (el 59,21\%), seguido por Guipúzcoa (22,63\%) y Álava (18,16\%). Es llamativo ver como Álava tiene casi el mismo número de delitos y faltas derivados al SMI que Guipúzcoa, dejando ver el claro interés que existe en esta provincia por la resolución de conflictos a través de la mediación penal. 


\begin{tabular}{|c|c|c|c|c|c|c|c|c|}
\hline & \multicolumn{2}{|c|}{ ARABA } & \multicolumn{2}{|c|}{ BIZKAIA } & \multicolumn{2}{|c|}{ GIPUZKOA } & \multicolumn{2}{|c|}{ TOTAL } \\
\hline \multirow{3}{*}{ DELITOS } & Graves & $\begin{array}{l}\text { Menos } \\
\text { graves }\end{array}$ & Graves & $\begin{array}{l}\text { Menos } \\
\text { graves }\end{array}$ & Graves & $\begin{array}{l}\text { Menos } \\
\text { graves }\end{array}$ & Graves & $\begin{array}{l}\text { Menos } \\
\text { graves }\end{array}$ \\
\hline & 0 & 30 & 0 & 193 & 0 & 67 & 0 & 290 \\
\hline & \multicolumn{2}{|c|}{$30(8,67 \%)$} & \multicolumn{2}{|c|}{$193(17,11 \%)$} & \multicolumn{2}{|c|}{$67(15,55 \%)$} & \multicolumn{2}{|c|}{$290(15,22 \%)$} \\
\hline FALTAS & \multicolumn{2}{|c|}{$316(91,33 \%)$} & \multicolumn{2}{|c|}{$935(82,89 \%)$} & \multicolumn{2}{|c|}{$364(84,45 \%)$} & \multicolumn{2}{|c|}{$1.615(84,78 \%)$} \\
\hline TOTAL $^{3}$ & \multicolumn{2}{|c|}{$346(18,16 \%)$} & \multicolumn{2}{|c|}{$1.128(59,21 \%)$} & \multicolumn{2}{|c|}{$431(22,63 \%)$} & \multicolumn{2}{|c|}{1.905} \\
\hline
\end{tabular}

Figura 9. Tipologías delictivas cerradas con mediación por territorio histórico. Fuente: Memoria 2014 SMI, p.28.

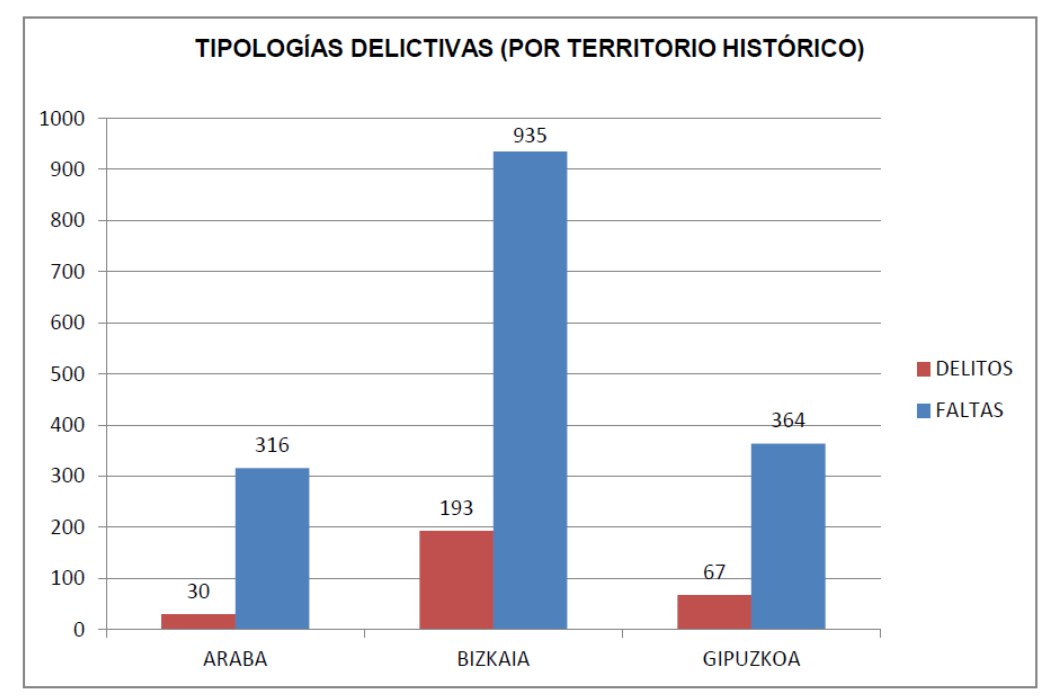

Figura 10. Tipologías delictivas cerradas por mediación por territorio histórico. Fuente: Memoria 2014 SMI, p.28.

En cuanto a los tipología delictiva, la memoria explica en la siguiente figura (6) los tipos delictivos, siendo predominantes el de lesiones (49,43\%), impago de pensiones (12,5\%). lesiones en violencia intrafamiliar (8,52\%) y daños (8,52\%). Como se observa no sólo tiene lugar una escasa variedad delictiva, sino que además todos son de leve gravedad, demostrando el interés del Gobierno Vasco y los Tribunales en la resolución de conflictos de escasa trascendencia penal al ser precisamente estos los más idóneos para la realización de una mediación. 


\begin{tabular}{|c|c|c|c|c|}
\hline \multicolumn{3}{|c|}{ DELITOS } & \multicolumn{2}{|c|}{$\mathrm{N}^{\circ}$} \\
\hline \multirow{2}{*}{ Lesiones } & \multicolumn{2}{|c|}{ Lesiones } & 87 & $(49,43 \%)$ \\
\hline & \multicolumn{2}{|c|}{ Lesiones en violencia intrafamiliar } & 15 & $(8,52 \%)$ \\
\hline \multirow{3}{*}{ Contra la libertad } & \multicolumn{2}{|c|}{ Amenazas } & 5 & $(2,84 \%)$ \\
\hline & \multicolumn{2}{|c|}{ Amenazas en violencia intrafamiliar } & & $(2,27 \%)$ \\
\hline & \multicolumn{2}{|c|}{ Coacciones } & & $(1,70 \%)$ \\
\hline Contra el honor & \multicolumn{2}{|c|}{ Injurias } & & $(0,57 \%)$ \\
\hline $\begin{array}{l}\text { Contra las relaciones } \\
\text { familiares }\end{array}$ & \multicolumn{2}{|c|}{ Impago de pensiones } & 22 & $(12,50 \%)$ \\
\hline \multirow{5}{*}{$\begin{array}{l}\text { Contra el patrimonio y el } \\
\text { orden socio-económico }\end{array}$} & \multicolumn{2}{|c|}{ Hurto } & 8 & $(4,55 \%)$ \\
\hline & \multicolumn{2}{|c|}{ Robo con fuerza } & & $(0,57 \%)$ \\
\hline & \multirow{2}{*}{ Defraudaciones } & Estafa & 5 & $(2,84 \%)$ \\
\hline & & $\begin{array}{l}\text { Apropiación } \\
\text { indebida }\end{array}$ & 10 & $(5,68 \%)$ \\
\hline & \multicolumn{2}{|c|}{ Daños } & & $(8,52 \%)$ \\
\hline & & TOTAL & & 6 \\
\hline
\end{tabular}

Figura 11. Tipologías delictivas. Fuente: Memoria 2014 SMI, p.29.

En cuanto a lo relativo a las faltas, las amenazas son la tipología más común por la que se acude a un proceso de mediación (23,87\%), pero seguida de cerca por las lesiones, (20,14\%), el incumplimiento de las obligaciones familiares (19,80\%) y las injurias (15,38\%). Las faltas, ya eliminadas del Código Penal y transformadas algunas de ellas en infracciones administrativas ${ }^{674} \mathrm{y}$ el resto en delitos leves, eran las

\footnotetext{
${ }^{674}$ Este punto ha creado bastantes controversias. Aunque desde el Gobierno Central se ha defendido la idea de que la eliminación de las faltas aduce a razones de liberación de carga de los Tribunales y a la aplicación del principio de intervención mínima, muchos son los que ven un interés recaudatorio, al ser convertidas en infracciones administrativas. Al ser castigadas a través de multas parece claro el interés que tiene el Gobierno en sacar provecho económico de estas pequeñas y banales infracciones, las cuales estarían mejor resueltas a través de prácticas restaurativas que sirviesen al infractor para el aprendizaje y resocialización. Como indica BONET ESTEVA, M., "Falacias diversas con respecto a la desaparición de las faltas del Código Penal”, en la web Agenda_Pública, 1 de julio de 2015, Disponible en: http://agendapublica.es (Última visita: 09/11/2017), quien textualmente indica que la reforma penal provoca una serie de conclusiones:

1) "La creación de los nuevos delitos leves y las nuevas infracciones administrativas parecen responder a un fin recaudatorio inmediato a través del rápido procedimiento de faltas o de la casi automática vía sancionadora administrativa.
} 
infracciones idóneas para la resolución a través de un proceso de mediación penal. Su escasa gravedad no provocaba un gran daño psicológico grande a la víctima al ser menor la coacción ejercida por el infractor. Además, la reparación es más sencilla en estos supuestos a consecuencia que en multitud de coyunturas una simple disculpa puede ser suficiente. Por último, muchas de estas infracciones se cometían en ámbitos de familia o vecindad, pudiendo servir el proceso de mediación para el restablecimiento de las relaciones perdidas por la infracción.

\begin{tabular}{|c|c|c|c|c|}
\hline \multicolumn{3}{|c|}{ FALTAS } & \multicolumn{2}{|c|}{$\mathrm{N}^{\circ}$} \\
\hline \multirow{7}{*}{ Contra las personas } & \multicolumn{2}{|r|}{ Lesiones } & 178 & $(20,14 \%)$ \\
\hline & \multicolumn{2}{|c|}{ Incumplimiento de obligaciones familiares } & 175 & $(19,80 \%)$ \\
\hline & \multicolumn{2}{|c|}{ Maltrato de obra } & 17 & $(1,92 \%)$ \\
\hline & \multicolumn{2}{|c|}{ Amenazas } & 211 & $(23,87 \%)$ \\
\hline & \multicolumn{2}{|c|}{ Amenazas en violencia intrafamiliar } & & $(0,34 \%)$ \\
\hline & \multicolumn{2}{|c|}{ Coacciones } & 74 & $(8,37 \%)$ \\
\hline & \multicolumn{2}{|r|}{ Injurias } & 136 & $(15,38 \%)$ \\
\hline \multirow{4}{*}{ Contra el patrimonio } & \multicolumn{2}{|r|}{ Hurto } & 25 & $(2,83 \%)$ \\
\hline & \multicolumn{2}{|r|}{ Daños } & 47 & $(5,32 \%)$ \\
\hline & \multirow{2}{*}{ Defraudaciones } & Estafa & 13 & $(1,47 \%)$ \\
\hline & & Apropiación indebida & 5 & $(0,57 \%)$ \\
\hline \multicolumn{3}{|r|}{ TOTAL } & \multicolumn{2}{|c|}{885} \\
\hline
\end{tabular}

Figura 12. Tipologías delictivas. Fuente: Memoria 2014 SMI, p.30.

En el año 2015, el SMI tuvo un número menor de asuntos que en el año precedente, atendiendo la cifra de 1.700 asuntos penales. De todos ellos, 1443 fueron

2) Al hacer, a través de los nuevos delitos leves, de la multa la pena estrella nos apartamos de la senda de la búsqueda de instrumentos alternativos a la privación de libertad breve que no sea el pago de una cantidad de dinero. Se pierde así fuerza reeducadora en su ejecución (art. 25 C.e.)

3) Finalmente, la tan cacareada descarga de los juzgados va a ser prácticamente nula puesto que ha quedado demostrado que, como en física, las faltas no han desaparecido, se han transformado". 
derivados por los Juzgados y Tribunales, los cuales, siguiendo la línea general, derivaron un menor número que el año anterior. De todos ellos, se han conseguido cerrar 1517 asuntos, de los cuales 825 tuvieron una resolución a través de un proceso de mediación realmente positivo. Todo esto nos indica que, aunque los datos sean ligeramente inferiores a los de campañas anteriores, se ha obtenido una estabilidad. Esta consistencia puede ser básica e imprescindible no sólo para el mantenimiento futuro del Servicio, sino para una mayor promulgación y desarrollo de la mediación penal.

En cuanto a los tipos de causas, como vamos a poder observar en la siguiente figura, más de la mitad proceden del juicio de faltas (62,23\%), seguido por procedimiento sobre delitos leves (23,49\%), diligencias previas 9,36 y Procedimiento abreviado (4,92). De todos estos datos podemos obtener una conclusión: el SMI se está centrando en la resolución de infracciones de ínfima gravedad en su gran mayoría, obviando o no pudiendo atender infracciones graves.

\begin{tabular}{|ll|rl|}
\hline FAL & - PROCEDIMIENTO DE FALTAS & $898 \quad(62,23 \%)$ \\
\hline LEV $\quad$ - JUICIO SOBRE DELITO LEVE & $339 \quad(23,49 \%)$ \\
\hline DIP $\quad$ DILIGENCIAS PREVIAS & $135 \quad(9,36 \%)$ \\
\hline DUR $\quad$ DILIGENCIAS URGENTES & $0 \quad(0 \%)$ \\
\hline JRA - JUICIO RÁPIDO & $0 \quad(0 \%)$ \\
\hline PAB $\quad$ PROCEDIMIENTO ABREVIADO & $71 \quad(4,92 \%)$ \\
\hline SUM - PROCEDIMIENTO SUMARIO & $0 \quad(0 \%)$ \\
\hline PTJ & PROCEDIMIENTO TRIBUNAL JURADO & $0 \quad(0 \%)$ \\
\hline & TOTAL & 1.443 \\
\hline
\end{tabular}

Figura 13. Tipos de causa. Fuente: Memoria 2015 SMI, p.12. 
En cuanto a la tipología delictiva, primero se va a analizar a nivel general, para proceder a un examen con carácter sectorial conforme a los distintos territorios históricos, siguiendo así la línea que desarrolla la memoria del SMI.

Se observa que las infracciones graves apenas tienen cabida dentro del Servicio en el año 2015. La dificultad que conlleva su implementación y desarrollo eficaz deriva ante una ausencia de aplicación de la mediación penal asuntos de mayor trascendencia. Podemos observar en la figura siguiente que solamente 24 delitos graves se han podido/querido resolver a través del SMI. Datos insuficientes pero a la vez esperanzadores pues, aunque sean muy ínfimos los casos, estos 24 delitos pueden ser una primera piedra en la construcción de un sistema de mediación penal enfocado en la resolución de delitos graves.

De los 715 delitos, 449 han sido de los considerados delitos leves y 242 delitos de pequeña gravedad. Se insiste, cuanta mayor gravedad en la tipología delictiva, menor número de mediaciones existentes; los mismos datos y pautas se repiten en otros servicios de mediación penal existentes. Todavía existen dificultades para fundir en un solo proceso la palabra mediación con los delitos de mayor gravedad, ya sea por la poca creencia de las víctimas, de los infractores o del propio sistema de justicia.

En cuanto a los demás datos indicados en la figura, podemos deducir que en total hay 2182 tipologías delictivas. Esta cifra, sorprendentemente, no coincide con los 1700 asuntos penales tratados. Se ha de advertir que diferentes causas judiciales pueden englobar varias tipologías delictivas y ello explicaría las diferentes cifras. De todas estas estadísticas lo más llamativo es que el 67,23\% de ellas son faltas, las cuales, aspecto ya expuesto en reiteradas ocasiones, son la infracción “estrella” de los servicios de mediación penal gracias a la facilidad existente para la consecución de un acuerdo. 


\begin{tabular}{|c|c|c|c|}
\hline & \multicolumn{3}{|c|}{ TOTAL CAPV } \\
\hline \multirow{3}{*}{ DELITOS } & Graves & Menos graves & Leves \\
\hline & 24 & 242 & 449 \\
\hline & \multicolumn{3}{|c|}{715 (32,77\%) } \\
\hline FALTAS & \multicolumn{3}{|c|}{$1.467(67,23 \%)$} \\
\hline TOTAL $^{8}$ & \multicolumn{3}{|c|}{2.182} \\
\hline
\end{tabular}

Figura 14. Tipología delictiva. Fuente: Memoria 2015 SMI, p.13.

\begin{tabular}{|c|c|c|c|c|c|c|c|c|c|}
\hline & \multicolumn{3}{|c|}{ ARABA } & \multicolumn{3}{|c|}{ BIZKAIA } & \multicolumn{3}{|c|}{ GIPUZKOA } \\
\hline \multirow{3}{*}{ DELITOS } & Graves & $\begin{array}{l}\text { Menos } \\
\text { graves }\end{array}$ & Leves & Graves & $\begin{array}{l}\text { Menos } \\
\text { graves }\end{array}$ & Leves & Graves & $\begin{array}{l}\text { Menos } \\
\text { graves }\end{array}$ & Leves \\
\hline & 2 & 46 & 67 & 11 & 134 & 276 & 11 & 63 & 106 \\
\hline & \multicolumn{3}{|c|}{$115(40,35 \%)$} & \multicolumn{3}{|c|}{$421(29,99 \%)$} & \multicolumn{3}{|c|}{$180(36,44 \%)$} \\
\hline FALTAS & \multicolumn{3}{|c|}{$170(59,65 \%)$} & \multicolumn{3}{|c|}{$983(70,01 \%)$} & \multicolumn{3}{|c|}{$314(63,56 \%)$} \\
\hline TOTAL & \multicolumn{3}{|c|}{285} & \multicolumn{3}{|c|}{1.404} & \multicolumn{3}{|c|}{494} \\
\hline
\end{tabular}

Figura 15. Tipología delictiva por territorio histórico. Fuente: Memoria 2015 SMI, p.13.

En cuanto a la tipología delictiva conforme al Territorio Histórico, podemos advertir una continuidad respecto a los términos de años anteriores; pero hay un dato fundamental a señalar. Tanto en Vizcaya como en Guipúzcoa, la diferencia en tanto por ciento entre delitos y faltas es considerable (de 30\% a un 40\%), mientras que en Álava es menor, de un 19\%. Ello nos indica que en Álava se ha dado un paso más allá para la resolución de delitos a través de esta figura que entendemos como un camino correcto. No es menos cierto que el menor número tanto de habitantes como de infracciones pueden dar lugar a unos mejores datos. Pero en verdad cabe observar que, en 
porcentajes, sus estadísticas son muy positivas, y pensamos que pueden ser un ejemplo a seguir para el futuro.

Aunque también Guipúzcoa es otro ejemplo a seguir. Como cabe examinar, de 180 delitos, 11 eran infracciones graves, las mismas que Vizcaya tras resolver un total de 421. Vemos que en Guipúzcoa se están derivando y resolviendo un tanto por ciento significativo de delitos graves conforme al total de delitos resueltos. Otro dato muy elocuente y esperanzador tanto para el SMI como para aquellos que propugnamos una implementación real y efectiva de los servicios de justicia restaurativa, no sólo en el ámbito de faltas y delitos leves, sino también en aquellos delitos que más afectan a la sociedad, los cuales son las infracciones de mayor gravedad.

\subsubsection{DELITOS GRAVES}

\begin{tabular}{|c|c|c|}
\cline { 2 - 3 } \multicolumn{2}{|c|}{} & \multicolumn{2}{c|}{ № } \\
\hline \multicolumn{2}{|c|}{ Lesiones } & $15 \quad(62,50 \%)$ \\
\hline \multirow{2}{*}{$\begin{array}{c}\text { Contra el patrimonio y el orden } \\
\text { socio-económico }\end{array}$} & Estafa & $4 \quad(16,67 \%)$ \\
\cline { 2 - 3 } & Apropiación indebida & $\mathbf{5}(20,83 \%)$ \\
\hline \multicolumn{2}{|c|}{ TOTAL } & 24 \\
\hline
\end{tabular}

Figura 16. Tipología delictiva: Delitos graves. Fuente: Memoria 2015 SMI, p.24.

En la figura 10 nos encontramos con la tipología delictiva respecto a los delitos graves. Como podemos advertir, más del 62\% de las infracciones las podríamos catalogar como lesiones, repartiéndose el resto en delitos contra el patrimonio tales como la estafa y la apropiación indebida. Es lógico que estas dos últimas estén incrementándose puesto que la situación económica actual nos ha conducido a un aumento en la comisión de estos tipos delictivos. Asimismo, al ventilarse un mayor número de estafas o apropiaciones indebidas en nuestros Juzgados y Tribunales, también podemos percibir un auge en el ámbito de la mediación penal. 
Respecto a las lesiones, estamos ante figuras con una gravedad especial a consecuencia de que para cumplir con las exigencias de ser consideradas como delitos graves, se han de dar unas especialidades en el tipo delictivo. Por ello, y como los delitos graves han de tener una pena de prisión superior a 3 años, las lesiones aquí recogidas serán las tipificadas en los artículos 148 y siguientes del CP.

Es primordial poder advertir la utilización de la mediación penal para la resolución de infracciones que revisten un cierto halo de gravedad. Y aunque el número de ellas no hayan sido excesivas (24 infracciones), suponen un gran avance pues en la anualidad anterior no existió procedimiento de mediación alguno, estando ante el inicio de una posible resolución de conflictos graves.

Acudiendo al análisis de los delitos de menor trascendencia penal, nos encontramos con una situación dispar. Aparecen nuevos tipos delictivos que van a aglutinar cierto protagonismo en los procedimientos restaurativos. Aunque, como sucede en todos los servicios de mediación, las lesiones continúan siendo las infracciones “estrella” suponiendo más de un 45\% de todos los delitos menos graves. En cuanto a la tipología restante se reparte entre apropiaciones indebidas (8,26\%), daños (10,33\%), estafas (3,72\%), amenazas (5,37\%), coacciones (4,13\%), impago de pensiones (2,48\%), sustracción de menores (0,83\%), o hurtos (2,48\%) entre otros. 
1.6.2. DELITOS MENOS GRAVES

\begin{tabular}{|c|c|c|}
\hline & & № \\
\hline \multirow{3}{*}{ Lesiones } & Lesiones & $110(45,45 \%)$ \\
\hline & Lesiones por imprudencia grave & $1(0,41 \%)$ \\
\hline & Lesiones en violencia intrafamiliar & $13(5,37 \%)$ \\
\hline \multirow{3}{*}{ Contra la libertad } & Amenazas & $13(5,37 \%)$ \\
\hline & Amenazas en violencia intrafamiliar & $2(0,83 \%)$ \\
\hline & Coacciones & $10(4,13 \%)$ \\
\hline \multicolumn{2}{|c|}{ Contra la integridad moral } & $2(0,83 \%)$ \\
\hline \multirow{2}{*}{ Contra la intimidad } & Descubrimiento y revelación de secreto & $1(0,41 \%)$ \\
\hline & $\begin{array}{c}\text { Divulgación no consentida de imágenes o } \\
\text { grabaciones íntimas }\end{array}$ & $3(1,24 \%)$ \\
\hline \multirow{2}{*}{ Contra el honor } & Calumnias & $1(0,41 \%)$ \\
\hline & Injurias & $3(1,24 \%)$ \\
\hline \multirow{2}{*}{$\begin{array}{l}\text { Contra las relaciones } \\
\text { familiares }\end{array}$} & Impago de pensiones & $6 \quad(2,48 \%)$ \\
\hline & Sustracción de menores & $2(0,83 \%)$ \\
\hline
\end{tabular}

\begin{tabular}{|c|c|c|}
\hline \multirow{9}{*}{$\begin{array}{l}\text { Contra el patrimonio y el } \\
\text { orden socio-económico }\end{array}$} & Hurto & $6 \quad(2,48 \%)$ \\
\hline & Robo con fuerza & $4 \quad(1,65 \%)$ \\
\hline & Robo con intimidación & $2(0,83 \%)$ \\
\hline & Estafa & $9 \quad(3,72 \%)$ \\
\hline & Apropiación indebida & $20 \quad(8,26 \%)$ \\
\hline & Daños & $25(10,33 \%)$ \\
\hline & Ocupación de bien inmueble-usurpación & $1(0,41 \%)$ \\
\hline & Alteración de lindes & $1 \quad(0,41 \%)$ \\
\hline & Societario & $3(1,24 \%)$ \\
\hline \multirow{2}{*}{ Falsedades } & Falsificación documento privado & $1 \quad(0,41 \%)$ \\
\hline & Usurpación del estado civil & $1(0,41 \%)$ \\
\hline $\begin{array}{c}\text { Contra la Administración } \\
\text { de Justicia }\end{array}$ & Quebrantamiento de condena & $1 \quad(0,41 \%)$ \\
\hline \multirow[t]{2}{*}{ Contra el orden público } & Desobediencia a la autoridad & $1(0,41 \%)$ \\
\hline & TOTAL & 242 \\
\hline
\end{tabular}

Figura 17. Tipología delictiva: Delitos menos graves. Fuente: Memoria 2015 SMI, p.24. 
En relación a los delitos leves ya citados anteriormente a modo general, se va a observar una modificación en cuanto a la tipología "estrella”. Anteriormente se examinaba una abundancia del tipo relativo a las lesiones, siendo la infracción más derivada a los procesos de mediación. En el año 2015 las circunstancias han mutado, manifestándose las amenazas en el primer escalafón, con un total del 42,76\% de las infracciones resueltas por este método. Se trata de un delito de escasa gravedad, pero muy común en las relaciones interpersonales de los ciudadanos, los cuales han optado por ventilar estos asuntos a través de la mediación penal. Resulta ser, sin duda, una figura idónea para este tipo de actuaciones. No sólo por la menor complejidad que va a suponer poner de acuerdo a ambas partes, sino porque servirá de base para pacificar esta relación y no agravar el asunto por la insatisfacción del uno y/o del otro.

En siguiente lugar aparece la infracción de las lesiones, con un total del 21,60\%. Este tipo delictivo como delito leve se configura como una opción idónea para la mediación. La escasa gravedad del asunto permite una mayor simplicidad para la consecución de acuerdos entre los implicados. Y aunque se observe una disminución del total de asuntos, no ha de olvidarse que las lesiones son uno de las infracciones más ventiladas por nuestros tribunales; y por ello la posibilidad de resolverlas a través de los procesos de mediación penal supondrá una descongestión de nuestro sistema de justicia. Aunque ese no es el verdadero e importante motivo por el que nos hemos de guiar para su derivación a los servicios de mediación penal. La mediación penal traerá paz física y psicológica a las víctimas; éstas podrán resolver el conflicto iniciado, sanarán sus heridas y, especialmente, existirá la posibilidad de salvar esa relación entre ellos maltrecha por la comisión de las lesiones.

El resto de las infracciones atribuidas al SMI son de muy variada tipología tales como las coacciones $(11,36 \%)$, daños $(5,12 \%)$, maltrato de obra $(4,23 \%)$, estafa $(3,56 \%)$ o hurto $(2,67 \%)$. 


\begin{tabular}{|c|c|c|}
\hline & & № \\
\hline \multirow{3}{*}{ Lesiones } & Lesiones en violencia intrafamiliar & $2(0,45 \%)$ \\
\hline & Lesiones & $97(21,60 \%)$ \\
\hline & Maltrato de obra & $19(4,23 \%)$ \\
\hline \multirow{5}{*}{ Contra las personas } & Amenazas & $192(42,76 \%)$ \\
\hline & Amenazas en violencia intrafamiliar & $11(2,4596)$ \\
\hline & Coacciones & $51 \quad(11,36 \%)$ \\
\hline & Coacciones en violencia intrafamiliar & $2(0,45 \%)$ \\
\hline & Acoso & $2(0,45 \%)$ \\
\hline Contra el honor & $\begin{array}{c}\text { Injurias y vejaciones injustas violencia } \\
\text { intrafamiliar }\end{array}$ & $5(1,11 \%)$ \\
\hline \multirow{5}{*}{$\begin{array}{l}\text { Contra el patrimonio y el } \\
\text { orden socio-económico }\end{array}$} & Hurto & $12(2,67 \%)$ \\
\hline & Estafa & $16(3,5696)$ \\
\hline & Apropiación indebida & $12(2,6796)$ \\
\hline & Daños & $23 \quad(5,1296)$ \\
\hline & Usurpación & $3(0,6796)$ \\
\hline Contra el medio ambiente & Maltrato animal & $1(0,22 \%)$ \\
\hline \multirow[t]{2}{*}{ Contra la intimidad } & Usurpación de identidad & $1(0,22 \%)$ \\
\hline & TOTAL & 449 \\
\hline
\end{tabular}

Figura 18. Tipología delictiva: Delitos leves. Fuente: Memoria 2015 SMI, p.24.

Con relación a las antiguas faltas, observamos que se sigue la línea previamente expuesta de "cuanta menor gravedad de la infracción existen más procesos de mediación que resuelven amenazas”. Cabe deducir que, respecto a este tipo de conductas delictivas de tan ínfima gravedad, el 23,04\% eran amenazas, seguido por injurias (20,38\%), lesiones (18\%), incumplimiento de obligaciones familiares (13,22\%), coacciones, $(8,86 \%)$, etc.

Estamos ante unos tipos delictivitos de escasa gravedad, acusando incremento de valor infracciones como el incumplimiento de obligaciones familiares o alteración del curso del agua, donde la mediación penal es realmente efectiva. Las relaciones interpersonales van a ser claves para la resolución de este tipo de procesos de mediación 
penal puesto que éstas no han quedado lo suficientemente dañadas por la comisión del hecho delictivo. Por consiguiente, la resolución de estas infracciones no debería de suponer grandes inversiones de tiempo y esfuerzo ya que el acuerdo es algo beneficioso para ambos ante la alternativa de acudir a los Tribunales de Justicia suponiendo un importante coste económico y temporal que la mediación penal libraría a ambos intervinientes.

FALTAS

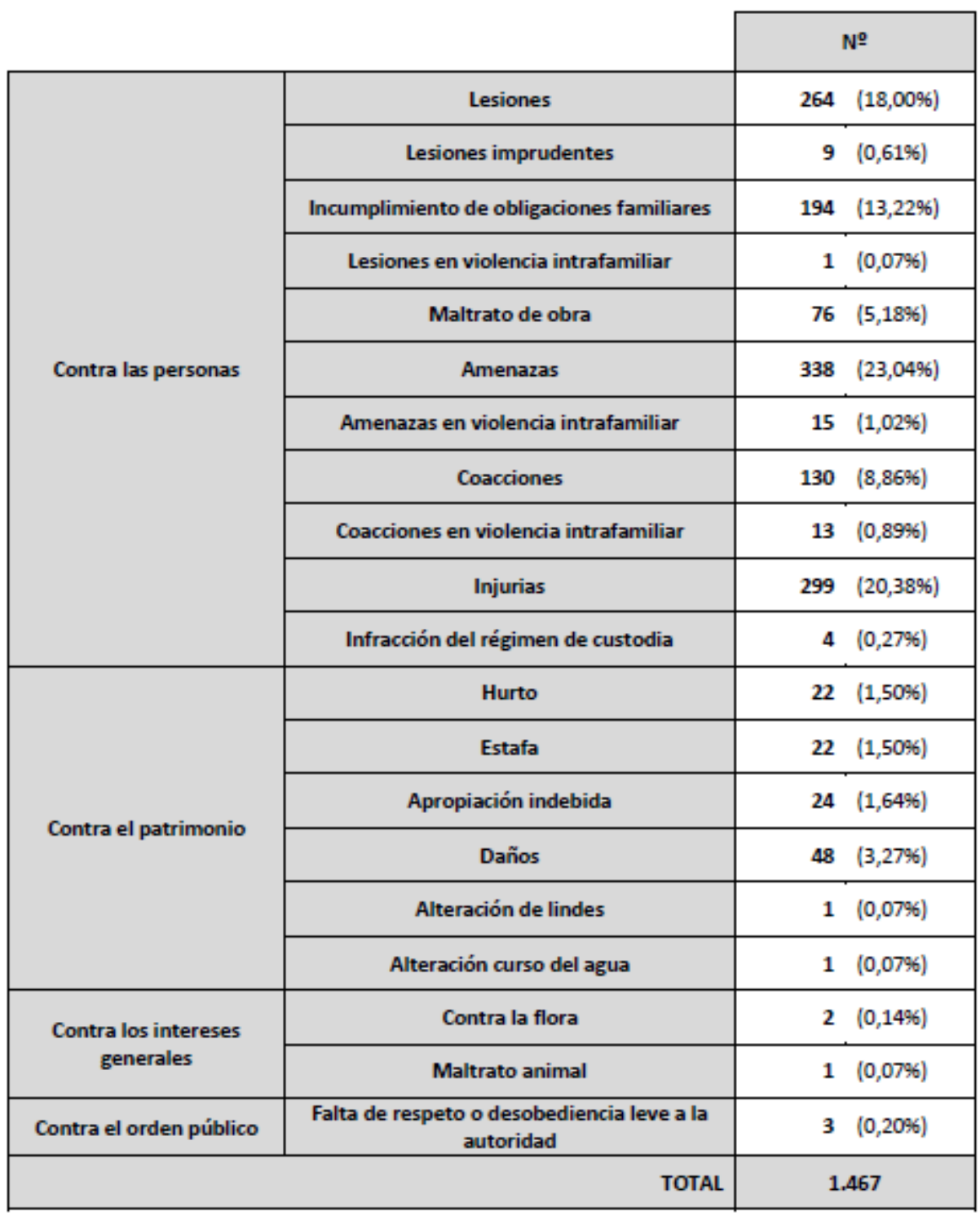

Figura 19. Tipología delictiva: Faltas. Fuente: Memoria 2015 SMI, p.24. 
En cuanto al año 2016 se observa una disminución de la carga de trabajo. Se tramitaron un total de 1414 expedientes, proviniendo 226 de años anteriores y 1231 del año 2016. Casi 300 expedientes menos que el curso anterior y prosiguiendo una línea descendente año tras año motivada en la supresión de las faltas del CP. De dicha cantidad se han cerrado un total de 1171 asuntos; 602 se resolvieron mediante un proceso de mediación penal con un 78\% de acuerdo; mientras que 569 se han cerrado sin un proceso de mediación

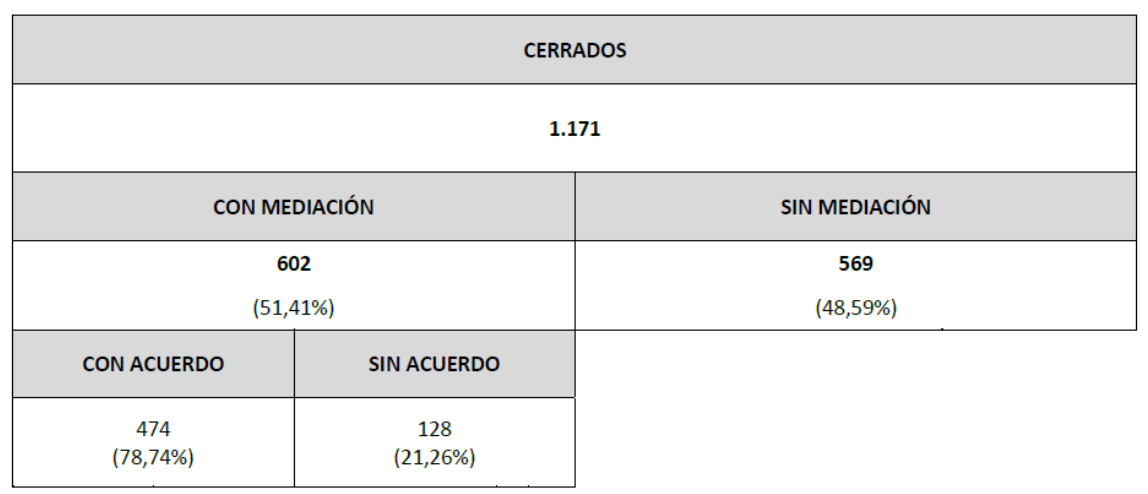

Figura 20. Total de expedientes cerrados. Fuente: Memoria 2016 SMI, p. 7

Aun cuando la derivación sigue recayendo casi en exclusiva en los Tribunales, se puede apreciar un sutil incremento en la iniciativa de las partes. Aspecto relevante el observar que los intervinientes han comenzado a confiar en la mediación como práctica resolutoria de sus conflictos penales. No obstante, y como punto contraproducente, la Fiscalía sigue sin ser parte activa en la derivación de asuntos aun cuando el artículo 3.10 de la ley 50/1981, de 30 de diciembre, por la que se regula el Estatuto Orgánico del Ministerio Fiscal, señala que es competencia del Ministerio Fiscal promover mecanismos de ayuda y asistencia a las víctimas, siendo considerada la Justicia Restaurativa como un mecanismo enfocado a tal fin en los artículos 15 y 29 del ya comentado Estatuto de la víctima del delito. 
La derivación en el año 2016, tanto en Vizcaya -785 asuntos derivados y 758 cerrados- como Guipúzcoa -190 asuntos derivados y 204 cerrados- ha ido decreciendo conforme al año anterior por motivos de diversa índole. El partido judicial de Bilbao ha sido el detonante de la disminución de asuntos en Vizcaya al ser quien ha disminuido su derivación; por el contrario, el resto de partidos judiciales ha mantenido la dinámica de años anteriores confiando en la mediación y el SMI. De los 758 asuntos cerrados, el $51 \%$ de ellos acabó en un proceso de mediación con un 77,78\% de finalización con acuerdo. Guipúzcoa por su parte ha supuesto un descenso más brusco, especialmente en Donostia e Irún por motivos de “disparidad de criterios actualmente existentes entre la judicatura y fiscalía” ${ }^{675}$. De los 204 asuntos cerrados, sólo el 46\% acabó en proceso de mediación, con un 72,34\% de finalización en acuerdo. En la contraparte se encuentra Álava, quien ha mantenido su carga de trabajo con 256 asuntos derivados 209 cerrados gracias a la destacada participación de los juzgados de instrucción de Vitoria-Gasteiz. En el 57\% de los asuntos se efectuó un proceso de mediación, acabando en acuerdo el 86\% de ellos. Podemos señalar que prácticamente la mitad de los asuntos que son derivados al SMI se resuelven a través de un proceso de mediación penal, obteniéndose en la mayoría de ellos un acuerdo satisfactorio para las partes.

${ }^{675}$ Memoría Servicio de..., op. cit., p. 2. 

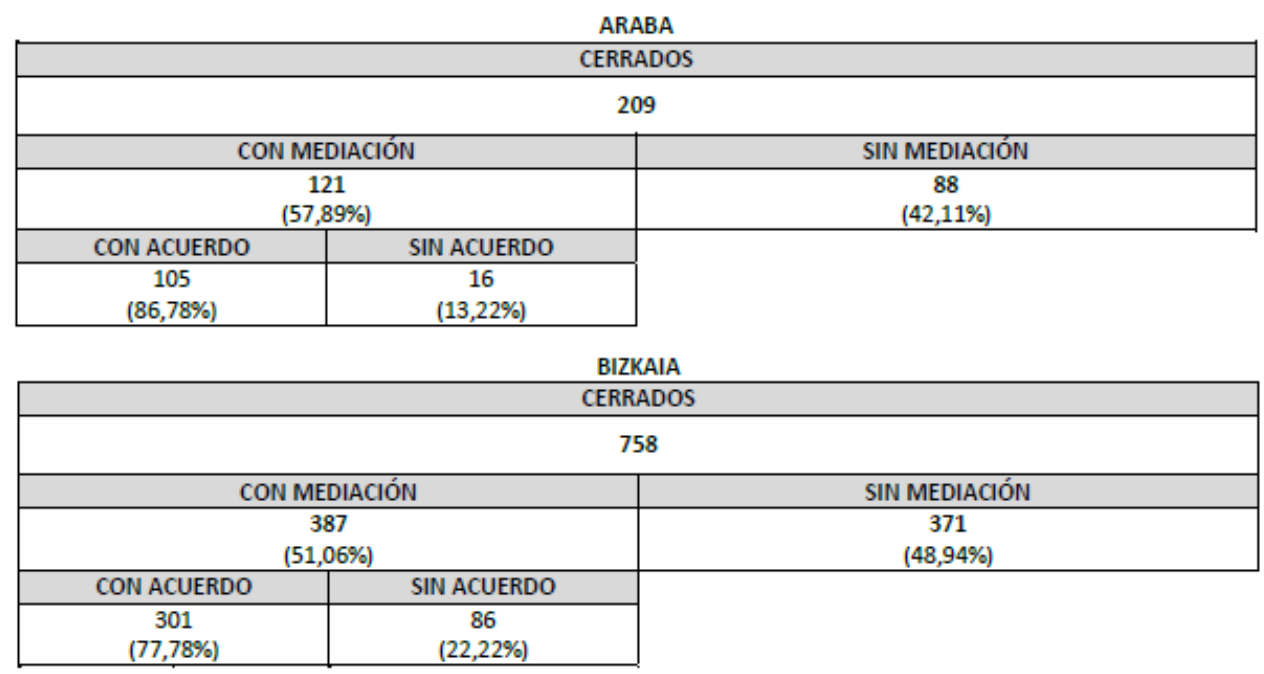

GIPUZKOA

CERRADOS

\begin{tabular}{|c|c|c|}
\hline \multicolumn{3}{|c|}{ CERRADOS } \\
\hline \multicolumn{3}{|c|}{204} \\
\hline \multicolumn{2}{|c|}{ CON MEDIACIÓN } & SIN MEDIACIÓN \\
\hline \multicolumn{2}{|c|}{$\begin{array}{c}94 \\
(46,08 \%)\end{array}$} & $\begin{array}{c}110 \\
(53,92 \%)\end{array}$ \\
\hline CON ACUERDO & SIN ACUERDO & \\
\hline $\begin{array}{c}68 \\
(72,34 \%)\end{array}$ & $\begin{array}{c}26 \\
(27,66 \%)\end{array}$ & \\
\hline
\end{tabular}

Figura 21. Total de expedientes cerrados por provincia. Fuente: Memoria 2016 SMI, p. 8

En cuanto a la tipología delictiva se continúa con la misma tendencia que años atrás. De las 1842 infracciones, el 81\% son delitos leves, correspondiendo una ínfima cuantía a delitos graves y delitos menos graves. 


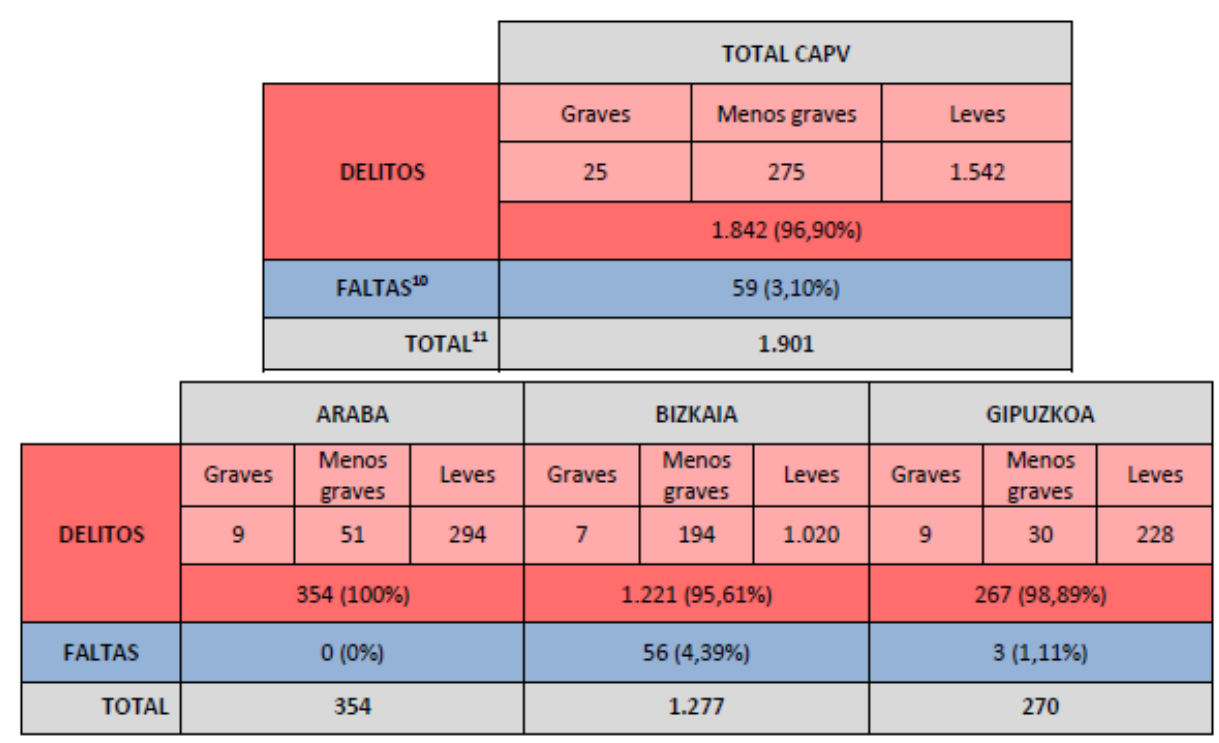

Figura 22. Tipología delictiva. Fuente: Memoria 2016 SMI, p. 17.

Respecto a la tipología delictiva por Territorios Históricos, las cifras son similares a las anteriores. Vizcaya atesora la gran mayoría de infracciones de toda la comunidad, estando también ante una mayoría de delitos leves (casi un 80\%). En la misma línea se sitúan Álava y Guipúzcoa, las cuales, aunque con una cuantía de infracciones total muy por debajo de Vizcaya, sus porcentajes son similares conforme a una mayoría de delitos leves.

Prosiguiendo con la tipología delictiva, podemos encontrarnos un total de 25 delitos graves de variada índole. La mayoría de ellos son lesiones, pero el de mayor aliciente es el asunto de homicidio resuelto por el SMI. Es interesante percatar la resolución de un asunto de tal gravedad a través de un proceso de mediación. En principio se considera la mediación penal como un proceso enfocado en la resolución de delitos de menor gravedad. Pero como se puede advertir el SMI ha iniciado actuaciones enfocadas en superar esta limitación y satisfacer los intereses de los participantes en cualquier tipo delictivo, sin concernir la gravedad del asunto derivado. 


\begin{tabular}{|c|rc|}
\cline { 2 - 3 } \multicolumn{1}{c|}{} & \multicolumn{2}{|c|}{ № } \\
\hline Homicidio & $1 \quad(4,00 \%)$ \\
\hline Lesiones & $15 \quad(60,00 \%)$ \\
\hline Detención ilegal & $1 \quad(4,00 \%)$ \\
\hline $\begin{array}{c}\text { Contra la integridad moral en violencia } \\
\text { intrafamiliar }\end{array}$ & $2 \quad(8,00 \%)$ \\
\hline Estafa & $4 \quad(16,00 \%)$ \\
\hline Apropiación indebida & $1 \quad(4,00 \%)$ \\
\hline $\begin{array}{c}\text { Tenencia, tráfico y depósitos de armas, } \\
\text { municiones o explosivos }\end{array}$ & $1 \quad(4,00 \%)$ \\
\hline
\end{tabular}

Figura 23. Tipología delictiva- Delitos graves. Fuente: Memoria 2016 SMI, p. 18.

En cuanto a los delitos menos graves y los delitos leves se observa unas ciertas similitudes. Las lesiones son la mayoría de las infracciones en delitos menos graves y en delitos leves, aunque en estos últimos las amenazas son las infracciones más derivadas a un proceso de mediación penal. Respecto a los demás delitos, se sigue con las estadísticas de años anteriores. 


\begin{tabular}{|c|c|c|c|c|c|}
\hline & \multicolumn{2}{|c|}{ № } & \multirow[b]{3}{*}{ Lesiones } & \multirow{2}{*}{\multicolumn{2}{|c|}{$N$ 우 }} \\
\hline Lesiones & & $(42,55 \%)$ & & & \\
\hline Lesiones por imprudencia grave & 3 & $(1,09 \%)$ & & 399 & $(25,88 \%)$ \\
\hline Lesiones en violencia intrafamiliar & 22 & $(8,00 \%)$ & Lesiones en violencia intrafamiliar & 16 & $(1,04 \%)$ \\
\hline Amenazas & 12 & $(4,36 \%)$ & \multirow{2}{*}{ Maltrato de obra } & \multirow[b]{2}{*}{121} & \multirow{2}{*}{$(7,85 \%)$} \\
\hline Amenazas en violencia intrafamiliar & 6 & $(2,18 \%)$ & & & \\
\hline Coacciones & 8 & $(2,91 \%)$ & Amenazas & 513 & $(33,27 \%)$ \\
\hline Acoso & 1 & $(0,36 \%)$ & \multirow[t]{2}{*}{ Amenazas en violencia intrafamiliar } & \multirow[t]{2}{*}{27} & \multirow[t]{2}{*}{$(1,75 \%)$} \\
\hline Allanamiento de morada & 3 & $(1,09 \%)$ & & & \\
\hline Calumnias & 1 & $(0,36 \%)$ & Coacciones & 172 & $(11,15 \%)$ \\
\hline $\begin{array}{l}\text { Quebrantamiento de los deberes de } \\
\text { custodia }\end{array}$ & & $(0,36 \%)$ & Coacciones en violencia intrafamiliar & 7 & $(0,45 \%)$ \\
\hline Impago de pensiones & 2 & $(0,73 \%)$ & \multirow[t]{2}{*}{ Acoso } & \multirow[t]{2}{*}{3} & \multirow[t]{2}{*}{$(0,19 \%)$} \\
\hline Hurto & 15 & $(5,45 \%)$ & & & \\
\hline Robo con fuerza & 7 & $(2,55 \%)$ & Usurpación de identidad & 2 & $(0,13 \%)$ \\
\hline Robo con intimidación & 2 & $(0,73 \%)$ & \multirow{2}{*}{$\begin{array}{l}\text { Injurias y vejaciones injustas en violencia } \\
\text { intrafamiliar }\end{array}$} & \multirow[t]{2}{*}{22} & \multirow{2}{*}{$(1,43 \%)$} \\
\hline Robo y hurto de uso de vehículos & 1 & $(0,36 \%)$ & & & \\
\hline Estafa & 11 & $(4,00 \%)$ & Hurto & 46 & $(2,98 \%)$ \\
\hline Apropiación indebida & 30 & $(10,91 \%)$ & Estafa & 58 & $(3,76 \%)$ \\
\hline$\frac{\text { Daños }}{\text { Societario }}$ & & $\begin{array}{l}(7,64 \%) \\
(0,36 \%)\end{array}$ & Apropiación indebida & 31 & $(2,01 \%)$ \\
\hline Contra la seguridad vial & 2 & $(0,73 \%)$ & Defraudación de electricidad, gas, aguas... & 3 & $(0,19 \%)$ \\
\hline Contra la seguridad pública & 1 & $(0,36 \%)$ & \multirow{2}{*}{ Alteración de lindes } & 2 & \multirow{2}{*}{$(0,13 \%)$} \\
\hline $\begin{array}{l}\text { Falsificación de documento público por } \\
\text { autoridad o funcionario }\end{array}$ & & $(1,45 \%)$ & & 2 & \\
\hline Falsificación de documento privado & 1 & $(0,36 \%)$ & Daños & 104 & $(6,74 \%)$ \\
\hline Quebrantamiento de condena & 1 & $(0,36 \%)$ & Usurpación & 15 & $(0,97 \%)$ \\
\hline Atentado & 1 & $(0,36 \%)$ & Maltrato animal & 1 & $(0,06 \%)$ \\
\hline Atentado contra funcionario público & 1 & $(0,36 \%)$ & & & \\
\hline
\end{tabular}

Figura 24. Tipología delictiva- Delitos menos graves y leves. Fuente: Memoria 2016 SMI, pp. 19-20.

Como conclusión de este examen de las actividades llevadas a cabo los años 2014, 2015 y 2016 por el SMI, se han aportado un conjunto de ventajas temporales y económicas, desatascando los sobresaturados Tribunales. Pero la mayor virtud de este servicio de mediación es la asistencia a las víctimas, las cuales recobran importancia en el sistema de justicia. De otra parte, los infractores podrán acudir a un procedimiento en el cual el arrepentimiento, la reparación y la resocialización son aspectos claves, suponiendo un gran paso en su reinserción social.

Se ha de proseguir con este tipo de actuaciones, asentándose el servicio de mediación penal e predicando una mayor potenciación en relación a los delitos de mayor gravedad. Así se podrá adaptar la mentalidad de los ciudadanos a las nuevas 
corrientes nacientes en diversos países como Canadá o Nueva Zelanda, acondicionando nuestro sistema para la implementación futura de otras figuras restaurativas más beneficiosas para la víctima, el infractor y la comunidad.

\subsection{Experiencias en Castilla y León: el Servicio de Mediación Penal de Castilla y León-AMEPAX}

En la Comunidad Autónoma de Castilla y León la institución de la mediación penal ha sido impulsada a través de la Asociación de Mediación para la Pacificación de Conflictos de Burgos (en adelante AMEPAX) ${ }^{676}$. Dicha institución surgió en el año 2006, con base en la ciudad de Burgos, con el fin de implantar allí primero, y después en Castilla y León, la mediación como un método para la resolución de conflictos. Gracias al esfuerzo de AMEPAX se están resolviendo conflictos a través de una vía más cercana y humana, generando un espacio de comunicación entre los partícipes del conflicto y otorgando el debido protagonismo a las víctimas.

El protocolo de actuación utilizado se ha ido adaptando a las características propias de cada conflicto y presentando la mediación como un modelo complementario al sistema de justicia penal. Los conflictos son derivados desde los Tribunales por la Fiscalía, quien pone en contacto con la víctima e infractor para mostrarles cómo va a ser el procedimiento y las ventajas que éste les puede aportar.

La asociación AMEPAX publica en su página web los resultados de sus actuaciones a través de unas memorias anuales. Vamos a utilizar las dos últimas memorias activas a la hora de elaborar este trabajo, las de 2013, 2014 y 2015.

\footnotetext{
676 Más información en la página web de la asociación https://sites.google.com/site/justiciarestaurativaamepax
} 
En el año $2013^{677}$ se derivaron 29 asuntos, siendo resueltos de forma satisfactoria un total de 22, habiendo dos asuntos en los que no se pudo iniciar por la imposibilidad de localizar a una de las partes, y otro que estaba pendiente en el momento del inicio de la memoria, no teniendo datos acerca de su desarrollo. De estos datos podemos indicar que en un $85 \%$ de los casos se inició la mediación penal. Hay que añadir que de los 29 asuntos, 26 eran sobre faltas, mientras que sólo versaban 3 sobre delitos, obteniéndose una solución exitosa en uno de ellos. Respecto a las faltas el éxito es rotundo ya que se han resuelto favorablemente el 91\% de los casos. En general podemos señalar que se ha mantenido el nivel de resolución de asuntos alcanzado en años anteriores ${ }^{678}$. A continuación incluimos una serie de gráficas elaboradas por AMEPAX que detallan con más exactitud los datos anteriormente indicados.

\section{Servicio de Mediación Penal de Castilla y León-Amepax (G09463548)}

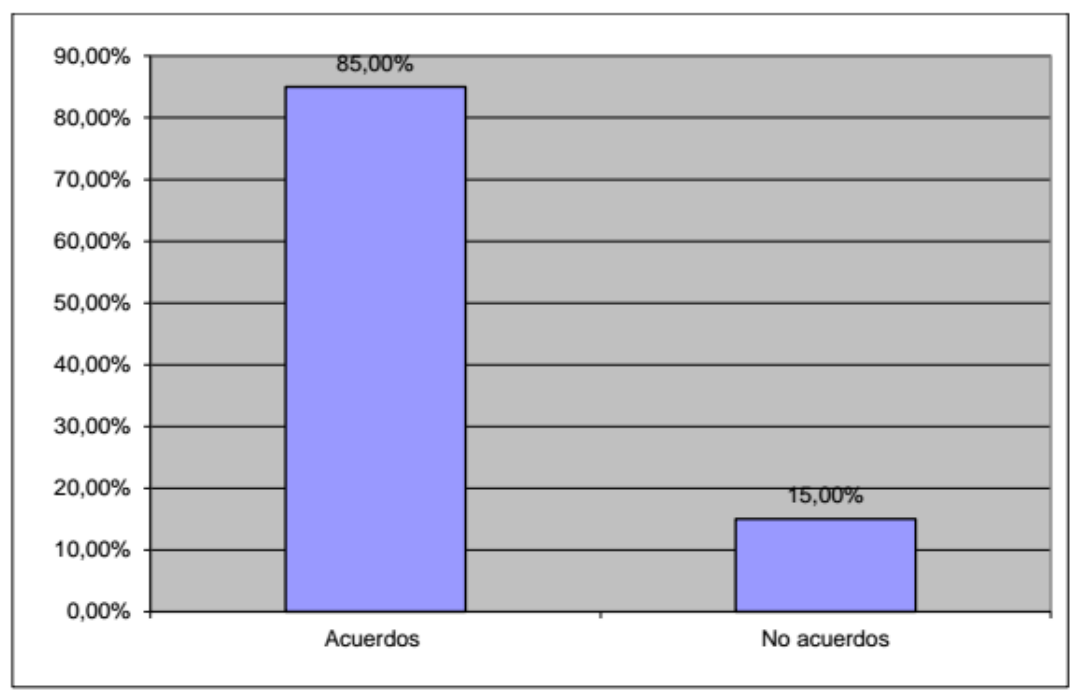

Figura 25. Porcentaje de acuerdos en la mediación penal. Fuente: Memoria 2013 AMEPAX, p.47.

La mayoría de los delitos no han acabado exitosamente (67\%), mostrando una dificultad para la consecución de acuerdos por parte de las partes implicadas en el

\footnotetext{
${ }^{677}$ Memoria del Servicio de mediación penal de Castilla y León-Amepax del año 2013. Disponible en https://sites.google.com/site/justiciarestaurativaamepax

${ }^{678}$ En el año 2012 se recibieron 26 asuntos; de ellos se pudieron intentar 23 acabando en éxito 20. En el año 2011, se recibieron 23 asuntos, 21 de ellos se intentaron y 18 acabaron en una reparación. Para más memorias de otros años acudir al registro de memorias de AMEPAX disponible en página web de la asociación ya citada.
} 
proceso, siendo de interés su análisis. La propia memoria nos señala que la mediación es perfecta para infracciones de mayor gravedad ${ }^{679}$, pero por los datos que nos ofrece, podemos observar que en las faltas (infracciones de escasa gravedad), el éxito de acuerdo se establece en un 91\%, mientras que en los delitos en un 33\%. Se puede deducir que, cuanta mayor gravedad, existe una mayor dificultad para la consecución de un acuerdo que repare el conflicto. Tras estos datos, entendemos a la mediación como un método obvio para la resolución de conflictos de escasa o leve gravedad, donde el daño producido a la víctima es menor y los intereses de las partes pueden ser reparados y consensuados con mayor facilidad, así como las relaciones entre los participantes en el acto suelen ser de parentesco o amistad, siendo, por tanto, más sencillo que resuelvan el conflicto y reestablezcan sus relaciones.

\footnotetext{
${ }^{679}$ La memoria nos indica, en la página 60, que "en los delitos más graves es cuando más puede ayudar la justicia restaurativa a sanar sus heridas y superar el trauma". No negamos que a la víctima le pueda servir la mediación para superar los efectos negativos que el conflicto le ha creado, pero los números sí que nos muestran que es más difícil llegar a un acuerdo que solucione el problema, no siendo en modo alguno positivo para el aspecto psicológico de la víctima ni para la resocialización del infractor.
} 

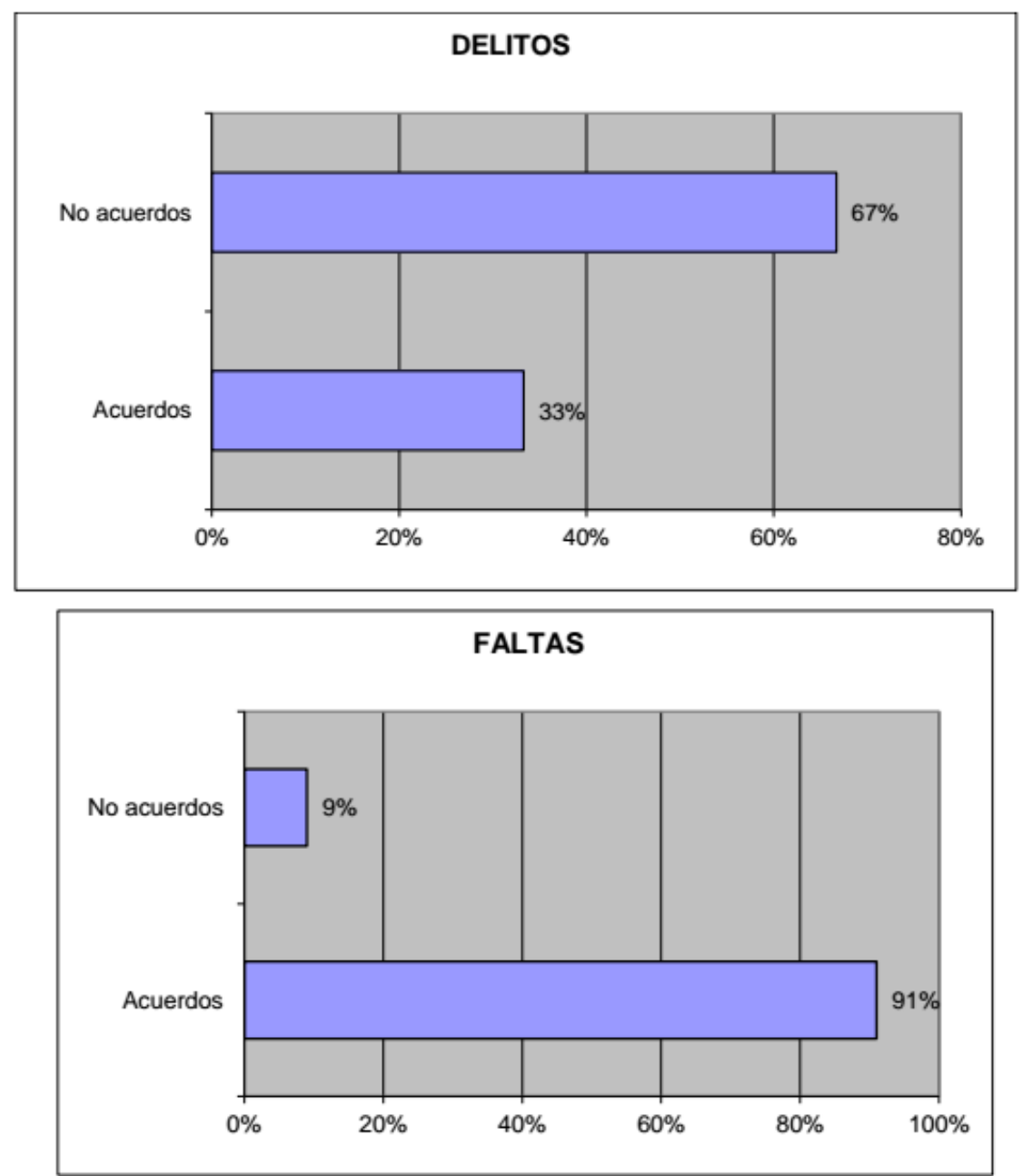

Figura 26. Porcentaje de delitos y faltas acabadas en “acuerdos” o en “no acuerdos”. Fuente: Memoria 2013 AMEPAX, p.48.

En cuanto a las solicitudes, la mayorías de ellas venían procedentes de la Fiscalía, que era quien derivaba los asuntos, pero desde 2007 esta inercia fue modificándose, acrecentando en mayor medida las solicitudes de particulares, llegando a ser de un 70\%, los cuales veían la opción de resolver su conflicto a través de los servicios de mediación penal ofrecidos por AMEPAX. Es llamativo pues está permitiendo que sean los propios ciudadanos quienes acudan interesadamente a la resolución de sus conflictos a través de prácticas restaurativas. Eso sí, en caso de una 
petición particular, los miembros de AMEPAX se pondrán en contacto directo con fiscales y jueces para la valoración del caso y la posibilidad ${ }^{680}$.

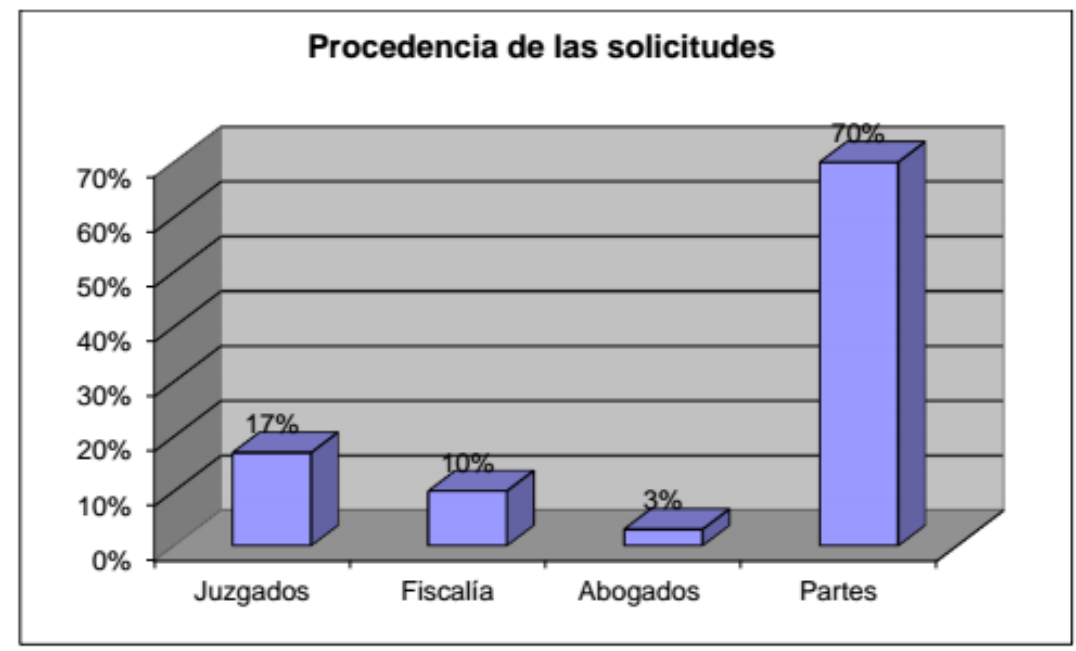

Figura 27. Procedencia de las solicitudes. Fuente: Memoria 2013 AMEPAX, p. 49

En un principio, el servicio de AMEPAX decidió implementar progresivamente la mediación a través de la resolución de conflictos de menor gravedad, tales injurias, calumnias, delitos contra el patrimonio, amenazas, agresiones y lesiones leves. Pero, con el transcurso del tiempo, se han ido ampliando las tipologías delictivas, con especial hincapié en relación a la gravedad delictiva.

Como observamos en el siguiente gráfico, las lesiones son el tipo de infracciones más cometidas por los victimarios que acudieron a un proceso de mediación, existiendo también un alto número de infracciones de injurias y amenazas. Los demás tipos de infracciones han disminuido respecto a los años anteriores excepto en relación a los hurtos, que en el año 2012 se situaba en un $9 \%{ }^{681}$ y en el 2013 ha ascendido a un 11\%.

\footnotetext{
${ }^{680}$ DOMINGO DE LA FUENTE, V. “Servicio de justicia restaurativa de Castilla y León-AMEPAX”, en V. Cervelló Donderis (Dir.), Cuestiones prácticas para la..., op. cit., pp. 353-377, esp. p. 360.

${ }^{681}$ Datos obtenidos de la memoria del año 2012, p. 62.
} 


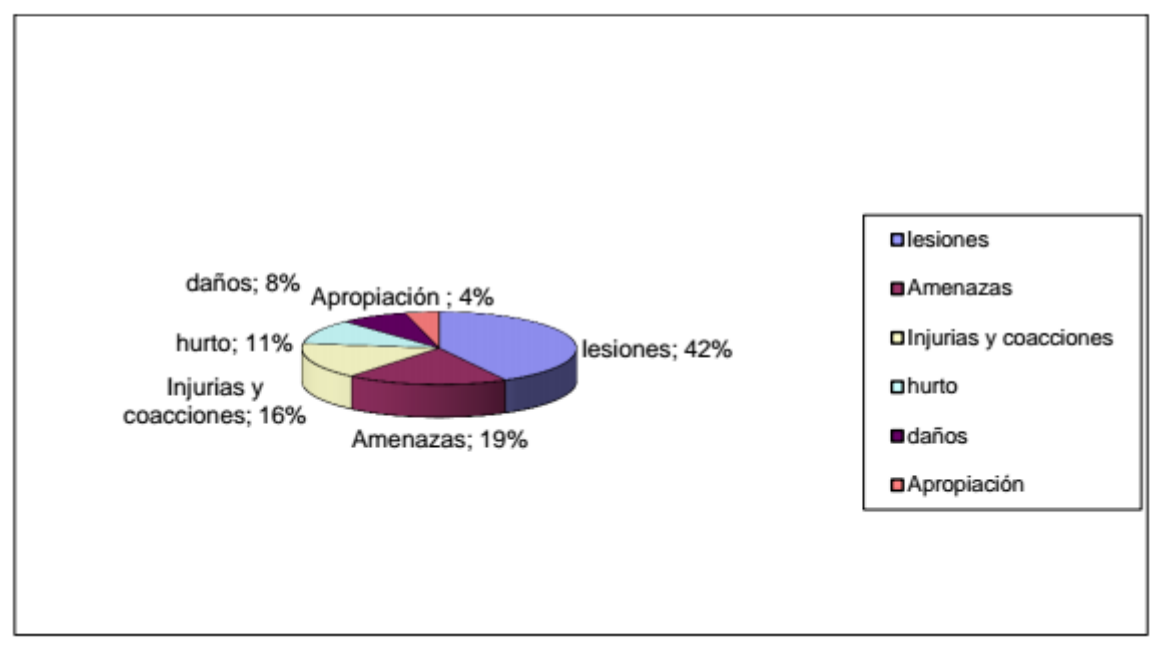

Figura 28. Tipología delictiva. Fuente: Memoria 2013 AMEPAX, p. 50

En relación a los tipos de acuerdo, hemos de empezar a señalar que es muy arduo alcanzar un acuerdo satisfactorio para ambas partes. De este modo se puede encontrar que asuntos sencillos no logran a un acuerdo o el acuerdo no es satisfactorio; y otros en cambio más complicados tienen resoluciones muy satisfactorias o provechosas para ambas partes $^{682}$.

En general podemos señalar que la mayoría (53\%) son acuerdos de actividad y moral. En el 97\% de los acuerdos hay reparación moral, mientras que sólo en un 3\% existe solamente una reparación económica. Estos nos muestra que la mayoría de las víctimas precisan una reparación moral antes que económica; es decir, requieren poder sanar los daños morales que les ha causado la infracción, ser escuchadas, desahogarse, y eso no se consigue con dinero, sino con actuaciones psicológicas. La mayoría de acuerdos que hace referencia la memoria se obtienen bajo la fórmula de en prestaciones del infractor a la víctima. No obstante también cabe encontrar un acuerdo mutuo, en los que ambos participantes acuerdan hacer o no hacer algo, lo cual normalmente son conductas de convivencia.

${ }^{682}$ DOMINGO DE LA FUENTE, V. “Servicio de justicia restaurativa ... op, cit, pp. 353-377, esp. pp. 360-361. 
Con este tipo de acuerdos se busca "educar" al infractor a través de la visualización del daño y de la reparación de éste. Muchas víctima no ambicionan una cuantía económica o una actividad sino que su verdadero objetivo es que el infractor se resocialice y no delinquir de nuevo, no sólo por el propio infractor, sino por otras posibles víctimas. No desean que otras personas vuelvan a padecer los duros efectos que supone sufrir una infracción.

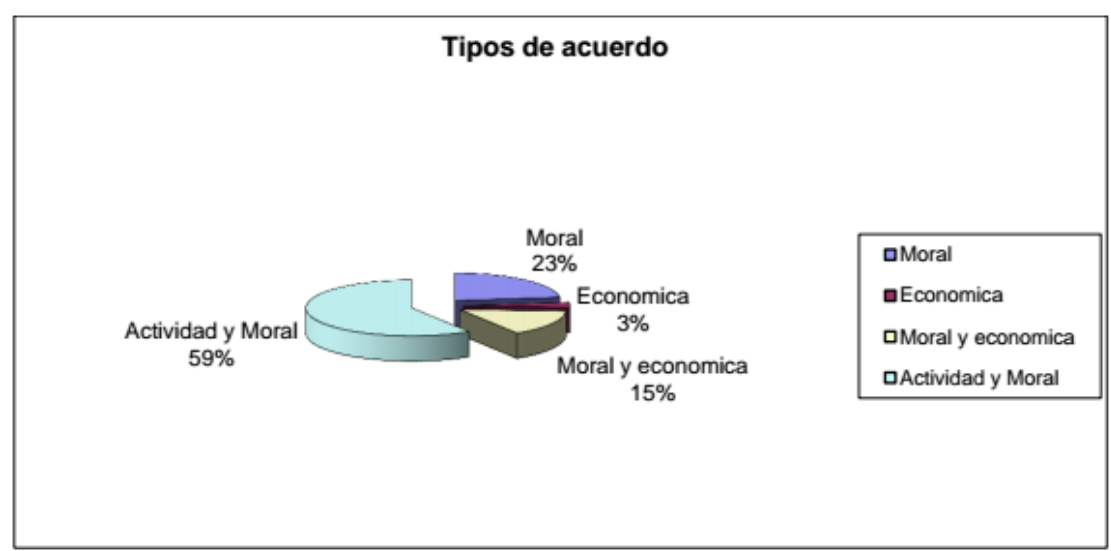

Figura 29. Procedencia de las solicitudes. Fuente: Memoria 2013 AMEPAX, p. 51

En cuanto a los tipos de mediación, ésta puede ser desarrollada de forma directa o indirecta, dependiendo de las necesidades y peticiones de la víctima. En AMEPAX también permiten el desarrollo por estas dos vías. Como podemos ver en el gráfico, el 48\% de los casos se han realizado a través de mediación indirecta, pudiendo elegirse esta modalidad por diferentes variables, como por ejemplo no querer tener un contacto directo con el infractor, no estar en la ciudad y utilizar un representante o que el mediador sea el que haga estas funciones o por la realización de las sesiones a través de carta, teléfono o medios telemáticos.

Es importante señalar como la mayoría de los ciudadanos prefieren acudir a una mediación directa, siendo conocedores así en primera persona del desarrollo del proceso y pudiendo establecerse un diálogo productivo que ayude a sanar los daños provocados 
por el conflicto, aunque en la práctica este anhelo no pueda satisfacerse, debiendo de conformarse con la ejecución de una mediación indirecta.

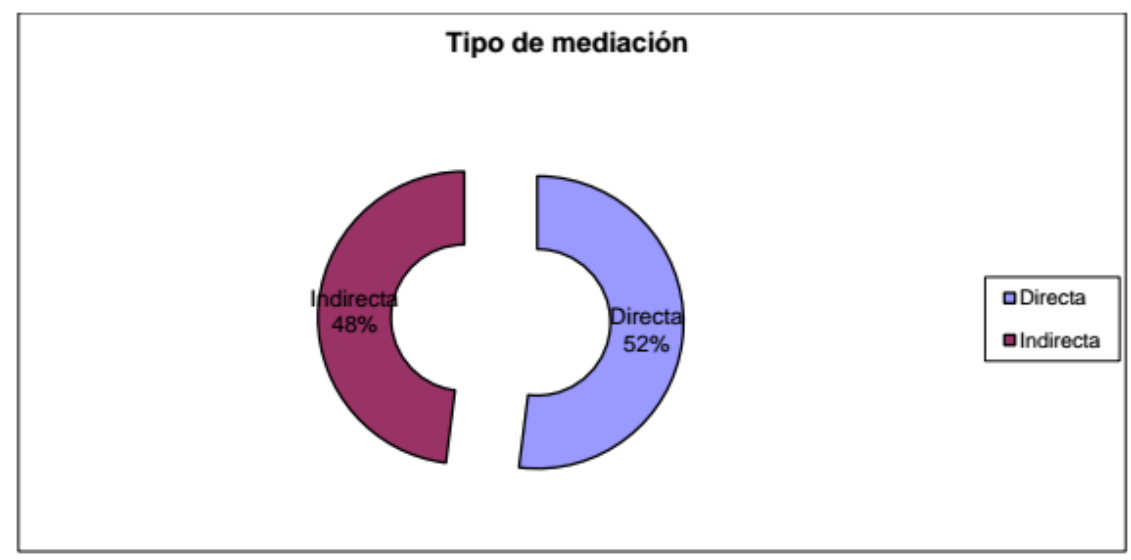

Figura 30. Procedencia de las solicitudes. Fuente: Memoria 2013 AMEPAX, p. 52

En el año 2014 los datos volvieron a ser realmente positivos, manteniéndose la línea de años anteriores gracias a la derivación de 32 asuntos. De esos 32 se iniciaron 24 proceso de mediación y 21 de ellos fueron resueltos satisfactoriamente. Podemos decir por tanto que en el 88\% de los asuntos derivados se pudo iniciar la mediación.

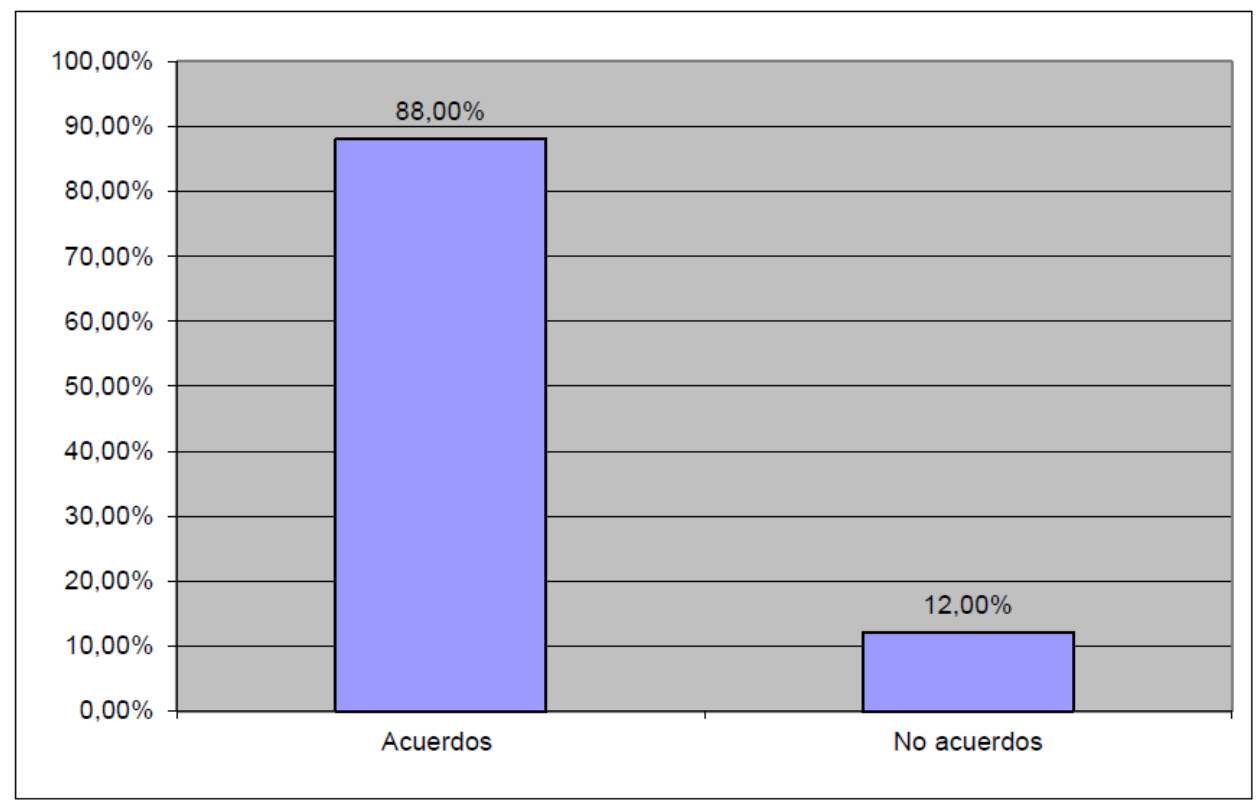

Figura 31. Inicio de la mediación penal. Fuente: Memoria 2014 AMEPAX, p. 35 
Conforme a la tipología delictiva, AMEPAX ha actuado en tres delitos. Podemos observar la complejidad existente para la resolución de delitos a través de procesos de mediación. Todavía no existe en España una clara confianza en el uso de estos métodos para la resolución de conflictos. A ello se une la dificultad de encontrar y hacer llegar al infractor la posibilidad de resolución del conflicto limitan mucho el uso de la mediación.

Se ha de trabajar para superar estos escollos. Es inadmisible que un proceso de mediación no se inicie por la dificultad o imposibilidad de contactar con el infractor pues estamos ante una opción para ambos, una opción de sanar y resocializar. Las ventajas que todo proceso de mediación puede suponer para ambos son motivo suficiente para la utilización todos los medios posibles para conseguir el inicio del proceso de mediación. La única excusa posible para el no inicio de la mediación ha de ser la negativa a éste por parte de alguno de los intervinientes.

Como vemos en la tabla siguiente, de los 3 delitos que han tratado en AMEPAX, se ha llegado a un acuerdo en uno de ellos. Un dato bajo para las opciones que nos ofrece la mediación y que nos demuestra la dificultad de resolver conflictos de cierta gravedad a través de esta práctica. 


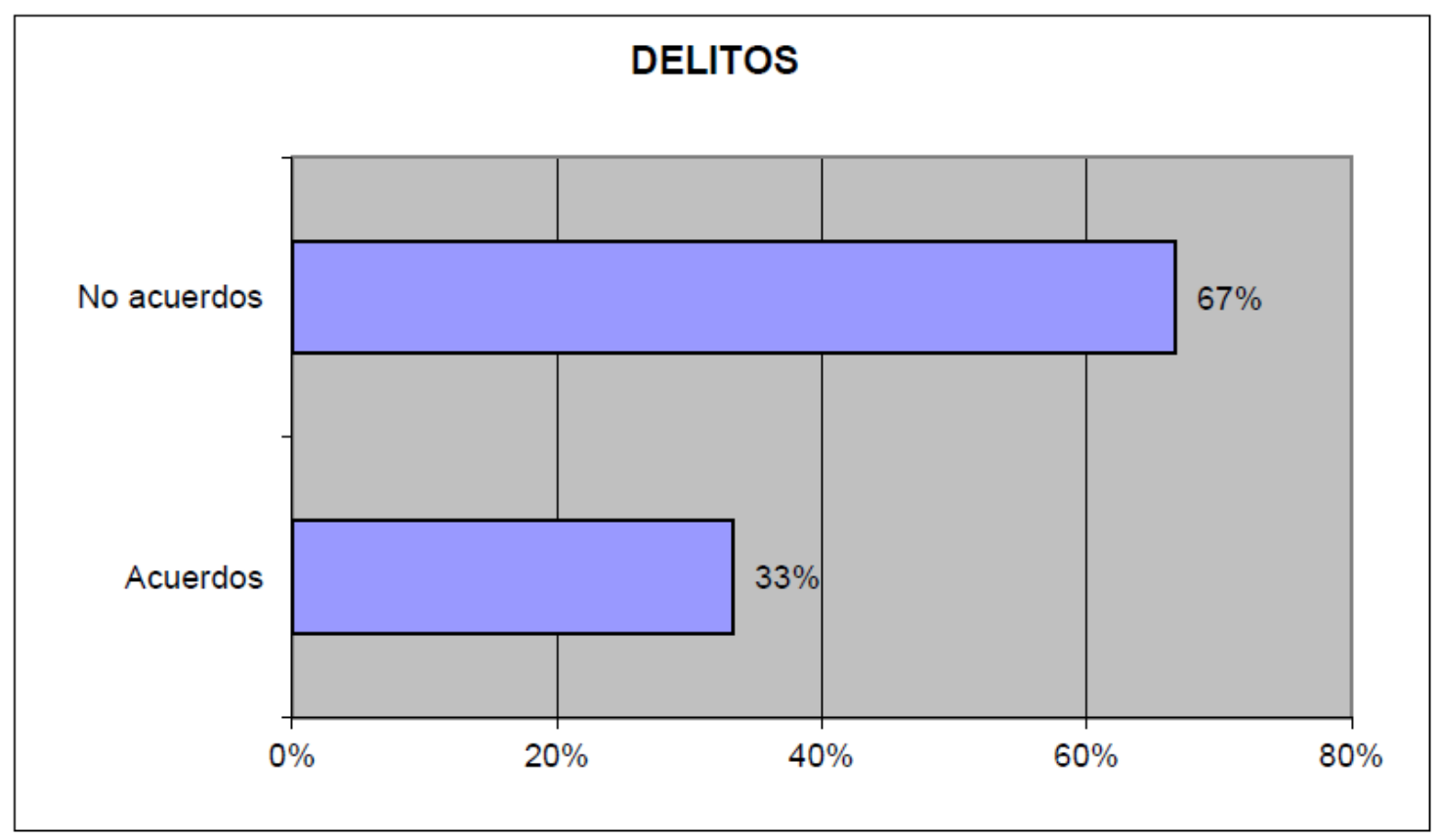

Figura 32. Resolución de delitos. Fuente: Memoria 2014 AMEPAX, p. 36

En relación con las antiguas faltas los datos cambian. Se han derivado 21 faltas, acabando de manera exitosa 19 de ellas. Está claro que a menor gravedad, mayores opciones de resolución positiva, algo que ya se ha indicado con anterioridad en numerosas ocasiones. Ello se justifica en la menor afectación de los sentimientos y/o emociones de los sujetos implicados, existiendo una mayor facilidad de llegar a un acuerdo para la resolución del conflicto nacido. El dolor de la víctima es menor por lo general y no va a ser un impedimento tan considerable para llegar a un acuerdo. 


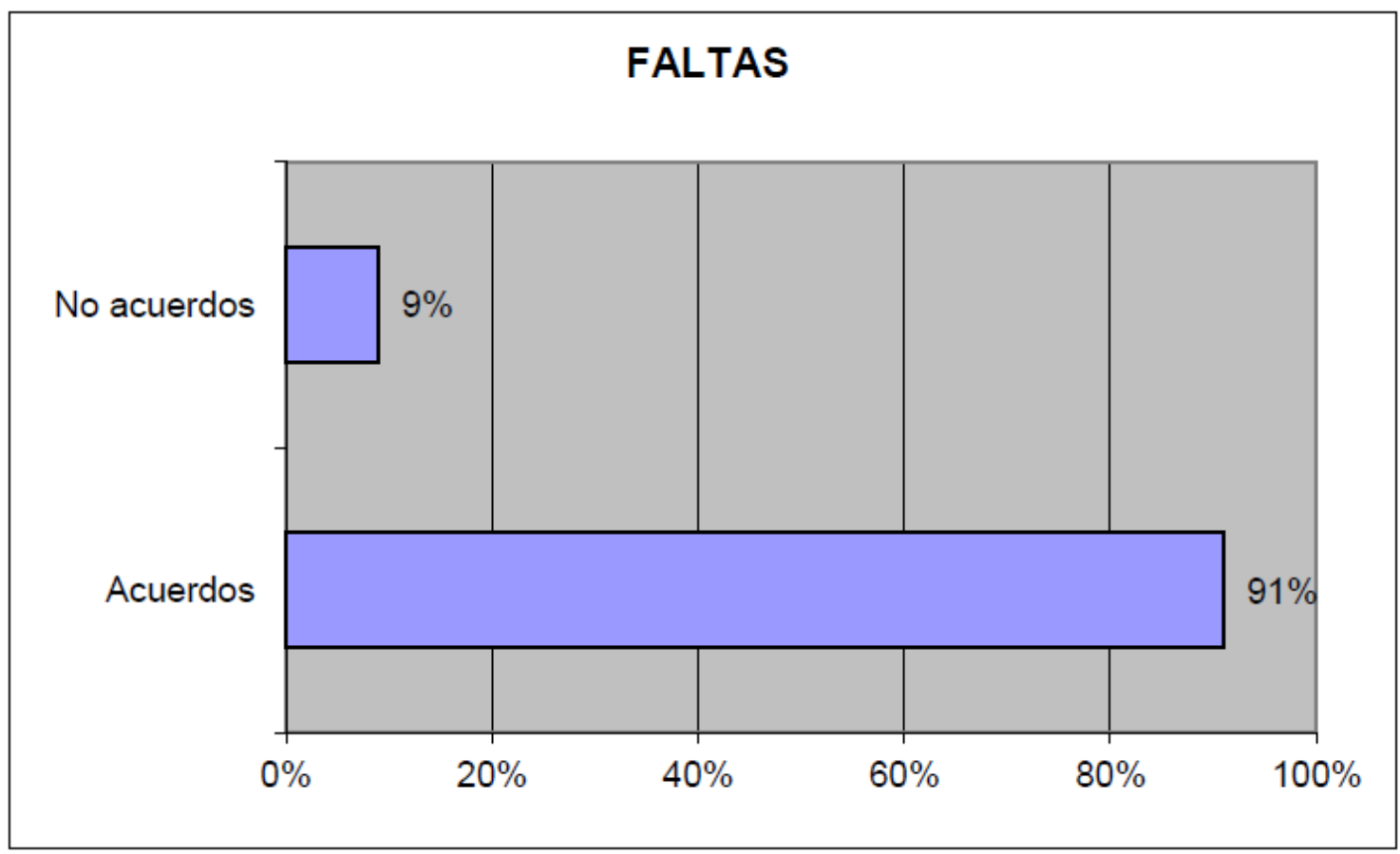

Figura 33. Resolución de faltas. Fuente: Memoria 2014 AMEPAX, p. 36

En cuanto a la derivación de los asuntos, podemos señalar que en el año 2014, la Fiscalía ha vuelto a ser el órgano “derivador” de la mediación penal a consecuencia que el $40 \%$ de los asuntos que han llegado a las oficinas de AMEPAX vienen derivados por su parte. Un dato muy interesante al observar el apoyo que realiza esta institución para promover la mediación penal.

Los juzgados también impulsan la mediación, derivando una gran cantidad de asuntos, exactamente un 30\% de ellos. El 30\% restante de los asuntos derivados se pueden dividir en un $20 \%$ las partes y un $10 \%$ los abogados. Este último dato es interesante puesto que observamos que la derivación por parte de los abogados es cada vez mayor, encontrándonos ante un aumento de la confianza por parte de los letrados. Esto es algo imprescindible pues, para que exista un éxito en cuanto al impulso de la mediación penal, es necesario que los abogados se impliquen en ello. 


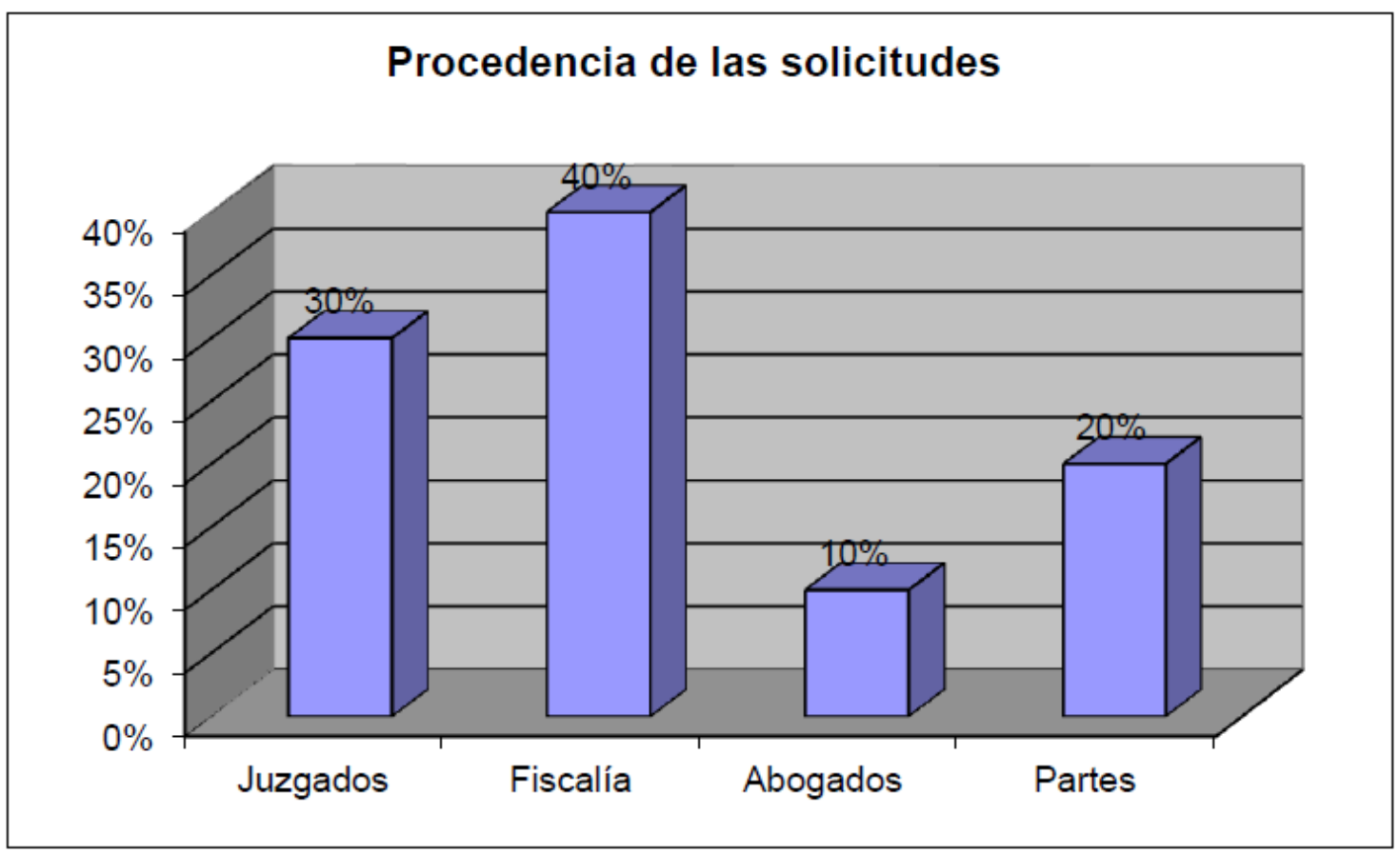

Figura 34. Procedencia de las solicitudes. Fuente: Memoria 2014 AMEPAX, p. 36

Pasando a la tipología de las infracciones, las amenazas y las injurias son las infracciones más destacadas con un 42\% y 25\% respectivamente. Es algo usual advertir estos datos ya que no sólo en mediación son las infracciones “estrella”, sino que en los propios juzgados son una ocupación diaria para los jueces. No dejan de representar “choques” de leve/media gravedad en las relaciones humanas, las cuales suelen quedar sin consecuencias pero que los ciudadanos prefieren resolver por la vía de los juzgados o la mediación penal.

Tanto los hurtos (12\%) como las estafas (4\%) siguen potenciándose. Es difícil prever el motivo de este crecimiento, pero podemos indicar que, a tenor de la situación de crisis económica actual, éste puede ser un motivo para su incremento. Ello, tanto en sede judicial como extrajudicial, ha dejado en un plano secundario los daños (4\%) y las lesiones (13\%), los cuales se mantienen e incluso descienden con el transcurso de los años. 


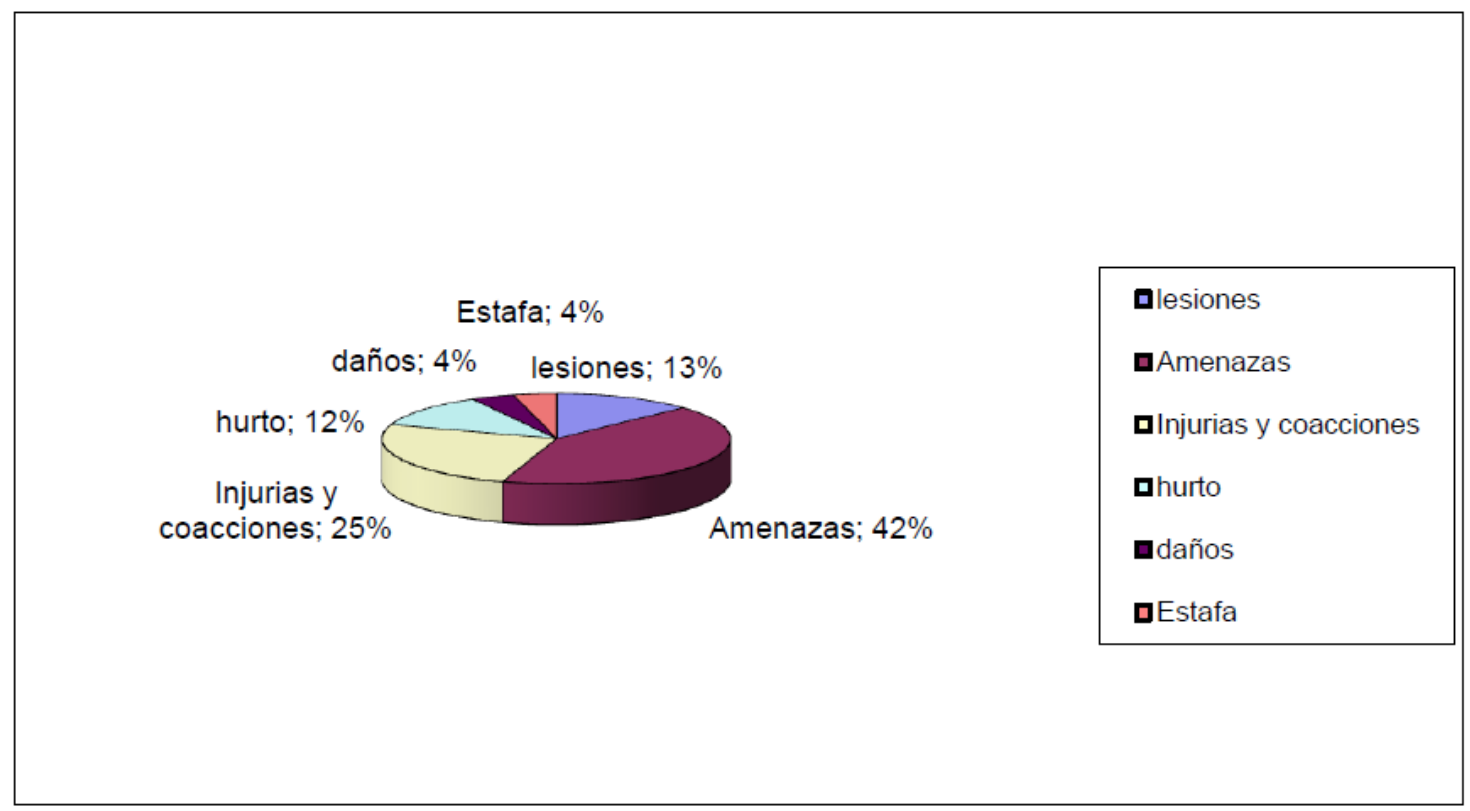

Figura 35. Tipología de las infracciones. Fuente: Memoria 2014 AMEPAX, p. 38

En cuanto a los acuerdos, al seguir la línea de años anteriores, sólo se ha de señalar que sigue prevaleciendo el acuerdo compuesto por actividad y compensación moral (48\%), quedando relegado a un 2\% la compensación económica.

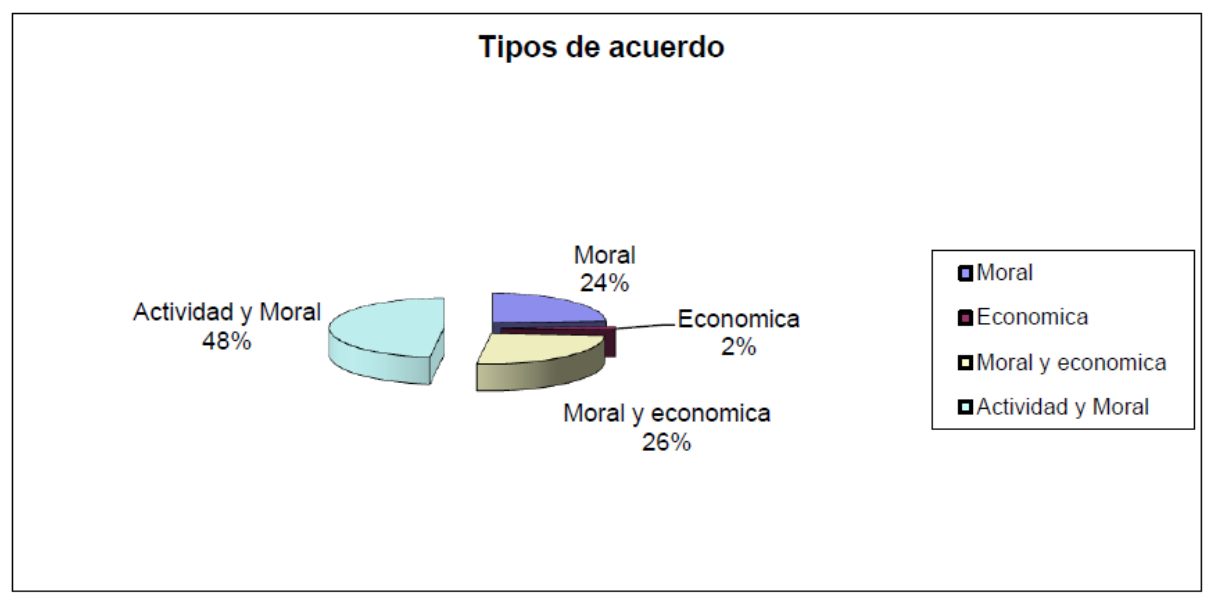

Figura 36. Tipos de acuerdo. Fuente: Memoria 2014 AMEPAX, p. 39 
El año 2015 el Servicio de AMEPAX prosiguió con su labor afianzándose gracias al mantenimiento de la prestación de un proceso de mediación penal en favor de la ciudadanía. 31 asuntos fueron derivados al Servicio, siendo intentados 25 de ellos y 23 resueltos con éxito.

Respecto a la tipología delictiva, se ha de indicar un éxito rotundo respecto a los delitos pues, a pesar de la leve gravedad de éstos, de las 3 infracciones derivadas todas ellas acabaron en un acuerdo exitoso. Así en el año 2015 se consigue finalizar con acuerdo en todos los delitos que han sido mediados, algo no sucedido en los años anteriores y nos muestra el gran avance y posibilidades que tienen tanto la figura como el Servicio de AMEPAX.

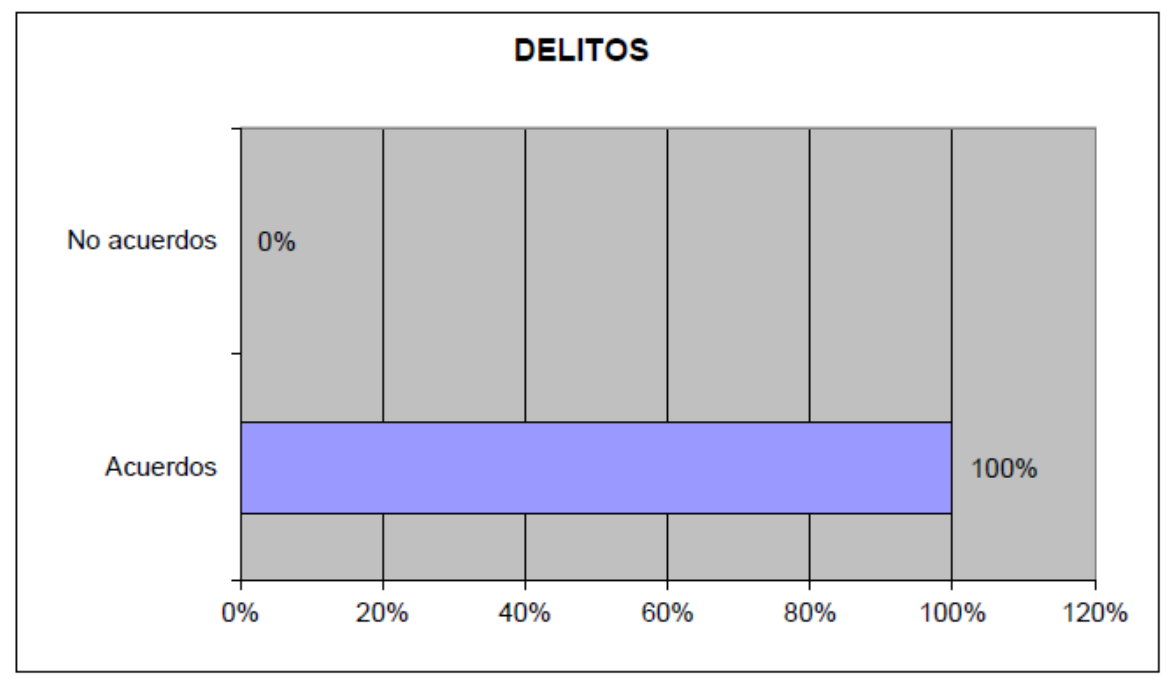

Figura 37. Resolución de delitos. Fuente: Memoria 2015 AMEPAX, p. 39

Respecto a las antiguas faltas la línea seguida es similar a la de anteriores ocasiones. En esta ocasión han sido 22 infracciones mediadas con un total de 20 finalizadas con éxito. Una vez más queda demostrado la mayor facilidad de obtención de un acuerdo en este tipo de infracciones leves. 


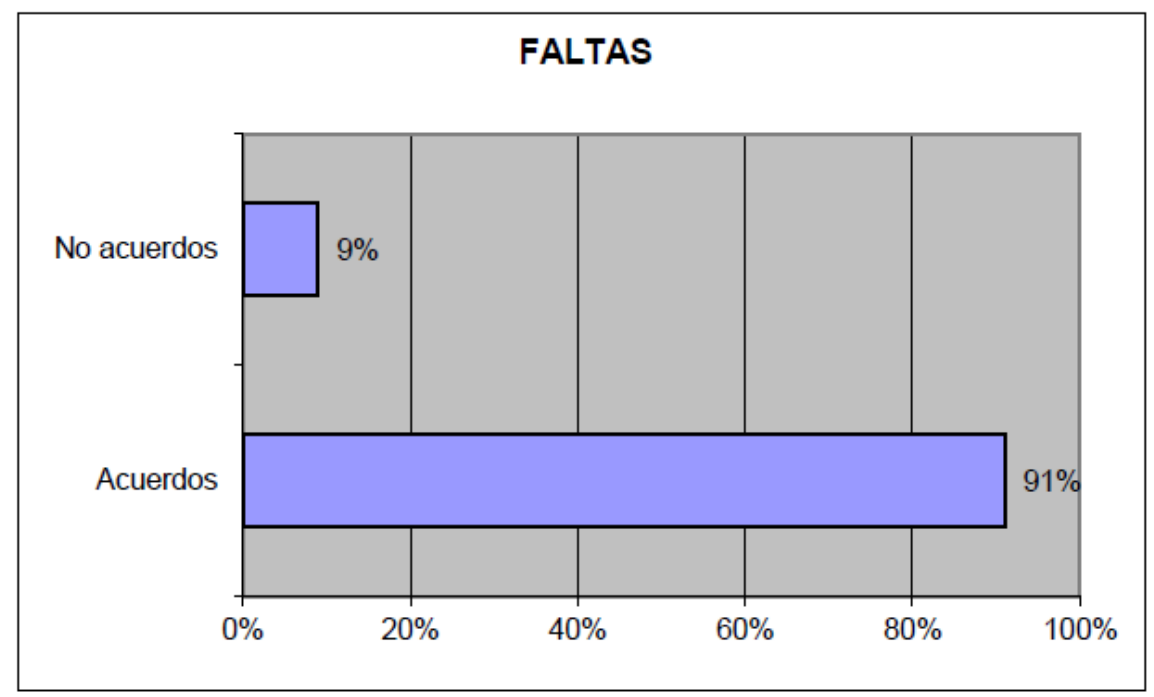

Figura 38. Resolución de faltas. Fuente: Memoria 2015 AMEPAX, p. 39

Respecto a la procedencia de las solicitudes, en el año 2015 los juzgados se sitúan en primer lugar con un total del $40 \%$ de los asuntos derivados, mostrando el interés de estos en el fomento de la mediación como práctica complementaria de resolución de conflictos. A resaltar que un $18 \%$ de las solicitudes provengan de las partes. Es de vital importancia que los ciudadanos conozcan las virtudes de la mediación y las posibles ventajas que pueden obtener en el supuesto de acudir a un proceso de este tipo.

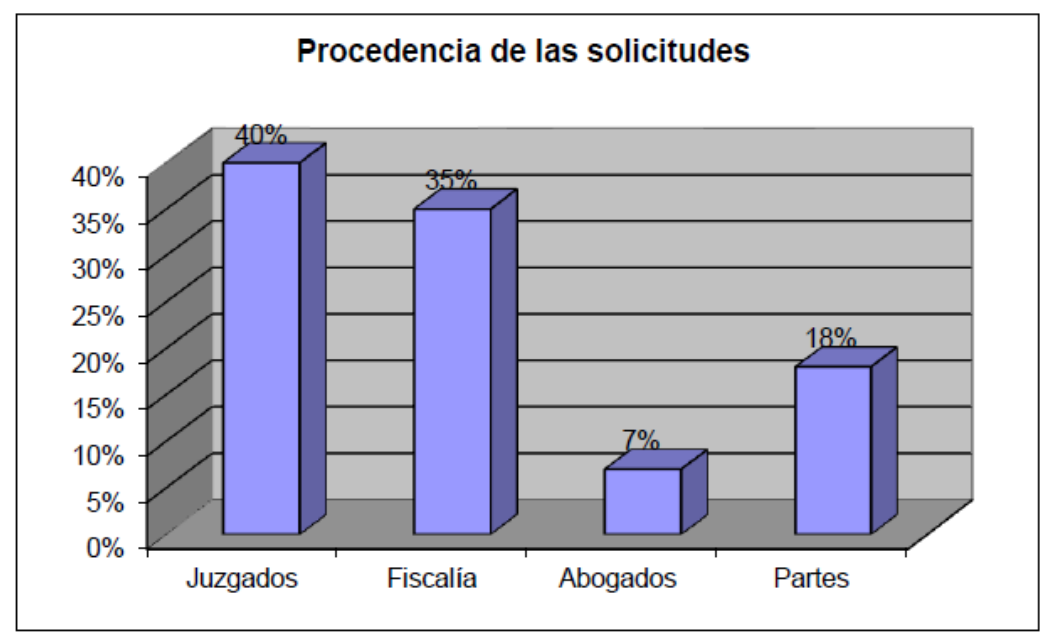

Figura 39. Procedencia de las solicitudes. Fuente: Memoria 2015 AMEPAX, p. 40. 
Conforme a los tipos de acuerdo, vuelve a prevalecer en el total la reparación no económica. Ello es como consecuencia de que los participantes en el proceso valoran las actuaciones como un conjunto de medidas restaurativas enfocadas en reparar los efectos nocivos derivados del delito, y no así como un medio de obtener una compensación económica, aspecto realmente relevante y fundamental para el desarrollo en delante de más procesos restaurativos.

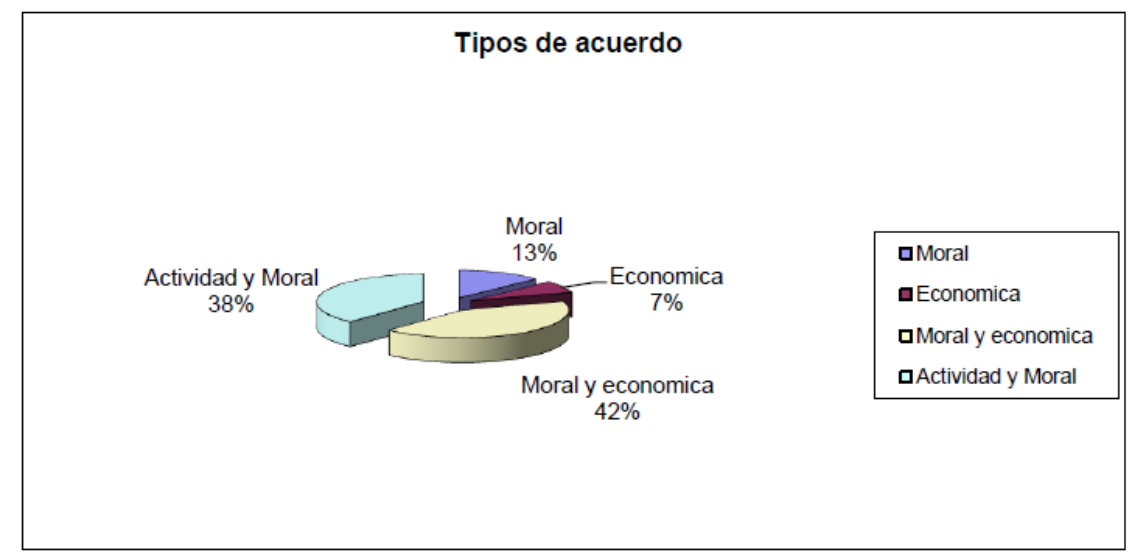

Figura 40. Tipos de acuerdo. Fuente: Memoria 2015 AMEPAX, p. 42.

A pesar de las diferentes experiencias llevadas a cabo, poder afirmarse la necesidad de un mayor impulso para el arraigo de esta institución en nuestro sistema procesal $^{683}$. Múltiples factores condicionan estas dificultades de implantación, tales como la todavía desconfianza existente entre los ciudadanos hacia las prácticas restaurativas, el exiguo fomento dado por el propio sistema de justicia así como, en opinión de GARCÍA HERRERA, el "excesivo garantismo respecto de los derechos del infractor" ${ }^{\circ 84}$.

Para acabar con este apartado-resumen del fantástico trabajo llevado a cabo por AMEPAX, y en palabras de su directora DOMINGO DE LA FUENTE, los procesos restaurativos nos están mostrando que "la mayoría de las víctimas tienen una serie de necesidades no pecuniarias, para sentirse reparadas necesitan superar el delito,

\footnotetext{
${ }^{683}$ Vid. «European judicial systems - Edition 2014 efficiency and quality of justice». Disponible en: http://www.coe.int (última visita 03/03/2018)

${ }^{684}$ GARCÍA HERRERA, A., “Justicia restaurativa: breve reflexión...”, op. cit. Disponible en: https://www.diariolaley.es (última visita 05/04/217)
} 
algunas solo quieren ser escuchadas, desahogarse y obtener respuestas, otras desean recibir una disculpa por parte del infractor y que le denunciante realice un compromiso serio de no volver a delinquir o a realizar la conducta contraria a derecho, lo que indica que se piensa en los otros miembros de la comunidad, y no se quiere que nadie sufra lo que ellas han sufrido, por eso, la mayoría opta por una reparación moral y moral y de actividad". 685

${ }^{685}$ DOMINGO DE LA FUENTE, V., “Servicio de justicia restaurativa ...”, op. cit, pp. 353-377, esp. pp. 376-377. 


\section{CAPÍTULO SEXTO}

\section{EL GRUPO DE COMUNIDAD O CONFERENCING}

“Si me preguntas cual es el tesoro más grande del mundo, yo te responderé, son las

personas"

Proverbio maorí

\section{Aspectos generales.}

La criminalidad es un problema a gran escala en nuestra sociedad, tanto en el ámbito de adultos como en el de menores, debiéndose de invertir recursos económicos y educativos para su erradicación.

La Justicia Restaurativa podría ser uno de esos recursos educativos que buscan acabar con los actos delictivos. Un método educativo que merma los efectos nocivos del acto al delincuente y resocializarle a través de actuaciones reparativas en favor de la víctima y el infractor. Nosotros vamos a centrarnos en uno de sus múltiples métodos, en el Conferencing, conocido en castellano como conferencias aun cuando, tal y como advierte PAZ-PEÑUELAS ${ }^{686}$, correctamente debería denominarse como encuentros.

A continuación se va a proceder al análisis de cómo se han implementado las Conferencias en los Estados del mundo. Muchos de ellos han ido realizando una implantación progresiva, adaptando el modelo originario neozelandés a sus modelos ya existentes $^{687}$. Empezaremos en Nueva Zelanda para ir desembarcando en diferentes ${ }^{686}$ PAZ-PEÑUELAS BENEDÉ, M.P., Conflicto y técnicas de gestión. En especial, la mediación en
asuntos civiles y mercantiles y su versión electrónica, Tirant lo Blanch, Valencia, 2017, p. 84 .
687 Este es el caso de Inglaterra y Gales, los cuales fueron implementando el Family Group Conferencing
en diversos proyectos piloto a través de los sistemas YISP's (Youth Inclusion and Support Panels),
consiguiendo un que el FGC fuese un elemento integrado y central desde el primer momento. Los
proyectos piloto establecidos en Gales e Inglaterra como Dockborough, Riverborough, Coburgh y
Welshboro consiguieron asentar el FGC en Inglaterra y Gales. Para más información, nos remitimos al
informe sobre los YISP's y los diversos paneles de apoyo juvenil: WALKER, J., THOMPSON, C.,
WILSON, G., LAING, K., COOMBES, M., y RAYBOULD, S., Family Group Conferencing in Youth
Inclusion and Support Panels: Empowering Families and Preventing Crime and Antisocial Behaviour?, 
países que han ido integrando en sus legislaciones las conferencias como un método para la resolución de conflictos. Estos ordenamientos jurídicos son muy diversos y nosotros nos quedaremos con las Conferencias en Australia, desde el Wagga Wagga model hasta las Conferencias de los Estados Federales de Australia, Irlanda del Norte, el Proyecto Piloto de Flandes o el servicio de Konfliktrådet de Noruega, todo ello para observar su posible inclusión en nuestro ordenamiento.

\section{El Conferencing como método de resolución de conflictos: concepto, clases y ámbito objetivo.}

Las Conferencias, consideradas por algunos autores como la institución más efectiva de la Justicia Restaurativa ${ }^{688}$, tienen su origen en Nueva Zelanda bajo las prácticas de los pueblos aborígenes residentes allí, y más concretamente del pueblo maorís. Un conjunto de prácticas tribales unidas a las ideas desjudicializadoras emergentes configuraron la idea de implantar prácticas pacíficas en la resolución de conflictos. Será objeto de este trabajo analizar el concepto de esta figura, su origen, ámbito, características y participantes, centrándonos para ello en el ejemplo del Family Group Conference neozelandés.

Se considera que es un paso más allá de la mediación y de sus límites ${ }^{689}$ por el número de intervinientes ya que, en el primero de los casos sólo participan víctima e infractor, mientras que en las Conferencias entran en el "juego" sujetos como policías, familiares, abogados, personas cercanas y asociaciones de apoyo. El Conferencing permite un diálogo restaurativo incluyendo a personas de apoyo del entorno de la

Youth Justice Board, University of Newcastle Upon Tyne, Newcastle Centre for Family Studies, 2007. Disponible en: http://www.netcare-ni.com (Última visita: 09/11/2017)

${ }^{688}$ O’MAHONY, D., y DOAK, J., Reimagining Restorative Justice..., op. cit., p. 8

${ }^{689}$ Véase. ZINSSTAG, E., EUNKENS, M., PALI, B., Conferencing: a way forward for restorative justice in Europe, European Forum for Restorative Justice, Leuven, 2011. Disponible en: http://euforumrj.org (Última visita: 09/11/2017) 
víctima o a miembros del grupo familiar que compensan así la posible debilidad de la víctima ante el agresor ${ }^{690}$.

Desde esta perspectiva el conflicto no sólo va a perjudicar a los protagonistas del delito, sino que la propia comunidad, normalmente representada por un policía, se ve también damnificada, debiendo participar como apoyo a ambas partes y como parte dañada por el delito, teniendo por tanto un rol doble ${ }^{691}$. Es fundamental la aparición de la sociedad en la resolución de conflictos puesto que se entiende que ésta queda beneficiada con la reparación del hecho y con la resocialización del infractor.

Dentro del Conferencing existen varios modelos o clases, siendo los más famosos el Family Group Conference (FGC), originario de Nueva Zelanda, y el modelo Wagga Wagga o Police Led Conferencing (PLC), que nace en Australia. Son dos modelos similares pero con ciertas peculiaridades.

Las Conferencias pueden ser utilizadas tanto en el ámbito penal de adultos como en el de menores, siendo más interesantes y exitosas en este último. A modo de ejemplo el modelo neozelandés, integrado dentro del sistema judicial de menores para delitos graves (con excepción de homicidio y asesinato) y que desarrollaremos posteriormente. Como ejemplo de un modelo integrado en el ámbito penal de adultos nos encontramos los modelos australianos, que aun siendo utilizados para ambos sistemas muestra mayor eficacia en el ámbito penal juvenil.

El modelo FGC es un modelo integrado dentro del sistema judicial de menores; empleado generalmente en delitos de mayor gravedad; la comunidad está representada a través un miembro de la policía que tiene por función encarnar a todo el global de ciudadanos de la sociedad en donde se cometió el hecho delictivo; se permite la

\footnotetext{
690 TAMARIT SUMALLA, J.M., "Procesos restaurativos más allá de la mediación: perspectivas de futuro”, en I.J. Subijana Zunzunegui et al., Justicia restaurativa, una justicia ..., op. cit., pp. 317-328, esp. p. 325

${ }^{691}$ MARSHALL, T., Restorative Justice. An Overview, Home Office, London, 1999.
} 
aparición de la figura de los abogados; otorga libertad de actuación al no seguir un guion preestablecido; y permite, como característica propia, una reunión privada entre el infractor y su familia. En contraparte, el modelo PLC o Wagga Wagga model es utilizado en delitos leves; con una intervención del policía como facilitador; se seguirá un guion preestablecido para el desarrollo del proceso; no se permite la intervención de letrados; y las sesiones no cuentan con una reunión privada entre víctima y su familia. Se observa que ambos modelos parten de unas mismas pautas y objetivos pero con diferencias en la ejecución práctica.

En todo proceso de Conferencing la aceptación de responsabilidad por parte del infractor es un requisito fundamental para el inicio de las actuaciones. Si el infractor no aceptase su error, no se podrá dar inicio al proceso, ya que su fin es la creación de un plan de trabajo que desemboque en una reparación y resocialización del infractor, cosa que no sucederá si no reconoce su autoría

Una vez admitida su responsabilidad e iniciado el proceso, las partes podrán exponer sus puntos de vista, apoyadas siempre por sus familias y demás miembros de apoyo. Si es un modelo neozelandés, habrá una reunión privada entre el infractor y su familia en el que se debatirá la reparación y demás medias exigidas por la víctima, así como las medidas de reparación que propongan. Se obtendrá un plan de reparación elaborado por ambas partes, por sus familias y personas de su entorno cercano, un plan trabajado y gratificante que satisfacerá a la víctima y ayudará al infractor a iniciar un nuevo camino en su vida como una persona resocializada.

El Conferencing es una significativa figura de la Justicia Restaurativa cada vez en mayor expansión. Se partirá del examen del FGC neozelandés para dar paso al análisis de las conferencias desarrolladas en los Estados Federados australianos ${ }^{692}$,

\footnotetext{
${ }^{692}$ Ejemplo de ello son el Wagga Wagga o Police Led model del distrito de Wagga Wagga, el Forum Sentencing y el Restorative Justice Unit de New South Wales, el Young Adult Restorative Justice Group Conferencing de Victoria, y los modelos de conferencing de Australian Capital Territory, Western Australia, y Queensland
} 
Estados Unidos, Canadá, Sudáfrica, Irlanda del Norte, Gales, Noruega, Países Bajos, Bélgica o Sudáfrica ${ }^{693}$.

Se exponen las conferencias como prácticas enfocadas en facilitar una mayor participación de la sociedad en el proceso. En concreto permiten que los miembros de la familia de las partes y sus más allegados puedan ayudar a restablecer la situación anterior al delito, sanando al herido, resocializando al ofensor (normalmente un menor) y pacificando la sociedad.

Es de prever que la implantación de esta figura en nuestro ordenamiento jurídico sea ardua y costosa, tal y como ha sucedido en otros lugares. Es por ello que hemos de “alimentarnos” de las diferentes experiencias teóricas, legislativas y prácticas habidas en nuestros países vecinos para poder adaptar dicho sistema a las peculiaridades legales y culturales de nuestro país y resolver así los conflictos a través de las prácticas del Conferencing.

La idoneidad de las conferencias permite una mayor eficacia en el ámbito penal de menores y no en el proceso penal de adultos, a tenor del carácter educativo y potencializador de la familia. La educación de los menores es fundamental para la consecución de una sociedad con un porcentaje mínimo de delitos. Respecto a la tipología delictiva, no consideramos óptimo el establecimiento de un numerus clausus ya que la erradicación de todo tipo de comportamientos delictivos y la educación de los menores es básica para la consecución de una sociedad pacífica y responsable con carácter general. Este componente didáctico es primordial para encauzar a los menores infractores, sea cual fuere el delito cometido así como el motivo. Este último es aspecto básico para la comprensión de la voluntad del menor así como la toma de medidas en el proceso de diálogo.

\footnotetext{
${ }^{693}$ El primer programa de conferencing en Sudáfrica, Comités pacificadores, nació en 1997 en la comunidad de Zwelethemba. Vid. Manual sobre programas de Justicia Restaurativa, Serie de Manuales sobre Justicia Penal, Naciones Unidas, Nueva York, 2006, p. 24. Disponible en: https://www.unodc.org (Última visita: 09/11/2017)
} 
Las sesiones, si pretenden resultar eficaces, no han de dilatarse indebidamente en el tiempo, ya que en caso de que así sucediese se acabaría creando un daño sobre los implicados y, por tanto, pecando de los mismos males que tiene el sistema actual de justicia. Por ello, consideramos que un plazo máximo de 3 meses, prorrogables por otros 3 meses serían suficientes para la realización de las sesiones preparatorias. Para las sesiones de encuentro y resolución de conflicto cabría otorgar un plazo de 12 meses, prorrogables por 6 meses más debidamente justificados, para la realización de las sesiones de encuentro y resolución del conflicto. Todo ello deberá de ser acompañado con una actuación de jueces y fiscales que controlen la legalidad del proceso del acuerdo, así como que permitan y obliguen a que lo acordado se cumpla.

Para una correcta adaptación a nuestro derecho se ha de valorar las regulaciones realizadas en otros países y utilizarlas como experiencias positivas para una posible futura regulación en el ámbito penal de menores. Ello se fundamenta en la necesidad de una justicia didáctica. Un menor no necesita un castigo para entender lo erróneo de su acto, sino que necesita una educación; en suma, una serie actuaciones que le enseñen cómo ha de convivir con los demás, qué actuaciones son positivas y cuales negativas, así como a responder ante los demás por sus actos. Y aunque siempre se haya indicado que "La letra con sangre entra", deberíamos decir que "La letra con educación, respeto, responsabilidad y apoyo entra”.

\section{El Family Group Conference, el origen de las Conferencias restaurativas.}

El Family Group Conference es el primer antecedente de la expansión de las Conferencias por el mundo. De ahí la necesidad de proceder al examen del origen de la figura, sus características, objetivos, regulación y participantes en el proceso al fin de analizar el contenido y utilidad dicha práctica restaurativa. 


\subsection{Origen, peculiaridades e intervinientes.}

No hay mejor definición que la aportada por MACRAE y ZEHR que definen el FGC “como un tipo de proceso de toma de decisiones que implica un encuentro cara a cara entre el ofensor, su familia, las víctimas y sus personas de apoyo, un representante de la policía y, si el caso lo requiere, otras personas" ${ }^{694}$. Es un proceso cara a cara entre ambas partes, centrado en el menor ofensor $^{695}$, pero como característica relevante intervienen otros sujetos como las personas de apoyo (familiares y amistades), un miembro de la policía y personal de organizaciones y asociaciones a las que pertenezca el menor infractor o aquellas que puedan tener un interés en la resolución del conflicto.

Respecto al origen del FGC y las motivaciones que impulsaron la figura se ha de acudir a Nueva Zelanda en los años 80', momento en el que sucede un cambio radical en su sistema de justicia juvenil. El acaecimiento de circunstancias arduas para la sociedad neozelandesa conllevaba una pérdida de las estructuras clásicas de familia ${ }^{696}$ y a una multitud de menores cometiendo crímenes y enjuiciados por los Tribunales de justicia. Los centros de menores estaban abarrotados, siendo la comunidad maorí la más representada y no en vano también la más señalada y dañada por la crisis que estaba sucediendo desde tiempo atrás. Todo ello llevó a una petición de dicha comunidad en favor del respeto de sus tradiciones y, en concreto, a la inclusión y potenciación de sus métodos de resolución de conflictos y a entregar más responsabilidades y potestades a las familias sobre los menores, suceso que además de reducir la criminalidad reduciría los costes ${ }^{697}$.

${ }^{694}$ GUARDiOlA, M.J., ALBERTí, M., CASADO, C., MARTINS S., y SUSANNE, G., ¿Es el conferencing una herramienta útil para los programas de mediación en el ámbito penal del Departamento de Justicia?, Generalitat de Catalunya, Barcelona, 2011, p. 67. Los autores parten de la definición de MACRAE, A., y ZEHR, H., The little book of family group conference. New Zealand Style, Nueva York, Good Books, 2004.

${ }^{695}$ Intervención de TIM CHAPMAN en el Congreso Europeo de Justicia Restaurativa y Terapéutica, celebrado en San Sebastián los días 16, 17, 18 de junio de 2016 .

${ }^{696}$ ZINSSTAG, E, TEUNKENS, M., y PALI, B., Conferencing: a way..., op. cit., p. 54.

${ }^{697}$ Véase. HUNTSMAN, L., Family group conferencing in a child welfare context, NSW Department of Community Services, Ashfield, 2006, p. 2 y ss. 
Al verse el Estado desbordado e ineficaz para resolver esta crisis sin precedentes $^{698}$, decidieron escuchar al pueblo maorí y aprender de sus prácticas ancestrales, las cuales estaban centradas en anteponer la reparación al castigo como método de aprendizaje y resocialización, algo novedoso y a la vez desconocido para el sistema de justicia penal clásico que imperaba en esos momentos.

Por todo ello el gobierno neozelandés acudió a dichas comunidades aborígenes e implementó un nuevo método para la resolución de conflictos basado en sus costumbres tribales y en una serie de conceptos básicos maorís como whānau (término referente en sus orígenes a una familia de tres o cuatro generaciones, pero en la actualidad se entendería por familia extensa ${ }^{699}$, es decir una familia compuesta por miembros de la propia comunidad aún sin lazos de sangre ${ }^{700}$ o incluso a un núcleo familiar pequeño ${ }^{701}$ ), hapū (sub tribu o grupos de familias) e iwi (tribu, confederación de tribus, nación ${ }^{702}$ ).

Tras esto, el gobierno elaboró el informe a través del Ministerial Advisory Committee de 1986, que sentó las bases de la Justicia Restaurativa en Nueva Zelanda y de la posterior Children, Young Persons and Their Families Act de $1989^{703}$, a través la cual se integraba dentro del sistema de justicia penal juvenil el modelo del FGC para menores que comprendan la edad de 14 a 17 años. Así podemos señalar que el FGC no se incluye como un sistema complementario, sino como el eje del sistema penal juvenil.

\footnotetext{
${ }^{698}$ MACRAE, A., y ZEHR, H., The little book of family ..., op. cit. pp. 10-17.

${ }^{699}$ MOLTZEN, R., MACFARLANE, H.A., "New Zealand: gifted and talented Maori learners", en B. WALLACE y G. ERIKSSON, Diversity in gifted education: International perspectives on global issues, Routledge, New York, 2006, pp. 305-307

700 THOMAS, T., LAGROW, S. J. y LEUNG, S., "Whanau workers: Providing services for the indigenous people of New Zealand”, en Journal of Visual Impairment \& Blindness 1994, n 88, pp. 8690, esp. p. 87.

${ }^{701}$ PERE, R., “Te oranga o te whanau: The health of the family”, en Hui Whakaoranga: Maori health planning workshop 1984, Hoani Waititi Marae, n ${ }^{\circ}$ 19-2.

${ }^{702}$ Vid. BALLARA, A., Iwi: The dynamics of Māori tribal organisation from c.1769 to c.1945, Victoria University Press,Wellington, New Zealand, 1998; DURIE, A. "Emancipatory Māori education: Speaking from the heart”, en Language Culture and Curriculum 1999, Vo. 11, nº 3, pp. 297-308; HEALEY, S. M., The nature of the relationship of the Crown in New Zealand with iwi Māori, University of Auckland, New Zealand, 2006; SHARP, A. "What if value and rights lie foundationally in groups? The Maori case", en Critical Review of International, Social and Political Philosophy 1999, no 2, pp. 1-28.

${ }^{703}$ Disponible en: http://www.legislation.govt.nz (última visita 31/01/2018)
} 
No hay que confundir el FGC con las propias prácticas maorís, sino que este sistema de conferencias está basado en la suma de las prácticas desjudicializadores existentes a la fecha y de las prácticas maorís, ya que "aunque es cierto que el cuestionamiento maorí al sistema de justicia criminal neozelandés fue un ingrediente central de la reforma de 1989, eso no significa que las conferencias restaurativas constituyan una práctica de justicia indígena. Las conferencias ofrecen, más bien, un modelo lo suficientemente flexible que puede adecuarse a los intereses y valores de las diferentes culturas involucradas"704. De ello se puede concluir que la Justicia Restaurativa es una filosofía cuyos fines están encaminados en la resolución pacífica de los conflictos a través de la sanación de la víctima, la resocialización del infractor y la pacificación de la sociedad mediante una serie de prácticas o instituciones tales como la mediación penal, las conferencias o los círculos.

Respecto a las conferencias son en conjunto un modelo restaurativo compuesto de la unión de prácticas de origen maorí con prácticas de justicia emergentes en el momento. Todo ello unido ofrece una institución capaz de amoldarse a las necesidades e intereses de los participantes teniendo un gran componente maorí al estar enfocada en un principio hacia su comunidad. Es toda la sociedad neozelandesa, tanto indígena como no, la que es parte de la confección de las conferencias a través de la aportación de su cultura e ideas de “justicia” para la obtención de un modelo capaz de solventar las circunstancias delictivas surgidas en cada momento.

A lo largo del tiempo fueron surgiendo diferentes modos de desarrollar las conferencias aún dentro de la línea original impulsada en 1989. Según ZEHR existen los siguientes modelos derivados del FGC ${ }^{705}$ :

1. Intention to Charge Conference: Este proceso alternativo tiene lugar cuando la policía, una vez cometido el delito, en vez de derivar el caso a los Tribunales

\footnotetext{
${ }^{704}$ MERA GONZÁLEZ-BALLESTEROS, A., “Justicia restaurativa y proceso penal garantías procesales: límites y posibilidades”, en Revista Ius et Praxis 2009, n² 2, pp. 165-195, esp. p. 169.

${ }^{705}$ GUARDIOLA, M.J., ALBERTÍ, M., CASADO, C., MARTINS S., SUSANNE, G. ¿Es el conferencing una ... op. cit., pp. 67-68.
} 
para su conocimiento, decide ponerlo en conocimiento del coordinador del FGC para iniciar un proceso restaurativo por esta vía. Para su inicio, el menor deberá aceptar su responsabilidad y en caso afirmativo, se dará inicio el procedimiento.

2. Charge Proven Conference: Este modelo tiene lugar en la fase de ejecución o post sentencia puesto que se da inicio cuando el menor infractor ya ha sido juzgado y declarado culpable en un juicio. Antes de que el juez dicte la pena se realiza un encuentro de FGC entre víctima, victimario, familiares y miembros del sistema de justicia en el que se busca realizar cierto tipo de medidas a tomar, la pena a aplicar, acuerdos alternativos, etc. Se utiliza en todo tipo de delitos menos en homicidios y asesinatos.

3. Custody Conference: Una vez se ha dictado sentencia y se ha condenado al menor, sigue sin acepta la responsabilidad de la infracción cometida y está bajo un régimen de "custodia” (ya sea con su familia, en un centro de menores o incluso con la policía), el juzgado puede el caso al FGC, el cual deberá de buscar alternativas a la situación del menor o a los programas y actividades en los que deba de participar. El objetivo es la resocialización del menor a través de actividades que le ayuden a admitir su responsabilidad y comprender su conducta errónea.

4. Charge Not denied Conference: Este proceso es derivado por el juez al FGC en fase de instrucción cuando el menor admite su responsabilidad sobre los hechos. Del proceso de FGC nos podemos encontrar variadas recomendaciones al juez como la modificación de la jurisdicción en la que debe de juzgarse el delito, modificación de los cargos, deber del menor de reparar mientras está en prisión provisional o libertad vigilada, e incluso la desistimiento de la acusación. Es una fase previa enfocada en los intereses del menor que servirá para ir encauzando el proceso ante los tribunales. 
Respecto a los participantes en un proceso de FGC, MACRAE y ZEHR ${ }^{706}$ señalan como intervinientes: los ofensores y sus familias (incluye familia extensa); víctimas o sus representantes y personas de apoyo ${ }^{707}$; cuidadores de los menores; representantes de la policía (Youth Aid Officer); abogados de los menores; abogados que aseguran que se respeten las especificidades culturales; trabajadores sociales que, ya por petición de la familia o por petición de las “agencias de custodia”, se necesitan para apoyar al menor infractor; informadores, los cuales aportan conocimientos específicos, ya sean escolares, religiosos, comunitarios, etc. Así también MAXWELL ${ }^{708}$ propone que los intervinientes han de ser los menores y sus abogados, el whanau o familia, la víctima o su representante, un miembro de la policía, el Youth Justice Co-ordinator ${ }^{709}$, un representante de organizaciones en favor de los menores y su resocialización (Youth and Family Service) y un trabajador social.

Tal y como se observa las Conferencias son un paso más allá de la mediación debido al amplio número de participantes tales como personas cercanas a víctima e infractor, miembros de policía y trabajadores sociales ${ }^{710}$. Existe una clara intención de que sean los seres cercanos y los representantes de la sociedad los que deben de intervenir en dichos procesos restaurativos, auxiliando a los intervinientes en aras de la resolución pacífica del delito. Al implicar a "los familiares de los delincuentes, es más fácil comprometerles en el plano de la rehabilitación del imputado y responsabilizarlos en el control del cumplimiento de las reglas impuestas en el acuerdo" ${ }^{711}$.

\footnotetext{
${ }^{706}$ MACRAE, A., Y ZEHR, H., The little book of family ... op. cit. pp. 29-30.

707 En el año 1994, como respuesta al informe del Ministerial Review Team to the Minister of Social Welfare, el Gobierno incorporó a la ley la posibilidad de que las víctimas puedan aportar personas de apoyo al encuentro.

${ }^{708}$ Véase MAXWELL, G.M., KINGI, V.M., ROBERTSON, J., MORRIS, A., CUNNINGHAM, C.W., Y LASH B., Achieving Effective Outcomes in Youth Justice, New Zealand: Ministry of Social Development, 2004.

${ }^{709}$ Es el facilitador, asumiendo un rol similar pero de mayor relevancia que el mediador, el que organiza el proceso de conferencia sin seguir un guion preestablecido y se asegura de la existencia de una responsabilización, reparación, plan de trabajo y seguimiento del plan de reparación asignado al menor.

${ }^{710}$ BELTRÁN MONTOLIU, A., “Modelo de mediación en ...”, op. cit., p.59.

${ }^{711}$ MARQUÉS CEBOLLA, C., La mediación. Un nuevo instrumento de la Administración de la Justicia para la solución de conflictos, Universidad de Salamanca, Salamanca, 2011, p. 355.
} 
Se trata de una práctica que solventaba a la fecha una situación de crisis en el país oceánico e impulsaba su sistema de justicia. Este hecho, que podríamos calificar de histórico en referencia la historia del derecho neozelandés, supone un gran paso, un paso necesario para el nacimiento de una nueva manera de entender y aplicar la justicia. Había nacido el Conferencing, una nueva estrella en la bandera neozelandesa.

\subsection{Objetivos y caracteres en definición del nuevo modelo.}

Las especialidades propias de la figura la configuran como una institución adaptada las características de las partes $^{712}$ y son de vital envergadura para la consecución de los objetivos primordiales de todo proceso de conferencias:

1. Que el menor infractor acepte la responsabilidad por sus actos en la fase preparatoria. Si no existiera esta circunstancia y el menor se negase a admitir su culpa, no estaríamos ante un fracaso de la conferencia, sino que se llegaría a declinar el inicio de las sesiones y actuaciones restaurativas.

2. La reparación del daño injusto creado a la víctima. Es fundamental que todo proceso de conferencias centre sus actuaciones en una restauración a la víctima por el daño creado a través de la comisión del acto delictivo. Si no se obtuviese dicha reparación, parte de las sesiones llevadas a cabo quedarían sin eficacia ya que se habría obviado el objetivo principal del proceso.

3. Participación de la víctima en la toma de decisiones, recuperando el protagonismo que merece en el proceso. Todo proceso restaurativo centra su interés en el otorgamiento de valía a la víctima. Es ella la que ha sufrido el daño, siendo lógico que sea quién decida cómo se ha de reparar y solucionar el conflicto. Ha de tener voz y respetarse su posición de interviniente en las sesiones.

\footnotetext{
${ }^{712}$ Algo sumamente importante debido a la gran diversidad de culturas radicadas en Nueva Zelanda: la cultura maorí, cultura pakeha, culturas provenientes de Europa (Italia, Irlanda, etc.), culturas asiáticas (China, Corea, Taiwán, Japón y Hong Kong) y culturas provenientes de indígenas y pueblos del pacífico (Samoa, Tonga y Fiyi son las islas del Pacífico que más población ha aportado a Nueva Zelanda) que se han instalado y adaptado en dicho país.
} 
4. Fortalecimiento de la familia, la cual tomará decisiones en busca de la reparación del daño. Así se demuestra que todas las familias pueden auxiliar a los menores a reparar los efectos de su delito; e incluso con estos actos restaurativos la propia familia gana protagonismo como fuerza común y se autoayuda $^{713}$.

5. Mantener a los menores alejados del sistema penal para una mejor resocialización y desarrollo. Se ha de tener en cuenta que el sistema penal clásico puede no ayudarles a su resocialización, al verse etiquetados los menores como delincuentes y por tanto, estigmatizados. En general, los delitos traen delitos; esto es, el contacto con el sistema penal aumenta la tasa delictiva pues no existe un enfoque resocializador efectivo. El sistema penal no tiene en cuenta sus necesidades ni características, pudiéndose ver afectados por el trato recibido.

6. El plan de reparación ha de ser consensuado con el trabajo de todos los miembros del FGC y adaptado a las características culturales de los participantes.

Podemos indicar que en el FGC se van a tratar todo tipo de delitos y así preferentemente los graves, con excepción del homicidio y el asesinato. Se fija a la familia como eje central de la sociedad, la cual adquiere potestad para la resolución de conflictos, para la obtención de un plan de reparación que satisfaga a la víctima. Para ello se deberá de respetar los derechos de los menores y los intereses de las víctimas teniéndose en cuenta que el aislamiento del menor de su comunidad ${ }^{714}$ crea en él una situación de ansiedad, miedo y odio, siendo más posible su futura reincidencia y por ello la aplicación se aplicará la medida menos restrictiva.

\footnotetext{
${ }^{713}$ Las familias se auto ayudan observando cómo, con el trabajo de todos y su consenso, pueden solucionar los problemas de un miembro de la familia, algo muy útil para los futuros problemas que tenga cualquier otro miembro del núcleo familiar o del clan en su conjunto,

${ }^{714}$ Hay que tener en cuenta la gran diversidad cultural de Nueva Zelanda cuando se habla de Comunidad. En nuestras fronteras este término estaría más dirigido a la familia y círculo cercano, mientras que en diversas culturas de Nueva Zelanda la Comunidad comprende, a parte de los ya citados, a personas que viven en su misma zona, tienen sus mismas creencias y su misma cultura.
} 
Para el cumplimiento de estos objetivos se han fijado una serie de caracteres y principios que han de regir todo proceso, y sin los cuales, no se podría desarrollar un proceso de Conferencias:

1. Sólo existirá proceso penal si hubiere un interés público. Se buscan alternativas para la resolución del conflicto, alternativas enfocadas en el consenso, diálogo y la reparación por encima del castigo penal.

2. Los derechos de los menores deben ser respetados y para ello se permite la asistencia de letrados para asegurar las garantías debidas del proceso.

3. Lo más importante es la víctima y sus intereses. Se ha de atender no sólo a la responsabilización del infractor, sino a la reparación de la víctima y sus intereses.

4. Se busca potenciar a las familias a través de una delegación de "poder". Si las familias ayudan a la creación de un plan de reparación y a la resocialización del infractor, éstas adquieren una fortaleza de la que antes no gozaban, incrementando su consideración dentro de la sociedad. Tanta es la valía que incrementan las familias que van a decidir el lugar donde se va a efectuar el proceso de FGC, pudiendo ser en las oficinas propias del Youth and Family Service, en casa de la familia o en la marae (casa de encuentro).

5. El encarcelamiento o aislamiento del menor de su comunidad crea ansiedad, miedo y odio en el menor, siendo más fácil su futura reincidencia. Un menor necesita a su comunidad ya que es ella la que le va a apoyar y a enseñar un comportamiento. Si se ve alejado o aislado de ella, será más difícil encontrarnos a un menor no infractor.

6. Se ha de aplicar la medida menos restrictiva para que su desarrollo como persona se vea lo menos afectado posible.

Debemos de tener en cuenta la edad del menor. La ley distingue dos tipos de menores: cuando se refiere a child, la edad comprendida es de 10-14 años, mientras que si se refiere a young person se está aludiendo a menores de edad comprendida entre 1417 años. Cuanto más joven sea, más fácil será reconducirlo por el camino correcto, y 
este proceso deberá realizarse siempre a través de FGC. Se tendrá en cuenta su edad de cara a las medidas a adoptar, así como a las actuaciones de reparación que deba de realizar, ya que no podrá exigirse las mismas actuaciones a un menor de 13 años que a uno de 16.

Para concluir este apartado se ha de analizar el principio básico de confidencialidad. La información obtenida mediante FGC es privilegiada y no debe ser publicada $^{715}$. Se restringe la información que se puede otorgar al Tribunal ${ }^{716}$. Se podrá publicar información acerca del desarrollo de los FGC pero no podrá revelarse testimonio que nos lleva a identificar a los participantes ${ }^{717}$.

Numerosas han sido las prácticas exitosas en Nueva Zelanda desde su impulso a finales de los años 80 e inicios de los años 90. No obstante, en los años 1990 y $1991^{718}$ la mitad de los jóvenes se sintieron involucrados en la decisión, aunque es verdad que la otra mitad sintieron su voluntad limitada por la de sus familiares, superando así la actitud pasiva que la mayoría de ellos sufre al acudir ante la Corte o Tribunales. Esto genera un alto grado de satisfacción y reducción de la reincidencia en un 85\% de los jóvenes infractores partícipes en el proceso, mientras que el 60\% de las víctimas sentía satisfacción por haber recibido ayuda gracias a la Conferencia. El contrapunto a todo ello es que parte de las víctimas también consideraban que el sistema fracasa en muchos procesos por el poco interés que suelen mostrar el ofensor y sus familiares en reparar y así con el escaso arrepentimiento real existente por el acto delictivo.

\footnotetext{
${ }^{715}$ Secciones 37 y 38 Children, Young Persons and Their Families Act 1989, que se aplica en virtud de la Sección 271 de dicha ley. Disponible en www.legislation.govt.nz

${ }^{716}$ Sobre este aspecto no hay unanimidad y podríamos decir que el principio restringe al juez del conocimiento de los motivos del no acuerdo.

${ }^{717}$ Sección 38(3) Children, Young Persons and Their Families Act 1989.

${ }^{718}$ MORRIS, A., y MAXWELL, G., "Restorative Justice in New Zealand: family group conferences as a case study” en Western Criminology Review 1998, n 1, pp. 1-17, esp. pp. 7-14.
} 


\subsection{Las tres fases para el desarrollo y culminación del proceso}

Existen tres fases en todo proceso de FGC como son la preparación, el encuentro y el plan de actuación y seguimiento. Todas estas actuaciones podrán ser realizadas en las oficinas del Youth and Family Service, en casa de la familia o en la marae (casa de encuentro). A continuación examinaremos escuetamente en qué consisten cada uno de estos actos.

\subsection{1 $1^{\text {a }}$ Fase: preparación.}

La fase de preparación es básica y primordial para un posterior desarrollo eficaz de las actuaciones restaurativas. Es aquella efectuada por los coordinadores en búsqueda de una preparación del proceso. El fin es garantizar si es conveniente o no el proceso, informando a las partes de su desarrollo, características, duración, lugar, etc.

Si la valoración es positiva se realizarán las debidas comunicaciones a las partes intervinientes, tanto a la víctima como al ofensor y a sus padres. Las comunicaciones serán por carta, y en caso de que en 72 horas no exista contacto alguno, se realizará una comunicación telefónica. Estos plazos especificados en la normativa neozelandesa están obsoletos conforme a los medios tecnológicos actuales que pueden efectuar dicha comunicación en breves lapsos de tiempo por las mismas vías.

Estas notificaciones tienen el fin de dar a conocer la entrevista y su desarrollo. En ella se indicará el proceso, características, grado de participación y miembros que acudirán, fecha, lugar y hora, así como los miembros comunitarios de apoyo que intervendrán en el proceso. Esta fase es de gran consideración al ser preparación de la víctima $^{719} \mathrm{y}$ del ofensor para el ulterior proceso clave para un futuro éxito del procedimiento.

\footnotetext{
${ }^{719}$ La víctima no está obligada a acudir al FGC, así como en los delitos de víctimas no identificables (un ejemplo de ello son los delitos de tráfico), su figura será sustituida por policías o por víctimas de delitos similares.
} 
La víctima ha de tener conocimiento en relación a sus derechos, de las características del procedimiento y de los efectos que éste supondrá en él. Así también se le sugerirán las asistencias que el sistema le otorga ${ }^{720}$, las personas que pueden participar y apoyarle, o la participación a través de representante o cualquier medio telemático. En cuanto al ofensor y su familia, se le han de señalar los cargos que se le imputan, debiéndose de comprobar su imputabilidad y madurez, así como comprobar su posible entendimiento del sistema de justicia restaurativo al que va a acceder; para ello se le hará indicación de las características, objetivos, personas que quiere que participen, apoyo de la familia cercana y extensa así como de la comunidad. Por último será esencial comprobar la voluntariedad del menor para su participación en el proceso.

\subsection{2 $2^{\mathrm{a}}$ Fase: encuentro.}

La fase del encuentro es la más significativa de todas al estar ante la puesta en común de todas las opiniones, emociones, justificaciones y necesidades. Los menores y sus abogados, el whanau, la víctima (es opcional su participación), un miembro del cuerpo de policía, el Youth Justice Co-ordinator, el Youth and Family Service y trabajadores sociales si así se decidiese oportuno.

Aspecto primordial será la adecuación del espacio de encuentro para una facilitación de expresión y diálogo. El emplazamiento ha de ser lo más holgado posible, con los suficientes asientos, permitiendo incluso una amplia distancia entre las partes, con la necesaria existencia de una pequeña sala para las reuniones privadas y los momentos de descanso. Normalmente la distribución en el aula suele ser en forma de

\footnotetext{
${ }^{720}$ Este sistema de FGC facilita a la víctima la asistencia necesaria para su participación en el proceso como desplazamientos o amoldamiento del horario del proceso según la jornada laboral de la víctima, pudiéndose hacer en cualquier hora del día o incluso a última hora de la tarde o en la noche. DOMINGO DE LA FUENTE, V., "Taller práctico de Justicia Restaurativa: Iniciación a las Conferencias Restaurativas", en el IV Congreso de Justicia Restaurativa y Mediación Penal: del desiderátum a la realidad práctica, Burgos, 17 y 18 de Marzo de 2016.
} 
círculo, sin perjuicio de una posible modificación del espacio en función de la situación y tensión que pueda resultar.

Cuando el espacio ya sea lo suficientemente propicio para el desarrollo del encuentro, se iniciará dicho encuentro, empezando por el posicionamiento de las partes dentro de la sala y el recitado de la Karakía ${ }^{721}$ si fuese necesario por razones de creencia. Tras las oraciones, se inician las presentaciones, tanto del facilitador, el cual será el primero en presentarse, como de los demás intervinientes. Será el momento de volver a recordar las características del proceso así como su adaptación a las necesidades de las partes, aclarándose todas las dudas que hubiesen podido surgir.

La lectura de los hechos efectuados por el menor utilizándose el sumario otorgado por la policía, dará lugar a la aceptación libre y voluntaria de la responsabilidad por el menor infractor. No se podrá continuar con el procedimiento si no existe esta aceptación o si fuere coaccionada por la policía, los familiares o por cualquier miembro. En caso de que el menor no acepte los hechos, la policía puede considerar la posibilidad de remitir el caso a la Youth Court $^{722}$ para la realización de una audiencia.

Una vez superado positivamente este trámite, se dará primero el turno de palabra de las víctimas, las cuales deberán relatar las consecuencias del delito, el impacto que éste ha tenido es sus vidas y el daño ocasionado. La víctima ha de exponer su dolor y su malestar libremente, sin ningún tipo de miedo o coacción ante todos los presentes. Así como el menor deberá replicar los motivos de su conducta y los sentimientos aflorados al escuchar las palabras de aflicción de la víctima.

\footnotetext{
${ }^{721}$ La Karakía son conjuros y oraciones maoríes utilizados para invocar guía espiritual y protección. Se utiliza para aumentar la buena voluntad espiritual de una reunión, a fin de aumentar la probabilidad de un resultado favorable. Más información en: http://maori.otago.ac.nz/reo-tikanga-treaty/te-reo/karakia ${ }^{722}$ El Juzgado de Menores es el encargado de conocer todas las causas relacionadas con los menores, excepto asesinato y homicidio; o cuando un niño o joven opta por un juicio con Jurado, o en algunas circunstancias cuando se los acusa de un adulto. Sólo se ocupa de la ofensa criminal de niños y jóvenes que es demasiado grave como para ser tratada por la policía en la comunidad. Para más información véase https://www.youthcourt.govt.nz.
} 
Así se entablan las primeras bases para el diálogo restaurativo entre las partes, iniciándose las aclaraciones y réplicas siempre dentro de un ánimo pacífico y constructivo entre todos los intervinientes. Esta labor será encargada al facilitador, que velará por la existencia de diálogos positivos ${ }^{723}$ y reconducirá las situaciones negativas en pos de una sesión provechosa.

Será de gran valía para una futura reparación observar la posición emocional de ambas, partes tanto en las sesiones como en el refrigerio, así como la fluidez en estos momentos de sosiego o la disgregación. El refrigerio o “momento de pausa” se realizará en una sala junto al aula principal en el momento en el que le facilitador observe que las partes no acercan posturas o sea necesario un descanso para asimilar el desarrollo de las actuaciones. Así todos los intervinientes podrán descansar entre sesiones, alimentarse y dialogar sobre el desarrollo de las sesiones. En supuesto de un acercamiento, significará que el encuentro está funcionando, el diálogo está acercando posturas y rebajando la tensión entre ellos. Pero si por el contrario permanecieren en salas diferentes, el facilitador tendrá que aceptar la dificultad de conexión entre ambas y a la poca disponibilidad positiva mostrada, siendo necesario un mayor trabajo común.

Existe una fase denominada de "reunión privada”, en el que la víctima y opcionalmente el ofensor se reúnen con su familia y personas de apoyo para tratar la situación. La víctima y su familia podrán dialogar sobre sus necesidades y el impacto que el proceso le está suponiendo, tanto con el facilitador como con cualquier miembro de dicho proceso, como por ejemplo el policía. El ofensor y su familia deberán de trazar un plan de reparación durante esta reunión, pudiendo tener la presencia de miembros de la parte de la víctima para la aclaración de dudas. Como bien indican MACRAE y $\mathrm{ZEHR}^{724}$, este momento es crítico ya que el ofensor y su familia tienen la posibilidad de

\footnotetext{
${ }^{723}$ GUARDiOlA, M.J., ALBERTí, M., CASADO, C. y SUSANNE, G. “Conferencing: origen, transferencia y ...”, op. cit., pp.237-267, esp. p. 248.

${ }^{724}$ Para más información relativa a dicho plan, vid. MACRAE, A., Y ZEHR, H. The Little book of Family..., op. cit., pp. 30-51.
} 
dialogar acerca de temas familiares que les acercarán a la definición de un plan de reparación.

Cuando el ofensor y su familia tengan elaborado el "plan de reparación”, será puesto en común ante la sala. El acuerdo debe de ser factible de cumplir y que satisfaga las necesidades de la víctima. Tal y como indica GUARDIOLA ${ }^{725}$, Así mismo, deberán de confeccionarse diferentes tareas enfocadas en la resocialización del menor. Dicho acuerdo debe centrarse únicamente en obligaciones para el menor, aunque pueda ayudarse en otras personas para su cumplimiento y seguimiento si fuera necesario. Nunca podrá suponer un resultado más lesivo que lo que hubiese supuesto una sentencia condenatoria ante los Tribunales. Y como aspecto más demostrativo del carácter didáctico del FGC es la posibilidad de que estas medidas y obligaciones que deba de realizar el menor puedan no estar dirigidas en favor de la víctima directamente, sino que tengan un efecto favorable con la comunidad y simbólico con la víctima.

Será el menor el que exponga las líneas básicas de actuación, indicando cómo y cuándo se realizará, cómo se reparará a la víctima y a la comunidad, quién supervisará su cumplimiento y recursos para hacerlo efectivo. Dicho acuerdo podrá ser modificado por el mediador en lo que considere oportuno en caso de inviabilidad de las medidas adoptadas. Ha de quedar claro que se ha de demostrar que el menor tiene los suficientes recursos para la ejecución de dicho plan de restauración. La víctima y su familia podrán realizar las cuestiones que crean oportunas así como pedir las modificaciones que consideren más óptimas para ellas. Por último, tanto los abogados como el policía darán una opinión técnica final así como una opinión en búsqueda de un beneficio de la comunidad. El acuerdo puede ser total, o simplemente acuerdos parciales.

Hay que tener en cuenta dos límites legales. El primero es que, en caso de que sea FGC tendrá lugar por derivación judicial, sólo se van a tener en cuenta los daños efectivos ocasionados, obviándose el daño secundario. El segundo es la limitación de

${ }^{725}$ GUARdiola, M.J., ALBertí, M., CASAdO, C., MARTiNS S., SUSANNE, G. ¿Es el conferencing una ..., op. cit., pp. 108-110. 
200 horas de trabajos por la comunidad. Y si cumple estos requisitos el acuerdo, el proceso se considera como finalizado, acabándose esta fase con un pequeño tiempo de interacción final entre los participantes ${ }^{726}$.

\subsection{3 $3^{a}$ Fase: seguimiento del plan de reparación.}

Una vez acordado el cumplimiento de las medidas acordadas en el plan de reparación se ha de proseguir con la fase de cumplimiento y seguimiento de este plan. Es una etapa controvertida en relación a que en los FGC el seguimiento del plan lo realiza normalmente un trabajador social. En la práctica, lamentablemente, muchos trabajadores sociales no cumplen su tarea, llegándose a situaciones de incumplimiento del plan de reparación o a un cumplimiento insatisfactorio ya que no llega a la víctima por culpa del trabajador social. MAXWELL ${ }^{727}$ acierta al pedir la introducción de diferentes estándares de actuación que permitan seguir el desarrollo del plan y tener informada a la víctima, suponiendo en la práctica una mayor labor para el facilitador al encargársele también las tareas de vigilancia y seguimiento con la ayuda de los trabajadores sociales y los sujetos seleccionados en dicho plan de reparación.

\section{Del Wagga Wagga Model a los sistemas imperantes en Australia}

Australia es uno de los Estados donde la Justicia Restaurativa está más asentada, ya sea a través de círculos, conferencias o mediaciones. Respecto a las Conferencias, hemos de indicar que la cercanía con Nueva Zelanda llevó a una rápida implementación de estas, la cual fue desarrollada por los diferentes Estados Federales Australianos ${ }^{728}$. A 726 GUARDIOLA, M.J., ALBERTÍ, M., CASADO, C. y SUSANNE, G. “Conferencing: origen,
transferencia y ...”, op. cit., esp. p. 249.
${ }^{727}$ MAXWELL, G.M., KINGI, V.M., ROBERTSON, J., MORRIS, A., CUNNINGHAM, C.W., y LASH
B., Achieving Effective Outcomes ... op. cit.
${ }_{728}$ Como indican GUARDIOLA, M.J., ALBERTÍ, M., CASADO, C., MARTINS S., SUSANNE, G. ¿Es
el conferencing una ..., op. cit.,: “Un rasgo distintivo clave es que Australia es un Estado federal
formado por seis Estados (New South Wales, Queensland, South Australia, Tasmania, Victoria y
Australia) y dos Territorios (Australian Capital Territory y Northern Territory). Los Estados delegan en
la Federación el poder legislativo y ejecutivo en ciertas materias, pero retienen competencias en otras
áreas, como es gran parte del Derecho Penal y políticas penales, respecto a las cuales pueden legislar de 
todo ello hay que añadirle aquí también la existencia de una comunidad indígena excluida que hasta 1975 , con la Racial Discrimination $A c t^{729}$, no consiguió una supresión de las discriminaciones y exclusiones que estaban sufriendo las diferentes comunidades indígenas australianas como son los Torres Srait Islander o los denominados aborígenes australianos ${ }^{730}$. Todo ello ha llevado a un alto índice de criminalidad de aborígenes, existiendo una sobrepoblación penitenciaria de origen aborigen. En palabras de DALY ${ }^{731}$, un $2,5 \%$ del total de la población australiana es aborígenes, pero representan un 24,5\% de la población penitenciaria.

Ello condujo a la adaptación del Conferencing como opción para la disminución de la reincidencia, implantándolo tanto en el ámbito de menores como en el ámbito de adultos, con diferentes especialidades conforme al Estado que lo haya regulado. Existen además conferencias en otros ámbitos como la protección de la infancia, escolar, familiar, de conflictos laborales o litigios en el ámbito empresarial ${ }^{732}$.

El inicio del cambio radicaba en una adaptación del sistema por el cual el castigo perdía consideración en favor de la reparación. Así, en el ámbito de menores, se apoyaba al menor respecto de la responsabilización por sus actos delictivos, se implicaba a su familia para la resolución del conflicto y se da la voz a la víctima para que opine acerca de sus necesidades ${ }^{733}$.

forma independiente. Así, cada Estado tiene su propio ordenamiento jurídico penal y dispone de un cuerpo de policía, de servicios penitenciarios y de administración de justicia también propios” (p. 87).

${ }_{729}$ Department of Foreign Affairs and Trade. About Australia. System of Government. About Australia fact sheet series. Department of Foreign Affairs and Trade. Australian Government, 2008.

${ }^{730}$ Para más información acerca de dichos pueblos: HORTON, D., The Encyclopedia of Aboriginal Australia: Aboriginal and Torres Strait Islander History, Society, and Culture, Aboriginal Studies Press, Canberra, 1994,

${ }^{731}$ DALY, K., Analysis of Australian Indigenous imprisonment and demographic information, School of Criminology and Criminal Justice Griffith University, Brisbane, 2009, p.3. Disponible en: https://www.griffith.edu.au (Última visita: 09/11/2017)

${ }_{732}$ GUARDIOLA, M.J., ALBERTÍ, M., CASADO, C., MARTINS S. y SUSANNE, G. ¿Es el conferencing una ..., op. cit. p. 87. Para un desarrrollo más amplio acerca de las difernetes mediaciones desarrolladas en Australia vid. DALY, K., "Conferencing in Australia and New Zealand: Variations, Research Findings and Prospects”, en MORRIS, A., y MAXWELL, G. (eds.). Restoring Justice for Juveniles: Conferencing, Mediation and Circles, Hart Publishing, Oxford, 2001, pp. 59-84.

${ }^{733}$ GUARDIOLA, M.J., ALBERTÍ, M., CASADO, C., MARTINS S. y SUSANNE, G. ¿Es el conferencing una ..., op. cit. p. 90. 
Gracias a la labor de Steve Ireland y John McDonald se pudo importar el FGC en Australia a través del proyecto piloto desarrollado en la ciudad de Wagga Wagga por los miembros del New South Wales Police Service, en el año 1991, para delitos leves cometidos por menores no reincidentes. Este proceso, el Conferencing Wagga Model (CWM en adelante), estaba desarrollado por el Servicio de Policía, siendo el facilitador un miembro de la policía -normalmente aquél que formó parte en la detención dl infractor- con el fin de darle mayor agilidad; de este modo se facilita la diversión y se acerca la justicia a las personas afectadas ${ }^{734}$. A la vez que se consigue una mayor integración de la policía se está limitando el principio de imparcialidad del facilitador pues ya no es un tercero independiente del asunto, sino que suele ser en la mayoría de las situaciones aquél miembro de los cuerpos de policía que llevó a cabo la detención del infractor, pudiendo tener una idea preconcebida antes de iniciar el proceso de mediación.

La gran particularidad de este modelo es la existencia de un guion prestablecido que utiliza el facilitador para el desarrollo del CWM. Así el facilitador se asegura de tratar unos temas determinados y seguir una línea progresiva que conforme una uniformidad a todos los procesos CWM, desmarcándose del FGC el cual da libertad para el desarrollo del proceso a los facilitadores y a las necesidades de las partes. En nuestra opinión este aspecto, aún positivo al unificar todos los procesos, hace perder libertad de actuación a las partes. El proceso va a seguir unas líneas desmarcándose de las posibles variaciones necesarias para la satisfacción de los intereses de las partes.

Este sistema se empezó a debatir en el resto de Australia, encontrado diferentes opiniones que han ido confeccionando un conjunto de programas híbridos entre el FGC y el CWM en los diferentes Estados Federales, todos ellos con un impacto social menor del deseado. El primer Estado en desarrollar esta figura fue South Australia a través de

734 GUARDIOLA, M.J., ALBERTÍ, M., CASADO, C., MARTINS S., SUSANNE, G. ¿Es el conferencing una ... op. cit. p. 91. Para un estudio pormenorizado respecto al sistema de conferencias de Wagga Wagga, vid. MOORE, D.B., y O’CONNELL, T., "Family conferencing in Wagga Wagga: a communitarian model of justice”, en Johnstone, G. (ed.). A Restorative Justice Reader, Willan Publishing, Cullompton, 2003, pp. 59-84. 
la Young Offenders Act $1993^{735}$, siguiendo mayormente el modelo neozelandés, obviando por tanto el guion prestablecido característico del modelo CWM y siendo un trabajador social el que ejerciese la función de facilitador ${ }^{736}$.

Los demás Estados fueron implementando diversas figuras de Conferencias, asemejándolas más o menos al sistema CWM o al FGC, dependiendo de las particularidades geográficas y sociales de cada Estado Federal. En todos ellos el objetivo es la minoración del contacto del menor con el sistema penitenciario y todos los efectos nocivos que este genera en el menor. Debido al limitado éxito y uso práctico de estas figuras se exponen unas líneas para cada uno de los cuatro modelos de Conferencias de menores de Australia ${ }^{737}$.

Siguiendo un orden cronológico el primero de los sistemas es el modelo de Queensland, el cual está regulado por la Youth Justice Act $1992^{738}$ para infractores menores que comprendan la edad de 10 a 16 años. Suelen derivarse a Conferencias los delitos de cierta gravedad y la derivación será realizada por la policía antes de iniciar el proceso judicial, o el Juzgado en cualquier fase del proceso judicial. Respecto a los participantes, la única característica diferente de los demás sistemas de Conferencias anteriormente estudiados, es la posibilidad que tiene el menor indígena - o cualquier menor aunque en su origen estaba enfocados en aquellos que procediesen de pueblos aborígenes- de ser acompañado por un representante de su comunidad o un representante de la justicia comunitaria de donde provenga dicho menor.

El programa Youth Justice Conferencing Scheme de New South Wales, regulado por la Young Offender Act de $1997^{739}$, está implementado para menores de 10 a 17 años que cometen delitos de cierta gravedad como robos con violencia, hurtos o daños a la

\footnotetext{
${ }^{735}$ Disponible en: https://www.legislation.sa.gov.au

${ }^{736}$ DALY, K. "Conferencing in Australia and ... op. cit., pp. 69-70.

${ }^{737}$ Más ampliamente GUARDiOLA, M.J., ALBERTÍ, M., CASADO, C., MARTINS S., y SUSANNE, G., ¿Es el conferencing una ... op. cit. pp. 86-113.

${ }^{738}$ Disponible en: https://www.legislation.qld.gov.au

${ }^{739}$ Disponible en: https://www.legislation.nsw.gov.au
} 
propiedad. La derivación va a recaer en el policía o en el juez de menores, dependiendo si se ha iniciado o no el proceso judicial. Respecto a los participantes, la ley no nos indica quienes están obligados a acudir, pero sí que regula aquellos que pueden presentarse voluntariamente, estando compuesta la conferencia por los mismos participantes que en el modelo FGC salvo por la inclusión de un miembro respetable de la comunidad.

El modelo de Australian Capital Territory está regulado por la Crimes (Restorative Justice) Act de $2004^{740}$ para infractores menores de 10 a 17 años para todo tipo de delitos excepto aquellos con los que venga aparejada una pena de prisión inferior a 14 años, delitos contra las personas con una pena de prisión de 10 años o superior y delitos sexuales o violencia doméstica. Como vemos, a diferencia de Queensland, se exceptúan de las Conferencias los delitos de cierta gravedad. La derivación va a recaer en la Office of Children and Young People, la Restorative Justice Unit y la policía siempre y cuando sea antes del inicio del proceso, pero si esta ya se hubiere iniciado, podrá derivarse en cualquiera de sus fases por el fiscal, el juzgado, y las dos organizaciones anteriormente indicadas. En cuanto a la participación no existe ningún carácter de relevancia a mencionar puesto que sigue la línea ya anteriormente mencionada de participantes del modelo FGC.

En cuanto al Group Conferencing Porgram del Estado de Victoria, está regulado por la Children, Youth and Families Act de $2005^{741}$ para infractores menores de edad pero que comprendan de 10 a 17 año. El ámbito material -el menos arriesgado por las infracciones recogidas- comprende delitos de pequeña gravedad, delitos que comporten una orden de supervisión o vigilancia o una medida alternativa. Las conferencias no se consideran importantes para delitos de cierta trascendencia. La derivación es realizada por el juez de menores antes de dictar sentencia.

\footnotetext{
${ }^{740}$ Disponible en: http://www.legislation.act.gov.au

${ }^{741}$ Disponible en: http://www.legislation.vic.gov.au
} 
Finalmente cabe añadir la existencia de un sistema de Conferencias en el ámbito de adultos en dichos Estados australianos ${ }^{742}$. El limitado auge de estas figuras debe su motivación a la creencia existente en Australia de que la Justicia Restaurativa sólo tiene funcionalidad en delitos leves y que es más factible de usar en el sistema de justicia juvenil, el cual es utilizado a modo de experiencias piloto, como un campo de pruebas $^{743}$. La idea es errónea a partir de la consecuencia de que, aunque las conferencias tienen una mayor experiencia y éxito en los procesos de menores, los procesos restaurativos parecen ser eficientes sin importar la edad de los sujetos. No se ha de valorar la edad de las partes, sino las particularidades propias de los sujetos que intervendrán. Serán los participantes quienes demuestren si un proceso restaurativo es factible o no, obviando las generalidades como factor diferenciador.

\section{La implantación en Irlanda del Norte.}

Realizar cualquier referencia a Irlanda del Norte y al Conferencing como base de su pacificación exige examinar su conflicto transcurrido el siglo pasado, el cual ha servido para la inclusión del diálogo y consenso dentro de la propia comunidad.

\subsection{El conflicto irlandés como antecedente al diálogo}

El siglo pasado no será olvidado por los habitantes de Irlanda del Norte a tenor de la escalada de violencia sufrida por los problemas de índole político-religiosos ${ }^{744}$. El denominado conflicto armado de Irlanda del Norte ${ }^{745}$ enfrentó a dos grupos de

\footnotetext{
${ }^{742}$ En los Estados Federales de Australia se realizan los siguientes Conferencing de adultos: New South Wales: se llevan a cabo el Forum Sentencing y el Restorative Justice Unit; Victoria: Young Adult Restorative Justice Group Conferencing; Queensland; Western Australia: Programa piloto en la ciudad de Fremantle y desarrollos posteriores; Australian Capital Territory

${ }^{743}$ STRANG, H., Restorative Justice Programs in Australia: A Report to the Criminology Research Council. 2001, pp. 4 y ss. Disponible en: http://www.criminologyresearchcouncil.gov.au (Última visita: 09/11/2017)

${ }^{744}$ Para un estudio relativo a los antecedentes del conflicto armado de Irlanda del Norte, vid. FUENTETAJA RUBIO, P., y GALVACHE VALERO, F., "Los antecedentes del Conflicto de Irlanda del Norte” en Reflexiones sobre la evolución del conflicto en Irlanda del Norte, Ministerio de Defensa, Madrid, 2007, pp 9-20.

${ }^{745}$ Denominado en inglés como The Troubles.
} 
habitantes; por una parte los unionistas de Irlanda del Norte o Fuerzas leales del Ulster, aquellos que defendían y practicaban la religión protestante y eran partidarios de mantenerse unidos aunque con autonomía con Reino Unido ${ }^{746}$; y por otra parte a los republicanos irlandeses, de religión católica y partidarios de una configuración territorial distinta, ya sea a través de la independencia o de la integración en la República de Irlanda y representados por el grupo IRA ${ }^{747}$ (Irish Republican Army) y sus diferentes facciones ${ }^{748}$ que se dividieron con el transcurso del tiempo ${ }^{749}$.

Las diferentes ideas políticas llevaron a Irlanda del Norte a una situación de violencia que se llegó a extender a Irlanda, Reino Unido e incluso Europa occidental hasta que la paz llegó a través del Acuerdo de Viernes Santo (The Good Friday or Belfast Agreement) celebrado el 10 de abril de $1998^{750}$. De este modo se establecía en Irlanda del Norte un Gobierno con idéntica representación de católicos y protestantes ${ }^{751}$,

\footnotetext{
746 ALONSO, R., Irlanda del Norte: Una historia de guerra y la búsqueda de la paz, Editorial Complutense, Madrid, 2001: “a pesar de la diversidad que la caracteriza, es posible encontrar un elemento homogeneizador en su preferencia constitucional para lo que hoy conocemos como Irlanda del Norte. En función de ella puede afirmarse que en la actualidad el término genérico de "unionistas" hace alusión a aquellos que son partidarios de mantener la unión entre Irlanda del Norte y el Reino Unido" (p. 7).

${ }^{747}$ A modo de ejemplo una noticia que repasa la historia del IRA: LEÓN, A., "IRA, 40 años de lucha sangrienta contra la dominación británica”, RTVE, 08/03/2009. Disponible en: http://www.rtve.es (Última visita (20/07/2017).

${ }^{748}$ Hay que recordar que desde la creación del inicial IRA han ido surgiendo diferentes grupos que, defendiendo la misma idea, han ido sembrando el terror en Irlanda, como el IRA Provisional, IRA Oficial, IRA de la Continuidad, IRA Auténtico o el actual IRA 2012. A modo de ejemplo véase AJA, J., “Tres grupos disidentes se unen en Irlanda del Norte para crear un nuevo IRA”, en Heraldo de Aragón, 27/07/2012, Disponible en https://www.heraldo.es (última visita 01/02/2018).

${ }^{749}$ Más ampliamente: MUÑOZ GIL, P., “Los actores violentos del conflicto”, en Reflexiones sobre la evolución..., op. cit., p. 49-70

${ }^{750}$ Más ampliamente, vid. BELL, C., “Dealing with the past in Northern Ireland” Fordham International Law Journal, $\mathrm{n}^{\circ}$ 26, 2003, pp. 1095-1147.

751 Más ampliamente véase AUGHEY, A., The Politics of Northern Ireland: Beyond the Belfast Agreement, Routledge, 2005, p. 7; ELLIOT, M., The Long Road to Peace in Northern Ireland: Peace Lectures from the Institute of Irish Studies at Liverpool University, Liverpool University Press, Liverpool, 2007, p 2; GILLESPIE, G., Historical Dictionary of the Northern Ireland Conflict, Scarecrow Press, 2008, p. 250; GOODSPEED, M., When reason fails: portraits of armies at war: America, Britain, Israel, and the future, Greenwood Publishing Group, Belfast, 2002, pp. 44-61; HOLLAND, J., Hope against History: The Course of Conflict in Northern Ireland, Henry Holt \& Company, 1999, p. 221.
} 
aunque todavía persisten facciones que exigen continuar con la violencia aun a muy pequeña escala ${ }^{752}$.

El gran número de víctimas por la violencia acaecida durante el siglo pasado ${ }^{753}$ ha llevado a que se describan estos hechos de diferentes maneras, tales como terrorismo $^{754}$, guerra de guerrillas ${ }^{755}$, conflicto étnico ${ }^{756}$ o guerra civil. Todo este conflicto desembocó en un proceso de paz el cual sentó un precedente de diálogo ${ }^{757}$, un diálogo que llevó a la implantación de las prácticas restaurativas. Es más, muchos de esos soldados condenados han acabado ejerciendo como mediadores/facilitadores ${ }^{758}$, utilizando la Justicia Restaurativa, y más concretamente las conferencias, como método para solucionar los problemas generados entre individuos derivados de dichos conflictos armados (problemas relativos a ideologías) así como aquellos nuevos que van surgiendo con el avance de la sociedad.

Aquí es donde radica la importancia de la Justicia Restaurativa, en la opción que ofrece a aquellos que han cometido delitos de poder rehacer su vida y redirigirla hacia una situación de mayor bienestar moral y beneficiosa para la comunidad. Algunos de

\footnotetext{
${ }^{752}$ Un ejemplo de ello fue el asesinato de diversos exmiembros del IRA: "Asesinado a tiros en Belfast un exmiembro del IRA” La Vanguardia, 13/08/2015. Disponible en: http://www.lavanguardia.com (Última visita 19/07/2017)

${ }^{753}$ Más de 3500 personas fallecieron por los hechos violentos acaecidos. Mayor información acerca del bando y status de los fallecidos: http://cain.ulst.ac.uk/sutton/tables/Status.html (Última visita 20/08/2017) 754 “ASESINO 102: IRA; historia de la banda terrorista irlandesa”, en Blog Biografía de asesinos, 14/03/2014. Disponible en: http://biografiasdeasesinos.blogspot.com.es (Última visita 19/07/2017)

Siguiendo la misma línea: ALONSO, R., "Terrorismo en Irlanda del Norte: Evolución y análisis de la situación”, en Cuadernos de pensamiento político 2013, pp. p-29, esp. p. 9-11. Disponible en: http://www.fundacionfaes.org (Última visita: 20/07/2017) Desde

${ }^{755}$ KNICKERBOCKER, B., "Classic Guerrilla war forming in Iraq", en The Christian Science Monitor, 20/09/2004. Documento en línea disponible en: http://www.csmonitor.com (Última visita: 21/07/2017). $\mathrm{Al}$ examinar los diferentes conflictos armado analiza el conflicto de Irlanda del Norte como una guerra de guerrillas.

${ }^{756}$ COAKLEY, J., "Ethnic Conflict and the Two-state Solution: The Irish Experience of Partition”, en los seminarios Ireland and Palestine - Divided Countries United By History, celebrados del 10-14 de Octubre de 2004 por PASSIA (Palestinian Academic Society for the Study of International Affairs) en Ramallah, Palestina. Disponible en: https://www.qub.ac.uk (última visita 01/02/2018)

${ }^{757}$ Para un estudio de este proceso de paz, véase: Procesos de paz: un Referente, Irlanda del Norte, Universidad Militar Nueva Granda, Instituto de Estudios Geoestratégicos y asuntos políticos, Bogotá, 2013. Disponible en: http://www.iegap-unimilitar.edu.co (Última visita 20/07/2016)

${ }^{758}$ Intervención de TIM CHAPMAN en el Congreso Europeo de Justicia Restaurativa y Terapéutica, celebrado en San Sebastián los días 16, 17, 18 de junio de 2016.
} 
aquellos soldados que intercambiaban disparos ahora pueden ayudar a que los ciudadanos dialoguen e intercambien opiniones que sirvan para la resolución de sus conflictos proporcionando una sociedad más justa. Aquellos que un día pasado llevaron a Irlanda del norte a una "guerra”, pueden llevarla ahora a una paz social.

\subsection{Las Conferencias norirlandesas: una inmersión en la restauración.}

Irlanda del Norte es uno de los países receptores del Conferencing, implementando una versión similar a la neozelandesa pero enfocado en la comunidad, en la justicia y derechos de los intervinientes ${ }^{759}$ a diferencia del FGC neozelandés, centrado en la familia. Para su instauración se tuvo en cuenta las dificultades que habían surgido en dicho territorio, preguntando a sus habitantes acerca de la idoneidad o no de la Justicia Restaurativa, acabando la inserción de estas figuras dentro del sistema de justicia penal $^{760}$ como una práctica complementaria para la resolución de conflictos.

Como acertadamente indican MCEVOY y MIKA ${ }^{761}$, CAMPBELL et al. ${ }^{762}$, así como ERIKSSON $^{763}$, la implantación de la Justicia Restaurativa en Irlanda del Norte, y en concreto las conferencias, se ha debido al desarrollo de un clima de paz que permite la solución de los problemas específicos del contexto norirlandés a través de mecanismos restaurativos. Así también DIGNAN y LOWEY ${ }^{764}$ promovieron estas figuras como método para modificar la mentalidad y relación de los ciudadanos con la

\footnotetext{
759 Intervención de TIM CHAPMAN en el Congreso Europeo de Justicia Restaurativa y Terapéutica, celebrado en San Sebastián los días 16, 17, 18 de junio de 2016 .

${ }^{760}$ El fin de esto es poder garantizar los derechos de los intervinientes y que estos no vean como la comunidad aplica medidas que ellos no desean o no pueden cumplir. Además consideraron que si estaba implementada dentro del sistema de justicia podría obtener un mayor éxito.

${ }^{761}$ MCEVOY, K., MIKA, H., "Restorative justice and the critique of informalism in Northern Ireland”, en British Journal of Criminology 2002, n 42, pp. 534-562.

${ }^{762}$ Para más información, vid. CAMPBELL, C., DEVLIN R., O’MAHONY, D., DOAK, J., JACKSON, J., CORRIGAN, T. et al., Evaluation of the Northern Ireland Youth Conference Service, Northern Ireland Statistics and Research Agency, Belfast, 2005.

${ }^{763}$ Para más información, vid. ERIKSSON, A., Justice in transition: Community restorative justice in Northern Ireland, Willan Publishing, Cullompton 2009.

${ }^{764}$ Para un entendimiento óptimo de la situación, vid. DIGNAN, J. AND LOWEY, K., Restorative justice options for Northern Ireland: A comparative view, Northern Ireland Criminal Justice Review Group, Belfast, 2000.
} 
justicia consiguiendo de este modo disminuir la hostilidad y desconfianza hacia la policía y el sistema de justicia penal.

A través del Acuerdo del Viernes Santo se implementan una serie de medidas restaurativas, modificándose el sistema penal entre 1998 y 2000 gracias a las consultas realizadas por el Criminal Justice Review Group y a los estudios de prácticas restaurativas existentes en otros Estados. Se consigue que la mayoría de ciudadanos apoyen la Justicia Restaurativa, su concepto y objetivos. No obstante y en contraparte, las discrepancias fueron mayores de lo esperado. La existencia de dudas sobre cómo se integrarían las conferencias dentro del sistema de justicia penal, sobre los delitos que pueden ser resueltos a través de esta práctica restaurativa y qué modelo instaurar utilización del modelo FGC o los modelos policiales, que ya estaban implantados como programas piloto en Irlanda del Norte as- creó una división. Parte de los ciudadanos consultados deseaban una integración dentro del sistema penal mientras que el resto consideraba las conferencias como una práctica alternativa al sistema de justicia penal. Así mismo las discrepancias existentes conforme al ámbito penal eran palpables existiendo una división conforme a un conjunto de ciudadanos que optaban por una aplicación en delitos de leve gravedad mientras que en su contraparte diferentes ciudadanos creían que cuanta mayor gravedad se podía obtener más utilidad en la Justicia Reestaurativa $^{765}$.

Se promulgó así la Justice (Northern Ireland) Act de 24 de julio de $2002^{766}$ en la que en su Capítulo 4, artículos 53 a 65 se regula la justicia juvenil o de menores, y dentro de ella, en los artículos 57-61 se da soporte legal a la Justicia Restaurativa ${ }^{767}$ a

\footnotetext{
765 GUARDiOlA, M.J., ALBERTí, M., CASADO, C., MARTINS S., SUSANNE, G., ¿Es el conferencing una ..., op. cit., p. 132.

${ }^{766}$ Disponible en: https://www.legislation.gov.uk

767 ZINSSTAG, E., y CHAPMAN, T., “Conferencing in Northern Ireland: Implementing restorative justice at the core of the criminal justice system”, en E. Zinsstag y I. Vanfraechem (eds.) Conferencing and Restorative Justice. International Practices and Perspectives, Oxford University Press, Oxford, 2012, pp. 173-188, esp. pp. 173-178.
} 
través del Youth Justice Conference Service ${ }^{768}$ como método para la resolución de conflictos en el ámbito penal de menores siguiendo el método del FGC neozelandés, al cual nos remitimos en cuanto a su procedimiento, características, intervinientes y objetivos. No obstante se señalan aquí algunas de las características propias que tiene esta figura.

Antes de entrar a valorar los caracteres de las Conferencias norirlandesas, se ha de indicar que el proceso se dirige a infractores menores de edad. Inicialmente el Youth Justice Conference Service se implantó en la ciudad de Belfast para infractores de 10 a 16 años, pero este mismo aspecto se fue extendiendo a las regiones de Fermanagh y Tyrone $^{769}$ y ampliándose hasta los 17 años ${ }^{770}$, aunque la mayoría de los infractores son chicos de 14 a 16 años de edad ${ }^{771}$.

En la actualidad, la situación de inestabilidad sigue conduciendo a la aparición de derivados de la actual inestabilidad económica y sociopolítica entre los miembros de la ciudadanía. Es por ello que la Universidad de Ulster ha iniciado el proyecto de investigación denominado "THE ALTERNATIVE” ${ }^{772}$. El estudio está enfocado en un impulso de la Justicia Restaurativa y, más concretamente, las conferencias a fin de resolver conflictos derivados del consumo de drogas, delitos de odio y conflictos interculturales derivados de creencias religiosas. Todo ello a través del entrenamiento de diferentes miembros de la comunidad así como del ofrecimiento a la ciudadanía de

\footnotetext{
${ }^{768}$ Creado en 2003 forma parte del organismo Youth Justice Agency y a su vez de la Northern Ireland Office, trabaja con menores de 10 a 17 años en diferentes regiones de Tyrone o Belfast llegando a resolver más de 900 procesos. Para más información vid. CAMPBELL, C., DEVLIN, R., O’MAHONY, D., DOAK, J., JACKSON, J., CORRIGAN, T., y MCEVOY, K., Evaluation of the Northern Ireland ..., op. cit; DOHERTY, K. "Restorative Youth Conferencing in Northern Ireland", en Newsletter of the European Forum for Restorative Justice 2011, n 1, pp. 3-5, esp. pp. 4-5.

${ }^{769}$ CAMPBELL, C., et al., Evaluation of the Northern Ireland ..., op. cit., p. 29.

${ }^{770}$ Vid. GUARDIOLA, M.J., et al., ¿Es el conferencing una ..., op. cit., p. 135

${ }^{771}$ BECKETT, H., CAMPBELL, C., O’MAHONY, D., JACKSON, J., DOAK, J., Interim evaluation of the Northern Ireland Youth Conferencing Scheme: Research and Statistical Bulletin 1/2005, Northern Ireland Statistics and Research Agency, Belfast, 2005.

772 Más ampliamente vid. CHAPMAN, T., CAMPBELL, H., WILSON, D., y MCCREADY, P., Exploring and crossing the frontiers of society: Restorative approaches to conflict between groups Comprehensive final report on RJ interventions in interethnic conflicts and multi-agency approach, 2015. Disponible en: http://www.alternativeproject.eu (Última visita: 09/11/2017)
} 
prácticas restaurativas para cambiar su enfoque hacia los demás miembros de la comunidad y mejorar las relaciones entre ellos. ${ }^{773}$.

\subsection{El Youth Conference Service: una figura adaptada a las necesidades de Irlanda.}

Conviene indicar ab initio que el Youth Conference Service centra su interés en la víctima y su reparación, dejando a un lado el modelo neozelandés que se centraba en la idea de familia ${ }^{774}$, situando al menor y a la familia en el centro de la comunidad ${ }^{775}$. La diferencia de este enfoque proviene de cultura y antecedentes históricos propios de cada región totalmente diferente. En Nueva Zelanda se buscó solucionar los problemas de delincuencia de los menores que venían de comunidades indígenas, con necesidades e ideas totalmente diferentes y con creencias centradas en la familia, respetando su cultura y no obligándoles abandonarla. Por el contrario, el sistema de Irlanda del Norte, aún con un latente conflicto político-religioso, busca reparar a la víctima como eje central del proceso, restaurarla en su situación y resocializar al menor infractor, sin importar aspectos culturales o raciales de los intervinientes, pues las diferencias de cultura entre los participantes son mínimas, existiendo una mayor preocupación en relación al damnificado por el delito; no así como sucedía ante Nueva Zelanda al existir dos culturas y formas de entender la vida tan dispares.

Como característica principal del modelo norirlandés hemos de señalar que las Conferencias han de ser derivadas por el Fiscal o por los juzgados de menores, teniendo ambos la última palabra para la valoración y aceptación del plan de reparación acordado

\footnotetext{
773 CHAPMAN, T., “Community and Restorative Justice”, en J.L. de la Cuesta y I. J. Subijana (dirs.), Justicia Restaurativa y Terapéutica. Hacia innovadores modelos de justicia, Tirant lo Blanch, Valencia, 2017, pp. 75-85, esp. pp. 78-82.

${ }^{774}$ CAMPBELL, C., et al., Evaluation of the Northern Ireland ..., op. cit., pp. 1-2.

775 Más ampliamente: HUDSON, J., MORRIS, A., MAXWELL G., y GALAWAY B., Family Group Conferences: Perspectives on Policy and Practice, Criminal Justice Pr, Monsey, 1996.
} 
por las partes intervinientes en el proceso, pudiendo modificarlo en lo que consideren oportuno $^{776}$.

En datos de CAMPBELL ${ }^{777}$, la mayoría de los procesos, un 69\%, son derivados por los juzgados de menores, mientras que el 31\% restante procede de la fiscalía. En el caso específico de delitos de pequeña gravedad, el 71,4\% son derivados a un proceso de Conferencing por los juzgados de menores, quedando en un $28,6 \%$ los derivados por fiscalía, siendo este un dato muy llamativo a consecuencia de que en general suele ser fiscalía quien deriva a procesos restaurativos los delitos de menos gravedad.

Se observa aquí la importancia asignada a jueces y fiscales dentro de la comunidad considerándose óptimo que el sistema de justicia penal clásico deba de realizar un último control de los procesos restaurativos para garantizar "los derechos de ofensores, víctimas y otros participantes en el proceso restaurativo" ${ }^{778}$. De este modo, en la línea afirmada, la Justicia Restaurativa se integra en la justicia penal clásica.

Jueces y fiscales son considerados como garantes de la justicia y por ello se les confía la derivación de los casos a procesos de conferencias, al ser los más capacitados para observar su conveniencia a favor de víctima e infractor, las posibilidades de éxito, la necesidad de una conferencia para educar al menor, la igualdad existente entre ambos, y la proporcionalidad de los acuerdos ${ }^{779}$. Tendrán la última palabra sobre el plan de reparación acordado entre las partes y en el supuesto de necesaria modificación. Se les otorga la facultad de repasar y modificar el acuerdo al que han llegado las partes a través del diálogo. Aunque en principio podría resultar criticable que el acuerdo al que llegan las partes no es respetado al poder ser modificado, nada más lejos de la realidad. Esta potestad asignada a jueces y fiscales sirve para controlar el proceso y poder suplir

\footnotetext{
${ }^{776}$ Intervención de TIM CHAPMAN en el Congreso Europeo de Justicia Restaurativa y Terapéutica, celebrado en San Sebastián los días 16, 17, 18 de junio de 2016.

${ }^{777}$ CAMPBELL, C., et al., Evaluation of the Northern Ireland ..., op. cit. p. 147

${ }^{778}$ GUARDIOLA, M.J., et al., ¿Es el conferencing una ..., op. cit., p. 133

779 CAMPBELL, C., et al., Evaluation of the Northern Ireland ..., op. cit., pp. 33-38 y pp.60-78. Nos indica en su obra la importancia que tiene el facilitador para asegurar el cumplimiento de la proporcionalidad, debiendo de tener la suficiente capacidad para conseguir este objetivo.
} 
los apartados acordados en los que no haya existido bona fide o no sean beneficiosos para las partes.

Un ejemplo de ello sería un plan de reparación que humilla al infractor menor o un plan de reparación que, no sólo no castiga al menor sino que, además, no se le obliga a la realización de ninguna acción restaurativa a favor de la víctima, quien no pudo mostrar su opinión, esta no fue tomada en cuenta a pesar de ser emanada o simplemente fue incapaz comprender el proceso o la reparación que allí se estaba discutiendo. Por consiguiente, nos parece fundamental esta potestad otorgada a jueces y fiscales para controlar el contenido de los acuerdos de reparación, una facultad que les reforzará en su posición de garantes de la seguridad jurídica y, en este caso, garantes del proceso de conferencias.

En cuanto a la participación, el número de intervinientes es muy similar al ya anteriormente citado en el modelo FGC: el menor infractor y sus familiares (son claves no sólo para la elaboración del plan sino para su cumplimiento ${ }^{780}$ ); el coordinador; el agente de policía; y la víctima y sus personas de apoyo, cuya participación es facultativa pudiendo hacer uso de medios telemáticos o a través de representante para ser parte en el proceso de conferencias en caso de imposibilidad de acudir presencialmente.

Siguiendo las conferencias neozelandesas se ha querido dar la oportunidad de no participar en el proceso restaurativo a la víctima, aun pudiendo producir un efecto positivo su participación ${ }^{781}$ a consecuencia su influencia, apoyo y ayuda que ofrecen al menor infractor para hacerle comprender lo erróneo de su conducta delictiva ${ }^{782}$, y el conocimiento del plan de reparación que se va a efectuar. Este punto está siendo controvertido puesto que en numerosas ocasiones las víctimas no tienen la oportunidad

\footnotetext{
${ }^{780}$ CAMPBELL, C., DEVLIN, R., O’MAHONY, D., DOAK, J., JACKSON, J., CORRIGAN, T., y MCEVOY, K., Evaluation of the Northern Ireland ..., op. cit., pp. 82-90.

${ }^{781}$ ZINSSTAG, E., TEUNKENS, M., y PALI, B., Conferencing: a way forward for ..., op. cit., p. 251: Entre los años 2009 y 2010, el 74\% de las víctimas tomaron parte en los procesos de conferencias, quedando el 74\% de ellas satisfechas y además el 90\% de las víctimas declaró que recomendaría el conferencing a otras víctimas.

${ }^{782}$ CAMPBELL, C., et al., Evaluation of the Northern Ireland ..., op. cit. p. 141.
} 
de adquirir noción alguna sobre el progreso y conclusión del plan de reparación ${ }^{783}$. En cuanto a la presencia de los abogados de las partes, aunque se recomienda que todos los intervinientes estén bien asesorados legalmente, su posición en el proceso es prácticamente nula. Sólo el $15 \%$ de los ofensores acude con un representante legal, mientras que en las víctimas casi ninguna acude con él ${ }^{784}$.

La comunidad participa en los procesos de conferencias a través de la intervención de familiares y amistades de los intervinientes, los cuales son parte de la representación de la comunidad. Y aún con un carácter más importante aparece la figura del agente de la policía. En Irlanda del Norte, tras todos los acontecimientos ocurridos en el siglo pasado, se ha querido otorgar notable consideración a la Comunidad y a sus representantes a la hora de resolver los conflictos, siendo importantes en la toma de decisiones y en las actuaciones prácticas ${ }^{785}$.

Las personas de apoyo -familiares y amistades- pueden conllevar un carácter fundamental para el devenir del proceso restaurativo pues sirven de asistencia al menor infractor, al quien le aconsejan y describen el efecto que ha tenido para todos -víctima, infractor y personas de apoyo de ambos- el hecho delictivo. Serán aquellos que haya elegido el menor infractor, pudiendo ser un familiar o alguna persona con la que exista confianza y ya hayan tratado anteriormente, pudiendo añadirse aquí cualquier persona que decida el menor. Su misión es auxiliar a los menores durante la conferencia y ser parte de la elaboración del plan de reparación tomando parte activa en las discusiones y alentando al menor para el cumplimiento del plan $^{786}$ que se ha comprometido a realizar $^{787}$. En la práctica también se comportan como víctimas al sufrir una serie de efectos negativos derivados del delito como tristeza, vergüenza o incluso miedo.

\footnotetext{
783 ZINSSTAG, E., TEUNKENS, M., y PALI, B., Conferencing: a way forward for ..., op. cit., p. 251

${ }^{784}$ GUARDIOLA, M.J., et al., ¿Es el conferencing una ..., op. cit., p. 140.

${ }^{785}$ Intervención de TIM CHAPMAN en el Congreso Europeo de Justicia Restaurativa y Terapéutica, celebrado en San Sebastián los días 16, 17, 18 de junio de 2016 .

${ }^{786}$ ZINSSTAG, E., TEUNKENS, M., PALI, B., Conferencing: a way forward for ..., op. cit., p. 250.

${ }^{787}$ DIGNAN, J., y LOWEY, K., Restorative justice options for..., op. cit.
} 
El agente de policía tiene el deber de dar testimonio sobre los hechos al inicio de la conferencia; es uno de los momentos clave del proceso, ya que si el menor discrepa profundamente sobre ellos puede que realmente no esté aceptando su responsabilidad $^{788}$. No obstante, pueden existir discrepancias sobre el punto de vista de los hechos, ya que cada persona que interviniente en un hecho delictivo puede interpretarlo de una manera u otra, y tales discusiones no serían sinónimo de una no aceptación de la responsabilidad. A esto hay que sumarle el apoyo que algunos agentes de policía realizan al menor, premiándoles públicamente por sus comportamientos positivos durante el proceso restaurativo.

Se finaliza, aún sin ser una característica propia de este modelo de conferencias, indicando que la participación del facilitador es fundamental para el desarrollo del proceso, debido a que es un profesional entrenados específicamente en estas labores que van a preparar la conferencia, preparar a todos los intervinientes, desarrollar las actuaciones bajo un clima de paz y seguridad y trabajar para la obtención de un plan de reparación que sea beneficioso para todos los presentes ${ }^{789}$ y especialmente para las víctimas.

\subsection{Algunos datos relativos a práctica.}

Las conferencias norirlandesas han tenido un cierto alcance positivo a tenor de los datos existentes. Aunque la mayoría de miembros del sistema de justicia estaba en contra de su implantación, en la actualidad el $80 \%$ de los jueces lo valora positivamente $^{790}$. Junto a la aceptación judicial existente “el 92\% de ofensores y el 78\% de víctimas opinaban que el encuentro había contribuido a ayudar al menor ofensor a darse cuenta del daño que había causado el delito. La mayor parte de ofensores (86\%)

\footnotetext{
${ }^{788}$ GUARDIOLA, M.J., op. cit., ¿Es el conferencing una ..., op. cit., pp. 135.

789 ZINSSTAG, E., TEUNKENS, M., PALI, B., Conferencing: a way forward for ..., op. cit., p. 252. Más ampliamente, véase CAMPBELL, C., et al., Evaluation of the Northern Ireland ..., op. cit. pp. 34-143. En dichas páginas se examina el proceso de conferencias profundizando en las labores de preparación, desarrollo, entrevistas, plan de reparación etc.

${ }^{790}$ Intervención de TIM CHAPMAN en el Congreso Europeo de Justicia Restaurativa y Terapéutica, celebrado en San Sebastián los días 16, 17 y 18 de junio de 2016.
} 
y de víctimas (88\%), recomendaría un encuentro a una persona en una situación similar [...] la tasa de reincidencia en el conferencing se sitúa, aproximadamente, un $10 \%$ por debajo de la del proceso tradicional” ${ }^{\text {,91. }}$.

Desde la promulgación de la ley de 2002, a tenor de los datos aportados por CHAPMAN $^{792}$, más de 90.000 personas -1 de cada 20- han participado en procesos de conferencias. El 26\% de estas conferencias ha tenido lugar por delitos graves, mostrando que esta figura también puede ser útil en infracciones de cierta gravedad. Del conjunto de todas las Conferencias practicadas el 94\% acabó en un acuerdo de reparación exitoso por su composición y por su ejecución. Estos acuerdos de reparación han conseguido reducir la reincidencia delictiva en un $43 \%$, disminuyendo un $22 \%$ en supuestos infractores que cometieron delitos graves. Datos significativos que nos muestran la efectividad de la institución aun sin la debida consolidación en el sistema judicial.

El Conferencing demuestra grandes resultados en la resolución de conflictos, sanando a las víctimas y ayudando a resocializar a los menores. Y desde una perspectiva económica supone un gran ahorro, puesto que un proceso de conferencias suele costar alrededor de 1200 libras, mientras que un proceso jurisdiccional clásico cuesta 3500 libras $^{793}$. Un ahorro de 2300 libras por litigio supone una cantidad considerable para las arcas del Estado y más observando los numerosos litigios existentes.

\section{La recepción en Bélgica}

En las páginas siguientes se examinará la adaptación y desarrollo que Bélgica ha llevado a cabo para la inclusión en su sistema legal del sistema de conferencias, a través de la implantación del proyecto piloto de Flandes y las posteriores regulaciones legales.

\footnotetext{
${ }^{791}$ GUARDIOLA, M.J., et al., ¿Es el conferencing una ..., op. cit., pp. 143-142.

${ }^{792}$ Intervención de TIM CHAPMAN en el Congreso Europeo de Justicia Restaurativa y Terapéutica, celebrado en San Sebastián los días 16, 17 y 18 de junio de 2016.

${ }^{793}$ ZINSSTAG, E., TEUNKENS, M., y PALI, B., Conferencing: a way forward for ..., op. cit., p. 249.
} 
Se realizará un mayor análisis del proyecto pues no en vano fue la base para la implantación en el ordenamiento legal belga de las conferencias.

\subsection{El Proyecto piloto de la Universidad Católica de Lovaina.}

Bélgica fue el primer país europeo continental en implementar la figura de las conferencias, y todo ello gracias al proyecto piloto desarrollado en la región de Flandes en el año 2000 en el ámbito de justicia penal de menores ${ }^{794}$ por la Universidad católica de Lovaina en aras a la resocialización de menores a través de métodos de justicia sin un componente punitivo ${ }^{795}$. Para ello contó con el apoyo de cinco organizaciones asentadas en Amberes, Hasselt, Lovaina y Bruselas ${ }^{796}$. Dicho Proyecto fue llevado a cabo por Lode Walgrave e Inge Vanfraechem del Grupo de Investigación en Criminología Juvenil de la Universidad Católica de Lovaina, y subvencionado con fondos del Departamento de Bienestar Social del Gobierno de la Región de Flandes

El sistema penal juvenil belga se ha caracterizado por buscar la resocialización de los menores, intentando siempre no castigar a este tipo de delincuentes. Para ello, los investigadores de Lovaina se dispusieron a realizar una adaptación del modelo neozelandés, el cual suponían perfectamente ajustable dentro de su sistema, pese a las diferencias existentes entre el Derecho de Europa continental, el Civil Law, con el Derecho anglosajón, el Common $\operatorname{Law}^{797}$. Al existir una regulación previa de mediación penal en el sistema de menores para la resolución de delitos leves, ello adelantaba las bases y experiencias necesarias presuponiendo un beneficio para una correcta implantación de las conferencias.

\footnotetext{
${ }^{794}$ ZINSSTAG, E., TEUNKENS, M., y PALI, B., Conferencing: a way forward for ..., op. cit., p. 262. ${ }^{795}$ VANFRAECHEM, I., y WALGRAVE, L., "Restorative conferencing in Belgium: can it decrease the confinement of young offenders?”, en Research Unit Criminal Law and Criminology 2004, n 7, pp. 7275.

${ }^{796}$ ZINSSTAG, E., TEUNKENS, M. y PALI, B., Conferencing: a way forward for ..., op. cit., p. 263. ${ }^{797}$ JIMENO BULNES, M., "El proceso penal en los sistemas de Common Law y Civil Law: los modelos acusatorio e inquisitivo en pleno siglo XXI”, en Justicia: revista de derecho procesal 2013, n ${ }^{\circ}$, pp. 207310.
} 
Por ello las investigaciones se centraron en la aplicación de las Conferencias en delitos graves -especial incidencia en delitos de carácter sexual $^{798}$-, ya extenderla a delitos leves resultaría reiterativo debido a su regulación como infracciones derivadas a mediación ${ }^{799}$ y el beneficio para los intervinientes sería menor ${ }^{800}$. Así se daba la posibilidad de resolver los conflictos graves a través de un método diferente al sistema de justicia clásico, el cual era la única oportunidad existente en el momento.

Este proyecto piloto, gracias a la ayuda del experto en materia de conferencias neozelandesas Allan MacRae ${ }^{801}$, se basó en las prácticas restaurativas llevadas a cabo en Nueva Zelanda. Por este modo se diseñaron 4 fases de actuación en todo proceso de conferencias, como son la preparación, sesiones de conferencia, plan de intenciones y ejecución del plan ${ }^{802}$. Al ser prácticamente idéntico al sistema de FGC ya indicado, se analizarán aquellos aspectos que ya sean por su especialidad o novedad, otorgan al sistema de conferencing flamenco una serie de características peculiares.

Existirán dos facilitadores para auxiliar y conducir el proceso hacia su resolución. Sus funciones no varían de las ya comentadas para otros sistemas salvo que, en ausencia de la víctima, uno de ellos podrá situarse en su posición como representante en aras de la defensa de sus intereses. Para una correcta ejecución de sus labores los facilitadores deberán ser debidamente entrenados por la organización Ondersteuningsstructuur Bijzondere Jeugdzorg ${ }^{803}$ y por aquellos facilitadores que

\footnotetext{
${ }^{798}$ Más ampliamente véase VANSEVEREN, B. "Hergo in Belgium: Flanders Developments in Flanders and Hergo in sexual assault cases", en Expert Seminar on Conferencing in Leuven, Belgica, 2010. Disponible en http://www.justicereparatrice.org (última visita 17/04/2018)

799 WALGRAVE, L., "Restorative conferences with serious juvenile offenders: an experiment in Belgium”, en el $4^{\circ}$ International conference on conferences \& circles, 2003, pp. 69-79, esp. p. 73. Disponible en: http://www.iirp.org (Última visita: 09/11/2017)

${ }^{800}$ VANFRAECHEM, I., y WALGRAVE, L., Conferencing Serious Juvenile Delinquents in Belgium: From November 2000 to October 2003, youth courts in Belgium piloted the use of the New Zealand model of Family Group Conferencing, 2005. Disponible en: http://www.justicereparatrice.org (Última visita: 09/11/2017)

${ }^{801}$ WALGRAVE, L., "Restorative conferences with ...”, op. cit., p. 75

802 ZINSSTAG, E., TEUNKENS, M., PALI, B., Conferencing: a way forward for ..., op. cit., p. 263

${ }^{803}$ Mayor información con relación a la organización "Estructura de apoyo para el cuidado especial de los jóvenes”. Disponible en http://2013.steunpuntjeugdhulp.be (Última visita: 09/011/2017)
} 
fueron formados por McRae, proviniendo todos ellos de diferentes ramas como la criminología o la psicología.

Respecto al resto de participantes en el proceso, existen múltiples similitudes con los anteriores sistemas implantados en Irlanda del Norte y Nueva Zelanda. Siguiendo al modelo neozelandés, la participación del agente de policía tendrá lugar como garante y representante de la comunidad, papel que muchos de los miembros del cuerpo de policía no entendieron y por el cual actuaron, en palabras de WALGRAVE, "sin garra" 804 . Se decidió incluir en el proceso a los abogados de las víctimas, los cuales ofrecieron una nueva visión del conflicto y un apoyo jurídico a las partes. El menor podrá, como sucede en Nueva Zelanda, acudir una reunión privada con su grupo de apoyo para el desarrollo del plan de reparación. Deberá poner dicho plan restaurativo en común con los demás intervinientes en el proceso, y, en caso de acuerdo, se denominará declaración general de intenciones ${ }^{805}$.

El juez, tal y como sucede en el Youth Conference Service de Irlanda del Norte, tendrá la última palabra sobre el acuerdo ${ }^{806}$, debiendo de revisarlo y en su caso modificar lo que considere oportuno. Es por ello que el acuerdo se denomina como “declaración general de intenciones”, porque se permite al juez otorgar una última valoración sobre el convenio al que han llegado los intervinientes así como revisar el cumplimiento total de lo pactado ${ }^{807}$. Ello supuso un sinfín de críticas debido la dificultad que ello conllevaba, sobre todo en lo relativo a la restauración de la sociedad $^{808}$.

\footnotetext{
${ }^{804}$ WALGRAVE, L., “Restorative Conferences with ...” op. cit., p. 76.

${ }^{805}$ GUARDIOLA, et al., ¿Es el conferencing una ..., op. cit., p. 151.

${ }^{806}$ WALGRAVE, L., "Restorative conferences ..." op. cit., p. 77 y ss.

${ }^{807}$ Se considera que el cumplimiento de un plan de intenciones puede durar entre seis meses y un año, debiendo de ser el juez quien valore su debido cumplimiento y quien cierre el proceso en caso afirmativo. ${ }^{808}$ VANFRAECHEM, I., y WALGRAVE, L., Conferencing Serious Juvenile Delinquents ..., op. cit.
} 
Así iba a nacer el sistema de conferencias denominado como "HERGO"809 (Hertelgricht Groepsoverleg), el cual fue definido por ZINSSTAG, TEUNKENS y PALI como "una reunión que se focaliza en la búsqueda de soluciones constructivas a las consecuencias del delito cometido por el menor. La víctima, el ofensor y las respectivas personas de apoyo se encuentran con el objetivo de buscar vías de reparación a la víctima y a la sociedad, y cómo prevenir la reincidencia” ${ }^{810}$. Al sistema “HERGO” le fueron remitidos 98 procesos, de los cuales se practicaron 53 Conferencias para 58 delincuentes menores, con una duración variable, pero siempre entre seis meses y dos años ${ }^{811}$ cada una de ellas. Las edades de los menores oscilaban entre los 13 y los 18 años, pero la mayoría tenían 16, siendo 57 chicos y una única chica ${ }^{812}$.

Se exponen los datos derivados del estudio alcanzado por de VANFRAECHEM y WALGRAVE ${ }^{813}$ relativos a la satisfacción de las partes e intervinientes en el proceso de conferencia "HERGO”.

\begin{tabular}{|l|l|l|l|l|}
\hline & Menores & Padres & $\begin{array}{l}\text { Víctimas } \\
\text { presentes }\end{array}$ & $\begin{array}{l}\text { Víctimas no } \\
\text { presentes }\end{array}$ \\
\hline $\begin{array}{l}\text { ¿Se le comentó que sucedería } \\
\text { en la conferencia? }\end{array}$ & $94.7 \%$ & $81.7 \%$ & $77.7 \%$ & $63.6 \%$ \\
\hline $\begin{array}{l}\text { ¿Se sintió bien preparado } \\
\text { para la conferencia? }\end{array}$ & -- & $75.6 \%$ & $61.5 \%$ & --- \\
\hline
\end{tabular}

Figura 41. Satisfacción con la preparación

\footnotetext{
${ }^{809}$ ZINSSTAG, E., TEUNKENS, M., y PALI, B., Conferencing: a way forward for..., op. cit., p. 263, HERGO es una contracción de Hertelgricht Groepsoverleg, que a su vez es una traducción de Family Group Conferencing o “Consulta Grupal Restaurativa” del idioma flamenco y neerlandés.

${ }^{810}$ GUARDIOLA, M.J., et al. ¿Es el conferencing una ..., op. cit., p. 152.

${ }^{811}$ VANFRAECHEM, I., y WALGRAVE, L., Conferencing Serious Juvenile Delinquents ... op. cit.

${ }^{812}$ VANFRAECHEM, I., y WALGRAVE, L., Restorative conferencing in Belgium: can it decrease... op. cit.

813 Traducción propia de las tablas elaboradas por VANFRAECHEM, I. y WALGRAVE, L., Conferencing Serious Juvenile Delinquents ... op. cit.
} 


\begin{tabular}{|l|l|l|l|l|}
\hline & Menores & Padres & $\begin{array}{l}\text { Víctimas } \\
\text { presentes }\end{array}$ & $\begin{array}{l}\text { Víctimas } \\
\text { no } \\
\text { presentes }\end{array}$ \\
\hline $\begin{array}{l}\text { ¿La Conferencia fue } \\
\text { ofrecida, de forma } \\
\text { voluntaria, a todos las } \\
\text { víctimas/infractores? }\end{array}$ & $75.7 \%$ & - & $61.5 \%$ & $91.7 \%$ \\
\hline $\begin{array}{l}\text { Si tuviera que realizarlo } \\
\text { todo de nuevo, ¿elegiría } \\
\text { de nuevo participar en una } \\
\text { conferencia? }\end{array}$ & $86.8 \%$ & $88.6 \%$ & $92.3 \%$ & $58.3 \%$ \\
\hline El daño es reparado & - & - & $48.1 \%$ & $50 \%$ \\
\hline
\end{tabular}

Figura 42. Satisfacción con el resultado de la conferencia.

Podemos observar la alta satisfacción de las partes intervinientes, tanto en la preparación de la conferencia como en su resultado. Es verdad que en cuanto a la reparación del daño, es cuando podemos observar una menor satisfacción, pero las cifras son positivas al mostrar como prácticamente todos los intervinientes volverían a participar en una conferencia, excepto en víctimas no presentes, que lógicamente disminuye su número a poco más de la mitad.

\subsection{Del éxito de Flandes a su asentamiento en Valonia y Bruselas}

El éxito del Proyecto de Lovaina fue notorio, cuajando en la promulgación de las Leyes 15 de mayo de 2006 y 15 de junio 2007, que establecen el Conferencing como método para la resolución de conflictos en el ámbito penal de menores, y la Circular Ministerial del 13 de junio de 2006. Este nuevo cuerpo legal, con base en los estudios 
teórico-prácticos de Flandes, supone un gran avance para el sistema penal juvenil y la Justicia Restaurativa en términos generales.

Aun así existen modificaciones respecto a la idea original. La primera de ellas es la prohibición de actuación de los abogados más allá de las fases preparatorias y restaurativas, vedando su participación en las sesiones de encuentro, a fin de evitar una negociación entre los abogados. El segundo punto alterado es el cambio de rol del policía. En el proyecto piloto se otorgaba al policía el papel de representante de la comunidad, mientras que en el nuevo proceso, el policía ve limitada su intervención, llegando incluso a abandonar las sesiones en el caso de que alguna de las informaciones que se estén comentando pueda llegar a ser perjudicial para el futuro del menor. Su presencia en el proceso denotará la preocupación pública existente por el delito y la presión pública para búsqueda de una solución ${ }^{814}$, pero la incomprensible limitación de funciones es una evidente pérdida de confianza en su figura.

El cambio de la figura de representante de la sociedad será otra de las consecuencias del sistema legal continental respecto al sistema legal anglosajón de Irlanda del Norte y Nueva Zelanda, asumida por el Ministerio Fiscal. Ejerce un papel de representante de la comunidad en el sistema legal de Bélgica, adquiriendo así las potestades que el sistema de Conferencing neozelandés otorgaba al policía y que había sido adoptado por el proyecto flamenco.

En la fase inicial no fue exitosa, siendo la región de Flandes la única que consiguió un adecuado fomento y desarrollo de la figura tal y como estipulaba la normativa. Ello fue gracias la organización $\mathrm{ALBA}^{815}$, la intervención de las demás asociaciones de mediación.

\footnotetext{
${ }^{814}$ WALGRAVE, L., "Restorative Conferences with serious ...”, op. cit. p. 76.

${ }^{815}$ Organización enfocada en la ayuda a menores de edad infractores a través de la utilización de prácticas de mediación, prácticas derivadas del proyecto "HERGO" y servicios comunitarios en las regiones de Bruselas y Flandes. Para mayor información relativa a los servicios que ofrece la organización ALBA. Disponible en: http://www.alba.be/bal_index.php
} 
El sector judicial en general no contribuyó a su desarrollo al no remitir prácticamente casos a los servicios al no confiar en las prácticas restaurativas. Y en el supuesto de remisiones, eran aquellos ya tratados por servicios de mediación. Por ello, y a pesar del ímpetu reformista y el auge de las conferencias flamencas, su uso práctico en la totalidad de Bélgica ha supuesto un gran reto plagado de dificultades. A modo de ejemplo hay que observar que Lovaina tiene 3 facilitadores y Bruselas 6, desarrollándose entre 10 y 25 conferencias en el primer año ${ }^{816}$, a pesar de ser ellos los investigadores y promulgadores del sistema "HERGO”.

A pesar de ello, la región de Valonia fue consiguiendo una mayor adaptación de la figura con el transcurso del tiempo. Cabe destacar las conferencias desarrolladas desde 2006 por la organización de Arpège de la ciudad valona de Lieja, en donde tales los procesos restaurativos se incrementan año tras año gracias a la confianza de la sociedad y de los jueces, los cuales remiten los delitos juveniles graves a esta organización para su resolución a través del expandido a toda Bélgica sistema “HERGO”.

Así, Bélgica consigue instaurar un sistema de resolución de conflictos alternativo al sistema penal clásico, centrado en el diálogo de víctima y menor, consiguiendo de este modo una solución pacífica basada en la reparación y resocialización de víctima e infractor respectivamente así como la obtención de una paz social de la comunidad. Es insólito examinar que, allí donde los estudios prácticos fueron los que exitosamente dieron lugar a la promulgación de un cuerpo legal, está siendo el lugar en donde menos desarrollo pragmático está desarrollándose tras la legislación el sistema de conferencias, como por ejemplo Lovaina. Y en cambio, en aquellos lugares en donde no existía una práctica anterior, han conseguido ir implantando la figura de manera progresiva y en beneficio de la sociedad, como por ejemplo la ciudad de Lieja.

${ }^{816}$ ZINSSTAG, E, et al., Conferencing: a way forward for... op. cit., p. 264 
Como conclusión se puede señalar la importancia del sistema "HERGO” como método de resolución de conflictos. Es irónico observar que en Flandes donde se desarrolló un proyecto piloto y parecía que mayor desarrollo práctico iba a ofrecer el Conferencing a través de la legislación belga, ha sido donde al final más esfuerzo ha supuesto la implantación de dicha práctica restaurativa. Por el contrario, en la región de Valonia, la cual carecía de experiencia restaurativa previa, ha ido consiguiendo un sistema de conferencias a través de la confianza en el por el sistema de justicia penal y la comunidad en general.

\section{Otros modelos de Conferencias.}

Seguidamente se expondrá el desarrollo de las conferencias en diversos países del mundo como Noruega, Sudáfrica, o Brasil, así como las peculiaridades propias que caracterizan a estos sistemas. Analizaremos aquí siquiera brevemente los dos primeros.

\subsection{El servicio de Konfliktrådet: el modelo de conferencing en Noruega}

En Noruega, la idea de Justicia Restaurativa está asentada en el sistema de justicia, existiendo una gran aceptación y utilización de los servicios de mediación y conferencias, todos ellos ofertados por la misma organización, la denominada The mediation and reconciliation service $\mathrm{y}$ en la actualidad The mediation service (Konfliktrådet). Bajo la dirección de un secretario general y del Ministerio de Justicia noruego con sede en Oslo ${ }^{817}$ existen 22 oficinas que ofrecen estos servicios, todas ellas dirigidas por un pequeño número de facilitadores. En términos generales se computan alrededor de 650 facilitadores/mediadores en toda Noruega, los cuales reciben “entrenamiento” para el ejercicio de esta profesión la cual comparten con un empleo principal $^{818}$.

\footnotetext{
${ }^{817}$ ZINSSTAG, E;., TEUNKENS, M., y PALI, B., Conferencing: a way forward for..., op. cit., p. 276 ${ }^{818}$ Idem, p. 280.
} 
Noruega, a diferencia de los anteriores países, no denomina a estas instituciones como programas de mediación o programas de conferencias, sino que utiliza el término “servicios”. Son considerados así debido a que los consideran como un servicio gratuito que ofrecen a la ciudadanía para la resolución de los conflictos surgidos en medio de las relaciones humanas ${ }^{819}$. Estos servicios relativos a mediación y conferencias, regulan “tanto las causas penales, es decir, la mediación penal [VOM], y la mediación en los casos civiles (como las conferencias familiares en grupo [FGC], la mediación en grupo, así como la VOM como complemento del procedimiento penal) ${ }^{\text {820 }}$.

Las conferencias fueron implementadas a través de la Ley de Mediación de 15 de marzo de 1991 Act $N^{o}$. 3 relating to Mediation and Conciliation by the Mediation Service, erróneamente mencionada como Municipal Mediation Boards Act ${ }^{821}$ y fueron adquiriendo mayor importancia con el paso de los años, renovándose la normativa y ampliándose el servicio ofertado a la ciudadanía, de manera que en 2010 se llevaron a cabo 250 conferencias $^{822}$.

El éxito de la institución también se debe a la amplia oferta de servicios de mediación en tierras noruegas, de tal modo que ha llegado un momento en que la diferencia entre las conferencias y la mediación es borrosa, llegando a ser utilizados indistintamente o mezclados entre ellos. En Noruega no se aplica un servicio de conferencias o de mediación puro, sino que ofrece un servicio mixto, amoldado a las necesidades de las partes en cada momento.

\footnotetext{
${ }^{819}$ Idem, p. 276.

${ }^{820}$ HYDLE, I., y KEMÉNY, S., "From local trial projects to state owned services -Empirical research on restorative justice in Norway”, en I. Vanfraechem, I. Aertsen y J. Willemsens (Eds.), Restorative justice realities: Empirical research in a European context, The Hague: Eleven International Publishing, 2010, pp. 207-218, esp. p. 207.

${ }^{821}$ KEMÉNY, S., "Victim-Offender Mediation with juvenile offenders in Norway", en A. Mestitz y S. Ghetti (Eds.) Victim-Offender Mediation with Youth Offenders in Europe, Springer, Dordrecht, 2005, pp. 101-114, esp. p. 103

822 ZINSSTAG, E; TEUNKENS, M y PALI, B., Conferencing: a way forward for..., op. cit., p. 277, nota 190.
} 
Las conferencias no se utilizan para un solo tipo delictivo o delitos de cierta gravedad sino que se trata de un sistema más abierto, en el que incluso se admite acudir al sistema o servicios de conferencias por conflictos civiles. Respecto a los conflictos civiles, cabe entender que se está ante una ampliación de lo que definido como conferencia. La Justicia Restaurativa aparece enmarcada al ámbito penal, a la resolución de conflictos nacidos del delito. Pero en Noruega dan un paso más y utilizan estos sistemas para la resolución de conflictos y disputas civiles, como son las disputas vecinales, problemas familiares, y responsabilidades civiles nacidas del delito. Acertada postura la suya pues si las conferencias pueden proporcionar resultados positivos en el ámbito penal como un método no sólo de resocialización sino de reparación, ¿por qué no se puede aplicar en el ámbito civil para la consecución de la ansiada resolución?

Respecto al empleo de los servicios de conferencias en los conflictos penales, no existe una lista cerrada, sino que podemos encontrarnos con conferencias relativas tanto a delitos leves como graves, siendo la mayoría de ellos delitos de robos, hurtos o bullying ${ }^{823}$. Es cierto que hay ciertos delitos que apenas se resuelven por estos medios, como asesinatos, delitos sexuales o delitos de violencia doméstica o de género, aunque nada impide su posible resolución por esta vía. Así existen diferentes proyectos existentes para su potenciación, como el proyecto de 2010 del Ministerio de Justicia para la resolución a través de sistemas restaurativos de delitos de delitos de violencia familiar u otro proyecto del mismo año relativo a órdenes de detención ${ }^{824}$.

Las características del proceso de conferencias noruego son similares a las ya analizadas con anterioridad para otros países. Solamente cabe indicar que este conferencing noruego no está diseñado única y exclusivamente para delincuentes menores sino que existe una gran paridad en este punto. Aproximadamente el $50 \%$ de los delincuentes son adultos y el 50\% restantes son menores, y el 70\% de todos ellos son hombres, encontrándonos con un 30\% de delincuentes mujeres ${ }^{825}$.

\footnotetext{
${ }^{823}$ HYDLE, I., y KEMÉNY, S., “From local trial projects to ...”, op. cit., p. 209.

${ }^{824}$ ZINSSTAG, E., TEUNKENS, M., y PALI, B., Conferencing: a way..., op. cit., pp. 278-279.

${ }^{825}$ HYDLE, I., y KEMÉNY, S., “From local trial projects to ...”, op. cit., p. 209.
} 
El acuerdo de reparación ha de ser planteado por las partes pero se necesita una confirmación positiva por parte del mediador o facilitador. Esto sólo ocurre en el ámbito penal ya que en la conferencia civil no es necesaria esta intervención del facilitador dado el carácter dispositivo del Derecho Civil. En ambos casos el acuerdo puede ser de muy diferentes índoles, como una disculpa, la realización de diferentes actuaciones en favor de la víctima o incluso de la sociedad, una cuantía económica, etc. Como dato positivo, el 95\% de los acuerdos alcanzados por las partes es cumplido satisfactoriamente ${ }^{826}$.

A modo de conclusión respecto del apartado noruego, se puede formular que, al igual que otros estudios similares en otros países, la utilización del conferencing crea un bienestar en los participantes, los cuales muestran su alto grado de satisfacción con el proceso y una disminución de la reincidencia ${ }^{827}$, mostrando una vez más la eficacia de estas figuras desde el punto de vista tanto jurídico como emocional.

\subsection{Sudáfrica y la idea de comunidad en la resolución de conflictos}

Existe poca información relativa a las prácticas de las Conferencias en Sudáfrica, las cuales, al igual que otros modelos de Justicia Restaurativa ${ }^{828}$, se aplican para la resolución de conflictos penales juveniles, superando la concepción existente allí respecto del infractor como eje central del sistema penal. Los lugares donde más asentados están los métodos restaurativos son KwaZulu-Natal, Gauteng, Western Cape y los Comités pacificadores de Zwelethemba. Estos últimos han combinado los estudios y actuaciones desarrolladas en nueva Zelanda con las prácticas indígenas propias de las regiones, dando lugar a procesos muy variados y de ardua comprensión.

\footnotetext{
${ }^{826}$ HYDLE, I., y KEMÉNY, S., “From local trial projects to ...”, op. cit., pp. 209 -201.

${ }^{827}$ Vid. KEMÉNY, S., “Victim - offender mediation...”... op. cit., pp. 110-111.

${ }^{828}$ Vid. NAUDÉ, B., y NATION, D., "An analysis of cases referred to restorative justice in Tshwane Metropolitan Area”, en Acta Criminologica 2007, $\mathrm{n}^{\circ}$ 20, pp. 138-153; SKELTON, A. AND BATLEY, M., "Restorative justice: a contemporary South African review”, en Acta Criminologica 2008, n 21, pp. 37-50.
} 
En todos los casos se busca revitalizar su sistema de justicia a través de las diversas prácticas restaurativas, a través de unas instituciones basadas en el diálogo y consenso por encima de la actuación punitiva clásica de la justicia retributiva. Basándose en sus tradiciones, así como las tradiciones de pueblos de diferentes lugares del mundo como las importadas por los estudiosos neozelandeses, dan un nuevo enfoque al sistema penal de menores.

Además, Sudáfrica ha seguido la misma línea que la mayoría de países que han adoptado el conferencing, introduciéndolo dentro de su sistema penal juvenil como proyecto piloto. Pero no sólo a modo un test para poder observar su eficacia, sino como una herramienta casi perfecta para la resolución de problemas nacidos en el ámbito de menores al estar basada en el aprendizaje y el apoyo de la comunidad más cercana.

De esta manera se podrá resocializar a los menores infractores consiguiendo en un futuro una sociedad más justa y con un menor índice delictivo, basada en el diálogo y trabajo común, sirviendo este conferencing en menores como base para la resolución de otros conflictos surgidos en la sociedad, tanto en el ámbito de la justicia de menores como en el de adultos. Unas pequeñas actuaciones basadas en prácticas indígenas que pueden conducir a la pacificación social.

\section{Las conferencias y sus especialidades: bullying y violencia de género.}

En el siguiente apartado abordaremos las posibilidades ofrecidas por estos métodos restaurativos para afrontar y erradicar dos de las conductas negativas que más lastran a fecha de hoy nuestra sociedad, el bullying y la violencia de género. 


\subsection{Las conferencias restaurativas como "medida anti-bullying"}

Como se ha expuesto con anterioridad, la posibilidad de hacer partícipe a familiares y, concretamente, a la comunidad, convierten las conferencias en un método oportuno y didáctico de especial relevancia para corregir conductas negativas desarrolladas por los menores de edad.

Una de las pautas de comportamiento de pernicioso efecto que más alarma al conjunto de la sociedad es el denominado bullying o acoso escolar. Se puede definir como todo aquel "maltrato físico y/o psicológico que se produce de forma deliberada y continua y que recibe un alumno por parte de otro y otros, que se comportan con él cruelmente con el objetivo de someterlo y asustarlo, con vistas a obtener algún resultado favorable para los acosadores o simplemente a satisfacer la necesidad de agredir y destruir que éstos suelen presentar ${ }^{\circledR 22}$.

El objetivo del proceso restaurativo dentro de las aulas es resolver el conflicto, sanar a la víctima, educar al alumno ofensor, restablecer las relaciones, y sobretodo, promover la convivencia en el centro escolar ${ }^{830}$.

Siguiendo los estudios de CAMERON y THORSBORNE ${ }^{831}$, en el año 1998, las prácticas realizadas en Australia para la erradicación del bullying a través del Conferencing se realizaron en 1998 centros escolares, con un total de 89 actuaciones llevadas a cabo y centradas en situaciones de gravedad. La satisfacción fue evidente entre los participantes, con una alta tasa de cumplimiento de los acuerdos. Así, la

\footnotetext{
${ }^{829}$ NICOLÁS GUARDIOLA, J. J., “Acoso escolar”, en Archivos de Criminología, Seguridad Privada y Criminalística 2011, no 7, pp- 1-8, esp. p. 2.

${ }^{830}$ PEREZ FANDIÑO, I., "La mediación y las conferencias como herramientas de resolución de conflictos ante la fenomenología del bullying”?”, en J.L. de la Cuesta y I. J. Subijana (Dirs.), Justicia Restaurativa y Terapéutica. Hacia innovadores modelos de justicia, Tirant lo Blanch, Valencia, 2017, pp. 447-468, esp. p. 462

${ }^{831}$ CAMERON, L., y THORSBORNE, M., "Restorative Justice and School Discipline: Mutually Exclusive?”, en H. Strang y J. Braithwaite (ed.), Restorative justice and civil society, Cambridge University Press. Cambridge, 2011, pp. 180-194.
} 
reincidencia en este tipo de tratos vejatorios disminuyó, incrementando el empoderamiento y sanación de las víctimas.

Ello deja abierta la puerta hacia una mejora en las relaciones entre los alumnos de los centros escolares, pudiéndose obtener un proceso que disminuya el maltrato hacia uno de ellos, sane a las víctimas, eduque a los ofensores, restituya las vías de comunicación y, especialmente, consiga un ambiente pacífico en las aulas.

\subsection{Las conferencias y la violencia de género. ¿Una posible solución?}

La notoriedad que ha adquirido la figura del Conferencing ha conducido a una superación de la barrera de resolver conflictos en el ámbito penal juvenil para implantarse en otro tipo de situaciones, como la violencia de género. Esta es una lacra difícil de erradicar que a pesar de las nuevas propuestas y normativas, como el Estatuto de la víctima, no termina de solucionarse.

La violencia de género denota una clara falta de educación y de valores por parte del agresor, el cual se auto considera superior a la mujer por razón de género. Esta situación de superioridad lleva a las víctimas a sufrir un infierno de maltratos físicos y psicológicos.

La Justicia Restaurativa ha surgido como una opción para acabar con esta violencia, una opción que inculca el apoyo y la educación. Aunque se analizará las posibilidades que los círculos ofrecen para la resolución de este tipo de conflictos dentro del capítulo siguiente, es importante examinar cómo las conferencias están siendo utilizadas con el mismo fin en diversos países tales en Inglaterra, Nueva Zelanda y Estados Unidos. 
El primer modelo a analizar se trata del Daybreak FCG Dove Proyect ${ }^{832}$ realizado entre 2001 y 2008 en el Reino Unido. Se caracteriza por tener varias fases; una primera de bienvenida e información para comunicar a los intervinientes cómo se va a desarrollar el proceso de conferencias y los efectos que éste va a suponer; la segunda fase versará sobre la discusión y preparación del plan de reparación que sane a la víctima y ponga fin al conflicto; y la tercera de ellas tendrá un fin de control del plan a través de diversas reuniones para su evaluación y aseguramiento del cumplimiento de las medidas acordadas por las personas designadas para ello. Este proceso busca apoyar a la mujer víctima de los maltratos, pero también a todos aquellos que hayan sufrido sus efectos y sean personas vulnerables, como los menores y adultos vulnerables por razón de edad o enfermedad.

El segundo modelo tiene lugar en Nueva Zelanda ${ }^{833}$-la cuna del Conferencingdonde se ha optado por utilizar también estas prácticas restaurativas para acabar con la violencia de género o, por lo menos, para reducir el número de agresiones, ayudar a las víctimas y mitigar los efectos. Siguiendo el interés de las conferencias, su objetivo no es sólo la sanación de la mujer víctima de la violencia machista, sino los menores que han sufrido los efectos y abusos de estos actos violentos, buscando un proceso reparativo en el que se escuche a los intervinientes, se les de la palabra y se otorgue a la propia familia la capacidad de solucionar el conflicto a través de sus propias necesidades ${ }^{834}$. Así, las familias consiguen aprender y educarse en un modelo de paz social y de apoyo.

El tercer modelo tiene lugar en la ciudad de Dulutuh en Minnessota, en los años ochenta, donde se experimentaron diversos modelos de conferencias que centraban su interés en dar una respuesta comunitaria para incidir en las aptitudes psicoeducativas del infractor, tales actuaciones tenían la finalidad de modificar su ideología machista basada

\footnotetext{
${ }^{832}$ Para más información, vid. www.daybreakfgc.org.uk (Última visita: 09/11/2017)

833 JÏLICH, S., "Restorative Justice and Gendered Violence in New Zealand: a Glimmer of Hope”, en J. Ptacek, Restorative Justice and Violence Agains Women, Oxford University Press, Oxford, 2009, pp. 239254.

${ }^{834}$ BELTRÁN MONTOLIU, A., “Justicia Restaurativa y violencia de género...”, op. cit., p. 272.
} 
en el control y el poder sobre la mujer ${ }^{835}$. A través del programa Duluth Domestic Abuse Intervention Project ${ }^{836}$ se consiguió que los maltratadores participasen en diversos programas de intervención (denominados battered's intervention programs) y que fuesen potenciados estos programas por los tribunales y los cuerpos de policía, los cuales se volcaron con estas actuaciones de apoyo a la víctima y de asunción de responsabilidad por parte de los maltratadores. Los tribunales han realizado diferentes experiencias que han obtenido unos datos francamente positivos como la participación de 911 juzgados o que $68 \%$ de los infractores participantes no vuelva a reincidir ${ }^{837}$.

Todo ello a través de diferentes modelos, como el sistema wheels, que buscan así mostrar como una serie de patrones de control y fuerza son los radios de la rueda. La violencia física y sexual se identifica con la llanta de la rueda y mantiene todo junto. De este modo se produce un efecto en el que es imposible a la víctima escapar de esta situación al estar inmersa en una rueda que absorbe a la víctima y la imposibilita ejercer su libertad.

\footnotetext{
${ }^{835}$ BELTRÁN MONTOLIU, A., “Justicia Restaurativa y violencia de género...”, op. cit., p. 273.

${ }^{836}$ Para más información acerca de este proyecto, vid. http://www.theduluthmodel.org

${ }^{837}$ BELTRÁN MONTOLIU, A., “Justicia Restaurativa y violencia de género...”, op. cit., p. 274.
} 


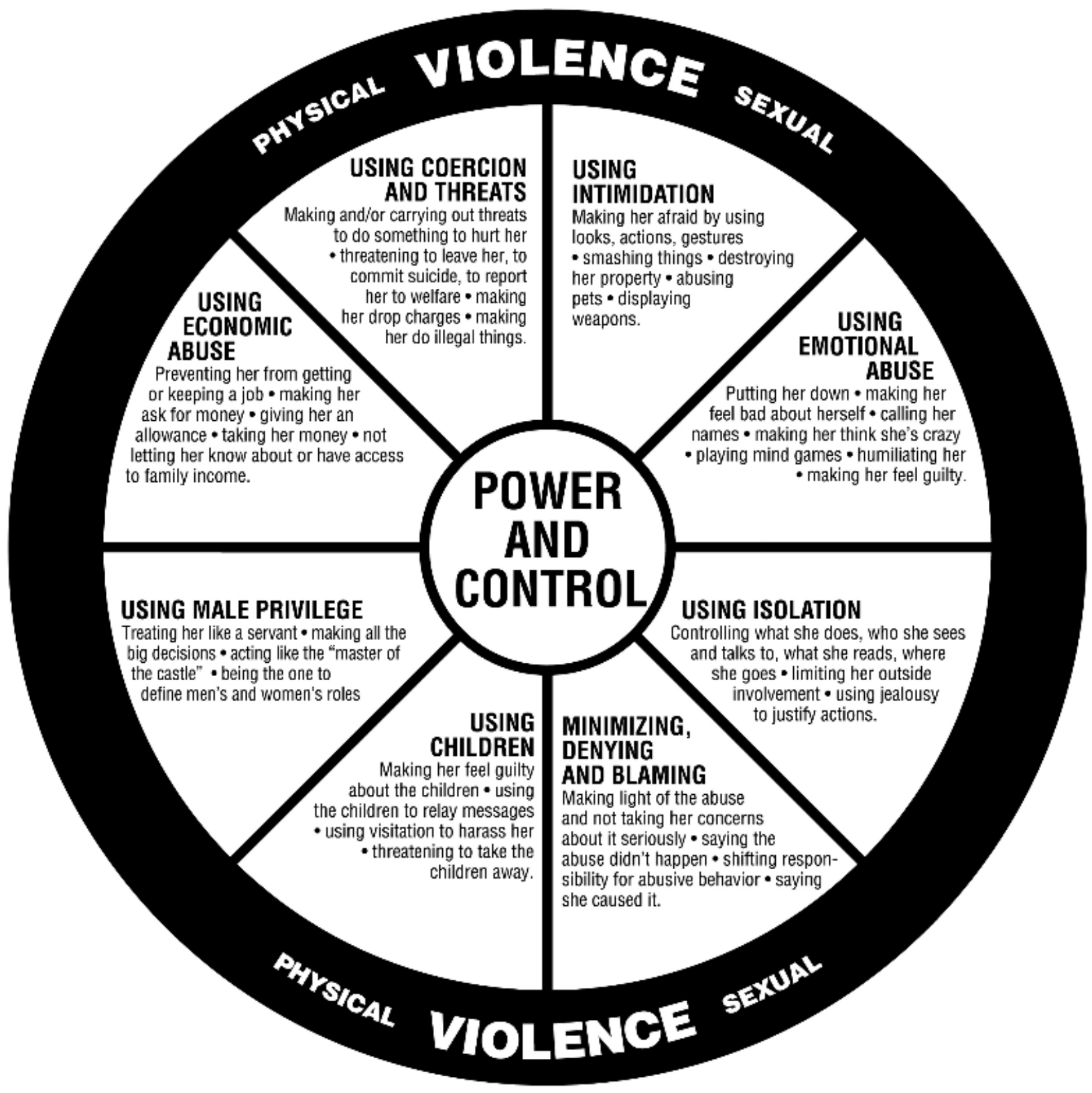

Figura 43. La rueda de poder y control. Fuente: The duluth model ${ }^{838}$

${ }^{838}$ Disponible en: http://www.theduluthmodel.org/pdf/PowerandControl.pdf (Última visita: 09/11/2017) 
Se configuran así las conferencias como un instrumento restaurativo con capacidad de resolver las situaciones derivadas de la violencia de género. El apoyo de los miembros cercanos a la víctima posibilita la ruptura del yugo establecido por el maltratador a su víctima, ayudándola a liberarse de las cadenas de la opresión física y psicológica con el auxilio de parte de la comunidad.

Así mismo, la práctica de conferencias en este tipo de conflictos suponen un amparo a los hijos e hijas quienes van a beneficiarse de la misma manera de este apoyo comunal, para la superación de los efectos nocivos provocados por la violencia ejercida contra su madre, y la liberación que supone para ellos su no utilización como instrumento y “arma” emocional por parte del maltratador. 


\section{CAPÍTULO SÉPTIMO}

\section{LOS CÍRCULOS: EL PODER DE LA COMUNIDAD EN LA RESOLUCIÓN DE CONFLICTOS.}

"No podemos resolver problemas usando el mismo tipo de pensamiento que usamos cuando los creamos"

Albert Einstein (1879-1955)

Una vez analizadas las anteriores figuras, es el momento de examinar el culmen restaurativo por excelencia, los círculos. Una de las figuras más apasionantes pero complicadas de la Justicia Restaurativa. Este instrumento depende mucho de la práctica, de modo que pueden existir diferentes terminologías para una misma acción. No existe un consenso para el desarrollo común de la institución o de su diferente tipología.

\section{Concepto, origen y caracteres.}

En este apartado analizaremos, en primer lugar, el concepto de los círculos para proseguir con un estudio de sus caracteres y su origen. Se ha de anticipar la dificultad de definir exactamente estas actuaciones al no existir un consenso sobre la institución y existir multitud de definiciones y variantes, dependiendo de las fuentes a las que se acuda para el estudio así como del área geográfica donde se esté desarrollando el círculo restaurativo.

No hay mejor forma de comenzar que a través de una definición de círculo, la cual podríamos decir que es un espacio seguro para que a través del diálogo se puedan manifestar sentimientos y emociones tales el dolor, el miedo o el enojo.

La dificultad de definir qué es un círculo al tener marcados caracteres geográficos e ideológicos (sobre todo de carácter religioso como veremos más adelante) 
obliga al análisis de las diferentes definiciones de la institución que han ido emanando de la incipiente práctica. KAY PRANIS realiza un buen estudio de esta práctica restaurativa y la define como "una forma de ser y de relacionarse grupalmente, que llevan al empoderamiento individual y colectivo de aquellas personas que participan de ellos" 839 .

A través de los círculos se reúnen a todas las personas implicadas en el conflicto, acompañadas por sus familiares, miembros del servicio de justicia, de los servicios sociales y, en general, miembros representativos de la sociedad. Es una figura variable en su composición, pudiéndose introducir diferentes miembros dependiendo de las necesidades y características del círculo.

Por medio del círculo todos los intervinientes pueden afrontar el conflicto surgido a través del diálogo, el cual romperá barreras permitiendo una manifestación de opiniones y lecciones. Se permite la participación de cualquier miembro de la ciudadanía que esté en condiciones de otorgar ideas provechosas y didácticas. Participa “cualquier persona representativa de la comunidad que tenga un interés en involucrarse en el asunto. Todos ellos se aplican como herramientas para la consecución de un fin último, la pacificación de la sociedad y la restauración del daño causado a la víctima y comunidad"840. Hay que tener claro que las personas que acuden a este tipo de prácticas van a manifestar su opinión y a instruirse, y por ello por ello es conveniente que cualquier persona con ánimo de ayudar y aprender pueda acudir al círculo. Es importante que la sociedad participe en la resolución de conflictos, que demuestre su valía y su apoyo a víctima e infractor, mostrándoles que hay salida a esta situación y que van a ser aceptados por los miembros de la sociedad; estos acuden al círculo, no a culpar a nadie, sino a conseguir reparar el conflicto, resocializar al infractor y sentar unas bases de aprendizaje para futuros problemas similares.

\footnotetext{
${ }^{839}$ PRANIS, K., Manual para facilitadores de Círculos, CONAMAJ, Costa Rica, 2006, p. 7. Así también BERNAL ACEVEDO, F., y ECHEVERRI ECHEVERRI, A., Manual para Facilitación de Círculos de Diálogo en Instituciones Educativas. Adaptación del Manual para facilitadores de círculos de Key Pranis, CONAMAJ, San José, 2009, p. 17.

${ }^{840}$ BELTRÁN MONTOLIU, A., "Modelo de mediación en ...”, op. cit., p.59.
} 
El círculo es una figura que se basa en una serie de valores y principios, y en el cual tienen una gran consideración las tradiciones y solemnidades culturales del lugar donde se esté efectuando. Estos rituales o ceremonias que inician el círculo pueden consistir en diferentes actuaciones, las cuales variarán dependiendo de los valores y de la cultura existente en dicho lugar, pudiendo ser un canto (como por ejemplo el himno de la zona), un acto con cierta simbolidad religiosa o cualquier actividad que sirva para iniciar el proceso.

El facilitador ha de potenciar que los miembros del círculo se esfuercen en dar su opinión acerca de ello y les ayuden para una óptima resolución del conflicto. Han de utilizarse una serie de técnicas, siendo importante el lenguaje utilizado por el facilitador $^{841}$, para la obtención de un proceso basado en una cultura de respeto, de voluntariedad, de diálogo o de trabajo. Como indica KAY PRANIS, los valores que nos encontramos en este tipo de actuaciones son: "respeto, honestidad, confianza, humildad, solidaridad, inclusión, empatía, valentía, perdón y amor"842.

Esta serie de valores comunes que imperan en los círculos dan lugar a a ver que exista una mentalidad muy similar en todos los lugares del mundo y en todas las personas, ya sean adultos o menores, infractores o víctimas. Es por ello que en la mayoría de territorios donde se han asentado, exista un ritual de apertura, como oraciones, poemas, canciones, haka, hawaiien oli, etc ${ }^{843}$. Pero lo importante es que todo ello nos acerca al diálogo, el cual nos va a aportar al acercamiento de posturas, al trabajo en equipo y en suma a una manera de comprometerse todos los participantes del círculo, a ofrecer una ayuda en común para la resolución de conflictos, dejando florecer todos los sentimientos y emociones ocultos y por ello se convierte por tanto una experiencia restaurativa beneficiosa para todos los participantes del círculo.

\footnotetext{
841 Intervención de Loren Walker en el Congreso Europeo de Justicia Restaurativa y Terapeútica, celebrado en San Sebastián los días 16, 17 y 18 de junio de 2016.

842 PRANIS, K., Manual para Facilitadores ..., op. cit., p. 10.

${ }^{843}$ Intervención de Loren Walker en el Congreso Europeo de Justicia Restaurativa y Terapeútica, celebrado en San Sebastián los días 16, 17 y 18 de junio de 2016.
} 
Los orígenes de esta figura son muy confusos y en principio podríamos señalar que casi cualquier comunidad indígena realizaba actuaciones similares a los círculos para la resolución de conflictos. Como acertadamente indica ISAACS, "no se ha encontrado todavía ninguna cultura indígena que no tenga la práctica de sentarse en círculo y dialogar” ${ }^{844}$. Aunque quizás sean las prácticas de los pueblos aborígenes de Canadá -First Nations- y Estados Unidos - Navajos- las que han precipitado que esta figura exista en nuestra actualidad y, cuyas comunidades poseían mayores similitudes entre ellas.

Situándonos ya en Canadá, las diferentes comunidades aborígenes se encontraban reprimidas por el Gobierno ${ }^{845}$. Muchos de los miembros de estas comunidades, debido a la situación que llevaban viviendo desde tiempo atrás, parecían problemas con el alcohol, los cuales les llevaban a una situación destinada a la delincuencia. Ello conducía a una no resocialización en los centros penitenciarios, creándose un círculo vicioso de alcohol y delincuencia que destrozaba a las comunidades aborígenes.

Es por ello que muchas de estas comunidades decidieron volver a sus orígenes y empezar a utilizar los métodos para la resolución de conflictos que empleaban sus ancestros. Partían de incluir a la comunidad en la resolución de un conflicto como un miembro más de la institución restaurativa que apoyará buscando la reparación y resocialización. El uso de los círculos no se limitó a la cultura de las Primeras Naciones ${ }^{846}$, llevándose incluso a los Tribunales, con el famoso caso de Philip Moses de $1991^{847}$, el cual fue un paso importantísimo en la expansión de los círculos que no

\footnotetext{
${ }^{844}$ ISAACS, W., Dialogue the Art of Thinking Together, Doubleday, New York, 1999, p. 16.

${ }^{845}$ Un ejemplo de ello es que los niños fueron arrebatados de sus padres para provocar la desaparición de la cultura nativa, prejuzgándoseles a todos los indígenas como delincuentes o futuros criminales. Vid. WEITEKAMP, E. G. M., Developing Peacemaking Circles in a European Context, Eberhard Karls University Tübingen, 2013, p.12.

${ }^{846}$ WEITEKAMP, E. G. M., Developing Peacemaking Circles ... op. cit., p. 13.

${ }^{847}$ CHOYA FORÉS, N., Prácticas restaurativas: círculos y conferencias. Justicia restaurativa: nuevas perspectivas en mediación. 2014 - 2015, p.21. Disponible en: http://www.sociedadvascavictimologia.org (Última visita: 09/11/2017)
} 
estuvo exento de críticas ${ }^{848}$. En dicho supuesto, el juez Barry Stuart decidió organizar un círculo de sentencia al observar que el imputado contaba con 43 condenas previas, demostrando un claro fracaso del sistema penal. Este empleo de los círculos fue expandiéndose con éxito, siendo utilizados en la actualidad tanto para infractores aborígenes como no aborígenes $^{849}$.

Aunque el antecedente anterior es fundamental para la implantación de los círculos, dichas figuras se empezaron a consolidar en Canadá a finales de los años 80 a través del programa Community Holistic Circle Healing con el fin de solucionar conflictos de todo tipo. Quizás la nota negativa del desarrollo de los círculos en Canadá es que, a pesar de su éxito en la práctica, el desarrollo legal en cambio ha sido escaso.

En el año 1994 se empezaron a utilizar en Ontario los Circles of Support and Accountability o círculos de apoyo al infractor gracias al trabajo del padre Harry Nigh, perteneciente a la comunidad religiosa de los menonitas y del Community chaplain of the Canadian Correctional Services. Un círculo de apoyo ${ }^{850}$ que pretendía ayudar a un preso, Charlie, condenado por delito sexual a un menor, a su resocialización e integración en la sociedad. La comunidad de Hamilton no apoyaba al preso, no quería verlo por las calles debido a su historial de delitos sexuales contra jóvenes y su reincidencia. La indignación y la ira inundaban la comunidad, todo el mundo atacaba a ese “monstruo”, y por ello era necesaria la utilización de medidas resocializadoras.

El círculo le fue ayudando a desarrollar las tareas ordinarias de su vida, labores financieras, actuaciones frente a diversos comportamientos y, sobre todo, el preso fue escuchado. Este círculo le auxilió cuando más lo necesitaba, conduciéndole una vida provechosa y alejada del comportamiento delictivo, y por ello se le denominó a dicho

\footnotetext{
848 Para un análisis de estas críticas véase WEITEKAMP, E. G. M., Developing Peacemaking Circles ... op. cit., p. 13 y ss.

849 SCHMID, D.J., "Restorative Justice: a new paradigm for criminal justice policy”, en Victoria University of Wellington Law Review 2003, vol. 34, pp. 91-133, esp. p.107.

${ }^{850}$ Fue denominado como el Círculo de Charlie debido al nombre del preso.
} 
círculo "los Ángeles de Charlie" ${ }^{851}$. Debido al éxito de este círculo, esta figura se expandió a otras localidades, como el círculo de Wray en Toronto. Ambas prácticas se caracterizaban por realizarse una vez el infractor ya había sido condenado y tener su desarrollo primero dentro del ámbito penitenciario y continuar una vez el preso ya había cumplido su condena y puesto en libertad.

\section{Desarrollo de los círculos.}

Su expansión por el mundo ha sido muy escasa, y se pueden encontrar prácticas de este tipo en los demás países de América, en países europeos como Reino Unido, Holanda o Bélgica y en países oceánicos como Australia. Se analizarán su impacto social y su importancia como método novedoso en la resolución de conflictos de los lugares citados.

\subsection{Los círculos en Norteamérica: evolución en Canadá y Estados Unidos}

En Canadá los círculos son una figura que tiene su origen en las costumbres de los Nativos Americanos pero que, con el paso del tiempo, otras organizaciones han ido haciéndose eco de estas prácticas y utilizándolas para la solución de conflictos. Un

\footnotetext{
${ }^{851}$ Para una mayor información relativa al círculo véase el Prólogo realizado por Harry Nigth para el European Handbook of CoSA: Circles Europe: Together for safety, 2011. El extracto completo de ese prólogo está recogido en GARCÍA DÍEZ, C., y SOLER IGLESIAS, C., Evaluación de necesidades y diseño de la intervención para la reintegración social de los delincuentes sexuales de alto riesgo. Adaptación de los Círculos de Apoyo y Responsabilidad al sistema de ejecución penal de Cataluña, Generalitat de Catalunya, Barcelona, 2013, pp. 17-19. A modo resumen se podría indicar que en él se manifiestan las motivaciones del padre Nigth y las dificultades existentes en el caso. Tanto Harry como Charlie se conocían de 15 años atrás por motivos de voluntariado religioso. Charlie, quien había sufrido abusos sexuales cuando era un niño, fue condenado 7 años de prisión por un delito sexual a un menor, y Harry era pastor de una congregación menonita en Hamilton. Al ser trasladado a una granja en dicha comunidad, se creó un círculo de apoyo que le sirviese como familia sustituta y evitar así su reincidencia. En Hamilton la prensa titulaba su excarcelación como "Calles del Miedo", repartiéndose su fotografía por toda la ciudad y montándose un dispositivo policial de un coste de 35.000 dólares. El círculo de Charlie se encontraba con él con regularidad, acompañándole a situaciones tan comunes como la lavandería, a hacer la compra y a encontrar muebles para su apartamento. En principio la policía seguía los movimientos de Charlie, pero tras acudir a varias sesiones, los miembros del cuerpo de policía de Hamilton comenzaron a apoyar la práctica restaurativa. De ahí se consiguió que los 12 años que vivió tras el inicio del círculo fuesen 12 años pacíficos gracias al apoyo y asistencia de la comunidad la cual, tras el miedo inicial, se convirtió en la familia que Charlie necesitaba y nunca tuvo .
} 
ejemplo de ello han sido las diferentes congregaciones religiosas en Norteamérica, las cuales han empleado las figuras como un método de apoyo a la víctima y de resocialización de infractores hasta conseguir que existan cerca de 200 círculos en Canadá. Basan su actuación en la resocialización de delincuentes sexuales que, una vez cumplida su condena, se disponen a iniciar reintegración en la sociedad, la cual la consiguen gracias al trabajo de los miembros de la comunidad tanto durante su estancia dentro del ámbito penitenciario como una vez excarcelado.

En Canadá el círculo se compone de un miembro central (el delincuente), de cinco a siete voluntarios de la comunidad, junto con un grupo de apoyo de profesionales y administradores. Todos ellos forman en realidad dos círculos, uno interior formado por los voluntarios y el delincuente, y un círculo exterior formado por los profesionales. La financiación de estos círculos canadienses proviene de presupuestos públicos del Gobierno Federal Canadiense, aunque algunas instituciones y fundaciones privadas han aportado también financiación debido a las diferentes solicitudes que las estaban llegando para la satisfacción de la continua creciente demanda ${ }^{852}$. Por su parte en Estados Unidos los círculos se utilizan como un método para la resolución de cualquier conflicto, pero es fundamentalmente en la resolución de conflictos sexuales donde mayor impulso han obtenido.

Así también, y a modo de ejemplo, encuentran cierto desarrollo práctico de esta figura es en Costa Rica y México, donde se están realizando numerosos círculos de todo tipo de conflictos, ya sean leves o incluso delitos “sangre”. Aquí la institución está impulsando la justicia, interesándose en la víctima, resocializando al infractor a través del análisis de las causas de su actividad delictiva y pacificando la sociedad. Pueden ser utilizadas en diferentes fases judiciales como previa a la fase oral, derivándose el asunto para un previo conocimiento a través de instituciones restaurativas y una posible solución tal y como sucede con los círculos de sentencia; durante la fase oral, como un

\footnotetext{
${ }^{852}$ Vid. WILSON, R., MCWHINNIE, A., PICHECA, J., PRINZO, M. y CORTONI, F., "Circles of Support and Accountability: Engaging Community Volunteers in the Management of High-Risk Sexual Offenders”, The Howard Journal 2007, Vol 46, n 1, pp. 1-15, esp. p. 10.
} 
complemento al propio juicio y mientras se desarrollen las sesiones ante los tribunales podrán realizarse actuaciones restaurativas tales como los círculos de sanación de víctimas o los Círculos CoSA, y post sentencia, como método complementario para satisfacer las demandas de resocialización de infractores a través de los Círculos CoSA o la sanación de víctimas una vez que ya se ha dictado sentencia condenatoria-. Gran número de estas actuaciones se están realizando en el ámbito escolar para prevenir y tratar los casos de bullyng que tantas víctimas están dejando en México ${ }^{853}$.

En Norteamérica la adaptación de estas instituciones se ha conseguido a través del impulso de ciertas congregaciones religiosas - especialmente de menonitas - y sociedades y organizaciones públicas con el objetivo de resocializar a infractores y conseguir un ambiente de paz en la comunidad. Todos ellos tienen lugar una vez ya se ha cumplido la condena o dentro del propio ámbito penitenciario cuando se esté cumpliendo el tiempo de pena de prisión estipulado en la sentencia. Algunos de los más trascendentes son los siguientes:

- Colorado $\operatorname{CoSA}^{854}$ : Nació en el año 2011 gracias al Departamento Penitenciario de Colorado, la Junta de Administración de Delincuentes Sexuales y la Iglesia Metodista, con el fin de dar apoyo a los delincuentes y proseguir con la labor que se estaba realizando en Canadá. Pero no fue hasta el año 2012 cuando incrementó su valía y comenzó a organizar los diferentes círculos de apoyo del lugar otorgando tratamiento al agresor sexual y representación legal, así como velando por los derechos de las víctimas y colaborando con la policía a través de la idea de "no más víctimas” y “nadie es desechable”. Estos círculos, situados en Denver, Fort Collins, Greeley, Boulder, Grand Junction, Pueblo y Colorado Springs, buscan "reducir sustancialmente el riesgo de una futura victimización sexual de miembros de la comunidad, ayudando y apoyando a hombres y mujeres que han cometido delitos sexuales en su tarea de integración con la comunidad y llevar vidas responsables y productivas”.

\footnotetext{
853 “El 60 por ciento de los suicidios en México son por bullying”. Noticia recogida en Diario Zócalo Saltillo, 22/11/2015. Disponible en: http://www.zocalo.com.mx (Última visita: 09/11/2017)

${ }^{854}$ Colorado CoSA. Disponible en: https://www.denvercosa.org (Última visita: 09/11/2017)
} 
- Durham $\operatorname{CoSA}^{855}$ : Situado en Carolina del Norte, tiene el objetivo de apoyar a las víctimas que han sufrido un delito sexual y resocializar a los infractores de este tipo de delitos. Debido a los elevados datos de delitos sexuales (en el año $2013^{856}$, 988 personas fueron encarceladas por delitos sexuales, sumando un total 4,930 encarcelados por dichos delitos con un coste de 136 millones de dólares) su necesidad dentro de la comunidad era un requerimiento. A través de estos círculos, en Durham han utilizado el diálogo como método para la resocialización de infractores, reduciendo en gran número la reincidencia. En delitos sexuales, la reincidencia es reducida en un $83 \%$ de las ocasiones, en delitos violentos se reduce un 73\% respecto a la reducción conseguida por el sistema punitivo clásico, y en general, la reincidencia en cualquier tipo de delitos disminuye un 70\% más cuando se acude a un círculo en vez de acudir al sistema penitenciario como única vía de resocialización. Pero, ¿Cómo lo están consiguiendo? A través de ofrecer una serie de servicios a los delincuentes arrepentidos como alojamiento, terapia psicológica, terapia contra el consumo de sustancias o adicciones, educación, trabajo, alimento, ropa, amistad, compañía, etc.

\footnotetext{
${ }^{855}$ Durham CoSA. Disponible en: http://www.durhamcosa.org (Última visita: 09/11/2017)

${ }^{856}$ Durham CoSA. No More Victims, Disponible en: http://www.durhamcosa.org (Última visita: 09/11/2017). En el año 2013, 988 personas fueron encarceladas por delitos sexuales, sumando un total 4,930 encarcelados por dichos delitos con un coste de 136 millones de dólares (p. 10).
} 


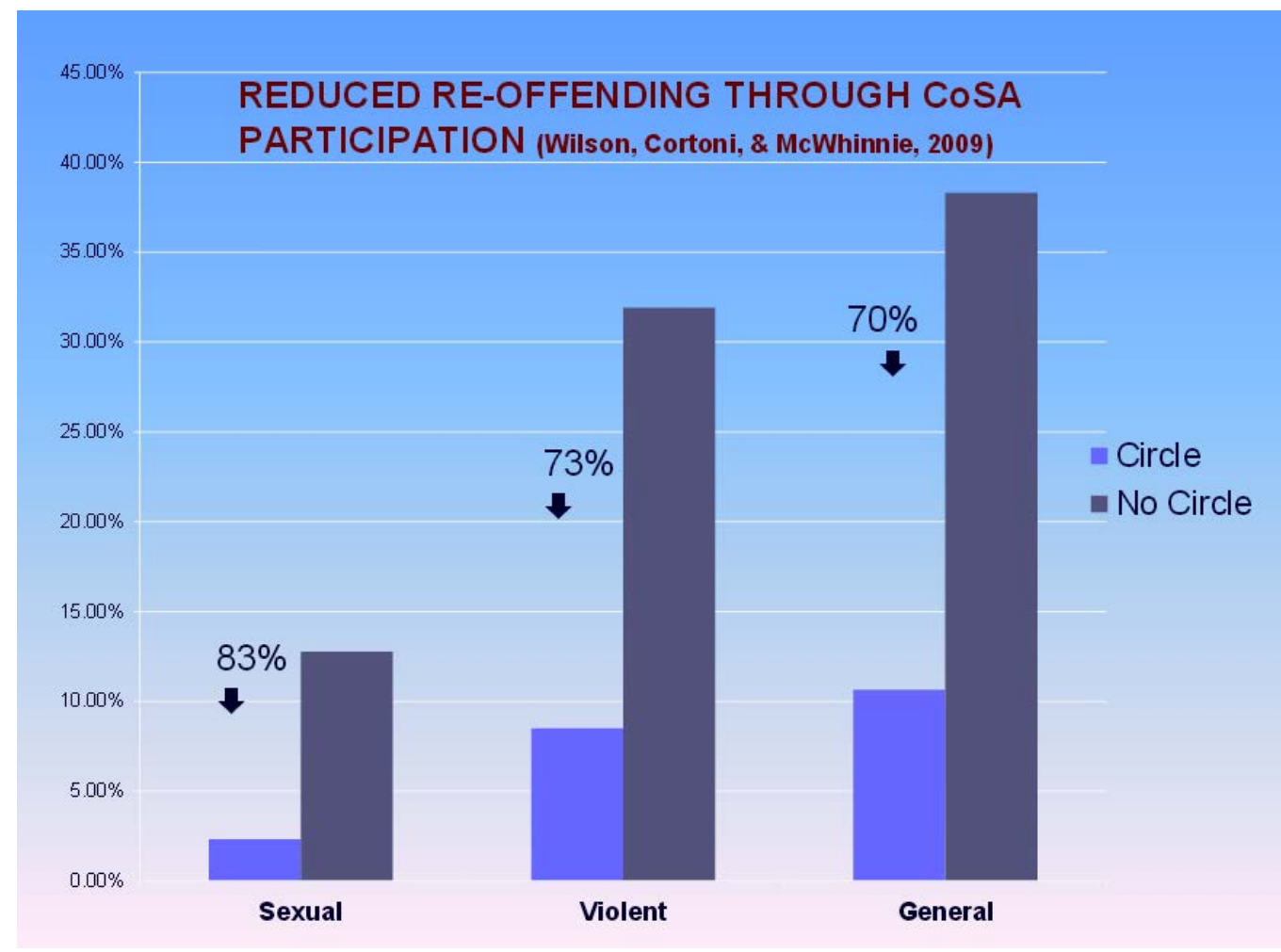

Figura 44. Reducción de la reincidencia ${ }^{857}$

- CoSA-Ottawa ${ }^{858}$ : Estos círculos tuvieron lugar alrededor de 1998 gracias a la Iglesia de San Juan Evangelista como respuesta a las necesidades de varios hombres que habían cometido delitos sexuales y buscaban ayuda para resocializarse y evitar a cometer los mismos hechos. El reverendo Garth Bulmer y el feligrés Pat Love consideraban que había que amparar a estas personas, y fueron desarrollando diversos círculos, los cuales iban ganando en formalidades con el paso de los años, llegando a ampliarse enormemente y convertirse en una organización benéfica registrada en mayo de 2013. Tal fue su consideración que el programa CoSa-Ottawa ha recibido multitud de apoyos de la comunidad y financiaciones de todo tipo, llegando a ser incluso galardonado en 2013 con el Premio Programa de Voluntarios en la Prevención del Crimen en Ottawa (Volunteer Program of the Year at Crime Prevention Ottawa's 2013 Community

\footnotetext{
${ }^{857}$ Informe Durham CoSA. No More Victims, p. 37. Disponible en: http://www.durhamcosa.org (Última visita: 09/11/2017)

${ }^{858}$ CoSA-Ottawa. Disponible en: https://cosa-ottawa.ca/ (última visita: 05/02/2018)
} 
Safety Awards) ${ }^{859}$. En el curso 2016-2017 ha contado con 51 voluntarios activos para la participación en los círculos y con 13 miembros centrales ${ }^{860}$.

- Minnesota Circles of Support and Accountability (MnCoSA): Creado en 2008 en el Estado de Minnesota gracias al Departamento Penitenciario para ayudar a delincuentes sexuales de nivel 2 de gravedad (intermedio-alto) que habían cumplido ya su condena y reintegrarse en la sociedad. Desde 2008, el éxito de esta figura la ha llevado a incrementar su proporción ofreciendo datos ${ }^{861}$ realmente interesantes, como la disminución de la reincidencia en un 62\% para la nueva detención, y un 84\% para cualquier retorno a prisión. Por cada dólar invertido en este programa, se genera un beneficio de $1,82 \$$, videlicet, proporciona un beneficio de un $82 \%$.

- CoSA Vermont ${ }^{862}$ : El Departamento Penitenciario de Vermont fue casi pionero en Estados Unidos en querer adoptar el modelo de círculos de apoyo CoSA y trabajó para su aplicación dentro de su territorio, objetivo que cumplió gracias a las subvenciones federales de hasta 2 millones de dólares que recibió en 2003, la cual le permitió poder implementar los círculos en diferentes ciudades como Burlington, Newport, St. Johnsbury, Barre, Montpelier o Brattleboro.

\subsection{La expansión de los círculos a Reino Unido (UK Circles)}

Merece la pena realizar una mención especial a las prácticas que se están desarrollando en Inglaterra y Gales, donde están comenzando a asentarse programas de

\footnotetext{
${ }^{859}$ Informe Circles of Support and Accountability Ottawa Annual Report 2014-2015, pp. 1-13. Disponible en: https://cosaottawa.files.wordpress.com (Última visita: 09/11/2017)

${ }^{860}$ Informe Circles of Support and Accountability Ottawa Annual Report 2016-2017, pp. 1-13, esp. p. 5. Disponible en: https://cosaottawa.files.wordpress.com (Última visita: 09/11/2017)

${ }^{861}$ Informe Minnesota Circles of Support and Accountability, Minnesota Department of Corrections, 2012. Disponible en: http://www.doc.state.mn.us (Última visita: 09/11/2017)

${ }^{862}$ Más ampliamente véase Circles of Support \& Accountability: Final Report Prepared for the State of Vermont Department of Corrections 2013 http://www.doc.state.vt.us (última visita 05/02/2018)
} 
círculos de apoyo en diferentes regiones y ciudades de la zona como se observa en la imagen siguiente:

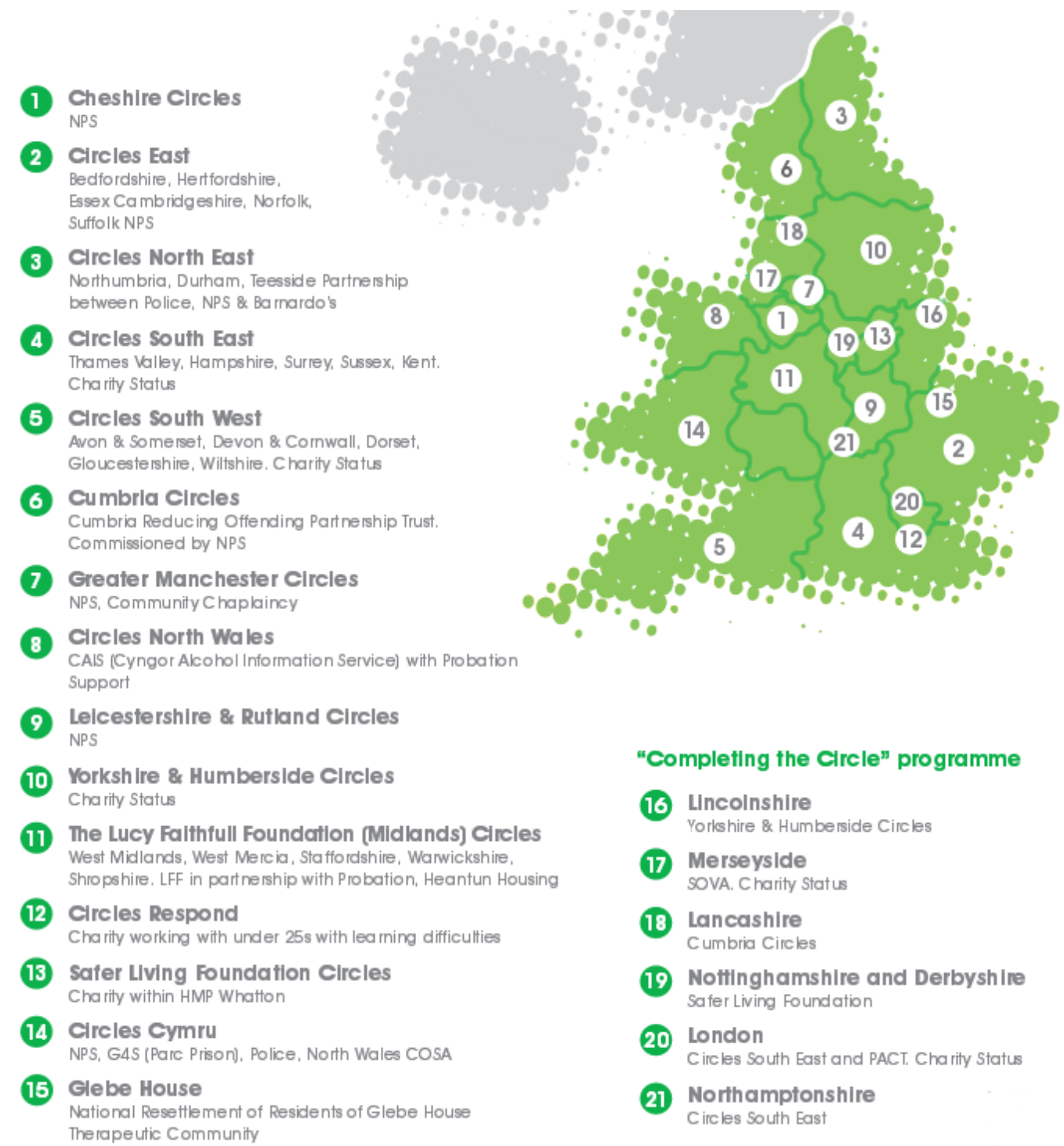

CArcles North Wales

Lelcestershire \& Rutiand Circles

Yorksh Ire \& Humberside Circles West Midlands, West Mercia, Staffordshire. Wanwickshire.

SOVA. Charity Status

Cumbria Circles

19 Nottinghamshire and Derbyshlre

Circles Cymru

21 Northamptonshire

Therape utic Community

Figura 45. Mapa de los proyectos de círculos de Inglaterra y Gales ${ }^{863}$

Estos círculos fueron implantándose gracias a las comunidades religiosas de cuáqueros (quakers) que fueron introduciendo esta figura alrededor del año 2002 en Reino Unido, consiguiendo un apoyo y financiación del propio Ministerio de Justicia para potenciar su uso y conseguir la disminución de los delitos sexuales a través de la

${ }^{863}$ Circles UK Annual Rewiew. 2014-2015. Disponible en: http://www.circles-uk.org.uk (Última visita: 09/11/2017) 
creación de la organización Circles UK. Una “organización nacional que coordina y apoya el desarrollo de los proyectos locales” ${ }^{864}$. A través de ellos no sólo se auxilia a la víctima, sino que se busca acompañar al infractor para conseguir su resocialización y una inserción social, terminando con el estigma social hacia el delincuente a través de un trabajo de aceptación de la comunidad. A continuación se realizar mención a algunos de los proyectos que se están trabajando, sobre los cuales cabe apreciar influencia de comunidades religiosas en su desarrollo:

- North West Circle ${ }^{865}$ : Instaurado en el año 2009 gracias a una donación del grupo local religioso de los cuáqueros con el fin de crear 6 círculos iniciales en el condado de Cumbria. El apoyo del condado de Lancashire ayudó a la instauración de 3 círculos más que buscan ayudar a aquellos que han cometido delitos con el fin de que puedan tener en el futuro una vida libre y responsable estableciéndose como una pieza valiosa en su comunidad. Actualmente existen 43 círculos repartidos entre Cumbria y Lancashire y el objetivo es la instauración de un total de 13 círculos en Lancashire para el año $2013^{866}$.

- Greater Manchester ${ }^{867}$ : Este proyecto de círculos empezó a utilizarse en marzo de 2009. El proyecto está firmemente arraigado gracias a una estrecha colaboración de diferentes instituciones públicas como son en concreto Greater Manchester Police, Greater Manchester Probation Trust y Greater Manchester Community Chaplaincy. Como se puede observar, el Cuerpo de Policía ha sido de valía para la potenciación de estos Círculos CoSA, ayudando a alcanzar la resocialización de los individuos junto a una gran implicación de diversos voluntarios de todas las secciones de la comunidad, tengan implicaciones religiosas o no, los cuales reciben una formación adecuada para ejercer estas

\footnotetext{
${ }^{864}$ GARCÍA DÍEZ, C., y SOLER IGLESIAS, C., Evaluación de necesidades y diseño de la intervención para la reintegración social de los delincuentes sexuales de alto riesgo. Adaptación de los Círculos de Apoyo y Responsabilidad al sistema de ejecución penal de Cataluña, Generalitat de Catalunya, Barcelona, 2013, p. 20. Disponible en: http://www.recercat.cat (última visita 05/02/2018)

${ }^{865}$ Informe North West Circles. Disponible en: http://cropt.org.uk (última visita: 05/02/2018)

866 Informe North West Circles. Annual Report 2016 - 2017, pp. 1-8, esp. p. 4. Disponible en: http://cropt.org.uk (última visita: 05/02/2018)

867 Para una mayor información visitar la página web de Circles UK relativa al proyecto Greater Manchester. Disponible en http://www.circles-uk.org.uk (última visita 14/04/2018)
} 
tareas. Los voluntarios apoyan al condenado (core member) para la búsqueda de una reinserción y eviten así una posible reincidencia, sobre todo en delito sexuales.

- South East England: Es uno de los dos primeros proyectos piloto financiados por el gobierno, el cual fue impulsado en 2008 gracias también a diversas organizaciones de beneficencia y fundaciones. Este es uno de los círculos más primordiales $^{868}$ ya que trabaja en colaboración con la policía y los servicios de libertad condicional en el Hampshire, Kent y zonas del valle del Támesis que operan como una agencia de protección pública con y para las comunidades. Se auxilia a los delincuentes sexuales a reintegrarse de forma segura en la comunidad a través del uso de grupos entrenados y supervisados de voluntarios que "cierran las heridas" abiertas por el delito entre la comunidad, el delincuente y organismos profesionales. Ha de ser la propia comunidad quien actúe en aras de la resocialización del infractor a través de una asistencia diaria y continua reducción la exclusión y discriminación sobre los infractores, ya condenados a través de sentencia, ya sea en el ámbito penitenciario o una vez cumplida su condena. A parte de la labor de círculo, se ofrece asesoramiento y servicios de tutoría a los delincuentes así como la impartición de formación profesional y asesoría legal a los voluntarios que trabajan en los círculos. En los últimos años se ha añadido un programa enfocado a jóvenes que cometen actuaciones sexuales dañinas así como un servicio de asesoramiento específico para víctimas de abusos sexuales.

- London Respond: Este Proyecto está asentado en el centro de Londres y se ha dedicado al trabajo con menores y adultos con discapacidades que han experimentado abuso, así como aquellos que han actuado como infractores, a

\footnotetext{
868 Es tanta su importancia que le ha llevado a la obtención de diversos premios como el The Lord Longford Award 2004, Special Merit Award, Howard League Community Programme Award 2006, el Outstanding Contribution to Engaging Communities, The Justice Awards 2006 y el Queen's Award for Voluntary Service 2010. Disponible en http://www.circles-uk.org.uk (última visita 15/04/2018)
} 
través de la psicoterapia, la incidencia, campañas y otros apoyos por más de 20 años. Las diferentes actuaciones con este tipo de personas han permitido alcanzar conclusiones tales como que el aislamiento puede desencadenar en actos sexuales violentos sobre los demás, debiéndoseles educar para prevenir estas conductas y realizar múltiples tareas de seguimiento sobre ellos.

- North East England: Fundado en abril de 2010 en Northumbria, el programa se financia por el Ministerio de Justicia Británico, que complementa financiaciones anteriores de otras organizaciones como la Fundación de Northern Rock, con partidas presupuestarias adicionales de North East Regional. Las actuaciones son llevadas por voluntarios, agentes de policía, agentes de libertad condicional y personal de la región de Barnard con el fin de evitar la reincidencia de agresores sexuales y su aceptación en la sociedad como personas resocializadas.

- Yorkshire, Humberside y Lincolnshire: Este exitoso ${ }^{869}$ proyecto nació en enero de 2011 tras las fructíferas experiencias piloto que se estaban llevando a cabo en el norte del condado de Yorkshire. El trabajo realizado por este proyecto ha supuesto círculos interesantes para la redención de los infractores de delitos contra la libertad sexual y su vuelta a la sociedad. El trabajar con los protagonistas del conflicto ha logrado que se puedan superar los sentimientos de impotencia, desesperanza, baja autoestima, soledad emocional y que se puedan combatir aquellos pensamientos sexuales problemáticos que puedan conllevar una posible reincidencia. Para la consecución de estos objetivos los círculos están compuestos por profesionales de la justicia criminal en activo y jubilados, miembros de la comunidad - ya sea de Yorkshire, Humberside o Lincolnshire cuáqueros, y facilitadores que aseguran los vínculos con la policía local, los agentes de libertad vigilada y los demás intervinientes. El objetivo general es

\footnotetext{
${ }^{869}$ Han ganado diversos premios por sus actuaciones como el POPS Positive Partnership award, The Butler Trust award, The Guardian Small Charity award, Duke of York Award y por ser finalistas en el Howard League Community Programme 2012. Disponible en http://www.circles-uk.org.uk (última visita $15 / 04 / 2018)$
} 
que no haya más víctimas y luchar por la reintegración en la comunidad de los delincuentes sexuales arrepentidos consiguiendo mejorar la seguridad de la sociedad en su conjunto.

- South West England: Tras dos anteriores exitosos proyectos pilotos en la región, fue en 2010 cuando se decidió dar vida a este proyecto con el objetivo de disminuir el número de víctimas y resocializar a los infractores. En el curso 2016-2017 coordinan 44 círculos en toda la región con un total de 170 voluntarios. Tal y como indica Circles $U K$, el mayor éxito de este proyecto es que ninguno de los infractores que ha participado en los círculos ha sido condenado por otros delitos sexuales, demostrando que su trabajo está evitando la reincidencia. Para ello se ha de creer en el poderoso papel que pueden desempeñar los miembros de la comunidad para la obtención de un cambio en la conducta del delincuente y la consecución de una sociedad más justa y segura.

\subsection{Europa, Brasil y Asia: una expansión "sin prisa pero sin pausa"}

El éxito de estos anteriores círculos CoSA se fue expandiendo a otros países, y fue Holanda la que, con ayuda de Circles UK, implementó diferentes círculos por todo el país bajo la coordinación de Circles Netherlands. Bélgica a la vez planeaba la realización de proyectos piloto sobre la materia, reuniendo las ideas restaurativas planteadas en Canadá, Estados Unidos y Reino Unido, pero sin el éxito esperado. Todos estos estudios llevaron a que la Unión Europea financiase diversos programas para su desarrollo en Europa, como el programa Daphne III o Circles $4 E U^{870}$, programa compuesto de 20 organizaciones que incluyen los Ministerios de Justicia, Universidades, ONG y Fundaciones y que ha servido para la inclusión de nuevos países como Bulgaria, Letonia, República Checa, Irlanda, Francia, Hungría y España

\footnotetext{
${ }^{870}$ Para mayor información relativa a las actuaciones, investigaciones, proyectos y participantes véase http://www.circles4.eu (última visita 05/02/2018)
} 
(especialmente en Cataluña) ${ }^{871}$ a los ya anteriormente estudiados en Europa como Inglaterra, Bélgica y Holanda. El consorcio del proyecto Cirlces4EU Juntos representan a 10 países europeos.

A través de este proyecto, la Unión Europea intentaba crear círculos CoSA dirigidos al tratamiento de delincuentes sexuales en la comunidad debido al impacto social que generan este tipo de conductas delictivas, una vez que han terminado de cumplir pena de prisión. El proyecto estaba coordinado por Reino Unido, Holanda y Bélgica, los cuales ya tenían experiencia previa en esta materia y estaba dirigido a los países anteriormente indicados, los cuales tendrían funciones de aprendizaje y práctica. Cataluña ${ }^{872}$, Bulgaria y Letonia aplicarían de forma piloto el programa Círculos durante el proyecto y mientras tanto Francia, Irlanda y Hungría tendrían una participación a modo de observador para el aprendizaje de estas figuras y su futura implantación en sus fronteras.

La Unión Europea buscaba de este modo expandir la figura de los círculos en Europa bajo estándares de calidad y supervisión por parte de los países que poseían cierta práctica con el fin de que su experiencia pueda servir de ejemplo a los países “novatos” a desarrollar esta figura correctamente. La finalidad es proteger a las víctimas de agresiones sexuales a través de la puesta en marcha de este modelo, mostrando apoyo, comprensión y al infractor para evitar una futura reincidencia. Y todo ello con la participación de la comunidad en las mismas líneas desarrolladas anteriormente: un círculo de 3-6 voluntarios que proporcione asistencia al miembro central y un círculo formado por profesionales de diversas ramas tales la psicología o el derecho para proporcionar un conocimiento experto sobre materias controvertidas o de difícil resolución.

\footnotetext{
${ }^{871}$ GARCÍA DÍEZ, C., y SOLER IGLESIAS, C., Evaluación de necesidades y diseño de ... op. cit., p. 21.

${ }^{872}$ Como bien nos indica el Departament de Justícia de la Generalitat de Catalunya, en dicha CCAA participan como socios diferentes organizaciones como la Dirección General de Servicios Penitenciarios, el Centro de Estudios Jurídicos y Formación Especializada, la Universidad de Barcelona y la Fundación La Caixa.
} 
En Cataluña esta figura ha contado con personal muy variado como profesionales de la Justicia, miembros del Departamento de Justicia, miembros de la Universidad de Barcelona, agentes de policía, ONG, Servicios de víctimas y voluntarios $^{873}$. Respecto a estos últimos, se contaba con 15 de muy variada educación, edad y experiencia:

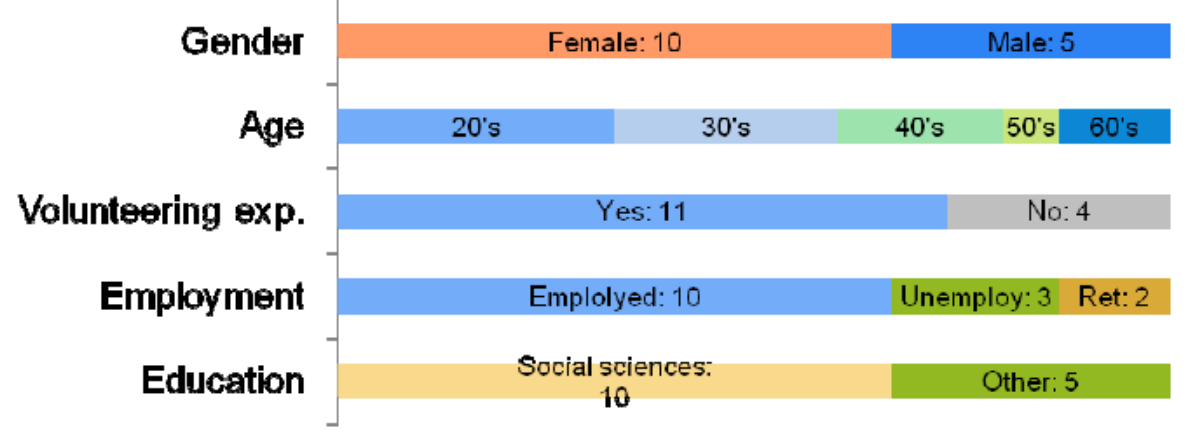

Figura 46. 15 Voluntarios entrenados. ¿Cómo son? ${ }^{874}$

Se ha de realizarse breve mención a los círculos restaurativos que están empezando a implantarse en Brasil y desarrollado por Dominic Barter. Estos se utilizan en el sistema de justicia de menores, así como para barrios desfavorecidos (ej. favelas) o para la resolución de conflictos escolares. Estos círculos restaurativos se basan en la comunicación no violenta, obviando la utilización del talking piece ${ }^{875}$ y utilizando una metodología y proceso diferente al utilizado en USA, UK o Canadá ${ }^{876}$ y adaptado a las necesidades y características culturales de los participantes.

Por el contrario, el modelo de círculos ha alcanzado apenas adaptación en Asia. En China encontramos diversos estudios sobre la materia, pero en todos ellos simplemente se aconseja su futura utilización. Siguiendo el estudio de TITI ZHONG ${ }^{877}$,

${ }^{873}$ CerclesCat, Development of CoSA in Catalonia, Departament de Justícia de la Generalitat de Catalunya, 2013, pp. 1-12, esp. p.3. Disponible en: http://justicia.gencat.cat (Última visita: 09/11/2017)

${ }^{874}$ CerclesCat, Development ..., op. cit., p.7.

${ }^{875}$ Recuérdese, objeto elegido por facilitador y utilizada para el otorgamiento del turno de palabra en las sesiones.

${ }_{876}$ WEITEKAMP, E. G. M., Developing Peacemaking Circles ... op. cit., p. 31.

877 TITI ZHONG, M., Using circles of support and accountability in China: prospects and problems, Simon Fraser University, Burnaby, 2010, pp. 53 y ss. 
podemos encontrar una serie de argumentos a favor y en contra de la implantación de los círculos. En cuanto a los argumentos favorables, el autor nos indica que la situación urbana de China potencia una cultura colectiva con interacciones sociales entre los residentes de la comunidad, siendo caracteres perfectos para el desarrollo de prácticas restaurativas.

El autor nos indica que el Gobierno Chino ya tiene normativa similar al indicarnos que el artículo 37 de la Ley de Prisión de la República Popular de China obliga a que se instaure un programa de apoyo a los delincuentes sexuales liberados, similar a lo practicado a través de los Círculos CoSA. A pesar de ello, considera que el sistema CoSA “puede ser beneficioso para cualquier tipo de delincuentes liberados en

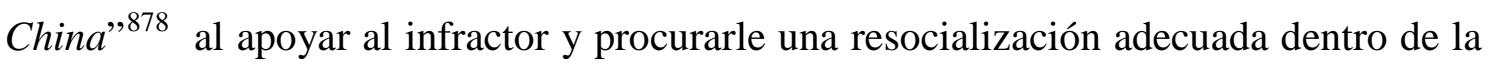
Comunidad.

En segundo lugar, en cuanto a inconvenientes se cita el factor religioso como traba al no existir un amplio número de creyentes, puede ser un problema para su inclusión ya que la mayoría de voluntarios y miembros de los círculos son creyentes. A esto le suma el problema de que las organizaciones religiosas no tienen poder en la comunidad, la cual está influenciada por las ideas de Confucio, debiendo quedar el sujeto en manos de las fuerzas del orden y del Gobierno. Erróneo a nuestro parecer ya que el ímpetu de auxilio no reside en las creencias de un sujeto sino de la propia alma. Como humano, el amparo al prójimo es base de nuestra civilización común, no siendo necesaria la fe en ningún dogma para la actuación. La agrupación en comunidades conlleva a un cometido de auxilio común no siendo obligatorio que este espíritu nazca de credo alguno sino de la inherente naturaleza de todo ser.

${ }^{878}$ TITI ZHONG, M., Using circles of support ... op. cit., p. 56. 


\subsection{La importancia de las comunidades aborígenes para la implementación de} los círculos en Australia.

Oceanía no ha quedado al margen de la expansión de los círculos, donde han empezado a ganar cierta relevancia aun sin alcanzar el éxito de las Conferencias. Como ha ocurrido en otros lugares, han tenido que ser diversas asociaciones, esencialmente religiosas, las que han otorgado el verdadero impulso a estas prácticas.

En Australia los círculos han sido aplicados para infractores aborígenes ${ }^{879}$ a través de los diversos movimientos restaurativos promovidos por John Braithwaite gracias a su teoría de la "vergüenza reintegrativa" ${ }^{880}$. Este movimiento restaurativo nos llevó a una utilización de círculos para delitos menores, tales como incumplimiento de órdenes de alejamiento o conducciones de vehículos a motor sin licencia ${ }^{881}$. Aunque la base de esta implantación tiene su fundamento en los altos niveles de delincuencia aborigen, existiendo 15 veces más de probabilidades que un indígena acabe en prisión que un no indígena ${ }^{882}$. En las recomendaciones de la Comisión Real sobre las Muertes Aborígenes en la Custodia (Royal Commission into Aboriginal Deaths in Custody) ${ }^{883}$,

\footnotetext{
${ }^{879}$ WEITEKAMP, E. G. M., Developing Peacemaking Circles ... op. cit., p. 35.

${ }^{880}$ Según John Braithwaite, existen dos tipos de vergüenzas: desintegrado y reintegrativa. La primera de ellas es aquella a través la cual existe una reprobación social del delito pero también del delincuente, estigmatizándole. Mientras que la vergüenza reintegrativa versa sobre una reprobación social al delito pero no al delincuente, respetándosele como persona: "se odia al pecado pero no al pecador", obteniéndose un mecanismo reintegrador tal y como sucede según el autor en Japón, disminuyendo así la tasa de criminalidad. Para una análisis más profundo del tema véase BRAITHWAITE, J., Crime, Shame and Reintegration, Cambridge University Press, Londres, 1989, pp. 229 y ss. En la misma línea DEL CANTO HUERTA, R., La vergüenza reintegrada y la justicia restaurativa: modelos innovadores en el ámbito de las medidas alternativas a la privación de libertad de menores de edad, Prof. Guía Loreley Friedmann Volosky, Tesis de licenciatura. Facultad de Derecho, Universidad de Chile, Santiago, Chile, 2004, p. 122; FRIEDMAN VOLOSKY, L., Justicia restaurativa. Nuevas formas de tratamiento para delincuentes juveniles, Instituto de Derecho Penal Europeo e Internacional, Publicaciones del Instituto de Derecho Penal Europeo e Internacional, p. 2. Disponible en: http://portal.uclm.es (Última visita: 09/11/2017); LANGÓN CUÑARRO, M., "La teoría de la vergüenza reintegrativa de John Braithwaite", en Revista de la Facultad de Derecho 2000, nº 18, pp. 63-67, esp. p. 63-64.

${ }^{881}$ FITZGERALD, J., "Does circle sentencing reduce Aboriginal offending?", en Crime and Justice Bulletin 2008, n¹15, pp. 1-12, esp. p.1.

${ }^{882}$ Datos extraídos del Australian Bureau of Statistics (ABS) 2003. Year book Australia 2003: Crime and Justice - Indigenous prisoners. Disponible en: http://www.abs.gov.au (Última visita: 06/11/2017)

${ }^{883}$ Para un conocimiento más amplio sobre la Comisión Real sobre las Muertes Aborígenes en la Custodia véase BRIGGS, D. y AUTY, K., "Koori Court Victoria - Magistrates' Court (Koori Court) Act 2002”, Law Text Culture 2004, nº 8, pp. 5-38.
} 
que manifestaban la necesidad de la participación de los indígenas en el sistema de justicia, así como en los diversos Acuerdos de Justicia que preveían un mejor sistema de justicia para los aborígenes, sí se permitía su participación en éste y por tanto, “tener voz en la Corte" ${ }^{884}$.

Todo ello se complementaría con los diversos estudios y prácticas llevados a cabo por Chris Vass en las Tierras del pueblo aborigen Pitjantjatjara ${ }^{885}$ y su promoción de la cultura y derechos aborígenes, dando lugar al nacimiento de diferentes tribunales donde se practican figuras restaurativas basadas en el modelo Nunga Court, de idéntico desarrollo que los círculos de sentencia canadienses, como las cortes de Victoria y Queensland nacidas en 2002, las cortes Port Augusta inauguradas en 2003, y cortes en diversas ciudades y pequeñas poblaciones rurales como Murray Bridge de 2001 o Ceduna en $2003^{886}$. Se crearon diferentes modelos (conforme se señala en la figura 47), todos ellos muy similares a lo que conocemos como círculos de sentencia, cuyo fin era la aplicación de justicia en el ámbito geográfico cubierto por el tribunal.

Así se disponían para el enjuiciamiento de delincuentes procedentes de etnias indígenas y con la intervención de personas aborígenes (normalmente de 1 a 4) de edad avanzada para que asesoren al Tribunal, así con la presencia de trabajadores sociales también aborígenes cuyas funciones residan desde la ayuda en la elaboración de un plan de sentencia, hasta el seguimiento del cumplimiento de dicho plan. Todo ello llevo a dos concepciones de percibir esta justicia indígena, como un ejemplo de la Justicia Restaurativa o Terapeútica ${ }^{887}$ o como un ejemplo de justicia propia ${ }^{888}$. Desde nuestro

\footnotetext{
${ }^{884}$ WELCH, C., "South Australian Courts Administration Authority: Aboriginal court day and Aboriginal justice officers”, en Indigenous law bulletin 2002, Vol. 5, n 14, pp. 5-6, esp. p.5.

${ }^{885}$ MARCHETTI, E., y DALY, K., "Indigenous courts and justice practices in Australia”, en Trends \& issues in crime and criminal justice 2004, $\mathrm{n}^{\circ}$ 277, Australian Institute of Criminology, pp. 1-6, esp. p.2. Disponible en: http://www.aic.gov.au (Última visita: 04/11/2017).

${ }^{886}$ ABORIGINAL JUSTICE ADVISORY COUNCIL., Circle sentencing involving Aboriginal communities in the sentencing process, Australia: Lawlink, Attorney General's Department of NSW, New South Wales, 2005. Documento en línea; MARCHETTI, E. y DALY, K., "Indigenous courts and justice practices...”, p.2.

${ }^{887}$ FREIBERG, A., “Problem-oriented courts: innovative solutions to intractable problems?” en Journal of judicial administration, 2001, $\mathrm{n}^{\circ} 11$, pp. 7-27, esp. p. 10 y ss.

${ }^{888}$ MARCHETTI, E., DALY, K., “Indigenous courts and ...”, p.4.
} 
punto de vista, este conjunto de actividades no son Justicia Restaurativa en sí, sino una vía de aplicación de ésta. Son una justicia propia adaptada a las necesidades socioculturales de la época que cumple los fines reparadores de la Justicia Restaurativa, pues esta última es una filosofía, un nuevo paradigma de entendimiento de la justicia cuyos fines pueden obtenerse a través del uso de muy variadas prácticas, y entre ellas comprenderían estos tribunales de círculos de sentencia propios de las culturas aborígenes.

\begin{tabular}{|c|c|c|c|c|c|}
\hline Jurisdiction & Locality & Name of court & $\begin{array}{l}\text { Date } \\
\text { established }\end{array}$ & $\begin{array}{l}\text { No. of elders or } \\
\text { respected persons } \\
\text { sitting with magistrate }\end{array}$ & Layout of the courtroom \\
\hline \multirow[t]{2}{*}{$\begin{array}{l}\text { New South } \\
\text { Wales }\end{array}$} & Nowra & Circle Court & Feb 2002 & $\begin{array}{l}\text { Four, selected from the } \\
\text { community }\end{array}$ & $\begin{array}{l}\text { Held in South Coast Aboriginal } \\
\text { Cultural Centre; sit in a circle (no } \\
\text { desk); closed court }\end{array}$ \\
\hline & Dubbo & Circle Court & Aug 2003 & $\begin{array}{l}\text { Four, selected from the } \\
\text { community }\end{array}$ & $\begin{array}{l}\text { Sit in a circle (no desk); closed } \\
\text { court }\end{array}$ \\
\hline \multirow[t]{2}{*}{ Queensland } & Brisbane & Murri Court & Aug 2002 & $\begin{array}{l}\text { One, selected from a pool } \\
\text { of } 15\end{array}$ & $\begin{array}{l}\text { Normal magistrates' courtroom } \\
\text { decorated with Indigenous } \\
\text { paintings }\end{array}$ \\
\hline & Rockhampton & $\begin{array}{l}\text { As yet unnamed; includes } \\
\text { three groups (Aboriginal } \\
\text { people, Torres Strait } \\
\text { Islanders and South Sea } \\
\text { Islanders) }\end{array}$ & Jun 2003 & $\begin{array}{l}\text { One, selected from a pool } \\
\text { of } 8-10, \text { but as many } \\
\text { elders as possible turn } \\
\text { up and observe }\end{array}$ & $\begin{array}{l}\text { Normal magistrates' courtroom } \\
\text { decorated with a painting and } \\
\text { other insignia that reflects the } \\
\text { participation of the three groups }\end{array}$ \\
\hline \multirow[t]{5}{*}{$\begin{array}{l}\text { South } \\
\text { Australia }\end{array}$} & Port Adelaide & Nunga Court & Jun 1999 & $\begin{array}{l}\text { Three, selected from } \\
\text { community (in 2003); } \\
\text { previously one elder sat } \\
\text { with the magistrate }\end{array}$ & $\begin{array}{l}\text { Normal magistrates' courtroom } \\
\text { with separate entrance decorated } \\
\text { with Indigenous paintings }\end{array}$ \\
\hline & Murray Bridge & Nunga Court & Jan 2001 & $\begin{array}{l}\text { One, selected from the } \\
\text { community }\end{array}$ & Normal magistrates' courtroom \\
\hline & Port Augusta & Special Aboriginal Court & Jul 2001 & $\begin{array}{l}\text { One, selected from the } \\
\text { community }\end{array}$ & Normal magistrates' courtroom \\
\hline & Port Augusta & Youth Aboriginal Court & May 2003 & $\begin{array}{l}\text { One, selected from the } \\
\text { community }\end{array}$ & Normal magistrates' courtroom \\
\hline & Ceduna & Aboriginal Court & Jul 2003 & $\begin{array}{l}\text { One, selected from the } \\
\text { community }\end{array}$ & Normal magistrates' courtroom \\
\hline \multirow[t]{2}{*}{ Victoria } & Shepparton & Koori Court & Oct 2002 & $\begin{array}{l}\text { Two, selected from a pool } \\
\text { of } 7 \text {; legislation permits } \\
\text { just one to assist in the } \\
\text { hearing }\end{array}$ & $\begin{array}{l}\text { Remodelled courtroom with an } \\
\text { oval table, } 3 \text { flags (Australian, } \\
\text { Aboriginal and Torres Strait } \\
\text { Islander), Indigenous paintings } \\
\text { and noticeboard }\end{array}$ \\
\hline & Broadmeadows & Koori Court & Mar 2003 & $\begin{array}{l}\text { Two, selected from a pool } \\
\text { of } 4 \text {; legislation permits } \\
\text { just one to assist in the } \\
\text { hearing }\end{array}$ & $\begin{array}{l}\text { Remodelled courtroom with an } \\
\text { oval table, } 3 \text { flags (Australian, } \\
\text { Aboriginal and Torres Strait } \\
\text { Islander) and Indigenous } \\
\text { paintings }\end{array}$ \\
\hline
\end{tabular}

Figura 47. Tribunales de círculos de Sentencia Indígena en Australia ${ }^{889}$.

El sistema de Círculos de Sentencia establecido especialmente en los territorios de New South Wales ${ }^{890}$ y, más concretamente en Nowra en 2002, es un sistema peculiar

\footnotetext{
${ }^{889}$ MARCHETTI, E., y DALY, K., “Indigenous courts and ...”,. p.3.

${ }^{890}$ Para ver ejemplos prácticos del desarrollo de estos círculos, vid. POTAS, I., SMART, J., BRIGNELL, G., THOMAS, B., y LAWRIE. R., Circle sentencing in New South Wales: a review and evaluation, Judicial Commission of NSW, Sidney, 2003, pp. 9-38 y 57-62. Disponible en: http://www.lawlink.nsw.gov.au (Última visita: 05/11/2017)
} 
y diseñado para delincuentes de alta gravedad o reincidentes, en el cual interviene toda la comunidad para la consecución de un plan de sentencia ${ }^{891}$. Este delincuente deberá de ser valorado por un grupo de miembros respetables de la comunidad (el denominado Aboriginal Community Justice Group) ${ }^{892}$, dando inicio así a las sesiones en un lugar apropiado para el delincuente y la comunidad indígena, alejado de los Tribunales de Justicia. Esta figura no está exenta de críticas al ser considerada como una justicia más suave, pero como acertadamente nos indica el Magistrado DICK en su favor, "the process is punishment, real punishment ${ }^{\text {}}{ }^{893}$.

El círculo está formado por cuatro miembros de la comunidad, todos ellos personas de edad avanzada y con reputación debidamente contrastada que permitirán que la experiencia embarazosa, temerosa y no significativa para muchos delincuentes indígenas de explicar la ofensa ante el tribunal ${ }^{894}$ quede limitada y enfocada de manera positiva, así como el magistrado, el oficial del proyecto indígena, el miembro central o delincuente, las personas de apoyo de este último, el abogado defensor, el fiscal, la víctima y sus personas de apoyo. Los diferentes objetivos que tienen estas prácticas, especialmente en el caso de los círculos desarrollados en New South Wales ${ }^{895}$, son los siguientes:

- La inclusión de miembros de comunidades aborígenes en el sistema de resolución de conflictos.

- El aumento de la confianza de las comunidades indígenas en el proceso ${ }^{896}$.

- Proveer a los delincuentes indígenas opciones de sentencia más apropiadas para sus circunstancias y necesidades.

\footnotetext{
${ }^{891}$ ABORIGINAL JUSTICE ADVISORY COUNCIL, Discussion paper: circle ..., op. cit. Documento en línea.

${ }^{892}$ POTAS, I., SMART, J., BRIGNELL, G., THOMAS, B., y LAWRIE. R., Circle sentencing in New South Wales: ..., op. cit., pp. 3 y ss.

${ }^{893}$ DICK, D., "Circle sentencing of Aboriginal offenders - victims have a say", en Journal of the Judicial Commission of New South Wales 2004, $\mathrm{n}^{\circ}$. 1, pp. 57-72, esp. p. 67.

${ }^{894}$ MCRAE, H., NETTHEIM, G., BEACROFT, L. y MCNAMARA, L., Indigenous legal issues: commentary and materials, Lawbook Co, Pyrmont, 2003, pp.35 y ss.

${ }^{895}$ POTAS, I., et al. Circle sentencing in New South Wales: ..., op. cit., p.4.

${ }^{896}$ La reducción de las barreras existentes en los años 90 y anteriores entre las comunidades aborígenes y los tribunales es fundamental para el impulso de estas prácticas restaurativas y la cooperación entre el sistema de justicia y los pueblos indígenas.
} 
- La proporción de un apoyo efectivo a las víctimas consiguiendo una mayor participación de los delincuentes aborígenes y sus víctimas en el proceso.

- El aumento de la conciencia de los delincuentes aborígenes de las consecuencias de sus delitos

- Reducción de la reincidencia de los delincuentes aborígenes.

En las diferentes sesiones que se efectúen como desarrollo de tales círculos se iniciará el diálogo encaminado a la elaboración de un plan de reparación que ha de cumplir el delincuente y que el propio círculo controlará a través de sesiones posteriores que evalúen el progreso de las actuaciones. Se observan actuaciones similares a aquellas practicadas en Canadá y Estados Unidos a través de los círculos de sentencia, salvo que aquí estas prácticas se adecúan a las costumbres y culturas propias de las diversas comunidades aborígenes.

Las Cortes Nunga tienen multitud de similitudes a los círculos de sentencia aunque a diferencia de estos últimos, las sesiones se practican en una sala especial dentro de los Tribunales. A dichas actuaciones pueden acudir entre 8 y 12 participantes en diferentes mesas, sin crearse necesariamente una figura en forma de círculo, aspecto diferente a los círculos desarrollados en otros lugares deliberándose entre todos ellos el plan de sentencia ${ }^{897}$. Se podría decir que es una figura que se quedaría a medio camino entre un círculo y un proceso común ante los Tribunales, pues tiene características de ambos. Al desarrollarse en dependencias judiciales y bajo un mayor control del sistema de justicia, se puede advertir una mayor posibilidad de integración en la justicia penal.

Estas prácticas restaurativas en forma de círculo o similares a ellos fueron desarrollando sus funciones en múltiples regiones ya mencionadas anteriormente así como los efectuados en las ciudades de Palm Island, Kowanyama, Calpe York y Pomparraw en la región de Queensland; los paneles o grupos de Justicia de Victoria; el

${ }^{897}$ MARCHETTI, E., DALY, K., “Indigenous courts and ...”, op. cit., pp. 3-4. 
Círculo de Yandeyarra en Pilbara en la región Western Australia ${ }^{898}$; los círculos de Walgett y Brewarrina en New South Wales basados en las prácticas de Nowra; y las actuaciones de Northen Territory, los cuales tienen en cuenta los castigos propios indígenas como el payback (reparación a través del pago de una cuantía económica decida en un acuerdo entre víctima y victimario) que opera como atenuante ${ }^{899}$.

El impulso de toda la comunidad para su desarrollo, superando el escepticismo inicial, ha impulsado los círculos australianos hasta un auge no concebido en sus primeros bosquejos. En palabras de Gail Wallace, oficial del proyecto de círculos de sentencia en Nowra, “La comunidad aborigen se mostró escéptica al principio, debido al temor histórico y a la desconfianza en el sistema de justicia penal. Los tribunales también eran escépticos, no sabiendo realmente cómo los ancianos se comportarían en el círculo [...] No vemos tantos delincuentes aborígenes en el juzgado en estos días. Aquellos que han pasado por un círculo de sentencia están diciendo a sus amigos que cambien sus vidas y transmitan ese conocimiento a los demás. Y la comunidad no aborigen está llegando y apoyándola también"900.

Otro ejemplo a tener en cuenta por su desarrollo eficaz son los círculos de apoyo o Círculos CoSA, desarrollados en la práctica por diferentes sociedades como Five8 Circles $^{901}$. Su confección se basa en grupos de 6 voluntarios que buscan dar un apoyo al exdelincuente a través de la amistad, el apoyo y la rendición de cuentas. Centra su interés en alejar al exdelincuente de aquellas influencias y circunstancias que le llevaron a la delincuencia procurándole una vivienda, un trabajo y una nueva red de amistades. Los voluntarios se reunirán con el delincuente en prisión y se efectuará un seguimiento una vez es puesto en libertad a través de reuniones informales individuales o en grupo

\footnotetext{
${ }^{898}$ El círculo de Yandeyarra está formado por dos ancianos de dicha comunidad, el infractor, el fiscal, el abogado defensor, el magistrado y la víctima más las personas de apoyo de ambos, buscando todos ellos un acuerdo de sentencia que solucione el conflicto.

${ }^{899}$ MARCHETTI, E., y DALY, K., “Indigenous courts and ...” op. cit., p. 4.

${ }^{900}$ LAM, M., "Understanding, but no soft options in the circle”, en Law Society Journal 2012, Vol. 50, pp. 27-29.

${ }_{901}$ Para más información visitar la página web del grupo FIVE8 Support for ex-offenders. Disponible en: http://www.five8australia.com.au (Última visita: 03/11/2017)
} 
durante un periodo mínimo de un año. Para ello se promueven una serie de valores como la honestidad, la integridad, la responsabilidad, la generosidad, la amistad, la comunidad, la sana espiritualidad y la formación.

Pero Five8 no sólo se interesa en la figura del infractor, sino que considera también las necesidades y preocupaciones de las víctimas y de los miembros de la comunidad. Busca logar una sociedad segura que salvaguarde la seguridad de víctimas potenciales y restablecer así la paz de la comunidad. Ello se alcanza con la resocialización de los infractores, aspecto de vital importancia para la pacificación social. A modo de ejemplo de la valía de estos procesos restaurativos es que muchos de los ex-delincuentes acuden posteriormente como voluntarios para ayudar a otros en su resocialización como se va a observar en el ejemplo siguiente, la historia de Glen:

"Viviendo en una pequeña comunidad del país, fue reprendido y condenado al ostracismo por todo el mundo que conocía y se escapó de las grandes luces de la ciudad. A los 14 años de edad, Glen era un adicto a la heroína y vendía su cuerpo en la zona de Kings Cross de Sydney para mantener su hábito. Contrajo hepatitis $C$ y muchas otras enfermedades de transmisión sexual. La vida era una espiral fuera de control. A los 19 años, estaba en la cárcel con un tramo de 2 años, el primero de los muchos que ascendería a casi 10 años en un período de 14 años. Glen finalmente ha abandonado su consumo de drogas y el crimen y controles establecidos por el círculo en torno a lo que hace y cómo lo hace. Ha estado fuera de la cárcel durante 4 años. Se centra en la construcción de una relación con sus dos niños de 7 y 12 años de edad y está estudiando para la obtención de un Certificado IV de alcohol y otras drogas y ejerce a su vez como voluntario para ayudar a otros que han vivido una vida dependiente de las drogas y el alcohol. Glen se aloja en un alojamiento temporal durante la rehabilitación y tiene un trabajo a tiempo parcial, pero necesita un coche para ver a sus hijos con más frecuencia ya que es difícil llegar a ellos por transporte público"902.

${ }^{902}$ Five8. Glen story. Disponible en: http://www.five8australia.com.au (Última visita: 03/11/2017) 
En la misma línea podemos encontrarnos la asociación NAPCAN ${ }^{903}$, la cual, junto a la Universidad de Western Sydney, entre una de sus múltiples labores comunitarias, elabora un programa de círculos con el fin de proporcionar enseñanza de métodos para la resolución pacífica de conflictos en las escuelas, con especial incidencia en chicas delincuentes aborígenes. Se proporciona un espacio seguro para el aprendizaje y desarrollo de las necesidades y emociones sociales de los menores, potenciando así sus habilidades. Estas destrezas enfocadas en la resolución pacífica de conflictos son desarrolladas a través de juegos y debates productivos entre todos ellos.

Estas prácticas están siendo potenciadas en las escuelas de toda Australia con el impulso de sus miembros, tanto el profesorado como el alumnado. Como consecuencia se está dando resultados positivos en las relaciones entre los partícipes y el comportamiento global de los estudiantes de primaria y secundaria. Las actividades son de muy variada índole, tales como campamentos comunales o participar en proyectos de servicio a la comunidad. Todo ello para afrontar sus necesidades y capacidades resolutivas de conflictos, y siempre con el apoyo de los miembros de mayor edad de la comunidad, los cuales aportan un conocimiento basado en la experiencia.

Se percibe la existencia de una clara influencia del factor religioso en el desarrollo de los círculos, tanto en Canadá, Estados Unidos, la propuesta de China y los desarrollados en Oceanía. Se confunden los valores religiosos con los valores morales e incluso se confunde creencia con resocialización. Ejemplo de ello es FIVE8, que en su página web ya referida anteriormente, nos indica como frase final de sus objetivos “...amistades de individuos que comparten el corazón de Jesucristo”.

A fecha de hoy no resulta cierto asegurar que sólo a través de los valores de las religiones se puede resocializar a una persona e incluso condicionar el voluntariado a la creencia de unos valores y principios basados en un credo se puede ser voluntario. Una persona por pertenecer o no a una fe no es mejor o peor, simplemente sigue un dogma.

\footnotetext{
903 National Association for Prevention of Child Abuse and Neglect. Para más información relativa a sus planes de acción y actividades, vid. http://napcan.org.au (Última visita: 03/011/2017)
} 
Las creencias presuponen una serie de valores morales, pero no por pertenecer a ese grupo religioso ya eres portador de ellos. Para buscar la resocialización de un delincuente, tanto por parte del propio infractor como de los voluntarios y profesionales que le apoyan, no es necesaria una creencia a la cual aferrarse, sino que la voluntad lo es todo, la voluntad de actuar.

\section{Tipos de circles y sus participantes: un estudio con poca unanimidad}

Como ya se ha puesto de manifiesto, la institución de los círculos adolece de falta de estudio y consenso en cuando a su definición. Por otra parte su práctica no atiende a principios sino a la experiencia práctica desarrollada en diferentes lugares siendo usual que las mismas actuaciones se denominen de diferente manera o exista una misma terminología para prácticas diferentes, ya sea por su desarrollo, objetivos o participantes, aspecto que se irá analizando a continuación. A parte de todo ello, cada círculo es totalmente diferente en relación a las necesidades de los participantes, el número de éstos - en toda sesión se pregunta a los interesados “¿Quién debería venir al círculo para ayudar a encontrar soluciones?”904, marcándose así el número de intervinientes- y del desarrollo que pretenda enfocar el facilitador en cuanto a su desarrollo, el cual también se verá influenciado en parte por aspectos religiosos o culturales.

Asimismo podemos encontrarnos una multitud de términos para definir la misma práctica como, por ejemplo, el error de diferenciar círculos de paz (peacemaking circles) de los círculos de sentencia (sentencing circles), los cuales constituyen la misma práctica pero difieren en que los círculos de paz son una denominación posterior a los círculos de sentencia, los cuales fueron los primeros en ser introducidos. El término “Círculo de paz” hace referencia a la pacificación de la sociedad como objetivo

\footnotetext{
${ }^{904}$ BANNINK, F., WALKER, L., Gestión de conflictos enfocada en la solución y círculos restaurativos, traducido por Gema Verano Martínez 2015. Disponible en: http://www.lorennwalker.com (Última visita: 03/11/2017)
} 
de estas prácticas, decidiéndose posteriormente otorgarle esta terminología más amplia $^{905}$.

Se procede así a exponer la clasificación de círculos más representativa del panorama práctico actual. Se analizarán los caracteres de mayor consideración que singularizan círculos de sentencia o pacificadores, los círculos sanadores, los círculos de apoyo, dejando para el final el examen de otro tipo de círculos secundarios como son los círculos escolares, cuya denominación responde a su aplicación de carácter sectorial al ámbito escolar.

\subsection{La participación de la comunidad: el amplio número de participantes.}

Ya hemos podido examinar que el círculo no sólo lo componen víctima e infractor, sino que diferentes miembros de la comunidad pueden acudir a él para ayudar en la resolución del conflicto o apoyar a la víctima-infractor. Pero, ¿es conveniente que en un círculo nos encontremos con una multitud de participantes?

En principio podemos decir que cuantos más participantes existan, más opiniones se escucharán, pero a la vez las sesiones serán más “pesadas” e incluso repetitivas. Escuchar la misma opinión, o una muy similar, de la voz de diferentes personas no sólo nos puede despistar del propio asunto, sino que puede provocar un efecto negativo en víctima e infractor.

La víctima puede llegar a entender el círculo como algo repetitivo y con poca utilidad. Escuchará a multitud de sujetos que se comparecerán de ella y ofrecerán diferentes soluciones, las cuales puede que ni le interesen lo más mínimo, o incluso si le interesan pueden suceder dos situaciones. La primera es que de tanto escuchar la misma solución llegue a cansarse y considerar el proceso como una pérdida de tiempo, lo cual le puede suponer efectos negativos equivalentes a los sufridos en un proceso retributivo.

${ }^{905}$ En esta línea PRANIS, K., STUART, B. y WEDGE, M., Peacemaking Circles: From Crime to Community, Living Justice Press, St. Paul, 2003, p. 21. 
Esta situación la haría desconfiar del círculo, viéndolo como un conjunto de actos que no le portan nada y le repercutiría en su situación psicológica.

La segunda consecuencia será que le dificultará prestar atención a las demás soluciones propuestas cuando ya exista una de ellas que desea, resultando para ella el resto de opiniones de una importancia mínima. Existen círculos que tienen sesiones que duran más de 9 horas, y cuando la solución para la víctima aparece al inicio, el resto de la sesión puede que no le fascinen, no atendiendo a los demás. Ello provocaría un efecto negativo en el círculo al afectar su comportamiento a todos aquellos miembros que han acudido al círculo para ayudar, los cuales verán como su opinión no es escuchada ni tenida en cuenta y llevándoles a una situación de desilusión respecto al círculo.

En principio, de todo lo que se ha indicado, puede parecer que mi posición es contraria a la existencia de muchos participantes en el círculo, pero nada más lejos que la realidad. Creo que el círculo es una opción para la intervención de la Comunidad en la resolución del conflicto. Es por ello que considero que el Círculo ha de estar abierto a toda la Comunidad, y cuando digo esto me refiero a cualquier miembro que viva en dicha sociedad. ¿Por qué una persona no va a poder entrar y opinar en la resolución del conflicto por no ser amigo, familiar o miembro de alguna organización?

El círculo se caracteriza por ser un espacio libre al que se acude a expresar emociones y sentimientos, y quizás una persona ajena completamente al conflicto pueda aportar una idea para la resolución del conflicto, una idea para la recuperación emocional y física de la víctima, e incluso participar en la aceptación por parte del resto de la sociedad de un infractor arrepentido.

En principio el círculo está abierto a todo el mundo, pero se suele preguntar a los afectados por el conflicto “¿Quién debería venir al círculo para ayudar a encontrar 
soluciones?”906 . Es más, depende del tipo de círculo que estemos realizando para la admisión o no de miembros específicos. Por ejemplo, y adelantando materia, en los círculos escolares es lógico que en la composición del círculo estén miembros de la escuela y apenas existan miembros externos a ellas, pudiendo ser sólo la de familiares de los niños y/o psicólogos para complementar y ayudar a los menores en la búsqueda de una solución.

Por ello, para la composición de los círculos hay que estar primero a qué tipo de círculo es y cuáles son sus fines. En general, la mayoría de círculos buscan una sentencia que solucione el conflicto (sentencing circles) ${ }^{907}$ y en ellos "el proceso está abierto a todos los demás miembros de una comunidad local, villa o grupo nativo”. Esto quiere decir que cualquier persona de la comunidad puede acudir a aportar su opinión, a ayudar a la víctima e infractor a la consecución de un plan de sentencia que ponga fin al conflicto, restaurando a la víctima y ayudando al infractor en su vuelta a la comunidad.

Desde nuestro punto de vista, cuantas más personas acudan al círculo, mejores soluciones vamos a poder encontrar y existirá una mayor facilidad para que la víctima y el infractor puedan volver a sentirse aceptados por la sociedad. A mayor número de intervinientes, aunque sea más difícil de controlar la sesión, mayor será el listado de pareceres, mayor será el sentimiento de compañía por parte de la víctima, la cual observará que no está aislada del mundo y que hay personas que la van a ayudar a superar el trauma, personas incluso sin ningún tipo de relación previa con ella. El infractor se sentirá apoyado para abandonar la senda de la delincuencia y aceptado para poder proseguir con una vida normal sin tener que ser señalado como delincuente ni sufrir una estigmatización por parte de la sociedad, la cual le ha perdonado y le permite llevar una vida normal después del cumplimiento del castigo por su infracción.

\footnotetext{
${ }^{906}$ BANNINK, F., y WALKER, L., Gestión de conflictos enfocada en la solución y círculos restaurativos, traducido por Gema Verano Martínez 2015. Disponible en: http://www.lorennwalker.com (Última visita: 03/11/2017)

${ }^{907}$ Manual sobre programas de Justicia Restaurativa, Serie de Manuales sobre Justicia Penal, Naciones Unidas, Nueva York, 2006, p. 65. Disponible en: https://www.unodc.org_(Última visita: 04/11/2017)
} 
La comunidad además se beneficiará de la participación de sus propios miembros, los cuales aprenderán a resolver conflictos, a apoyar a una víctima con un trauma y auxiliar a superarlo, y a reintegrar y perdonar a un infractor arrepentido. Todas estas actuaciones mejorarán las relaciones de la propia comunidad y ayudarán a sentar un precedente de ayuda común para la resolución de futuros conflictos, así como disminuirán los pensamientos de venganza y la reincidencia de los delincuentes.

3.2 Círculos de sentencia o de paz: la comunidad y la obtención de un acuerdo.

Los círculos de sentencia o pacificadores son aquellos que se centran en la creación de un plan de sentencia o reparación que busque la solución del conflicto ${ }^{908}$. Una acertada definición se proporciona por BAZEMORE y UMBREIT al indicar que: “Círculo de sentencia es una estrategia holística reintegradora diseñada no sólo para atender el comportamiento criminal y delictivo de los delincuentes, sino también para tener en cuenta las necesidades de las víctimas, las familias, y la comunidad" ${ }^{909 .}$

En ellos participan la víctima y sus familiares, el infractor y sus familiares, policías, personal del ámbito de la justicia y demás miembros de la comunidad. Constituyen un sistema centrado en el aprendizaje de la comunidad como método para la resolución del conflicto ${ }^{910}$. Desde nuestra opinión, la participación ha de estar abierta a cualquier miembro de la sociedad que tenga un criterio que aportar y diferentes opiniones a aprender. Los círculos de paz "deben ser accesibles a todos los que deseen participar y nadie debe ser excluido"911 porque "la participación de todos es fundamental para el logro de la justicia" ${ }^{912}$. Como indica PRANIS, la inclusión de todas las personas provoca el sentimiento de que el círculo tiene un mayor potencial

\footnotetext{
${ }^{908}$ Manual sobre programas ..., op. cit., p. 65.

909 BAZEMORE, G., y UMBREIT, M., “A comparison of four restorative conferencing models”, en Juvenile Justice Bulletin, 2001, pp. 1-20, esp. p.6.

${ }^{910}$ WEITEKAMP, E. G. M., Developing Peacemaking Circles ..., op. cit., p. 14.

${ }^{911}$ WEITEKAMP, E. G. M., Developing Peacemaking Circles ..., op. cit., p. 14.

${ }^{912}$ PRANIS, K., STUART, B., y WEDGE, M., Peacemaking circles: from ..., op. cit., p. 17.
} 
para la búsqueda de una solución ya que es apoyado por la comunidad y beneficioso para ella misma ${ }^{913}$.

Aunque se denomine círculo de sentencia, como indica el juez STUART, existe el problema "que si tú lo llamas círculo de sentencia, las únicas personas que estás invitando son a los miembros de justicia [...] El círculo de sentencia trata de una "construcción de la comunidad"; se trata de "curar" a los afectados por la delincuencia, y al que lo cometió. Se está reparando las relaciones; haciendo a víctimas y a los autores "sentirse mejor" [...] es para que los delincuentes puedan sentir el amor de la comunidad" ${ }^{914}$.

A través de esta figura todo el mundo va a ser respetado pudiendo intervenir y estando en una posición de igualdad que le permita contar historias, anécdotas, emociones y sentimientos como el enfado, la frustración, la alegría, la ira, la desesperación y la esperanza.

A través del círculo los participantes buscarán llegar a un acuerdo de cómo hay que resolver el conflicto surgido que repare a la víctima, resocialice al infractor y satisfaga las necesidades de paz social de la comunidad en las sesiones que se estime oportunas y con la duración necesaria, pudiendo variar estas desde varias horas hasta un día completo ${ }^{915}$. Pero, lo más importante en estos casos, es la creación de un espacio seguro donde fluya el diálogo entre todos los intervinientes; un diálogo que sane las heridas emocionales y restituya las relaciones dentro de la comunidad. Este espacio seguro en el que fluya el diálogo ha de conseguirse a través de diferentes actuaciones encaminadas a compartir, por parte de los participantes, aspectos personales que aclaren las historias y objetivos de los miembros del círculo y ayuden a crear un mejor punto de partida para el diálogo ${ }^{916}$.

\footnotetext{
${ }^{913}$ PRANIS, K., STUART, B., y WEDGE, M., Peacemaking circles: from ..., op. cit., pp. 54-55.

914 “Sentencing circles for aboriginals: Good justice?”, en National Post, 27/02/2009. Disponible en: http://www.nationalpost.com (Última visita: 01/11/2017)

${ }^{915}$ SCHMID, D.J., “Restorative Justice: a new ...”, op. cit., pp. 91-134, esp. p. 108.

${ }^{916}$ WEITEKAMP, E. G. M., Developing Peacemaking Circles ..., op. cit., p. 17.
} 
La pacífica discusión que se ocasiona en el círculo no sólo sirve para comentar el hecho delictivo de ese momento, sino que suele suscitar diferentes debates acerca de hechos similares que se han ocasionado en la comunidad, los motivos que se dieron para la comisión de estos crímenes, las medidas que se tomaron y el impacto que generaron en la víctima y en la sociedad ${ }^{917}$, y todo ello como un método de aprendizaje para la resolución de ese círculo. La analogía con supuestos similares crea un precedente en los participantes presentes para la conclusión satisfactoria del círculo a través de ideas que ya sirvieron en su momento. Además se realizará un análisis retrospectivo de cómo era la sociedad y la víctima previamente a la comisión del hecho delictivo; las actuaciones que se deben de tomar para la prevención de estos comportamientos delictivos; el impacto que han sufrido tanto las víctimas como sus familiares; las medidas a tomar para la resocialización del delincuente y la curación de la víctima y la sociedad; un plan de sentencia que solucione el conflicto; el responsable de la ejecución y cumplimiento de dicho plan; el responsable de la vigilancia del cumplimiento de las medidas adoptadas; las sesiones en las que se valorará si se están cumpliendo o no los objetivos y; la medida final de reparación con el plan de sentencia perfectamente elaborado y listo para ser presentado y ratificado por el juez ${ }^{918}$.

Antes de adoptar el acuerdo final, se van a encomendar laborares concretas a cubrir de inmediato al infractor, y así en las diferentes reuniones o sesiones se irá comprobando el cumplimiento de estos objetivos antes de que se complete el círculo de sentencia $^{919}$. El acuerdo al que se llega en el círculo no evita una posterior pena en la sentencia condenatoria, pero sí que es cierto que el juez sentenciador suele optar por la utilización de otras medidas restaurativas junto al acuerdo, como indemnizaciones o servicios comunitarios, dependiendo de la gravedad del hecho delictivo.

\footnotetext{
${ }^{917}$ SCHMID, D.J., "Restorative Justice: a new ...”, op. cit., p. 108.

${ }^{918}$ Vid. SCHMID, D.J., Restorative Justice in New Zealand: A Model For U.S. Criminal Justice, Ian Axford Fellow in Public Policy, Wellington, New Zealand, 2001, p. 23

${ }^{919}$ SCHMID, D.J., “Restorative Justice: a new ...”, op. cit., p. 108.
} 
La ejecutabilidad del acuerdo alcanzado en el círculo será competencia del juez, pudiendo adherirlo a una sentencia posterior, ratificarlo total o parcialmente. En la cultura general, la ciudadanía suele creer que con un acuerdo de este tipo al que suelen equiparar con una simple disculpa, el delincuente queda absuelto y preparado para la comisión de nuevos hechos delictivos, y así continuamente. Hemos de contradecir estas opiniones al considerarlas inexactas.

El círculo tiene varios fines, como la reparación de la víctima o la resocialización del infractor. Pero nunca su fin es sustituir a la pena y establecer un castigo basado en las disculpas simplemente. Por el contrario el círculo admite la pena como método complementario a él para la aplicación de justicia, y sólo un infractor va a "librarse de la pena” en infracciones de pequeña gravedad, siempre y cuando el juez considere que el plan de reparación cumple de forma suficiente los fines reparatorios y resocializadores. Es el propio círculo el que vigila el cumplimiento de lo acordado en él, pudiendo pedirse su ejecución o incluso, desde nuestro punto de vista, que en caso de negativa a cumplimiento de las actuaciones acordadas, la iniciación de vista oral.

Para la iniciación de un círculo de sentencia se han de cumplir una serie de requisitos como la aceptación de la responsabilidad por parte del delincuente, un deseo de resocialización y abandono de la delincuencia, y una derivación por parte del juez o fiscalía, sin obviar las posibles solicitudes de iniciación de prácticas restaurativas por parte de víctima y/o infractor.

Los círculos de sentencia son el mejor ejemplo de participación de la comunidad en la resolución del conflicto al permitir la involucración de cualquier miembro de la sociedad $^{920}$ en el proceso en búsqueda de la resolución del conflicto. La víctima puede o no acudir a las sesiones y, si decide acudir, puede acudir sola, con familiares o con su grupo de apoyo ${ }^{921}$. Este proceso va a ser realizado por un Comité de Justicia

\footnotetext{
${ }^{920}$ Manual sobre programas de Justicia ..., op. cit., p. 23.

${ }^{921}$ SCHMID, D.J., “Restorative Justice: a new ...”, op. cit., p. 108.
} 
Comunitaria, el cual no sólo se centra en la resolución del conflicto, sino en dar apoyo a víctima e infractor por parte de la comunidad ${ }^{922}$.

Dada la participación de la comunidad en la conformación del círculo, nos ha llevado a la existencia de diferencias conforme al lugar de realización lugar donde se está realizando. Aun así siempre existen una serie de características propias, tales como: la sentencia es sólo una parte de la solución, siendo más importante el diálogo y acciones realizadas en el círculo; el delito es una consecuencia de un problema más arduo existente en la comunidad; se busca un trabajo de toda la sociedad, acudiendo los diferentes miembros a aportar ideas para la resolución del conflicto y al asentamiento de unas bases de resolución de futuros conflictos a través de la escucha y el aprendizaje de las diferentes opiniones vertidas en el círculo; no importa sólo el hecho actual, sino que hay que centrarse también en las causas que lo originaron y en los efectos que va a tener en el futuro, siendo por tanto fundamental el apoyo a víctima e infractor para el restablecimiento de la paz social.

\section{Cortes penales}

- El conflicto es el delito

- La sentencia resuelve el conflicto

- Se enfoca en el comportamiento pasado

- Adopta una visión estrecha del comportamiento

- Recibe una disculpa

- Evita una mayor preocupación por los conflictos sociales

- El resultado (la sentencia) es lo más importante

- Confía en profesionales

\section{Círculos comunitarios}

- El incidente delictivo se considera una parte pequeña de un conflicto/dinámica más grande

- La sentencia es una pequeña parte de la solución

- Se enfoca en la conducta actual y futura

- Tiene una visión más amplia, holística

- Enfoque en el conflicto social

- El resultado es menos importante-el proceso lo es más, ya que el proceso forma y a veces sana las relaciones entre las partes

- Fortalece a la comunidad

Figura 48. Diferencias entre Tribunales penales y Círculos ${ }^{923}$

${ }^{922}$ PRANIS, K., et al, Peacemaking Circle From Crime ..., op. cit., p. 128. 
Los círculos de sentencia son el claro ejemplo de que los conflictos pueden resolverse a través del trabajo de la comunidad, la cual utilizando el diálogo pueden llegar a solventar el problema, reparar a la víctima, resocializar al infractor. Además, tal y como señalan las Naciones Unidas ${ }^{924}$, los círculos también:

- Vuelven a familiarizar individuos, familias y comunidades.

- Reconstruyen relaciones que estaban perdidas dentro de las comunidades.

- Promueven el respeto por los valores y la vida de los demás miembros de la comunidad.

- Se centran en satisfacer las necesidades de víctima e infractor por igual.

- No sólo entran a conocer las repercusiones inmediatas del conflicto sino que se enfocan en las causas que lo han originado.

- Coordinan el uso de todo tipo de recursos tanto locales como gubernamentales.

- La resolución de los conflictos crea una serie de antecedentes que no sólo ayudan a la resolución de futuros problemas sino que generan medidas preventivas.

Para la realización de un Círculo de sentencia o pacificador, todos los intervinientes han de sentarse en forma de círculo, estando presidido el círculo por el “Guardián del círculo” (circle keeper) pudiendo ser este un miembro respetado dentro de la comunidad, un facilitador o un juez ${ }^{925}$.

La duración del círculo dependerá de las necesidades de las partes y del desarrollo de las sesiones, los temas a debatir, actuaciones restaurativas acordadas y cualquier asunto a tratar que tenga relación con el conflicto y sea necesario para la resolución de éste o incluso para el asentamiento de bases sólidas para futuros conflictos similares acaecidos en la comunidad. Para que se puedan resolver todos los temas y las sesiones se desarrollen con normalidad, se suele establecer un límite máximo de

\footnotetext{
${ }^{923}$ Manual sobre programas de Justicia ..., op. cit., p. 24. Adaptado de GRIFFITHS, C., Canadian Criminal Justice: A Primer, Nelson College Indigenous, Toronto, 2014, p. 212.

${ }^{924}$ Manual sobre programas de Justicia Restaurativa ..., op. cit., pp. 24-25.

${ }^{925}$ SCHMID, D.J., Restorative Justice in New Zealand ..., op. cit., p. 23.
} 
participantes fijado entre quince y cincuenta personas ${ }^{926}$. Así se “vulnera” uno de los principios básicos de los círculos restaurativos: su apertura a toda la comunidad, la cual será partícipe directa de la resolución del conflicto.

Para conseguir este objetivo de intervención de toda la sociedad se establecen una serie de voluntarios - su número dependerá de las necesidades y actuaciones - que serán parte de la representación de la comunidad. A ellos se les agregarán miembros y representantes de organizaciones en favor de las víctimas y colectivos que tengan un interés directo en el asunto, personas cercanas a víctima e infractor, miembros del sistema de justicia - juez y fiscal que conocían del asunto -, miembros del cuerpo de policía, profesionales de diversas ramas como por ejemplo la psicología, miembros destacados de la comunidad personados y cualquier otro sujeto que se considere óptimo para el desarrollo eficaz del proceso restaurativo. Una vez iniciado el círculo, se establecerá por parte del facilitador y las partes en la primera sesión un plazo aproximado de duración, así como el número de sesiones, sin obviar que ello puede modificarse en aras a las necesidades de los intervinientes y al desarrollo del propio proceso.

El círculo se basa en el diálogo común de todos los intervinientes siempre y cuando se respeta el turno de palabra que marca el talking piece u objeto de hablar, que nos señalará el sujeto que tiene voz en la sesión en ese momento. Será entregado por el facilitador siguiendo un orden lógico, empezando por víctima e infractor, y prosiguiendo con sus familiares y amistades, personal del sistema de justicia, miembros del cuerpo de policía personados, profesionales de diferentes ramas, miembros destacados de la comunidad, voluntarios y representantes de organizaciones. Todos ellos deberán respetar las preguntas que realice el circle keeper a víctima e infractor, las cuales buscarán ahondar en sus sentimientos más profundos y despertar un sentimiento de culpabilidad en el infractor.

${ }^{926}$ SCHMID, D.J., Restorative Justice in New Zealand ... op. cit., p. 23. 
Para que los círculos puedan ser implantados exitosamente se necesita una sana colaboración entre el sistema formal de justicia y la comunidad ${ }^{927}$. Para ello se ha de formar a los facilitadores y voluntarios, con el fin de que puedan asesorar y dirigir adecuadamente el proceso, y posteriormente, dependiendo de la cultura del lugar, las prácticas irán modificándose para amoldarse a la comunidad.

El proceso del círculo no será rígido, sino que irá evolucionando conforme a las situaciones y emociones que se estén viviendo en el círculo hasta que se consiga llegar (o no) a un acuerdo o plan de sentencia que ponga fin al conflicto y permita a las partes volver a reanudar pacíficamente su vida integradas en la comunidad.

Ello nos conduce a la pregunta, ¿puede introducirse esta figura en nuestro Derecho? En principio no cabría una respuesta negativa. Tal y como se puso de manifiesto en el capítulo relativo a la mediación penal, la posibilidad de regulación puede efectuarse a través de una norma especial de Justicia Restaurativa o una modificación de la LECrim con la introducción de los preceptos relativos a las instituciones reparadoras.

Ya se ha puesto de manifiesto la importancia que está teniendo esta figura desde el punto de vista práctico, pero también se ha mencionado la escasa o nula regulación legal existente. Hemos de fijarnos en los círculos de otros lugares para poder hacernos una idea respecto a sus actuaciones y procesos para "servir como una fuente de inspiración para encontrar una manera de crear círculos que se adaptan a la configuración de Europa occidental" ${ }^{928}$, o mejor dicho, de España

Estas figuras ya tienen un soporte legal reciente como el regulado en el considerando 46 de la Directiva relativa al Estatuto de la víctima que nos indica: “Los

\footnotetext{
927 Informe Sentencing Circles, California Courts, pp.1-2, esp. p.1. Disponible en: http://www.courts.ca.gov (Última visita: 03/11/2017)

${ }^{928}$ WEITEKAMP, E. G. M., Developing Peacemaking Circles ... op. cit., p. 37.
} 
servicios de justicia reparadora, incluidos, por ejemplo, la mediación entre víctima e infractor, las conferencias de grupo familiar y los círculos de sentencia, pueden ser de gran ayuda para la víctima”. Gracias a este considerando, podemos observar, como indica WEITEKAMP" ${ }^{929}$, que "el modelo del círculo está oficialmente reconocida incluso en un contexto europeo" y que "los círculos caen bajo el ámbito de aplicación de la presente Directiva”. Este aspecto es importante puesto que es la propia Unión Europea la que está admitiendo este nuevo modelo de resolución de conflictos, abriendo una oportunidad a que los propios Estados Miembros regulen las figuras como un método que sirva de apoyo a la víctima y de lucha contra la victimización secundaria.

Se propone una regulación de los círculos adaptándolos al ordenamiento jurídico español como un sistema complementario para intentar obtener un proceso dialogado que resuelva los conflictos penales, sane a las víctimas y disminuya la reincidencia, observando la necesidad de contribuir a un mayor empleo y estudio de la institución ${ }^{930}$.

En cuanto al ámbito material consideramos que se han de establecer dos fases de implantación. En la primera de ellas se han de regular aquellos delitos con una pena de prisión inferior a 5 años, puesto que al afectar levemente las emociones de los ciudadanos, conllevan una mayor facilidad para la entablación de diálogo entre los intervinientes. En el supuesto de éxito en el desarrollo pragmático de los círculos de sentencia, puede verse ampliado el catálogo de delitos susceptibles de resolución por un proceso de círculos en una segunda fase con la ampliación del ámbito material a cualquier tipo delictivo, incluyendo aquí aquellas infracciones que más afectan a la sociedad en general y a las víctimas en particular, tales como homicidio o asesinato.

La derivación podrá ser realizada por el juez o magistrados, el fiscal, una de las partes o ambas o incluso sus letrados. Ello no tendrá consecuencia alguna si no existe

\footnotetext{
${ }^{929}$ WEITEKAMP, E. G. M., Developing Peacemaking Circles ... op. cit., p. 51.

${ }^{930}$ WALKER, L., "Restorative Reentry Planning Circles for Imprisoned People”, en J.L. De la Cuesta y I. J. Subijana (dirs.), Justicia Restaurativa y Terapéutica. Hacia innovadores modelos de justicia, Tirant lo Blanch, Valencia, 2017, pp. 315-329, esp. p. 327.
} 
una aceptación de los intervinientes. Sólo se iniciaría un proceso de círculo con la aceptación de víctima e infractor. Si cualquiera de ellos rechaza la participación, no podrá incoarse el círculo de sentencia, prosiguiendo las actuaciones conforme al proceso judicial establecido en la ley.

En relación a los miembros del círculo, cabe considerar que éstos han de estar abiertos a toda la sociedad, y por tanto, han de estar compuestos por la víctima, el infractor, el facilitador, psicólogos, médicos, policías, miembros del sistema de justicia (fiscal, juez, etc.), personas afines a los implicados por el conflicto, y representantes de la sociedad. Cualquier persona que pueda aportar una solución o una idea, por pequeña que sea, no ha de verse obviada por el círculo, debiéndosele permitir su participación. Desde nuestro punto de vista es importante este aspecto puesto que los círculos fomentan la participación ciudadana, y para ello es importante que abramos el círculo a esta como no sólo un método de resolución de conflictos, sino como un método de aprendizaje de toda la sociedad.

A parte de todo esto, la ley deberá establecer unos plazos para la realización de las diferentes sesiones. Existe una gran dificultad en este punto debido a que jugamos con los sentimientos, emociones y la integridad física y psicológica de las personas, y el establecimiento de un límite puede ser perjudicial para la víctima y el infractor. Pero también hemos de observar que la no imposición de un periodo de tiempo puede provocar que el círculo se dilate en el tiempo, creándose entonces otro perjuicio. Es por ello que el límite, en nuestra opinión, tiene que ser de 6 meses máximo para las fases preparatorias, dependiendo del conflicto y la situación, pudiendo ser prorrogadas por otros 3 meses.

Respecto a las sesiones, estas también tendrán un periodo de 12 meses como máximo con una prórroga de otros 12 meses en caso de que el facilitador y el fiscal lo consideren oportuno de cara a tratar nuevos aspectos, realizar sesiones individuales o esperar al cumplimiento de ciertas condiciones hasta el inicio de la nueva sesión. El 
número de sesiones dependerá de las necesidades de las partes. Será el facilitador quien considerará cuantas serán necesarias, la duración de las sesiones y la posibilidad de modificación de los términos pactados al inicio, pudiendo ampliar o reducir el número de participantes o incluso dar por finalizado el círculo si considerase la existencia de una imposibilidad de acuerdo entre las partes.

No creemos que sea necesario regular el desarrollo de las sesiones. La Justicia Restaurativa trata con personas afectadas por el delito, siendo cada persona un caso diferente y necesitando unas actuaciones dispares. Tal y como señala STUART, “un proceso para la resolución de conflictos debe adaptarse a las circunstancias especiales” ${ }^{931}$. Se necesita dar al facilitador la libertad para llevar el proceso de la manera más eficiente y más conveniente para las partes. Además, está dentro de la propia Justicia Restaurativa la espontaneidad y capacidades del facilitador para la ayuda a la solución del conflicto, para la conducción del proceso a tenor de las características y situaciones que se estén desarrollando en el círculo.

Por último se ha de mantener el principio de confidencialidad. Así todo lo expuesto en un círculo quedará en el círculo, existiendo privacidad con la sociedad y con el posible juicio oral que exista después en caso de que no se haya llegado a un acuerdo en el círculo.

Es importante esta figura a consecuencia de permitir, como en cualquier otro delito, hacer coexistir tres círculos a la vez: puede formarse un círculo CoSA en favor del infractor, que le ayude a superar su vida delictiva y resocializarse; un círculo de sanación en favor de la víctima, formado por diferentes miembros de la comunidad y que le ayude a superar los daños y efectos provocados por el delito; y un Círculo de sentencia, el cual es el principal y que busca resolver el conflicto. En principio, la no terminación exitosa de este último no nos llevaría a una finalización de los demás

\footnotetext{
${ }^{931}$ STUART, B., "Circle sentencing in Yukon Territory, Canada: A partnership of the community and the criminal justice system”, en International journal of comparative and applied criminal justice 1996, ${ }^{\circ}$ 20, pp. 291-309.
} 
círculos pues, una falta de acuerdo en uno de ellos no nos ha de impedir resocializar al infractor o sanar a la víctima. Es más, puede incluso que nos encontremos con que una de ambas partes quiera que, tras la finalización exitosa del círculo CoSA o de sanación, se retome el círculo de sentencia para la búsqueda de un acuerdo más eficaz.

\subsection{Círculos de víctimas o de sanación: la víctima y la superación de sus} miedos.

Los círculos de víctimas o de sanación son una de las instituciones más notables que se pueden encontrar en la Justicia Restaurativa. Aun así las diferencias terminológicas conllevan una amplia confusión conforme a esta figura, pudiendo ser denominada como panel restaurativo. La confusión existente deriva, entre otros aspectos, del origen de la institución como una práctica centrada en la sanación de la comunidad en general.

\subsubsection{El círculo de sanación, análisis y fundamento.}

Su origen radica en el programa de Hollow Water (Hollow Water Healing Program), en Manitoba, Canadá. A través de los líderes tribales ${ }^{932}$ se iniciaron un conjunto de círculos enfocados en resolver los problemas que acaecían en la comunidad. Se trataba de dar una respuesta al incesto y a los delitos sexuales que sufrían los miembros de la comunidad aborigen Ojibwa, enfrentando así "las disposiciones sociales que permiten el florecimiento de la violencia"933. El origen de esta violencia se atribuía al alcoholismo que estaba damnificando a las comunidades aborígenes.

Ello condujo a un renacimiento de su cultura introduciendo los círculos restaurativos como un método para abordar los problemas y percatarse que toda la comunidad era víctima de una serie de problemas que se iban reiterándose de

\footnotetext{
932 McCOLD, P., “The recent history of restorative justice. Mediation, circles and conferencing” en Delito y Sociedad 2013, $2^{\circ}$ semestre, pp. 9-44, esp. p. 18.

933 TARASCHI, S., "Peacemaking criminology and aboriginal justice initiatives as a revitalization of justice", Contemporary Justice Review 1998, n ${ }^{1}$, pp. 103-121, esp. p. 117.
} 
generación en generación. BUSHIE ${ }^{934}$ analiza el desarrollo de los primeros Círculos de sanación recogiendo y relatando las primeras vivencias y cómo los aborígenes Ojibwa fueron examinando cómo los abusos sexuales fueron parte de su vida puesto que fueron víctimas en su infancia y abusadores en su edad adulta, utilizando estos círculos como un método de sanación entre todos los miembros de la comunidad. El enfoque no era resolver penalmente el conflicto sino sanar emocionalmente a todas las víctimas, tanto presentes como futuras.

Su uso ha seguido potenciándose en Hollow Water como un método de auxilio entre los miembros de la comunidad, sanándose a través del análisis que las consecuencias del delito les afectaron, tanto a nivel individual como colectivo. Todo ello ha propiciado una respuesta restaurativa altamente positiva en los delitos de carácter sexual a tenor de lo establecido en los datos del Servicio de Consejería de Alberta $^{935}$.

De dichos círculos de víctimas de Hollow Water se han ido derivando unos caracteres que han desembocado en los actualmente conocidos Círculos de sanación. A diferencia de los círculos de sentencia, esta institución se centra en proporcionar un apoyo emocional y psicológico a la víctima, la cual está sufriendo un dolor por un hecho traumático que le fue ocasionada por el delincuente, sin interesarse en la resolución del conflicto.

Su fin principal es por tanto apoyar a la víctima, mostrarla que no está sola y las diferentes vías que tiene para superar su dolor y volver a su vida cotidiana. Se le muestra que la comunidad está junto a ella y las altas posibilidades existentes superación del hecho traumático y reanudación de su vida tal y como la desarrollaba antes del delito. Más que ante una práctica jurídica propiamente dicha, se valora como

\footnotetext{
${ }^{934}$ Para un mayor análisis de la situación véase BUSHIE, J., "CHCH reflections", en Ministry of the Solicitor General of Canada (ed.), The Four Circles of Hollow Water, Aboriginal Peoples' Collection, Public Works and Government Services, Ottawa, 1997, pp 95-143.

${ }^{935}$ McCOLD, P., “The recent history ...”, op. cit., p. 18.
} 
una institución con un alto grado psicológico por sus valores emocionales. En la práctica su utilización puede ser realizada de dos maneras.

En primer lugar puede practicarse un Círculo de sanación una vez cometido el delito e iniciado el proceso ante los Tribunales en cualquier fase del procedimiento, ya sea en fase de instrucción, fase intermedia, juicio oral o post sentencia. Su desarrollo será complementario al proceso penal judicial siendo dependiente de éste en aras a las medidas a desarrollar en las sesiones de sanación y a los intervinientes a participar.

En segundo lugar puede desarrollarse un Círculo de sanación como vía complementaria y paralela al desarrollo de otra práctica restaurativa. Una vez que el asunto es derivado a una institución reparadora, normalmente un Círculo de sentencia, se iniciaría un Círculo de sanación que obvia los aspectos materiales de la reparación y centra su foco de interés en una reparación emocional de la víctima con la implicación de parte de los intervinientes del Círculo de sentencia. Al mismo tiempo que se debate en una práctica restaurativa la responsabilidad del infractor y cómo ha de restaurar a la víctima, se inicia otro círculo centrado únicamente en su dolor emocional con un conjunto de participantes similares o incluso casi diferentes con el fin de ayudar a la víctima a superar los efectos nocivos que el hecho delictivo ha supuesto en su vida.

A través de estos círculos, la víctima puede desahogarse sentimentalmente y compartir todas las experiencias que está viviendo: “contar su vivencia, exponer su dolor y sentirse escuchada”936. Es una manera a través la cual la comunidad pueda observar el sufrimiento que crea un delito y pueda adaptar su conducta para solventar estos daños que está sufriendo la víctima. En estos círculos participan una o varias víctimas, sus familiares y personas de apoyo, voluntarios, otras víctimas que ya superaron el dolor causado por el hecho delictivo, profesionales e incluso el infractor en alguna sesión si se considerase óptimo y necesario.

\footnotetext{
${ }^{936}$ CHOYA FORÉS, F., Prácticas Restaurativas: Círculos y Conferencias, 2015, p. 23. Disponible en: http://www.pensamientopenal.com (última visita 08/09/2017)
} 
Respecto a los miembros participantes del círculo de sanación, en vez de, tal y como existe en la actualidad, un círculo que aglutina a todos los participantes, deberían existir dos círculos, uno interno y otro externo, tal y como sucede en los Cículos CoSA que se analizarán. El interno debe de estar compuesto por voluntarios de la sociedad, los cuales, como indica TITI ZHONG "pueden acompañar a la víctima durante la fase de investigación y el enjuiciamiento. Ellos ayudan a la víctima frente a la situación estresante y a recuperarse de su experiencia traumática"937. El círculo externo deberá de estar compuesto de profesionales de diferentes ámbitos, como médicos, psicólogos y profesionales del derecho que ayuden tanto a la víctima como a los voluntarios. Y en medio de los dos círculos debe de existir un facilitador que sirva de nexo y coordine las diferentes sesiones.

Los voluntarios serán sujetos de la propia comunidad que deciden adiestrarse para un continuo auxilio a la víctima. Servirán de ayuda para el cumplimiento de algunos de los fines de las sesiones, como la superación de estigmatizaciones y miedos. A modo de ejemplo, si la víctima sufrió le hecho delictivo en un lugar abandonado u oscuro, los voluntarios le acompañarán en situaciones similares como muestra de la no existencia de peligro. Su labor es un apoyo y auxilio constante en la superación de los efectos perjudiciales que el hecho delictivo le ocasionó.

Respecto a profesionales, se mencionan a trabajadores sociales, miembros del sistema de justicia penal, abogados, médicos o psicólogos, los cuales pueden realizar una aportación muy interesante. El psicólogo es una pieza básica ya que podrá guiar a los demás participantes para que su conducta se adecue a las necesidades de la víctima ahondando en sus sentimientos y emociones para intentar que supere esta experiencia traumática. Así mismo, la participación de profesionales del derecho supone un conocimiento experto sobre dicha rama que podrán volcar en las sesiones para asesorar a la víctima, así como para introducir la figura dentro del sistema penal como un

${ }^{937}$ TITI ZHONG, M., Using circles of support and accountability ..., op. cit., p. 60. 
complemento de éste gracia a la colaboración de los miembros del sistema de justicia penal.

Por su parte, la intervención de miembros de organizaciones y trabajos sociales ya que su continuo trabajo en la materia puede ser básico en el trato a la víctima. Un ejemplo de esto es la participación de organizaciones de apoyo a víctimas de violencia de género cuando la víctima haya sufrido un delito de estas características. Su aportación al círculo será crucial. Tendrá experiencia para ayudar a la víctima a superar el dolor provocado por el delito, y esa misma experiencia servirá como un método de aprendizaje a los demás miembros del círculo, los cuales aprenderán cómo actuar para no sólo ese círculo, sino para círculos posteriores. Por tanto, la participación de este tipo de organizaciones supondrá un aprendizaje continuo, e incluso ellas mismas aprenderán del resto de participantes aspectos que les serán válidos para el futuro tratamiento de víctimas.

Cuando se refiere a "otras víctimas que ya superaron el dolor” se está aludiendo a aquellas personas que ya sufrieron un hecho delictivo igual o similar pero que, ya sea a través de procesos restaurativos o no, se sobrepusieron a los efectos nocivos provocados por el delito. Estos miembros del círculo vienen a aportar su experiencia en favor de la víctima. Pondrán en común los hechos acaecidos sobre ellas, cómo sufrieron el delito, que consecuencias les produjo, como lo superaron y cómo es su vida en la actualidad. Todo ello le mostrará a la víctima que sí existe salida a su situación, serán sus referentes ${ }^{938}$.

Desde nuestro punto de vista esta figura puede ser importada a nuestro ordenamiento como un método complementario a nuestro proceso penal clásico. Es un círculo que busca apoyar a una víctima dolorida, ¿por qué no puede usarse siempre y en cualquier proceso? Nuestro sistema actual se olvida de la víctima y la trata como un mero testigo, obviando que realmente es una persona que ha sufrido un delito y está

${ }^{938}$ CHOYA FORÉS, F., Prácticas Restaurativas: ..., op. cit., p. 23. 
pareciendo las consecuencias de ello. Así que, sería perfecto su implementación como un complemento, como un método asistencial en favor de la víctima que le ayude a afrontar con mayores garantías psíquico-emocionales en proceso penal. Mientras se está realizando un juicio oral o cualquier práctica restaurativa la víctima podría estar acudiendo a este tipo de círculos para reparar el dolor sufrido.

A modo de ejemplo, y para ilustrar las diversas actuaciones prácticas que este instrumento nos ofrece, así como sus beneficios, vamos a recoger la experiencia llevada a cabo en Schleswig-Holstein ${ }^{939}$ e inspirado en el modelo efectuado en Bélgica y denominado Uit de schaduw van de dader (Más allá de la sombra del delincuente: asesoramiento grupal para víctimas del delito) ${ }^{940}$. A través de este programa se consiguió, reuniendo a un grupo de víctimas, la realización de diferentes actuaciones encaminadas a la superación de los efectos nocivos del delito. Los diferentes módulos sirvieron a las víctimas para conocer diferentes presos que ya participaban en programas de entrenamiento de la empatía con víctimas del delito, conocer sus reacciones, motivos y emociones. A través de ello se obtuvo la participación conjunta de las víctimas, las cuales se consiguieron unificar en un grupo; la interacción con otros sujetos, tales como infractores; diferentes reuniones donde el debate emocional era un pilar de la superación del dolor; y un trabajo conjunto para la obtención de una gran flexibilidad en las actuaciones que suponía una participación activa de todos los intervinientes, debiendo de ponerse de acuerdo para que ninguno de ellos quedare excluido de las actuaciones por problemas de transporte y/o horarios.

\footnotetext{
${ }^{939}$ HAGEMANN, O., “Restorative Justice at post-sentencing level - a delayed way to social peace?”, en J.L. De la Cuesta y I. J. Subijana (dirs.), Justicia Restaurativa y ..., op. cit., pp. 285-314, esp. pp. 296297.

${ }^{940}$ Más ampliamente, vid. MUYLKENS, L., y SMEETS, K., "Beyond the offender: Group counselling for victims of crime”, European Forum for Restorative Justice Newsletter 2008, n 2, pp. 3-4.
} 


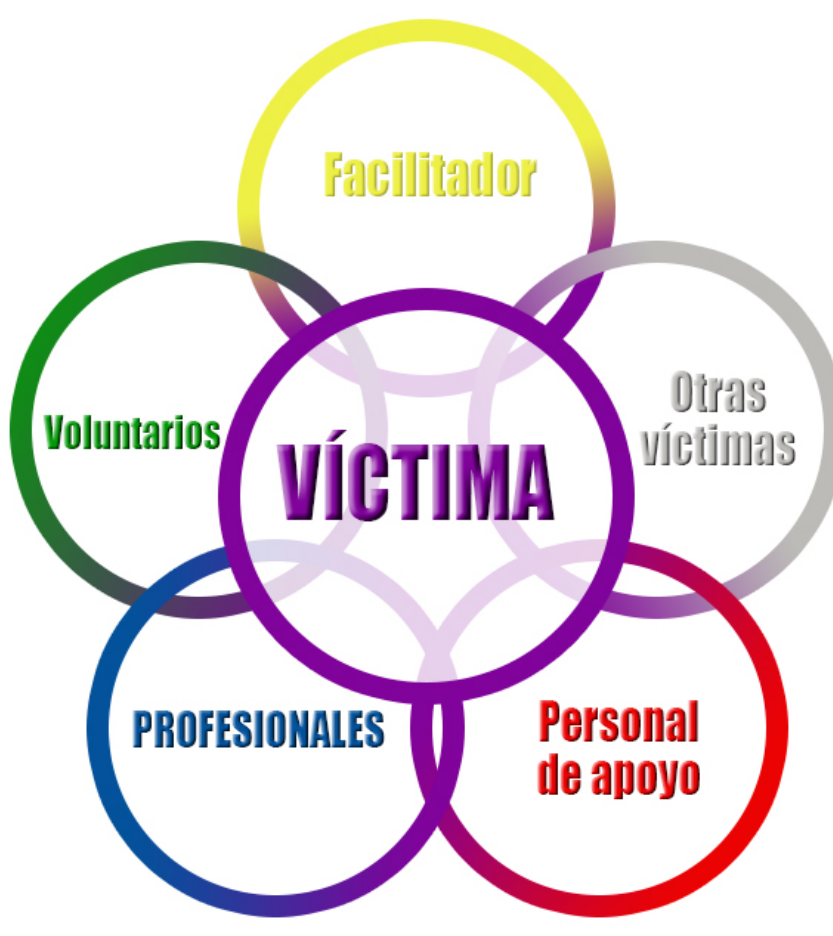

Figura 49. Los círculos de sanación. Fuente: Elaboración propia

3.3.2. Los Círculos de sanación y su proyección audiovisual. El ejemplo de "Jessica Jones"

Iniciando nuestro estudio acerca de la inclusión y adaptación de los círculos en diversas series de televisión, hemos de empezar por la serie de Netflix, Marvel’s Jessica Jones ${ }^{941}$, donde podremos observar la realización de un círculo de sanación, más concretamente, el círculo de víctimas de Killgrave, como un perfecto ejemplo del desarrollo de las actuaciones, su integración dentro de la sociedad norteamericana y su aceptación para la sanación físico-emocional de las víctimas.

${ }^{941}$ La serie está disponible a la fecha que se escriben estas líneas (14 de junio de 2018) en la Plataforma de pago de Netflix. 
La serie televisiva estadounidense Jessica Jones está basada en el la heroína de los comic Marvel Jessica Jones, ubicada en el mundo de ficción denominado "Universo cinematográfico de Marvel”, compuesto por numerosas series y películas ${ }^{942}$ y basadas en las historias de cómic creadas por, entre otros, Stan Lee ${ }^{943}$, obteniendo un gran reconocimiento por parte de muchísimos fans ${ }^{944}$. El éxito de este Universo de ficción no sólo podemos constatarlo con el numeroso conjunto de obras, sino con la intervención de Robert Downey Jr (Tony Stark/Iron Man), Chris Evans (SteveRogers/Capitán América), Scarlett Johansson (Natasha Romanoff/Black Widow), Chris Hemsworth (Thor), Tom Hiddleston (Loki), Benedict Cumberbatch (Doctor Strange), etc. De todo el éxito construido alrededor de esta franquicia, Marvel, en colaboración con Netflix, decidió dar un paso más con la creación de diversas series de televisión, como Daredevil, Jessica Jones o Luke Cage. Por nuestra parte se analizará las dos últimas series citadas al ser aquellas que tratan los círculos, y en este punto vamos a desarrollar la primera de ellas.

\footnotetext{
${ }^{942}$ Las películas que componen este Universo de Marvel son: Iron Man (estrenada en el año 2008), The Incredible Hulk (estrenada en el año 2008), Iron Man 2 (estrenada en el año 2010), Thor (estrenada en el año 2011), Captain America: The First Avenger (estrenada en el año 2011), The Avengers (estrenada en el año 2012), Iron Man 3 (estrenada en el año 2013), Thor: The Dark World (estrenada en el año 2013), Captain America: The Winter Soldier (estrenada en el año 2014), Guardians of the Galaxy (estrenada en el año 2014), Avengers: Age of Ultron (estrenada en el año 2015), Ant-Man (estrenada en el año 2015), Captain America: Civil War (estrenada en el año 2016), Doctor Strange (estrenada en el año 2016), Guardians of the Galaxy Vol. 2 (a estrenarse 2017), Spider-Man: Homecoming (a estrenarse 2017), Thor: Ragnarök (a estrenarse 2017), Avengers: Infinity War (a estrenarse 2018), Black Panther (a estrenarse 2018), Ant-Man and The Wasp (a estrenarse 2018), Captain Marvel (a estrenarse 2019), Avengers 4 (Infinity War 2) (a estrenarse 2019), Spider-Man untitled sequel (a estrenarse 2019).

En cuanto a las series que componen este famoso Universo: Agents of S.H.I.E.L.D. (2013-), Agent Carter (2015-2016), Daredevil (2015-), Jessica Jones (2015-), Luke Cage (2016-), Iron Fist (2017), The Punisher (2017), The Defenders (2017), Inhumans (2017), Damage Control (piloto), Cloak and Dagger (2018), New Warriors (-), Runaways (-).

${ }^{943}$ Stan Lee es uno de los dibujantes de comics más importantes de la historia, creador de diversos súper héroes como Sipder-Man, Hulk, Iron Man, X-Men, Daredevil o Doctor Strange. A parte, es Productor ejecutivo de todas las películas Marvel, en las cuales suele aparecer brevemente realizando un pequeño "cameo". Ha ganado diversos premio tales The Will Eisner Award Hall of Fame (1994), Saturn Award (2002) o Hollywood Walk of Fame (2011). Para más información véase http://www.imdb.com (Última visita: 04/01/2017)

${ }^{944}$ Tal es el reconocimiento que ha obtenido que diversas ciudades norteamericanas como Long Beach o Los Ángeles, han declarado el 28 de octubre como el día de Stan Lee. Información disponible en los siguientes enlaces: http://losangeles.cbslocal.com, http://comicbook.com, http://themarvelreport.com (Última visita: 04/01/2017)
} 
Esta serie relata la historia de la heroína Jessica Jones ${ }^{945}$ (interpretada por Krysten Ritter), contándonos brevemente sus orígenes para centrarse en su vida como investigadora privada tras ser traumatizada por el delincuente Killgrave ${ }^{946}$ con sus poderes de manipulación mental. Hechos traumáticos que no sólo le afectan a ella, sino que afectan a otro grupo de personas, como Malcolm Ducasse ${ }^{947}$, creador del Círculo de víctimas de Killgrave para poder sanar las heridas psicológicas provocadas por el delincuente.

Esta serie fue una de las primeras que nos mostró en una serie de televisión una figura restaurativa, y más concretamente un círculo. Pero no se queda ahí, sino que va desarrollando en multitud de capítulos la estructura del círculo, su utilidad y los sentimientos que van floreciendo por parte de los intervinientes.

Puede observarse como aquellas personas que sufrieron los efectos nocivos del delito consideran óptimo una reunión común para tratar su dolor al margen del sistema judicial, estando por consiguiente ante una práctica restaurativa alternativa al proceso penal con el fin de empoderar a las víctimas y con un marcado carácter psicológico. Todos ellos se congregan en diferentes lugares, tales como cafeterías o las oficinas de una de las víctimas, y posicionándose normalmente en forma de círculo, inician el diálogo restaurativo. Las conversaciones entre los participantes siguen todas una misma línea: el apoyo común.

En la primera aparición del Círculo de víctimas de Killgrave los participantes van comentando su primer encuentro con el delincuente, qué delito sufrieron y cómo les afectó en su vida cotidiana. Así también tratan la necesidad de auxilio por parte del sistema penal, el cual les abandona al enfocarse únicamente en la figura del infractor.

\footnotetext{
${ }^{945}$ Interpretada por la actriz estadounidense Krysten Ritter. Para más información respecto a su carrera artística, vid. www.imdb.com (Última visita: 04/01/2017)

${ }^{946}$ Interpretado por el actor escocés David Tennant, ganador de multitud de premios gracias, a, entre otras, su actuación como Doctor Who. Para más información respecto a su carrera artística, vid. www.imdb.com (Última visita: 04/01/2017)

${ }^{947}$ Interpretado por el actor australiano Eka Darville. Para más información respecto a su carrera artística, vid. http://www.imdb.com (Última visita: 04/01/2017)
} 
Este aspecto está muy candente en nuestro ordenamiento con la reciente promulgación del Estatuto de la víctima del delito para satisfacer las necesidades de todo sujeto que sufra un delito y sus consecuencias nocivas.

Las siguientes sesiones desarrolladas en capítulos posteriores versan sobre la afectación psicológica del delito en la vida de las víctimas. Cada una de ellas va compartiendo sus emociones y sufrimientos, las necesidades que el sistema penal no les ha satisfecho pero que el Círculo de sanación ha conseguido subsanar. Se va demostrando la importancia de estas figuras en la superación de los efectos nocivos del delito como una opción viable para empoderar a la víctima y prepararla para afrontar de manera óptima el desarrollo del proceso penal.

Como punto final a este primer análisis, hemos podido comprobar la cada vez mayor importancia que tienen las figuras restaurativas en nuestra sociedad, y en concreto, el círculo de sanación. Sí que es cierto que no es un círculo tradicional, pero comparte gran cantidad de similitudes con lo estudiado anteriormente. Esta exitosa ${ }^{948}$

\footnotetext{
${ }^{948}$ La crítica y el espectador han acompañado a esta serie, pudiéndose observar algunas opiniones muy favorables. A modo de ejemplo:

La web sensacine recoge las opiniones de los aficionados, pudiéndose ver que tiene una nota de 4,1 sobre 5 y críticas muy positivas de los telespectadores. Vid. http://www.sensacine.com (Última visita: 04/01/2017)

La web Gizmodo, en el texto escrito por Eduardo Marín, titula el análisis como: “Jessica Jones: esto es lo mejor que ha hecho Marvel para la televisión”. Vid. http://es.gizmodo.com/jessica-jones-esto-es-lomejor-que-ha-hecho-marvel-par-1744060723

La web Filmaffinity puntúa la serie con una nota de7 sobre 10, recogiendo críticas de expertos de diversos medios de comunicación como las siguientes:

- "Fascinante y única (...) 'Jessica Jones' parece ser otro éxito de Netflix para Marvel”. Daniel Fienberg: The Hollywood Reporter

- $\quad$ "La serie, que cuenta con una excepcional interpretación de Krysten Ritter y la mano firme de la productora ejecutiva Melissa Rosenberg (...) es uno de los nuevos dramas más destacables del año." Maureen Ryan: Variety

- " "Sin lugar a dudas, 'Jessica Jones' es lo mejor que ha producido Marvel Television.” Merrill Barr: Forbes

- "Es una fantasía oscura que refleja un mundo demasiado real (...) Krysten Ritter está muy bien como Jessica (...) La fotografía captura la belleza gótica del Nueva York real." Melissa Maerz: Entertainment Weekly.

- "'Jessica Jones' de Marvel es un thriller eficaz." David Wiegand: San Francisco Chronicle

- "La nueva serie de Netflix 'Jessica Jones' (...) es una maravilla." Mary McNamara: Los Angeles Times
}

Vid. http://www.filmaffinity.com (Última visita: 04/01/2017) 
serie ha sido un primer paso de promoción de la Justicia Restaurativa como un instrumento en favor de las víctimas, una promoción eficaz que esperemos no sea la última y que vaya consiguiendo una mayor concienciación en la sociedad de la utilidad de estas figuras. Por ello resulta recomendable el seguimiento de la serie, no sólo como un entretenimiento y una oportunidad de disfrutar con las interpretaciones de Krysten Ritter o David Tennant, sino como un medio de aprendizaje sobre los círculos de sanación de las víctimas y sus posibles futuras utilidades, al tratarse aspectos relativos al miedo, la vergüenza de haber sufrido un delito, el dolor, la puesta en común de las emociones, y la superación conjunta de todos los efectos nocivos del delito.

\subsection{Circles of Support and Accountability}

Los círculos de apoyo o Circles of Support and Accountability son la figura más utilizada e implementada a escala mundial. Buscan la reintegración del delincuente (denominado como miembro central una vez iniciada la práctica) en la sociedad a través de un periodo de comprensión y aceptación por parte de la comunidad, la cual le perdonará la infracción que cometió y le ayudará a la reinserción a través de un apoyo diario en multitud de sus actuaciones. La idea es clara, “las personas con problemas tienden a hacerlo mejor cuando tienen a otros para ayudarles a hacer frente a esos problemas [...] disfrutamos de la vida con la ayuda y compañía de otros”949.

\subsubsection{El análisis de la institución}

Como previamente se ha podido constatar, esta figura fue uno de los precedentes de los círculos en Canadá a través del “caso Los ángeles de Charly” o el “caso Moses” y es la figura que se está importando a Europa, siendo el ejemplo más práctico los Circles $U K$, los cuales se centran en los delincuentes de carácter sexual. Sencillamente, los círculos CoSA cambian a las personas al ofrecerles un nuevo modo de vivir ya que "al

\footnotetext{
${ }^{949}$ WILSON, R., y MCWHINNIE, A., "Circles of Support \& Accountability: An innovative approach to community-based risk management for high-risk sexual offenders" en M. Herzog-Evans (ed.), Transnational criminology manual, Wolf Legal Publishing, Oisterwijk, Netherlands, 2010, pp. 241-260, esp. p.245.
} 
vivir con seguridad en la comunidad y mantener fuertes lazos con sus nuevas familias CoSA, estos dos hombres y los que vinieron después de ellos nos han enseñado a todos algo de la verdadera naturaleza de la comunidad" ${ }^{950}$.

Pero no hemos de olvidarnos que esta práctica, enfocada en aportar una resocialización del infractor y una disminución de la reincidencia, puede realizarse en cualquier tipo de delitos, siendo tan eficaz en un delito sexual como en cualquier otro. Su uso en este tipo de actuaciones delictivas exclusivamente se debe a la gravedad de estos hechos y a la búsqueda de una mayor seguridad para las víctimas que lo sufren, las cuales quedan marcadas de la forma más cruel posible. Junto a todo ello hemos de indicar que los delitos sexuales tienen un alto impacto en la sociedad, siendo los delincuentes sexuales los que "provocan el mayor grado de preocupación profesional y protesta de la comunidad”.

Los Círculos de apoyo no han de confundirse con los denominados Grupos de trabajo con delincuentes o Entrenamientos para la empatía con la víctima (Victim Awareness (Empathy) Training) ${ }^{952}$, desarrollados en Alemania, Inglaterra y Portugal, ya que en este último supuesto no se trata ante una figura restaurativa, sino de instrumentos para facilitar el desarrollo de las diversas figuras o prácticas existentes. Estos Grupos de entrenamientos constituyen en un grupo de trabajo dentro del ámbito penitenciario con presos, enfocado en la consecución de una mayor empatía con los demás, especialmente dirigido a aquellos que sufrieron las consecuencias del delito.

Estas nuevas habilidades permiten a los delincuentes una mayor facilidad a la hora de acometer los encuentros restaurativos con sus víctimas, poner en práctica las reparaciones acordadas o incluso afrontar eficazmente el rechazo de la víctima a encontrarse con él, pudiendo proceder a las sesiones de los programas de Círculos

\footnotetext{
${ }^{950}$ WILSON, R., MCWHINNIE, A., y WILSON, C., “Circles of Support and Accountability ...”, op. cit. pp. 26-36, esp. p. 36. Disponible en: http://www.robinjwilson.com (Última visita: 05/11/2017)

${ }_{951}$ WILSON, R., et. al. "Circles of Support and Accountability: Enganging ...", op. cit., p. 6.

${ }^{952}$ HAGEMANN, O., “Restorative Justice at ...”, op. cit., p. 297.
} 
CoSA sin la participación de la víctima pero con el consentimiento del ofensor y su voluntad de resocialización. Se trata de una institución que cumple uno de los fines de la Justicia Restaurativa: la resocialización de los infractores. Como se ha de recordar, la Justicia Restaurativa es una filosofía enfocada en la resolución pacífica de los conflictos, la sanación de las víctimas y la resocialización de los victimarios, y todo ello con la intervención activa de los miembros de la comunidad. A través de los Círculos CoSA se consigue el abandono de la vida delictiva de los delincuentes a través de un proceso enfocado única y exclusivamente en el cumplimiento de este fin.

El objetivo de los programas CoSA es la "reducción sustancial del riesgo de una futura victimización sexual de los miembros de la comunidad a través de asistencia y apoyo a los individuos liberados en su tarea de integración en la comunidad y llevar vidas serias, productivas y responsables... [...]proporcionando apoyo, soporte, y una manera de ser responsables de manera significativa a cambio de vivir seguros en la comunidad"953.

Según el European HandBook ${ }^{954}$, existen unos requisitos básicos para una implantación exitosa de los Círculos CoSA:

1) La existencia de recursos financieros suficientes para desarrollar y mantener los diversos proyectos de Círculos.

2) Un estudio de la adaptación necesaria respecto del modelo original que muestre las diferentes líneas a seguir.

3) Una descripción comprensible del método.

4) Un plan de desarrollo (escenario, calendario de difusión, etc.).

5) Un plan de comunicación estratégica.

6) Una red de organizaciones profesionales en el campo de la gestión de riesgos.

7) Personal que esté dispuesto y tenga capacidad suficiente como para ejecutar los proyectos de Círculos.

\footnotetext{
${ }^{953}$ WILSON, R. y MCWHINNIE, A., “Circles of Support \& Accountability ...”, op. cit., p. 246.

${ }^{954}$ European Handbook. COSA, Circles of Support and Accountability, Circles4EU, 2015, p. 51.
} 
8) Una estructura organizativa del proyecto con una descripción de las diferentes tareas y responsabilidades, líneas de comunicación, etc.

9) Seguimiento y gestión de la calidad en cooperación con un Instituto u organización de Investigación.

10) La cooperación internacional con los proyectos de círculos surgidos en otros países europeos.

Estos círculos pueden ser aplicados en cualquier tipo delictivo al ser su objetivo es acabar con la reincidencia y resocializar al infractor. Y todo ello a través de la técnica de la responsabilización del delincuente, la cual ayuda a que sea consciente del daño que ha producido, se arrepienta de ello y vea que existen personas que lo apoyan, personas que van a actuar como si fueran su familia o un grupo de amigos cercanos ${ }^{955}$.

Esta figura busca la prevención del delito, examinado las condiciones y acontecimientos que pueden acaecer en la vida de un delincuente e intentando abordar los dos factores de mayor riesgo para que vuelva a caer en la delincuencia, el "aislamiento social y la soledad emocional"956. Es una figura de gran valía pues un infractor necesita para su resocialización una supervisión de la comunidad y atención profesional, pero son los más propensos a no recibir atención ni supervisión alguna por la estigmatización existente en torno a ellos ${ }^{957}$.

Puede observarse como los círculos de apoyo están siguiendo unas pautas generales en cuento a su desarrollo estableciendo un modelo variable pero adaptado a las necesidades del victimario. Antes de iniciar el círculo se necesitan realizar una serie de actuaciones preparatorias, las cuales pueden llegar a durar hasta 9 meses ${ }^{958}$ incluso. La fase preparativa es de vital importancia. El infractor ha de estar presto para afrontar el círculo y todas las opiniones de la comunidad vertidas en él o incluso en otros

\footnotetext{
${ }^{955}$ WILSON, R. y MCWHINNIE, A., “Circles of Support \& Accountability ...”, op. cit., p. 249.

${ }^{956}$ GARCÍA DÍEZ, C. y SOLER IGLESIAS, C., Evaluación de necesidades y diseño de ..., op. cit., pp. 21 y ss.

${ }_{957}$ WILSON, R., et al., “Circles of Support and Accountability: Enganging ...”, op. cit., p. 6.

${ }^{958}$ European Handbook..., op. cit., p. 51.
} 
ámbitos, en la cual se encontrará con personas que no le acepten y le vean como un “monstruo”. Las experiencias emanadas por el infractor, sus familiares, voluntarios de la propia comunidad deben servir de ayuda en su reintegración, así como las actuaciones encaminadas al mismo fin de profesionales de diferentes ámbitos como de la justicia, de la policía o de la psicología. A nuestro juicio cabría pensar en la participación de otros victimarios ya resocializados que puedan aportarle experiencias y formas de actuar en el futuro.

Siguiendo a GARCÍA DÍEZ y SOLER IGLESIAS ${ }^{959}$, los participantes de estos círculos son un delincuente de riesgo sexual medio-alto (denominado como miembro central) que tiene un amplio historial de delitos sexuales ${ }^{960}$ y de 3 a 6 voluntarios (miembros de la comunidad y no profesionales) ${ }^{961}$ dentro del llamado círculo interno, el cual sirve para asistirle emocionalmente, mantenerle responsable frente a la sociedad y guiarle en sus comportamientos. Estos voluntarios tienen a su vez el apoyo de un círculo externo compuesto por diversos profesionales (psicólogos, abogados, etc.) los cuales proporcionarán asesoramiento experto ${ }^{962}$ y apoyo técnico en el área controvertida. La comunicación entre ambos círculos se va a realizar a través de un Coordinador ${ }^{963}$, el cual tendrá funciones de intermediario y de garante del círculo.

\footnotetext{
959 GARCÍA DÍEZ, C. y SOLER IGLESIAS, C., Evaluación de necesidades y diseño de ..., op. cit., p. 22.

${ }^{960}$ WILSON, R., FRANCA CORTONI, F., y MCWHINNIE, A., "Sexual Abuse: A Journal of Research and Treatment. Circles of Support \& Accountability: A Canadian National Replication of Outcome Findings”, en SAGE Journals 2009, $\mathrm{n}^{\circ}$ 4, pp. 412-430, esp. p. 415 . Disponible en: http://journals.sagepub.comp.

${ }_{961}$ European Handbook..., op. cit., p. 53.

${ }^{962}$ WILSON, R. y MCWHINNIE, A., “Circles of Support \& Accountability ...”, op. cit., p.246.

963 El número de Coordinadores del círculo es discutible. Normalmente se indica, como pasa en Reino Unido, que tienen que existir al menos 2 coordinadores y un máximo de 10 si es muy complicado el asunto, pero en otros lugares, como Bélgica, sólo existe un coordinador, el cual recibe apoyo de otros miembros del grupo.
} 


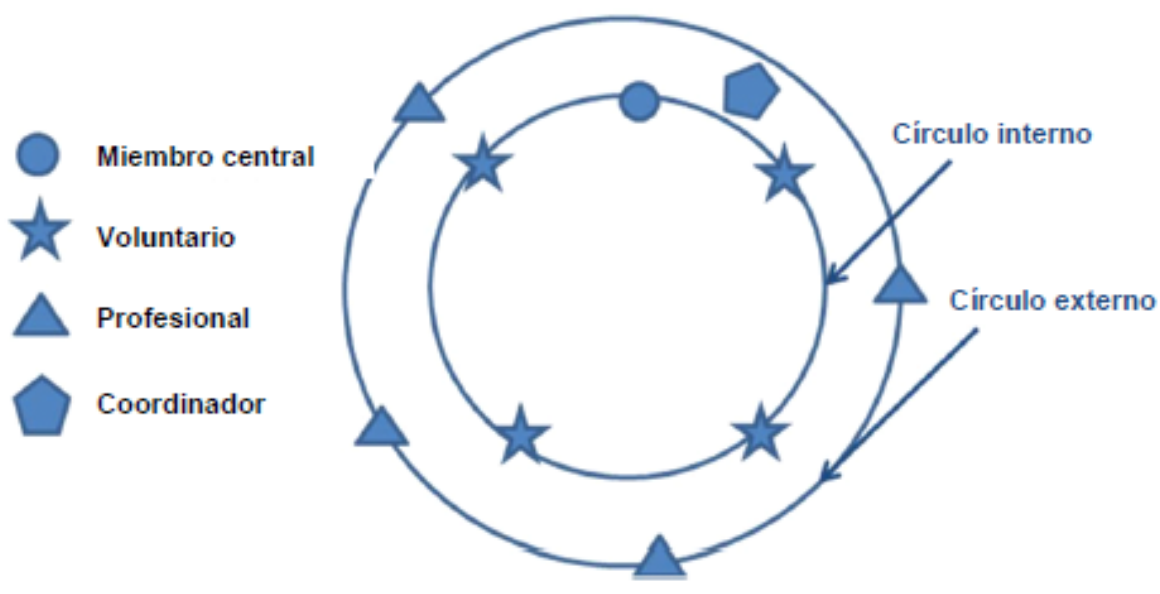

Figura 50. Estructura del círculo CoSA ${ }^{964}$

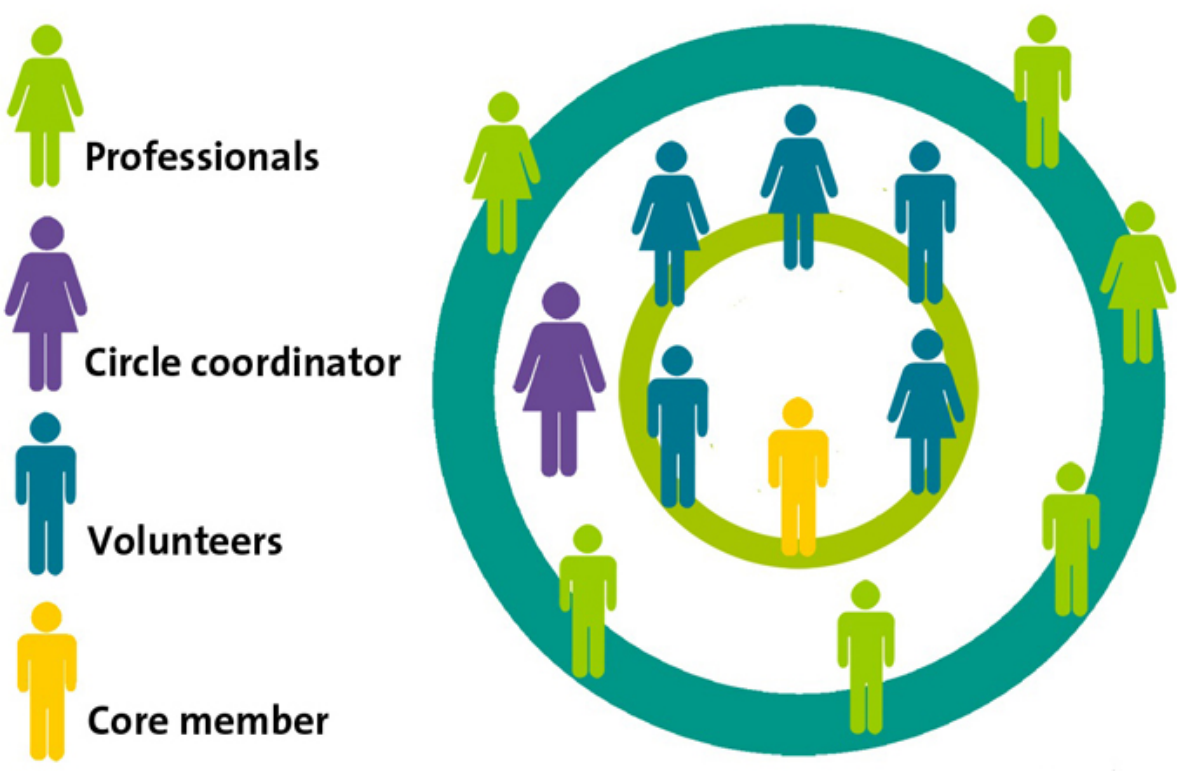

Figura 51. Estructura del círculo CoSA 965

Para que se inicie este procedimiento, el delincuente ha de reconocer el delito y aceptar una serie de condiciones como "que haya hecho un tratamiento antes de salir de

${ }^{964}$ GARCÍA DÍEZ, C. y SOLER IGLESIAS, C., Evaluación de necesidades y diseño de ..., op. cit., p. 22, adaptando la figura del European Handbook of CoSA

${ }_{965}$ Figura extraída del informe Ecumenical Ministries of Oregon. Disponible en: http://emoregon.org (Última visita: 07/11/2017) 
prisión, que este tratamiento tenga continuidad durante el proceso de supervisión comunitaria, que se haya aplicado un protocolo de evaluación de riesgo, y que haya un plan de prevención de recaídas compartido con el círculo"966. Los voluntarios intentarán que el delincuente cambie su red personal de contactos, buscando una relación con personas alejadas al ámbito delictivo. Y no sólo eso, sino que los propios voluntarios servirán de ejemplo de actuación al delincuente a través de sus actos y consejos, de los que aprenderá para actuaciones futuras; la experiencia continua reflejada en las actuaciones de los voluntarios será un conocimiento práctico para moldear su comportamiento.

Los voluntarios son una pieza fundamental en el engranaje del sistema de Círculos CoSA y por ello han de ser seleccionados y entrenados cuidadosamente con el objetivo que tengan la debida preparación y motivación para actuar. Por consiguiente, su aprendizaje es crucial, pero tampoco es necesario conseguir unos voluntarios expertos. La enseñanza ha de ir encaminada a que puedan familiarizarse con la situación y los problemas que va a tener que afrontar así como con las situaciones en las que necesitará acudir al círculo externo para obtener la ayuda de los expertos. Sus funciones no han de ser de psicoterapia o similares pues no son profesionales, sino que su labor es aconsejar un lugar pacífico para vivir al miembro central y apoyarle en las circunstancias diarias que puedan surgir con la convivencia, debiendo de dejar a los profesionales expertos en caso de apreciarse conductas extrañas o rasgos de enfermedad mental $^{967}$.

Se requiere que los voluntarios sean personas con empatía, con capacidad de escuchar, que sepan trabajar en equipo, con iniciativa, respetuosos, con conocimiento de leyes y con gran capacidad de comunicación con el delincuente sabiendo separar el hecho que hizo con la persona. Para ello se necesita personas que tengan diferentes motivaciones tales como haber sido víctima de este u otro tipo de delitos, ser una persona cercana al miembro central, querer la existencia de más seguridad o querer

${ }^{966}$ GARCÍA DÍEZ, C. y SOLER IGLESIAS, C., Evaluación de necesidades y diseño de ..., op. cit., p. 26 ${ }^{967}$ WILSON, R., y MCWHINNIE, A., “Circles of Support \& Accountability ...”, op. cit., pp. 247-248. 
resocializar al infractor. En los países anglosajones hablan de motivos religiosos como un motivo fundamental pero tal y como ha sido puesto de manifiesto no es a nuestro juicio una condición esencial.

Con ayuda de los Círculos CoSA el delincuente modifica su conducta, su modo de ver la vida y la propia imagen que tiene él sobre sí mismo. Y con ello se reinsertará en la sociedad participando en los asuntos de la propia comunidad, la cual le aceptará y le concederá una nueva oportunidad. Su motivación irá in crescendo, obteniendo capacidades para autorregularse y hábitos de actuación que irán disminuyendo las conductas de riesgo de reincidencia, y así hasta que se llegue a un desistimiento y arrepentimiento total con la consiguiente resocialización y reinserción en la comunidad.

Por consiguiente, las nuevas emociones surgidas en él, su nueva red de contactos y sus nuevas capacidades le permitirán integrarse en la sociedad con cierto éxito. Con esta actuación se ven beneficiados todos los sujetos: los delincuentes o miembros centrales, los cuales se resocializan y llevan una vida significativamente más productiva - libre o renovada de delitos sexuales ${ }^{968}$; la víctima, la cual puede ver como aquél delincuente que la dañó y ya ha pagado por ello y no volverá a realizar un daño a otras personas; y la comunidad, la cual gracias al trabajo de los voluntarios y profesionales, va a obtener más seguridad para víctimas del pasado y potenciales víctimas ${ }^{969}$, con capacidad de diálogo y resolución de los conflictos surgidos entre sus miembros.

Como ya se ha hecho hincapié en apartados anteriores, el éxito de esta figura está siendo bastante elevado, provocando reducciones de la reincidencia entre 50\% y 60\% en delitos de carácter sexual. Analizando los datos de GARCÍA DÍEZ y SOLER IGLESIAS $^{970}$, podemos observar como en el año 2012, en Duwe (Minnesota), los datos

\footnotetext{
968 WILSON, R., MCWHINNIE, A. y WILSON, C., "Circles of Support and Accountability: An international partnership in reducing sexual offender recidivism”, Prison Service Journal 2008, $\mathrm{n}^{\circ} 138$, pp. 26-36, esp. p. 36.

${ }_{969}$ WILSON, R. y MCWHINNIE, A., “Circles of Support \& Accountability ...”, op. cit., p.246.

${ }^{970}$ GARCÍA DÍEZ, C., SOLER IGLESIAS, C., Evaluación de necesidades y diseño de ..., op. cit., p. 3435
} 
relativos a la reincidencia de los sujetos no son elevados. En el supuesto específico de delitos sexuales se sitúa entre el $0 \%$ y el 3,2\%, obteniéndose un beneficio de 0,82\$ por dólar invertido. Grandes datos que nos hacen pensar y creer en el éxito de esta figura. En la misma línea, ELLIOT y BEECH muestran unas estadísticas favorables en Reino Unido: la reincidencia esperada se sitúa entre el $8 \%$ y el 16\%, obteniéndose un beneficio de 0,179 libras por libra invertida. En Ontario, la reincidencia sexual es del $5 \%$ al $16,7 \%$ y la reincidencia por delito violento es mayor, entre el 15\% y el 35\%. En la totalidad de Canadá la reincidencia sexual es del 2,27\% al 13,67\% y la reincidencia por delito violento es entre el 9,09\% y el 34,09\%.

La reincidencia disminuye sus valores elevados cuando se emplean las figuras de los Círculos CoSA. El apoyo social y la obtención de una vivienda y una vida estable reducen la reiteración de conductas negativas de varios tipos de infractores, incluyendo aquí a los delincuentes sexuales. Los Círculos CoSA ofrecen un apoyo al infractor, promoviendo que no se encuentre en una situación de aislamiento o soledad y proporcionándole influencias positivas ${ }^{971}$.

Los círculos CoSA no son un proceso con un periodo de tiempo limitado, sino que emplearán el lapso temporal todo lo necesario para conseguir la resocialización del infractor, y como indican WILSON, MCWHINNIE y WILSON “aunque se esperaba originalmente que un CoSA tendría una duración de alrededor de dos años, con lo cual el miembro de núcleo sería lo suficientemente funcional para seguir adelante con su propia vida, hemos aprendido que la mayoría de los miembros del núcleo son personas tan dañadas y socialmente marginadas que el círculo se convierte en un sustituto virtual de la familia y amigos que perdieron como consecuencia de su comportamiento como infractor" ${ }^{972}$.

\footnotetext{
${ }^{971}$ WILSON, R., FRANCA CORTONI, F., y MCWHINNIE, A., Sexual Abuse: A Journal of ..., op. cit. p. 426.

972 WILSON, R., MCWHINNIE, A., y WILSON, C., “Circles of Support and Accountability ...”, op. cit., p. 29.
} 
Los Círculos CoSA se han mostrado como una oportunidad de resocialización de los delincuentes. Su inclusión dentro de nuestro sistema judicial, y más concretamente penitenciario, puede ser una oportunidad ocasión idónea para el cumplimiento de los objetivos de resocialización plasmados en el artículo 25.2 de la carta magna al establecer programas educativos orientados en la reeducación.

La reincidencia es un hecho, y los números tan elevados existentes nos demuestran la poca eficacia de las penas tradicionales. Según los datos de la Fundación Atenea ${ }^{973}$, "2 de cada 3 personas presas regresa a la cárcel por nueva condena y un 13\% de la población penitenciaria había estado ingresada, antes de llegar a prisión, en un centro de reforma para menores”. Estos datos son muy elevados y necesitan ser combatidos, necesitan un nuevo modelo para acabar con la reincidencia.

Desde aquí se proponen unas pautas para su inclusión en nuestro ordenamiento jurídico:

- Figura de carácter voluntario y complementaria al sistema punitivo clásico o a cualquier otro método para la resolución de conflictos.

- Posibilidad de realización en cualquier momento, ya sea durante la investigación, durante el juicio oral o durante el desarrollo de otras prácticas restaurativas, aunque con más hincapié en el ámbito penitenciario al tener un mayor enfoque en su resocialización cuando abandone la prisión, pudiéndosele aplicar la denominada Libertad condicional ${ }^{974}$, calificara ahora como suspensión de la ejecución del resto de la pena de prisión por el art. 90 del CP en el supuesto de muestra de reinserción social efectiva tras el cumplimiento del plan de reparación, muestras reales de su posibilidad en la conjetura de abandono del ámbito penitenciario e incluso aceptación de participar en un Círculo CoSA para la consumación de su resocialización. Tal y como señala GONZÁLEZ CANO, y adaptándolo a la institución de los círculos, la libertad condicional anticipada,

\footnotetext{
973 Fundación Atenea, La cárcel se ceba con la exclusión social y las drogas, Disponible en: http://fundacionatenea.org/(Última visita: 06/11/2017)

${ }^{974}$ Para un mayor estudio relativo a esta institución véase SALAT PAISAL, M., "Libertad condicional”, en G. Quintero Olivares (dir.) Comentario a la reforma penal del 2015, Aranzadi, Cizur Menor, 2015, pp.189-201.
} 
“extinguida la mitad de la condena, por haber desarrollado continuamente actividades laborales, culturales u ocupacionales y se acredite, además, la participación efectiva y favorable en programas de reparación a las víctimas o programas de tratamiento"975, siendo aspectos positivamente valorados $\mathrm{y}$ efectuados dentro de la institución de los círculos CoSA, puede ser una respuesta del ordenamiento jurídico positivo hacia el infractor encaminado voluntariamente a su reinserción social.

- Conforme al ámbito material de los Círculos CoSA, se ha de permitir su desarrollo sea cual fuere la infracción que dio origen al internamiento del infractor.

- En cuanto al número de participantes, estos deben estar abiertos a toda la sociedad, pudiendo cualquier miembro participar en la ayuda del infractor. Eso sí, deberán existir unos miembros “permanentes”. En el círculo interno, entre 5 y 6 voluntarios, en el círculo externo diferentes profesionales de la psicología y el derecho que aporten una visión científica de los hechos, y un facilitador que sirva de nexo.

- Posibilidad de sesiones conjuntas con el fin de tratar problemas y reunir al delincuente con otros ex-delincuentes que ya han superado la vida delictiva y viven resocializados en la comunidad.

- Estos círculos no han de tener establecidos unos límites temporales. El infractor ha de estar siempre apoyado y han de durar el tiempo que sea necesario y se considere oportuno por parte de los intervinientes, tanto voluntarios como profesionales.

Esta nueva visión puede dar al exdelincuente la oportunidad de rehacer su vida, de olvidar el pasado delictivo y empezar un camino no sólo socialmente aceptado, sino moralmente pleno. Es importante que estas figuras nos ayuden a la resolución de los conflictos, a la sanación de las víctimas, y la resocialización de un infractor, siendo los círculos CoSA la oportunidad que tienen muchas personas de salir del fango y volver a

${ }^{975}$ GONZÁLEZ CANO, M.I., “La integración de la ...”, op. cit., p. 694. 
la vida que perdieron. Sólo a través de estas figuras el infractor puede aprovechar la segunda oportunidad que se le otorga al observar su error y aprender de él. Una “segunda oportunidad no significa nada si no aprendiste de tu error”.

\subsubsection{Los Círculos CoSA y su proyección audiovisual. El ejemplo de "Orange is the new Black"}

La siguiente figura a analizar es el Círculo penitenciario realizado es la exitosa serie norteamericana Orange is the new black. Estamos ante una serie de comediadrama, creada por Jenji Leslie Kohan, producida por Lionsgate Television y emitida por la plataforma Netflix ${ }^{976}$. Está basada en la obra autobiográfica de Piper Kerman Orange Is the New Black: Crónica de mi año en una prisión federal de mujeres, la cual relata cómo transcurrió parte de su vida en la cárcel.

La serie versa sobre Piper Chapman ${ }^{977}$, una joven con una vida estable, pero afectada por un delito que cometió en el pasado y que creyó haber dejado atrás. Un delito de contrabando de drogas que cometió junto a su pareja Alex Vause ${ }^{978}$, le lleva a

${ }^{976}$ La serie está disponible en la Plataforma de pago de Netflix. Disponible en: https://www.netflix.com (Última visita: 05/01/2017)

${ }^{977}$ Interpretada por la actriz estadounidense Taylor Schilling. Esta exitosa actriz ha cosechado numerosos premios gracias a la serie Orange is the new Black como:

- En el año 2013 recibió por parte de la Asociación Satellite Awards el premio Satellite Award a la mejor actriz - Serie de televisión musical o comedia y el premio Satellite Award al mejor elenco - Serie de televisión

- En el año 2013 recibió por parte de la Asociación Webby Awards el premio Webby Awards a la mejor actriz

- En el año 2015 recibió por parte de la Asociación del Sindicato de Actores el premio Mejor Interpretación de un Reparto en una Serie de Comedia.

- En el año 2016 recibió por parte de la Asociación Satellite Awards el premio Satellite Award a la mejor actriz - Serie de televisión musical o comedia

- En el año 2016 En el año 2015 recibió por parte de la Asociación del Sindicato de Actores el premio Mejor Interpretación de un Reparto en una Serie de Comedia.

Para más información relativa a su carrera artística, vid. http://www.imdb.com/name/nm2279940/?ref_=tt_cl_t1

${ }^{978}$ Interpretada por la actriz estadounidense Laura Prepon. Gracias a su interpretación en Orange is the new Black ha conseguido los siguientes premios:

- En el año 2013 recibió por parte de la Asociación Satellite Awards el premio Satellite Award al mejor elenco - Serie de Televisión. 
ingresar en la prisión de Litchfield, Nueva York. De aquí irán surgiendo diferentes tramas que han dado un gran éxito a la serie. La que nos interesa se encuentra desarrollada en el capítulo 9 y siguientes de la tercera temporada.

Desarrollando ya la figura restaurativa de Orange is the new Black, podemos examinar que, aunque es breve la aparición del círculo CoSA penitenciario, es muy intenso y educativo, pues se explican, en pocos minutos, bastantes desarrollos de estas técnicas, siendo uno de los mejores escenarios para la adquisición de unos conocimientos básicos de esta figura.

La primera aparición del círculo es en el capítulo $9^{979}$ y es a modo de idea, de propuesta por uno de los oficiales del ámbito penitenciario de Litchfield a una de las internas, como un método para sustituir el castigo punitivo de aislamiento por el mal comportamiento e infracción de las normas internas. Observamos la idea de creación del círculo, los primeros intereses en desarrollar esta figura como apoyo a las presas y sobretodo, como un método resocializador en su favor. Nos parece muy llamativo poder observar que es dentro del propio ámbito penitenciario donde nace la idea de formar el círculo. La prisión ha de ser el lugar resocializador de todo infractor, y los círculos son uno de los métodos para la obtención de la resocialización de estos individuos. Por ello, ¿Qué mejor que la realización de estas figuras dentro del ámbito penitenciario? Así se podría obtener aquel ideal resocializador que toda prisión tiene a través de métodos novedosos, emotivos y complementarios al proceso penal clásico.

- En el año 2013 recibió por parte de la Asociación Satellite Awards el premio Satellite Award a la mejor actriz de reparto - Serie, Miniserie o Cine y Televisión.

- En el año 2015 recibió por parte de la Asociación del Sindicato de Actores el premio a la Mejor Interpretación de un Reparto en una Serie de Comedia.

Para más información relativa a su carrera artística, vid. http://www.imdb.com/name/nm0696059/?ref_=tt_cl_t28

979 Episodio 9 de la segunda temporada: "40 Oz. of Furlough". Dirigido por S. J. Clarkson. Escrito por Lauren Morelli. Fecha de estreno: 6 de junio de 2014. 
Es en los capítulos $10^{980}$ y $11^{981}$ cuando ya puede visualizarse las prácticas restaurativas y su desarrollo dentro de la ficción. Se muestran diferentes circunstancias propias de las figuras reparativas, sus participantes e incluso la sociedad. Desde un inicio se comparte la idea de resocializar, pero a su vez las dudas relativas a la eficacia de la figura son la base de las primeras sesiones. Es usual que en la práctica ocurran estas situaciones, pues muchos ciudadanos todavía no creen en la Justicia Restaurativa, siendo escépticos en cuanto a su planteamiento y desarrollo. Es considerada como una utopía en donde el único beneficiado es el infractor, el cual se librará del castigo para poder quedar libre sin consecuencia alguna por su delito.

La serie prosigue con la intervención de los diferentes participantes los cuales van a compartir sus experiencias y emociones. El facilitador centra su interés en los sentimientos, tanto positivos como negativos, de las internas. La superación del trauma y por tanto de la vida delictiva se consigue a través de aceptar las emociones, exponerlas y enfrentarse a ellas. No se puede abandonar una conducta si se profundiza en los motivos de su realización, así como en las emociones previas y posteriores al delito. Ante la negativa de participar y exponer públicamente sus sentimientos, el facilitador del círculo expone una frase crucial y básica de este tipo de prácticas: "Hablar de nuestros problemas facilita el hecho de procesar nuestros sentimientos y nos ayuda a darnos cuenta de que no estamos solos”.

Prosiguen las actuaciones con una gran fidelidad a las prácticas restaurativas llevadas a cabo por facilitadores profesionales en el marco de la resolución de conflictos. Ejemplo de ello es el uso de un objeto de hablar o, como denominan en la serie, the talking stick. Sólo podrá participar quien tenga en su poder dicho objeto y conseguir así un diálogo fluido entre los intervinientes, dentro de un espacio seguro, pues así se ayuda a procesar nuestras emociones, a compartir nuestro dolor ante la

\footnotetext{
${ }^{980}$ Episodio 10 de la segunda temporada: "Little Mustachioed Shit". Dirigido por Jennifer Getzinger. Escrito por Sian Heder. Fecha de estreno: 6 de junio de 2014

${ }^{981}$ Episodio 11 de la segunda temporada: "Take a Break from Your Values". Dirigido por Constantine Makris. Escrito por Nick Jones. Fecha de estreno: 6 de junio de 2014
} 
comunidad. Y el poder compartirlo ante los demás es esencial para poder superar la situación. No se supera sólo por el hecho de compartirlo, de hacerlo público, sino por el hecho de obtener la respuesta de la sociedad.

Puede visualizarse un círculo casi desarrollado a la perfección gracias a la multitud de detalles propios de esta exitosa y novedosa práctica restaurativa. No hemos de olvidarnos del uso del talking stick, del término facilitador, la privacidad del círculo, el apoyo común, la solución derivada del trabajo común, la profundización en los sentimientos y emociones y el análisis de las causas y consecuencias de la actividad delictiva.

Se trata (como sucedía en Jessica Jones) una figura restaurativa, desconocida para el gran público, pero que gracias a la repercusión que ha tenido esta serie, multitud de espectadores han podido observar el desarrollo de esta práctica. Es por ello de la importancia que doy a las críticas y premios que reciben las series, pues cuanto mayor es su repercusión y espectadores, mayores personas han conocido la Justicia Restaurativa. Y aunque no sea un conocimiento clásico a través de libros, curso o sedes de prácticas restaurativas, los espectadores han podido percatarse del funcionamiento de estas figuras, las cuales han obtenido visibilidad ante el público general, los cuales quien sabe si podrán dar uso o apoyo en un futuro a alguna de estas prácticas observadas.

3.5 Los círculos en el ámbito escolar: la enseñanza restaurativa en las escuelas.

En este punto vamos a desarrollar el círculo como método resolutivo de conflictos nacidos dentro del ámbito escolar. Esta figura puede estar dirigida al niño con 
mal comportamiento, agresivo o el niño aislado, rechazado, víctima o con necesidades especiales $^{982}$.

\subsubsection{El desarrollo de los círculos escolares.}

Los conflictos nacidos en las aulas pueden afectar seriamente las relaciones de los menores, llegando a provocar problemas graves de conductas difíciles de solucionar si no se afrontan con seriedad. En esas edades se suele imponer el castigo para la solución de conflictos, medida que, más que acabar con el problema, le adhiere un parche temporal.

El castigo separa a los participantes del conflicto e impone una pena a uno de ellos o a varios. Además califica a los sujetos según su comportamiento como "bueno" o "malo”. Este planteamiento es incorrecto, y más cabe aún en el ámbito escolar, pues simplemente existen acciones erróneas que han de ser corregidas. Se han de poner en práctica medidas basadas en el diálogo, la comprensión y la educación que ahonden en las causas del comportamiento negativo y en los sentimientos de ambos, la víctima y el “infractor".

Los círculos pueden ser la fórmula para la resolución de los conflictos, ya que permiten una fluctuación de los sentimientos y emociones de los sujetos. Una fórmula de "abrir" a los alumnos, solucionar sus conflictos y enseñarles un método para conseguir estas soluciones en el presente y en el futuro. Y no sólo así se forman a los alumnos, sino que los profesores y demás miembros del centro aprenden (y deben de aprender) a la resolución de conflictos a través de los círculos.

En este tipo de círculos, el "énfasis se pone en el significado que se esconde detrás del comportamiento, conflicto o evento en cuestión, en quién se ha visto afectado, en los sentimientos y pensamientos de todos en ese momento y en la reunión,

${ }^{982}$ FERNÁNDEZ, I., Prevención de la violencia y resolución de conflictos. El clima escolar como factor de calidad, $2^{\mathrm{a}}$ edición, Narcea, Madrid, 1999, p. 153. 
en cómo se puede reparar el daño, cómo se puede satisfacer la necesidad de la persona, y corregir el asunto, y en qué se puede hacer para evitar que la misma situación ocurra de nuevo" 983.

Para la realización de un círculo educativo se necesitan unas sesiones preparatorias en las que, reuniéndose con los miembros afectados por el hecho, se valora cómo va a desarrollarse dicho círculo, quiénes van a intervenir en él (normalmente son los alumnos del centro afectados o incluso la clase entera, los profesores, director del centro y familiares de los alumnos) y la fecha y el lugar donde se van a efectuar las sesiones.

Las sesiones pueden empezar de múltiples maneras, ya sea con un rito religioso, una canción u obviándose este tipo de actuaciones e iniciándose con una presentación simple. Todos los asistentes se sentarán en círculo y será el facilitador el que decida cómo se debe actuar, pudiendo empezar con un turno de preguntas a los afectados, tales como un “¿Qué tal te sientes? ¿Qué hubieses hecho de estar en el lugar del otro? ¿Qué harías ahora de volver a la situación previa al conflicto?” o con preguntas específicas para las víctimas y los ofensores.

Tras ello, se elegirá un objeto como un bolígrafo o una pelota (talking piece o talking stick) que otorgará el derecho de hablar al que lo tenga, debiendo los demás de escucharlo y respetar el turno de palabra. Normalmente aquí los alumnos o profesores hablan del problema, de cómo les afecta o cómo está afectando a los demás y proponen diferentes soluciones. Estas actuaciones dentro del círculo no son interrogatorios sino que sirven para promover el diálogo y la responsabilidad. Una vez que todos los intervinientes hayan expuesto sus diferentes opiniones, la sesión se puede dar por concluida, indicándose unas medidas a tomar las cuales se valorarán en la siguiente sesión.

983 CHANKOVA, D. y POSHTOVA, T., Módulo E: Práctica preventiva y de integración Unidad. E4: Enfoques restaurativos en la escuela: hacia una "escuela restaurativa". Traducción de AM Consultores. p. 11. Disponible en: http://www.vista-europe.org (Última visita: 07/11/2017) 
La segunda sesión se inicia con los mismos participantes que en la primera, aunque puede que alguno de ellos esté ausente. Aquí se analizará en primer lugar la conducta que han tenido las partes, así como si ha cumplido o no con las medidas tomadas en la primera sesión. Se volverá a utilizar el talking peace dándose así voz a los intervinientes, los cuales valorarán positiva o negativamente las diferentes conductas. Dependiendo de las valoraciones y el cumplimiento o no de los acuerdos alcanzados en la primera sesión, se tomarán unas disposiciones u otras. Si las valoraciones son positivas, las decisiones serán continuistas del trabajo bien realizado; pero si las valoraciones son negativas, se tendrán que aplicar otras medidas más estrictas, buscándose que a través del diálogo en el círculo y sesiones individuales, el "infractor" pueda percatarse de su error y modificar su conducta.

¿Por qué los círculos restaurativos resultan una opción favorable en el ámbito escolar? La respuesta es sencilla:

- Favorecen el respeto.

- Fomentan el conocimiento y la educación.

- Otorga a todos la posibilidad de expresarse sobre el asunto.

- Permiten la exteriorización de sentimientos y emociones.

- Aportan confianza, seguridad y desarrollan la autoestima ${ }^{984}$ de los participantes.

- Permiten a los participantes en él ser parte de la solución del conflicto.

- Permiten reestructurar relaciones rotas por el conflicto y crea nuevos vínculos.

- Crean un precedente para la resolución de conflictos futuros.

- Son confidenciales, no haciéndose público lo expresado en el círculo.

- No obligan a nadie a participar en él, sino que la participación es voluntaria, tanto para iniciar el círculo como para intervenir en él una vez ya iniciado.

- Mejoran el clima escolar y la convivencia entre los alumnos y los profesores y los alumnos entre sí.

${ }^{984}$ CHANKOVA, D., POSHTOVA, T., Módulo E: Práctica preventiva ..., op. cit., p. 11. 
Los alumnos que actúen de voluntarios para apoyar a la víctima o conseguir que el infractor no vuelva a realizar abusos a otros compañeros también salen beneficiados ya que, como indica FERNÁNDEZ, aprenden a: "Ver más allá de la conducta superficial y observar las necesidades no expresadas; Desarrollar la habilidad de expresar sentimiento y reconocer ajenos (Empatía); Desarrollar habilidades de resolución de conflictos y discernir entre decir y dar consejo, y; Desarrollar la habilidad de escucharse unos a otros, comentar sobre lo dicho y valorar las aportaciones de cada miembro del círculo"985.

Estos procesos son muy valiosos pues permiten resolver conflictos surgidos en las aulas de una manera satisfactoria y educadora. Conflictos de todo tipo ${ }^{986}$ como mal comportamiento, peleas, insultos al profesorado o a otros alumnos pueden resolverse a través de los círculos, los cuales están abiertos a todos los miembros de la comunidad escolar con el fin de mejorar sus relaciones en dicho ámbito ${ }^{987}$. Si usamos los círculos los menores no sólo aprenderán lo erróneas que eran sus conductas sino abrirán sus ojos, sus oídos, su corazón, su mente ${ }^{988}$ y obtendrán un antecedente para la resolución de futuras controversias y para la pacificación de la sociedad escolar.

Pero esta figura tiene especial importancia de cara a la resolución de los abusos o bullying, tanto físicos como psicológicos a otros compañeros. Citando a FERNÁDEZ ${ }^{989}$, podríamos decir que se considera abuso y/o maltrato siempre y cuando el acto reúna una serie de condiciones:

- “La acción tiene que ser repetida”. Se exige que el acto no sea esporádico, sino que ocurra en varias ocasiones durante un periodo de tiempo.

\footnotetext{
${ }^{985}$ FERNÁNDEZ, I., Prevención de la violencia y ..., op. cit., p. 156.

${ }^{986}$ Para examen de diferentes ejemplos de círculos restaurativos así como su desarrollo y resolución: Justicia y Prácticas Restaurativas. Los Círculos Restaurativos y su aplicación en diversos ámbitos, Fundación Universitaria Iberoamericana, 2011, pp. 60 y ss. Disponible en: https://docs.google.com (Última visita: 07/11/2017)

${ }^{987}$ CHANKOVA, D. y POSHTOVA, T., Módulo E: Práctica preventiva ... op. cit., p. 11.

988 Intervención de Loren Walker en el Congreso Europeo de Justicia Restaurativa y Terapeútica, celebrado en San Sebastián los días 16, 17 y 18 de junio de 2016.

989 FERNÁNDEZ, I., Prevención de la violencia y..., op. cit., p. 48.
} 
- “Exista una relación de desequilibrio de poder”. Con ello se están refiriendo a que no haya una posición de igualdad entre la víctima y el agresor, teniendo este último una ventaja sobre la víctima, ya sea física o psicológica.

- “La agresión puede ser física, verbal o psicológica”. Podemos encontrarnos con acciones como golpes, insultos, apodos vejatorios, aislamiento, etc.

Los diferentes estudios realizados en Irlanda del Norte llegan a una misma conclusión, indicándonos la eficacia que tienen los círculos escolares frente al acoso o abuso en las escuelas. Mediante ellos se consigue no sólo la resolución del conflicto, sino cambiar el dolor y el daño por experiencias positivas, como en el siguiente relato: “.... nos sentimos como si no hubiera realmente un ofensor y una víctima. Había una dinámica de clase así que los sacamos de clase... y literalmente hicimos un círculo en el aula y alejamos las mesas y teníamos un círculo... los estudiantes empezaron a darse cuenta de que cualquier pequeña cosa que estaban haciendo le estaba afectando, por lo que no es bueno decir 'yo no fui el que lo golpeó'; Todos eran parte de ella ${ }^{990}$.

Estas prácticas están siendo desarrolladas en multitud de lugares como en Canadá, Estados Unidos, México, etc. No obstante merecen destacarse los círculos escolares de Porto Alegre, Hull y Son Gotleu, obteniendo estos dos últimos grandes resultados gracias a un trabajo conjunto de colaboración, seguimiento y recomendaciones ${ }^{991}$. Como consecuencia a estas figuras, los participantes adquieren "un sentido de desarrollo personal y una conciencia de cuidado y dedicación a otros"992.

Según un estudio publicado por la revista "The Lancet Psychiatry"993, el "acoso escolar puede ser más terrible que el abuso sexual [...] Los gobiernos han concentrado

\footnotetext{
990 PAYNE, B. y CONWAY, V., “A Framework for a Restorative Society? Restorative Justice in Northern Ireland”, en European Journal of Probation 2011, Vol. 3, n 2, pp. 47-73, esp. p.59.

991 POMAR FIOL, M.B. y VECINA MERCHANTE, C., "Prácticas restaurativas: construyendo la comunidad desde los centros de enseñanza”, en Educació i cultura: Revista mallorquina de pedagogía 2013, n² 24, pp. 213-224, esp. p. 220.

992 FERNÁNDEZ, I., Prevención de la violencia y ..., op. cit., p. 157.

993 Información extraída de: http://mediacionyviolencia.com.ar/bullying-dana-mas-que-el-maltratofamiliar-y-el-abuso/
} 
sus esfuerzos y sus recursos en el maltrato familiar más que en el bullying, pero en todo el mundo uno de cada tres chicos reporta haber sufrido el acoso de sus pares y es claro que los chicos acosados tienen peores enfermedades mentales en su vida que aquellos que fueron maltratados”, señaló Dieter Wolke, uno de los autores del estudio y profesor de la Universidad de Warwick [...] Para los chicos, es mucho más importante la opinión de los pares que la de los propios padres, sobre todo en la adolescencia [...] El acoso escolar deja una herida a la dignidad de la persona. No es un golpe cualquiera. Los pares me confirman como persona, entonces la víctima se siente tan agraviada que el dolor le produce una huella traumática que puede durarle toda su vida”.

\subsubsection{La teoría de las sociedades paralelas y los círculos restaurativos.}

La escuela es una imagen del desarrollo de nuestra sociedad donde los alumnos repiten las conductas que ven a los mayores o exteriorizan las consecuencias de esos actos. A todo ello hay que sumarle la escasa o nula capacidad que tienen los menores para entender dichas actuaciones así como las consecuencias de las mismas, pudiéndose crear auténticos conflictos con numerosos daños. Podríamos añadir también la existencia de una serie de factores de riesgo en el aumento de la agresividad de los menores en las escuelas, como por ejemplo los indicados por FERNÁNDEZ ${ }^{994}$ :

- "La desestructuración de la familia, cuyos roles tradicionales son cuestionados por la ausencia de uno de los progenitores o por falta de atención.

- Los malos tratos y el modelado violento dentro del seno de la familia, donde el niño aprende a resolver los conflictos a través del daño físico o la agresión verbal.

- Los modelados familiares mediante los que se aprende que el poder se ejerce siendo el más fuerte, con falta de negociación y diálogo.

- Los métodos de crianza, con prácticas excesivamente laxa o inconsistente, o a la inversa restrictiva y en algunos casos excesivamente punitiva.

${ }^{994}$ FERNÁNDEZ, I., Prevención de la violencia y ..., op. cit., p. 35. 
- La falta de afecto entre cónyuges con ausencia de seguridad y cariño, lo que provoca conflictividad familiar."

Todos estos factores van a desencadenar en un aumento de la agresividad del menor, el cual podrá repetir estas actuaciones agresivas y punitivas en la escuela, creándose un efecto espejo de la sociedad de adultos (S1) a la sociedad de la escuela (S2), creando así una adaptación propia y personalizada de las teorías de la astrofísica sobre los multiversos y/o universos paralelos ${ }^{995}$ pero a nivel de la sociedad.

La S2, la escuela, es paralela a la S1, teniendo ambos los mismos defectos y ventajas, actuando de "espejo" al reproducir todo aquello que observa en la S1; en suma todas las conductas que sus padres o personas adultas realizan le marcan y las reproduce. Por tanto, en ambas sociedades nos encontramos con conflictos surgidos por el choque de intereses pero, en la sociedad dos nos encontramos con la imitación de conductas y experiencias negativas que se realizan en la sociedad uno, siendo éstas más difíciles de erradicar al encontrarnos con personas que no están todavía debidamente formadas a nivel físico y psicológico.

Multitud de estas conductas negativas de la S1 son resueltas de manera pacífica, en ámbito judicial (o incluso ni se resuelven ya que no llegan a conflicto alguno conforme a su escasa gravedad), pero en la sociedad dos el resultado es más gravoso. Al no tener los menores un desarrollo emocional suficiente, cuando repiten estas actuaciones provocan más dolor en la víctima ya que no se impone ningún límite a sus hechos. Vamos a indicar dos hechos ficticios de fuente propia que pueden servir como ejemplo aclarativo:

“Caso 1- En una escuela, los padres de Juanjo, un alumno de la escuela, deciden divorciarse, hecho que es comentado por los padres de otros alumnos que acuden a la misma clase. Los comentarios son de todo tipo,

\footnotetext{
995 Más ampliamente sobre el tema GREENE B. R., The Hidden Reality: Parallel Universes and the Deep Laws of the Cosmos, Penguin, 2011; HAWKING, S. y ELLIS, G. F. R., The Large Scale Structure of Space-time, Cambridge University Press, Cambridge, 1973; HAWKING, S. Black Holes and Baby Universes and Other Essays, Bantam Books, Nueva York, 1994; TEGMARK, M., "Universos paralelos", en Investigación y Ciencia 2006, nº 43, pp. 14-26.
} 
pero algunos de los negativos, como por ejemplo “¿pues sí que se querían esos dos eh? ¿Qué habrá pasado para que hayan durado tan poco? ¿Habrán existido infidelidades?”, se hacen en presencia de Christian, compañero de Juanjo. Días después, existe una pequeña disputa entre Juanjo y Christian, la cual se agrava cuando el segundo de ellos se burla de Juanjo por el divorcio de sus padres, repitiendo las palabras que escuchó a sus padres e iniciándose una pelea que acaba con lesiones en ambos alumnos."

“Caso 2- Mateo es un chico de 15 años en plena adolescencia e iniciando sus relaciones con los demás. En su hogar, observa como su padre maltrata habitualmente a su madre. Este maltrato se lleva ejerciendo desde que él era pequeño, algo que Mateo ve como normal. En la escuela, Mateo empieza a tratar con sus compañeras con la agresividad que observa en su hogar, llegando a maltratar física y psicológicamente a algunas de ellas de la misma manera que lo observa en su hogar, con un claro desprecio a la mujer por el hecho de ser mujer. Para él estos actos no son nada reprochables pues son algo que vive su madre constantemente y a lo que él lo considera como algo normal en las relaciones entre pareja, $e$ incluso en las relaciones entre compañeros de clase."

Como podemos observar, en ambos casos los menores están copiando una conducta negativa del mundo de adultos. En el primer supuesto, un comportamiento como unas faltas de respeto comentadas entre dos adultos delante de un alumno, son utilizadas por este para insultar a su compañero y hacerle daño. En el segundo caso observamos como un maltrato continuado de un hombre a su mujer englobable dentro del fenómeno de violencia de género es reproducido por el hijo en la escuela y en sus relaciones personales con sus compañeras, a las cuales considera inferiores tal y como observa que sucede en su hogar. 
Estas conductas de adultos son aceptadas como normales por los hijos y desarrolladas de forma muy grave en las aulas, sin vacilación alguna. Si no son tratadas en el momento exacto, el problema se va a agravar, esencialmente en el segundo caso, creándose una concienciación en el alumno de que su comportamiento es el correcto o incluso de que, aunque esté obrando mal, su comportamiento no va a ser reprendido, pudiendo realizarlo las veces que quiera y sacar ventaja de ello.

De una manera mucho más clara y sencilla, MENDES DOS SANTOS, KRIEGER GROSSI y TERESINHA SCHERER nos hablan sobre dichas actuaciones indicándonos “muchos de los comportamientos presentados por los estudiantes de la escuela son reproducciones de sus experiencias en las comunidades en las que viven, en las familias y en la sociedad, que requieren intervenciones más amplias. La escuela es reproductora y también productora de aprendizaje, comportamientos, sentimientos y experiencias de la sociedad que engloba a la comunidad escolar" ${ }^{996}$.

En la misma línea podemos encontrarnos el spot publicitario "Children see, Children do"997 elaborado por la ya mencionada organización NAPCAN. Dicho anuncio televisivo nos muestra la imitación de conductas, tanto positivas como negativas, efectuadas por los menores una vez que las observan el mundo de adultos. Esta réplica de acciones negativas puede ocasionar en el menor una serie de malos hábitos, los cuales irá reproduciendo con el transcurso del tiempo.

Muchas de estas acciones negativas no tienen por qué tener un resultado delictivo, pero sí que incrementan las posibilidades de entrar en conflicto con otros menores o incluso adultos. Este conflicto creado no es sino una reproducción del comportamiento de los adultos, con la característica de la inexistencia de un

\footnotetext{
${ }^{996}$ MENDES DOS SANTOS, A., KRIEGER GROSSI, P. y TERESINHA SCHERER, P., "Bullying nas escolas: a metodologia dos círculos restaurativos”, en Revista Educação 2014, n 2, pp. 278-287, esp. p. 281.

997 NAPCAN, Children see, Children do, spot publicitario, 2013, Disponible en https://www.youtube.com/watch?v=jOrGsB4qG_w
} 
conocimiento o asimilación de las consecuencias negativas que pueden ocasionar estas actuaciones.

Dicho spot quiere, a través de colores vivos, resaltar cómo no importa el lugar ni la situación económica de los sujetos. Son las acciones de los adultos las que, al ser la referencia de los menores, son reproducidas. No tiene trascendencia qué tipo de persona sea y qué acción realice, el menor tenderá a imitarla. Y si estamos ante un comportamiento negativo, sus efectos serán perjudiciales para el menor, los damnificados y la propia comunidad en el que sucedan los hechos o vivan los sujetos involucrados.

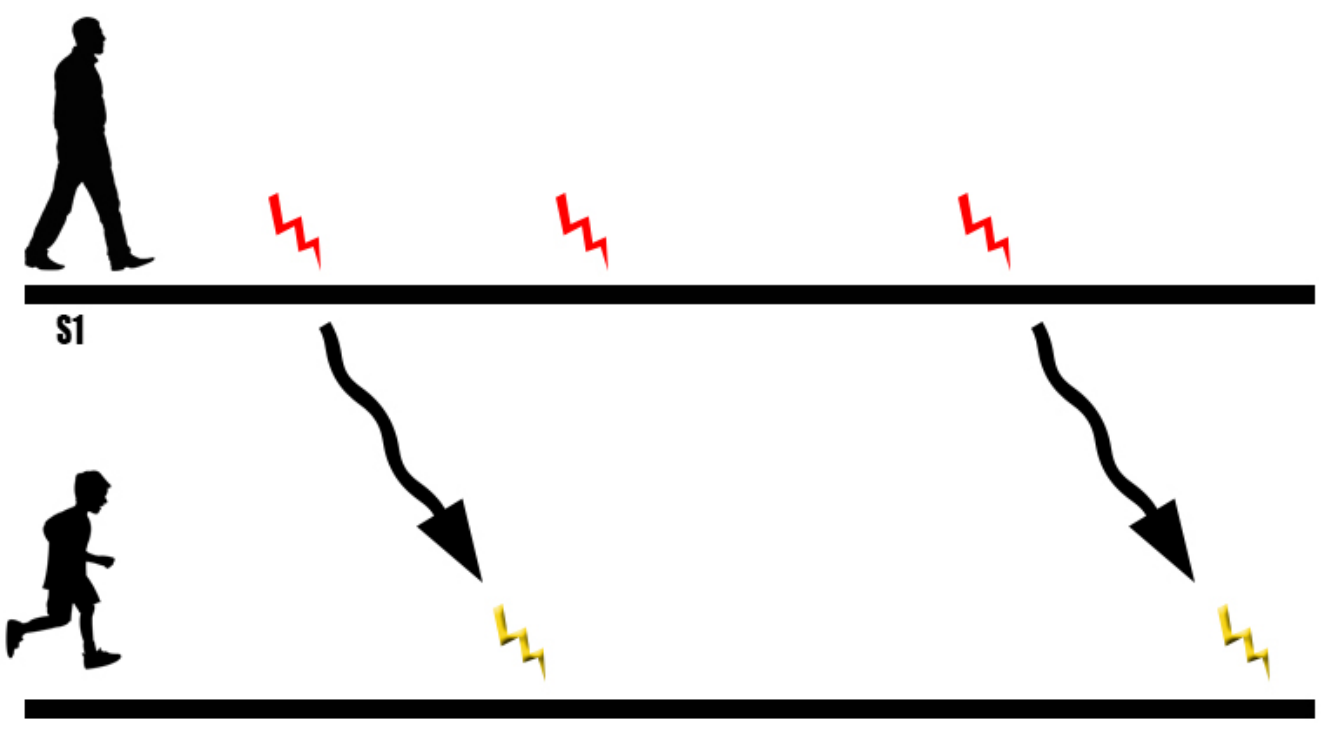

S2

\begin{tabular}{|c|l|}
\hline S1 & SOGIEDAD DE ADUITOS \\
\hline S2 & SOGIEDAD DE MENORES \\
\hline 4 & GONDUGTA NEGATIVA \\
\hline 4 & ASIMILAGIÓN DE GONDUGTA \\
\hline 4 & CONDUGTA NEGATIVA IMITADA POR EL MENOR \\
\hline
\end{tabular}

Figura 52. La imitación de comportamientos. Fuente: Elaboración propia 
Como puede examinarse en la imagen, existen dos sociedades, la S1 y la S2. Ambas se desarrollan durante el periodo elegido, un año. Como podemos observar, en ambas sociedades existen conflictos de intereses que son inevitables y no suponen un castigo penal y son consecuencias de las relaciones entre las personas. No obstante, la imitación de conductas negativas no delictivas por el menor puede suponer el agravamiento de su conducta e incluso la comisión de un hecho delictivo. Un simple insulto o burla en la sociedad de adultos puede no infligir daño en la persona quien lo recibe, pero entre menores puede suponer un perjuicio moral serio que puede encaminarse en un continuo maltrato a través de esa burla. A modo de ejemplo e ilustración, el insultar a alguien por llevar gafas no suele generar un daño en un adulto, pero en un menor puede suponerle un complejo. Esta conducta de manera reiterada generará un mayor trastorno en un menor que en un adulto.

En la escuela han de aprender los menores que esas actuaciones son dañinas para la sociedad, y uno de los mejores métodos de aprendizaje y resolución de los conflictos son los círculos. A través de ellos los alumnos expondrán sus problemas, los orígenes de estos y los motivos de su comportamiento, para afrontar el error que han cometido, el daño que ocasionado, así como las posibilidades de reparación.

Con toda esta información se podrá poner fin al conflicto a través de un diálogo honesto y seguro en el que tanto el alumno que causa el conflicto como los demás puedan aprender lo errónea de esa conducta, aprendiendo nuevos hábitos que no sólo les van a beneficiar a ellos, sino que además pueden ayudar, tanto en casa como en un futuro a la sociedad. La educación es básica para el desarrollo eficaz y pacífico del menor, y los círculos otorgan la capacidad de reparación del daño ocasionado a través del aprendizaje. Y al estar involucrados sus familiares, ellos podrán también adquirir estas capacidades restaurativas y didácticas, pudiendo poner fin a la conducta negativa que asimiló el menor y acabo ocasionando un conflicto. 
Los adultos son un espejo al que se miran los menores. La posible eficacia que los círculos pueden suponer en la resolución pacífica de conflictos emanados de las relaciones sociales entre adultos. Si en dicha "sociedad" el restablecimiento de los canales de diálogo puede ser auxiliar a conectar a los sujetos de una comunidad y permitirles crear una respuesta común frente al delito que beneficie a todos pacifique a la sociedad, a fortiori los menores obtendrán un proceso de aprendizaje en edades tempranas que establecerá en ellos un pensamiento restaurador con utilidad en el presente e incluso en el futuro.

\subsection{Los círculos y la violencia de género}

Como ya se ha anticipado en páginas anteriores las diferentes prácticas que ofrece la Justicia Restaurativa pueden ser una opción para la resolución de casos de violencia de género, pese a la prohibición legislativa vigente en nuestro país ${ }^{998}$. Los círculos, con las características ya expuestas, pueden constituir una oportunidad de resolver ese tipo de conflictos, dando una respuesta satisfactoria tanto a la víctima como al infractor.

La mera creación del círculo restaurativo, gracias a la participación de la sociedad, otorga un poder a la víctima, un empowerment o empoderamiento, que asienta su posición frente a la postura machista y maltratadora del infractor, creándose así una situación de igualdad en favor de la víctima, una situación de protección y apoyo por parte de toda la comunidad. Para MUNUERA GÓMEZ y BLANCO LARRIEUX, los procesos de mediación son muy ventajosos debido a la responsabilidad que adquieren las partes, y pudiéndose aquí sustituir la palabra mediación por círculo, e indicar que estos permiten a las partes "responsabilizarse de sus actos en un ambiente de igualdad y respeto que les permite expresarse libremente y escuchar al otro así como

\footnotetext{
${ }^{998}$ Recuérdese el artículo 87 ter Ley Orgánica 6/1985, de 1 de julio, del Poder Judicial que prohíbe la práctica de la mediación en supuestos de violencia de género. No obstante no existe redacción similar que vete otras prácticas restaurativas tales como las conferencias o los círculos.
} 
revalorizar su actuación personal por su participación en el manejo y solución de sus conflictos, buscando intereses comunes"999

Incluso los círculos pueden presentarse en este ámbito como solución más ventajosa que la mediación o las conferencias dado al mayor número de participantes y por consiguiente la obtención de una resolución más consensuada. En la mediación podemos encontrar dos partes formadas por víctima y maltratador. Las conferencias amplían el proceso a otros miembros de la comunidad, sujetos cercanos a ambos que van a servir de apoyo psicológico. Pero los círculos van más allá, suponen una intervención de toda la comunidad a través de voluntarios debidamente entrenados y sin cercanía sobre ambos sujetos, proporcionándoles una imparcialidad en sus actuaciones y una capacidad de sanar a la víctima y resocializar al infractor.

La intervención de este amplio número de participantes proporciona una protección y apoyo mayor sobre la víctima, la cual se empodera y adquiere la independencia que el legislador parece que no la otorgó al establecer la prohibición de la mediación penal en el ámbito de la violencia de género ${ }^{1000}$. Es muy importante este aspecto ya que para la consecución de un proceso claro e igualitario la mujer ha de superar la situación de indefensión e inferioridad y adquirir el estatus que el maltratador le ha suprimido, asentándose con fuerza en su nueva posición de toma de decisiones.

Así mismo el propio círculo le ayudará, no sólo a superar los daños provocados por el agresor, sino a evitar la victimización secundaria, o dicho de otro modo, aquellos daños que "emanan del propio sistema al que la víctima acude solicitando justicia y protección”1001. Es significativo recalcar que el apoyo de todos los intervinientes, así como el trato cuidadoso y decoroso de cada uno a la víctima le harán sentirse

\footnotetext{
${ }^{999}$ MUNUERA GÓMEZ, M.P. y BLANCO LARRIEUX, M.P., "Una mirada hacia mediar o no mediar en casos de violencia: Sara Cobb”, en Revista de mediación 2011, nº 7, pp. 32-37, esp. p. 37.

1000 CASTILLEJO MANZANARES, R., TORRADO TARRÍO, C. y ALONSO SALGADO, C., "Mediación en violencia ...”, op. cit., pp. 38-45, esp. p. 43.

1001 CASTILLEJO MANZANARES, R., TORRADO TARRÍO, C. y ALONSO SALGADO, C., “Mediación en violencia ...”, op. cit., pp. 38-45, esp. p. 39.
} 
importante, ser escuchada y especialmente, sentirse una pieza clave para el desarrollo del procedimiento.

El agresor también obtiene apoyo por el círculo, recibiendo la atención y ayuda necesaria no sólo para poder sanar a la víctima, sino para resocializarse. La resocialización le ayuda a él como ser humano en cuanto a la convivencia futura, así como a la propia víctima y a la comunidad, los cuales podrán hacer desaparecer el miedo de futuras agresiones a la misma víctima o a otras.

3.7 El círculo como un sanador social más allá del delito: el ejemplo de Alcohólicos Anónimos.

Ha sido tal el desarrollo práctico del sistema de círculos que su práctica ha penetrado profundamente en las sociedades donde se han implementado estas figuras, siendo algo innato a su propia comunidad. Así mismo, la idea de cooperación y auxilio común entre los miembros de la comunidad que proyectan las figuras restaurativas ha sido una percepción de casi todas las civilizaciones, siendo habitual encontrar práctica con las características propias de los círculos para la resolución de conflictos nada que ver con el ámbito penal. El mayor ejemplo de todo ello ha sido Estados Unidos, donde, uniendo el éxito de la figura a ser el país uno de los lugares de origen y desarrollo de los círculos, se ha podido observar una utilización muy extendida por todo el territorio, tanto a nivel de conflictos penales como familiares o de convivencia.

Un ejemplo de ello es la adaptación de los círculos como un método para la ayuda de personas con adiciones, como el notable ejemplo de la asociación Alcohólicos Anónimos ${ }^{1002}$, nacida en Akron, en Estados Unidos, en 1935 como un método para compartir experiencias y autoayuda entre miembro de la comunidad con problemas de

\footnotetext{
${ }^{1002}$ Asociación conocida como Alcohólicos Anónimos y con enlace en España a http://www.alcoholicosanonimos.org
} 
alcoholismo $^{1003}$. Se observa en ambos supuestos la continuación de una misma línea de actuación: reunión en un círculo; diálogo positivo entre los participantes a través de sus experiencias a los demás miembros; los intervinientes son personas con el mismo problema o voluntarios de la asociación; y sesiones de control y análisis del impacto en el sujeto del programa así como de sus posibles mejoras o recaídas.

Lo importante aquí es que el círculo sirve para poner en común un problema ante la comunidad, la cual a través de voluntarios ayuda al sujeto a superar dicho contratiempo. En los círculos penales, el problema es un delito, ya sea el sufrimiento de este, o la necesidad de resocialización del infractor. En Alcohólicos Anónimos el problema es la adicción a la bebida, poniéndose este problema en común ante el grupo o comunidad para la consecución de una terapia social que ayude al adicto a superar su adicción. Se sigue una misma metodología: un objetivo sanador; un abandono de una vida nociva; una ayuda común a un sujeto con problemas; el compartir la experiencia como base de la redención.

En nuestra opinión se podría observar la posible inclusión de un Círculo de Alcohólicos Anónimos ${ }^{1004}$ en un Círculo de sentencia o CoSA como una actividad complementaria a ellos y enfocada en el abandono de adicciones como un paso más para la rehabilitación del sujeto infractor con un conjunto de caracteres:

- El facilitador del Círculo de Alcohólicos Anónimos debe de mantener el orden dentro del círculo y conseguir un ambiente lo suficientemente relajado y amigable para que los intervinientes participen y puedan narrar sus experiencias. Todo ello bajo la supervisión del facilitador del Círculo de sentencia o CoSA que derivó al delincuente a dicha asociación para el

\footnotetext{
1003 Para mayor información sobre su origen y primeras prácticas véase WILSON, B., Alcoholics Anonymous Big Book, Hazelden Distributed Titles, New York, 2001.

${ }^{1004}$ En realidad se podría introducir aquí cualquier práctica encaminada al abandono de cualquier tipo de adicción, pero al ser Alcohólicos Anónimos origen de todas las demás asociaciones que han ido surgiendo - como por ejemplo Narcóticos Anónimos - es a la que se hace aquí referencia como modelo de cualesquiera otras.
} 
tratamiento de sus adicciones. Entre ambos establecerán el número de sesiones convenientes e incluso adaptarán las prácticas restaurativas si fuere necesario para posibilitar la rehabilitación y abandono del consumo de las sustancias.

- Participación del Miembro Central o infractor como un interviniente más dentro del Círculo de Alcohólicos Anónimos, debiendo de cumplir con las pautas pactadas y abandonar el consumo de sustancias. Puede que sea necesaria la rehabilitación del sujeto como paso previo a la resocialización y cumplimento de los fines reparativos del proceso restaurativo. El cumplimiento eficaz de las pautas marcadas en Alcohólicos Anónimos será parte fundamental para una futura conclusión eficaz del círculo restaurativo enfocado en su resocialización y/o la reparación de la víctima y resolución del conflicto.

- La participación de la comunidad es fundamental para la consecución de los fines de ambas figuras. Los voluntarios van a aportar apoyo psicológico a aquellos que sufren, les van a demostrar que no están solos y que la propia sociedad quiere que resuelvan su problema. La ayuda será muy variada y dependerá de las necesidades de cada persona. Son fundamentales en el desarrollo eficaz del proceso pues su intervención va más allá del propio círculo, otorgan a la persona una aceptación, ayuda y comprensión necesaria para aquel que quiere superar su problema y se observa alejado de la sociedad. Es por ello, que evitarán el aislamiento social de aquel que sufre a través de su compañía y asistencia durante las sesiones del círculo e incluso fuera de ellas, complementando así las actuaciones en ambos círculos y consiguiendo un proceso más eficaz en el cumplimiento de los objetivos inicialmente señalados.

Como se advierte el círculo no es sólo un instrumento de vital valía para la resolución de conflictos, sino que su ámbito de aplicación va más allá del propio 
sistema de justicia penal. Los círculos pueden ser utilizados como un método sanador y resocializador, un medio para la restitución del dialogo y relaciones entre los ciudadanos así como una práctica social encaminada a auxiliar a cualquier ciudadanos en relación a sus problemas a través del diálogo y puesta en común con diversos miembros de la comunidad. Ello nos lleva a una práctica multidisciplinar capaz de adaptarse a las necesidades de los intervinientes de cualquier proceso judicial con el fin de resolver los conflictos a través de la sanación de la víctima y resocialización de los infractores, conduciendo a la comunidad a la pacificación social. 
“El hombre no será sabio hasta que resuelva toda clase de conflictos con las armas de la mente y no con las físicas" Wernher von Braun (1912-1977) 


\section{CONCLUSIONES}

I. El conflicto es inherente a la sociedad. Nace de la simple relación entre los miembros de la comunidad. Lo trascendental no es la disputa en sí misma, sino la necesidad de resolución para el restablecimiento de las líneas comunicativas. Las diferentes opciones existentes en la actualidad proporcionan a la ciudadanía un amplio abanico para la resolución de conflictos, adquiriendo una mayor relevancia los voluntarios Métodos de Resolución Alternativa de Controversias en relación a las ventajas ofrecidas conforme a los métodos tradicionales de justicia.

II. Desde la década de los años setenta se han asentado en los variados ordenamientos jurídicos, tanto en el ámbito civil, penal o social, los denominados modelos de resolución alternativa de disputas. El reciente impulso como una alternativa al proceso nos ha conducido a la necesidad de implantación de estas nuevas figuras. La potenciación de métodos no adversariales promueve un espíritu de diálogo y compromiso en la ciudadanía, fomentándose una resolución pacífica de las controversias. La utilidad de la negociación, la conciliación, el arbitraje o la mediación resulta acreditada, con múltiples ejemplos como el Arbitraje de Consumo, el Tribunal de Arbitraje Deportivo o la potenciación de la mediación a través de la Ley 5/2012, de 6 de julio, de mediación en asuntos civiles y mercantiles.

III. Desde su nacimiento basada en antiguas costumbres tanto en Asia como en el viejo continente, la expansión de la mediación como una posibilidad de resolución pacífica de conflictos en cualquier ámbito ha sido evidente. Estamos ante un encuentro comunicativo entre las partes de la disputa en aras de poner fin pacíficamente a tal controversia. Una resolución que satisfaga a todos los 
intervinientes, permitiendo mejorar el sistema de justicia a través de la satisfacción de todos los partícipes, la agilidad del proceso y la economización de todos los recursos disponibles, garantizando un amplio cumplimiento de los acuerdos resolutorios del conflicto.

IV. No hemos de entender que estos instrumentos, en cualquier ámbito jurisdiccional, conllevan la renuncia al monopolio estatal de la justicia. Estamos ante una serie de prácticas que permiten reforzar nuestro sistema, otorgando a los ciudadanos la posibilidad de ser partícipes activos en el proceso, tener voz y capacidad decisoria con el fin de obtener una resolución más adecuada a sus necesidades.

V. La elaboración de la Ley 4/2015, de 27 de abril, del Estatuto de la víctima del delito, es un reflejo del reciente entusiasmo científico por la víctima. Ello permite un estudio pormenorizado de los derechos que han de asistirle en todo proceso penal y que le posicionan en un estatus protegido dentro de las actuaciones judiciales. La regulación de esta normativa supone un gran avance en la consolidación de la posición de la víctima, la cual ve reforzados sus derechos. En el mismo cuerpo legal se plantea la posibilidad de acceso a los Servicios de Justicia Restaurativa para la obtención de una reparación material y moral de los perjuicios derivados del delito adecuada a sus necesidades.

VI. La Justicia Restaurativa, nacida como una filosofía encaminada a la resolución pacífica de los conflictos a través del diálogo y el trabajo en común, tiene su origen en la conjunción de los estudios doctrinales llevados a cabo por Howard Zehr en los años setenta junto la praxis restaurativa desarrollada principalmente en Canadá. Todo ello sin obviar las múltiples y pretéritas prácticas indígenas que asentaron la base para la concepción moderna de este nuevo paradigma. 
VII. La heterogeneidad de la Justicia Restaurativa se representa a través de la variedad de prácticas restaurativas existentes, las cuales no están presentes únicamente como una alternativa, sino como un complemento en la aplicación de la tutela judicial efectiva. En primer orden, y como figuras básicas de todo proceso restaurativo, cabe destacar la mediación, las conferencias y los círculos son el eje circular de la materia. No obstante, la existencia de una praxis eminentemente adecuada a las necesidades de las partes y características regionales del lugar donde se desarrollan, dan lugar a múltiples variantes nacidas de la fusión de distintas características de ellas, algunas o simplemente la reducción de caracteres propios para un acondicionamiento al momento temporal y emocional requerido. Así, la aparición de Indigenous Justice, Neighborhood Conferences o Healing Circles entre otros serán figuras adaptadas a las necesidades propias de un proceso pero sin caracteres innatos que les diferencien de las tres principales citadas con anterioridad.

VIII. La mediación penal es un proceso técnico encaminado a la resolución de conflictos mediante un encuentro cara a cara entre víctima e infractor. A pesar de las ventajas emocionales, económicas y restaurativas que supone complementar la mediación con el proceso penal actual nos encontramos con una escasez de regulación de la materia a consecuencia, principalmente, de la dificultad de inclusión de esta figura en nuestro ordenamiento. La coordinación entre el incipiente principio de oportunidad junto al vigente principio de legalidad, tal y como sucede en el proceso penal de menores, constituye una serie de dificultades y controversias que han imposibilitado la legislación exitosa de la práctica. Una futura regulación legislativa daría más visibilidad y sentido al florecimiento de Proyectos Piloto de Mediación Penal en nuestro Estado, tales como AMEPAX o el Servicio de Mediación Penal de Euskadi. 
IX. La mediación penal, a pesar de la praxis y opiniones favorables existentes, no basta para una resolución eficaz de los conflictos nacidos en el ámbito de la violencia de género. La falta de igualdad formal entre las partes puede ocasionar, desde el punto de vista sustantivo y de fondo, dificultades en la obtención de un acuerdo que satisfaga los intereses de la víctima. Se defiende aquí la práctica de otras figuras restaurativas, como las conferencias o los círculos, que impulsan la participación de otros sujetos de la comunidad, empoderando a la víctima a través de un apoyo de la sociedad y resocializando al infractor a través de una enseñanza común.

X. El apogeo de la figura entre la literatura conduce a la propuesta de regulación de la mediación penal en nuestro ordenamiento como un método complementario e integrado en el propio sistema judicial. Cualquier fase procesal, ya sea instrucción, enjuiciamiento penal o post sentencia puede ser adecuada para el efectivo desarrollo de dicha práctica restaurativa, siendo primordial el control de las actuaciones por parte de los Tribunales y el Ministerio Fiscal en aras al aseguramiento de la legalidad, imparcialidad e igualdad de partes. No obstante el acuerdo de mediación será valorado por el juez antes de emitir sentencia en la cual se tome aquello acordado en el proceso de mediación para la elaboración del dictamen.

XI. El establecimiento de un marco legal definido será clave para un correcto desarrollo de las labores. Aunque es evidente la incertidumbre generada en relación a delitos de mayor gravedad, los cuales plantean el problema de la posible vulneración de la posición de equilibrio entre las partes. Así, la legislación de esta práctica ha de establecerse a través de fases o etapas. La primera de ellas instaura un marco normativo limitado, en el cual, a pesar de la acotación de delitos mediables, no vulnere los principios de libertad de forma que envuelven todo proceso de mediación. Y con respecto a dicha delimitación delictiva, la legislación dedicaría su interés en delitos de menor gravedad, es 
decir, aquellas infracciones que supongan una pena de prisión inferior a cinco años al ser más óptimos para la resolución del conflicto a través de la institución de la mediación penal. La segunda fase, si se estimare oportuno conforme a unas prácticas exitosas, supondría una ampliación del ámbito de delitos mediables, permitiéndose la resolución de todo tipo de conflictos, salvo los delitos de homicidio y asesinato, los cuales.

XII. La incidencia cada vez más considerable de las Conferencias nos dirige a la aplicación de pretéritas prácticas maoríes adaptadas a las novedosas visiones restaurativas. El trabajo en equipo de personas allegadas a víctima e infractor así como miembros de la policía y de los servicios sociales muestra una posibilidad de obtención de un acuerdo exitoso que ponga fin al conflicto. El fortalecimiento de la familia ha sido pieza clave para la potenciación de esta figura, centrando su mayor interés en el ámbito penal de menores, aunque no existe impedimento alguno para una posterior ampliación al proceso penal de adultos si se estimara conveniente. Se aprecia que la práctica llevada a cabo por Estados como Nueva Zelanda, Australia, Irlanda del Norte, Bélgica o Noruega nos ha mostrado resultados mucho más favorables en el ámbito de menores que en el de adultos. Ello sirve de ejemplo para una regulación futura, tomando sus regulaciones y adaptándolas a nuestras necesidades y peculiaridades, enfocándolo en el procedimiento penal juvenil para una mayor satisfacción de los intereses generales.

XIII. La regulación de las Conferencias ha de respetar los principios propios de la figura, buscando una libertad de actuación de los intervinientes, así como el afán educativo de las medidas desarrolladas en las sesiones. Todo ello bajo unos límites temporales de 12 meses, prorrogables hasta los 18 meses en total, en aras de una no dilatación del proceso hasta límites en los cuales la reparación y resocialización sean objetivos inaccesibles. Respecto a la tipología delictiva, no consideramos óptimo el establecimiento de límite material alguno. La 
erradicación de este tipo de comportamientos delictivos y la educación de los menores es básica para la consecución de una sociedad pacífica y responsable. Las sesiones deberán estar bajo el control de jueces y fiscales para el cumplimiento de la legalidad del proceso, la obtención de un acuerdo beneficioso para ambas partes, así como para la ejecución de lo acordado en el plan de reparación.

XIV. Conforme al ámbito material y, con mayor consideración, para en la consecución de los dos objetivos básicos de las conferencias, la restauración de la víctima y la resocialización del menor se ha de otorgar libertad para el inicio de un proceso de conferencias sea cual fuere la infracción cometida. Este componente didáctico es primordial para encauzar a los menores infractores, sin importar el delito cometido. Su foco de interés está fijado más en un análisis del motivo para la comprensión de la voluntad del menor en el momento de la comisión de los hechos así como la evolución sufrida durante el proceso para la toma de medidas restaurativas en el proceso de diálogo en favor de la reparación de la víctima y el abandono del cauce delictivo por parte del menor.

XV. La participación del conjunto de la comunidad es primordial para la obtención de un acuerdo totalmente reparativo. Los círculos son el mayor representante de la Justicia Restaurativa al reunir esta característica. Se erige como la más eficaz expresión de este nuevo paradigma al ampliar su ámbito de actuación a la totalidad de sociedad, la cual tendrá voz en el proceso a través de la participación de profesionales de diferentes ramas del conocimiento y voluntariado. Todo ello ofrece un espacio abierto en el cual la confrontación se sustituye por el diálogo pacífico. Las emociones fluyen en las sesiones, y son básicas para la comprensión del delito y la reparación a consecuencia de que permiten a la víctima superar los miedos y sufrimientos que la conducta del 
delincuente le ocasionó, el cual, a su vez, podrá resocializarse y desarrollar una vida pacífica y alejada del delito.

XVI. La virtualidad de los círculos, así como de cualquier otra práctica restaurativa, reside en su integración en el proceso penal para la resolución de los conflictos nacidos del delito. Basadas en las antiguas prácticas de la cultura indígena de las Primeras Naciones, el desarrollo de las sesiones se caracteriza por sesiones basadas en el respeto mutuo, tales como la igualdad de todos los intervinientes y el respeto del turno de palabra a través del denominado Talking Piece u "objeto de hablar”. Y en la misma línea, al tener un alto componente emocional, las oportunidades que la nueva institución ofrece permite una perfecta adaptación a las necesidades de los intervinientes, obteniendo por ende una reparación que les satisfaga plenamente e incluso a la comunidad a la que pertenecen. Por ello, podemos distinguir múltiples actuaciones tales como los Sentencing Circles o Peacemaking Circles, Healing Circles y Circles of Support and Accountablity.

XVII. En primer lugar, los denominados círculos de sentencia o de paz tiene su función en la creación de un espacio de diálogo común para la elaboración de un plan de reparación que aglutina una restauración en favor de la víctima y un programa de resocialización para el infractor con la participación de diferentes agentes de la comunidad. Es necesaria una regulación progresiva de la institución para una correcta implantación como un proceso complementario. Para ello, en nuestro país, la estipulación de una serie de fases adaptativas será fundamental. En una primera fase se propone la regulación de los círculos como método para la resolución de conflictos en delitos con una pena de prisión inferior a 5 años, debiéndose de establecer una serie de patrones que anclen la figura, los cuales no han de menoscabar las características propias de la figura. En segunda fase procederá a una ampliación del ámbito objetivo, permitiéndose la aplicación de los círculos en cualquier tipo delictivo. 
XVIII. Prosiguiendo el tema y en segundo lugar, los círculos de sanación son un método complementario a la resolución de conflictos caracterizados por la sanación física y emocional de la víctima. Se debe potenciar y regular el desarrollo de esta figura para cualquier infracción ya que su enfoque restaurativo genera un beneficio en el sujeto pasivo del delito al ser asistida por la totalidad de la comunidad, la cual le ampara para la superación de los trastornos y efectos traumáticos ocasionados por el hecho delictivo. La valía de esta práctica se pone de manifiesto al poder desarrollarse conjuntamente con cualquier otra actuación, ya sea ante los Tribunales o diferentes prácticas restaurativas. E incluso puede ser efectiva ejercida en cualquier fase del proceso, ya sea instrucción, enjuiciamiento, o una vez ya dictada sentencia puesto que su único fin es apoyar y auxiliar a la víctima del delito en aras a la superación de los traumas.

XIX. En tercer lugar, el auge de los Círculos CoSA y el efecto de disminución de la reincidencia en hasta un $80 \%$ en delitos de carácter sexual en aquellos países donde se ha fomentado su práctica, tales como Canadá, Estados Unidos, Reino Unido, Países Bajos o Australia, muestra las posibilidades de la figura. Una correcta adaptación de la práctica puede suponer una disminución sustantiva de la "recaída en la vida delictiva”, sin importar el momento procesal en el que se lleve a cabo. No obstante, aun pudiendo ser realizados tanto en fase de instrucción como enjuiciamiento, su mayor efectividad será mostrada una vez ya haya sido dictada la sentencia condenatoria y el infractor se encuentre dentro del ámbito penitenciario o ya haya cumplido su condena. Un método complementario a cualquier otra actuación restaurativa o incluso a un proceso ante los Tribunales, en el cual se respete la voluntariedad del delincuente y la libertad para el desarrollo de las sesiones conforme a las necesidades surgidas en los diferentes momentos temporales a través de la intervención de la comunidad en general y del propio aparato judicial en particular. 
XX. La violencia en las aulas es un problema que afecta a multitud de escolares durante sus horas lectivas. Parte de estas conductas negativas son meras reproducciones de los comportamientos observados por los menores a sus padres y resto de adultos con los que tienen contacto. Meras peticiones que pueden derivar en problemas de bullyng que afecten la conducta del menor. Cualquier práctica restaurativa, pero más concretamente los círculos, pueden ser una institución de interés para la resolución pacífica de los conflictos nacidos en las escuelas, basando sus actuaciones en el diálogo pacífico y el aprendizaje. Si las diferentes experiencias han evidenciado las posibles resoluciones dialogadas de infracciones entre ciudadanos adultos, a fortiori los círculos enfocados en menores, y más concretamente en el ámbito escolar, pueden ser adecuadas para la pacificación de este tipo de disputas. No sólo como un método de resolución de conflictos en el presente, sino con una visión futura de enseñanza a menores conductas positivas que podrán reproducir en su futura vida adulta en aras de una mejora de la convivencia de la comunidad y educar así a las próximas generaciones en la restauración y la paz social.

XXI. Lamentamos que el escaso interés y conocimiento de la Justicia Restaurativa por la mayor parte de los agentes judiciales así como la ausente regulación haya dado lugar a un desconocimiento de la figura por los ciudadanos, aunque afortunadamente el enfoque restaurativo está irrumpiendo en la agenda. Son un conjunto de instituciones que impulsan la participación de la comunidad en la resolución de disputas a través de su inclusión dentro del propio sistema de justicia como unas figuras complementarias y auxiliares encaminadas a ofrecer una resolución más acorde a los intereses y necesidades de los participantes. No todas las víctimas se sentirán plenamente sanadas, ni todos los infractores se resocializarán, pero la consecución de estado de paz social sólo puede conseguirse a través de una justicia más justa y más humana, que otorgue el control de la toma de decisiones a los miembros de la sociedad, los cuales satisfarán sus intereses y el del conjunto de la colectividad a través de acuerdos 
restaurativos. Ello sin que la regulación legal de estas prácticas acabe conformando una figura rígida y obligatoria, encaminada a "drenar" el sistema actual, perdiendo así todas las características que marcaron su identidad y crearon un interés en los apasionados ciudadanos e investigadores que enfocarán su fascinación en la praxis restaurativa. 
"Remarkable claims require remarkable proof"

Carl Sagan (1934-1996) 


\section{Bibliografía}

ACALE SÁNCHEZ, M., La discriminación hacia la mujer por razón de género en el Código Penal, Reus, Madrid 2006.

AERTSEN, I., y WILLEMSENS, J., The European Forum for VictimOffenderMediation and Restorative Justice, Leuven University Press, Leuven, 2000.

ALCALÁ-ZAMORA Y CASTILLO, N., Proceso, autocomposición y autodefensa, $2^{\mathrm{a}}$ edición, UNAM, México, 1970.

ALCOVER DE LA HERA, C., "La mediación como estrategia para la resolución de conflictos: una perspectiva psicosocial”, en M. Gonzalo Quiroga (Dir.), Métodos alternativos de solución de conflictos: perspectiva multidisciplinar, Dykinson, Madrid, 2006, pp. 113-129.

ALONSO, R., Irlanda del Norte: Una historia de guerra y la búsqueda de la paz, Editorial Complutense, Madrid, 2001.

ALONSO, R., “Terrorismo en Irlanda del Norte: Evolución y análisis de la situación”, en Cuadernos de pensamiento político 2013, n 38, pp. 9-28.

ALONSO SALGADO, C., La mediación en el proceso penal, Tirant lo Blanch, Valencia, 2018.

ÁLVAREZ GARCÍA, H., “La premediación como presupuesto procesal de admisibilidad versus el derecho fundamental de acceso a la jurisdicción”, en R. Cabrera Mercado (dir.) y P.M. Quesada López (coord.), La mediación como método para la resolución de conflictos, Dykinson, Madrid, 2017, pp. 85-96.

ARANGÜENA FANEGO, C., "La mediación penal en el ámbito de la violencia de género ¿ha llegado el momento para replantearse su prohibición?”, en X. Abel Luch (coord.), Las medidas preventivas de conflictos jurídicos en contextos económicos inestables, Bosch, Barcelona, 2014, pp. 145-162.

ARMENTA DEU, T., “Justicia restaurativa, mediación penal y víctima: vinculación europea y análisis crítico", en Revista General de Derecho Europeo 2018, n 44, pp. 204-243. 
ARMENTA DEU, T., "Principio de legalidad vs Principio de oportunidad: una ponderación necesaria”, en J. Picó Junoy (dir.), Principios y Garantías Procesales. Liber Amicorum en homenaje a la profesora $M^{a}$. Victoria Berzosa Francos, Bosch Editor, Barcelona, 2013, pp. 441-456.

ASHWORTH, A., "Some doubts about restorative justice”, en Criminal Law Forum 1993, Vol. 4, n 2, pp. 277-299.

AUGHEY, A., The Politics of Northern Ireland: Beyond the Belfast Agreement, Routledge, Nueva York, 2005.

BANNINK, F., y WALKER, L., Gestión de conflictos enfocada en la solución y círculos restaurativos, traducido por G. Verano Martínez, 2015. Documento en línea. Disponible en: http://www.lorennwalker.com (Última visita: 11/07/2017).

BARNETT, R.E., "Restitution: a new paradigm of criminal justice”, en Ethics 1977, no 4, 279-301.

BARONA VILAR, S., Solución extrajurisdiccional de conflictos. Alternative dispute resolution (ADR), y Derecho Procesal, Tirant lo Blanch, Valencia, 1999.

BARONA VILAR, S., (dir.), La mediación penal para adultos. Una realidad en los Ordenamientos jurídicos, Tirant lo Blanch, Valencia, 2009.

BARONA VILAR, S., “El presente y el futuro de la mediación en España”, en J. Tamarit Sumalla (coord.), Víctimas olvidadas, Tirant lo Blanch, Valencia, 2010, pp. 229-254.

BARONA VILAR, S., "Las ADR en la justicia del siglo XXI, en especial la mediación”, en Revista de Derecho Universidad Católica del Norte 2011, Año 18, n 1, pp. 185-211.

BARONA VILAR, S., Mediación penal. Fundamento, fines y régimen jurídico, Tirant lo Blanch. Valencia, 2011.

BARONA VILAR, S., Mediación en asuntos civiles y mercantiles en España, Tirant lo Blanch, Valencia, 2013.

BARONA VILAR, S., Proceso penal desde la historia, Tirant lo Blanch, Valencia, 2017. 
BARQUÍN SANZ, J., y CANO PAÑOS, M. A., "Justicia penal juvenil en España: una legislación a la altura de los tiempos”, en Revista de Derecho Penal y Criminología 2006, nº 18, pp. 37-95.

BAZEMORE, G., “A Vision for Community Juvenile Justice”, en Juvenile and Family Court Journal 1998, Vol. 49, nº 4, pp. 55-87.

BAZEMORE, G. y UMBREIT, M., “A comparison of four restorative conferencing models”, en Juvenile Justice Bulletin 2001, $\mathrm{n}^{0}$ 4, pp. 1-20, https://www.ncjrs.gov (Última visita: 11/07/2017).

BECKETT, H., CAMPBELL, C., O’MAHONY, D., JACKSON, J., y DOAK, J., Interim evaluation of the Northern Ireland Youth Conferencing Scheme: Research and Statistical Bulletin 1/2005, Northern Ireland Statistics and Research Agency, Belfast, 2005.

BELL, C., "Dealing with the past in Northern Ireland”, en Fordham International Law Journal 2003, n² 26, pp. 1095-1147.

BELLOSO MARTÍN, N., "Mediación penal ¿Beneficios reales o potenciales?“, en Revista Criminología y Justicia 2012, nº 4, pp. 21-34.

BELLOSO MARTÍN, N., “Anotaciones sobre alternativas al sistema punitivo: la mediación penal”, en Revista Eletrônica de Direito Processual 2016, Vol. V, pp.146186.

BERISTAIN IPIÑA, A., “¿La sociedad/judicatura atiende a sus víctimas/testigos?”, en AA.VV, Nueva Criminología desde el Derecho Penal y la Victimología, Tirant lo Blanch, Valencia, 1994, pp. 233-290.

BERLANGA, A., “La mediación policial”, en V. CERVELLÓ DONDERIS (Dir.), Cuestiones prácticas para la aplicación de la mediación penal, Tirant lo Blanch, Valencia, 2016, pp. 411-434.

BERNAL ACEVEDO, F., y ECHEVERRI ECHEVERRI, A., Manual para Facilitación de Círculos de Diálogo en Instituciones Educativas. Adaptación del Manual para facilitadores de círculos de Key Pranis, CONAMAJ, San José, 2009.

BLANCO CARRASCO, M., Mediación y sistemas alternativos de resolución de conflictos. Una visión jurídica, Reus, Madrid, 2009. 
BOLAÑOS HURTADO, E., “Justicia Restaurativa: una mirada panorámica” Conferencia impartida en la Mesa redonda "La Justicia Restaurativa en el contexto internacional: hacia una construcción de un modelo universal”, en el IV Congreso de Justicia Restaurativa y Mediación Penal: del desiderátum a la realidad práctica, Burgos, 17 y 18 de Marzo de 2016.

BOLDÓ RODA, C., La mediación en asuntos mercantiles, Tirant Lo Blanch, Valencia, 2015.

BOLDT, R.C., "Criminal Law: Restitution, Criminal Law, and the Ideology of Individuality”, en Journal of Criminal Law and Criminology 1986, Vol. 77, n 4, pp. 969-1022.

BONET NAVARRO, A., Proceso civil y mediación: su análisis en la Ley 5/2012, de mediación en asuntos civiles y mercantiles, Aranzadi, Pamplona, 2013.

BORN, G., International Commercial Arbitration, Kluwer Law International, 2009.

BRAITHWAITE, J., Restorative Justice and Responsive Regulation, Oxford University Press, Oxford, 2002.

BRAITHWAITE, J., Crime and Justice, University of Chicago, Chicago, 1999.

BRIGGS, D., y AUTY, K., "Koori Court Victoria - Magistrates' Court (Koori Court) Act 2002", Comunicación presentada en Australian and New Zealand Society of Criminology Conference, Sydney, 2003.

BROWN, K., y CONCEPCIÓN RAYÓN, M., Mediación: Experiencias desde España y alrededor del mundo, Universidad Complutense de Madrid, Madrid, 2016.

BUERGUER, M.E., PETROSINO, A.J. y PETROSINO, C., "Extending the police role: implications of Police Mediation as a problem- solving tool”, en Police Quarterly 200 Vol. 2, no 2, pp. 125-149.

BUJOSA VADELL, L., y RODRÍGUEZ GARCÍA, B., “Algunos apuntes sobre el derecho a la tutela judicial efectiva en la jurisprudencia constitucional”, en La Ley: Revista jurídica española de doctrina, jurisprudencia y bibliografía 1999, $\mathrm{n}^{\circ} 2$, pp. 1828-1840. 
BUSHIE, J., "CHCH reflections", en Ministry of the Solicitor General of Canada (ed.), The Four Circles of Hollow Water, Aboriginal Peoples' Collection, Public Works and Government Services, Ottawa, 1997, pp 95-143.

CALAMANDREI, P., Instituciones de Derecho Procesal Civil según el nuevo Código, traducción de Santiago Sentís Melendo, Depalma, Buenos Aires, 1943.

CAMERON, L., y THORSBORNE, M., "Restorative Justice and School Discipline: Mutually Exclusive?”, en H. Strang y J.Braithwaite (eds.) Restorative justice and civil society, Cambridge University Press. Cambridge, 2011, pp. 180-194.

CAMPBELL, C., DEVLIN R., O’MAHONY, D., DOAK, J., JACKSON, J., CORRIGAN, T. et al., Evaluation of the Northern Ireland Youth Conference Service, Northern Ireland Statistics and Research Agency, Belfast, 2005.

CANO PAÑOS, M. A., "La acusación particular en el proceso penal de menores. ¿La represión como alternativa?”, Revista del poder judicial 2004, nº 76, pp. 283-319.

CARNELUTTI, F., Sistema de Derecho Procesal Civil -Tomo I: Introducción y Función del Proceso Civil, traducción de Niceto Alcalá-Zamora y Castillo y Santiago Sentís Melendo, Uteha, Argentina, Buenos Aires, 1944.

CARNELUTTI, Las miserias del proceso penal, Temis, Bogotá, 2005.

CASTILLEJO MANZANARES, R., TORRDAO TARRÍO, C., y ALONSO SALGADO, C., "Mediación en violencia de género", en Revista de Mediación 2011, nº 7, pp. 38-45.

CASTILLEJO MANZANARES, R., “La mediación en el proceso de menores”, en Revista de Derecho Penal 2011, n 32, pp. 9-28.

CASTILLEJO MANZANARES, R., "La figura del mediador concursal en el "acuerdo extrajudicial de pagos"'”, en Cuaderno electrónico de estudios jurídicos 2013, n 1, pp. 19-36, esp. p. 24.

CASTILLEJO MANZANARES, R., La mediación: Nuevas realidades, nuevos Retos. Análisis en los ámbitos civil y mercantil, penal y de menores, violencia de género, hipotecario y sanitario, La Ley, Madrid, 2013.

CASTILLEJO MANZANARES, R., “Mediación con víctimas especialmente vulnerables”, en Iuris: Actualidad y práctica del derecho 2014, n² 215, pp. 38-43. 
CASTILLEJO MANZANARES, R., SANDE MAYO, M.J. y TORRADO TARRÍO, C., Justicia restaurativa y violencia de género. Más allá de la LO 1/2004, Universidad Santiago de Compostela, Santiago de Compostela, 2014.

CASTILLEJO MANZANARES, R., "Hipótesis de partida acerca de la posibilidad de mediación en supuestos de violencia de género”, en Diario la Ley 2016, nº 8882. Disponible en: www.diariolaley.es (última visita 19/04/2018).

CASTILLEJO MANZANARES, R., "El estatuto de la víctima y las víctimas de violencia de género", en Diario La Ley 2016, N $^{\circ}$ 8884. Disponible en: www.diariolaley.es (última visita 19/04/2018).

CASTILLEJO MANZANARES, R., “Justicia Restaurativa, mediación penal y víctima”, en M. De Hoyos Sancho (coord.) La víctima del delito y las últimas reformas procesales penales, Aranzadi, Cizur Menor, 2017, pp. 275-294.

CAVALLI BUSTOS, M.C., y QUINTEROS AVELLANEDA, L. G. Introducción a la gestión no adversarial de conflictos, Reus, Madrid, 2010.

CERETTI, A. et al., "Giustizia riparativa e mediazione penale: esperienze e pratiche a confronto”, en F. Scaparro (dir.), Il coraggio di mediare, Guerini e Associati, Milano, 2001, p. 307- 356.

CERVELLÓ DONDERIS, V., “La mediación en el sistema penal español”, en V. Cervelló Donderis (dir.), Cuestiones prácticas para la aplicación de la mediación penal, Tirant lo Blanch, Valencia, 2016, pp. 69-108.

CHANKOVA, D. y POSHTOVA, T., Módulo E: Práctica preventiva y de integración Unidad. E4: Enfoques restaurativos en la escuela: hacia una "escuela restaurativa". Traducción de AM Consultores. Encargados de proyecto: Alberto Blanco y María Dolores Rodríguez. Disponible en: http://www.vista-europe.org (última visita 07/11/2017).

CHAPMAN, T., CAMPBELL, H., WILSON, D., y MCCREADY, P., Exploring and crossing the frontiers of society: Restorative approaches to conflict between groups Comprehensive final report on $R J$ interventions in interethnic conflicts and multiagency approach, 2015. Disponible en: http://www.alternativeproject.eu (última visita 09/11/2017). 
CHOYA FORÉS, N., Prácticas restaurativas: círculos y conferencias. Justicia restaurativa: nuevas perspectivas en mediación. 2014 - 2015. Disponible en: http://www.sociedadvascavictimologia.org (última visita 18/04/2018).

CHRISTIE, N., Limits to pain, Universitetsforlaget, Oslo, 1981.

CID MOLINÉ, J. “El incremento de la población reclusa en España entre 1996-2006: Diagnóstico y remedios”, en Revista Española de Investigación Criminológica 2008, $\mathrm{n}^{\circ}$ 6. Disponible en: https://dialnet.unirioja.es (Última visita: 11/07/2017).

COAKLEY, J., "Ethnic Conflict and the Two-state Solution: The Irish Experience of Partition”, en los seminarios Ireland and Palestine - Divided Countries United By History, celebrados del 10-14 de Octubre de 2004 por PASSIA (Palestinian Academic Society for the Study of International Affairs) en Ramallah, Palestina. Disponible en: https://www.qub.ac.uk (última visita 01/02/2018).

COBB, S., "A narrative perspective on mediation: towards the materialization of the "storytelling" metaphor", en J. Folger y T. Jones (dirs.), New Directions in Mediation: Communication Research and Perspectives, Sage Publications, California, 1994, pp. 48-66.

CORDÓN MORENO, F., El Arbitraje de Derecho Privado. Estudio breve de la Ley 60/2003, de 23 de diciembre, de Arbitraje, Aranzadi, Cizur Menor, 2005.

CORDÓN MORENO, F., Arbitraje y jurisdicción: algunas cuestiones polémicas, Cuadernos Civitas, Navarra, 2010.

CHRISTIE, N., “Conflicts as property”, en A. von Hirsch y A. Ashworth, (eds), Principled Sentencing. Readings on Theory and Policy, Hart Publishing, Oxford, 1998, pp. 312-316.

CRESPO PÉREZ, J., y LEÓN LLEÓ, A., “La asistencia jurídica gratuita ante el CAS”, en Revista Aranzadi de Derecho de Deporte y Entretenimiento 2014, n 42, pp. 563578.

CUADRADO SALINAS, C., “La mediación: ¿Una alternativa real al proceso penal?”, en Revisa Electrónica de Ciencia Penal y Criminología 2015, no 17, pp. 1-25. Disponible en: http://criminet.ugr.es (Última visita: 11/07/2017). 
DALY, K., "Conferencing in Australia and New Zealand: Variations, Research Findings and Prospects”, en A. Morris y G. Maxwell, (dirs.), Restoring Justice for Juveniles: Conferencing, Mediation and Circles, Hart Publishing, Oxford, 2001, pp. 5984.

DALY, K., y HENNESSEY H., "Restorative justice and conferencing in Australia", Trends \& issues in crime and criminal justice, $\mathrm{n}^{\circ} 186$, Australian Institute of Criminology. Disponible en: http://hdl.handle.net/10072/4022 (Última visita: 11/07/2017).

DALY, K., "Restorative Justice: the real story”, en Punishment \& Society 2002, vol 4, $\mathrm{n}^{\mathrm{0}}$ 1, pp. 55-79.

DALY, K., Analysis of Australian Indigenous imprisonment and demographic information, School of Criminology and Criminal Justice Griffith University, Brisbane, 2009.

DANDURAND, Y., Manual sobre programas de Justicia Restaurativa, Oficina de las Naciones Unidas contra la Droga y el Delito, Nueva York, 2006.

DELGADO ÁLVAREZ, C., 161 respuestas sobre la violencia de género, Globalia Artes Gráficas, Salamanca, 2008.

DEL CANTO HUERTA, R., La vergüenza reintegrada y la justicia restaurativa: modelos innovadores en el ámbito de las medidas alternativas a la privación de libertad de menores de edad, Tesis de licenciatura, inédito. Facultad de derecho, Universidad de Chile, Santiago, Chile, 2004. Disponible en: http://biblio.uchile.cl (última visita 12/04/2018).

DEL POZO PÉREZ, M., “¿Es adecuada la prohibición de mediación del art.22.5 de la Ley Orgánica 1/2004?”, en F. Martin Diz (coord.), La mediación en materia de familia y derecho procesal: Estudios y análisis, Andavira, Santiago de Compostela, 2010, pp. 291-320.

DEL RÍO FERNÁNDEZ, L., "El reto de la mediación penal: el principio de oportunidad”, en Revista La Ley 2006, nº 6520. Disponible en: www.diariolaley.es (última visita 15/04/2018).

DE LA CUESTA, J.L., y SUBIJANA, I. J., (dirs.), Justicia Restaurativa y Terapéutica. Hacia innovadores modelos de justicia, Tirant lo Blanch, Valencia, 2017. 
DE LA OLIVA SANTOS, A. "Mediación y justicia: síntomas patológicos”, en Otrosí 2011, nº octubre-diciembre, pp. 7-14.

DÍAZ LÓPEZ, A., "Propuestas para la práctica de la mediación penal. Delitos patrimoniales cometidos entre parientes y responsabilidad penal de las personas jurídicas”, en InDret 2011, nº 3, pp. 1-50.

DICK, D., "Circle sentencing of Aboriginal offenders - victims have a say", en Journal of the Judicial Commission of New South Wales 2004, $n^{\circ}$. 1, pp. 57-72.

DIGNAN, J. y LOWEY, K., Restorative justice options for Northern Ireland: A comparative view, Northern Ireland Criminal Justice Review Group, Belfast, 2000.

DIGNAN, J., Understanding Victims and Restorative Justice, Open University Press, Nueva York, 2005.

DOHERTY, K. "Restorative Youth Conferencing in Northern Ireland”, en Newsletter of the European Forum for Restorative Justice 2011, vol. 12, n 1, pp. 3-5.

DOMINGO DE LA FUENTE, V., “Acerca de qué es mediación, mediación penal y otros conceptos similares y para muchos confusos”, Criminología y Justicia 2012, n 4 , pp. 12-14.

DOMINGO DE LA FUENTE, V., “En busca de la Justicia”, Criminología y Justicia 2012, n ${ }^{\circ}$ 4, p. 3.

DOMINGO DE LA FUENTE, V., “¿Qué es la Justicia Restaurativa?”, Criminología y Justicia 2012, nº 4, pp. 6-11.

DOMINGO DE LA FUENTE, V., “¿Por qué la Justicia Restaurativa es buena para las víctimas incluso de delitos graves?”, Criminología y Justicia, 2014. Disponible en: https://cj-worldnews.com (Última visita: 11/07/2017).

DOMINGO DE LA FUENTE, V., "Servicio de justicia restaurativa de Castilla y LeónAMEPAX”, en V. Cervelló Donderis (Dir.), Cuestiones prácticas para la aplicación de la mediación penal, Tirant lo Blanch, Valencia, 2016, pp. 353-377.

DOMINGO DE LA FUENTE, V., "Justicia restaurativa como derecho de las víctimas”, Revista jurídica de Castilla y León 2017, n 41, pp. 130-153. 
DUFF, R., "Restorative punishment and punitive restoration” en G. Johnstone (dir.), A Restorative Justice Reader. Texts, sources, context, Willan Publishing, Michigan, 2003, pp. 82-100.

DÜNKEL, F., "Reacciones en los campos de la administración de justicia y de la pedagogía social a la delincuencia infantil: un estudio comparativo a escala europea”, en Cuadernos de Derecho Judicial, CSPJ, Madrid, 2001, pp. 119-186.

ELliOT, M., The Long Road to Peace in Northern Ireland: Peace Lectures from the Institute of Irish Studies at Liverpool University, Liverpool University Press, Liverpool, 2007.

ERIKSSON, A., Justice in transition: Community restorative justice in Northern Ireland, Willan Publishing, Cullompton, 2009.

ESQUINAS VALVERDE, P., La mediación entre víctima y agresor en la violencia de género, Tirant lo Blanch, Valencia, 2009.

ETXEBERRIA MAULEÓN, X., "Justicia retributiva y restaurativa ante los delitos de terrorismo”, en Justicia para la convivencia. Los puentes de Deusto. Encuentro «Justicia retributiva y restaurativa: su articulación en los delitos de terrorismo, Universidad de Deusto, Bilbao, 2012, pp. 151-158.

ETXEBARRIA ZARRABEITIA, X., “Justicia para la convivencia”, en Justicia para la convivencia. Los puentes de Deusto. Encuentro «Justicia retributiva y restaurativa: su articulación en los delitos de terrorismo, Universidad de Deusto, Bilbao, 2012, p. 143150.

FERNÁNDEZ FUSTES, M.D., La intervención de la víctima en el proceso penal (especial referencia a la acción civil), Tirant lo Blanch, Valencia, 2004.

FERNÁNDEZ GARCÍA, I., Prevención de la violencia y resolución de conflictos. El clima escolar como factor de calidad, 2ª edición, Narcea, Madrid, 1999.

FERNÁNDEZ LÓPEZ, A., La mediación en procesos por violencia de género, Aranzadi, Cizur Menor, 2015.

FERREIRAS MARCOS, C.E., SIRVENT BOTELLA, A., SIMONS VALLEJO, R., y AMANTE GARCÍA, C., La mediación en el Derecho Penal de menores, Dykinson, Madrid, 2011. 
FERNÁNDEZ MANZANO, M.L. y GOMÁ LANZÓN, I., “¿Mediación versus Derecho?”, en El Notario del Siglo XXI 2015, n 60, pp. 176-178.

FISHER, R., et al., Getting to Yes: Negotiating Agreement without Giving in, Houghton Mifflin, Boston, 1991.

FISHER, R., URY, W., PATTON, B., Getting to Yes: Negotiating an Agreement Without Giving In, Random House Business Books, Londres, 1999.

FITZGERALD, J., “Does circle sentencing reduce Aboriginal offending?”, en Crime and Justice Bulletin 2008, $\mathrm{n}^{\mathrm{o}}$ 115. Disponible en: http://www.bocsar.nsw.gov.au (Última visita: 11/07/2017).

FODDAI, M.A., "Responsabilita e Giustizia Riparativa”, Rivista italiana di diritto e procedura penale 2016, vol. 59, nº 4, pp. 1703-1723.

FOUCHARD, P. y GOLDMAN. B., Fouchard, Gaillard, Goldman on International Commercial Arbitration, Kluwer Law International, 1999.

FRANCÉS LECUMBERRI, P., SANTOS ITOIZ, E., "La mediación penal, ¿un modelo de justicia restaurativa en el sistema de justicia penal?”, Revista nuevo foro penal 2010, vol. $6, \mathrm{n}^{\circ} 75$, pp. 53-93.

FRANCÉS LECUMBERRI, P., "El principio de oportunidad y la justicia restaurativa”, en InDret, Revista para el Análisis del Derecho 2012, $\mathrm{n}^{\circ}$ 4. Disponible en: http://www.indret.com (Última visita: 11/07/2017).

FREIBERG, A., "Problem-oriented courts: innovative solutions to intractable problems?”, en Journal of judicial administration 2011, Vol. 11, nº 1, pp. 7-27.

FRIEDMAN VOLOSKY, L., Justicia restaurativa. Nuevas formas de tratamiento para delincuentes juveniles, Publicaciones del Instituto de Derecho Penal Europeo e Internacional, 2016. Disponible en: http://www.cienciaspenales.net (Última visita: 09/11/2017).

FUENTES, P., “Ley Orgánica del Poder Judicial y mediación”, en Procuradores, Revista del Consejo General de procuradores 2016, n 115, p. 19-20.

FUENTETAJA RUBIO, P., y GALVACHE VALERO, F., "Los antecedentes del Conflicto de Irlanda del Norte”, Reflexiones sobre la evolución del conflicto en Irlanda del Norte 2007, Ministerio de Defensa, Madrid, 2007, pp. 9-20. 
FUENTES SORIANO, O., "La constitucionalidad de la Ley Orgánica de medidas de protección integral contra la violencia de género”, en Diario La Ley 2005, no 6362, Disponible en: www.diariolaley.es (Última visita: 13/03/2018).

GARCIANDÍA GONZÁLEZ, P. M., "La regulación de la mediación penal en España: opciones legislativas y contenidos mínimos”, en J.L. Gómez Colomer, S. Barona Vilar, M. Pía Calderón Cuadrado (coords.), El derecho procesal español del siglo XX a golpe de tango. Liber Amicorum, en homenaje y para celebrar su LXX cumpleaños, Tirant lo Blanch, Valencia, 2012, pp. 1005-1032.

GARCIANDÍA GONZÁlEZ, P. M., y SOLETO MUÑOZ H. (dirs.), Sobre la mediación penal (posibilidades y límites en un entorno de reforma del proceso penal español). Aranzadi, Cizur Menor, 2012.

GARCÍA DÍEZ, C., SOLER IGLESIAS, C., Evaluación de necesidades y diseño de la intervención para la reintegración social de los delincuentes sexuales de alto riesgo. Adaptación de los Círculos de Apoyo y Responsabilidad al sistema de ejecución penal de Cataluña, Generalitat de Catalunya, Barcelona, 2013.

GARCÍA HERRERA, A., "Justicia restaurativa: breve reflexión sobre su integración en el marco del proceso penal en España”, en La Ley 2015, ${ }^{\circ}$ 8654. Disponible en: https://www.diariolaley.es (última visita 05/04/217).

GARCIA PÉREZ, O., "La mediación en el sistema español de justicia penal de menores”, en Revista Criminalidad 2011, vol. 53, n² 2, pp. 73-98.

GARCÍA RODRÍGUEZ M.J., "La Importancia de Los Servicios de Asistencia a las Víctimas en la Administración de Justicia para minimizar el riesgo de su doble victimización en el proceso de violencia de género", en III Congreso para el estudio de la violencia contra las mujeres, Justicia y Seguridad. Nuevos retos, Granada: Consejería de Justicia e Interior de la Junta de Andalucía, 2012. Disponible en: http://www.violenciageneroasistenciavictimas.es (última visita 15/02/2017).

GILLESPIE, G., Historical Dictionary of the Northern Ireland Conflict, Scarecrow Press, Belfast, 2008.

GIMÉNEZ ROMERO, C., "Modelos de mediación y su aplicación en mediación intercultural”, Revista Migraciones 2001, nº 10, pp. 1-32. 
GIMÉNEZ ROMERO C., “¿Cómo hemos llegado y por qué estamos aquí? Sobre las etapas, retos, oportunidades y riesgos de la mediación intercultural”, Revista Asociación de enseñantes con gitanos 2007, $\mathrm{n}^{\circ} 29$, pp. 6-17.

GIMÉNEZ-SALINAS I COLOMER, E., "La mediación en el sistema de justicia juvenil: una visión desde el Derecho comparado”, Cuadernos de Derecho judicial 1996, $\mathrm{n}^{\mathrm{o}}$ 15, pp. 53-81.

GÍMENEZ-SALINAS I COLOMER, E., "La justicia juvenil en España: un modelo diferente”, en T. Martín López (coord.), La responsabilidad penal de los menores, Ediciones Universidad de Castilla-La Mancha, Cuenca, 2001, pp. 19-44.

GIMÉNEZ-SALINAS I COLOMER, E., "La otra cara del maltrato: ¿Una tercera victimización?", en A. García-Pablos (coord.), Víctima, prevención del delito y tratamiento del delincuente, Comares, 2009, pp. 3-16.

GOLDING, J.M., "Intimate Partner Violence as a Risk Factor for Mental Disorders: A Meta-Analysis”, en Journal of Family Violence 1999, vol. 14, n 2, pp 99-132.

GOLDSTEIN, H., Problem-oriented policing, McGraw-Hill, USA, 1990.

GOLLWITZER, M. y DENZLER, M., "What makes revenge sweet: Seeing the offender suffer or delivering a message?”, en Journal of Experimental Social Psychology 2009, n 45, pp. 840-844.

GÓMEZ COLOMER, J.L., El proceso penal en la encrucijada. Homenaje al Dr. César Crisóstomo Barrientos Pellecer. Vol. I, Universitat Jaume I, Castelló de la Plana, 2015.

GÓMEZ COLOMER, J.L., Estatuto Jurídico de la Víctima del Delito: la posición jurídica de la víctima del delito ante la Justicia Penal. Un análisis basado en el Derecho comparado y en las grandes reformas que se avecinan, Aranzadi, Cizur Menor, 2015.

GONZÁLEZ CANO, M.I., “La mediación en el proceso penal: especial consideración de la decisión marco del consejo de la Unión Europea de 15 de marzo de 2001 (2001/220/JAI)", en J. F. Etxeberria Guridi (dir.) Estudios sobre el significado e impacto de la mediación: ¿una respuesta innovadora en los diferentes ámbitos jurídicos?, Aranzadi, Cizur Menor, 2012, pp. 299-330.

GONZÁLEZ CANO, M.I., “La promoción de la mediación en el ámbito de la Unión Europea: la Directiva 2008/52/CE sobre ciertos aspectos de la mediación en asuntos civiles y mercantiles y su incorporación al derecho español”, en J. Martín Ostos (coord.) 
El Derecho Procesal en el espacio judicial europeo: estudios dedicados al catedrático Faustino Gutiérrez-Alviz y Conradi, Atelier, Barcelona, 2013, pp. 235-270.

GONZÁLEZ CANO, M.I., “Cooperación judicial penal, tutela de la víctima y justicia restaurativa (especial consideración de la directiva 2012/29/UE, del Parlamento Europeo y del consejo, de 25 de octubre de 2012, por la que se establecen normas mínimas sobre los derechos, el apoyo y la protección de las víctimas de los delitos)”, en M.I. González Cano (dir.) Cooperación judicial penal en la Unión Europea: Reflexiones sobre algunos aspectos de la investigación y el enjuiciamiento en el espacio europeo de justicia penal, Tirant lo Blanch, Valencia, 2015, pp. 411-434.

GONZÁLEZ CANO, M.I., “La integración de la mediación en el sistema procesal penal a través de medidas de diversión”, en M. Jimeno Bulnes y J. Pérez Gil (coords.), Nuevos horizontes del derecho procesal: libro-homenaje al Prof. Ernesto Pedraz Penalva, Bosch, Barcelona, 2016, pp. 671-695.

GONZÁLEZ CANO, M.I., y ROMERO PRADAS, M.I., "Perspectivas actuales de la medicación civil y laboral”, en Crónica Jurídica Hispalense: revista de la Facultad de Derecho 2012, n 10, pp. 405-453.

GONZÁLEZ CUSSAC, J.L., "Responsabilidad penal de las personas jurídicas: Arts. 31 bis, ter, quarter y quinquies”, en J. L. González Cussac, E. Górriz Royo y Á. Matallín Evangelio (dir.), Comentarios a la reforma del Código Penal de 2015, Librería la Jurídica, Barcelona, 2015, pp. 151- 155.

GÓNZALEZ VIDOSA, L.F. y DE JORGE DE MESA, F., “Mediación: primera experiencia de adultos en España”, en Poder Judicial 1995, nº 40, pp. 727-743.

GOODSPEED, M., When reason fails: portraits of armies at war: America, Britain, Israel, and the future, Greenwood Publishing Group, Westport, 2002.

GORDILLO SANTANA, L.F., La justicia restaurativa y la mediación penal, Iustel, Madrid, 2007.

GREENE B. R., The Hidden Reality: Parallel Universes and the Deep Laws of the Cosmos, Penguin, 2011.

GRIFFITHS, C., Canadian Criminal Justice: A Primer, Nelson College Indigenous, Toronto, 2014. 
GUARDIOLA LAGO, M.J., "La víctima de violencia de género en el sistema de justicia y la prohibición de la mediación penal”, Revista General de Derecho Penal 2009, no 12. Disponible en: http://www.iustel.com (Última visita: 11/07/2017).

GUARDIOLA, M.J., ALBERTÍ, M., CASADO, C., MARTINS S. y SUSANNE, G. ¿Es el conferencing una herramienta útil para los programas de mediación en el ámbito penal del Departamento de Justicia?, Generalitat de Catalunya, Barcelona, 2011.

GUIMERA I GALIANA, A., "La Mediación-Reparación en el Derecho penal de adultos: un estudio sobre la experiencia piloto de Cataluña”, Revista Española de Investigación Criminológica 2005, n³ 3, pp. 1-22.

HARCOURT, B.E., Illusion of order: the false promise of broken Windows Policing, Harvard University Press, Massachusetts, 2001.

HAWKING, S., Black Holes and Baby Universes and Other Essays, Bantam Books, Nueva York, 1994.

HAWKING, S., y ELLIS, G. F. R., The Large Scale Structure of Space-time, Cambridge University Press, Cambridge, 1973.

HEALEY, S. M., The nature of the relationship of the Crown in New Zealand with iwi Māori, University of Auckland, Auckland, 2006.

HIERRO SÁNCHEZ-PESCADOR, L., “Aspectos éticos de los medios alternativos de solución de controversias (ADR): ética y deontología en la mediación”, en Anuario de la Facultad de Derecho de la Universidad Autónoma de Madrid 2008, n 11, pp. 27-48.

HIGHTON, E.I., ÁLVAREZ, G.S., y GREGORIO, C.G., La resolución alternativa de disputas y Sistema penal, Ad-Hoc, Buenos Aires, 1998.

HOLLAND, J., Hope against History: The Course of Conflict in Northern Ireland, Henry Holt \& Company, Belfast, 1999.

HORTON, D., The Encyclopedia of Aboriginal Australia: Aboriginal and Torres Strait Islander History, Society, and Culture, Aboriginal Studies Press, Canberra, 1994.

HOYLE, C., "Restorative justice policing in Thames Valley", en Journal of Police Studies 2009, Vol. 11, n 2, pp. 189-213. 
HOYLE, C., y NOGUERA, S., "Supporting Young offenders through restorative justice: Parents as (in) appropriate adults”, en British Journal of Community Justice 2008, Vol. 6, nº 3, pp. 67-85.

HOYLE, C., YOUNG, R., y HILL, R., Proceed with caution: An evaluation of the Thames Valley Police initiative in restorative cautioning, Joseph Rowntree Foundation, York, 2002.

HUALDE MANSO T., La mediación en asuntos civiles y mercantiles. La transposición de la Directiva 2008/52 en Francia y España, La Ley, Madrid, 2013.

HUDSON, J., y GALAWAY, B., Restitution in Criminal Justice: A Critical Assessment of Sanctions, Lexington Books, Lexington, 1977.

HUDSON, J., MORRIS, A., MAXWELL G., y GALAWAY B., Family Group Conferences: Perspectives on Policy and Practice, Criminal Justice Pr, Monsey, 1996.

HUNTSMAN, L., Family group conferencing in a child welfare context, Centre for Parenting \& Research, Ashfield, 2006.

HYDLE, I., y KEMÉNY, S., "From local trial projects to state owned services Empirical research on restorative justice in Norway", en I. Vanfraechem, I. Aertsen y J. Willemsens (dirs.), Restorative justice realities: Empirical research in a European context , Eleven International Publishing, 2010, pp. 207-218.

IBOLEÓN SALMERÓN, B., El proceso arbitral: una perspectiva procesal del arbitraje de consumo, Dykinson, Madrid, 2012.

ISAACS, W., Dialogue the Art of Thinking Together, Doubleday, Nueva York, 1999.

JÏLICH, S., "Restorative Justice and Gendered Violence in New Zealand: a Glimmer of Hope”, en J. Ptacek (dir.), Restorative Justice and Violence Agains Women, Oxford University Press, Oxford, 2009, pp. 239-254.

JIMENO BULNES, M., "El proceso penal en los sistemas de Common Law y Civil Law los modelos acusatorio e inquisitivo en pleno siglo XXI", en Justicia: revista de derecho procesal 2013, $\mathrm{n}^{\circ}$ 2, pp. 207-310.

JIMENO BULNES, M., “¿Mediación penal y/o justicia restaurativa? Una perspectiva europea y española”, Diario La Ley 2015, $\mathrm{n}^{\circ}$ 8624. Disponible en http://www.diariolaley.es (última visita 12/04/2016). 
JIMENO BULNES, M., "La giustizia riparativa nel sistema spagnolo", en L. Luparia (coord.), Lo statuto europeo delle vittime di reato : modelli de tutela tra diritto dell'Unione e buone pratiche nazionali, Wolters Kluwer, 2015, pp. 165-181.

JOHnStOnE, G., Restorative Justice. Ideas, Values, Debates, Willan Publishing, Devon, 2002.

JOHNSTONE, G., Restorative Justice, Routledge, Londres, 2011.

KEMELMAJER DE CARLUCCI, A., "En búsqueda de la tercera vía. La llamada Justicia Restaurativa, Reparativa, Reintegrativa o Restitutiva”, en, S. García Ramírez (coord.) Memoria del Congreso Internacional de Culturas y Sistemas Júridicos Comparados, Instituto de Investigaciones Jurídicas de la UNAM, Mexico D.F., 2005, pp.271-324.

KEMÉNY, S., "Victim - offender mediation with juvenile offenders in Norway", en A. Mestitz y S. Ghetti (dirs.), Victim offender mediation with youth offenders in Europe: An overview and comparison of 15 countries, Springer, Dordrecht, 2005, pp. 101-114.

KURKI, L., "Evaluating Restorative Justice Practices” en A. Von Hirsch, Restorative Justice and Criminal Justice: Competing or Reconcilable Paradigms?, Hart Publishing, Oxford, 2003, pp. 293-314.

LABORDA VALLE, E., Protección de los consumidores y mediación penal, Editorial Jurídica Sepín, Madrid, 2014.

LAM, M., "Understanding, but no soft options in the circle”, en Law Society Journal 2012, vol. 50, nº September, pp. 27-29.

LANDROVE DÍAZ, G., Victimología, Tirant lo Blanch, Valencia, 1990.

LARRAURI PIJOAN, E., “La reparación”, en J. Cid Moliné y E. Larrauri Pijoan, Penas alternativas a la prisión, Bosch, Barcelona, 1997, pp. 169-196.

LARSEN, J.J., Restorative justice in the Australian criminal justice system, Research and Public Policy Report $n^{\circ}$ 127, Australian Institute of Criminology, Sydney, 2014.

LAURENZO COPELLO, P., "La violencia de género en el Derecho Penal: un ejemplo de paternalismo punitivo", en P. Laurenzo Copello, M.L. Maqueda Abrue y A. Rubio Castro, Género, violencia y Derecho, Tirant Lo Blanch Valencia, 2008, pp. 329-362. 
LAUCIRICA ARRIOLA, N., "Propuesta de la regulación legal de la figura y funciones de la persona mediadora”, Reforma penal: personas jurídicas y tráfico de drogas; Justicia restaurativa, Cuadernos José María Lidón 2011, nº 8, pp. 209-216 .

LEW, J.D.M., MISTELIS, L.A., y KRÖLL, S., Comparative International Commercial Arbitration, Kluwer Law International, 2003.

LOBO GUERRA, M., y SAMPER LIZARDI, F., “¿Es posible la mediación en aquellos casos en los que ha existido violencia de género?”, Revista de mediación 2011, nº 7, pp. 8-19.

LÓPEZ LÓPEZ, A.M., Ley Orgánica reguladora de la responsabilidad penal de los menores (Comentarios, concordancias y jurisprudencia), Comares, Granada, 2004.

LORCA NAVARRETE, A.M., La mediación en asuntos civiles y mercantiles, Instituto Vasco de Derecho Procesal, San Sebastián, 2012.

MACRAE, A., y ZEHR, H., The little book of family group conferences, Good Books New Zealand Style, Nueva York, 2004.

MANZANARES SAMANIEGO, J., Mediación, reparación y conciliación en el Derecho Penal, Comares, Granada, 2007.

MANZANARES SAMANIEGO, J.L, "La Mediación Penal”, Diario La Ley 2008, n 6900. Disponible en http://www.diariolaley.es (última visita 11/10/2017).

MARCHENA GÓMEZ, M., Y GONZÁLEZ-CUÉLLAR SERRANO, N., La reforma de la Ley de Enjuiciamiento Criminal en 2015, Castillo de Luna Ediciones Jurídicas, Madrid, 2015.

MARCHETTI, E., y DALY, K., "Indigenous courts and justice practices in Australia”, en Trends \& issues in crime and criminal justice 2004, $\mathrm{n}^{\circ}$ 277. Disponible en: https://aic.gov.au (Última visita: 04/11/2017).

MARQUÉS CEBOLLA, C., La mediación. Un nuevo instrumento de la Administración de la Justicia para la solución de conflictos, Universidad de Salamanca, Salamanca, 2011.

MARSHALL, T., "The evolution of restorative justice in Britain”, European Journal on Criminal Policy and Research 1996, Vol. 4, n 4, pp. 21-43.

MARSHALL, T., Restorative Justice. An Overview, Home Office, Research Development and Statistics Directorate, London, 1999. 
MARSHALL, T., y MERRY, S., Crime and Accountability, HMSO, 1990, Londres.

MARTÍN BARBERÁN, J., DAPENA MÉNDEZ, J. y CANO LÓPEZ F., "La transformación del campo del control de la criminalidad y la justicia penal” en $\mathrm{P}$. Casanovas Romeu, L. Díaz Echenique y M. Poblet Balcells (coords.), Materiales del Libro Blanco de la Mediación en Cataluña, Centre d’Estudis Jurídics i Formació Especializada, Generalitat de Catalunya, Barcelona, 2009, pp. 95-96.

MARTÍN CARO, J.A., “El Fiscal y la Instrucción en el Proceso de Menores”, en Estudios Jurídicos. Ministerio Fiscal (VI), Centro de Estudios Jurídicos de la Administración de Justicia, Madrid, 1998, pp. 47-74.

MARTÍN DIZ, F., “Mediación en materia de violencia de género. Análisis y argumentos”, en M. De Hoyos Sancho (coord.), Tutela jurisdiccional frente a la violencia de género. Aspectos procesales, civiles, penales y laborales, Lex Nova, Valladolid, 2009, pp. 669-688.

MARTÍN DIZ, F., La mediación: sistema complementario de Administración de Justicia, Consejo General del Poder Judicial, Madrid, 2010.

MARTÍN DIZ, F., Mediación en materia de familia y derecho penal, Andavira, Santiago de Compostela, 2011.

MARTÍN DIZ, F., "Presunción de inocencia como derecho fundamental en el ámbito de la Unión Europea”, en Revista europea de derechos fundamentales 2011, n 18, pp. 133-166.

MARTÍN DIZ, F., "Ley 5/2012, de 6 de julio, de mediación en asuntos civiles y mercantiles [BOE n. ${ }^{\circ}$ 162, de 7-VII-2012]", en Ars Iuris Salmanticensis: AIS : revista europea e iberoamericana de pensamiento y análisis de derecho, ciencia política y criminología 2013, vol. 1, nº 1, pp. 212-213.

MARTÍN DIZ, F., “Real Decreto 980/2013, de 13 de diciembre, por el que se desarrollan determinados aspectos de la Ley 5/2012, de 6 de julio, de mediación en asuntos civiles y mercantiles [BOE n. ${ }^{\circ}$ 310, de 27-XII-2013]", en Ars Iuris Salmanticensis: AIS : revista europea e iberoamericana de pensamiento y análisis de derecho, ciencia política y criminología 2014, vol. 2, nº 1, pp. 268-269.

MARTÍN DIZ, F., "Del derecho a la tutela judicial efectiva hacia el derecho a una tutela efectiva de la justicia”, en Revista europea de derechos fundamentales 2014, n 23, pp. 161-176. 
MARTÍN DIZ, F., "Real Decreto 1109/2015, de 11 de diciembre, por el que se desarrolla la Ley 4/2015, de 27 de abril, del Estatuto de la Víctima del delito, y se regulan las Oficinas de Asistencia a las Víctimas del Delito [BOE n. ${ }^{\circ} 312$, de 30-XII2015]”, en Ars Iuris Salmanticensis: AIS : revista europea e iberoamericana de pensamiento y análisis de derecho, ciencia política y criminología 2016, vol. 4, nº .1 , pp. 342-345.

MARTÍNEZ ESCAMILLA, M. "Justicia reparadora, mediación y sistema penal: diferentes estrategias, ¿los mismos objetivos?” en AA.VV., Estudios penales en homenaje a Enrique Gimbernat, Tomo I, Edisofer, Madrid, 2008, pp. 465-498.

MARTÍNEZ ESCAMILLA, M., y SÁNCHEZ ÁLVAREZ, M.P., (coords.), Justicia restaurativa, mediación penal y penitenciaria: un renovado impulso, Reus, Madrid, 2011.

MARTÍNEZ GARCÍA, E., "Violencia de género, igualdad y autonomía de la voluntad. Claves para entender la prohibición de mediar en el proceso penal por estos delitos” en E. Martínez García, J.C. Vegas Aguilar, F.J. Boix Reig (coords.), La prevención y erradicación de la violencia de género. Un estudio multidisciplinar y forense, Aranzadi, Cizur Menor, 2012, pp. 413-434.

MATEFI, G., “Mediation bei häuslicher Gewalt?”, FamPra.ch, Die Praxis des Familienrechts 2003, n 2, pp. 260-273.

MAXWELL, G., KINGI, V.M., ROBERTSON, J., MORRIS, A., CUNNINGHAM, C.W., y LASH B., Achieving Effective Outcomes in Youth Justice, New Zealand: Ministry of Social Development, Wellington, 2004.

MAXWELL, G., y MORRIS, A., "Putting restorative justice into practice for adult offenders”, en Howard Journal of Criminal Justice 2001, Vol. 40, n 1, pp. 55-69.

MAY, S., Language and Minority Rights: ethnicity, nationalism and the politics of language, Routledge, 2011, Nueva York.

MAY, S., "Indigenous immersion education: International developments", Journal of Immersion and Content-Based Education 2013, n 1, pp. 34-69.

McCOLD, P., y WACHTEL, T., Restorative Policing Experiment: The Bethlehem Pennsylvania Police Family Group Conferencing Project, Department of Justice, Washington DC, 1998. 
McCOLD, P., y WACHTEL, T., "Restorative justice theory validation", en E. Weitekamp y H.J. Kerner (eds), Restorative Justice: Theoretical Foundations, Willan Publishing, Cullompton, 2002, pp. 110-142.

McCOLD, P., "The recent history of restorative justice. Mediation, circles and conferencing” en Delito y Sociedad 2013, $2^{\circ}$ semestre, pp. 9-44.

MCEVOY, K., y MIKA, H., "Restorative justice and the critique of informalism in Northern Ireland”, British Journal of Criminology 2002, Vol. 42, nº 3, pp. 534-562.

MCRAE, H., NETTHEIM, G., BEACROFT, L., y MCNAMARA, L., Indigenous legal issues: commentary and materials, Lawbook Co, Pyrmont, 2003.

MENDES DOS SANTOS, A., KRIEGER GROSSI, P., TERESINHA SCHERER, P., "Bullying nas escolas: a metodologia dos círculos restaurativos”, Revista Educação 2014, nº 2, pp. 278-287.

MERA GONZÁLEZ-BALLESTEROS, A., “Justicia restaurativa y proceso penal garantías procesales: límites y posibilidades”, Revista Ius et Praxis 2009, vol. 15, n 2, pp. 165-195.

MIERS, D., An International Review of Restorative Justice, Home Office, Londres, 2001.

MIERS, D. et al., And Exploratory Evaluation of Restorative Justice Schemes, Londres, Home Office, Londres, 2001.

MIGUEL BARRIO, R., "La Euroorden ¿Es recomendable cuando el infractor está inmerso en un proceso de justicia restaurativa?”, en J. Burgos Ladrón de Guevara (coord.), La cooperación judicial entre España e Italia. La Orden europea de detención y entrega en la ejecución de sentencias penales, Instituto Vasco de Derecho Procesal, San Sebastián, 2017, pp. 115-135.

MIRANZO DE MATEO, S., “Quiénes somos, a dónde vamos... origen y evolución del concepto de mediación”, en Revista de Mediación 2010, n 5, pp. 8-15.

MOLTZEN, R.; MACFARLANE, H.A., "New Zealand: gifted and talented Maori learners", en B. Wallace y G. Eriksson (eds.), Diversity in gifted education: International perspectives on global issues, Routledge, New York, 2006, pp. 305-307.

MONJARDET, D., "Professionnalisme et mediation de l'action policière. Les partages de la sécurité”, en Les cahiers de la sécurité interieure 1998, n³3, pp. 21-49. 
MONJARDET, D., "Réinventer la police urbaine. Le travail policier à la question dans les quartiers”, en Les Annales de la Recherche Urbaine 1999, nº 83, pp. 14-22.

MOORE, D.B., y O’CONNELL, T., “Family conferencing in Wagga Wagga: a communitarian model of justice”, en G. Johnstone (dir.). A Restorative Justice Reader, Willan Publishing, Cullompton, 2003, pp. 15-44.

MORA ALARCÓN, J.A., Derecho penal y procesal de menores (Doctrina, jurisprudencia y formularios), Tirant lo Blanch, Valencia, 2002.

MORRIS, A., y MAXWELL, G., "Restorative Justice in New Zealand: family group conferences as a Case Study”, en Western Criminology Review 1998, Vol. 1, nº 1, pp. 117.

MUERZA ESPARZA, J. "La autonomía de la voluntad en el proceso penal: perspectivas de futuro", Revista electrónica del Departamento de Derecho de la Universidad de La Rioja 2011, nº 9, pp. 191-202.

MUNNÉ CATARINA, F., La administración del arbitraje. Instituciones arbitrales y procedimiento prearbitral, Aranzadi, Cizur Menor, 2002.

MUNUERA GÓMEZ, M.P. y BLANCO LARRIEUX, M.P., "Una mirada hacia mediar o no mediar en casos de violencia: Sara Cobb”, Revista de mediación 2011, n 7, pp. 3237.

MUÑOZ CONDE, F., "De nuevo sobre el derecho penal del enemigo", en Revista Penal 2005, n 16, pp. 123-137.

MUÑOZ DE MORALES. M., "La aplicación del principio de interpretación conforme a las Decisiones Marco, ¿hacia el efecto directo? Especial referencia al caso Pupino”, en L. A. Arroyo Zapatero, A. Nieto Martín y M. Muñoz de Morales Romero (coords.), El Derecho Penal de la Unión Europea. Situación actual y perspectivas de futuro, Universidad de Castilla-La Mancha, Cuenca, 2007, pp. 291-324.

MUÑOZ GIL, P., "Los actores violentos del conflicto”, en AA.VV. Reflexiones sobre la evolución del conflicto en Irlanda del Norte, Ministerio de Defensa, Madrid, 2007, pp. 49-70.

MUYLKENS, L., y SMEETS, K., "Beyond the offender: Group counselling for victims of crime”, European Forum for Restorative Justice Newsletter 2008, n 2, pp. 3-4.

NAUDÉ, B., y NATION, D. “An analysis of cases referred to restorative justice in Tshwane Metropolitan Area”, Acta Criminologica 2007, Vol. 20, n² 2, pp. 138-153. 
NICOLÁS GUARDIOLA, J. J., “Acoso escolar”, en Archivos de Criminología, Seguridad Privada y Criminalística 2011, nº 7, pp- 1-8.

NORDENSTAHL, U. C. E., Mediación penal. De la práctica a la teoría, Librería Histórica, Buenos Aires, 2005.

O'BRIEN, M. y YAR, M., Criminology, the key concepts, Routledge, Nueva York, 2008.

O’MAHONY, D., y DOAK, J., Reimagining Restorative Justice, Hart Publishing, Portland, 2017.

OLALDE ALTAREJOS, A. J., "Encuentros restaurativos en victimización generada por delitos de terrorismo: bases teóricas”, en E. Pascual Rodríguez (coord.), Los ojos del otro; Encuentros restaurativos entre víctimas y ex miembros de ETA, Sal Terrae, Santander, 2013, pp. 33-84.

OLWEUS, D., Agression in the schools: Bullies and whipping boys, Hemisphere, Washington, 1978.

ORNOSA FERNÁNDEZ, M.R., Derecho penal de menores: comentarios a la Ley Orgánica 5/2000, de 12 de enero, reguladora de la responsabilidad penal de los menores, reformada por la Ley Orgánica 8/2006, de 4 de diciembre y a su Reglamento, aprobado por el Real Decreto 1774/2004, de 30 de julio, Bosch, Barcelona, 2003.

ORTUÑO MUÑOZ, J. P., HERNÁNDEZ GARCÍA, J., Sistemas alternativos a la resolución de conflictos (ADR) la mediación en las jurisdicciones civil y penal, Fundación Alternativas, Madrid, 2007.

OTERO PARGA, M., “Los modelos teóricos de la mediación”, en M. Otero Parga, y H. Soleto Muñoz (coords.), Mediación y Solución de conflictos: Habilidades para una necesidad emergente, Tecnos, Madrid, 2007, pp. 158-171.

PALENSKI, J.E., “The use of mediation by Police”, Mediation Quarterly 1984, $\mathrm{n}^{0}$ 5, pp. 33-38.

PASCUAL PLANCHUELO, V.C., "Reflexiones sobre el concepto de justicia”, en Revista Aposta 2005, n 19. Disponible en: http://www.apostadigital.com (última visita 12/04/2018).

PASQUAL DEL RIQUELME HERRERO, M., Mediación penal: marco conceptual y referentes: Guía conceptual para el diseño y ejecución de planes estratégicos nacionales de mejora y fortalecimiento de la mediación penal, Secretaría General de la Conferencia de Ministros de Justicia de los Países Iberoamericanos (COMJIB), 2013. 
PAYNE, B., CONWAY, V., "A Framework for a Restorative Society? Restorative Justice in Northern Ireland”, European Journal of Probation 2011, vol. 3, n 2, pp. 4773.

PAZ-PEÑUELAS BENEDÉ, M.P., Conflicto y técnicas de gestión. En especial, la mediación en asuntos civiles y mercantiles y su versión electrónica, Tirant lo Blanch, Valencia, 2017.

PEMBERTON, A., “Terrorism, Forgiveness and Restorative Justice”, Oñati socio-legal series 2014, vol. 4, n 3, pp. 369-389.

PERE, R., "Te oranga o te whanau: The health of the family", en K. Whakahaere (dir.) Hui Whakaoranga: Maori health planning workshop, Hoani Waititi Marae, , New Zealand: New Zealand Department of Health, Wellington, 1984.

PÉREZ CEPEDA, A. I., "Las víctimas ante el Derecho penal. Especial referencia a las vías formales e informales de reparación y mediación”, en Luis A. Arroyo Zapater, I. Berdugo Gómez de la Torre (coord.), Homenaje al dr. Marino Barbero Santos: “in memoriam”, Universidad de Castilla-La Mancha y Universidad de Salamanca, Cuenca, 2001, pp. 443-478.

PÉREZ SANZBERRO, G., Reparación y conciliación en el sistema penal. ¿Apertura de una nueva vía?, Comares, Granada, 1999.

PETERS, T., "Victim-Offender Mediation: Reality and Challenges", en AA.VV., Victim-Offender Mediation in Europe. Making Restorative Justice Work, Leuven University Press, Lovaina, 2000, pp. 9-18.

PICÓ I JUNOY, J., Las garantías constitucionales del Proceso, Bosch, Barcelona, 1997.

POMAR FIOL, M.B., VECINA MERCHANTE, C., "Prácticas restaurativas: construyendo la comunidad desde los centros de enseñanza”, Educació i cultura: Revista mallorquina de pedagogía 2013, n² 24, pp. 213-224.

PORTELA, J. G., “Estructura y fases de la mediación”, en H. Soleto Muñoz y M. Otero Parga (coords.), Mediación y solución de conflictos. Habilidades para una necesidad emergente, Tecnos, Madrid, 2007, pp. 215-224.

POTAS, I., SMART, J., BRIGNELL, G., THOMAS, B. y LAWRIE. R., Circle sentencing in New South Wales: a review and evaluation, Judicial Commission of NSW, Sidney, 2003. 
POWELL, E., "Victim-offender Reconciliation program: bringing Restorative to the Local Community”, Quaker Comité on Jails \& Newsletter 1997, $\mathrm{n}^{\circ}$ 40. Disponible en: http://restorativejustice.org (última visita 10/05/2017).

PRANIS, K., STUART, B., y WEDGE, M., Peacemaking Circles: From Crime to Community, Living Justice Press, St. Paul, 2003.

PRANIS, KAY., Manual para facilitadores de Círculos, CONAMAJ, San José, 2006.

QUERALT JIMÉNEZ, J., "Víctimas y garantías: algunos cabos sueltos. A propósito del proyecto alternativo de reparación”, en J. M. Silva Sánchez (dir.) Política criminal y nuevo derecho penal. Libro homenaje a Claus Roxin, Bosch, Barcelona, 1997, pp. 145172.

QUINTERO OLIVARES, G., “Sobre la mediación y la conciliación en el sistema penal español: Situación y perspectiva de futuro”, en R. Castillejo Manzanares (dir.), Violencia de género, justicia restaurativa y mediación, La Ley, 2011, pp. 501-528.

QUINTERO OLIVARES, G., "El nuevo paradigma de la justicia restaurativa: la pretensión de superación del modelo vigente”, en R. Castillejo Manzanares, M. J.Sande Mayo, C. Torrado Tarrío (coords.) Justicia Restaurativa y violencia de género: más allá de la Ley Orgánica 1/2004, Universidad de Santiago de Compostela, Santiago de Compostela, 2014, pp. 146-165.

RAMOS MÉNDEZ, F., Arbitraje y litigios transfronterizos en un foro global, Atelier, Barcelona, 2005.

REDORTA LORENTE, J., “Aspectos críticos para implantar la medición en contextos de policía”, en Revista Catalana de Seguretat pública 2004, nº 15, pp. 29-46.

RÍOS MARTÍN, J.C., BIBIANO GUILÉN. A., SEGOVIA BERNABÉ, J.L. y PACUAL RODRÍGUEZ, E., La mediación penal y penitenciaria: experiencias de diálogo en el sistema penal para la reducción de la violencia y el sufrimiento humano, $2^{\mathrm{a}}$ Ed., Colex, Madrid, 2008.

RÍOS, J., PASCUAL, E., SEGOVIA, J.L., ETXEBARRIA, X. y LOZANO, F., Mediación Penal, Penitenciaria y encuentros restaurativos, Experiencias de diálogo en el sistema penal para la reducción de la violencia y el sufrimiento humano, Universidad Pontífica Comillas, Madrid, 2016.

RÍOS MARTÍN, J.C., Justicia Restaurativa y transicional en España y Chile, Comares, Granada, 2017. 
ROBINA BLANCO-MORALES, A., El dopaje en el deporte. La ley frente al dopaje, Dykinson, 2016.

ROIG TORRES, M., "Suspensión de la ejecución de las penas privativas de libertad”, en J.L. Gonzalez Cussac, A Matallin Evangelio, y E. Górriz Royo (coords.), Comentario a la Reforma del Código Penal de 2015, Tirant lo Blanch, Valencia, 2015, pp. 325-341.

ROSS, H., “Alternative Dispute Resolution: Mediation in the federal courts began in 70’s”, The Alaska Bar Rag 2007, nº enero-marzo, pp. 30-31.

ROXIN, C., “Pena y reparación”, en ADPCP 1999, vol. LII, pp. 5-15.

SÁEZ RODRÍGUEZ, C., La mediación familiar. La mediación penal y penitenciaria. El estatuto del mediador. Un programa para su regulación, Aranzadi, Cizur Menor, 2008.

SALAT PAISAL, M., “Libertad condicional”, en G. Quintero Olivares (dir.) Comentario a la reforma penal del 2015, Aranzadi, Cizur Menor, 2015, pp.189-201.

SAN CRISTÓBAL REALES, S., "Sistemas alternativos de resolución de conflictos: negociación, conciliación, mediación, arbitraje, en el ámbito civil y mercantil”, en Anuario Jurídico y Económico Escurialense, 2013, nº XLVI, pp. 39-62.

SANCHA MATA, V., "Reparación extrajudicial del daño en el ámbito del derecho penal de menores”, en Cuadernos del Instituto Vasco de Criminología 2001, n 15, pp. $153-165$.

SÁNCHEZ MARTÍN, P., “Incidencia de la mediación en el proceso civil”, La Ley Práctica de los Tribunales 2012, nº 98, pp. 60-71.

SÁNCHEZ TOMÁS, J.M., "El renacer de las víctimas y el reconocimiento de sus derechos en la Unión Europea”, en M. Martínez Escamilla y M.P. Sánchez Álvarez (coords.), Justicia Restaurativa mediación penal y penitenciaria: un renovado impulso, Reus, Madrid, 2011, pp. 69-108.

SANZ-DÍEZ DE ULZURRUN LLUCH, M., "La víctima ante el derecho: la regulación de la posición jurídica de la víctima en el derecho internacional, en el derecho europeo y en el derecho positivo español", Anuario de Derecho Penal y Ciencias Penales 2004, $\mathrm{n}^{\circ}$ 57, pp. 219-310.

SCANNICCHIO, N., “La conciliazione extragiudiziale Italiana nell 'esperienza dell' a.d.r. europeo", en AA.VV., Mediación y arbitraje de consumo: una 
perspectiva española, europea y comparada, Tirant lo Blanch, Valencia, 2010, pp. 253-306.

SCHMID, D.J., Restorative Justice in New Zealand: A Model For U.S. Criminal Justice, Wellington, New Zealand, 2001.

SCHMID, D.J., “Restorative Justice: a new paradigm for criminal justice policy”, en Victoria University of Wellington Law Review 2003, nº 34, pp. 91-133.

SHAFER, S., The victim and his criminal: a study in functional responsibility, Ramdon House, Nueva York, 1968.

SHARP, A. "What if value and rights lie foundationally in groups? The Maori case", Critical Review of International, Social and Political Philosophy 1999, n 2, pp. 1-28.

SHERMAN, L.W. y STRANG, H., Restorative justice: the evidence, The Smith Institute, Londres, 20017.

SIGÜENZA LÓPEZ, J., y GARCÍA-ROSTÁN CALVÍN, G., Estudios sobre mediación y arbitraje desde una perspectiva procesal, Aranzadi, Cizur Menor, 2017.

SKELTON, A. AND BATLEY, M., "Restorative justice: a contemporary South African review”, Acta Criminologica 2008, n² 21, pp. 37-50.

SLAIKEU, C.A, Para que la sangre no llegue al río. Una guía práctica para resolver conflictos, Granica, Barcelona, 1996.

SOLAR, M., "Justicia Restaurativa con adolescentes infractores de ley penal en el marco de la convención de los derechos del niño”, Revista de Derechos del Niño 2003, n 2, pp. 253-264.

SOLDEVILLA MARTÍNEZ, I. y GUARDIOLA GARCÍA, J., "Mediación penal en adultos: una comparativa de experiencias piloto", ReCRIM: Revista de l'Institut Universitari d'Investigació en Criminologia i Ciències Penals 2011, nº 5, pp. 1-3.

SOLETO MUÑOZ, H. (dir.), Carretero Morales, E. (coord.), Ruiz López, C. (coord.), Mediación y resolución de conflictos: técnicas y ámbitos, Tecnos, Madrid, 2011.

SOLETO MUÑOZ, H., "La nueva normativa estatal sobre mediación civil y mercantil y el proceso civil”, en Diario La Ley 2012, n 7834. Disponible en www.laley.es (última visita 11/04/2018). 
SOLETO MUÑOZ, H., “Aciertos y desaciertos de la nueva normativa estatal sobre mediación civil”, Iuris: Actualidad y práctica del derecho 2012, nº 171, pp. 18-24.

SOLETO MUÑOZ, H., y RUIZ LÓPEZ, C., "Elementos esenciales del derecho colaborativo”, Anuario de mediación y solución de conflictos 2015, n 3, pp. 95-117.

SOTO NIETO, F., “La legítima defensa completa e incompleta”, Diario La Ley 2005, $n^{0}$ 6231. Disponible en http://www.diariolaley.es (última visita 22/10/2017).

STRANG, H., Restorative Justice Programs in Australia: A Report to the Criminology Research Council. 2001. Disponible en: http://crg.aic.gov.au (última visita 12/04/2018).

STUART, B., "Circle sentencing in Yukon Territory, Canada: A partnership of the community and the criminal justice system”, en International journal of comparative and applied criminal justice 1996, $\mathrm{n}^{\circ}$ 20, pp. 291-309.

STUART, B., "Guiding principles for peacemaking circles”, en G. Bazemore y M. Schiff (dir.), Restorative Community Justice. Repairing harm and transforming communities, Ander-son Publishing Co., Cincinatti, 2001, pp. 219-241.

SUARES, M., Mediando en sistemas familiares, Paidós, 2002, Barcelona.

SUARES, M., Mediación. Conducción de disputas, comunicación y técnicas, Paidós, Buenos Aires, 2010.

SUBIJANA ZUNZUNEGUI, I.J., et al., Justicia restaurativa, una justicia para el siglo XXI: potencialidades y retos, Publicaciones de la Universidad de Deusto, Bilbao, 2013.

SUBIJANA ZUNZUNEGUI, I. J., PORRES GARCÍA, I., y SÁNCHEZ RECIO, M., "El modelo de justicia restaurativa: una propuesta de aplicación tras la entrada en vigor de la Ley 4/2015 del Estatuto de la víctima del delito”, Revista de victimología 2015, ${ }^{\circ}$ 2, pp. $125-150$.

SULLIVAN, D., y TIFFT, L., Handbook of Restorative Justice: A Global Perspective, Routledge, Nueva York, 2006.

TAMARIT SUMALLA, J., “La victimología. Cuestiones conceptuales y metodológicas”, en E. Echeburúa Odriozola, E. Baca Baldomero y J.M. Tamarit Sumalla (coords.), Manual de Victimología, Tirant lo Blanch, Valencia, 2006, pp. 1750 . 
TAMARIT SUMALLA, J. M., "La justicia reparadora en el Derecho penal de menores”, en AA.VV., Derecho penal y psicología del menor, Comares, Granada, 2007, pp. 137-168.

TAMARIT SUMALLA, J., (coord.), La Justicia Restaurativa, desarrollo y aplicaciones, Comares, Granada, 2012.

TAMARIT SUMALLA, J.M., "El necesario impulso de la Justicia Restaurativa tras la Directiva Europea de 2012”, en Ars Iuris Salmanticensis 2013, nº 1, pp. 139-160.

TAMARIT SUMALLA, J.M., "Procesos restaurativos más allá de la mediación: perspectivas de futuro”, Cuadernos penales José María Lidón 2013, nº 9, pp. 317-328.

TAMARIT SUMALLA, J.M., "Paradojas y patologías de la construcción social, jurídica y política de la victimidad”, en InDret 2013, nº 1, pp. 1-31.

TAMARIT SUMALLA, J.M., El Estatuto de las víctimas de delitos. Comentarios a la Ley 4/2015, Tirant lo Blanch, Valencia, 2015.

TARASCHI, S., "Peacemaking criminology and aboriginal justice initiatives as a revitalization of justice", Contemporary Justice Review 1998, n 1, pp. 103-121.

TEGMARK, M., “Universos paralelos”, en Investigación y Ciencia 2006, n 43, pp. 1426.

THOMAS, T., y LAGROW, S. J., "Whanau workers: Providing services for the indigenous people of New Zealand”, Journal of Visual Impairment \& Blindness 1994, $\mathrm{n}^{\circ} 88$, pp. 86-90.

TITI ZHONG, M., Using circles of support and accountability in China: prospects and problems, Simon Fraser University, Burnaby, 2010.

TOCH, H., GRANT, J.D., Police as problem solvers, Plenum Press, Nueva York y Londres, 1991.

TORRES GÁMEZ, A., "Mediación intrajudicial civil. Reflejo Jurisprudencial”, Revista Aranzadi Doctrinal 2015, n³ 3 , pp. 243-263.

TOULLIER, M., "Restorative justice in France: status artis and future perspectives”, en L. Luparia (dir.), Victims and criminal justice: european standards and national good practices, Wolters Kluwer, 2015, pp. 139-152.

URBANO CASTRILLO, E., “La justicia restaurativa penal”, La ley penal 2010, $\mathrm{n}^{0}$ 73, pp. 5-22. 
VALBUENA GONZÁLEZ, F., "Incidencia de la Ley 60/2003, de arbitraje, en el sistema arbitral de consumo”, Revista vasca de derecho procesal y arbitraje 2005, vol. 17, n ${ }^{\circ}$ 2, pp. 395-408.

VALBUENA GONZÁLEZ, F., "La directiva europea sobre resolución alternativa de litigios (ADR), en materia de consumo”, Justicia 2014, n² 2, pp. 409-443.

VALBUENA GONZÁLEZ, F., "La plataforma europea de resolución de litigios en línea (ODR) en materia de consumo”, Revista de Derecho Comunitario Europeo 2015, $n^{\circ}$ 52, pp. 987-1016.

VALBUENA GONZÁLEZ, F., "La protección del consumidor europeo: alternativas a la vía judicial”, en Revista de estudios europeos 2015, n 66, pp. 52-74.

VALL RIUS, A., y VILLANUEVA REY, N., El programa de mediación en la jurisdicción penal ordinaria; un estudio sobre tres años y medio de experiencia, Generalitat de Cataluña, Centro de estudios jurídicos y formación especializada, Barcelona, 2003.

VALL RIUS, A., "El desarrollo de la Justicia restaurativa en Europa: Estudio comparado con la legislación española”, en Diario La Ley 2006, nº 6528. Disponible en http://www.diariolaley.es (última visita 11/10/2017)

VANFRAECHEM, I., y WALGRAVE, L., "Restorative conferencing in Belgium: can it decrease the confinement of young offenders?”, en Research Unit Criminal Law and Criminology 2004, $\mathrm{n}^{\circ}$ 7, pp. 72-75.

VANFRAECHEM, I., y WALGRAVE, L., Conferencing Serious Juvenile Delinquents in Belgium: From November 2000 to October 2003, youth courts in Belgium piloted the use of the New Zealand model of Family Group Conferencing, 2005. Disponible en: http://www.justicereparatrice.org (última visita: 09/11/2017)

VANSEVEREN, B., "Hergo in Belgium: Flanders Developments in Flanders and Hergo in sexual assault cases”, en Expert Seminar on Conferencing in Leuven, Belgium, 2010. Disponible en http://www.justicereparatrice.org (última visita 17/04/2018).

VARONA MARTÍNEZ, G., La mediación reparadora como estrategia de control social. Una perspectiva criminológica, Comares, Granada, 1998.

VARONA MARTÍNEZ, G., Justicia restaurativa a través de los servicios de mediación penal en Euskadi. Evaluación externa de su actividad (octubre 2008-setiembre 2009), Instituto Vasco de Criminología, Donostia-San Sebastián, 2009. 
VON LISZT, F., La idea del fin en el Derecho penal penal (trad. de César Pérez del Valle), Universidad Autónoma de México, México D. F., 1994.

WALGRAVE, L., "Restorative conferences with serious juvenile offenders: an experiment in Belgium”, en el $4^{\circ}$ International conference on conferences \& circles, 28 de Agosto de 2003. Disponible en: http://www.iirp.org (Última visita: 09/11/2017).

WALKER, J., THOMPSON, C., WILSON, G., LAING, K., COOMBES, y M., RAYBOULD, S., Family Group Conferencing in Youth Inclusion and Support Panels: Empowering Families and Preventing Crime and Antisocial Behaviour?, Youth Justice Board, University of Newcastle Upon Tyne, Newcastle, 2007.

WEITEKAMP, E. G. M., Developing Peacemaking Circles in a European Context, Eberhard Karls University Tübingen, Tübingen, 2013.

WELCH, C., "South Australian Courts Administration Authority: Aboriginal court day and Aboriginal justice officers”, Indigenous law bulletin 2002, vol. 5, n 14, pp. 5-14.

WILSON, B., Alcoholics Anonymous Big Book, Hazelden Distributed Titles, New York, 2001.

WILSON, R., FRANCA CORTONI, F., y MCWHINNIE, A., "Sexual Abuse: A Journal of Research and Treatment. Circles of Support \& Accountability: A Canadian National Replication of Outcome Findings”, en SAGE Journals 2009, n 4, pp. 412-430.

WILSON, R., MCWHINNIE, A., PICHECA, J., PRINZO, M., CORTONI, F., "Circles of Support and Accountability: Engaging Community Volunteers in the Management of High-Risk Sexual Offenders”, The Howard Journal 2007, Vol. 46, nº 1, pp. 1-15.

WILSON, R., MCWHINNIE, A., WILSON, C., "Circles of Support and Accountability: An international partnership in reducing sexual offender recidivism”, en Prison Service Journal 2008, nº 138, pp. 26-36.

WILSON, R., MCWHINNIE, A., "Circles of Support \& Accountability: An innovative approach to community-based risk management for high-risk sexual offenders” en $\mathrm{M}$. Herzog-Evans (ed.), Transnational criminology manual, Wolf Legal Publishing, Oisterwijk, Netherlands, 2010, pp. 241-260.

WRIGHT, M., “Restorative justice: For whose benefit?”, en AA.VV., Victim-offender mediation in Europe: Making restorative justice work, Leuven University Press, Leuven, 2000, pp. 19-38.

WRIGHT, M., Justice for victims and offender: a restorative response to crime, Waterside Press, Winchester, 2002. 
WRIGHT, M., "The court as last resort. Victim-sensitive, community-based responses to crime” en The British Journal of Criminology 2002, n 42, pp. 654-667.

ZARAGOZA HUERTA, J. y VILLAREAL SOTELO, K., “Justicia restaurativa”, en M. Gonzalo Quiroga, F. J. Gorjón Gómez y A. Sánchez García (coord.), Métodos alternos de solución de conflictos: herramientas de paz y modernización de la justicia, 2011, Dykinson, Madrid, pp. 93-106.

ZEHR, H., "Retributive justice, restorative justice", en New Perspectives on Crime and Justice 1985, nº 4, pp. 2-18.

ZEHR, H., Changing lenses, Herald Press, Indiana, 1990.

ZEHR, H., Trascending. Reflections of Crime Victims: Portraits and Interviews, Good Books, Pennsylvania, 2001.

ZEHR, H., The Little Book of Restaurative, Justice, Good books, Pennsylvania, 2002.

ZEHR, H., y MIKA, H., "Fundamental Concepts of Restorative Justice”, en Contemporary Justice Review 1998, Vol. 1, nº 1, pp. 47-55.

ZINSSTAG, E., y CHAPMAN, T., “Conferencing in Northern Ireland: Implementing restorative justice at the core of the criminal justice system", en E. Zinsstag y I. Vanfraechem (eds.) Conferencing and Restorative Justice. International Practices and Perspectives, Oxford University Press, Oxford, 2012, pp. 173-188.

ZINSSTAG, E., TEUNKENS, M., y PALI, B., Conferencing: a way forward for restorative justice in Europe, European Forum for Restorative Justice, Leuven, 2011.

ZINSSTAG, E., y VANFRAECHEM, I., Conferencing and Restorative Justice. International Practices and Perspectives, Oxford University Press, Oxford, 2012. 


\section{ÍNDICE FIGURAS}

Figura 1. Diferencias entre los diferentes procesos para resolver conflictos. Fuente: La posición del abogado en el proceso de Mediación. P. 68

Figura 2. Mediación intrajudicial vs Mediación extrajudicial. Fuente: Elaboración propia. P. 77.

Figura 3. Porcentaje unitario sobre el total de actuaciones. P. 228.

Figura 4. Grado de resolución. P. 229

Figura 5. Percepción por parte de los usuarios del grado de satisfacción con el servicio. P. 229

Figura 6. Expedientes por territorio histórico. Fuente: Memoria 2014 SMI. P. 234.

Figura 7. Porcentaje de expedientes cerrados acabados en mediación o no. Fuente: Memoria 2014 SMI. P. 235

Figura 8. Expedientes cerrados por territorio histórico. Fuente: Memoria 2014 SMI. P. 236

Figura 9. Tipologías delictivas cerradas con mediación por territorio histórico. Fuente: Memoria 2014 SMI. P. 237

Figura 10. Tipologías delictivas cerradas por mediación por territorio histórico. Fuente: Memoria 2014 SMI. P. 237

Figura 11. Tipologías delictivas. Fuente: Memoria 2014 SMI. P. 238

Figura 12. Tipologías delictivas. Fuente: Memoria 2014 SMI. P. 239

Figura 13. Tipos de causa. Fuente: Memoria 2015 SMI. P. 240.

Figura 14. Tipología delictiva. Fuente: Memoria 2015 SMI. P. 242.

Figura 15. Tipología delictiva por territorio histórico. Fuente: Memoria 2015 SMI. P. 242.

Figura 16. Tipología delictiva: Delitos graves. Fuente: Memoria 2015 SMI. P. 243.

Figura 17. Tipología delictiva: Delitos menos graves. Fuente: Memoria 2015 SMI. P. 245.

Figura 18. Tipología delictiva: Delitos leves. Fuente: Memoria 2015 SMI. P. 247. 
Figura 19. Tipología delictiva: Faltas. Fuente: Memoria 2015 SMI. P. 248.

Figura 20. Total de expedientes cerrados. Fuente: Memoria 2016 SMI

Figura 21. Total de expedientes cerrados por provincia. Fuente: Memoria 2016 SMI. P. 249.

Figura 22. Tipología delictiva. Fuente: Memoria 2016 SMI. P. 251.

Figura 23. Tipología delictiva- Delitos graves. Fuente: Memoria 2016 SMI. P. 252.

Figura 24. Tipología delictiva- Delitos menos graves y leves. Fuente: Memoria 2016 SMI. P. 254.

Figura 25. Porcentaje de acuerdos en la mediación penal. Fuente: Memoria 2013 AMEPAX. P. 256.

Figura 26. Porcentaje de delitos y faltas acabadas en "acuerdos" o en "no acuerdos". Fuente: Memoria 2013 AMEPAX. P. 258.

Figura 27. Procedencia de las solicitudes. Fuente: Memoria 2013 AMEPAX. P. 259.

Figura 28. Tipología delictiva. Fuente: Memoria 2013 AMEPAX. P. 260.

Figura 29. Procedencia de las solicitudes. Fuente: Memoria 2013 AMEPAX. P. 261.

Figura 30. Procedencia de las solicitudes. Fuente: Memoria 2013 AMEPAX. P. 262.

Figura 31. Inicio de la mediación penal. Fuente: Memoria 2014 AMEPAX. P. 263.

Figura 32. Resolución de delitos. Fuente: Memoria 2014 AMEPAX. P. 264.

Figura 33. Resolución de faltas. Fuente: Memoria 2014 AMEPAX. P. 265.

Figura 34. Procedencia de las solicitudes. Fuente: Memoria 2014 AMEPAX. P. 266.

Figura 35. Tipología de las infracciones. Fuente: Memoria 2014 AMEPAX. P. 267.

Figura 36. Tipos de acuerdo. Fuente: Memoria 2014 AMEPAX. P. 267.

Figura 37. Resolución de delitos. Fuente: Memoria 2015 AMEPAX. P. 268.

Figura 38. Resolución de faltas. Fuente: Memoria 2015 AMEPAX. P. 269.

Figura 39. Procedencia de las solicitudes. Fuente: Memoria 2015 AMEPAX. P. 269.

Figura 40. Tipos de acuerdo. Fuente: Memoria 2015 AMEPAX. P. 270. 
Figura 41. Satisfacción con la preparación. P. 312.

Figura 42. Satisfacción con el resultado de la conferencia. P. 312.

Figura 43. La rueda de poder y control. Fuente: The duluth model. P. 325.

Figura 44. Reducción de la reincidencia. P. 336.

Figura 45. Mapa de los proyectos de círculos de Inglaterra y Gales. P. 338.

Figura 46. 15 Voluntarios entrenados. ¿Cómo son? P. 344.

Figura 47. Tribunales de círculos de Sentencia Indígena en Australia. P. 348.

Figura 48. Diferencias entre Tribunales penales y Círculos. P. 362.

Figura 49. Los círculos de sanación. Fuente: Elaboración propia. P. 375.

Figura 50. Estructura del círculo CoSA. P. 380.

Figura 51. Estructura del círculo CoSA. P. 381. 